

\title{
Educoģão
} Populatr e

$\mathrm{e}$

do

compor

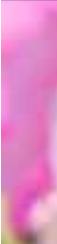

II
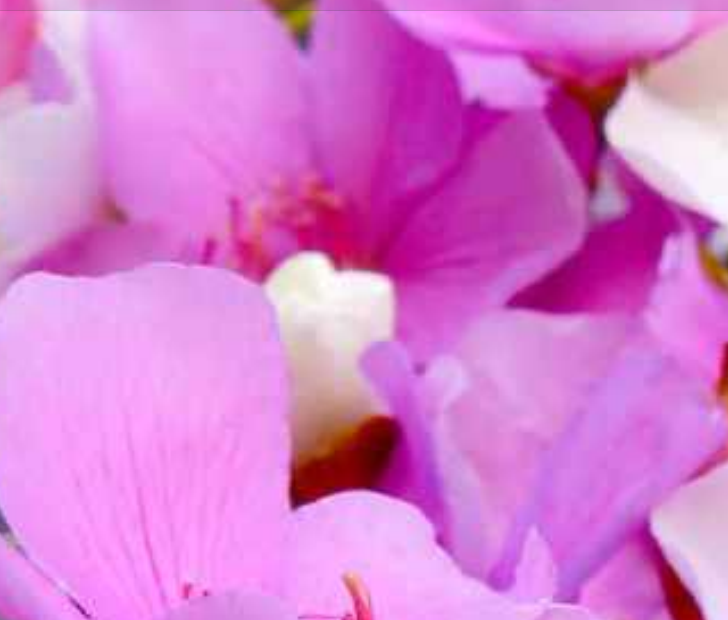

LIVRO I

Encantos de desencantos após o PRONACAMPO

Olhares sobre interfaces e contextos históricos

\section{Wender Faleiro}

Alessandro Rodrigues Pimenta

Antonio Cláudio Moreira Costa

Organizadores

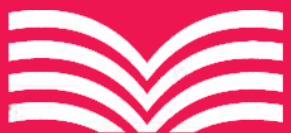

NAVEGANDO 



\section{Wender Faleiro \\ Alessandro Rodrigues Pimenta \\ Antonio Cláudio Moreira Costa \\ Organizadores}

\section{ENCANTOS E DESENCANTOS APÓS O PRONACAMPO: OLHARES SOBRE INTERFACES E CONTEXTOS HISTÓRICOS}



Uberlândia / Minas Gerais

Navegando Publicações

2019

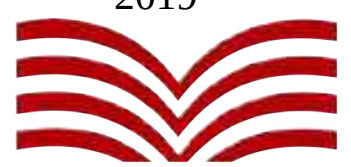

NAVEGANDO 


\section{Navegando Publicações}

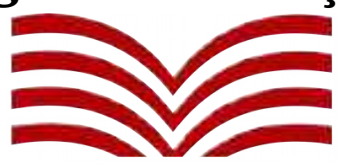

NAVEGANDO

www.editoranavegando.com

editoranavegando@gmail.com

Uberlândia - MG,

Brasil

\section{Copyright $@$ by autor, 2019.}

En12 - Faleiro, Wender; Pimenta, Alessandro Rodrigues; Costa, Antonio Cláudio Moreira (Orgs.). Encantos e desencantos após o Pronacampo: olhares sobre interfaces e contextos históricos. Uberlândia: Navegando Publicações, 2019.

ISBN: 978-85-53111-56-5

d. $10.29388 / 978-85-53111-56-5-0$

1. Educação 2 Pronacampo. I. Wender Faleiro, Alessandro Rodrigues Pimenta, Antonio Cláudio Moreira Costa. II. Navegando Publicações. Título.

CDD - 370

CDU - 37

Revisão/ Diagramação - Lurdes Lucena

\section{Índice para catálogo sistemático}

Educação

370 
Navegando Publicações

NAVEGANDO www.editoranavegando.com editoranavegando@gmail.com Uberlândia - MG Brasil

\section{Editores}

\author{
Carlos Lucena - UFU, Brasil \\ José Claudinei Lombardi - Unicamp, Brasil \\ José Carlos de Souza Araújo - Uniube/UFU, Brasil
}

\section{Conselho Editorial}

Afrânio Mendes Catani - USP, Brasil

Alberto L. Bialakowsky - Universidad de Buenos Aires, Argentina.

Ángela A. Fernández - Univ. Autónoma de Sto. Domingo, República Dominicana

Anselmo Alencar Colares - UFOPA, Brasil

Carlos Lucena - UFU, Brasil

Carlos Henrique de Carvalho - UFU, Brasil

Carolina Crisorio - Universidad de Buenos Aires, Argentina

Cílson César Fagiani - Uniube, Brasil

Christian Cwik - University of the West Indies, St.Augustine, Trinidad \& Tobago

Christian Hausser - Universidad de Talca, Chile

Daniel Schugurensky - Arizona State University, EUA

Dermeval Saviani - Unicamp, Brasil

Elizet Payne Iglesias - Universidad de Costa Rica, Costa Rica

Fabiane Santana Previtali - UFU, Brasil

Francisco Javier Maza Avila - Universidad de Cartagena, Colômbia

Gilberto Luiz Alves - UFMS, Brasil

Hernán Venegas Delgado - Universidad Autónoma de Coahuila, México

Iside Gjergji - Universidade de Coimbra - Portugal

Iván Sánchez - Universidad del Magdalena -Colômbia

João dos Reis Silva Júnior - UFSCar, Brasil

Jorge Enrique Elías-Caro - Universidad del Magdalena, Colômbia

José Carlos de Souza Araújo - Uniube/UFU, Brasil

José Claudinei Lombardi - Unicamp, Brasil

José Jesus Borjón Nieto - El Colégio de Vera Cruz, México

José Luis Sanfelice - Univás/Unicamp, Brasil

Lívia Diana Rocha Magalhães - UESB, Brasil

Mara Regina Martins Jacomeli - Unicamp, Brasil

Miguel Perez - Universidade Nova Lisboa - Portugal

Newton Antonio Paciulli Bryan - Unicamp, Brasil

Paulino José Orso - Unioeste - Brasil

Raul Roman Romero - Universidad Nacional de Colombia - Colômbia

Ricardo Antunes - Unicamp, Brasil

Robson Luiz de França - UFU, Brasil

Sérgio Guerra Vilaboy - Universidad de la Habana, Cuba

Silvia Mancini - Université de Lausanne, Suíça

Teresa Medina - Universidade do Minho - Portugal

Tristan MacCoaw - Universit of London - Inglaterra

Valdemar Sguissardi - UFSCar - (Aposentado), Brasil

Victor-Jacinto Flecha - Universidad Católica Nuestra Señora de la Asunción, Paraguai

Yoel Cordoví Núñes - Instituto de História de Cuba, Cuba 



\section{SUMÁRIO}

Prefácio

Xavier Carvalho de Sousa Neto

DOI - 10.29388/978-85-53111-56-5-0-f.1-6

Apresentação

Wender Faleiro, Alessandro Rodrigues Pimenta, Antonio Cláudio Moreira Costa

DOI- 10.29388/978-85-53111-56-5-0-f.7-16

Capítulo 1

Educação pública, educação alternativa, educação popular e educação do campo: caminhos e convergências, desvios e divergências.

Carlos Rodrigues Brandão

DOI - 10.29388/978-85-53111-56-5-0-f.17-70

Capítulo 2

Learning and teaching in the rural school: from the global to the portuguese case.

António M. Duarte - Belmiro G. Cabrito

DOI - 10.29388/978-85-53111-56-5-0-f.71-94

Capítulo 3

Decolonialidade \& educação do campo como movimentos de resistência

Magno Nunes Farias - Wender Faleiro

DOI -10.29388/978-85-53111-56-5-0-f.95-140

Capítulo 4

O protagonismo dos movimentos sociais: possíveis interfaces entre as escolas do campo e o Programa Nacional de Educação do Campo Ramofly Bicalho dos Santos

DOI - 10.29388/978-85-53111-56-5-0-f.141-176

Capítulo 5

Formação de professores na licenciatura em educação do campo: contexto de leitores e leituras

Célia Beatriz Piatti

DOI -10.29388/978-85-53111-56-5-0-f.177-210 
Educação popular: gestão, política e formação de professores

Jussara Bueno de Queiroz Paschoalino - Priscila Andrade Magalhães

Rodrigues - Luciene Cerdas

DOI - 10.29388/978-85-53111-56-5-0-f.211-232

Capítulo 7

As políticas públicas voltadas a educação do campo: olhares e concepções de licenciandos em Ciências da Natureza

Crisna Daniela Krause Bierhalz - Eril Medeiros da Fonseca

Vitor Garcia Stoll

DOI -10.29388/978-85-53111-55-8-0-f.185-250

Capítulo 8

Perspectivas para o ensino de artes visuais no contexto da educação do campo brasileira

Milena Guerson - Hertha Silva - Daniela Schneider

DOI - 10.29388/978-85-53111-55-8-0-f.185-250

Capítulo 9

Programa Nacional de Educação do Campo: seu discurso formulador e os princípios da Educação do Campo

Cátia Wanderley Lubambo - Wivianne Fonseca da Silva Almeida

DOI - 10.29388/978-85-53111-55-8-0-f.293-322

Capítulo 10

Formação de professores em ciências humanas e sociais na educação do campo

Alexandre Alves de Andrade - Marcos Paulo de Azevedo

DOI - 10.29388/978-85-53111-55-8-0-f.323-334

Capítulo 11

PRONACAMPO: os desafios para a consolidação da educação do campo como política Pública

Alessandra Gomes de Castro - Patricia Basilio Teles Stabile

DOI - 10.29388/978-85-53111-55-8-0-f.335-356

Capítulo 12

Marcas do campesinato: a luta pela terra e educação no cerrado goiano Fernanda Lima Ferreira - Adão Machado Lima - Juliano da Silva Martins de Almeida

DOI - 10.29388/978-85-53111-55-8-0-f.357-374 
El modelo CRA (colegio rural agrupado): una alternativa organizativa de la escuela rural en España

Pilar Abós Olivares - Juan Lorenzo Lacruz

DOI - 10.29388/978-85-53111-55-8-0-f.375-412

Capítulo 14

Educação rural, no campo e do campo: origens e percursos históricos Sebastiana Aparecida Moreira - Maria Zeneide Carneiro Magalhães de Almeida - Nívea Oliveira Couto de Jesus

DOI - 10.29388/978-85-53111-55-8-0-f.413-430

Capítulo 15

Políticas públicas em educação do campo no Brasil: tecendo fios Darlene Camargo Queiroz - Ramofly Bicalho - Renata Felicio Maia DOI - 10.29388/978-85-53111-55-8-0-f.431-460 



\section{PREFÁCIO}

Prefaciar a Coleção "Educação Popular e do Campo", resultante do Congresso Interinstitucional Brasileiro de Educação Popular e do Campo - CIBEPoC, foi um desafio - iniciado quando aceitei o convite dos Professores Wender Faleiro e Alessandro Pimenta - e motivo de satisfação pessoal, acadêmica e profissional. Para não desmerecer esta produção coletiva de autores renomados e tampouco criar falsas expectativas aos leitores, fiz várias circunspecções nos textos antes de emitir minhas impressões. Revistar as páginas trouxe inspiração e condição para retratá-la conjuntamente. Por ser um trabalho coletivo considerei as particularidades de cada uma das produções, objetivando o pretendido. Aqui, exponho um pouco do descoberto, compreendido e aprendido nas leituras realizadas.

Os estudos da Educação popular e do Campo se apresentam como questões fundantes desta produção. Os artigos trazem reflexões e contribuições, a partir de diversas perspectivas que perpassam por fundamentos sociais, históricos, políticos, culturais, filosóficos, pedagógicos e psicopedagógicos à relatos de experiências, evidenciando as relações entre a dimensão da Formação de Professores, sujeitos e práticas de ensino em espaços escolares e não escolares, conhecimento, cultura e desigualdades educacionais, dentre outros aspectos.

Além da qualidade acadêmica dos textos individualmente (expressam o potencial dos autores e demarcam suas trajetórias pessoal, acadêmica e de trabalho) e do conjunto da obra (potencializada pelos diversos olhares entrelaçados harmonicamente por perspectivas epistêmicas, princípios e concepções de mundo, sociedade Educação) destacam-se também outros fatores qualitativos: a organicidade dos textos e as disposições formais (refiro-me a cronologia dos artigos dentro do contexto sócio histórico) que enriquecem a exposição dialógica e dialética das conjuntu- 
ras e problemáticas históricas da Educação, especialmente do Campo brasileiro. Nesse contexto, traçam correlações sócio-políticas contextualizadas em cada momento histórico, considerando dimensões e implicações sociocultural, econômica e territorial do processo educativo.

As abordagens dos capítulos têm uma estrutura organizacional que permitem ao leitor reflexões a partir de dados contextualizados nas dimensões de tempo versus espaços: do antigo ao agora, do local ao universal e vice-versa. Essa proeza deu leveza aos textos e possibilitou o desvelo do perverso cenário sócio educacional do Brasil, de forma crítica, mas sem vieses vistos nas literaturas que tratam desse assunto. Percebe-se que os autores imprimem nos textos seus cotidianos e suas trajetórias pessoais, vinculando-os às suas práticas acadêmicas e de produção que se refletem e são refletidas (retroalimentam-se) nos contextos sociais. Nesse contexto, as contribuições estão articuladamente fundamentadas em aspectos histórico-sociológicos, agregando valores a esta produção científica.

A Coleção "Educação Popular e do Campo" apresenta um horizonte (talvez vários) de contribuições das construções históricas dos processos educacionais que demarcaram e tiveram (e têm) consequências na construção da Educação do Brasil. Retrata as adversidades do processo educacional e consequente da Educação destinada aos povos do Campo. A discussão sinaliza erros históricos dos governantes e das governanças, fazendo correlações com as potencialidades do meio rural: questões geopolíticas, perspectivas social e educacional, formas de organizaçãosocial (artes, cultura, crenças...), lutas por conquistas e manutenção de direitos fundamentais, dentre outros.

A obra apresenta reflexões com potencial motivador de decisões política e técnica para as diversas áreas de planejamento e implementação de políticas públicas de curto, médio e longo prazos. Em síntese tem potencial para orientar ações de governantes, governança e técnicos. 
Assim, apresenta contribuições para superação das perspectivas superadas de sociedade que hegemonicamente se construíram dos/nos processos educacional e social díspares das perspectivas de gestão democrática, do regime de colaboração e das garantias de direitos propugnados na Constituição Federal de 1988, na Lei de Diretrizes e Bases da Educação (LDB) -Lei 9394/1996, no do Plano Nacional de Educação (PNE) - Lei no 13.005/2014, dentre outas legislações que tratam dos princípios, das diretrizes e das finalidades educacionais para o conjunto da população.

Os autores postulam uma concepção de Educação do Campo a partir deste lugar: suas reais necessidades, potencialidades e perspectiva de garantia de direitos integral para todos os povos. Pedagogicamente sinaliza como fundamento a necessidade de ser reconhecer na/para produção do conhecimento universal, além das bases cientificas/ lógicas/cartesianas, os saberes/conhecimentos de bases empíricas produzidos por diferentes povos, em diferentes tempos e à luz de diferentes culturas.

Salienta a necessidade de uma educação emancipatória fundamentada nos princípios e valores humanitários, ressaltando que os sistemas de ensino precisam conhecer a forma de vida do campo e entender seus desafios, limites e suas potencialidades. Enfim, os autores discutem o panorama de reconstrução do homem e de sua forma de vida. Apontam a perspectiva de que uma nova sociedade não só é possível, mas também necessária. Evidencia que o Campo e todo seu conjunto de "coisas" é também um manancial - um seleiro - que precisa efetivamente ser considerado e ocupar seu papel social. Pode-se aferir à luz das perspectivas dos autores, com as quais comungo, que a lógica educacional e social construída historicamente (para além das fronteiras do Brasil, mas com raízes profundas neste) é perversa, excludente, limitada e até criminosa: promotora de injustiças e desigualdades sociais profundas, caracterizadas na cultura de guerra, individualista, patrimonialis- 
ta, potencialmente genocida e perversa à vida humana e de outras espécies. Que processo civilizatório é esse? Até quando se conviverá com essas armaduras? São reflexões/ questões que o texto nos provoca suscitar!

O livro traz para o leitor a visão sistêmica do processo educacional. Incorpora aspectos fenomenológicos que propiciam reflexões e novos desvelos do conjunto de questões apresentadas. Nessa direção, a/s forma/s que os autores observam ou interpretam os fenômenos e as questões do mundo/sociedade, em boa medida, retratando a geopolítica do meio rural e urbano relacionando-os ao retrato e papel da Educação Popular, do Campo e da Escola.

Há diversos olhares na construção deste livro. Não obstante, o olhar epistêmico parece ser único, norteado por princípios, materializado nas questões fundantes apresentadas. Assim os autores comungam questões que fazem sentido e têm significados para o conjunto das sociedades. Esses valores são norteados por princípios humanitários, prevalência da dignidade humana, respeito às diferenças e garantia de direitos: à vida, à educação, à cultura, à liberdade de expressão, nas diversas formas de manifestação. Ausência desses elementos caracterizaria uma sensação de limites e de incapacidade humana. Uma negação do conhecimento que se constrói das ações coletivas de todos os humanos.

As análises dos atores também abarcam questões como: a) formação inicial e continuada de professores do Campo à luz de suas especificidades e necessidades; b) infraestrutura das escolas - saneamento básico (agua, luz, esgoto) e de outra ordem (telefone, internet, biblioteca, livros didáticos); c) valorização dos professores (carga horária de trabalho, salario, plano de carreira e de saúde; d) fechamento de escolas do Campo; e) transporte escolar; f) condições de acesso e permanência; g) qualidade do ensino, dentre outros aspectos, tem importância vital para quebra de certos paradigmas, quando não dogmas que 
parecem cristalizados nas sociedades.

Este livro vai além das discussões de Educação (Popular e do Campo) e suas questões. Pelos registros históricos e acadêmicos, apresentados com traços literários crítico-reflexivos, trata-se de um trabalho coletivo, construído partir de olhares de professores, pesquisadores e educadores, com grande contribuição para a história da Educação. Ele considera e perpassa a questão diagnóstica, e apresenta subsídio para compreender a realidade sociocultural e educacional local/universal. Aponta que a Educação do Campo é um espaço em disputa contínua e que as conquistas dessa área são, majoritariamente, resultantes das lutas dos povos campesinos ante um processo sócio educacional histórico caracterizado por clivagens eurocêntrica-urbanísticas estruturais e estruturantes construídas e/ou descontruídas a partir de valores e de conhecimentos de certas perspectivas hegemônicas.

Note-se que, em boa medida, uma produção acadêmica requer para ser compreendida e desenvolvida a/s revelação/s materialista (s) e histórica (s) dos seus criadores. Nesse aspecto, as trajetórias pessoal, acadêmica e de trabalho dos autores, manifestadas de várias formas (objetivas ou subjetivas) nas suas práxis (ações-reflexões-ações) pesam muito no conjunto qualitativo da obra. O livro revela a convergência dos autores com a sua história, seu trabalho, finalidade e objetivos pretendidos.

Dentre outros aspectos, pelas reflexões e fundamentos teórico-práticos que apresenta, essa coletânea traz contribuições essenciais a categorias, seguimentos, setores e atores sociais ligados às áreas sociais, especialmente da Educação, como pesquisadores, docentes, discentes, governantes, autoridades públicas, técnicos, membros de movimentos sociais e sindicais ligados à Educação. A Coletânea é, portanto, um brinde aos leitores, sobretudo os que comungam de perspectivas educacionais com qualidade socialmente referenciada, capazes de contribuir, me- 
diante processos contínuos, na construção de uma sociedade socialmente justa.

\section{Xavier Carvalho de Sousa Neto}

Mestre em Educação pela Universidade de Brasília Técnico em Assuntos Educacionais (NS) do MEC

Responsável Técnico do Projeto Escola da Terra - CGPEC/SECADI/ MEC 


\section{APRESENTAÇÃO}

A coleção "Educação do popular e do campo" do Congresso Interinstitucional Brasileiro de Educação Popular e do Campo - CIBEPoC é uma obra financiada pela Capes (Propostra640602 -03/2017). A coleção reuni trabalhos de diversos autores nacionais e internacionais que se debruçam sobre os estudos da Educação popular e do campo em diversas perspectivas desde os fundamentos sociais, históricos, políticos, culturais, filosóficos, pedagógicos e psicopedagógicos a relatos de experiências, evidenciando as relações entre a dimensão da Formação de professores, sujeitos e práticas de ensino em espaços escolares e não escolares, conhecimento e cultura e desigualdades educacionais.

Esse livro 1 da coleção visa evidenciar que a Educação do Campo é uma conquista de processos de lutas e debates que envolvem diversos setores da sociedade brasileira, e apesar de ser oficializada, a Educação do Campo é ainda pouco conhecida e sua temática fica relegada a segundo plano nas discussões educacionais. Logo, compreender e difundir a Educação do Campo e em especial, analisando as mudanças ocorridas com a implantação do PRONACAMPO, nos diversos setores e níveis educacionais com a proposição de ações efetivas de enfrentamento de seus desafios constitui-se num passo importante e necessário a valorização da Educação do Campo e a possibilidade da garantia do exercício pleno de direitos pelos povos do campo.

Abrimos o livro com o capítulo Educação Pública, Educação Alternativa, Educação Popular e Educação do Campo: caminhos e convergências desvios e divergências, do Prof. Dr. Carlos Rodrigues Brandão. O capítulo 2 dos autores portugueses António M. Duarte \& Belmiro G. Cabrito objetiva analisar a literatura sobre aprendizagem e ensino na escola rural em termos globais e considerando 
o caso português em particular. Após uma introdução, o capítulo começa considerando as características gerais do mundo rural, progride para o retrato das escolas rurais versus urbanas, um exame das especificidades da aprendizagem nas escolas rurais (aprendizado e processo de aprendizagem) e um escrutínio de as particularidades do ensino e do contexto de aprendizagem nas escolas rurais. Uma análise da educação rural em Portugal é então realizada, com ênfase em seu contexto histórico, político e econômico somado ao futuro previsível.

A colonialidade/modernidade se constituem a partir de movimentos de colonização da América, sendo assim, sob o crivo eurocêntrico vem sendo discutido no Capítulo 3 por Magno Nunes Farias \& Wender Faleiro, bem como suas bases são intrínsecas ao urbanocentrismo, que se constrói sobre a égide da civilidade, e pautado nas construções de dicotômicas entre o urbano-superior e o rural-inferior. Assim, os sujeitos do campo sofrem historicamente e atualmente a ferida colonial pela colonialidade do poder, do saber, do ser e da Natureza (colonialidade da terra). Nesse processo, há a subalternização dos povos do campo, deslegitimando-os enquanto sujeitos de enunciação epistêmica, econômica, cultural e social na constituição do Brasil. Isso reflete na construção da Educação escolar brasileira, que sempre esteve sob o crivo urbanocêntrico/colonial/ moderno, (re) produzindo relações de inferiorização dos povos do campo, tendo suas marcas desde a constituição da educação colonial até a república atual. Desta maneira, esse trabalho debruça-se sobre as construções dessas educações no Brasil, e como a colonialidade/modernidade/ urbanocentrismo estruturou especificamente a educação dos povos do campo, a partir da realização de uma revisão bibliográfica e uma reflexão crítica sobre as temáticas.

Ramofly Bicalho dos Santos, traz no quarto capítulo intitulado "O protagonismo dos movimentos sociais: possíveis interfaces entre as escolas do campo e o programa nacional de 
educação do campo", onde investiga os princípios desenvolvidos pelos movimentos sociais e a luta por uma Educação do Campo, como fatores políticos e pedagógicos na formação de novos sujeitos sociais. Ressalta as políticas públicas que sobressaíram neste cenário, em especial, o Programa Nacional de Educação do Campo (Pronacampo). Esta política representou a capacidade de articulação dos sujeitos, apontando a crescente necessidade de garantir projetos populares no campo, cuja organização tenha como referência a cultura, o trabalho, a transformação da sociedade, a conquista de uma nova hegemonia e atuação dos movimentos sociais nas escolas do campo. O percurso metodológico foi realizado através das rodas de conversas, pesquisas documentais e bibliográficas junto ao Programa de Educação Tutorial - PET Educação do Campo e Movimentos Sociais e à docência na Licenciatura em Educação do Campo, ambas na UFRRJ - Universidade Federal Rural do Rio de Janeiro. Na seleção da vasta bibliografia sobre o PRONACAMPO, nosso destaque foi para os documentos oficiais produzidos pelo MEC - Ministério da Educação e por movimentos sociais. Utilizaram ainda revistas, jornais, dissertações, teses, livros e artigos em periódicos científicos que demonstram a relevância de tal temática. Nos resultados, embora os movimentos sociais defendam que o campo é mais que uma concentração espacial geográfica, cenário de uma série de lutas e embates políticos, ponto de partida para uma série de reflexões sociais, espaço culturalmente próprio, detentor de tradições, místicas e costumes singulares, constatamos que durante séculos a formação destinada às classes populares do campo, vinculou-se a modelos "importados" de educação urbana, historicamente tratados com descaso, subordinação e inferioridade.

O capítulo 5, "Formação de professores na licenciatura em educação do campo: contexto de leitores e leituras", de Célia Beatriz PIATTI, da UFMS apresenta dados levantados no 
âmbito da investigação "Sentidos e significados necessários e possíveis para a constituição do professor leitor para além da formação inicial, na licenciatura de Educação do Campo" - que compõe a pesquisa "Políticas educacionais e formação: produção, projetos e ações de educação e psicologia", aprovada em dezembro de 2015 pelo Conselho Nacional de Desenvolvimento Científico e Tecnológico CNPq (financiada na Chamada CNPq/ MCTI № 25/2015 Ciências Humanas, Sociais e Sociais Aplicadas) que teve por objetivo investigar as políticas educacionais de formação inicial e/ou continuada, por meio da análise da produção, de programas, de projetos e de ações em Educação e Psicologia em Mato Grosso do Sul, evidenciando articulações com o contexto social, cultural e educacional do Estado.

Educação popular: gestão, política e formação de professores, capítulo 6, de autoria da Prof. . Dra. Jussara Bueno de Queiroz Paschoalino traz a discussão dos percursos da Educação Popular na atualidade, a partir das dimensões que envolvem a visibilidade da temática e sua repercussão no âmbito acadêmico. A compreensão de que a Educação Popular é uma temática no campo acadêmico e que teve a inserção do seu Grupo de Trabalho na Associação Nacional de Pós-Graduação e Pesquisa em Educação - GT na ANPED em 1981 possibilita compreender a sua trajetória. Nesse sentido, o percurso metodológico escolhido se alicerçou na análise qualitativa do material bibliográfico selecionado a partir do levantamento dos trabalhos apresentados nas últimas cinco reuniões da ANPED (2010 a 2015). A opção pelos GTs ANPED se pautou em dois fundamentos importantes: Primeiramente pela relevância desse espaço de socialização da produção teórica e acadêmica da área da educação e também pela forma democrática de disponibilizar os textos no site para consulta pública, facilitando o acesso aos trabalhos. A análise partiu da leitura dos 63 títulos de trabalhos aceitos no Gts da ANPED, no período 
estabelecido nas últimas cinco ANPEDs e posteriormente dos resumos, com objetivo de delinear o mapeamento da trilogia dos conceitos Gestão, Política e Formação de Professores, que consideramos arcabouços da ação docente e basilares da Educação Popular.

O capítulo 7 intencionou compreender as concepções que norteiam a formação inicial de professores de Ciências da Natureza, da Universidade Federal do Pampa - Unipampa - Campus Dom Pedrito, no que tange às políticas públicas do campo. Este estudo de caso, de caráter qualitativo e explicativo, teve como público 20 acadêmicos, do quinto semestre da Licenciatura em Ciências da Natureza. Os dados foram coletados a partir de um questionário semiestruturado e por meio da análise de conteúdo de Bardin (2009), emergiram quatro categorias à posterior: Pertencimento; Formação Pedagógica; Atuação Pedagógica e Concepções sobre políticas públicas do campo. Os resultados analisados evidenciaram que os licenciandos desconhecem em sua maioria a realidade das escolas do campo, por conseguinte as políticas públicas, tais como: Procampo, Pronacampo e Pronera. O projeto pedagógico da Licenciatura não apresenta em suas ementas nenhuma menção a Educação do Campo, no entanto não é possível afirmar que não sejam exploradas pelos docentes do curso. Os discentes consideram pertinente a temática apenas através de componentes optativos e não tem interesse em lecionar Ciências em uma escola do campo. Assim, os resultados apontam para o compromisso acadêmico, tanto da universidade, como dos cursos de licenciatura, em garantir o diálogo sobre todas as modalidades de ensino como espaços democráticos para emancipação, bem como suas políticas na formação docente.

Perspectivas para o Ensino de Artes Visuais no contexto da Educação do Campo brasileira, é o título do capítulo 8 o qual busca colocar em paralelo a História do Ensino de Arte e a História da Educação do Campo, identificando os 
vieses que surgem na interação dessas duas áreas de conhecimento no contexto da Educação brasileira. Com isso, intenta propor algumas reflexões que possibilitem pensar composições acerca de uma docência que conjuga Artes Visuais e Educação do Campo. Para elaboração do texto, valeu-se de uma pesquisa de cunho teórico bibliográfico, trazendo referências das teorias da Educação do Campo, da Arte/Educação, do campo da Cultura Visual, bem como outras referências que auxiliam no pensar filosófico da temática da produção docente. O texto estrutura-se da seguinte forma: primeiramente, trata de uma contextualização do Ensino de Artes Visuais no Brasil, apresentando os pontos nevrálgicos da área; em seguida, dedica-se a uma composição entre pressupostos teóricos e críticos da Arte/ Educação e da Educação do Campo; em um terceiro movimento, aponta para a Cultura Visual como possibilidade de pensar convergências entre Artes Visuais e Educação do Campo. Por fim, trazendo algumas notas conclusivas, propõe pensar uma Arte/Educação do Campo, pautada por uma autonomia criadora e por meio da experiência com Arte, que busca na Arte os modos de o sujeito produzir-se enquanto docente.

Cátia Wanderley Lubambo \& Wivianne Fonseca da Silva Almeida da UFPE, trazem no capítulo 9, a análise do Programa Nacional de Educação do Campo (Pronacampo), buscando contribuir na compreensão dos diversos fatores e elementos imbricados no âmbito do referido programa, que configuram resposta oficial do Estado às históricas reivindicações dos movimentos sociais do campo. Traçou como objetivo verificar a convergência entre o discurso formulador do Pronacampo e os princípios/diretrizes da concepção de Educação do Campo presente na literatura e adotada neste estudo. Teoricamente, revisaram-se autores centrais que debatem a Educação do Campo, como: Alencar (2010), Arroyo (2004), Caldart (2000, 2009), Caldart et al. (2012), Kuhn (2015) e Ribeiro (2010). Meto- 
dologicamente, optaram por observar o objeto de estudo na sua totalidade, adotando-se uma pesquisa de cunho qualitativo. Utilizaram-se informações oficiais acerca do programa estudado, além de depoimentos de pessoas envolvidas, coletados em entrevistas e por ocasião de fóruns temáticos. Para a interpretação dos dados, utilizaram da análise de conteúdo na proposição de Bardin (2011). Em linhas gerais, tal análise permite afirmar que por seus elos críticos, o Pronacampo está mais próximo de uma "política rural" do que dos sujeitos e das práticas sociais que constituem a Educação do Campo.

O Capítulo 10 traz para a discussão a Formação de professores em ciências humanas e sociais na educação do campo. Já o décimo primeiro capítulo versa sobre a luta dos movimentos sociais pelo acesso à Política Pública de Educação. O intento geral é realizar uma reflexão sobre o processo de construção da Educação do Campo pelos movimentos sociais do campo até a instituição do Programa Nacional de Educação do Campo (Pronacampo). Utilizaram como recurso metodológico, o levantamento bibliográfico e a pesquisa documental a respeito da Educação voltada para os povos do campo até a instituição do Pronacampo. No primeiro momento do texto é feito um apanhado das práticas educativas populares e como a Educação para os povos do campo foi sendo construída coletivamente no Brasil. Discorreram sobre como as práticas educativas da Educação Popular e as lutas dos sujeitos do campo contribuíram para o germinar da Educação do Campo. Posteriormente, discute-se o Pronacampo e os desafios para a sua implementação como uma Política Pública. Nesse sentido, apesar do avanço no debate e efetivação de políticas públicas e programas governamentais nos últimos anos como respostas às lutas dos movimentos socais do campo, ainda se tem um longo caminho a ser trilhado para alcançar os objetivos almejados para uma educação libertadora levando-se em conta os projetos antagônicos em disputa 
no modo de produção capitalista.

Há seis décadas, o território geográfico brasileiro atravessou por uma série de significativas mudanças no que diz respeito à ocupação de seus espaços, em grande parte impulsionada pela modernização das cadeias produtivas agrícolas, relativamente independentes dos demais complexos. No século passado, o Brasil viveu as ocupações da Amazônia, do Centro-Oeste e de Rondônia. Logo, o capítulo 12 apresenta um relato de experiência de uma moradora do campo, mais especificamente uma assentada, que conquistou o ingresso na universidade; problematizar conceitos de grande valor e caros a esta temática: fronteira, território, frente de expansão e frente pioneira, bem como mapear a realidade de conflitos no Cerrado Goiano entre os anos de 2014 e 2016, dados divulgados pela Comissão Pastoral da Terra (CPT). Este artigo nasce do anseio de tentar-se descobrir que motivações têm o homem do campo e como ele, em meio a tantas adversidades, permanece firme no duplo propósito de, no campo, melhoria da terra $\mathrm{e}$, no ambiente urbano, desenvolver-se intelectualmente e conquistar o curso superior. Demonstra também a garra de quem vive no campo e precisa enfrentar os desgastes e as humilhações de alguns habitantes da cidade e ainda assim, via elementos positivos nesta experiência e tornou-se educadora de crianças também do campo.

Os autores espanhóis Pilar Abós Olivares \& Juan Lorenzo Lacruz, do Departamento de Ciências da Educação da Universidade de Zaragoza, com a apresentação do modelo das chamadas Escolas Associadas Rurais em torno das quais a escola rural está organizada na maioria das Comunidades Autônomas da Espanha. A partir de uma breve história da escola rural espanhola desde o final do século XIX, é apontado como se desenvolveu a partir da escola unitária através do sistema de concentrações até o atual modelo em vigor desde o final da década de 1980. Este modelo é analisado a partir de uma perspectiva 
quantitativa e qualitativa, não tanto do ponto de vista dos processos de ensino-aprendizagem que se desenvolvem dentro dele, mas como modelo organizacional e relacionamento com o território. Isto tem como objetivo valorizar a validade e a idiossincrasia deste modelo, bem como avaliar as possibilidades e limitações que ele representa para a educação no contexto rural espanhol do século XXI.

Sebastiana Aparecida Moreira; Maria Zeneide Carneiro Magalhães de Almeida \& Nívea Oliveira Couto de Jesus traz a reflexão da tensão entre os interesses do Estado Brasileiro, da sociedade civil e dos empresários do agronegócio a Educação do Campo vem sendo construída. E, fechando o livro, temos o texto refletindo as Políticas Públicas em Educação do Campo no Brasil, dos autores Darlene Camargo Queiroz; Ramofly Bicalho \& Renata Felício Maia, o artigo tem como objetivo central apresentar algumas reflexões acerca das atividades realizadas no Fórum de Políticas Públicas em Educação do Campo, no CIBEPOC - Congresso Interinstitucional Brasileiro de Educação Popular e do Campo, ano de 2017. Neste Fórum aprofundamos, entre outras, as seguintes temáticas: 1) Movimentos sociais; 2) Reforma agrária e agroecologia; 3) Escola do campo; 4) Educação do Campo X Educação Rural; 5) ENERA; 6) PRONERA; 7) Diretrizes Operacionais para a Educação Básica nas escolas do campo; 8) PROCAMPO; 9) Pedagogia da alternância; 10) PRONACAMPO; 11) Fechamento de escolas do campo. Oriundas da mobilização das organizações e movimentos sociais, essas políticas públicas evidenciam que a luta pela reforma agrária transcende à luta pela terra, uma vez que compreende a ocupação de diversos outros espaços. A produção coletiva do saber em parceria com educandos/as, educadores/as, comunidades e movimentos sociais de luta pela terra pode dialogar com suas histórias, memórias e reconhecimento identitário, fortalecendo os debates em torno da educação do campo. Esta articulação é um dos principais desafios a serem en- 
frentados pelo Movimento da Educação do Campo.

E fechamos com o capítulo "Políticas públicas em Educação do Campo no Brasil: tecendo fios", o qual traz toda a discussão da temática desse livro.

Esperamos que tenham uma boa leitura! Os organizadores. 


\section{CAPÍTULO 1}

\section{EDUCAÇÃO PÚBLICA, EDUCAÇÃO ALTERNATIVA, EDUCAÇÃO POPULAR E EDUCAÇÃO DO CAMPO: caminhos e convergências desvios e divergências}

Carlos Rodrigues Brandão

Cinquenta e quatro anos depois, o que há ainda para falar a respeito da educação popular? O que há para praticá-la? Quando? Junto a quem? Em nome de quem? Do que? Como?

Não esqueçamos que nos "tempos originais", tanto para a cultura popular quanto para uma de suas vocações, realizada como uma ação social através da cultura: a educação popular - o que nos movia então eram palavras que continham ideias e acentuavam propostas regidas por: participação, transformação, revolução. Transformação de estruturas da mente, da consciência, da cultura, da sociedade, do mundo. Transformações radicais (desde as raízes), estruturais (não de partes ou sistemas da sociedade, mas dela toda) e socialmente populares (centradas em lutas e políticas "de classe"). Ou seja, transformações de toda uma sociedade e não adaptações modernizadoras e ilusoriamente realizáveis de acordo com o estilo desenvolvimentista do sistema capitalista hegemônico.

Paulo Freire e outros muitos "educadores libertadores" - a expressão "educação popular" será tardia nos livros de Paulo - não foram exilados apenas porque pretendiam semear pelo País uma educação de cunho libertário e socialista - revolucionário, portanto. Foram presos e exilados por se voltarem contra uma "educação do Estado colocada a serviço dos interesses hegemônicos da ordem do capital e, não rara estreita e ardilosamente patriótica ${ }^{1}$.

${ }^{1}$ Este poderia ser o momento oportuno para lembrar que o Instituto Paulo Freire editou, junto com outras instituições do Brasil, Pedagogia do Oprimido em edição fac-símile. Na edição do manuscrito de Freire é possível descobrir 
Lembro que este escrito está dividido em tópicos que valem mais como crônicas críticas do passado e do presente, do que como unidades orgânicas de um todo coerente, tal como se deveria esperar de um artigo sobre a educação. Quero acreditar que minhas palavras haverão de ser antecedidas e completadas por outras, de outros autores convidados a este colóquio-por-escrito. Pessoas que desde anos mais próximos ao presente do que eu, saberão dar aos dilemas e caminhos de uma educação popular de hoje sentidos e rumos bastantes mais convincentes e confiáveis do que os meus.

\section{Platão... educador popular?}

Alguns estudiosos do alvorecer da educação, quando na Grécia Clássica ela começou a ser pensada e vivida como uma escolha, uma vocação, uma prática e uma política, logo, como uma questão social e um dilema que obrigam a um refletir e a um agir que envolve tanto o filósofo quanto o educador, (não raro ambos na mesma pessoa), recordam que ao longo de sua história, entre Homero e Sólon, a educação grega oscilou entre dois polos de uma sempre possível, mas difícil interação.

Em seus primeiros momentos, entre os primitivos "reinos" da Hélade (lembrar a Ítaca da Ulisses) e das cidades-estados (lembrar Esparta, Tebas e Atenas), a formação do "homem grego" através da paidéia, ou seja, da educação regular e escolar, era um direito da comunidade políti-

passagens importantes e pequenos esquemas desenhados que não constam das edições "oficiais". É possível notar também a presença de um tópico com este nome: teoria da revolução que não aparece nas edições oficiais. Lembro ainda que desde os Estados Unidos da América e a caminho de seu exílio na Europa, Paulo Freire enviou o manuscrito de Pedagogia do Oprimido para Jacques Chonchol, no Chile, dando a ele liberdade de fazer do manuscrito o que lhe parecesse melhor. Há até agora entre nós dúvidas sobre como Pedagogia do Oprimido foi originalmente. Existe mesmo a estranha versão de que ele foi originalmente publicado em Inglês e nos EUA. Foi depois editado em Espanhol e somente anos mais tarde publicado no Brasil. 
ca - a polis - e um dever da pessoa destinada e convocada a estudar e a educar-se. Logo, ela era um dever imposto à família responsável por uma criança ou um jovem como uma obrigação para com o Estado.

"Homem grego" aqui dever ser tomado num duplo sentido da palavra. Mesmo em tempos de Aristóteles ele acolhe homens e não mulheres - à exceção originalmente de Esparta - envolve gregos e não os "bárbaros" - isto é, "todos dos outros de todos os povos" - e abarca apenas os "cidadãos" já formados ou em formação. Ou seja, os filhos das famílias que compunham a cidadania da polis, de que estavam excluídos os camponeses, os artesãos e, claro, os escravos.

O sujeito-livre era educado para servir à sua polis e a ela devia a sua formação. A educação foi originalmente um direito do Estado e um dever da pessoa. Atingir a arete, através da sequência de aprendizados e práticas da paidéia equivalia a formar-se e aperfeiçoar-se para, individualmente, realizar ao longo de uma vida de-quem-estuda-e-aprende um ser-humano na plenitude de si mesmo. E o lugar de aferição desta excelência de realização do belo, do bem e do verdadeiro em uma pessoa educada, não era ela própria. Era a sua polis. Era a comunidade política à qual ela estava destinada a servir, justamente por haver estudado para tornar-se uma "pessoa cidadã". Um alguém cuja medida do que aprendeu resolvia-se na qualidade de sua presença e participação entre os negócios da polis, isto é, os deveres devidos a uma cidade-estado. Assim, à dimensão em que em uma pessoa educada resolvia-se em uma sophia que através da interação com uma ética, com uma estética e mesmo com uma erótica, realizava-se afinal como uma política. Três eram então as virtudes essenciais do "homem grego": sophia (sabedoria), andréa (coragem) e sophrosine (temperança).

Sócrates educou-se para servir a Atenas, primeiro como um soldado exemplar e, depois, como um filósofo e 
um educador. Quando Atenas desconfiou dos rumos de seu ensino público, realizado entre praças e ginásios onde os jovens (e as jovens, em Esparta) exercitavam ao mesmo tempo "o corpo e a mente", ele foi acusado de "perversão", foi julgado publicamente pelos seus pares e foi condenado à morte.

Séculos foram necessários para que a primeira direção da dívida política através da pedagogia grega fosse em parte ou no todo - bem mais tarde - invertida. Apenas com o advento de uma Grécia não mais centrada em cidades-estados, e após dois ou três milênios de experiências, guerras e polêmicas, é que a educação do homem grego alterou a relação entre os seus polos e passou a ser um dever do Estado e um direito da pessoa.

A plena realização de si-mesma através da formação escolar - mas não apenas dela - torna-se um direito individual da pessoa-educanda e, por extensão, de suas comunidades de afiliação: a família, a parentela, o clã. A educação salta do coletivo da comunidade política para a individualidade da pessoa pertencente a ela. O estoicismo será em uma Grécia já bem para além de Sócrates, Platão e Aristóteles, a filosofia desta progressiva mudança. Passa a ser então em nome da plenitude da realização de um si-mesmo - agora pensado como uma pessoa-de-direitos e não apenas um Cidadão-para-o-Estado - que o jovem grego vai à escola e recebe a sua formação, entre o pedagogo que o conduz pela mão da casa à escola, e que não raro é o seu primeiro mestre doméstico, e o professor que em uma escola não raro situada no mercado ensina ao jovem as "primeiras letras" e as "primeiras contas".

Com o advento do cristianismo e, sobretudo, através da difusão das ideias cristãs de Paulo de Tarso (um judeu de formação grega) uma inversão mais radical do sentido da formação humana salta de sua realização plena "aqui na Terra" e ao longo da vida, em direção a uma preparação da pessoa para o cumprimento de seu destino "aqui 
na Terra" e depois e fora dela. Eis também o memento em que pela primeira vez a educação salta dos limites de uma sociedade nacional para o círculo imaginário e bastante mais amplo de uma "humanidade".

Vista através desta ótica podemos compreender que até os nossos dias uma oposição entre uma educação a serviço de um poder de Estado a que serve a pessoa educada versus uma educação para a realização de um si mesmo a quem serve o Estado, divide ideias, imaginários e ideologias na educação. E não apenas nela. Em uma direção e na outra um afã de encontrar um ponto de equilíbrio entre uma vocação da educação e a outra tem sido um desafio entre educadores, entre pensadores da educação e entre pensadores da sociedade e da pessoa através da educação.

Trago agora o depoimento de um dos estudiosos da educação com quem aprendi boa parte do que escrevi acima. Talvez Werner Jaeger exagere um pouco naquele que eu considero o mais belo, denso e completo livro sobre a educação dos seres humanos. Na página 1347 de Paidéia - a formação do homem grego, já quase ao final do livro e também ao final das muitas páginas dedicadas ao pensamento político e pedagógico de Platão, Jaeger escreve a expressão "educação popular" ${ }^{2}$. Pelo menos assim o que ele escreveu foi traduzido para o Português e, imagino, para o Espanhol.

E esta foi, até onde eu me lembro, a única vez em que vi estas duas palavras aparecerem juntas em um livro sobre a educação de povos da antiguidade. E Werner Jaeger vai além, ao afirmar que entre os gregos, e talvez pela primeira vez de forma explícita e como um programa de Estado, é o aristocrata Platão quem reclama uma paidéia para o conjunto de todas as pessoas de uma polis. Vejamos

\footnotetext{
2 Tenho comigo duas edições deste livro em Português. Uma, mais antiga, é da Editora Herder, de São Paulo e da Editorial Aster, de Lisboa, e não traz a data em lugar algum. A outra é uma edição mais atual e foi publicada pela Editora Martins Fontes, de São Paulo. Tenho comigo a 3 $3^{\mathbf{a}}$ edição, de 1995. Sei que há excelentes edições deste livro essencial em Espanhol.
} 
bem, ele não defende uma educação escolar apenas para homens e para sujeitos-cidadãos, mas uma educação por igual estendida a todas as categorias de pessoas da sociedade. Ou quase todas, pois não fica claro se nela estariam os escravos incluídos.

Jaeger lembra que Platão vai mais além ainda do próprio Sócrates, com quem aprende a filosofar, e muito mais além dos sofistas com quem polemiza ao longo da vida, ao reclamar para "o povo" não apenas a instrução funcional que gera o homem-prático-destinado-ao-trabalho-manual, mas uma formação integral que educa, forma e aperfeiçoa o sujeito-teórico-destinado-ao-trabalho-político, E "político" deve ser lido aqui no sentido ancestralmente grego desta palavra: o sujeito corresponsável pela gestão de sua polis. Um sentido ao longo dos séculos retomados por vários educadores, de que Paulo Freire será apenas um entre outros pensadores e homens de ação próximos. "Teórico" também deve ser pensado em seu sentido grego original, como aquele que de algum lugar observa algo e pensa criticamente o que vê e compreende, para em seguida agir crítica, isto é, politicamente.

Dou a palavra a Werner Jaeger:

Na realidade a criação dum sistema completo de educação elementar, encarado como paidéia do povo e base da alta educação de que nas obras anteriores se ocupara, constituiu uma das mais audaciosas inovações de Platão, digna do seu grande gênio educativo. É o último passo para a realização plena do programa do movimento socrático, um passo chamado a ter uma importância incalculável, apesar de nenhum legislador do seu tempo se ter sentido tentado a tornar realidade o ideal platônico duma educação geral da massa do povo. Como se pôs em evidência, foi quando a educação pretendeu ser mais do que uma aprendizagem meramente técnica e profissional, com o primitivo ideal aristocrático de formação da personalidade humana no seu conjunto, que, como sempre sucede no mundo, a história da paidéia grega começou. Este ideal de arete foi transplantado para a educação dos cidadãos que, sob novas condições sociais da Cidade-Estado grega do período clássico, desejavam participar na kalokagathia das classes mais cultas; 
mas, mesmo na democracia ateniense esta missão estava inteiramente confiada à iniciativa privada individual ${ }^{3}$. O passo revolucionário que Platão dá nas Leis e que constitui a sua última palavra sobre o Estado e a educação consiste em instituir uma verdadeira educação popular a cargo do Estado. Platão atribui nas Leis a este problema a mesma importância que na República concedia à educação dos governantes. E é lógico que assim seja; com efeito, onde é que este problema havia de encontrar a atenção merecida, senão no Estado educativo das Leis, baseado na harmonia ideal entre o governo e a liberdade ${ }^{4}$

${ }^{3}$ Werner Jaeger lembra que não existe em nossas línguas uma palavra que bem traduza o sentido grego de arete. "Virtude" seria a mais próxima, mas é ainda imperfeita. Atingir a arete era o ideal primeiro da aristocracia homérica, depois, do cidadão grego dos tempos de Sócrates. E elevar o homem a uma sempre aperfeiçoável arete era o supremo ideal da educação grega. A palavra deve ser pronunciada aretê.

Entenda-se bem que o eu não é o sujeito físico, mas o mais alto ideal de Homem que o nosso espírito consegue forjar e que todo o nobre aspira a realizar em si próprio. Só o mais alto amor deste eu, em que está implícita a mais elevada arete. (Paidéia: 32, na edição original em Português, sem data)

${ }^{4} \mathrm{Na}$ edição de onde extraí a citação, todo este texto vem dentro de [ ]. E está escrita a seguinte observação do tradutor: $O$ texto entre [ ] não consta na edição alemã; foi acrescentado pelo autor na edição espanhola revista pelo autor - NT. Esta observação do tradutor de Paidéia é extremamente instigante. Afinal, quais os motivos pelos quais uma passagem tão relevante compareça na edição espanhola entre colchetes, e não exista na edição original em alemão? Observemos que a tradução espanhola foi revista pelo autor, o que descarta a ideia de que de forma ousada e não muito honesta o tradutor a tivesse incluído por conta própria. Terá Werner Jaeger aprendido com os espanhóis o que os alemães não lhe ensinaram? Ou terá ele ousado deixar na edição em Espanhol o que não se atreveu a escrever na alemã? Terá ele deixado em uma edição e negado na outra uma afirmação de resto bastante controvertida em Platão? Platão, bastante mais aristocrata do que seu mestre, Sócrates, teria no final de sua vida "democratizado" tanto as suas ideias políticas a ponto de estender direitos de cidadania e, entre eles, o de uma educação popular oferecida pelo estado a todos os habitantes da polis, e não apenas à restrita categoria dos "cidadãos" de seu tempo, da qual ele mesmo fazia parte? Na citação acima de Paideia todas as palavras grifadas são do autor, menos educação popular, que corre por minha conta. 


\section{Educação pública... educação popular?}

A epígrafe de Darcy Ribeiro no começo deste escrito não está ali ao acaso. Darcy Ribeiro foi um antropólogo, um indigenista, um educador, um criador de universidades no Brasil e fora dele; foi ministro da educação, foi senador e foi romancista. E foi exilado político. Suas confissões de fracasso nada têm a ver com o que criou como cientista e como um romancista. Tem a ver com suas lutas e experiências com e através do poder público. Ele aprendeu a duras penas a lição que não devemos esquecer. Quase sempre em nossas nações anunciam "público" como "do povo", da "sociedade civil" e realizam esta palavra e as ações que a acompanham como "do estado", "do poder público", "do governo". Fora "a salvação dos índios", as palavras de Darcy Ribeiro poderiam ser endossadas por Paulo Freire. Sabemos bem que começou a sua vida de professor em um órgão de uma universidade pública federal ${ }^{5}$. Ele trabalhou com a sua primeira "equipe nordestina" no Serviço de Extensão Comunitária da Universidade do Recife (depois Universidade Federal de Pernambuco). Ali a equipe elaborou a proposta não apenas de um "Método Paulo Freire de Alfabetização", mas todo um "Sistema Paulo Freire de Educação", que previa em 1961 até mesmo a criação de uma "Universidade Popular" e de um "Instituto Internacional

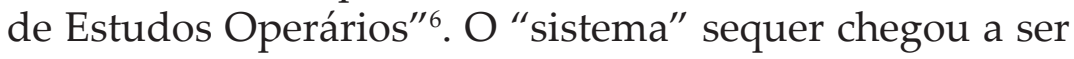

\footnotetext{
${ }^{5}$ Lembro que no Brasil as universidades públicas, inteiramente "bancadas" pelo poder público, podem ser federais, estaduais (criadas e geridas por Estados da Federação Brasileira) e até mesmo municipais. De outra parte, entre as instituições "particulares" existem universidades comunitárias e as francamente empresariais. São estas últimas as que proliferam entre crescimentos geométricos.

${ }^{6}$ As experiências inauguradas a partir da passagem de Paulo Freire e sua primeira e equipe pelo Serviço de Extensão da Universidade do Recife aparecem escritas pela primeira vez rito no número 4 da Revista de Cultura da Universidade do Recife, com a data de abril/junho de 1963, Paulo Freire e parte dos integrantes de sua equipe pioneira publicam uma pequena série de artigos. Vale a pena relembrar seus títulos: Conscientização e Alfabetização: uma nova
} 
ensaiado. Paulo Freire e sua equipe foram convocados pelo Ministério da Educação em Brasília para implantarem uma ampla e radical Campanha Nacional de Alfabetização, que tinha Cuba como horizonte. Os militares se anteciparam com o golpe de $1^{\circ}$ de abril de 1964. Paulo foi detido e exilado. Em seu exílio ele participou e apoiou experiências de alfabetização e educação continuada de adultos do povo no Chile e, sobretudo, em colônias recém-libertadas do domínio português, a partir da iniciativa de governos revolucionários chegados ao poder na África. Os primeiros tempos foram promissores e seus "livros africanos" o revelam. Mas o que aconteceu a seguir, entre guerras internas e novas ditaduras mais uma vez revelou o dilema do deslocar da classe insurgente e das comunidades civis de poder para um poder de estado um "dever de educar" depressa transformado em um "poder de educar".

De volta ao Brasil depois de treze anos de exílio Paulo Freire ingressou em duas universidades de São Paulo, uma pública e outra particular-comunitária: A Universidade Estadual de Campinas e a Pontifícia Universidade Católica de São Paulo, onde nós nos reencontramos. Mas é na "católica" que ele encontrou um bem mais acolhedor "espaço de docência". E é ela e não a UNICAMP que criou a até hoje existente Cátedra Paulo Freire. Chamado como secre-

visão do processo, escrito por Paulo Freire (ps. 5 a 22); Fundamentação teórica do Sistema Paulo Freire de Educação, escrito por Jarbas Maciel (ps. 25 a 58); Educação de adultos e unificação da cultura, escrito por Jomard Muniz de Brito (ps. 61 a 69); e Conscientização e alfabetização: uma visão prática do Sistema Paulo Freire, escrito por Aurenice Cardoso, onde pela primeira vez o "Método Paulo Freire de Alfabetização" é publicado (ps. 71 a 79).

Lembro que no artigo escrito Paulo Freire a palavra "cultura" aparece logo na segunda página. A palavra "educação" - sem qualquer qualificador - aparecerá bem mais adiante e apenas em dois momentos da "I $\mathrm{I}^{\mathrm{a}}$ parte" do texto. Antes de descrever sumariamente o seu método de alfabetização, na "II ${ }^{a}$ parte" do seu artigo Paulo Freire subordina a sua proposta de educação a um processo de "democratização da cultura". E será "cultura" o conceito-chave de todo o seu escrito. Os quatro artigos pioneiros foram anos mais tarde reeditados por Osmar Fávero, no livro: Cultura popular e educação popular-memória dos anos sessenta. 
tário de educação do governo de Luiza Erundina, Paulo Freire e seus companheiros criam o MOVA-São Paulo, um movimento público e popular de alfabetização que irá se tornar modelo para outros vários "Movas" espalhados pelo Brasil. Nas eleições governamentais seguintes um candidato de direita assume o governo de São Paulo, e em menos de seis meses o MOVA-São Paulo é desmontado.

Quando anos mais tarde à frente do Partido dos Trabalhadores (de que Paulo Freire é um dos signatários fundadores) Luís Inácio Lula da Silva assume a presidência do País, ao contrário do que esperávamos todos, a experiência exitosa do MOVA é descartada e o Ministério da Educação implanta em todo o País um estranho "Brasil Alfabetizado", vivo (e agonizante) até hoje. Mesmo ao longo de governos petistas Paulo Freire muito raras vezes foi chamado a colaborar com o Governo Federal. Ele apoiou algumas iniciativas estaduais e municipais sob governo do PT. Inúmeras experiências de converter em popular uma política pública de educação são desfiguradas ao longo do tempo, ou são depressa desarticuladas após derrotas do PT e de outros partidos de esquerda em eleições. Este educador que hoje dá nome a mais de cinquenta escolas públicas em todo o Brasil, e que recentemente foi proclamado como "Patrono da Educação Brasileira", partiu sem haver logrado de forma consistente e duradoura realizar como efetivamente "popular" uma educação "pública". Isto é, uma educação escolar criada e conduzida por agentes do povo e de instituições da sociedade civil, e realizada em seu nome e a seu favor e, não, como um projeto de empoderamento puro e simples do poder partidário de estado. Sou testemunha de que seu tempo, suas ideias e seu empenho dirigiram-se no final de sua vida muito mais aos movimentos populares do Brasil do que as iniciativas governamentais.

Que a memória do que Paulo Freire acompanhou em momentos "insurgentes" no Brasil, no Chile, em Angola, 
em Moçambique e na Nicarágua (onde estivemos juntos em 1980) e viu com pesar desaparecer cedo do horizonte, nos ajude a lembrar que a educação pública não surge como nós aqui e ali a idealizamos, ao opô-la à educação e à escola privadas, particulares e confessionais. A duras penas Paulo, Darcy e quantas e quantos de nós aprendemos que é temerário confiar em uma educação que nas democracias pode mudar de mãos e de mentes a cada quatro anos, e onde cada secretário de educação (não raro rival do que acaba de sair) resolve "apagar tudo o que foi feito e começar tudo de novo"? Como confiar em uma educação que entre governos autoritários à esquerda e à direita, depressa hegemoniza como uma "política de estado" ou um "projeto de partido" o que em algum momento foi sonhado como sendo algo "do povo"?

Foram locais e momentos de exceção - não raros efêmeros - em sua forma moderna, a educação pública surge ao lado do nascimento de estados-nação na Europa. Ela aparece e depressa se difunde em países submetidos a conflitos internos ou externos em um tempo entre fins do século XVIII e o século XIX, quando guerras entre velhas e novas nações europeias eram mais a regra do que a exceção. Surge, portanto, no interior e a serviço de sistemas políticos nacionais fortemente militarizados, entre os armamentos, os exércitos, e a educação ofertada a suas crianças e jovens. Um de seus locais pioneiros de origem e acelerada expansão é a Prússia, o mais militar e belicoso dos países da Europa de seu tempo.

Seu modelo mais imediato é o exército e não a sociedade. Depois será a empresa e, não, a comunidade. E fora breves momentos de exceção, à direita e à esquerda uma educação pública de matriz europeia dirige-se através de suas escolas "abertas a todos" a instruir e formar crianças e jovens entregues à tutela de um poder de estado empenhado em gerar cidadãos letrados, esclarecidos e disciplinados, ou seja, pessoas prontas a "viver e morrer pela Pá- 
tria". Sabemos que o abecedário pedagógico de muitas de nossas escolas ainda começa com a letra " $\mathrm{d}$ ", e da palavra "disciplina" derivam todas as outras. Uniformes, formaturas de estilo militar, cultos aos "símbolos da Pátria" serão a sua rotina diária.

Um discreto acento humanista-iluminista apenas em parte escondia o teor uniformemente disciplinador da escola pública em suas origens. Entre outros estudiosos muito conhecidos é delas que fala Michel Foucault. E como tanto ele quanto outros pensadores críticos e pós-críticos são nossos insistentes conhecidos, quero trazer aqui um inesperado depoimento.

Ao tempo de Marx e Engels, Leon Tolstoi, um escritor russo e um aristocrata dissidente escrevia isto sobre as escolas não apenas de seu país.

Nas mãos das classes dirigentes estão o exército, o dinheiro, as escolas, a religião, a imprensa. Nas escolas, elas atiçam o patriotismo nas crianças com histórias que descrevem o próprio povo como sempre correto e melhor do que todos os outros; nos adultos atiçam este mesmo sentimento com espetáculos, cerimônias, monumentos e uma imprensa patriótica mentirosa; e, o mais importante, atiçam o patriotismo pelo fato de que, ao promover todo o tipo de injustiça e crueldade contra outros povos, despertam neles a hostilidade contra seu próprio povo e depois utilizam essa hostilidade para despertar atitudes hostis em seu próprio $\mathrm{povo}^{7}$.

Em boa medida, esta é a primeira matriz de uma pe-

\footnotetext{
${ }^{7}$ Está na página 166 do livro Liev Tolstoi - os últimos dias, da Penguin Companhia/Companhia das Letras, de São Paulo, com data de 2011. Corresponde ao artigo Patriotismo e governo, escrito por Tolstoi em 1900. Lembro que após ser já um escritor universalmente consagrado e depois de haver sido excomungado pelo Sínodo da Igreja Ortodoxa Russa, devido a suas ideias sobre a religião e, especialmente, por suas ásperas críticas ao governo e à religião em seu país, Liev Tolstoi criou em sua propriedade, Iasnaia Poliana, uma escola para os filhos dos seus servos, os "mujiques". Ele mesmo dedicou-se a lecionar nesta escola e escreveu inclusive uma cartilha popular (existe tradução em Português). Há versões de que a escola simplesmente "não seguiu adiante". Mas há também outras versões segundo as quais a escola de Tolstoi foi fechada por ordem do "governo imperial".
} 
dagogia oficial da escola pública dos séculos XVIII e XIX, que as políticas públicas diferenciadamente importam para a América Latina.

A Inglaterra da revolução industrial dá à educação pública a sua outra face. Em um país que desde cedo aprendeu a separar - ao estilo grego arcaico - a elite aristocrática e, depois, a burguesia florescente que deveria governar e administrar, da massa das "pessoas comuns" (professoras/es incluídas) destinadas a obedecer e a trabalhar, reduziu no essencial o acento militarmente patriótico de suas escolas e incorporou a elas o que outros países da Europa tardaram a acrescentar às deles, e que depressa os Estados Unidos da América do Norte inovaram e tornaram o centro do espírito do ensino de suas escolas públicas: o foco sobre a formação de cidadãos competentes-competitivos direcionados à empresa e à indústria em tempos de paz, e ao exército em tempos de guerra. Algo cedo descoberto como um outro "bom negócio". E esta tem sido de forma acelerada nos últimos trinta anos, a outra face que também depressa as nossas políticas públicas incorporam aos currículos de suas escolas.

À direita e à esquerda, entre as ideologias e os regimes políticos de vocação totalitária, praticamente todos os educadores, de Sócrates a Paulo Freire, foram colocados à margem, oficialmente proscritos ou "esquecidos'; foram tidos como curiosos criadores de estranhas pedagogias e escolas "alternativas", quando não presos, exilados ou mortos. As ideias e as propostas pedagógicas cultural e/ ou politicamente inovadoras, fora as raras exceções das diferentes escolas alternativas, de que as "antroposóficas" são talvez o mais conhecido e universalmente difundido exemplo, são aceitas como experiências singulares, quase sempre dirigidas "aos que podem pagar". Mas quando, em outra direção, são criadas pelo operariado e diretamente dirigidas ao povo, do século XIX às ditaduras latino-americanas do século passados elas foram severamen- 
te perseguidas e, aqui e ali, fechadas, não raro entre tiros e prisões, tal como ocorreu com as "escolas anarquistas" de vocação libertária durante algum tempo implantadas no Brasil por operários emigrantes europeus e dirigidas a filhos de trabalhadores ${ }^{8}$.

Uma "educação pública popular" é quase sempre regularmente efêmera ou deprava-se como uma educação pública submetida a um poder de Estado através da subserviência do povo, mesmo ou principalmente quando se anuncia como uma educação a "serviço da sociedade civil". No Brasil, durante a vigência do Partido dos Trabalhadores, no governo da Federação, em alguns estados e inúmeros municípios, a "educação popular" foi decretada oficialmente como a própria "política da escola pública". Foi então o breve e fecundo tempo da criação de "escolas cidadãs", de "escolas candangas" e outras "escolas populares" com outros nomes e uma declarada vocação de ruptura transformadora. Foi o tempo das assembleias populares sobre educação, dos coletivos pedagógicos, das gestões partilhadas, dos orçamentos participativos, das pesquisas prévias junto às comunidades de acolhida das escolas para a elaboração de propostas curriculares questionadoras. Hoje, fora alguns casos muito raros, tudo o que se fez resta na memória saudosa de algumas professoras e em algumas dissertações e teses de pós-graduação.

Na vigência presente do governo federal, Paulo Freire foi decretado "Patrono da Educação Brasileira", e o ministério da educação elaborou um documento que funda na educação popular a política pública de educação no País. Não há nada que torne uma confiável prática esta vaga proposta e, ao contrário, as pessoas que militam no Conselho Nacional de Educação resistem como podem a um avanço evidente e crescente do ideário neoliberal, de-

\footnotetext{
${ }^{8}$ Norma Elizabeth Pereira Coelho defendeu na Faculdade de Educação da Universidade Federal do Rio Grande do Sul uma tese de doutorado sobre este assunto: os libertários e a educação no Rio Grande do Sul (1895-1926), Porto Alegre, 1987.
} 
fensor da "escola para a empresa" e da "educação como negócio".

A citação abaixo poderia ser tomada como o "mote" de apenas uma face das críticas que educadores contrários a este horizonte pedagógico oficial no Brasil fazem à escola pública.

Numa breve perspectiva histórica, na América Latina, especialmente no Brasil, a escola pública não tem sido uma instituição pensada para o acolhimento das classes populares. $[\ldots]$

Na América Latina, nos países cujos modelos políticos e econômicos se pautam pela ideologia desenvolvimentista, a escola, especialmente a escola pública, teve como um de seus principais objetivos, junto às classes populares, prepará-las para o mundo do trabalho, garantindo uma força de trabalho minimamente educada, além de inculcar e difundir a ideologia liberal de aceso e democratização do conhecimento socialmente produzido para todos ${ }^{9}$.

Conhecemos de sobra algumas razões visíveis a respeito da distância ou mesmo de uma dissonância entre a educação pública-estatal e a educação popular. Uma delas é difundida o bastante para não ser mais do que apenas sumariamente relembrada aqui. A educação popular não se apresenta como um serviço cultural através da educação estendida ao povo, mas como uma ação pedagógica colocada a serviço do povo. Colocada, na contramão, a serviço direto de sua endo-formação e de seu empoderamento como um agente ativo de transformações sociais quase sempre hostis a poderes de estado liberais, neoliberais ou liberalmente populistas. Hostis a tais políticas e, mais ainda, aos interesses dos polos político-econômicos aos quais serve o poder público colonizado.

Mas há também um outro um motivo do descolamento entre a educação popular e as nossas políticas governamentais de educação. Desde as origens dos movi-

\footnotetext{
${ }^{9}$ Esta passagem está no artigo de Maria Teresa Esteban e Maria Tereza Goulart Tavares: Educação popular e a escola pública - algumas questões e novo horizontes, na página 293 de Educação popular - lugar de construção social coletiva, livro organizado por Danilo Streck e Maria Teresa Esteban.
} 
mentos de cultura popular no Brasil dos anos sessenta e muito depressa, quando a educação popular se difunde por toda a América Latina, que já em Paulo Freire será a sua assinatura político-pedagógica, e que me parece hoje em dia algo quase esquecido.

Vejamos. Ao deslocar de um poder-de-estado para instituições e frentes de lutas populares o seu lugar de inserção, a educação popular desqualifica a essência do teor nacionalista-patriótico de qualquer educação pública. Veremos mais adiante como a educação popular, a partir de Paulo Freire, em muito breve tempo passa de "nordestina" a "brasileira", de "brasileira" a "latino-americana" e de "latino-americana" a "altermundista". Altermundista aqui num duplo sentido da palavra. Primeiro: universalista a partir das classes e dos movimentos populares - de que hoje em dia a Via Campesina é um exemplo eloquente. Segundo: integrada à vocação de que cabe ao povo nós incluídos, segundo a minha visão - a criação de "um outro mundo possível".

Assim, como um educador popular, diante do enfrentamento entre movimentos camponeses paraguaios e a política expansionista de meu País, o Brasil, eu me coloco ao lado dos camponeses paraguaios e contra a política agrária de meu País. E com eles aproveito para aprender a reler uma outra versão da "Guerra da Tríplice Aliança", no Brasil até hoje ensinada nas nossas escolas como uma triunfante... "Guerra do Paraguai"10. Uma primeira lição

${ }^{10}$ Enquanto escrevo estas anotações, separadas por apenas dois dias, milhares de pessoas saíram na semana passada às ruas na imensa maioria das cidades brasileiras. Na sexta feira, capitaneadas pela Central Única dos Trabalhadores, pelo Movimento dos Trabalhadores Rurais sem Terra e por outros movimentos e agremiações "de esquerda", saíram homens e mulheres que foram às ruas apoiar o atual governo do Partido dos Trabalhadores (e sua frágil e detestável "coligação de partidos") e a presidente Dilma Roussef. Ficaram de fora partidos e agremiações de extrema-esquerda, inclusive os que lançaram candidatos à presidência da república nas últimas eleições. A cor vermelha foi absolutamente dominante entre as bandeiras, as faixas, as roupas e as cores pintadas no rosto.

No domingo multidões muito maiores ganharam as ruas para "protestar con- 
difícil de ser aprendida entre nós é a de que a partir do momento em que "para além do nacional" você se coloca "ao lado do povo", toda esta criação das elites governantes chamada "nacionalismo" torna-se algo a superar em nome de um pan-universalismo fraterno.

No Dicionário da Educação do Campo, que daqui em diante estará nos acompanhando o tempo todo, em seu longo verbete sobre Educação do Campo, Roseli Caldart, em nome da autonomia e do protagonismo das classes e dos movimentos populares, radicaliza a ideia de que não cabe a um poder de estado tutelar políticas públicas de educação. Que o governo responda obrigatoriamente pela economia da educação pública. Mas de modo algum pelo seu controle político-pedagógico.

A Educação do Campo, principalmente como práticas dos movimentos sociais camponeses, busca conjugar a luta pelo acesso à educação pública com a luta contra a tutela política e pedagógica do Estado (reafirma em nosso tempo que não deve ser o Estado o educador do povo ${ }^{11}$. Grifos e parênte-

tra o governo". Entre os sapatos, as roupas e os rostos dava para se perceber uma "diferença de classes sociais" mais do que evidente. As cores vermelhas, exageradas na sexta feira, deram lugar a torrentes humanas de verde-amarelo-azul-e-branco, as "queridas cores do povo brasileiro". Entre gritos de repúdio e palavras de ordem extremamente agressivas, o Hino Nacional Brasileiro foi cantado inúmeras vezes. De uma maneira criativa e desonesta, justamente aqueles que não encontrariam problemas em desnacionalizar o que ainda nos resta, foram os que simbolicamente empurraram os manifestantes "vermelhos" para uma "esquerda de ladrões e comunistas", e se apropriaram - como nas escolas - de hinos, cores, palavras, cantos e outros símbolos "amados', para dizerem de si que "somos nós o povo brasileiro"

${ }^{11}$ Está na página 262 do Dicionário de Educação do Campo. Este "dicionário" composto de longos verbetes-artigos escritos por diferentes pessoas diretamente ou não ligadas ao Movimento dos Trabalhadores da Terra e de uma nascente Educação do Campo, foi publicado pela Editora Expressão Popular, de São Paulo em 2012. Roseli Caldart tem sido a mais conhecida e persistente educadora corresponsável pela condução dos debates sobre a linha pedagógica do Movimento dos Trabalhadores Rurais sem Terra, tanto no que se refere ás escolas dos acampamentos e assentamentos da Reforma Agrária, quanto na elaboração de uma "pedagogia de movimento" bastante mais ampla e politicamente consequente com o ideário do MST, onde a própria ideia de educação vai muito além da escola e da educação formal. Vimos e veremos que 


\section{Educação popular e o desafio do diálogo}

Há, pelo menos, duas variantes na compreensão do que seja educação popular.

Primeira: ela é uma modalidade de pensamento, de prática pedagógica e de ação política dela derivada, dirigida às/pelas classes populares e devotada a participar de processos em que elas se tornam protagonistas de transformações sociais. Ela surge por volta dos anos 60 na América Latina e radicaliza teórica, pedagógica e politicamente o que também na Europa foi em alguns momentos e lugares chamado de educação popular. Isto porque ela não se dirige como um serviço suplementar da educação às classes populares, mas porque ela pretende se colocar pedagogicamente a serviço das classes populares para que elas próprias estabeleçam o seu destino como classe e as suas ações políticas transformadoras.

Segunda: aquilo a que damos agora o nome de $e d u-$ cação popular é algo que ao longo da trajetória humana acontece em diferentes momentos e em diversos lugares sociais. Com diferentes assinaturas e diversas ideologias políticas e propostas pedagógicas de sua realização, há um acontecer de uma educação popular sempre que uma crítica radical a uma política a uma hegemonia econômica, a uma cultura política e a uma educação derivada delas associa-se a um projeto originado das classes populares. Um projeto que justamente repensa a educação como cultura, a cultura como política e a política como transformação social de vocação popular.

No caso brasileiro e para ficarmos aqui na escolha da primeira alternativa, lembremos que embora os Movi-

entre educadores provenientes do mundo da academia e muito conhecidos no Brasil, o MST conta com a presença ativa de Miguel Arroyo e Gaudêncio Frigotto. 
mentos de Cultura Popular da aurora dos anos sessenta surjam tanto "no campo" quanto "na cidade", em sua vocação freireana e mais difundida uma educação popular é dirigida diretamente ao campesinato. As primeiras experiências nordestinas de fato marcantes são rurais, a começar pelas "Quarenta horas de Angicos". E o Movimento de Educação de Base, a mais expandida e expressiva instituição derivada dos MCPs é absolutamente rural. Entre a educação popular dos anos sessenta - apenas tardiamente assumida com este e nome "educação popular" - e a educação do campo há um intervalo de mais de cinquenta anos.

Ora, uma peculiaridade nuclear da educação popular, desde suas origens remotas até os dias de hoje, separa-a ideológica, política e pedagogicamente de outras vertentes de educações de vocação classista, transformadora e revolucionária. No imaginário da educação popular não deve existir um polo central, uma agremiação de teoria-e-prática, um partido ou o que seja diretor dos processos de saber-fazer, no encontro entre $\mathrm{m}$ "nós" educadores populares não "do-povo". E "eles', educadores populares no duplo sentido da palavra "popular".

A educação popular tem no diálogo não uma metodologia pragmática de ação pedagógica, de que o "círculo de cultura" será a mais conhecida imagem. O diálogo é, nela, o começo e o final de todo o acontecer do ensinar-a-aprender. Em suas formas mais radicais - aquela que eu pessoalmente assumo - a sua "palavra de ordem" é a desordem pedagógica. É a ideia de que com um mínimo de propostas de base tudo o que se realiza como e através da educação popular parte de um encontro igualitário de saberes e significados. De uma "turma de alfabetizandos" a uma instituição ampla de criação de uma "proposta de educação popular", são coletivos tão igualados e igualitários quanto possível de poder de pensar, dizer e decidir os que geram e gerenciam um trabalho de educação popular. A simples leitura da "bibliografia" ao final de uma 
"linha do tempo" que vai dos primeiros livros e artigos de educação popular até os mais atuais, deixará claro que mesmo quando uma crítica da sociedade tem em autores como Marx e Gramsci os seus fundamentos, a partir do próprio Paulo Freire, uma vocação dialogicamente humanista - entre as infinitas variações desta ampla e não rara vaga palavra - será o seu horizonte. E isto nos acompanha até hoje, se quisermos ser francos e transparentes. Desde o começo dos anos sessenta Cuba nos foi um horizonte inclusive para militantes cristãos - e a educação cubana nos era um modelo escolar. Mas pensadores e educadores cubanos foram e seguem sendo entre nós, educadores populares latino-americanos absolutamente raros. Até onde posso me lembrar eles não comparecem nos livros de coletâneas de textos mais recentes.

Em um livro a meu ver absolutamente atual Alfonso Torres Carrilo radicaliza este suposto.

A militância cristã de Freire e o carácter humanista de sua proposta fez com que sua proposta tivesse acolhida dentro da Igreja; primeiro o MEB do Brasil (o Movimento de Educação de Base, ao qual pertenci - CRB) assume a sua metodologia e posteriormente a Conferência Episcopal de Medellin (1968; deste modo os fundamentos e a metodologia de Freire influem naquilo que posteriormente seria a Teologia da Libertação. Muitos religiosos e cristãos comprometidos com os pobres veriam na Educação Conscientizadora a metodologia mais coerente com as ações pastorais e educativas ${ }^{12}$.

Ainda que as palavras acima possam ser relativizadas, sobretudo quando estendidas ao contexto de toda a

\footnotetext{
${ }^{12}$ Está na página 28 de La educación popular - trayectória y actualidad, justamente no tópico: "los inícios - la educacion liberadora de Paulo Freire, quando Carillo comenta justamente a conjuntura brasileira do começo dos anos sessenta. Chamo a atenção para a expressão "liberadora', indicativa de que a própria palavra "popular" no começo dos anos sessenta no Brasil não qualificava a proposta pedagógica de Paulo Freire, e servia apenas a unificar a ideia de uma "cultura popular", de que uma "educação liberadora" seria uma dimensão e uma frente de ações entre outras.
} 
América Latina, não resta dúvidas de que um dos pontos críticos entre militantes de uma educação popular de vocação freireana e outros que em nome de uma ação política mais diretamente classista defendiam ser mais diretivamente centrada em polos partidários ou não as propostas de transformações da sociedade e de uma formação política das classes populares, este sempre foi um ponto densamente polêmico.

A radicalidade de uma pedagogia centrada num diálogo entre pessoas, culturas e classes sociais na construção de cada momento e do todo o acontecer da educação, foi e segue sendo desde os anos pioneiros até o momento presente, ao mesmo tempo força humanamente pedagógica e a debilidade política da educação popular. Não apenas as ideias, mas as experiências pessoais de Paulo Freire e de incontáveis seguidores seus ao longo do tempo são a evidência de uma coisa e da outra. Ele foi ao longo de toda a sua vida um defensor radical da dialogicidade na/da educação. Sou testemunha da maneira como não aceitava, sob pretexto algum, a imposição não apenas de ideias, mas de projetos e propostas pré-construídas por unidades de educadores e depois "levadas prontas" ao povo. Um dos entraves de sua atuação como educação junto ao Partido dos Trabalhadores estava justamente em sua não-aceitação de que em programas de educação um partido pudesse "levar pronta" uma proposta, mesmo quando saída de debates entre seus dirigentes ou militantes mais diretamente ligados à educação.

\section{Educação pública, educação alternativa, educação popular e educação do campo}

Um dos mais estranhos costumes de antropólogos é o deixar de procurar compreender "o que está acontecendo" com o olhar dirigido a macro-dimensões da política, da economia e de outros amplos campos da sociedade, 
como o das "políticas públicas de educação", e simplesmente procurar "olhar ao redor". É o que farei desarmadamente aqui.

Quando percebo como procedem as "pessoas comuns" (eu incluído) ao meu redor; quando procuro compreender o que pensam, em que fundamentos se baseiam e como agem e em nome do quê; quando leio o que leio - e não apenas nos "livros e artigos de ponta", mas também nas inúmeras revistas sobre a educação editadas por instituições da sociedade civil, por secretarias municipais de educação (prática muito comum no Brasil) ou mesmo compradas em bancas de jornaleiros - quando acompanho não tanto os "grandes debates sobre a educação no Brasil e no mundo", mas as conversas de corredores de escolas, ou mesmo de mesas de bar (sempre caras a Paulo Freire), constato que as pessoas com quem convivo, as que leio e me são próximas (sobretudo entre brasileiras e hispano-americanas), as que estudo a fundo e de quem sigo aprendendo, eu as encontro repartidas de uma maneira que sumariamente poderia desenhar assim.

1 a . Algumas pessoas estão empenhadas em trabalhar intensamente em favor da educação e da escola pública. Seja porque são educadores e/ou gestores da educação, vinculados a alguma instituição oficial do poder público federal, estadual ou municipal, seja porque são educadores e docentes de universidades públicas, e desde elas defendem a primazia de uma "educação pública, democrática, cidadã, de qualidade e ofertada a todas e todos", ou seja, ainda porque são militantes de sindicatos ou de outras instituições classistas-docentes, como a Central Única dos Trabalhadores. Vários dos mais conhecidos e consequentes educadores e pensadoras da educação no Brasil estão neste caso.

$2^{a}$. Algumas pessoas identificam-se publicamente como educadores populares; reconhecem-se como seguidoras das ideias originárias de Paulo Freire e de outros 
pioneiros da educação popular no Brasil e na América Latina e, ao lado de uma afiliação ao ideário de defesa da escola pública, agregam a isto uma militância direta junto a agremiações e movimentos populares. Existem várias instituições da sociedade civil, como o Instituto Paulo Freire e inúmeras outras especificamente dedicadas a uma "educação popular". De igual maneira, movimentos sociais populares com frequência afirmam-se como afiliados à educação popular. Em termos da América Latina, o Conselho Latino-americano de Educação de Adultos é, desde há vários anos, o mais importante porta-voz de uma educação popular freireana ${ }^{13}$.

$3^{a}$. Algumas pessoas - e seu número é crescente nos últimos anos - lançam-se em projetos e ações de criação de "escolas alternativas" em busca de "uma outra educação". Sob este nome estou alocando aqui desde experiências vindas da Europa ou dos EUA, de que a Escola Antroposófica, e sua Pedagogia Walldorf constituem a experiência mais conhecida e difundida no Brasil, até recentes iniciativas de criação de cooperativas de educação, de escolas comunitárias, de escolas criadas em nome de uma moderada ou mesmo radical transferência do foco da educação do "ensino de quem educa" para a "aprendizagem de quem se educa" 14 .

Dentre as pessoas que se afiliam a um difuso quase "movimento de educação alternativa", estão duas voca-

\footnotetext{
${ }^{13}$ Em uma recente consulta sobre a educação popular realizada pelo CEAAL, responderam 118 instituições da sociedade civil afiliadas à educação popular, provenientes de praticamente todos os países da América Latina. (Carrillo, 2012, páginas 139 e 140).

${ }^{14}$ No Brasil, ademais das "escolas antroposóficas", bastante difundidas pelo País, existem em alguns Estados da União "escolas logosóficas". São escolas criadas a partir do pensamento de Carlos Bernardo Gonzáles Pecothce - Raumsol - um pensador argentino cujas ideias encontraram inúmeros seguidores no Brasil, onde todos os seus livros foram traduzidos. Existe um Sistema Logosófico de Educação, e no Paraná há um Instituto Gonzáles Pecotche. Raumsol criou uma primeira escola logosófica em Córdoba, na Argentina. Ignoro se existe em seu país, tal como no Brasil, uma "Rede de Escolas Logosóficas".
} 
ções polares. Uma é a das pessoas preocupadas com "a formação de meus filhos", e adeptas de uma educação especial, altamente qualificada e de ampla liberdade de ação e pensamento, em geral afiliadas a escolas alternativas pagas e caras. Outra a das pessoas que se lançam em busca de uma "alternativa de educação" que a partir de experiências pioneiras possa sem ampliada e democraticamente difundida, se possível invadindo o próprio território da educação pública ${ }^{15}$. Pensadores que vão de Tolstoi,

\begin{abstract}
${ }^{15}$ Sei que no Brasil e em diferentes países da América Latina cresce entre educadores uma resistência à imposição de grades curriculares rígidas. Uma polêmica entre educadores francamente" conteudistas" e educadores que pretendem centrar o processo de ensino-aprendizagem em práticas ativas, para quem o "aprender a aprender" (um dos "quatro pilares da aprendizagem" segundo a UNESCO) é em tudo mais essencial do que o aprender conteúdos disciplinares. Algumas escolas alternativas formulam propostas pedagógicas em que é dada às crianças o direito à escolha direta daquilo que desejam dialogar e aprender em cada momento de cada "dia na escola". Chamo a atenção para o fato de que no correr de todas as polêmicas atuais sobre estes e outros "rumos da educação" e de modalidades de práticas pedagógicas o nome de Carl Rogers - o psicólogo e educador norte-americano criador do "ensino centrado no aluno" -esteja quase sempre ausente. No entanto, a meu ver suas ideias foram fundadoras, inclusive durante os primeiros tempos da educação popular. Se posso tomar o exemplo do Movimento de Educação de Base, recordo que praticávamos, desde nossas reuniões até as aulas de alfabetização através do rádio, práticas dialógicas centradas em "dinâmica de grupos" vindas muito mais de Max Pagés, Carl Rogers e outros, do que de autores mais sociológicos e mais politicamente situados à esquerda.

Devo relembrar também um longo documentário em Espanhol a respeito de experiências alternativas na América Latina. Este documentário que assisti em vídeo em um canal cultural da televisão, concentra uma crítica radical aos sistemas oficiais de educação. Seu nome é "La Educación Excluída" e não constam dele experiências alternativas no Brasil e também a opinião de educadores brasileiros. Por outro lado, um dos educadores hoje mais presentes em encontros e seminários sobre a educação no Brasil é o professor português José Pacheco. Em seu país ele criou a "escola da Ponte", uma experiência governamental franca e radicalmente alternativa. Havendo-a conhecido, Rubem Alves (talvez o único educador mais lido no Brasil do que Paulo Freire) tornou conhecida em um livro a Escola da Ponte. Rubem Alves (o defensor intransigente do ingresso de Paulo Freire na Faculdade de Educação da Universidade Estadual de Campinas, onde o seu nome foi questionado no conselho universitário por não ser Paulo um "doutor", oficialmente). José Pacheco aposentou-se em Portugal e hoje vive no Brasil. No presente momento vive a experiência de uma escola alternativa dentro de uma Instituição Âncora (não governamental) na cidade de Cotia, na periferia de São Paulo. A escola está situada na
\end{abstract}


O'Neill, Rousseau, Claparede, Freinet, Montessori a outros mais recentes, são suas fontes de origem.

4․ Finalmente, há pessoas que em linha direta, desde o começo dos anos sessenta até hoje identificam-se como educadores populares e acreditam-se envolvidos com teorias, propostas e práticas da educação popular. São elas as mais afiliadas em linha direta ao pensamento e à herança político-pedagógica de Paulo Freire. Mas será entre eles que uma divisão sempre existente, mas que tornará mais clara e definida uma linha de fronteira irá se estabelecer.

É importante levar em conta que mesmo tendo ainda "nas ideias de Freire" o seu fundamento, as pessoas praticantes de alguma modalidade de educação popular reconhecem que 'os tempos são outros", cinquenta e alguns anos após a publicação dos primeiros escritos da "equipe pioneira", e que face a alguns acontecimentos de dimensão internacional, latino-americana e nacional (sobretudo entre os países que atravessaram tempos de governos militares) não apenas conjunturas de ação, mas até mesmo fundamentos e horizontes da educação popular foram e seguem sendo reconceitualizados. Na verdade, a expressão utilizada por alguns educadores populares da atualidade é "refundamentação da educação popular". Que uma vez mais nos fale Alfonso Torres Carrillo. Referindo-se em 2007 a um livro seu de 2000, ele afirma isto.

Para Alfonso Torres (2000:21) a refundamentação está associada a múltiplos fatores como o esgotamento dos referentes discursivos a respeito da pluralização de práticas e atores da EP, a crise do socialismo histórico e a atração exercida por novas colocações teóricas provenientes das ciências sociais; "desde mediados dos oitenta começamos a sentir uma

confluência de quatro grandes favelas e é dirigida a crianças e jovens delas. Não ao acaso recebi nestes uma mensagem informando que a Finlândia se tornou o primeiro país a abolir a materialidade conteudista e programática da educação pública. A quem interesse, o site que recebi, ele é este.

http://rescola.com.br/finlandia-sera-o-primeiro-pais-do-mundo-a-abolir-a-divisao-do-conteudo-escolar-em-materias/. 
certa insatisfação a respeito dos discursos que orientavam as nossas experiências, eles nos pareciam limitados para dar conta do que estávamos fazendo; os referentes teóricos com que interpretávamos a realidade, orientávamos os projetos e compreendíamos os sujeitos que os protagonizavam não expressavam tudo o que queríamos dizer ou não correspondia à realidade sobre a qual estávamos atuando ${ }^{16}$.

Acredito que os termos e os rumos da refundamentação da educação popular a partir dos anos oitenta sejam bastante conhecidos. Mas ainda em diálogo com Alfonso Torres Carrilo quero sintetizar alguns deles.

A partir do próprio Paulo Freire de seus últimos escritos, a educação popular abre-se a um diálogo com outras modalidades de ação social - no que recupera em boa medida a tradição original vinda da "Cultura Popular" dos anos sessenta no Brasil - com a contribuição de outras e pluri-diversas teorias e propostas vindas das ciências sociais e de ramas humanistas da filosofia, e com diversas vocações outras da própria educação, inexistentes ou incipientes nas duas décadas antecedentes, como a educação dos (e não apenas "para os" movimentos sociais), a educação ambiental, a educação para a paz, a educação e direitos humanos, e mais outras. Na verdade, é preciso lembrar que a redemocratização relativa de países da América Latina e o empoderamento de alguns movimentos populares forçou a própria educação popular, pelo menos em algumas de suas vertentes mais próximas a tais movimentos e frentes de luta, a se colocarem como instancias de apoio político-pedagógico a ações educativas presentes e ativas nos/dos próprios movimentos populares.

De outra parte, algumas vocações mais recentes e uni-direcionadas de educações posteriores não raro aproximavam-se da educação popular e identificavam suas práticas setoriais como também populares. Este é o sentido

\footnotetext{
${ }^{16}$ Está nas páginas 77 e 78 de Educación popular - trayectória y actualidad. É curioso que na bibliografia ao final do livro o autor tenha esquecido de mencionar o seu livro de 2000 lembrado na citação.
} 
em que aqui e ali fala-se em educação ambiental popular.

Esta abertura inevitável em múltiplas direções e em diálogo com diversos atores sociais levou a educação popular em boa medida a migrar de uma exclusiva ou prioritária "leitura classista ortodoxa da sociedade à incorporação de outras perspectivas e categorias analíticas como hegemonia, movimentos sociais, sociedade civil e sujeitos sociais" (Torres, 2012;78). A própria categoria "povo" passou a receber diversos e não raro divergentes sentidos entre educadores populares. Este é também o tempo histórico em que sobretudo em países pluriétnicos e culturais, como Brasil, outros atores étnicos, culturais e sociais se fazem e obrigam a própria educação (inclusive as das políticas públicas) tato a uma completa revisão de conteúdos pedagógicos, quanto á incorporação de novas escolas e educações: como a educação indígena, a educação em comunidades quilombolas e outras mais. Também serão os educadores populares destes países os mais sensíveis a incorporar ao círculo dos saberes, sentidos, significados, sensibilidades e sociabilidades de "outros povos e de outras culturas", ao núcleo não apenas do campo teórico-ideológico dos saberes, mas também ao de outras éticas, estéticas, eróticas e políticas.

Uma pedagogia "conscientizadora e politizadora" destinada em seu horizonte a transformações radicais da sociedade, através de uma conquista popular do poder tende a ser relativizada e repensada no campo das diferenças entre os diversos contextos sociais. Ainda que para a maior parte de educadores populares o povo - no sentido original de classe-para-si - seja o, ou um sujeito protagônico de processos de luta e mudança social, há um alargamento do sentido político das próprias transformações e seus horizontes. Trago neste sentido o depoimento de Marilena Chauí, filósofa, professora laureada da Universidade de São Paulo e ativista do Partido dos Trabalhadores por muitos anos. Em um momento de um livro com este 
nome: Civilização e barbárie, ao analisar a questão da atualidade dos fundamentalismos religiosos de nosso tempo, Marilena Chauí recorda ideias de David Harvey, E ela relembra então que teorias e projetos de ação social que sugerem transformações radicalmente essenciais entre o pensar e o agir tenderiam a parecer um ilusório conjunto quase conservador de ideias e de propostas.

Acrescentemos à descrição de Harvey algo que não pode ser esquecido nem minimizado, ou seja, o fato de que a perda de sentido do futuro é inseparável da crise do socialismo e do pensamento de esquerda, isto é, do enfraquecimento da ideia de emancipação do gênero humano. [...] Perdeu-se, hoje, a dimensão do futuro como possibilidade inscrita na ação humana como poder para determinar o indeterminado e para ultrapassar situações dadas, compreendendo e transformando o sentido delas ${ }^{17}$.

A persistente crise da busca de um modelo histórico de sociedade para além da capitalista estaria exercendo junto a muitos pensadores do presente e do futuro próximo uma descrença não apenas na viabilidade de transformação social em direção a um outro modelo, como também até mesmo o horizonte da possibilidade de um projeto de futuro em nome de um mundo que desloque do mercado e do capital para o ser humano e o mundo da vida social o eixo de poder de transformação do presente e de gestação e gestão de um "outro futuro".

Sensível a um diálogo com vertentes de pensamento teórico, de construção do conhecimento e de suas derivações para a educação fundadas em autores que não raro provém mais da física quântica e da biologia do que da economia e da política, de formas bastante diferenciadas, educadores populares acolhem novas compreensões de fundo "holístico", "multicultural", "integrativo-interativo" e dialogicamente "transdisciplinar". Esta derivação

${ }^{17}$ Está na página 151 do livro Civilização e barbárie, coordenado por Adauto Novaes. O capítulo de Marilena Chauí tem este título: Fundamentalismo religioso: a questão do poder teológico-político. 
inevitável, ao ver de alguns, desloca uma primazia da questão social de um plano socioeconômico, em direção a compreensões mais totalizadoras não apenas do acontecer humano, mas também da complexidade da sociedade.

Tal como ocorre dentro das próprias vertentes marxistas, entre educadores populares questões relacionadas à individualidade, identidade, afetividade e conectividade centrada em dimensões que chegam a submeter a racionalidade à afetividade, tendem a constituir agora o próprio centro das reflexões teóricas, das teorias de conhecimento-consciência e, por consequência, as linhas de direção de uma educação que somente pode ser "popular" se for popularmente sensível e totalizantemente humanizadora.

Enfim, mesmo entre os herdeiros mais fiéis das tradições originais freireana, na trilha dos próprios últimos escritos de Paulo Freire, educadores populares latino-americanos migram da unicidade de metodologias de pedagogia e pesquisa centradas de forma direta ou indireta em abordagens dialéticas, em direção ao diálogo com outras correntes de pensamento e ação. Neste sentido e apenas como um exemplo entre outros, creio ser oportuno chamar a atenção para um deslocamento recente e essencial, pelo menos no caso brasileiro. Após muitos anos de absoluto distanciamento de pensadores e educadores portugueses, hoje em dia o Brasil abre-se a um diálogo expressivamente crescente com pedagogos de universidades de Portugal. E um fecundo e pluri-dirigido diálogo pessoas como Antônio Nóvoa e Boaventura de Souza Santos é bem a mostra dessa fecunda e tardia evidência. Lembro apenas de passagem que Paulo Freire foi fortemente influenciado por Franz Fanon, e em mais de uma ocasião nos confidenciou que não raro aprendia mais com os seus "mestres africanos", como Samora Machel e Amilcar Cabral, do que com reconhecidos pensadores da Europa.

Ora, no começo dos anos 80, o recém-criado Partido dos Trabalhadores encargou a quatro educadores um pe- 
queno documento que ajudasse o partido a pensar fundamentos de uma "educação dos trabalhadores". Até onde eu me lembro a expressão "educação popular" não foi então utilizada. Paulo Freire, Demerval Saviani, Moacir Gadotti e eu escrevemos cada um de nós um pequeno texto. Coube a Moacir Gadotti reuni-los e chegar a um documento de síntese ${ }^{18}$.

Retornado ao Brasil Paulo Freire era então professor da Faculdade de Educação da UNICAMP, ao lado de Demerval Saviani. Moacir Gadotti era professor da Faculdade de Educação da USP e eu era professor de antropologia no Instituto de Filosofia e Ciências Humanas da mesma UNICAMP. Meus companheiros pedagogos me acolhiam como representante de uma rara e estranha espécie de educador, e sobretudo, com Paulo os meus diálogos eram mais fecundos, pois recordo que em seu pensamento originário a palavra sagrada entre os antropólogos "cultura', era também germinal em seu vocabulário. Mas esta seria outra história.

Este terá sido um dos últimos momentos em que Paulo e Demerval trabalharam próximos. Creio que neste mesmo ano fundamos na UNICAMP o Centro de Estudos e Pesquisa de Educação - CEDES, e já Demerval Saviani estava ausente da equipe fundadora, que contava agora com a presença de Maurício Tratenberg, professor também da UNICAMP e conhecido teórico e ativista anarquista. Escrevo estas memórias para recordar que entre pensadores essenciais da educação brasileira talvez o momento da "refundamentação" da educação popular talvez tenha apenas retomado uma clivagem entre compreensões "dialógicas" e "dialéticas", que na verdade já estão presentes na complexa polêmica sobre o sentido de "Cultura Popular" (escrito então com iniciais maiúsculas) dos primórdios dos anos sessenta. Momentos essenciais desta polêmica estão

${ }^{18}$ Em sua forma original o que escrevemos saiu em um dos Cadernos do Trabalhador. Depois os escritos foram reunidos no livro. 
em alguns artigos reunidos por Osmar Fávero em Cultura Popular e Educação Popular - memória dos anos sessenta. Uma clivagem que acompanhará a trajetória de educação popular e de outras pedagogias de vocação emancipatória durante as suas trajetórias e até o momento presente. Afinal, o dilema grego de 3000 anos atrás, a respeito do sentido da educação e da sua "direção da dívida", ainda não foi resolvido. E eu espero que nunca seja.

Demerval Saviani e outros intelectuais de reconhecida importância irão se afastar de uma definida vertente freireana da educação popular. Saviani elaborará a teoria de uma pedagogia histórico-crítica ${ }^{19}$. Sua proposta pedagógica esteve restrita ao âmbito estritamente acadêmico durante vários anos, ao contrário do que ocorreu desde as suas origens com a educação popular, que ingressou inicialmente na universidade pela porta dos fundos e até hoje em algumas delas dificilmente consegue chegar até a sala de visitas.

Acredito, no entanto que uma vertente dialética esteve sempre presente no ideário e nas propostas de uma pedagogia militante em diferentes movimentos populares na América Latina. Penso que no Brasil ela é a, ou uma das principais fontes de ideias, propostas pedagógicas e projetos concretos de educação e escola de movimentos populares hoje envolvidos em frentes de luta pela conquista de diversos territórios, territórios da terra onde se planta a territórios do saber que se semeia.

\section{O surgimento da educação do campo}

A recente educação do campo talvez seja a sua melhor evidência. E não ao acaso Demerval Saviani é um dos au-

\footnotetext{
${ }^{19}$ Dentre os vários livros e artigos de Demerval Saviani a respeito de sua proposta pedagógica talvez um dos mais importantes para a sua compreensão seja Pedagogia Histórico-Crítica, publicado em 2000, pela Editora Autores Associados, de Campinas.
} 
tores mais lembrados entre os verbetes do Dicionário da Educação do Campo, cuja primeira edição é, relembro, já do século XXI, assim como os documentos que estabelecem a sua proposta ${ }^{20}$. De igual maneira neste dicionário Paulo Freire é lembrado de passagem, quando não omitido, e quase sempre apenas através de Pedagogia do oprimido. $\mathrm{O}$ mesmo acontece com outros educadores populares da vertente freireano-dialógica, à exceção justamente do verbete: educação popular.

O Dicionário da educação do campo traz os seguintes longos verbetes relacionados à educação: educação básica do campo, educação corporativa, educação de jovens e adultos, educação do campo, educação ominilateral, educação politécnica, educação popular, educação profissional, educação rural. Entre todos os verbetes, escritos por educadores de linha dialética ou não, a educação corporativa é apresentada como uma iniciativa colonizadora do capital e uma tradicional educação rural é criticada como uma "educação pública" desqualificadora da "gente do campo".

Assim, no verbete educação rural, Marlene Ribeiro escreve o seguinte:

Deduz-se daí que a política educacional destinada às populações camponesas teve maior apoio e volume de recursos quando contemplava interesses relacionados à expropriação da terra e à consequente proletarização dos agricultores. Associado a esses interesses, identificava-se o projeto de implantação, por parte das agências de fomento norte-americanas, de um modelo produtivo agrícola gerador da dependência científica e tecnológica dos trabalhadores do campo. Deste modo, a educação rural funcionou como

${ }^{20}$ O surgimento da expressão "Educação do Campo" possui datas bem definidas. Em um primeiro momento ela e a sua proposta surgem com este nome: educação básica do campo, durante os momentos de preparação da I Conferência Nacional por uma Educação Básica do Campo, realizada em Luziânia, Goiás, de 27 a 30 de julho de 1998. Poucos anos mais tarde ela passou a ser oficialmente denominada educação do campo a partir de um Seminário Nacional, realizado em Brasília, de 26 a 29 de novembro de 2002 A decisão do novo nome foi depois reafirmada nos debates da II Conferência Nacional, realizada em julho de 2004 . 
um instrumento formador tanto de uma mão de obra disciplinada para o trabalho rural quanto de consumidores dos produtos agropecuários gerados pelo modelo da agricultura importado. DEC: 297.

Uma diferença radical justifica a criação de um modelo de educação dirigido ao campesinato e pelo campesinato. Uma nova educação vinda do campesinato e das suas instituições próprias de identidade, pensamento e luta, em oposição à educação rural, e também em uma linha de teoria e ação crescentemente distanciada da tradição da educação popular.

Os movimentos sociais não possuem controle algum sobre uma educação rural sob controle do poder de Estado, e a sua prática pedagógica na verdade difunde em "meio rural", como vimos na citação acima, a mesma pragmática ideologia hegemônica do ensino público das escolas da cidade. Eis o sentido em que uma proposta de educação do campo pretende ser a sua contra-face. A partir das experiências pedagógicas dos movimentos camponeses ela projeta a criação e a consolidação de uma educação escolar e para-escolar financiada pelo poder público, mas agora sob controle direto e pleno dos movimentos sociais do campo $^{21}$.

${ }^{21}$ Como política de movimento social popular, o MST estabelece acordos a nível nacional, estadual e municipal com o poder público. Lembro que no Brasil o "ensino fundamental" é competência de governos municipais, embora haja uma legislação nacional de educação, cujas leis e fundamentos são alterados periodicamente. Há um entendimento de que o Governo federal da União financia as escolas do MST (mais de 1800 no país), através, sobretudo do PRONERA (um programa de apoio à educação do Instituto Nacional da Reforma Agrária). No entanto entende-se que quem estabelece diretrizes de educação escolar e de jovens e adultos nos acampamentos e assentamentos da reforma agrária são coletivos do MST. Em seu verbete Roseli Caldart defende com todas as letras que não cabe ao poder de estado e nem a qualquer política governamental a gestão ideológica e pedagógica da educação do campo. Ela o expressa da seguinte maneira: A Educação do Campo, principalmente como práticas dos movimentos sociais camponeses, busca conjugar a luta pelo acesso à educação pública com a luta contra a tutela política e pedagógica do Estado (reafirma em nosso tempo que não deve ser o Estado o educador do povo). (DEC:262). Grifos e parênteses da autora. 
No verbete: educação básica do campo, Lia Maria Teixeira de Oliveira retoma a ideia central de uma educação ativamente contra-hegemônica centrada no protagonismo direto das classes e dos movimentos populares.

\begin{abstract}
A rebeldia como sentimento/luta pela emancipação é um traço pedagógico de diversas populações campesinas, indígenas, caiçaras quilombolas, atingidas por barragens, de agricultores urbanos, que estão buscando a educação a partir de uma perspectiva contra-hegemônica, conforme Gramsci nos ensina ${ }^{22}$. Foi exatamente isso que produziu a diferenciação da Educação do Campo da histórica educação rural: o protagonismo dos movimentos sociais do campo na negociação de políticas educacionais, postulando nova concepção de educação que incluísse suas cosmologias, lutas, territorialidades, concepções de natureza e família, arte, práticas de produção, bem como a organização social, o trabalho, dentro outros aspectos locais e regionais que compreendem as especificidades de um mundo rural. (DEC:238) grifos da autora.
\end{abstract}

Roseli Caldart nos acompanhará aqui em duas citações suas. Ela defende que a educação do campo não é uma mera modalidade pedagógica (educação) e geopolítica (do campo) que se contrapõe á educação das escolas rurais ofertadas pelo poder público. Ela é "um fenômeno da realidade brasileira atual". Sem precisar lembrar o que aconteceu também, vindo do campo para a cidade, com a educação popular dos anos sessenta, ela sugere que no Brasil de agora, uma educação não apenas para campone-

\footnotetext{
${ }^{22}$ Lembro que no caso brasileiro - e ele poderá ser comum em outros países da América Latina - os movimentos sociais mais mobilizados dividem-se de acordo com os seus sujeitos étnicos, culturais e sociais. E embora formem uma ativa "frente única" inclusive contra políticas e omissões governamentais recentes, guardam as suas especificidades. Assim, existem várias frentes de luta: de povos indígenas, de comunidades quilombolas e de movimentos de negros, de pescadores ribeirinhos ou marinhos (caiçaras), de populações rurais desalojadas por barragens e hidroelétricas, de diferentes "povos da floresta" na Amazônia (seringueiros, castanheiros), ao lado de agremiações sindicais e de classe no campo e na cidade. Alguns deles encontram em instituições da Igreja Católica os seus mais ativos e persistentes apoiadores, como o Conselho Missionário Indigenista (CIMI) e a Comissão Pastoral da Terra (CPT).
} 
ses, mas a partir de lutar originadas em seus movimentos, uma nova educação emerge com a proposta de recuperar uma radicalidade emancipatória talvez diluída ao longo dos anos. Vejamos como ela afirma isto em uma primeira citação.

A Educação do Campo nomeia um fenômeno da realidade brasileira atual, protagonizado pelos trabalhadores do campo e suas organizações, que visa incidir sobre a política da educação desde os interesses sociais das comunidades camponesas. Objetivo e sujeitos remetem às questões do trabalho, da cultura, do conhecimento e das lutas sociais dos camponeses e ao embate (de classe) entre projetos do campo e entre lógicas da agricultura que têm implicações no projeto de país e de sociedade e nas concepções de política pública, de educação e de formação humana. (DEC:257). Grifos da autora.

Não muito diferente é o que escreve Gaudêncio Frigotto em seus verbetes: educação ominilateral e educação politécnica ${ }^{23}$. Ao lado de uma crítica direta e radical há oferta de educação através de políticas públicas (de governos do Partido dos Trabalhadores, logo, considerados como "de esquerda") um novo acontecer na educação brasileira, a partir da proposta da educação do campo, pretende também recolocar em termos de classe e de luta de classes algo que ao longo dos anos tenderia a haver sido diferenciado e diluído em boa parte das teorias da "reconceitualização" da educação popular a partir dos anos oitenta. Em Frigotto, um educador especialista em educação e mundo do trabalho, tal como em outros educadores dialéticos, a categoria "cultura" dá lugar à categoria "trabalho", e uma ideia de "povo" como a coletividade ampliada de pessoas e coletivos da sociedade civil empenhados em frentes de lutas emancipatória, retorna à ideia de povo como classe e de processos de transformação social como algo cujo chão

\footnotetext{
${ }^{23}$ Seus dois verbetes vão da página 265 à página 279 do Dicionário da educação do campo.
} 
é a luta de classes ${ }^{24}$.

A denominação EDUCAÇÃO DO CAMPO, constituída a partir do processo de luta do Movimento dos Trabalhadores Rurais sem Terra (MST),engendra um sentido que busca confrontar, a um tempo, perspectiva restrita, colonizadora, extensionista, localista e particularista da educação (crítica direta da escola pública oficial - CRB) e as concepções de natureza fragmentária e positivista de conhecimento. Por centrar-se na leitura histórica e não linear da realidade, o processo educativo escolar (da educação do campo - CRB) vincula-se à luta por uma nova sociedade, e, por isso, vincula-se também aos processos formativos mais amplos que articulam ciência, cultura, experiência e trabalho. (DEC:277).

\begin{abstract}
Retorno a Roseli Caldart, a partir dos documentos fundadores da Educação do Campo (alguns de seus autores escrevem com maiúsculas), ela lança mão de uma diferença entre preposições, para opor o "do" ao "para" e até mesmo ao "com", a fim de fundar a radicalidade popular da educação do campo. Afinal, a quem no fim das contas uma educação pertence? Quem é não apenas o seu usuário, o seu destinatário ou mesmo um seu coagente, mas o seu criador, educador e gestor da educação
\end{abstract}

Na sua origem o "do" da Educação do Campo tem a ver com esse protagonismo: não é "para" e nem mesmo "com": é dos trabalhadores, educação do campo, dos camponeses, pedagogia do oprimido [...] Um do que não é dado, mas que precisa ser construído pelo processo de formação dos sujeitos coletivos, sujeitos que lutam para tomar parte da dinâmica social, para se constituir como sujeitos políticos, capazes de influir na agenda política da sociedade. Mas que representa, nos limites impostos pelo quadro em que se insere, a emergência efetiva de novos educadores, interrogadores da educação, da sociedade, construtores (pela luta/ pressão) de políticas, pensadores da pedagogia, sujeitos de

${ }^{24}$ Chamo a atenção para o fato de que em seu verbete no mesmo dicionário: educação popular e educação do campo - nexos e relações, Conceição Paludo, uma educadora popular de linha freireana, dialoga com Marx, com Ricardo Antunes (sociólogo marxista especializado em mundo do trabalho) com João Pedro Stédile, ideólogo do MST, com Demerval Saviani e com Gaudêncio Frigotto. Já em seu verbete educação popular e sistematização de experiências, Oscar Jara deixa de fora educadores e outros pensadores de linha dialética entre os lembrados por Conceição Paludo e outros. 


$$
\text { práticas }{ }^{25} \text {. }
$$

Em nome da proposta de uma nova educação do campo, através de diferentes convênios entre movimentos sociais populares e universidades brasileiras, são criados cursos e programas de estudos que vão da alfabetização de adultos a escolas para crianças e jovens de acampamentos e assentamentos da reforma agrária, e delas a cursos superiores de formação de educadores especialmente preparados para atividades pedagógicas "do campo", e não apenas "rurais". Cursos de Pedagogia da Terra em nível graduação, de especialização e mesmo de mestrado forma anualmente uma nova modalidade de educador no Brasil.

Deixo a outras pessoas a tarefa de descer bastante mais a fundo nesta questão cujo esboço apenas desenho aqui. Assim, quero encerrar este tópico perguntando se no momento presente não estaremos diante de, pelo menos, três vertentes no interior de, ou em áreas de fronteira daquilo que em sua gramática mais ampla e generosa poderá ainda ser chamado de educação popular.

No canto à direita podemos situar as mais diversas iniciativas, entre a teoria e a prática, que associam uma cada vez mais polissêmica e, não raro, vaga ideia de educação popular a diversas vertentes e vocações de ações sociais e, de forma mais específica, daquelas que se apresentam como uma das várias modalidades de pedagogias fundadas

${ }^{25}$ Está na página 5 de um documento originalmente mimeografado em Porto Alegre, com este nome: Educação do campo - notas para uma análise do percurso. A mesma citação pode ser encontrada no artigo de Ademar Bogo, um conhecido militante do MST: A questão da educação do campo e as contradições da luta pelo direito, na página 96. O artigo de Ademar Bogo é um dos escritos de um livro bastante recomendável a quem se interesse pelo próprio surgimento e o processo de consolidação muito recentes de uma Educação do Campo. O livro é: Educação do Campo e contemporaneidade - paradigmas, estratégias, possibilidades e interfaces. O livro foi publicado em 2013 pela Editora da Universidade Federal da Bahia onde se concentra um dos mais ativos coletivos vinculados à educação do campo, sob coordenação do professor Antônio Dias Nascimento. O livro contém também o importante documento do Fórum Nacional de Educação do Campo - FONEC - notas para análise do momento atual da Educação do Campo, celebrado em Brasília entre 15 e 17 de agosto de 2012. 
em "princípios freireanos", redesenhados por releituras que os atualizam e/ou os ajustam a esta ou aquela direção especializada de uma educação vocacionada. A educação ambiental popular é um bom exemplo, assim como são outros as diferentes propostas de: educação para a paz, educação e direitos humanos, educações em nome de minorias sociais, étnicas ou sexuais.

No centro de nosso desenho situo a educação popular em sua tradição freireano-dialógica mais direta. Aqui estão situados educadores que se reconhecem como herdeiros em linha direta das propostas originárias da educação popular-dialógica. Aqueles que realizaram juntos, e como um acontecimento territorialmente latino-americano, o processo de reconceitualização. Aqueles que continentalmente reúnem-se em torno ao CEAAL, e que preservaram até hoje tanto uma diferenciada matriz essencialmente dialógica de ações pedagógico-políticas emancipatórias. No limite, situo aqui educadores que mesmo quando leitores e usuários de teorias críticas provenientes do marxismo, não se consideram praticantes de uma educação dialética com base centrada na luta de classes, embora o povo e os movimentos populares sejam ainda reconhecidos como o eixo do protagonismo em processo de transformação social.

Finalmente, à esquerda de nosso desenho devo colocar as diferentes vertentes de algum modo afiliadas a uma leitura dialética da sociedade e da educação. Vertentes todas elas fundadas em leituras provenientes de alguma origem marxista e centrada no acontecer histórico da luta de classes. Acredito serem hoje cada vez mais raros os ativistas e educadores comprometidos diretamente com movimentos e processos de lutas populares que se consideram "organicamente freireanos", ou que ainda se assinam como educadores populares. Educadores que mesmo quando preservam ainda algo das ideias originais de Paulo Freire, não o leem mais como o roteiro de seu mapa nas 
lutas de conquista de territórios e, menos ainda, como o porto de chegada.

Acredito ainda que a recente instauração da educação do campo no Brasil e no "campo" das lutas e propostas do Movimento dos Trabalhadores Rurais sem Terra e de outros movimentos afiliados, constitui hoje o lugar social de teor político em que uma nova vertente de educação emancipatória surge e se afirma.

\section{Da cultura ao território}

Havia uma palavra geradora nos começos do que veio a ser a educação popular? Sim. E ela não era "educação", mas "cultura". Relembro que cultura popular era o movimento que nos unia. Lembro também que na primeira experiência de alfabetização no Nordeste do Brasil, "fichas de cultura" destinavam-se a ser criticamente decodificadas pelos alfabetizandos em seus dialógicos "círculos de cultura". E a "ideia de cultura", entre uma filosofia e uma antropologia embrionária que desaguavam em uma pedagogia crítica, dialógica e "libertadora", atravessava todas as "fichas", da primeira à última. Relembro aqui que a sequência de nossas ações de então eram de algum modo estas: tornar uma pedagogia fundada na ideia de cultura uma ação pedagogicamente cultural; criar com o povo uma "nova cultura", a partir de mudanças de qualidade na consciência do educando, com um progressivo teor assumidamente político; dotar este " teor político" de um sentido contra-hegemônico orientado a ações transformadoras e emancipatórias.

Mesmo quando a atuação dos primeiros movimentos de cultura popular foi dirigida a camponeses e a comunidades rurais - e eles eram, em grande maioria - a relação entre a educação popular e uma luta popular pela terra era ainda vaga e francamente idealizada e difusa. Exceção foram as "Ligas Camponesas" da Paraíba e de Pernambuco. 
Muitos anos mais tarde, a partir das frentes de lutas pela terra do Movimento dos Trabalhadores Rurais sem Terra e de outros movimentos camponeses equivalentes, associados a frentes de luta de povos indígenas e, logo a seguir, das inúmeras comunidades quilombolas, uma outra categoria, antes quase esquecida, sobrepõe-se à ideia geradora de "cultura" e passa a consolidar o próprio "chão" de uma emergente modalidade de educação, vinda diretamente dos movimentos camponeses. Sua palavra-chave é: "território".

Entre camponeses, indígenas e quilombolas, um horizonte para além daquilo que dá sentido a uma ação por conquista local e geográfica de terras ou de territórios, desafia a desmontagem oficial e capitalista de uma ancestral geopolítica e de uma político-cartografia do País. Trata-se agora de não apenas conquistar terra expropriada e transformada em latifúndio improdutivo ou entregue à voragem do agronegócio, assim como territórios ancestrais de índios e de negros cercados por grandes fazendas, quando não por empresas nacionais ou transnacionais de mineração e de exploração da madeira. Trata-se agora de a partir da conquista ampliada de terras camponesas, quilombolas e indígenas, reescrever, de dentro para fora e de baixo para cima toda uma nova cartografia popular.

Ora, desde então o educador vinculado a algum dos movimentos populares de luta geopolítica e social por territórios de vida e de sentido de vida, vê-se agora comprometido com uma luta em nome de ações político-pedagógico-cartográficas cuja "escrita" não se traduz apenas em e entre novos textos, mas também no e através de um redesenho inovador de novos mapas sociais. Não basta re-pronunciar, re-dizer ideologicamente o Brasil - ou a América Latina - como nos anos pioneiros e depois deles. É preciso re-mapear geopoliticamente o País e o Continente.

Da floresta para o campo e do campo para a cidade (pois também nela inúmeros movimentos sociais dos 
"sem-teto" estão ativos) diferentes atores sociais apagados, desconhecidos, mal conhecidos, demonizados ou folclorizados, agora entram em cena e sem máscaras "mostram a sua cara". Camponeses, caiçaras, seringueiros, castanheiros e outros "povos da floresta", povoadores de quilombos, de terras-de-santo, de faxinais, de fundos de pasto, ao lado dos inúmeros povos e das tribos indígenas das etnias do Brasil saem a campo. Saem organizados em frentes de luta, e a partir de suas difíceis, lentas, mas sucessivas conquistas nos ajudam a reinventar o "mapa do Brasil", e a recriar uma nova e real cartografia social.

"Território", "territorialização", "processos de territorialização", estas palavras apenas técnicas entre geógrafos do passado recente assumem com as frentes de lutas dos movimentos camponeses, quilombolas, indígenas e outros uma conotação francamente pedagógica, e, portanto, emancipadoramente política. Este novo dizer-e-mapear passa a significar não apenas algo que ao longo da história de um povo demarca uma "natural" expansão de fronteiras e uma ocupação de território. Ele ousa re-significar todo um processo ativo de reconquista de territórios usurpados historicamente, ao lado de uma re-escrita de cartografias. Novas leituras da vida e dos lugares-da-vida que passam de uma geografia física onde as ações humanas são quase complementares, a uma crítica geopedagógica em que as ações humanas recriam e significam agora o próprio "físico" de um território.

Sem esquecer todo o labor de movimentos sociais populares de vocação urbana e todo o trabalho de educação popular realizado entre fábricas e favelas, uma vez mais, como na aurora dos anos sessenta no Nordeste do Brasil, é do campo e do campesinato que uma polissêmica e desafiadora re-escrita de alternativas de educação dos movimentos populares e a serviço dos movimentos populares emerge. É no bojo dos movimentos que em boa medida acabam de publicar o Relatório da Comissão Camponesa da 
Verdade, que uma educação popular para o século XXI desloca de uma então ainda vaga "ideia de cultura", para a concretude geopolítica do "território", não apenas o lugar social, mas toda uma simbologia de frentes de luta e de conquistas $^{26}$.

Sem que teorias, propostas e práticas de teor freireanos tenham perdido ou estejam perdendo ao longo da América Latina a sua atualidade, acredito que no percurso de sua trajetória elas fazem interagir diferentes focos e eixos de ação emancipatória, na mesma medida em que, sem esquecer os seus primeiros passos, elas saltam de uma antropopedagogia da cultura junto ao povo, para uma sociopedagogia dos movimentos populares. E desde ela e através dela, convergem a uma geopedagogia cartográfica das lutas populares por conquista de territórios ${ }^{27}$.

${ }^{26}$ Este documento que levou anos para ser elaborado, e cujo conhecimento
está ainda restrito a círculos muito pequenos acaba de ser publicado. Trans-
crevo aqui o começo da introdução do relatório.

"Em 2012 foi criada a Comissão Camponesa da Verdade (CCV), um dos frutos do Encontro Unitário dos Trabalhadores, Trabalhadoras e Povos do Campo, das Águas e das Florestas. Este evento reuniu, em Brasília, em 2012, milhares de camponeses de mais de quarenta organizações e movimentos ligados à luta pela terra e por territórios, em memória ao 1o Congresso Camponês, realizado em 1961, em Belo Horizonte. Além de celebrar os mais de cinquenta anos do congresso de Belo Horizonte, o Encontro Unitário articulou a diversidade das organizações do campo na construção de alternativas políticas, econômicas e sociais ao agronegócio para o campo brasileiro. Alternativas e bandeiras baseadas na defesa da reforma agrária, no respeito ao meio ambiente, na produção de alimentos saudáveis e na soberania alimentar, na defesa dos direitos territoriais, na geração de renda e na melhoria da qualidade de vida no meio rural, entre outras bandeiras e lutas".

${ }^{27}$ E não apenas no Brasil. Sobretudo nos países marcadamente pluriétnicos, como a Bolívia, o Equador, o Peru, a Colômbia, os da América Central e Caribe, o México e o Brasil, etnia-e-território somam-se agora como duas frentes sociais e simbólicas de uma mesma luta popular. Neste sentido recomendo alguns pequenos (grandes) livros de uma nova coleção de estudos populares colombianos. A Ediciones Desde Abajo está publicando uma Colección 
Há uma passagem de Miguel Arroyo, em um dos verbetes do Dicionário da Educação do Campo, que traduz com felicidade o que descrevo aqui. No fluxo de ações do Movimento dos Trabalhadores Rurais sem Terra e de outros movimentos da Via Campesina, desde uma luta de trinta anos em favor não apenas de uma reforma agrária, mas de toda uma transformação da sociedade brasileira através de conquistas populares sobre a terra, perpassa uma ideia que polissemiza e amplia o sentido e o teor simbolicamente político e pedagógico de "território".

Convivemos com vários e entrelaçados territórios geográficos, sociais e culturais expropriados, desde os quais lutamos em nome de reconquista não somente de terras, mas de saberes, sentidos e significados que foram expropriados junto com a ter, e envolve justamente a educação e o seu lugar social mais eloquente: a escola. Através de projetos de criação popular de um outro-saber um lugar social a ocupar militantemente é o território-escola. Eis o que Miguel Arroyo anota no verbete: Pedagogia do Oprimido.

A Pedagogia do Oprimido encontra sua afirmação nos processos educativos extraescolares, sobretudo, mas também inspira outra escola, outras práticas educacionais escolares. O traço mais radical: ocupar o território-escola. Os movimentos sociais, ao lutarem por terra, espaço e território, articulam as lutas pela educação, pela escola - as lutas por direitos a territórios. Mostram a articulação entre todos os processos históricos de opressão, segregação e desumanização, e reagem lutando em todas as fronteiras articuladas de libertação. Escola é mais do que escola na pedagogia dos movimentos. Ocupemos o latifúndio do conhecimento como mais uma das terras, como mais um dos territórios negados.

A escola, a universidade e os cursos de formação de professores do campo, indígenas e quilombolas são mais outros

Primeros Pasos, dirigida a ativistas populares e a movimentos e instituições de mediação. Entre os seus primeiros livros recomendo especialmente: Producción social del espácio; el capital y las luchas sociales em la disputa territorial, de Carolina Jiménez e Edgar Novoa; Hacer história desde Abajo u desde el Sur, de Alfonso Torres Carrillo. 
territórios de luta e de ocupação por direitos. A negação, a precarização da escola, é equacionada como uma expressão da segregação-opressão histórica da relação entre classes. Já a escola repolitizada é mais um território de luta e ocupação, de libertação da opressão. A Pedagogia do Oprimido é radicalizada na pedagogia escolar pelas lutas dos movimentos por educação do campo, por escola do campo no campo $^{28}$.

Aquilo que nos anos sessenta/setenta atribuíamos à cultura e compreendíamos como a tarefa pedagógica de uma educação popular entendida como uma região da cultura, ao mesmo tempo em que tratávamos de atribuir com a companhia frequente de Antônio Gramsci - à ideia de cultura o seu esquecido teor político, é agora retomado, sobretudo pela educação do campo, como uma cartografia de valor político-popular que recoloca no "chão da história" os termos das alternativas de uma educação emancipatória de movimentos indígenas, quilombolas, populares, enfim.

Tanto "naqueles tempos" como agora a história se repete e, como em Marx, redesenha, entre velhos e novos termos - como "capitalismo neoliberal" ou "globalização" - ora a sua farsa, ora a sua tragédia. Ontem como hoje há expropriações que são simbólicas, há apropriações que são culturais, há latifúndios que são de saberes e, mais do que "naqueles tempos", há não apenas pessoas - entre quase-escravos e operários mal pagos - produtores de mercadorias, mas um sistema de mercado que transforma agora as pessoas em mercadoria. Há, portanto, lutas de conquistas territoriais que devem operar também nestes e sobre estes

${ }^{28}$ Esta longa passagem faz parte do verbete Pedagogia do Oprimido, que vai da página 553 à página 560 do Dicionário da Educação do Campo. A citação de Miguel Arroyo está nas páginas 559 e 560. A ideia de territórios simbólicos, logo culturais e pedagógicos e de uma luta popular por territorializações outras, está presente em recentes trabalhos do educador colombiano Marco Raul Mejía. Mejía é hoje um dos mais fecundos e ativos educadores populares em diálogo com o momento presente, sobretudo da América Latina e um dos mais lúcidos críticos dos processos atuais de colonização simbólica, entre a mídia e a escola. Ver indicações dos livros na bibliografia. 
domínios.

Mesmo devendo confessar por escrito que não me aprofundei devidamente neste tema, devo dizer que acredito que com uma força talvez ainda inadvertida entre nós, a educação popular - tomada aqui em seu sentido mais generosamente abrangente - mescla-se com a ideia de território em, pelo menos, duas direções. Uma delas é mais antiga, e a outra mais atual, pelo menos quando associada a novas formas de ação pedagógica desde movimentos populares do campo.

A primeira está no fato de que com o advento da educação popular - como um acontecer cultural situado e datado - ao lado de um diálogo crescente entre movimentos sociais do continente, uma nova geografia política da América Latina surge e se impõe. Em direção diversa do currículo oficial de nossas escolas públicas, uma leitura de América Latina e Caribe (e, por extensão, todo o Mundo) nos obriga a des-fronteirizar toda uma "história nacional nacionalista" que até hoje ocupa quase todos os livros de nossas "histórias pátrias". Enquanto as empresas multinacionais de agronegócio ("Monsanto", por exemplo) "globalizam" terras e territórios, frentes indígenas e camponesas de lutas emancipatórias "desterritorializam" falsas fronteiras em nome de não apenas territórios, mas de povos emancipados. Povos que, justamente por estarem lutando por sua emancipação, podem incorporar à mesma luta um outro mapa popular de um mundo afinal sem fronteiras, ou com fronteiras afinal aberta à acolhida dos outros que não nós.

A segunda reside a meu ver na evidência de que, sobretudo entre camponeses militantes da Via Campesina e, mais ainda, através dos movimentos dos povos-testemunho (indígenas e outros), entre os Andes e a Amazônia uma nova endoeducação associa-se a uma luta emancipatória vivida em nome de não apenas a afirmação de direitos a territórios ancestrais e à salvaguarda de modos 
patrimoniais de ser e de viver. Vivida e praticada também em nome da expansão de saberes, sentidos e significados ancestrais e assumidamente primitivos, que desde a selva à cidade nos propõem com uma inocente e aguerrida ousadia, outras formas de pensar, de sentir, de viver e de ser. Novas alternativas do imaginário e da vida que poderiam acrescentar aos novos saberes e valores ainda acentuadamente ocidentais e europeus, toda uma outra ciência. Ou, mais ainda um outro saber menos subalterno à ciência e mais atento e aberto à sabedoria ${ }^{29}$.

\section{A educação popular a descoberta de nós mesmos}

De vez em quando Paulo Freire gostava de dizer que nós, aqui da "banda do Sul do mundo", quando nos sentirmos meio perdidos não devíamos dizer que "eu perdi o meu Norte", mas o "meu Sul". E a inovadora palavra "sulear" era comum em sua boca.

Nunca realizei investigação alguma a este respeito e espero nunca precisar realizar. Mas até onde alcança a minha memória e a de pessoas do Brasil, da América Latina e de outros cantos do mundo com que conversei, tudo leva a crer que, pelo menos, nos últimos sessenta anos, em apenas três momentos e por causa de três criações exclusiva ou parcialmente latino-americanas, pessoas e centros de estudos e/ou de ação social nos leram e nos ouviram como instauradores de algo que afinal ressoou para fora do continente. Entre os seus possíveis nomes escolho estes para nomeá-las aqui: a educação popular, a pesquisa participante $e$ a teologia da libertação. Convoco Paulo Freire, Orlando Fals Borda e Gustavo Gutierrez como testemunhas - um brasileiro, um colombiano e um peruano - e permaneço à espera de quem me complete ou corrija. 
Desde um ponto de vista identitário e dialógico esta evidência é importante, pois nem que seja em boa medida "pela porta dos fundos" com a educação popular por uma primeira vez de fato dialogamos com educadores de todo o mundo não mais como quem ouve, copia, aprende e adapta, mas como alguém que também tem o que dizer e propor de novo e de transformador.

E antes de nós, quero convocar aqui o testemunho do próprio Paulo Freire. Quem leia com atenção Pedagogia do Oprimido, assim como os seus livros em diálogo com a África, verá que suas leituras percorrem autores do "primeiro mundo", e também "terceiro-mundistas" como Amilcar Cabral, Samora Machel, Franz Fannon e Alfredo Memni. Em reiterados depoimentos "ao vivo" Paulo nos incentivava a "sulear" nossas leituras e mentes. E nos desafiava a buscar em autores entre a África e a Nicarágua insurgentes, pelo menos boa parte das fontes originais e essências de nossos diálogos.

E esta é apenas a ponta da meada de algo que vivemos intensamente aqui na América Latina desde o alvorecer dos anos sessenta. Mas algo de que com frequência nos esquecemos, talvez de tanto nos acostumarmos a haver vivido o que vivemos. Falo aqui do fato de que tanto no campo exclusivo da educação quanto no de ações sociais contestatórias a ela associadas de algum modo, pela primeira vez um modo de pensar, de propor e de praticar "uma educação" como uma "pedagogia do oprimido", nos latinoamericaniza.

Em que outro momento de nossa história nacional e, sobretudo, latino-americana, alguma modalidade de prática emancipatória através (também) da educação, nos faz saltar fronteiras e nos coloca face a face, em diálogo, após as sucessivas independências (sempre relativas) de nossas sociedades nacionais? Provavelmente apenas em algumas situações ora efêmeras, ora mais duradouras, de movimentos emancipatórios de cunho socialista e/ou 
anarquista $^{30}$.

No entanto, até onde meus estudos e a minha memória alcançam, reconheço que apenas com o advento da educação popular - e também da teologia da libertação, da pesquisa participante e de outras práticas emancipatório-populares estilo "MST brasileiro" - é que dois acontecimentos a meu ver de extrema importância ocorrem, entre o começo dos anos sessenta e a maturidade dos setenta. O primeiro: a educação popular cala uma leitura vinda do Norte, e em pouco tempo gera os seus autores-atores, ao lado de um crescente e vigoroso repertório de teorias, de propostas e programas de ação e de práticas emancipatórias. $\mathrm{O}$ que mais deve ser ressaltado neste acontecer é o fato de que ele não se limita, por exemplo, a "Países do Cono Sul", mas estende-se dos desertos do Norte do México aos da Patagônia Argentina.

Trago aqui o meu próprio exemplo. Durante anos que vão de 1963 a 1966/8 conheço e leio educadores populares brasileiros que associo a pensadores da Europa. A partir de 1966/68 inverto radicalmente o eixo de minhas leituras, de autores que "fazem a minha cabeça" e de educadores com quem dialogo, e reduzo em algo a leitura dos "apenas brasileiros" e reduzo bastante a de "educadores do primeiro mundo" ${ }^{\prime 3}$. Em poucos anos dialogo, entre en-

\footnotetext{
${ }^{30}$ Lembro que em alguns locais do Brasil, especialmente em São Paulo e no Rio Grande do Sul, foram criadas e floresceram "escolas anarquistas". Algumas delas, dedicadas a operários e a filhos de operários, foram violentamente reprimidas por "ditaduras de plantão" nos começos e meados do século XX. Desconheço experiências semelhantes em outros países, mas tenho motivos para desconfiar de suas existências. Não sei se algum intercâmbio extrafronteira existiu em algum momento.

${ }^{31}$ Mas devo confessar que esta "conversão a nós mesmos" é parcial. Sendo ao mesmo tempo um ativista social através da cultura e da educação popular, a partir de 1972 inicio a minha formação como um antropólogo. Minhas leituras acadêmicas, sobretudo em meu "Mestrado em Antropologia" na Universidade de Brasília, são francamente inglesas, norte-americanas e, mais tarde, francesas através de Lévi-Strauss. Durante anos fui obrigado a ler ingleses e norte-americanos e em inglês. Apenas mais tarde e mais autônomo, pude participar de todo o um afã de diálogo com cientistas sociais e sobretudo an-
} 
contros, cursos e outras vivências, com educadores populares latino-americanos, como faço deles os até hoje meus interlocutores e "mestres" mais frequentes e mais essenciais $^{32}$.

A segunda. E ela é derivada direta da primeira. Por uma primeira vez somos obrigados a saltar fronteiras. Somos convocados a abrir a porta estreita de "nossos autores nacionais" e estabelecer um aberto diálogo transnacional com pessoas de outros países, de outras formações, de outras escolas de pensamento. A bibliografia de nossos estudos, a menos que seja referida a algum tema restritamente "nacional" (como "a luta pela escola pública na Argentina durante a ditadura militar") não pode deixar de buscar referentes entre educadores de vários de nossos países e de vários momentos do acontecer da educação popular, de ações sociais emancipatórias e de movimentos sociais populares.

Imagino que de forma tão ampla e dialógica, apenas a literatura - e mesmo assim em termos e a longo prazo

tropólogos da Espanha e da América Latina. Os da Europa e dos EUA me aportaram conhecimento e ciência. Os da América Latina consciência e sabedoria. E, em termos de "sabedoria", mais os camponeses e os negros com quem convivi e pesquisei (e sem pesquisar mais convivo até hoje) do que os antropólogos que me ensinaram a pesquisá-los.

${ }^{32}$ Um estranho e hoje conhecido acontecimento pessoal pode bem ilustrar tudo isto. Entre 1969 e 1971 participo de uma pequena equipe que através do Centro Ecumênico de documentação e Informação viaja pela “América Espanhola", durante anos de plena ditadura no Brasil, difundindo ideias de educação popular e do "método Paulo Freire". Como resultado desta experiência, escrevo pequenos textos que são mimeografados d difundidos, mais nos Andes do Equador do que no Nordeste do Brasil. Resolvemos em uma reunião em Montevideo reunir os meus escritos em um livro e publicá-lo. Uma editora da Argentina, a Siglo XXI o acolhe e o edita. Dado o temor de que o livro saia em meu nome, ele é publicado em nome de Júlio Barreiro, um amigo teólogo uruguaio. Com o golpe militar na Argentina o livro: Educación popular y processo de conscientizacion passa a ser editado no México e depois na Espanha. Ele alcança mais de 15 edições e apenas dez anos depois da primeira edição em espanhol ele é publicado no Brasil, pela Editora VOZES, aparecendo eu mesmo como tradutor de meu livro. Uma breve leitura tornará evidente como já então um diálogo com latino-americanos surge no livro. No Brasil o mesmo livro conheceu apenas duas edições. 
- terá produzido entre nós uma tão desbragada abertura dialógica latino-americana e, entre latino-americanos, tão extrafronteiras. Depois de Paulo Freire - ele mesmo um homem que sem se desnacionalizar (e "desnordestinizar", em seu caso específico) depressa se reconhece um educador de vocação popularmente universalista - a educação popular dialoga entre nós a partir e desde um não-lugar.

A partir de uma descentralidade tão perene e tão visível que resulta improcedente buscar na América Latina um qualquer lugar nacional onde ela possa ser hoje "mais central". Para recordar apenas algumas pessoas de nossos "tempos pioneiros", lembro que ao longo de vários anos as pessoas mais presentes em minhas leituras e diálogos eram Pablo Latapi, Felix Cadena, Oscar Jara, Beatriz Bebiano Costa, Moacir Gadotti, Osmar Fávero, Carlos Alberto Torres, Sergio Martinic, Jorge Osório, João Bosco Pinto, Paulo Rosas, Orlando Fals Borda, Maria Tereza Sirvent, Pancho Vio Grossi, Sylvia Schmelkes, Adriana Puigrós, Ricardo Cetrullo, Isabel Hernandez, Adriana Puigross, Rosa Maria Torres, Baldoino Andreolola, Marcela Gajardo, Marco Raúl Mejía, Alfonso Torres Carrilo, Eduardo Galeano, Augusto Boal (e seu teatro do Oprimido) e, claro... Paulo Freire. E eram tempos em que em minha velha vitrola misturavam-se discos long-plays de Chico Buarque, Milton Nascimento, Geraldo Vandré, Daniel Vigiletti, Anibal Ponce, Victor Jara, Violeta Parra, Pablo Milanez e até Joan Baez.

Era através de nós mesmos que íamos "aos outros", os de mais longe e do outro lado do Oceano Atlântico e do Equador. Descolonizados geopoliticamente, cedo aprendemos a nos descolonizar continentalmente. Mesmo em tempos de Paulo Freire retornado de seu longo exílio e ativamente presente entre nós, inclusive agora como professor de universidades paulistas, de modo algum o Brasil se constitui como uma "pequena Meca" da educação popular. Lembro-me das várias vezes em que viajamos juntos, 
entre lugares do Brasil e a Nicarágua Sandinista, mesmo quando lhe tocava uma solene palestra de abertura de algo, na maior parte do tempo ele se colocava mais como um ouvidor dialogante atento do que como um alguém quase-único a ser ouvido.

Entre nós nenhum país torna-se central. Nenhuma universidade latino-americana ou outro qualquer "centro de estudos" é em momento algum hegemônico. Nenhuma, nenhum de nós, dentre os "mais antigos" aos "mais jovens" foi ou é "referência notável". A metáfora dos "círculos de cultura" dos anos sessenta torna-se a realidade metonímica de todos os anos e eras seguintes.

Insisto em que em termos de história e de pedagogia militante, este fato não é nem marginal e nem folclórico. Ele me parece essencial, e custa crer que em suas acadêmicas miopias uma "história oficial da educação na América Latina", possa atravessar os anos, dos sessenta aos dias de hoje, sem se dar conta da importância cultural e transcultural deste acontecimento.

\section{REFERÊNCIAS}

CALDART, R. S. et al (Orgs.). Dicionário a educação do campo. 2. ed. Rio de Janeiro: Expressão Popular, 2012.

CARRILLO, A. T. La educación popular - trayctória y actualidad. 2. ed. Bogotá: Editorial El Buho, 2012.

COELHO, N. E. P. Os libertários e a educação no Rio Grande do Sul (1895-1926). Tese (Doutorado) Universidade Federal do Rio Grande do Sul, Porto Alegre, 1987.

DUSSEL, E. Política da libertação - história mundial e crítica. v. 1. Passo Fundo: Editora IFIBE, 2014.

FAVERO, O. (Org.). Cultura popular e educação popular memória dos anos sessenta. Rio de Janeiro: Editora Graal, 1983. 
JIMÉNEZ, C.; NOVOA, E. Producción social del espácio; el capital y las luchas sociales em la disputa territorial. Bogotá: Ediciones Abajo. 2010.

FREIRE, P. Pedagogia do Oprimido. Edição fac-símile. São Paulo: Editora do Instituto Paulo Freire, 2014.

GADOTTI, M.; TORRES, C. A. (Orgs.). Educação popular utopia latino-americana. São Paulo: Editora Cortez, Editora da USP, 1994.

IBÁNEZ, A.; AGUIRRE, N. L. Buen vivir, vivir bien - una utopia en processo de construcción. Bogotá: Ediciones Abajo, 2010.

JAEGER, W. Paidéia - a formação do homem grego. São Paulo: Editora Martins Fontes, 2009.

JARA, O. H. La sistematización de experiencias - practica y teoria para otros mundos posibles. Colleción: Educación popular y saberes libertários. Lima: Centro de estudios y publicaciones ALFORJA/CEAAL, 2014.

NASCIMENTO, D. N.; RODRIGUES, R. M.; SODRÉ, M. D. (Org.). Educação do Campo e contemporaneidade - paradigmas, estratégias, possibilidades e interfaces. Salvador: Editora da Universidade Federal da Bahia, 2013.

NOVAES, A. A invenção das crenças. São Paulo: Edições SESC/SP, 2011.

Letras, 2004.

Civilização e barbárie. São Paulo: Companhia das

SAVIANI, D. Pedagogia histórico-crítica. Campinas: Editora Autores-Associados, 2000.

STRECK, D.; ESTEBAN, M. T. (Orgs.). Educação popular - lugar de construção social. Petrópolis: Editora VOZES, 2013.

TOLSTOI, L. Liev Tolstoi - os últimos dias. São Paulo: Companhia das Letras, 2011. 
TORRES, A. C. La educación popular - trayctória y actualidad. 2. ed. Bogotá: Editorial El Buho, 2012.

Hacer história desde Abajo y desde el Sur. Bogotá:

Ediciones Abajo, 2010. 



\section{CAPÍTULO 2}

\section{LEARNING AND TEACHING \\ IN THE RURAL SCHOOL: \\ From the global to the Portuguese case}

António M. Duarte ${ }^{1}$

Belmiro G. Cabrito ${ }^{2}$

Teaching and learning are not independent of their context, which besides involving factors like the educational system, the public educational institutions, the school organization or the classrooms, also encompass the specific territory where they take place.

This territory, viewed as a socio-spatial system which is constructed, lived and appropriated by his actors, acts as a potent generator of identity and symbols and actively interacts with the schools that are implanted in it (Charlot, 1994). The interest on a "rural education" (as well as the one on an "urban education") might be therefore justified based on an approach focused on the influence of the territorial context on teaching and learning.

Rural education is defined as the kind of education that happens in the rural territorial context (see a definition of rural context under) although some studies (e.g., Lippman et al., 1996, as cited in Khatri et al., 1997) refer as "rural" schools the ones located in a rural community, a small city or a town of fewer than 50.000 that is not a sub-

\footnotetext{
${ }^{1}$ António Manuel Duarte é licenciado em Psicologia, com Mestrado e Doutoramento em Psicologia da Educação, pela Faculdade de Psicologia da Universidade de Lisboa. É professor e investigador da mesma faculdade, nas áreas da Psicologia Educacional e da Psicologia da Arte. E-mail: amduarte@psicologia.ulisboa.pt

${ }^{2}$ Belmiro Gil Cabrito é licenciado em Economia e em Ciências Sociais e Políticas pela Universidade Técnica de Lisboa, com Mestrado e Doutoramento em Ciências da Educação, pela Universidade de Lisboa. É investigador do Instituto de Educação desta Universidade, nas áreas da Economia e Financiamento da Educação e Formação. Email: b.cabrito@ie.ulisboa.pt
} 
urb of a large city or part (in the specific case of the U.S.A.) of an Indian reservation. One way or the other, rural education constitutes a significant part of the educational system and we find that to comprehend rural education it is necessary to understand the specific nature of the rural context.

\section{Rural Context}

Rural context refers to contexts in geographical locations with certain characteristics - other contexts are referred as urban and sub-urban (Khatri et al., 1997). A rural area has been defined (e.g., U.S.A Census Bureau) as a region with a population of less than 2500 (Khatri et al., 1997). Nevertheless, other aspects of a geographical area seem to be also relevant to consider it as rural, urban or sub-urban like the type of employment available in the area and its degree of isolation from an urbanized area (Khatri et al., 1997).

Compared with urban areas, rural ones generally present, besides lower population density, a less diversified economy, offering less occupational opportunities (Crocket et al., 2000, as cited in Hardré et al., 2009), mostly in the "low-skill" service sector - e.g., farming, mining (Hodgkinson, 1994, as cited in Khatri et al., 1997). Rural areas also tend to a less degree of specialization, heterogeneity, bureaucratization and environment control trough rational planning (Nachtigal, 1982, as cited in Harmon \& Weeks, 2002). Many actual rural locations suffered economic stagnation that resulted in poverty and unemployment (Fitchen, 1995, as cited in Khatri et al., 1997). Moreover, in certain regions of the world (e.g., Amazonia) rural/ natural areas are subject to forms of urban/industrial "colonization", based on extraction of resources, that involve their destruction or decharacterization, (Marques, 2017). For all these reasons, as well characterized by Kelly (2009, 
p. 2), nowadays rural locations can be “(...) places of great loss - of people, natural resources and, often, as a result, any vision of long-term sustainability. In such places, loss as a persistent condition of life is vividly felt".

Besides this general characterization, we should consider that rural contexts are also characterized by diversity, as rural communities are unique in terms of their values and specific opportunities (Hardré et al., 2009). Furthermore, rural areas reproduce nowadays many of the conditions typical of urban contexts-which might imply a transformation of their culture (e.g., MacTavish \& Salomon, 2003, as cited in Yang \& Fetsch, 2007). Effectively, we typically find in the rural context a valorization of local rural workplace skills, like farming or fishing (Wondrue, 2004, as cited in Hardré et al., 2009) and a higher valorization of family, stability and local roots - in confrontation with typical urban valorization of mobility, acquisition and status (Howley et al., 1996 as cited in Hardré et al., 2009). Rural cultures seem also to valorize more the connection of individuals to the community (Khatri et al., 1997) being characterized by more personal/tight relationships, while in urban areas relationships tend to be more impersonal/loose (Nachtigal, 1982, as cited in Harmon \& Weeks, 2002). This is consistent with the fact that while in rural areas there is a greater valorization of verbal communication and of the recipient of messages in urban contexts the emphasis in on written memos and on the content of messages (Nachtigal, 1982, as cited in Harmon \& Weeks, 2002). There is also a significant difference between the sense of time in rural versus in urban environments -as Nachtigal (1982, as cited in Harmon \& Weeks, 2002) states, in rural areas time is measured by seasons of the year while in rural areas is measured by the clock. Rural cultures also typically valorize more a sense of place (Khatri et al., 1997). Moreover, in rural areas there is an higher valorization of informal community decision-making mechanisms (Khatri et al., 
1997), entrepreneurship and self-sufficiency - while in urban areas tendency is for corporatization and dependency on experts (Nachtigal, 1982, as cited in Harmon \& Weeks, 2002), hard work, stewardship and frugality (Hansley \& Hansley, 2010) and traditional values - while urban areas have more liberal values (Nachtigal, 1982, as cited in Harmon \& Weeks, 2002).

This "rural culture", constituted as patterns of ideas, feelings and values, integrate into the identity of individuals (Greewood, 2009, as cited in Hardré et al., 2009) and, as know from general studies on culture, the later acts as a kind of "software" for the mind (Hofstede, 1991) affecting learning and learning context (Hofstede, 1986).

\section{Rural versus Urban Schools}

The results from research that compares urban and rural schools are mixed (Hardré et al. 2009) and studies often lack adequate control variables (e.g., socioeconomic status; parents' educational level) making it difficult to interpret if a result can be attributed to "rurality" or to a concomitant factor - e.g. poorness (Khattri et al., 1997).

Comparatively with urban education, rural education is commonly seen as more problematic. Effectively, in the rural context schools present a higher probability of being situated in remote locations, of having smaller budgets, less technology resources and fewer offers of courses, special programs and extra-curricular activities (Khattri et al., 1997). Rural schools tend also to have fewer experienced school psychologists (Clopton \& Knesting, 2006).

Nevertheless, research focused on the effects of rural schools characteristics on students' outcomes suggests that, after excluding the factor of poorness (that is a risk factor for rural or urban students), specific aspects of rural school seem to act in reducing educational failure (Khattri 
et al., 1997). As a consequence an argument developed that we can all learn something important from rural schools, with relevance for school reform in other locations (Ballou \& Podgursky, 1995) namely in urban communities, where schools grounded on the "industrial model of education" (more prone to decontextualized learning and to separate from local communities) might comparatively increase the risk of students failure (Pelavin Research Institute, 1996).

\section{Learning in Rural Schools}

Research that characterizes learning variations between rural and urban students is scarce and mostly focused on learning achievement, therefore almost neglecting the learning process.

\section{Learning Achievement in Rural Schools}

Studies that compare rural with non-rural students' achievement produced mixed results.

Some studies report that students of rural areas tend to present lower school success (D'Amico et al., 1996, Lichter et al., 2003, National Research Council, 1993, as cited in Hardré et al., 2009) and that dropout rates in remote rural schools can be much higher (National Center for Educational Statistics, 2001, as cited in Hardré et al., 2009) and more premature (Gándara et al., 2001, Kao \& Tienda, 1998 as cited in Hardré et al., 2009). Actually, there is evidence of the existence of various risk factors for learning achievement in the context of rural schools. Besides the already mentioned characteristics (i.e., remote localization; smaller budgets; less technology resources; fewer offers of courses, special programs and extra-curricular activities; fewer experienced school psychologists) rural schools involve families with lower education levels, more socioeconomic problems (Flora et al., 2003, National Center for 
Educational Statistics, 2004, Stern, 1994, as cited in Hardré et al., 2009; Kattri et al, 1997) and lower expectations for students' achievement (Harmon \& Weeks, 2002). Other achievement risk factors can be situated in the students' learning process itself (see Emotions and Motivation in the next subsection).

Oppositely, a study by Campbell and collaborators (1996, as cited in Kattri et al., 1997) revealed a higher or equal performance of rural students and that of urban students, with the performance of both groups being lower of the one of sub-urban students. An analysis by Reeves and Bylund (2005, as cited in Yang \& Fetsch, 2007) revealed that performance of elementary rural students might be better, which might be due to a smaller proportion of rural students in high poverty schools since that, at least in some countries (e.g., U.S.A.), poverty can tend to be more concentrated in central cities (Kattri et al, 1997) and poor rural families can tend to be employed (Summers, 1995, as cited in Kattri et al, 1997). Other studies indicate that dropout rate is lower for rural students but more definitive (Sherman, 1992, as cited in Kattri et al., 1997) and that rural high school completation is higher but college aspiration lower (Snyder et al., 1996, as cited in Kattri et al., 1997). It is also relevant to mention that rural students' are less exposed to some specific risk factors for school failure, like belonging to ethnic minorities (Sherman, 1992, as cited in Kattri et al., 1997), substance abuse (Tompkins \& Deloney, 1994, as cited in Kattri et al., 1997) and absenteeism (Lippman et al., 1996, as cited in Kattri et al., 1997).

More elaborated studies that focused on the effects of rural schools characteristics on students outcomes, suggests that, after excluding the factor of poorness (that is a risk factor for rural or urban students) specific aspects of rural schools seem to act in reducing educational failure (Khattri et al., 1997). Some U.S.A. studies imply that students' achievement in poor rural context is better 
when compared with that of students in poor urban areas (NAEP, 1992, as cited in Kattri et al, 1997) and a study by Gjelten (1982, as cited in Kattri et al, 1997) indicates that students from economically stable rural areas perform better in achievement tests. Some aspects of students' learning process seem also to be aligned with the notion of an advantage of rural students (see Learning Style in the next subsection).

\section{Learning process in Rural Schools}

Research on the specificities of the learning process in rural schools (i.e., the complex psychological course of learning, involving a myriad of interconnected variables like emotions, academic self-concept, motivation or learning style) is still scarce.

Concerning emotions involved in learning, some authors defend that rural students, being more confronted with possible contrasting messages from the school and their local communities (e.g., valuing of urban workplace skills versus local workplace skills; valuing of mobility \&acquisition and status versus family, stability and local roots) might experience emotional and personal conflict (DeYoung et al., 1995, Faircloth, 2009 as cited in Hardré et al., 2009) which might act as a factor of resistance to school (Corbett, 2007 as cited in Hardré et al., 2009). When compared with urban students, rural students seem to experience greater conflicts between educational goals and their family connections, a condition associated with lower educational aspirations and delay of postsecondary education (Hecktner, 1995 as cited in Hardré et al., 2009). Exposure to externally-defined goals and expectations might stimulate promising rural students to out-migrate (Flora et al., 2003, as cited in Hardré et al., 2009) and not to return or to return in failure, due to the an inauthenticity of the goals they sought (Crocket et al. 2000, as cited in Hardré et al., 2009). 
Considering academic self-concept, a study with rural students from the third through the seventh grade founded that those presented feelings of academic self-competence higher than the norm (Yang \& Fetsch, 2007), which makes these authors concluding for a still protective function of rural living for the academic self-concept of students.

Regarding motivation to learn, some studies account that in rural contexts students tend to present lower levels of motivation, which constitutes a risk factor for learning achievement (D'Amico et al., 1996, Lichter et al., 2003, National Research Council, 1993, as cited in Hardré et al., 2009). As Hardré and collaborators (2009) state, in the rural context, where there are less occupational opportunities, students' perceptions of instrumentality/value for what they are learning in school might be more jeopardized concerning subjects perceived has having less relevance for the available rural professions (e.g., algebra). Several studies also suggest that rural students distinguish themselves by the fact that they perceive teachers support and the context that those create as the much strong factor of their motivation (Hardré et al. 2009; Hardré \& Reeve, 2003; Hardré \& Sullivan, 2008). This is probably related to the typical special connection of rural teachers to their students (Ballou \& Podgursky, 1995 - see section on Learning Context in Rural Schools).

Finally, we should refer to differences in learning style (i.e., individual preferred mode of learning) since at least one study suggests that rural and urban students differ regarding this variable. Cox and collaborators (1988) administered the Secondary Learning Styles Inventory to a large sample of 9th-12th grade students of rural and urban high school and founded that rural students tended to be significantly higher on serious, analytical learner characteristics (i.e., rational-careful-logical-reflective-associative thinking in new-difficult topics) and in some $a c$ tive, practical learner characteristics (i.e., learning through 
practice-experience). The authors interpret these findings as suggesting that rural students tend to show more concern and engagement in the educational process than their urban counterparts. We should point out that being rural students frequently organized in multigrade groups (i.e., groups of students in different grade levels that prevent teacher's to attend simultaneously to the all class) they are potentially encouraged to take autonomous initiative and use reciprocal teaching and so become actors of their education and learning. These findings are partly consonant with results of another study (Dolly \& Katz, 1987) that investigated the impact of different types of instructional activities on elementary rural students' achievement regarding nutrition learning. These authors found that as teachers less approach teaching in a traditional way (i.e., routine lectures; display of information; classroom discussion) higher was learning achievement (i.e., knowledge, attitude and behaviors about nutrition). Nevertheless, this study did not detect a significant impact on learning achievement from the use of nontraditional teaching (i.e. practical activities; study visits). When compared with urban students, rural students questioned by Cox and collaborators (1988) were also higher, although not so much, in some observation-centered learner characteristics (i.e., learning by observation), some concrete, detail, fact-oriented learner characteristics (i.e., detail analysis) and some passive learner characteristics (i.e., listening in class; and orientation to the present).

\section{Teaching and Context of Learning in Rural Schools}

The context where rural students' learning occurs presents a set of specific characteristics that create both potential negative and potential positive conditions for learning. 
Starting with the potential negative conditions, in rural areas with scattered population students might have to travel long distances to attend school, a fact that constrains their lives and increases dropout probability (Fox, 1996, as cited in Khattri et al., 1997). Rural schools have budgets that are often small, compromising the resources schools make available to students (Hedges et al., 1994, as cited in Khattri et al., 1997). Rural schools also offer students a lower number of courses, college preparatory courses, special programs (Ballon \& Podgursky, as cited in Khattri et al., 1997) and extracurricular activities (Lippman et al., 1996, as cited in Khatri et al., 1997). Moreover, rural schools have lower technological implementation, frequently lacking the infrastructure and resources to do it (Howley \& Howley, 1995, as cited in Khattri et al., 1997).

As mentioned by Hamon and Weeks (2002), referring specifically to the rural learning context in the third world, lack of school supplies might mechanize teaching and make teacher rely more on rote learning.

Furthermore, despite the challenges of teaching in rural settings rural schools tend to present fewer experienced and highly trained teachers (Khattri et al., 1997). This might be considered a special problematic condition since, due to the typical small amount of students in most rural schools, teaching in this context tends to demand that same teacher teaches in multiple subject areas and for multigrade groups (Colangelo et al., 1999, Fowler \& Walberg, 1991, Lemke, 1994, as cited in Hardré et al., 2009).

Rural teachers also face a higher probability of entering in cultural conflict with the local community values and therefore of increasing their absenteeism (Hamon \& Weeks, 2002). Regardless of the specificity of the rural context many rural schools seem to use a decontextualized mode of education, non-sensible to the local culture. As Corbett (2007, as cited in Kelly, 2009) showed in "Learning to leave: the irony of schooling in a coastal community", 
this might contribute to the depopulation of rural areas by instating in rural students' values opposed to the local ones.

However, despite the existence of potential negative conditions for learning, rural education also presents potential positive conditions that have been offered as "shielding students against educational failure" (Khattri et al., 1997).

First of all, rural schools tend to be smaller, due to isolation and lower population density of rural communities (Heake et al. 1996, as cited in Khattri et al., 1997) a condition that some studies found as beneficent (Howley, 1994, as cited in Khattri et al., 1997), by facilitating teacher's knowledge of their pupil's and a closer relationship with them (Harmon \& Weeks, 2002). Effectively, teaching in the rural context has been characterized as involving a special teacher-student connection, based on interpersonal relatedness, less typical in large schools (Ballou \& Podgursky, 1995; Hardré, 2007 as cited in Hardré et al., 2009). This mostly constitutes a powerfull tool for motivating students to learn (Hardré et al., 2009).

It has also been pointed (Hamon \& Weeks, 2002) that several education "best practices" have their origin, due to necessity, in the context of rural schools: cooperative learning; peer tutoring; interdisciplinary studies; multigrade teaching (i.e., teaching groups with students from different grade levels, which preventing teacher's to attend simultaneously to all students demands more autonomy from these ones). Besides, rural schools present a higher tendency to promote learning beyond the context of the classroom (Khattri et al., 1997) and to use the surrounding community as a curricular resource, due to a greater intimacy with it (Stern, 1994, as cited in Khattri et al., 1997). Relevant to this is a study with high performing rural schools (Barley \& Beesley, 2007) that found the following ensemble of perceived factors for success (by prin- 
cipals, teachers parents and community members): strong connection between school and its community; clear goals; high academic expectations; aligned curriculum, instruction and assessment; and use of student data.

In a matter of fact, rural schools present a tendency to a tight link to their communities in the form of a more active interaction with local governance, business and social organizations, families and other rural schools (Theobald \& Nachtigal, 1995, as cited in Khattri et al., 1997). For example, it is known that rural schools tend to involve more the parents in students' education (Sun et al, 1994, as cited in Khattri et al., 1997). This tight link with the community is also probably the main factor of the possibility that rural schools have of significantly helping to consolidate local cultures (Faricloth \& Tippeconnic, 2010). Actually, rural education can even act as a factor of the empowerment and political emancipation of rural communities, a perspective widely exploited in Latin American countries like Brazil (Basso, Neto \& Bezerra, 2016; Neto, Bezerra \& Caiado, 2011).

\section{Rural Education in Portugal}

Research on rural school is part of a problem that has not been the subject a systematic and continued study in Portugal. Effectively, rural school is not a reality that aroused deep interest in research since it was for years a poor and politically oppressed relative of education, under a dictatorial government that considered education was a subversive instrument that can be used against the status quo. Only a small number of researchers, among which are Alberto de Melo, Rui Canário and Abílio Amiguinho, have first included this issue under investigation and, even then, not always occupying the first place in their concerns. 


\section{What is a Rural School in Portugal?}

First, it is important to describe the Portuguese educational system in order to localize rural education in it.

In Portugal, the educational system consists of three levels: the basic education, which last for nine years, composed by the primary education, that is the first four years, and the upper segment, that lasts five years; the secondary education, which lasts for three years; and the higher education, comprising two cycles, according the Bologna Declaration, the first cycle lasting for three years and the second cycle lasting for two years. The compulsory education includes the twelve years of basic and secondary education.

The first cycle of basic education, the primary education, lasts for four years and is aimed at young people between six and ten years old. It is in this education period that Rural School is situated when we refer about it in the country.

Most primary schools are located in urban territory, due to the progressive urbanization of the country, even if the territory is largely rural. In fact, rural and urban are categories many times opposed according the more agricultural or more industrialized economy region, embodying the opposition between the developed world and the world that is characterized by lack of development (Canário, 2000).

Therefore, in Portugal, the urban and the rural are the expression of the existence or not existence of the predominance and diversification of industrial activities and services or the predominance of agricultural and artisanal activities.

Due to the urbanization process of the country, the Rural School is an entity minority voted naturally to its disappearance, on behalf of "development" and "progress." Rural schools are doomed to disappear along with 
their own rural territory, which will be forced to develop itself, that is, to grow and to modernize, into the paradigm of modern capitalist production and financial capital, "forgetting" its specific culture, way of life, people relationship and community values.

On the other hand, the country assists to an exodus from the rural regions to urban territory where more services and goods may be found. This phenomenon contributes to the desertification of the countryside and brings more difficulties to the permanence of the rural school, due to the decrease of the population including children. This population decrease gives the political justification to the governments that implement policies of concentration of schools in "rural" urban centers, being children from rural areas displaced every day from the school near their houses to group of schools in the "city".

So, what is the Rural School in the country? The rural school developed "(...) in the context of regression and desertification demographics, aging population, loss of social vitality and dynamism, which is reflected in indicators of school and educational failure, dropout, illiteracy and incomplete courses, converging the need for a broad socio-intervention" (Vendramini, s/d). Thus, the Rural School is a school that is characterized primarily by being in rural areas or peri-rural, generally small in size and number of pupils, and often isolated.

Bearing in mind that there is no specific legislation for the Rural School in Portugal, its identity manifests primarily according to the specific territory where it is placed bearing a specific potential namely concerning pedagogic materials and relationship with the community. It is this capability to build and to appropriate educational practices, being of formal and informal learning and reinvented on the context surroundings and surpassing the limits inherent to the way formal school and formal learning acts, that distinguish rural schools and rural education, contra- 
ry to the opinion of those who consider it to failure because it turned obsolete (Canário, 2000, p. 125).

Besides, in rural schools, as it happens in some non-rural schools, Basic Education tends to be conducted in multilevel classrooms, where a same teacher simultaneously teaches students of various education levels.

\section{The political sense of the rural school in Portugal}

To characterize nowadays the rural school in the country it requires a little reflection on the educational policies of the country and its "tradition". During the Salazar dictatorship that lasted from 1926 to 1974 (The "Estado Novo" - New State - period), the development of education, particularly basic education, has never been an important policy objective. In dictatorship, obscurantism was cherished by the government (and church) that saw the development of education a threat to the dominant economic and political system settled on an agricultural economy and mercantile capital. The school was expected to fulfill its function of ideological State apparatus, in the sense given by Althusser (1985): play the dominant class. As a result, the primary school, and other educational levels, was frequented primarily by children of those in power. Workers and their sons were not expected to learn more then read and write. Portugal during the dictatorship had a graded school, a school heavily elitist (Monica, 1978).

All along the 48 years of dictatorship, education did not change a lot. Modifications were felt in the Portuguese educational system in the years immediately after World War II as a result of the economy needs for technical and skilled workers that would ensure the development of industrialization that the country started during the war. This policy is embodied, however, in post-primary education (Cabrito, 2002), with the appearance of a vocational 
nature of educational provision (Education Reform, 1948) to initiate a dual educational system that would remain until the Democratic Revolution of 1974.

Investment resulting from the educational reform of 1948 did not extended to primary education, with even more negative effects in rural areas. In these regions, away from the capital circuits, the school was, in general, a small school with all levels of education in the same classroom. Moreover, sometimes the teacher himself was not truly a teacher but an individual that had pedagogical and scientific training to teach. In fact, for many years, the schoolteacher at rural regions was someone who had only attended primary school for three or four years and his or her basic job was to teach some reading and arithmetic. On the contrary, in rich neighborhoods, mostly in urban territory in primary schools, especially on private primary schools attended by rich children, teachers had training while school subjects included reading, arithmetic, history, geography and drawing.

This state of affairs has undergone a great change after the April Revolution of 1974, because of the democratic ideas that anchored this socialist revolution. Through the April Revolution, a revolution that aimed to restore democracy in Portugal, the Portuguese society developed from the democratic and social point of view. The new Constitution, adopted in 1976, safeguards the fundamental rights of citizens, among them the right to education for all, on equal terms. With the April Revolution, all individuals have come to enjoy the same rights, freedoms and guarantees.

Of course, the highly social nature of the new political regime, embodied in the text of the Constitution, influenced the educational unit and the school became (or wanted to become) a device of equality and fairness. In this sense, a unified teaching has developed - all teaching being equal for all children regardless of their social back- 
ground - and the school (including the rural one) came to play an important social role: it became a keystone for the development of local communities.

\section{The "future" of the Rural School in Portugal}

The elementary school, especially in rural areas, has become a privileged instrument of development and socialization of the territory (Buddy, 2004). Going now further than teaching reading and arithmetic, the rural school is a key partner that collaborates with local authorities and other social institutions in the development of rural areas. In its classrooms, pupils experience new and old "recipes" for teaching. Media and ITC enter the school through projects and teaching practices that link it to the community and open the classroom to the artisan, the peasant, the local raw materials, the old "professions", the religious festivals and all other local cultural events.

In this framework, the primary teacher reinforces its importance in the social fabric, not only because he or she teaches reading and writing, but particularly because he or she heads projects and local development associations. The Rural School becomes a vehicle for cultural promotion, local development and strengthening of ties of solidarity and neighborhood. The isolation of rural areas is then often broken by outside teachers and networks with colleagues from other rural schools (Amiguinho, 2008).

However, this social function of rural schools has been sinking against an attack of which has being targeted, especially from the late eighties. Changes in international economic framework, which promoted the globalization of economies and crisis of financial capital, give to successive governments the justification to attack rural school of a supposedly "lack of efficiency." The work of the rural school became strictly measured against monetary indicators. The rural school, with its small number of students, 
became too expensive for governments budget pressured by LEAN politics of efficiency and effectiveness.

As a result, concentration of primary and secondary schools in horizontal and vertical clusters has been the dominant measure of educational policy in Portugal since the 1990s, in order to maximize the efficiency of public spending for education. This reality in Portugal aligns with a trend observed equally in other education systems, such as the Brazilian (Sales \& Pimenta, 2010). In this sense, Portuguese schools with a small number of students, which still happens with most of the rural schools, have been closed in the name of economic efficiency.

Since 2000, 4500 "isolated" schools have been closed in Portugal with the consequence that rural students have to dislocate from their place of residence to the cities. This attack to the little schools, especially rural schools, is an unprecedented process in Portugal, despite reactions that unites teachers, families and local leaders in challenging government policies.

The primary school, particularly in depressed economic territory, such as rural areas in the country, has become a hotbed of local development projects and teaching practices, which carries a unique change. In these circumstances, to question the Rural School is to question the existence, survival and future of the rural world itself. Furthermore, to support the Rural school is both to fight against standardization and uniformity and to care for a laboratory of alternative social and economic experiences that use all dimensions of human development (Melo, 1991), therefore contributing to a sustainable alternative to the consumerist and schizophrenic logic that characterizes the current urban environment.

Recently, a series of studies with relevance for rural education have been conducted in Portugal. These studies connect with one of the research lines (i.e., "Variabilidade territorial da aprendizagem / Territorial variability of learn- 
ing") of the "Programa de Investigação em Concepções de \& Abordagens à Aprendizagem / Research Programme on Conceptions of \& Approaches to Learning" 3 , from the Faculty of Psychology of the University of Lisbon. These studies focus on the relationship of learning and learning context with the territory and are framed both on "SAL - Students Approaches to Learning" theory (e.g., Biggs, 2003) and on a perspective that stresses the importance of the territory for education (e.g., Champollion, 2013). The main objectives of these studies are to characterize the territorial variation (mainly urban-rural) of different components of the educational process: students' characteristics; learning contexts; approaches to learning; learning outcomes; and the relationships between these variables. Within this line of research, a variety of studies have been conducted under four main themes: 1) teaching practices in rural and urban schools (Boix, \& Duarte, 2014; Duarte et al., 2015; Duarte \& Fernandes, 2005; Duarte, Fernandes \& Paasimäki, 2005; Figueira, 2017; Silva, Figueira \& Duarte 2014); 2) learning in urban and rural schools (Boix, Champollion \& Duarte, 2015ab; Figueira, 2017); 3) relationships of urban/rural learning with learning context (Duarte \& Figueira, 2017); and 4) artistic participation of urban and rural students (Ferraz, 2016).

Regarding teaching practices in rural Portuguese schools, Silva, Figueira and Duarte (2014) observed a variety of "active" practices (i.e., interdisciplinary, cooperative learning, reciprocal teaching, use of school's context, relationship with community, teacher/student close relationship and learning by projects). Moreover, Duarte and collaborators (2015) found a higher use of "participatory" teaching (i.e., emphasis on understanding, on teacher-student relationship, on ongoing evaluation and on teaching that promotes questioning and reflec $\neg$ tion) in rural than in urban teachers.

3 https://sites.google.com/site/programainvestigacao 
Despite these promising results, concerning learning in rural Portuguese schools, Figueira (2017) found that when compared with urban students, rural students present an higher "time restricted conception of learning" (i.e., notion of learning as restricted in time) and a higher "extrinsic motivation" (i.e., motivation for the avoidance of punishment and gain of external reinforcement: prizes, grades, experiences and relationships).

As regards to the relationship of learning to the learning context in rural Portuguese schools, Duarte and Figueira (2017) found an association between a higher exposure to an "open" learning context (i.e., student centred) and an higher students' use of a "deep" approach to learning (i.e., active learning).

Finally, vis-à-vis artistic participation of rural Portuguese students, Ferraz (2016) found a higher involvement in reading of literature and a lower involvement in dancing, singing and acting, when compared with urban students.

\section{Conclusion}

The processes of teaching and learning in rural contexts has a specificity that comes from the proper nature of the rural territory, which influences schools, teachers, students and families in a very particular way.

Despite the possible but not inevitable problems of rural education (mainly due to isolation and eventual lack of resources) global research findings suggests that rural school also have characteristics that might be a potential advantage in terms of teaching practices (e.g., cooperative learning; peer tutoring; interdisciplinary studies; multigrade teaching; contextualized teaching) of students' learning process (e.g., more autonomy due to multigrade classes) and of consequent rural students' achievement.

This image is partly corroborated in the specific case 
Portugal. The main problems rural schools present in this country is a threat to their survival or identity, due to desertification of rural areas, and politics for reducing expenses with schools with few pupils, or to urbanization of rural territory. Besides, in Portugal rural students are exposed to the particular risks of educational failure, dropout, illiteracy and incompleteness of courses. Nevertheless, besides these problems rural education in Portugal also presents potential advantages. Effectively, in Portugal the rural school tends to be characterized by a kind of practices aligned with a more "open" view of education. For instance, rural schools tend to invest in a contextualization of learning in the local environment (through local materials and contents), in multigrade and interdisciplinary teaching or in developing significant relationships with their local communities. These practices seem to be associated with some positive results, with a particular emphasis on the fact that that some rural areas develop their sustainability, reducing their isolation and developing.

Overall, the analysis of rural education, both on the global and on the considered national level suggests the need to reinforce rural schools because of their importance on sustaining the rural world, preserving its identity and exploiting the benefic potential of learning on rural contexts. Besides, some characteristics of rural schools might help to critically analyze and improve educational practices in other contexts, specifically the urban one.

\section{REFERENCES}

BALLOU, D.; PODGURSKY, M. Rural schools - fewer highly trained teachers and special programs, but better learning environment. Rural Developmental Perspectives, Washington, D.C., 10 (3), 6-16, 1995. Disponível em: <https://naldc.nal.usda. gov/download/IND20532391>. Acesso em: 15 jun. 2011. 
BARLEY, Z. A.; BEESLEY, A. D. Rural school success: What can we learn? Journal of Research in Rural Education, Orono, ME, 22(1), 2007. Disponível em: <https://eric.ed.gov /?id=EJ751592>. Acesso em: 15 jun. 2011.

\section{BASSO, J. D., NETO, J. L.; BEZERRA, M. C. Pedagogia}

Histórico - Crítica e Educação do Campo. História, Desafios e Perspectivas. Atuais. São Carlos: Pedro \& João Editores, 2016.

BOIX, R. ; CHAMPOLLION, P. ; DUARTE, A. Territorial specificities of teaching and learning - Introduction. Sisyphus:

Educational Sciences Journal, Lisboa, 3(2), 7-11, 2015a. Disponível em: <http://revistas.rcaap.pt/sisyphus/article/download/7880/5580>. Acesso em: 22 jan. 2016.

Teaching and learning in rural contexts. Sisyphus:

Educational Sciences Journal, Lisboa, 3(2), 28-47, $2015 b$. Disponível em : <http://revistas.rcaap.pt/sisyphus/article/ view/7883>. Acesso em: 22 jan. 2016.

CANÁRIO, R. A Escola no Mundo Rural: Contributos para a construção de um objeto de estudo. Educação, Sociedade e Culturas, Porto, 14, p. 121-139, 2000. Disponível em : <http:// www.fpce.up.pt/ciie/revistaesc/ESC14/14-7-Canário.pdf>. Acesso em: 15 jun. 2011.

CLOPTON, K. L.; KNESTING, K. Rural school psychology: re-opening the discussion. Journal of Research in Rural Education, Orono, ME, 21(5), p. 1-11, 2006. Disponível em : <http:// jrre.vmhost.psu.edu/wp-content/uploads/2014/02/21-5.pdf >. Acesso em: 15 jun. 2011.

COX, D. E., SPROLES, E. K. ; SPROLES, G. B. Learning style variations between rural and urban Students. Research in Rural Education, Orono, ME, 5(1), p. 27-31, 1988. Disponível em : <http://jrre.vmhost.psu.edu/wp-content/uploads/2014/02/5-1_5.pdf.>. Acesso em: 15 jun. 2011.

DOLLY, J. P.; KATZ, D. P. The relationship of instructional practices to student learning in rural schools. Research in Rural Education, Orono, ME, 4(I), p. 35-37, 1987. Disponível em : <http://jrre.vmhost.psu.edu/wp-content/uploads/2014/02/4-1_6.pdf>. Acesso em: 15 jun. 2011. 
DUARTE, A. M.; et al. Teaching practices for passive and active learning in rural and urban elementary teachers. Sisyphus: Educational Sciences Journal, Lisboa, 3(2), p. 134-154, 2015. Disponível em : <http://revistas.rcaap.pt/sisyphus/article/view/7891>. Acesso em: 22 jan. 2016.

DUARTE, A. M.; FIGUEIRA, A. I. La relación de los contextos de aprendizaje "abierto" versus "cerrado" con los abordajes de aprendizaje de los estudiantes rurales de primer ciclo. Aula Abierta, Barcelona, 45, p. 55-62, 2017. DOI: <https://doi. org/10.17811/rifie.45.2017.55-62>.

HARDRÉ, P. L.; REEVE, J. (2003). A motivational model of rural students' intentions to persist in, versus drop out of high school. Journal of Educational Psychology, Washington D.C., 95(2), p. 347-356, 2003. Disponível em: <https://bmri.korea. ac.kr/file/board_data/publications/1277341222_1.pdf >. Acesso em: 15 jun. 2011.

HARDRÉ, P. L. ; SULLIVAN, D. Classroom environments and student differences: How they contribute to student motivation in rural high schools. Learning and Individual Differences, New York, 18, p. 471-485, 2008.

HARDRÉ, P.L.; SULLIVAN, D.W.; CROWSON, H.M. Student Characteristics and Motivation. In: Rural High Schools. Journal of Research in Rural Education, Orono, ME, 24(16), 2009. Disponível em: <http://jrre.psu.edu/articles/24-16.pdf>. Acesso em: 15 jun. 2011.

HOFSTEDE, G. Cultural differences in teaching and learning. International Journal of Intercultural Relations, New York, 10(3), p. 301-320, 1986. Disponível em: <https://doi. org/10.1016/0147-1767(86)90015-5>. Acesso em: 15 jun. 2011.

HOWLEY, C. B.; HOWLEY, A. Poverty and school achievement in rural communities: A social-class interpretation. In: SCHAFFT, K. A.; JACKSON, A. Y. (Eds.). Rural education for the twenty-first century: Identity, place, and community in a globalizing world. PA: The Pennsylvania University Press, 2010. p. 34-50.

KELLY, U. A. Learning to lose: Rurality, transience, and 
belonging (a companion to Michael Corbett). Journal of Research in Rural Education, Orono, ME, 24(11), 2009. Disponível em: <http://jrre.vmhost.psu.edu/wp-content/uploads/2014/02/24-11.pdf>. Acesso em: 15 jun. 2011.

KHATTRI, N.; RILEY, K.W.; KANE, M. B. Students at risk in poor, rural areas: A review of the research. Journal of $\mathbf{R e}-$ search in Rural Education, Orono, ME, 13(2), p. 79-100, 1997. Disponível em: <http://jrre.vmhost.psu.edu/wp-content/uploads/2014/02/13-2_5.pdf>. Acesso em: 15 jun. 2011.

SALES, S.; PIMENTA, A. Educação básica e educação do campo: análise das características e dos limites da política educacional no município de Arraias (TO). Educativa, Goiás, 13(1), p. 177-187, 2010. Disponível em: <http://seer.ucg.br/index.php/ educativa/article/view/1254/922>. Acesso em: 15 jun. 2011.

SILVA, J. A.; FIGUEIRA, A. I; DUARTE, A. M. Aprendre i ensenyar en una escola rural portuguesa: Testimonis del diari d'una mestra. Guix - Elements d'Acció Educativa, Barcelona, 402, p. 18-22, 2014. Disponível em: <https://www.researchgate. net/publication/277708794_Aprender_y_ensenar_en_una_escuela_rural_portuguesa>. Acesso em: 8 abr. 2015.

VENDREMINI, C.. Movimentos Educativos Emancipatórios em Portugal. 28 $8^{\text {a }}$ Reunião Anual da Anped, Rio de Janeiro, Anped, 2005. Disponível em: < http://www.anped.org.br/biblioteca/item/movimentos-educativos-emancipatorios-em-portugal>. Acesso em: 14 jul. 2011.

YANG, R. K.; FETSCH, R. J. The self-esteem of rural children. Journal of Research in Rural Education, Orono, ME, 22(5), 2007. Diponível em: <http://jrre.vmhost.psu.edu/wp-content/ uploads/2014/02/22-5.pdf>. Acesso em: 15 jun. 2011. 


\title{
CAPÍTULO 3
}

\section{DECOLONIALIDADE \& EDUCAÇÃO DO CAMPO COMO MOVIMENTOS DE RESISTÊNCIA ${ }^{1}$}

\author{
Magno Nunes Farias ${ }^{2}$ \\ Wender Faleiro ${ }^{3}$
}

Um dos pontos centrais que deram vida a esse artigo se baseia nas discussões que sinalizaram as contradições intrínsecas nas relações de poder que constituem a Educação Brasileira, e em especial, como essas relações se desembocam e desembocaram na educação dos territórios camponeses. Para pensar esses processos centrou-se nas compreensões sobre a trama da colonialidade/modernidade e urbanocentrismo e a Educação dos povos do campo, na tentativa de compreender essas relações na construção e não construção da educação nesses territórios.

Essa busca baseia-se na necessidade de se entender os processos a partir da historização dos movimentos educativos consolidados no Brasil, compreendendo a educação enquanto prática cultural, social e histórica que se constrói a partir de formas distintas e plurais de acordo com os territórios, as finalidades, os tempos e os grupos que estão envolvidos nessa prática. Assim, reconhece-se que

${ }^{1}$ Texto já publicado em outros meios de divulgação acadêmica.

${ }^{2}$ Doutorando em Educação pela Universidade Federal de São Carlos - UFSCar. Mestre em Educação pela UFG/ Regional Catalão. Grupo de Pesquisa "Cidadania, Ação Social, Educação e Terapia Ocupacional". Núcleo de Extensão e Pesquisa em Educação e Desenvolvimento do Campo - NEPCampo. E-mail: magnonfarias@hotmail.com

${ }^{3}$ Professor da Unidade Acadêmica Especial de Educação e do Programa de Pós-Graduação em Educação - Universidade Federal de Goiás/Regional Catalão. Licenciado e Bacharel em Ciências Biológicas e Pedagogia; Mestre em Ecologia e Doutor em Educação pela Universidade Federal de Uberlândia. Pós-Doutorando em Educação - PUC/Goiás. Líder Grupo de Pesquisa e Extensão em Ensino de Ciências e Formação de Professores - GEPEEC e Vice-Líder Núcleo de Extensão e Pesquisa em Educação e Desenvolvimento do Campo - NEPCampo. E-mail: wender.faleiro@gmail.com 
não existe uma educação, mas sim educações, em variadas formas (GONDRA; SCHUELER, 2008). Desta maneira, a partir da revisão bibliográfica e movimentos de reflexão crítica, esse trabalho debruça-se sobre as construções dessas educações no Brasil, e como a colonialidade/modernidade/urbanocentrismo estruturou especificamente a educação dos povos do campo, e ao final sinaliza-se as experiências de resistência e decolonialidade que caracteriza o movimento sociopolítico e cultural Educação do Campo.

\section{Colonialidade/Modernidade e Urbanocentrismo}

Primeiramente é essencial sinalizar sob qual paradigma se constrói esse estudo, principalmente seus aspectos geo-corpo-políticos ${ }^{4}$, tendo em vista que esses fatores são determinantes para se compreender o desenvolvimento desse estudo. Desta maneira, esse trabalho tem por base os estudos decoloniais latino-americanos, que se constituem centralmente a partir da rede de estudos modernidade/ colonialidade. Essa rede de estudos vem se construindo desde o final do século XX, a partir dos diálogos de diversos autores (Castro-Gómez, Dussel, Grosfoguel, Lander, Maldonado-Torres, Porto-Gonçalves, Walsh, entre outros) latino-americanos que se propõem a elaborar questionamentos sobre os processos de modernidade/colonialidade que envolveram os povos Latinos Americanos a partir de relações eurocêntricas, de dominação, inferiorização e su-

\footnotetext{
${ }^{4}$ Entende-se que a geografia (lugar, território a qual pertence) e a corporalidade (marcas do corpo - gênero, sexo, raça, sexualidade) são critérios decisivos nas relações de poder. Hegemonicamente as relações de poder (re) produziram e ainda reproduzem a supremacia geográfica (eurocêntrica) e corpórea (homem, sexo masculino, branco, heterossexual), que produzem a dominação colonial (QUIJANO, 2009). Porém, nesse trabalho a geo-corpo-política se dá a partir da decolonialidade, centrando-se em enunciações geograficamente e corporalmente marginalizadas, ou seja, produções latino-americanas, não-brancas e que busca desestabilizar padrões de gênero e a heteronormatividade.
} 
bordinação cultural, social, epistêmica e ontológica.

Assim, buscam discutir, afirmar e potencializar movimentos de resistências, em uma perspectiva decolonial, ou seja, superar padrões de poder eurocêntricos que perpassam as relações sociais. Além disso, a perspectiva decolonial vem romper silenciamentos e ausências de grupos marginalizados, afirmando esses sujeitos enquanto agentes epistemológicos, políticos, sociais, para se pensar modos de conceber a existência de outros, que foram sufocados pela modernidade/colonialidade. Desta forma, esses estudos estão estreitamente ligados com os Movimentos Sociais (Camponês, Indígena, Negro, Feminista) na América Latina (SILVA et. al., 2014; CASTRO-GÓMEZ e GROSFOGUEL, 2007; BALLESTRIN, 2013).

O grupo Modernidade/Colonialidades se caracteriza como um espaço recente, que se apoio em pensamentos sociais do século XX e XXI (teorias pós-coloniais, marxistas contemporâneos, análises do sistema-mundo, correntes dos movimentos sociais), e vem compartilhando "noções, raciocínios e conceitos que lhe conferem uma identidade e um vocabulário próprio, contribuindo para a renovação analítica e utópica das Ciências Sociais latino-americanas do século XXI" (BALLESTRIN, 2013, p. 99).

Assim, nesse trabalho procura-se compreender como a educação dos povos camponeses vem se articulando nesses movimentos da modernidade/colonialidade, compreendendo os efeitos nocivos, e expondo as práticas decolonias de resistência a essa "ordem geopolítica mundial que é conformada por uma clivagem estruturante moderno-colonial e que só pode ser compreendida a partir dessa tensão que a habita" (PORTO-GONÇALVES, 2005, p.3/4).

\section{Colonialidade/Modernidade e Urbanocentrismo}

Quijano (2005) pontua historicamente como as forças colonialistas e capitalistas europeias consolidaram um 
novo padrão de poder e dominação mundial, exercido pelos processos de inferiorização étnicos-raciais, territoriais, controle das relações de produção, recursos, força de trabalho com base no capital e no mercado mundial, consolidando a construção de uma supremacia branca europeia. A consolidação desse padrão de poder etnocêntrico (eurocêntrico) sobre o mundo, centralmente sobre a América e a África (a partir da exploração desses povos e da inferiorização de suas identidades), se constrói um padrão cognitivo, ou seja, onde o conhecimento do não-europeu (o negro e índio) se torna passado, primitivo, irracional e inferior.

Assim, sobretudo no século XVII, a Europa consegue se consolidar enquanto centro do mundo, com base na exploração e inferiorização da América e com base na exploração de mão-de-obra escrava. Desta forma, a Europa constitui-se como centro da civilização e do conhecimento, consolidando o eurocentrismo. $\mathrm{O}$ "processo de modernidade, produziu uma perspectiva de conhecimento e um modo de produzir conhecimento que demonstram o caráter do padrão mundial de poder: colonial/moderno, capitalista e eurocentrado" (QUIJANO, 2005, p.126). Nesse sentido, a Europa constrói o mito da modernidade eurocentrada, onde eles passam a ser os modernos da humanidade, colocando-se como os principais protagonistas da história do mundo. O mais intrigante disso tudo é que eles " foram capazes de difundir e de estabelecer essa perspectiva histórica como hegemônica dentro do novo universo intersubjetivo do padrão mundial do poder" (QUIJANO, 2005, p.122).

Logo, o processo se consolidou pautado em dois movimentos: apropriação das populações colonizadas, na busca do desenvolvimento do capitalismo que beneficiasse o centro europeu; e na repressão de diferentes "formas de produção de conhecimento dos colonizados, seus padrões de produção de sentidos, seu universo simbólico, seus padrões de expressão e de objetivação da subjetivi- 
dade" (QUIJANO, 2005, p. 121), na procura pelo despojamento das formas de existência, epistemologias e cultura dos povos colonizados, deslegitimando as experiências vividas não europeias.

Desse modo, o colonialismo se qualifica com uma das mais estruturadas armas do euocentrismo econômico, sociocultural, epistêmico e político, e mesmo com o fim colonialismo político (dominação que nega a independência política de povos subjugados), não se colocou fim nas desigualdades e hegemonias por ele geradas, o que permaneceu na forma de colonialidade. "La colonialidad, en consecuencia, es aún el modo más general de dominación en el mundo actual, una vez que el colonialismo como orden político explícito fue destruido." (QUIJANO, 2014, p.63). Assim, essa colonialidade é exercida nos dias atuais, ou seja, se estrutura em um padrão de poder, saber e ser centrado em uma ciência eurocêntrica, resultado do colonialismo, que ainda invisibiliza e deslegitima outras formas de conhecimento a partir de outras experiências sociais. O colonialismo/colonialidade leva a produção de uma cegueira aos modos de existir, pensar e conceber a realidade não-europeias, levando a reprodução das relações coloniais/imperiais pautadas em uma modernidade etnocêntrica, é uma perspectiva que impede observar que não há somente a Europa como espaço de ativo de enunciação de pensamentos, epistemologias e modos de organizar a realidade social (MALDONADO-TORRES, 2009; PORTO-GONÇALVES, 2005).

Um exemplo das questões que envolvem a colonialidade/modernidade, que se coloca a partir do capitalismo atualmente, é o neoliberalismo, e sua capacidade de se colocar como concepção hegemônica, "conhecimento objetivo, científico e universal e sua visão da sociedade moderna como a forma mais avançada, e, no entanto, a mais normal da experiência humana, está apoiada em condições histórico-culturais específicas" (LANDER, 2005, p.08). E, 
que não se torna apenas hegemonicamente na economia, mas na difusão de modos de vida pautados nessa lógica, tencionando e deslegitimando ações alternativas a essa concepção capitalista/colonial/moderna.

Nesse percurso, entende-se que a modernidade está intrínseca a colonialidade, bem como o capitalismo (MALDONADO-TORRES, 2009), Mignolo (2005) afirma que "não pode haver modernidade sem colonialidade; que a colonialidade é constitutiva da modernidade, e não derivativa". Assim, se sustenta o Eurocentrismo, partindo da criação da modernidade europeia, e as relações de colonialidade com o resto do mundo, dominando os processos e desenvolvimento desses países, e criando para subalternidades aos sujeitos não-eurocêntricos.

\begin{abstract}
Desse ponto de vista, as relações intersubjetivas e culturais entre a Europa, ou, melhor dizendo, a Europa Ocidental, e o restante do mundo, foram codificadas num jogo inteiro de novas categorias: Oriente-Ocidente, primitivo-civilizado, mágico/míticocientífico, irracional-racional, tradicional-moderno. Em suma, Europa e não-Europa (QUIJANO, 2005, p.122).
\end{abstract}

Nota-se que a colonialidade/modernidade/capitalista se sustentam a partir dessas dicotomias que afirmam o lugar de dominação da Europa contra a não-Europa, nessa tônica há a constituição de classificações sociais - sujeitos inferiores (dominados - índios, negros, camponeses) e superiores (dominadores - supremacia branca, masculina, urbana) (DUSSEL, 2005). Pautados nas questões raciais, geopolíticas e no fortalecimento da Europa enquanto centro da modernidade, que justifica a invasão cultural, econômica e política de outros continentes.

A partir das transformações sociais, como a superação do colonialismo, há a consolidação dos Estados-nações periférica, em um sentido eurocêntrico (QUIJANO, 2005), onde ainda perpassa e finda as relações de colonialidade global. Essa colonialidade global se configura, não saindo 
da sua característica eurocêntrica, mas se potencializando a partir de outras perspectivas, como o próprio imperialismo norte-americano e europeu, que tem articulado formas de dominação socioeconômica e cultural com a América Latina. O reflexo disso são as perspectivas neoliberais, já citadas anteriormente, que vem se colocando a partir das novas instituições do capital, como a Fundo Monetário Internacional (FMI), Banco Mundial, bem como instituições de inteligência que se consolidaram pós-segunda guerra e vem mantendo as relações de subordinação com a América Latina, a partir da ideia de globalização ${ }^{5}$.

Cabe sinalizar que o eurocentrismo não beneficia apenas populações europeias, mas pôr as populações de origem ou que assimilam as concepções europeias que estão em "todas partes del mundo que gozan de los privilegios de la supremacía blanca en relación a poblaciones de origen no-europeo" (GROSFOGUEL, 2016, p.04). Assim, a crítica a esse movimento se dá a todos os sujeitos que fazem manutenção desses sistemas de dominação para se colocar em lugares de poder.

Por esse ângulo, o Urbanocentrismo também está intrínseco à construção da colonialidade/modernidade, tendo em vista que o ideal moderno e civilizatório para se constituir o homem moderno, estava vinculado com os modos de vida (cultura, comportamentos) e produção (capitalista - industrial) urbanos, as inserções nos espaços rurais se dão apenas por vias que deslegitimam e desqualificam os modos de existência expressão cultural desses, ou na exploração da natureza - como o agronegócio, ou estratégias que legitimam estereótipos e inferiorização. Sempre sobre a égide da civilização/urbano/colonial/capitalista. Essa concepção "privilegia o polo urbano do conti-

\footnotetext{
5 "A globalização em curso é, em primeiro lugar, a culminação de um processo que começou com a constituição da América e do capitalismo colonial/moderno e eurocentrado como um novo padrão de poder mundial" (QUIJANO, 2005 , p. 117). E atualmente se mobiliza centralmente a parir da globalização neoliberal.
} 
nuum como a fonte do progresso e dos valores dominantes que se impõem ao conjunto da sociedade. O extremo rural do continuum, visto como o polo atrasado tenderia a reduzir-se sob a influência avassaladora do polo urbano" (WANDERLEY, 2001, p.32). Assim, o espaço não-urbano é deslegitimado enquanto território de enunciação epistêmica, ontológica, econômica e cultural.

Os vestígios dessa concepção podem ser vistos a partir das análises realizadas por González Stephan (1995) ao estudar os manuais de urbanidade impostos a América Latina no século XIX, que tinha como objetivo direcionar a formação de sujeitos civilizados, para atingir o ideal de modernização eurocêntrica, a partir de um padrão de cidadania normatizado e que exclui qualquer existência que fuja do padrão normativo-moderno-eurocêntrico. "A aquisição da cidadania é, então, um funil pelo qual só passarão aquelas pessoas cujo perfil se ajuste ao tipo de sujeito requerido pelo projeto da modernidade: homem, branco, pai de família, católico, proprietário, letrado e heterossexual" (CASTRO-GÓMEZ, 2005), e, obviamente, urbana. Não existiam manuais para que direcionassem a constituição de um perfil ideal de camponês, de negro ou de índio, pois esses já eram considerados no âmbito da barbárie, da irracionalidade, da impossibilidade de vivenciar e enunciar modos de vida legítimos. Os manuais eram para sujeitos que estava sob um território (urbano) legítimo de enunciação epistêmica, moral, racional e estética. Assim, pensa-se centralmente na constituição, a partir da colonialidade, de bons cidadãos, constrói-se o ideal de cidadania .

La cuestión, era ser um hombre o mujer de apariencia $<<$ civilizada $>>$; que sus modales no dejaran translucir ningún rasco o gesto que recordara viejos usos rurales, probablemente tildados de <<inciviles $>>$ o $<<$ bárbaros $>>$ por esta nueva sociedad cada vez más estirada como moderna (GONZÁLEZ STEPHAN, 1995, p.434).

Assim, há a construção de um pensamento abissal 
, onde a "A "entrada" no banquete da modernidade demandava o cumprimento de um receituário normativo que servia para distinguir os membros da nova classe urbana que começava a emergir em toda a América Latina durante a segunda metade do século XIX" (CASTRO-GÓMEZ, 2005, p.82). Onde os territórios rurais e seus sujeitos não possuem espaço, criando o abismo - a inexistência desses. Consolida-se o abismo entre um "nós" modernos-urbanos-eurocêntrico-normativos, e os "outros" que estão no âmbito da barbárie, irracionalidade, atraso, antigo. Pois, esse processo de diferenciação exigia ampliar os mecanismos e as ideias de distinção, para legitimar a norma enquanto o ideal e o correto, assim, a urbanidade se torna o critério de distinção fundamental para a consolidação do padrão de poder urbano/eurocêntrico/moderno (GONZÁLEZ STEPHAN, 1995).

Criar a identidade do cidadão moderno na América Latina implicava gerar uma contraluz a partir da qual essa identidade pudesse ser medida e afirmada como tal. A construção do imaginário da civilização exigia necessariamente a produção de sua contraparte: o imaginário da barbárie (CASTRO-GÓMEZ, 2005, p.82, grifos do autor).

Cabe destacar que a criação dessa estrutura abissal, e assim, a ideia de modernidade eurocêntrica, se dá desde o descobrimento das Américas e o processo de colonização, para assim, justificar o padrão de dominação aos outros povos, caracterizando também as relações pré-capitalistas ${ }^{6}$ (QUIJANO, 2005). Essas normas de existência, difundidas e legitimadas na América Latina, exclui então a existência, enquanto sujeitos, agentes de direitos e legitimidade cultural e social, dos povos que vivem no campo. Não poden-

\footnotetext{
6 "[...] o capitalismo como sistema de relações de produção, isto é, a heterogênea engrenagem de todas as formas de controle do trabalho e de seus produtos sob o domínio do capital, no que dali em diante consistiu a economia mundial e seu mercado, constituiu-se na história apenas com a emergência da América" (QUIJANO, 2005, p.126).
} 
do esquecer que esse padrão de ser, posto arbitrariamente, está baseado na constituição do homo economicus, onde o capitalismo vai tomando a centralidade como modelo socioeconômico ideal moderno (CASTRO-GÓMEZ, 2005).

Desta maneira, entende-se que esses padrões de poder pautados no eurocentrismo/colonialidade/modernidade e urbanocentrismo, que se constrói desde a Invasão das Américas (e a invenção do outro, a partir de dicotomias) e vão se fortalecendo no decorrer dos séculos, perpassam a existência, e, sobretudo, configura-se sob a dominação e subordinação da população do campo. Desta forma, no próximo tópico busca-se compreender como esses processos se dão olhando especificamente para as colonialidades que atingem esses sujeitos.

\section{Colonialidades e os sujeitos do Campo}

Pode-se identificar que essa colonialidade perpassa a existência e as relações social nos seguintes eixos: colonialidade do poder, do saber, do ser e da natureza. Sob o viés freireano, essas colonialidades se dão pela invasão cultural, ou seja, na "penetração que fazem os invasores no contexto cultural dos invadidos, impondo a estes sua visão do mundo, enquanto lhes freiam a criatividade, ao inibirem sua expansão" (FREIRE, 1987, p.86). Desta forma, as colonialidades que se discorre aqui, se dão a partir desse movimento, focando, especialmente, nos povos do campo brasileiro. Assim, pretende-se refletir sobre os impactos dessas colonialidades, que são intrínsecas a modernidade, urbancentrismo e ao capitalismo, nos sujeitos do campo que sofreram e sofrem a ferida colonial.

A Colonialidade do Poder se refere é a construção do padrão de poder historicamente constituído sob as bases da modernidade/eurocentrismo, que se apoio a partir dos critérios raciais/étnicas, gênero, território, trabalho e sobre a ideia de racionalização, padrão de pensar e de se viver. 
Assim, tudo que foge dos padrões impostos pela colonialidade do poder (que confere poder de dominação) não possui legitimidade para o exercício de poderes, pois não seguem os critérios coloniais/modernos/europeus, pelo contrário servem para legitimar a superioridade eurocêntrica e seu poder de dominação. Se constroem então classificações sociais, que legitima lugares do dominador e dominado - opressor e oprimido - patrão e empregado - superioridade racial/étnica/geográfica e inferioridade racial/étnica/geográfica (QUIJANO, 2005).

Silva et al. (2014) sinalizam que a colonialidade do poder subsidia a construção da dicotomia cidade-campo, onde, a partir do urbanocentrismo, a cidade é tomada como lócus de enunciação legítimo e o campo é subalternizado a vida citadina, por meio da inferiorização cultural, social, epistemológica, racial/étnica e econômica (SILVA, TORRES e LEMOS, 2012). Ou seja, a identidade camponesa é marginalizada para potencializar o padrão eurocêntrico, moderno, colonial e capitalista da identidade urbano, que vira a referência de bom cidadão (SILVA e SILVA, 2014). Existe, assim, a estruturação de um padrão de poder urbano, que busca criar representações sociais de um campo bárbaro, atrasado, inferior, onde as existências dos sujeitos que ali se constroem são desumanizadas. Procura-se criar complexos de inferioridade, na busca de silenciamento desses sujeitos, para que assim o padrão urbano não tenha qualquer ameaça de imperar enquanto verdade natural. Essa colonialidade, a partir de um padrão de existência urbano, se constrói a partir da epistemologia eurocêntrica, e assim, transforma-se também um uma colonialidade do Saber.

A Colonialidade do Saber aponta para a ferida em uma perspectiva epistemológica eurocêntrica, que deslegitima e inviabiliza olhar para outros sujeitos epistemológico não-eurocêntricos, minando a constituição de processos que considerem a diversidade de pensamento que as múlti- 
plas experiências no mundo desenvolvem (PORTO-GONÇALVES, 2005). Isso leva a um epistemicídio ${ }^{7}$, através do silenciamento e dos próprios genocídios que ocorreram nas resistências coloniais. O padrão de saber eurocentrado realiza ações para reprimir "as formas de produção de conhecimento dos colonizados [...]" (QUIJANO, 2005, p.121).

Esse processo impacta nos sujeitos do campo "impondo a validade epistêmica ao lócus urbano e retirando a credibilidade das epistemologias campesinas, originadas das matrizes culturais desses povos considerados inferiores e, portanto, não validados a produzir conhecimento" (SILVA et al., 2014, p.15). Assim, esse lugar que não atende a norma arbitrariamente imposta enquanto natural, é descartada enquanto lugar de enunciação de conhecimento, de saberes válidos, impossibilitando a inserção de suas perspectivas de mundo nos processos de constituição social (SILVA, TORRES e LEMOS, 2012). Esses eixos da colonialidade acabam desenvolvendo a colonialidade da própria existência do ser, o que não pode e o que não sabe acaba não sendo - Colonialidade do Ser.

A Colonialidade do Ser resulta da dinâmica da colonialidade do poder e do saber, se dá nos processos de dominação que foram vivenciados historicamente e culturalmente, gerando feridas coloniais. Há a produção de representações sociais a partir da colonialidade do ser, e esta é base para constituição do ser negro, ser camponês, ser mulher, ser latino-americano, ser superior, ser inferior. Maldonado-Torres (2007) aponta essa construção a partir da ideia cartesiana "penso, logo existo", dinâmica difundida a partir do eurocentrismo, modernidade e urbanocentrismo. Assim, quem pensa é o sujeito moderno/europeu, logo ele existe, ele é (ser). Porém, a partir da colonialidade do saber, os sujeitos colonizados/latino-americanos, não

\footnotetext{
${ }^{7}$ Processo onde a "riqueza imensa de experiências cognitivas [dos sujeitos colonizados e marginalizados - não eurocêntricos] tem vindo a ser desperdiçada" (SANTOS, 2009, p.52), anulada e morta.
} 
pensam (pois possuem suas epistemológicas deslegitimadas - aponta como irracional - representadas socialmente nesse sentido), sendo assim, eles não existem, não são (ser).

Essa ideia tem suas raízes nos processos de colonização, e se potencializa com a ideia cartesiana, através agora não mais da teologia (seu papel se torna secundário), mas da construção da ciência moderna/ocidental. "La ausencia de la racionalidad está vinculada en la modernidad con la idea de la ausencia de "ser" en sujetos racializados" (MALDONADO-TORRES, 2007, p. 145). Ademais, a partir da colonialidade há o aniquilamento das possibilidades de ser, de se construir identidades e ontologias a partir da sua existência negra, indígena, camponês, feminina, entre outras, é a negação da humanidade (QUIJANO, 2005).

Esses aspectos atingem os sujeitos do campo na medida que agenciam processos de incorporação banalizados por concepções estereotipadas, inferiores, de atraso e ignorância do ser do campo, pois esses não possuem como referência a urbanidade estabelecida. Justificando ordens de desumanização, ou seja, retirando suas potencias enquanto sujeitos políticos, sociais, epistêmicos e culturais e de direitos, silenciamento do ser (SILVA et al., 2014; SILVA, TORRES e LEMOS, 2012). "A colonialidade do Ser refere-se ao processo pelo qual o senso comum e a tradição são marcados por dinâmicas de poder de caráter preferencial: discriminam pessoas e tomam por alvo determinadas comunidades" (MALDONADO-TORRES, 2009, p.363). Fortalecendo as dicotomias entre cidade-campo, reforça-se a discriminação do campo, para que assim, não haja qualquer possibilidade de considerá-los enquanto sujeitos que são (SILVA e SILVA, 2014).

Colonialidade da Natureza, esse eixo se consolida segundo a construção de um binarismo entre natureza e sociedade, que se dá ela própria ideia de colonialidade do poder e saber, fundada na ideia eurocêntrica/moderna/civilizatória/urbana, relação do homem colonizador com a 
natureza acontece alicerçado na dominação, exploração e expropriação. De acordo com Walsh (2008), isso se constrói no momento que há a deslegitimação das relações entre o mágico-espirítual-social-ancestral e a natureza enquanto sistemas integrados de muitos povos subalternizados da América Latina (índios, negros, camponeses).

Al negar esta relación milenaria, espiritual e integral, explotar y controlar la naturaleza y resaltar el poder del individuo moderno civilizado (que aún se piensa con relación al blanco europeo o norteamericano) sobre el resto, como también los modelos de sociedad «moderna»y «racional» con sus raíces europeo-americanas y cristianas, este eje de la colonialidad ha pretendido acabar con todo la base de vida de los pueblos ancestrales, tanto indígenas como afrodescendentes (WALSH, 2008, p.139).

As relações com a natureza, que demarcam outras experiências sociais, voltadas para conservação, ancestralidade e integração, vão de desencontro com a dominação colonial, e fundamentalmente com as lógicas socioeconômicas capitalista. Assis (2014) coloca a Colonialidade da Natureza como uma estratégia de acumulação de capital fundada na exploração dos territórios e recursos naturais da América latina. Assim, ocorre uma construção a partir da égide modernidade/colonialidade/eurocentrismo/urbanidade de formas de exploração econômica-instrumentais de expropriação da natureza para a acumulação de capital e a conservação do poder socioeconômica eurocêntrico, ou seja, conservação do padrão de poder moderno/colonial. Essa colonialidade toma a existência de hegemonias de extração e compreensão da natureza, considerando-a como recursos mercadológico, e nesse sentido, deslegitima as relações de respeito dos negros, indígenas e camponeses com a natureza para justificar as relações de poder e dominação com a terra e com os sujeitos que vivem nela.

Essa colonialidade atinge os sujeitos do campo, pois seus territórios passam a ser considerados como espaço a 
serem explorados pelo capital - agronegócio. Há a coisificação do território dos sujeitos do campo, onde o homem moderno - que preza o progresso econômico - tem o poder e o direito de explorar esse território (SILVA, TORRES e LEMOS, 2012). Para o camponês é um território de vida, de produção de subjetividade, de sentidos, ancestralidade e cultura, assim, já para a ordem da colonialidade é um espaço a ser explorado e seus habitantes silenciados.

“De acordo com os eixos da Colonialidade os sujeitos não podem, não sabem e não são, portanto, seus territórios de origem são insignificantes" (SILVA et al., 2014, p.16). Nota-se então a construção de um movimento complexo de colonialidade, onde se estabelece pelo silenciamento, abafamento e extermínio dos modos de existência dos povos do campo, a partir de múltiplos processos urbanocentrado/eurocentrados/civilizatórios/modernos, que se consolidam historicamente e atualmente a partir de diversas estratégias de dominação socioeconômica, cultural e educacional. Desta maneira, a partir desse entendimento, que dá luz a reflexão que o trabalho se propõe, tenta-se aqui olhar como se consolida a Educação nos territórios do campo, tendo em vista a Colonialidade do poder, saber, ser e da natureza que subalternizam os sujeitos do campo.

\section{EDUCAÇÃO E CAMPO - Colonialidade da Educação}

A educação é compreendida como prática social, cultural e histórica, que se caracteriza a partir de movimentos de formação de sujeitos, ocorrendo em espaços institucionais e não-institucionais (GONDRA e SCHUELER, 2008). Aqui as reflexões serão realizadas apoiada nesses dois contextos, porém, centralizaremos em aspectos que envolvem a construção da educação institucional no Brasil - a educação escolar - enquanto espaço de reprodução e produção, perpassa a existência de variadas finalidades 
de acordo com a conjunturas e a historicidades. Destarte, a sociedade, a família, a religião, a estrutura sociopolítica e cultura em determinados contextos históricos delegaram a educação escolar finalidades, que dentro das estruturas de poder se colocam em certa medida submetidas a essas demandas no processo de transmissão de conhecimento e difusão de certos comportamentos. Porém, entende-se que esse lugar não é apenas reprodução dessas demandas, mas também se estabelece e se produz processos próprios, estratégias próprias no processo de educação de sujeitos, marcados pelas demandas externas, mas que produzem funcionamentos internos, que acaba caracterizando a cultura escolar ${ }^{8}$ (JULIA, 2001).

Deste modo, compreende-se que as colonialidades perpassam a existência, consolidação, reformas, dinâmicas e finalidades da Educação Escolar, na consolidação das suas finalidades, e por consequência na produção da cultura escolar - que estão estreitamente realidade com os aspectos do colonialismo/colonialidade/modernidade/eurocentrismo. Desta maneira, aqui busca-se constatar que no Brasil perpassa um processo que se denomina aqui como a Colonialidade da Educação, ou seja, há a consolidação de uma estrutura de educação institucional que é cortada pelo colonialismo e pela colonialidade, e todos os movimentos de modernidade/urbanocentrismo/civilidade/ eurocentrismo/capitalismo que estão intrínsecas a essas perspectivas. Tendo como finalidade compreender, especificamente, como a Educação nos territórios rurais foram se constituindo dentro desse processo.

A escola historicamente se constrói enquanto lugar de incorporação das ideias da modernidade, e assim, en-

\footnotetext{
8 "Para ser breve, poder-se-ia descrever a cultura escolar como um conjunto de normas que definem conhecimentos a ensinar e condutas a inculcar, e um conjunto de práticas que permitem a transmissão desses conhecimentos e a incorporação desses comportamentos; normas e práticas coordenadas a finalidades que podem variar segundo as épocas (finalidades religiosas, sociopolíticas ou simplesmente de socialização). " (JULIA, 2001, p.10).
} 
quanto espaço urbanocentrado, tendo suas demandas direcionadas para os aspectos que marcam a cidade. Na realizada nacional essas perspectivas se consolidam fundadas no colonialismo e logo em seguida na colonialidade.

Dentro dessas questões a escola tem sua forma articulada com as finalidades da modernidade/urbanocentrismo, porém, a escola não se coloca na reprodução dessa nova ordem, mas também acaba participante das produções de modos de existência que as legitime, em busca da ordem - normatização de corpos a partir da civilidade. Assim, a normas eurocêntricas desencadeiam historicamente no Brasil, onde as ideias de modernidade urbanocêntrica e civilidade tomam a escola como lócus privilegiado das ações para disseminação das ordens, onde é espaço de desenvolvimento social e cultural em prol do progresso moderno (GONZÁLEZ STEPHAN, 1995). Assim, pode-se "dizer[...] que existem temas e momentos do fazer histórico em que é possível visualizar com muita nitidez este cruzamento entre o escolar e o urbano" (FARIA FILHO, 2005, p.31).

Assim, dentro da égide da modernidade eurocêntrica e colonial, a Escola se constrói enquanto espaço onde os processos pedagógicos institucionais se articulam para a materialização de um país com base na modernidade. "A escola transforma-se num espaço de internamento onde se forma esse tipo de sujeito que os ideais reguladores [...]. O que se busca é introjetar uma disciplina na mente e no corpo [...]" (CASTRO-GÓMEZ, 2005, p.82) que legitime a ideias das colonialidades, e a partir da epistemicídio de outras maneiras de se conceber a realidade. Há uma busca pela homogeneização dos sujeitos, onde o comportamento “deverá ser regulamentado e vigiado, submetido à aquisição de conhecimentos, capacidades, hábitos, valores, modelos culturais e estilos de vida" (CASTRO-GÓMEZ, 2005, p. 82) eurocentrados, e que são dispostos para uma parcela privilegiada da população, onde o acesso se res- 
tringem aos sujeitos que possuem uniformidade a partir dos critérios de raça, gênero, comportamento e epistemologia. A escola se consolida assim, como o lugar de difusão e homogeneização de sujeitos predisposto (brancos, elites, urbanos) a se encaixar dentro dos critérios da modernidade. Historicamente há inserções, onde os mulheres, negros, camponeses e índios são introduzidos dentro desses espaços escolares, mas há uma infinidade de critérios, que permanecem inferiorizando e (re) produzindo modelos de dominação. Como o processo de introdução da Educação nos territórios rurais, que aconteceu depois de séculos de invisibilidade, e que ocorreu (re) produzindo ideias de marginalização e inferiorização cultural, deixa de lado dentro dos planos estatais, pois a urbanidade sempre foi priorizada enquanto espaço de vida legitimas, ou seja, conservando estruturas de poder (LEITE, 1999).

“Em outras palavras, como parte do novo padrão de poder mundial, a Europa também concentrou sob sua hegemonia o controle de todas as formas de controle da subjetividade, da cultura, e em especial do conhecimento, da produção do conhecimento" (QUIJANO, 2005, p.121). Compreende-se que os ideais baseados nos padrões de poder, saber, ser e na compreensão da natureza, perpassa a consolidação da Educação, enquanto instituição urbano/ moderna, que foi e ainda é utilizada para (re) produzidor esses padrões ao conceber as formas educacionais nos territórios do campo.

Busca-se aqui apontar suas marcar a partir das teorias da colonialidade/modernidade, tentando apontar brevemente para a historicidade que marca esse movimento, essencialmente no Brasil. Pois, Leite (1999, p.14) afirma

A educação rural no Brasil, por motivos socioculturais, sempre foi relegada a planos inferiores, e teve por retaguarda ideológica o elitismo acentuado do processo educacional aqui instalado pelos jesuítas e a intepretação política-ideológica da oligarquia agrária conhecida popularmente na expressão: "gente da roça não carece de estudos. Isso é coisa 
Assim, a trama que envolve a Educação nesses territórios geograficamente demarcados, mas que, sobretudo, comportam modos de vida diversos, é desenvolvida historicamente a partir de diversas ideologias, demarcada pela dicotomia rural-inferior e urbano-superior. Silva, Torres e Lemos (2012) pontuam essas trajetórias de marginalização dos povos do campo, que marcam desde as capitanias hereditárias até o processo do agronegócio, enquanto espaço sempre de expropriação dos sujeitos e dos objetos, onde é Educação escolar se articulou enquanto possibilidade para inculcar ideias de inferiorização, urbanocêntrica e desumanizadora.

Esses movimentos na educação brasileira são nítidos em cada período, seja em uma perspectiva teológica (renascentista, cristã) ou egológica (moderna, cartesiana), sendo a ideia de modernidade eurocêntrica universalizada, e assim, intrínseca dentro de todo esse processo, bem como o urbanocêntrico e o capitalismo enquanto sistema universal. É importante reafirmar que quando se refere a grupos que legitimam e (re) produzem a colonialidade, não se refere somente aos sujeitos de origem europeia, mas também aos próprios grupos (elites locais) brasileiros que se beneficiaram e exerceram o processo de dominação eurocêntrica, com base na modernidade, branca e no urbanocentrismo - as elites intelectuais, religiosos, políticas, latifundiários. Assim, a crítica se dá a todos esses sujeitos, que subordinaram e subordinam através do eixo da modernidade/colonialidade, os povos negros, indígenas, as mulheres e os povos do campo.

O marco da Colonialidade da Educação, é na própria colonização do Brasil, onde constroí-se as identidades sociais (europeu, negro, índio) a partir das relações de poder e hierarquia racial, onde há a inferiorização do povo que já habitava esse território, e do povo negro escravizado, fun- 
dando a ideia da superioridade europeia enquanto a identidade superior nas relações coloniais (QUIJANO, 2005).

A Educação é marcada com a chegada dos Jesuítas, que instituem uma forma escolar que tem papel central na organização social da colônia portuguesa, na difusão da cultura portuguesa/eurocêntrica, e no processo de alfabetização e catequização dos índios e cristãos, assim a teologia direcionava centralmente essa educação. Esse processo estava imerso aos ataques entre índios e colonizadores, pois a colonização não ocorreu de forma pacífica, a luta contra os índios foi traçada no sentido de dominação territorial e também cultural. Assim, a escola operava, sobretudo, um processo de aculturação, pautada na colonialidade do poder, saber, ser, e assim, da própria natureza (território indígena), índios eram impensáveis enquanto sujeitos de enunciação cultural e epistemológica. Isso ocorre também nas relações com os negros escravizados, porém, esse não tinha a perspectiva nem da aculturação, pois não eram considerados em nenhum sentido seres humanos. Em certo momento a própria catequização dos índios é sinalizada como desnecessária, sendo a Educação escolar direcionada apenas para filhos (homens brancos) dos principais (elite europeia), que seriam os sujeitos hegemonicamente dominantes na constituição colonial, dotados de marcas teológicas, culturais, raciais, europeias, que marcariam sua superioridade, para serem vigilantes culturais da cultura portuguesa, e também articular normas e comportamentos com base em virtudes cristãs/eurocêntricas/colonizadoras/urbanas/latifundiárias (PAIVA, 2003).

Assim, a escola se torna espaço de articulação e difusão cultural, na formação da elite que comandaria essas novas terras, que em determinados momentos quis aculturar os índios via a escolarização, buscado a domesticação dos mesmos. E o negro, objetificado e animalizado, não entrava, sequer, como possibilidade de ser pensado no processo de escolarização. Paiva (2003, p.44) aponta 
que "os portugueses colonizadores só tinham uma visão de sociedade, visão esta que se realizava na sua sociedade e, portanto, tendo-a como modelo, agiam segundo em seu relacionamento com as demais culturas". Nesse sentido, a escola consolida a partir de apenas uma epistemologia, colonizadora, onde se inicia o processo em que a Europa se coloca como centro do mundo a partir das relações de poder fundadas com a América, e que se fundamentava sobre a busca obsessiva pelo novo (PORTO-GONÇALVES, 2005).

Há um epistemicído de outras visões de sociedade e de organizações de vida. A formas de vida indígenas e negras são exterminadas, não apenas no abafamento epistêmico, mas no próprio genocídio dessas populações, que de se certa maneira se aproximam, do que veio a se consolidar enquanto a população rural, com suas relações ancestrais, históricas e culturais com o meio ambiente, as relações comunitárias, as alternativas agrícolas. Pode-se dizer que essas estruturas já dita o urbanocentrismo, e já estereotipa os sujeitos que vivem em proximidade com a natureza, como animais, bárbaros, sem alma e sem cultura. A colonialidade do ser, a partir do padrão de poder e saber e dominação territorial ocorre, os "padrões de produção de sentidos, seu universo simbólico, seus padrões de expressão e de objetivação da subjetividade" (QUIJANO, 2005, p.121) não-europeus são reprimidos e exterminados, onde na escola apenas a cultura eurocêntrica é passível de enunciação, com base fundamental na religião, que forma vigilantes culturais para não permitir outras formas de expressões na sociedade brasileira.

Essas marcas permanecem com as transformações das Reformas Pombalinas (com a expulsão dos Jesuítas da estrutura escolar), que agora se assenta sob uma nova perspectiva de modernidade, centrada principalmente na construção da ciência moderna (BOTO, 2011). Então, ainda sob a construção eurocêntrica, na tentativa de supe- 
rar as perspectivas teológicas (na verdade ela é secundarizada), os pensamentos ilustrados e cartesianos impõem um novo sentido na modernidade que vem se construído desde a colonização. Compreendendo que "[...] las políticas teo- y ego-lógicas del conocimiento se basaron en la supresión tanto de la sensibilidad como de la localización geo-histórica del cuerpo " (MIGNOLO, 2011, s/p), que se colocaram enquanto universais em uma só perspectiva (eurocêntrica). Desta maneira, ambas percepções articulam epistemicídios, porém, agora, a perspectiva egológica os atributos vinculados a Deus se direcionam para o homem branco-ocidental-urbano-moderno, e seu poder de enunciar perspectivas universais de conhecimento, comportamento, existência se potencializa com base na ciência moderna (GROSFOGUEL, 2009). Pois, como já demarcamos anteriormente quem pensa e logo existe está marcado por atributos que não se encaixam no ser camponês - colonialidade do ser, saber e poder.

Desde o século XVIII, sobretudo com o Iluminismo, no eurocentrismo foi-se afirmando a mitológica ideia de que a Europa era pré-existente a esse padrão de poder, que já era antes um centro mundial de capitalismo que colonizou o resto do mundo, elaborando por sua conta, a partir do seio da modernidade e da racionalidade. E que nessa qualidade, a Europa e os euro $\neg$ peus eram o momento e o nível mais avançados no caminho linear, unidi $\neg$ reccional e contínuo da espécie. Consolidou-se assim, juntamente com essa ideia, outro dos núcleos principais da colonialidade/modernidade eurocên $\neg$ trica: uma concepção de humanidade segundo a qual a população do mundo se diferenciava em inferiores e superiores, irracionais e racionais, primitivos e civilizados, tradicionais e modernos (QUIJANO, 2009, p.75).

A construção dessas dicotomias, afirmam e direcionam para a própria dicotomia campo-cidade, afirmando a cidade enquanto sinônimo do processo e moderno. Assim, a Educação se mantém dentro desses vieses, porém agora inicia-se a construção da educação gratuita à população da colônia, mas ainda não de forma igualitária em todo 
território, e fortemente voltadas para políticas educacionais banalizadas no ideário ilustrado de enaltecer o Império Português. Com o processo que transformou o Rio de Janeiro em sede do Império Português a política Joanina articula a criação da cidade "em símbolo da civilização" (GONDRA e SCHUELER, 2008, p.25). Essa ideia segue na consolidação de uma educação para afirmação da elite ilustrada. Ocorre ações precárias de educação nas áreas rurais, porém a centralidade é no espaço urbano. Focando na assimilação de um ideal eurocêntrico para a formação dos vigilantes da cultura, e para a próprio crescimento econômico e consolidação da ciência moderna (BOTO, 2011). Consequentemente, a difusão de qualquer espaço para a enunciação de povos subalternos na consolidação política, economia e cultural no sistema educacional é inviabilizada, o Brasil ainda é um apêndice de Portugal, marcado pela dominação do saber, ser e saber propriamente colonial.

Fonseca (2009, p.323) reitera que "A urbanidade e a civilidade, pilares importantes para a educação das elites, teriam, assim, na figura do mestre o centro irradiador do exemplo", onde a educação toma como prioridade a inculcação desses comportamentos civilizatórios - urbanos, onde o próprio docente se torna exemplo desses aspectos do iluminismo, marcados pela moralidade cristã e a ciência moderna. Essa ideia se internaliza por toda a história de Educação Brasileira, baseada na negação e marginalização do campo enquanto espaço de produção epistêmica e cultural para compor o projeto societário. Nobert Elias aponta para esses processos civilizatórios, que ocorrem desde o século XVI com a colonização da América, e tem a escola como papel fundamental, para assim, disciplinar corpos e mentes, inculcar comportamento, distinções, classificações sociais vinculadas com a ideia eurocêntrica de superioridade, que se reiteram ao longo das conjunturas (BOTO, 2014).

Mesmo direcionado por esse processo de moderni- 
zação eurocêntrica, o Brasil se torna um Estado independente - Império do Brasil ${ }^{9}$ (GONDRA e SCHUELER, 2008). Esse processo é essencial para compreensão da colonialidade no Brasil, pois aqui, a dominação europeia-moderna-colonial, deixa de ser marcada pelo colonialismo formal, pois há uma emancipação política, e se torna uma dominação baseada na Colonialidade na essência do conceito. Ou seja, a colonialidade

[...] se refiere a un patrón de poder que emergió como resultado del colonialismo moderno, pero que en vez de estar limitado a una relación formal de poder entre dos pueblos o naciones, más bien se refi ere a la forma como el trabajo, el conocimiento, la autoridade y las relaciones intersubjetivas se articulan entre sí, a través del mercado capitalista mundial y de la idea de raza" (MALDONADO-TORRES, 2007, p.131).

Assim, sinaliza-se a consolidação do Império Brasileiro não como uma emancipação total, mas onde o colonialismo se consolida e se estruturam de forma diferentes - Colonialidade.

A ideia de modernização e civilidade se potencializa, difundindo de maneira contundente as dicotomias entre cidade - rural, pois, além dos povos do campo não estarem nos espaços de difusão da cultura arbitraria (urbana e eurocêntrica), esses apresentavam forma de vida desarmônica com a nova lei da modernidade/capitalista/ branca/letrada, tendo seu papel subalternizado no desenvolvimento dessa nação, pois não passavam pelo funil que determinava a civilidade (CASTRO-GÓMEZ, 2005), para a consolidação de um projeto nacional (invenção do Brasil),

${ }^{9}$ Utiliza-se os eventos político-administrativos para se compreender a constituição da sociedade brasileira em três formas: Colônia (1500-1822), Império (1822-1889) e República (1889 - atualmente). Assim, entende-se que esses períodos são formas importantes para entender a constituição da Educação escolar nesse território. Porém, também é importante sinalizar suas insuficiências para explicar acontecimentos tão complexos, sendo necessário perceber os acontecimentos que fogem dessa normativa (GONDRA e SCHUELER, 2008). 
a partir de novas marcas culturais e urbanas, ainda de base eurocêntrica, para a constituição da comunidade nacional.

O Império se constrói no desejo por esse projeto político calcado na ideia de nação, com base no colonialismo/ colonialidade e na modernidade, se manifesta "no incentivo às instituições educacionais, culturais e cientificas e no mecenato às artes e à produção cultural" (GONDRA e SCHUELER, 2008, p.28). Objetivando a formação escolar de elites especialistas que iriam difundir e produzir a ciência moderna, a literatura, língua pátria, conhecer o território do novo império, que (re) produziu as bases do colonialismo/colonialidade para se beneficiarem, e legitimarem sua supremacia branca, burguês e urbana em território nacional.

A Educação imperial, de forma geral, dentre os diversos avanços, que almejavam uma educação pública nas províncias e o surgimento de leis educacionais, ainda tinha o acesso à Educação escolar pautado nas relações de distinção sob o crivo da superioridade e inferioridade. Assim, os negros, índios e camponeses ainda estava a margem, considerados não-cidadãos, marcando principalmente os negros escravizados. Porém, ainda há a inserção e discussão de uma educação voltada para os índios, negros libertos, mulheres, se dando a partir da domesticação desses corpos, civilização, sob critérios de civilidade branca/ europeia/burguesa, com bases racistas, elitistas e moralista. Tendo em vista, que o próprio modelo de monarquia constitucional defendidos pelos defensores da liberdade da colônia eram brancos e proprietários de escravos com o desejo de um Império que

[...] preservasse os seus privilégios como, por exemplo, as propriedades e os regimes de trabalho escravo [...]. E este foi o modelo de Estado implantado no Brasil: uma monarquia constitucional, regida por homens brancos e com a manutenção do trabalho escravo" (GONDRA e SCHUELER, 2008, p.48). 
Assim, na constituição do Estado-nação, há a negação da participação dos povos subalternizados nas tomadas de decisões na organização social, política e educacional, a minoria branca se coloca no poder em agir e afirmar sua supremacia, mantendo sua expansão territorial (latifundiária) econômica, religiosa e cultural, com fonte no trabalho escravo. E, sobretudo, articulando políticas educacionais que tinha como foco a afirmação dessa supremacia e seus signos urbanos, tendo o campo como fonte de exploração. Quijano (2005, p. 134) afirma "os negros não eram nada além de escravos e a maioria dos índios constituía-se de povos da Amazônia, sendo desta maneira estrangeiros para o novo Estado. [...] [A configuração é a seguinte: ] Estados independentes e sociedade coloniais", marcando a colonialidade arraigada nesses movimentos, onde a classe dominante eurocêntrica realizavam ações de manutenção do colonialismo sob a tônica da civilização de um país e formação de um povo.

Até aqui, nota-se processos que estabelecem um status quo, pois há estratégias de receitas transplantadas (coloniais/eurocêntricas/modernas) para as questões brasileiras. Assim, essas ações não surgem de análises críticas da realidade nacional, mas que se consolidam na conservação de padrões de dominação que conservam a elite dominadora - que se beneficiam da colonialidades e as (re) produzem (FREIRE, 2016). A partir da República essas estruturas colonialistas se conservam, mas mais uma vez tomam formas diferentes, e é onde a pauta da Educação escolar dos povos do campo tomam, em alguma medida, visibilidade, porém com variadas contradições para se manter o status quo da colonialidade.

Com a iniciação República (1889 - atualmente) o ideal urbanocêntrico se centraliza mais do que nunca, a modernização e a colonialidade busca prescrever dinâmicas "con el nuevo estilo urbano de vida que se estaba deseando como emblema de la soñada $<<$ civilización $>>$ " 
(GONZÁLEZ STEPHAN, 1995, p.432). Desta maneira, há a criação do urbano como espaço unicamente passível de progressos nacionais - os signos rurais colocados são colocados incivilizados, abafando qualquer produção advinda desse território.

A escola permanece articulada com a agenda política-cultural para a civilização/modernidade/urbanização, onde se estabelece como o lugar onde se aprende comportamentos, gestos, formas e modos de existir elaborados a partir desses critérios arbitrários (BOTO, 2014). Cria-se liturgias nesse espaço que legitima a superioridade da vida civilizada/urbana, que, logicamente, baseia-se na construção do rural enquanto sinônimo do atraso. Cabe reafirmar que esse processo se potencializa na República, porém suas raízes são históricas, a base desse processo pode ser vista a partir da análise da definição de ensino no Dicionário de lingual português de 1813: ensino - "instrução, educação, urbanidade, direções, preceitos, máximas prudenciais e morais" (Dicionário, 1813, p.707 apud BOTO, 2014). Assim, as concepções que coloca o ensinar no ambiente escolar como a busca e a imposição de estratégias de aculturação fundamentada na cultura arbitraria urbana, moral, religiosa, eurocêntrica, branca se reitera e se afirmar na República, ganhando grande força com a expansão do sistema capitalista, que coloca a cidade com o centro da industrialização. Ademais, as liturgias da aprendizagem e do ensino estão estreitamente relacionadas com as normas do comportamento civil-urbano e a negação e inferiorização de signos que constituem a vida rural.

Boto (2014, p.112) sinaliza que "a civilidade é um dos princípios estruturais do processo de socialização escolar", sendo uma civilização conservadora, pois essa se tange sob os discursos de hierarquia e classificação sociais, de superioridade e inferioridade, subordinação entre pessoas. Assim, com a ideia de urbanidade, a subordinação do campo pela cidade ocorre nesse processo de socialização, 
além de outros aspectos de gênero, raça e classe, que são intrínsecos nessa classificação. Pode-se afirmar aqui que a cultura urbana, sob a ideia de civilidade-superioridade- progresso, adentra a construção da cultura escolar, que além da cidade ser os lócus de privilégio das ações, ela também produz e difunde ideologias dominantes que inferiorizam o campo, pois "trabalha teórico e retoricamente com um conjunto de dicotomias, tais como bárbaro e civilizado, arcaico e moderno, velho e novo, rural e urbano, entre muitas outras" (FARIA FILHO, 2005, p.31). A missão posta pela educação e o espaço urbano passa a basear a modernidade e o progresso, e na República isso se reitera com grande força, pois a noção de civilidade, cidadania, urbanidade, modernidade.

O que afirma essa perspectiva é o fato de, por exemplo, em terras mineiras, em 1908, a escolas infantis terem como disciplina básica urbanidade, assim há elementos para a construção de uma cultura escolar que passa a produzir as dicotomias entre campo e cidade (FARIA FILHO, 2005). Além disso, Pinto (2012), ao discorrer sobre as tensões na constituição da Escola Primária em Goiás na Primeira República, conclui que as ações focalizavam estratégias reformistas dando ênfase no urbano, em uma sociedade goiana ainda rural, o que desencadeou os fracassos dos movimentos de reforma. Essas reformas tinham como referência escolas urbanas da capital paulista, que se pautava no desejo de modernidade, tendo a Educação a função moralizadora, moderna, progressistas e, sobretudo, civilizatória.

Nessa dimensão infere-se a força de como a urbanidade perpassa as normas e práticas do espaço escolar, a partir da finalidade civilizatória que busca transmitir conhecimento e incorporar comportamentos de cidadãos urbanos, partindo dos contrapontos e dicotomias entre urbano-rural. Assim, atesta-se que há a difusão, a partir da escola (baseada na modernidade/colonialidade/capi- 
talismo), de "modos de pensar e de agir largamente difundidos no interior de nossas sociedades, modos que não concebem a aquisição de conhecimentos e de habilidades senão por intermédio de processos formais de escolarização" (JULIA, 2001, p.11), que marca a cultura escolar dessas instituições. Essas normas e práticas até certos momentos históricos foram centralmente teológicos e a partir de movimentos da ilustração se tornaram egológicos (secundarizando o teológico, que jamais deixa de existir), assim, essas práticas e normas escolar são marcadas pelas finalidades sociais, que a própria escola produz, tomando como alicerce a dominação colonial/moderna, onde as culturas dominantes urbanas subjugam as produções de existência rurais.

Além disso, a construção urbana, que gera formas de relações, modos de expressão e existência específica desse território (e de seus elementos e representações), consolida hegemonicamente a formas de educação escolar, que passam a ter essa urbanidade como referência de experiências, onde o campo, além de ser inferiorizado ou romantizado, passa a ter suas experiências e ruralidades invisibilizadas enquanto experiência singulares. A referência para pensar a Escola é urbanocentrada, e dessa maneira, eurocêntrica, dicotômica, sob o viés das colonialiades dos povos do campo.

A escolarização se torna o ponto fundamental para o progresso - República Educadora -, há então uma expansão da escolarização, devido às transformações sociais e econômicas, para as classes médias e pobres urbanas. Porém, até a década de 1930, a escolarização no território rural "continuou descontínuo e desordenado, como sempre fora" (LEITE, 1999, p.28). As experiências rurais continuavam marginalizadas, sendo o urbano o principal ponto de investimento, ações políticas, administração e desenvolvimento, sob a ideia moderna de projeto societário urbano-industrial. Nessa lógica, a visão eurocêntrica/moderna 
ainda continua a ser exercida na ordem geopolítica brasileiro, onde o campo é coloca como lugar menor, que constrói "o "outro" mediante uma lógica binária que reprimia as diferenças" (CASTRO-GÓMEZ, 2005, p.80), ou seja, o Estado cria os critérios de civilidade, para homogeneização dos sujeitos, negando e invisibilizando as diferenças em suas ações em prol do projeto de modernidade/urbano/capitalista.

Por volta de 1910/20 acontece um movimento latente de êxito rural, pois sem condições dignas para a vida no campo, e sob a égide da cidade como lugar do progresso, a imigração se configura como alternativa. Assim, as cidades passam a ser tomadas pela ruralidade, os sujeitos do campo passam a ser vistos, e passam a configurar problemas sociais nos centros urbanos. Os bárbaros vieram para as cidades e agora? Como lidar com a desestabilização da ordem citadina? Pois, com eles também vem seus modos de vida, de comportamento, cultura e organização, e a própria desconfiguração do espaço agroexportador, que era a base para o processo urbano. Além disso, a imigração é uma ameaça epistemológica, comportamental, econômica e cultural. A partir do momento que essas diferenças não são mais passíveis de ser invisibilizadas, pois a questão é latente na cidade, passa-se a pensar na educação em território rural, como estratégias para a fixação do homem no campo (LEITE, 1999).

No século XX a escolarização no campo foi usada "ora como instrumento adequado para fixar o homem no campo [...], ora como instrumento ideal para transformar mentalidades arcaicas e rurais em mentalidade citadinas" (FREITAS e BICCAS, 2009, p.27). Nessa acepção, entende-se que a educação sempre teve elementos pautadas na transformação das mentalidades do campo (a partir do ideal de modernidade), e assim, inferiorizando seus processos, mesmo quando era para fixar esses sujeitos no campo ou para domesticar na constituição de mão de obra.

O Ruralismo Pedagógico foi uma experiência do come- 
ço do século XX que se deu com a emergência da fixação do homem no campo, um movimento que passou a olhar para o campo a partir de suas especificidades, que além de conter o problema da imigração, também se calcava sob a égide da compreensão das especificidades do campo e sua valorização (LEITE, 1999). Busca-se então estratégias para fixar os camponeses no campo, desta forma, mesmo que essa perspectiva tivesse olhando para a especificidade do campo, ela não busca romper lógicas de dominação e alienação desses sujeitos, no sentido de não pensar uma educação para dar possibilidades de vida, direcionadas pelos desejos dos camponeses (de ficar ou não no campo), mas como alternativa de fixar, limitando a autonomia dos sujeitos - caracterizando uma violência colonial. Porém, essa ideia, que mesmo a partir do objetivo de fixar, compreendia especificidade, foi posta de lado, logo a partir da 1930, a tônica para educação no território rural passou a ser da Educação Rural.

A Educação Rural que estava relacionada com o desenvolvimento econômico urbano-industrial, se firmou no começo dos anos 1930, e se potencializou durante o processo de industrialização dos anos 1950, 1960 e 1970, associado, contraditoriamente, com a Reforma Agrária, no intuito do Estado fornecer escolarização e formação técnico-profissional para formar mão de obra qualificada para atuarem no processo de industrialização e modernização do campo, para que assim o desenvolvimento do capitalismo no campo pudesse ocorrer de forma mais intensa e rápida (RIBEIRO, 2012).

Assim se compreende que o sistema capitalista tenha incorporado[...], a Reforma Agrária, porém, associada aos interesses de classe, visando a modernização do campo, pela introdução de máquinas, insumos agrícolas, métodos de administração rural etc.; e isso requeria alguma forma de escolarização, o que explica a relação entre educação rural, o desenvolvimento econômico e a Reforma Agrária" (RIBEIRO, 2012, p. 295, grifo nosso). 
Essa concepção de educação estava vinculada aos interesses da elite e oligarquias agrárias, sob um projeto que tendia intensificar a submissão do trabalho ao capital, se opondo a formulação da educação como processo de libertação das relações de opressões dos camponeses. Desta maneira, a Educação Rural está a serviço do mercado e da economia, e assim da própria colonialidade dos sujeitos do campo, oferecendo uma educação unicamente nesses moldes, anulando suas condições de existência, suas lutas e seus modos de vida, os conferindo funções e educação alienadoras para gerar de mão de obra para sujeição ao capitalismo.

Calazans, Castro e Silva (1981) apontam que a Educação Rural lançou mão de diversos programas, projetos e ações direcionadas para o campesinato, porém sempre teve uma importância quase irrelevante para o setor público. Caracterizando assim, as contradições dessas ações, que ao oferecer uma Educação Rural alienada, ainda a fazia de maneira desestruturada. Esses programas se estruturavam como um pacote fechado, sem qualquer participação dos sujeitos do campo nas suas elaborações, sendo utilizadas como práticas para desviar a atenção sobre as reais necessidades do campo, que os Movimentos Sociais do Campo reivindicavam. Pois, assimilaram a Reforma Agrária sob o interesse da industrialização/modernidade/ colonialidade dos territórios, usando a escolarização desqualificada para domesticar e limitar as possibilidades de vida desses sujeitos.

Além disso, a Educação Rural que é a forma escolar que perpassa várias décadas rurais, está sob a tônica do processo de transplantar uma educação urbana para a realidade rural, sem nenhum critério, há um transplante de uma escola urbanocentrada, que se constrói a partir das ideias de colonialidade/modernidade que geram a dicotomia entre rural e urbano. Deste modo, há uma dupla violência colonial exercida pelo Estado: a de levar e impor uma 
educação que não dialoga com a necessidade camponesas e sim com o processo de expansão capitalista; e o impor uma educação que está baseada na inferiorização epistêmica, linguística, existência, cultural, social e política desses povos. Nesse momento o capitalismo toma a centralidade (que já vinha conquistando) na estrutura educacional, e especifica, dos sujeitos do campo, replicando estrutura de dominação e colonialidade do poder (QUIJANO, 2005). Já que as relações de trabalho escravo e servidão tinha acabado, e o trabalho assalariado toma a centralidade, a escola passa a ser o locús para a formação de mão de obra. Além disso, esse movimento deixa latente principalmente a Colonialidade da Natureza, com o processo de industrialização e modernização do campo, onde o campo se torna para o capitalismo lugar a ser explorado, e os camponeses vidas a serem expropriadas pelos latifundiários e agronegócio.

Destarte, estende-se que mesmo quando essa escola é no território rural, ela é pensada sob a égide urbanocentrado (cultural, políticas, organização, econômica e social urbana), ela passa a reproduzir e produzir-se sob o viés de uma organização que é da experiência urbana. Estando envolta de toda a arbitrariedade construída a partir da colonialdiade/modernidade/eurocêntrico, cria-se a ideia de que o rural é a extensão do urbano (pois ele não tem potencial de produzir formas de saber, de ser, de produzir, de cultura), assim a escola urbanocentrada pode estar naquele lugar sem nenhum problema, há sempre a incivilidade e inferiorização da ruralidade. Pois, não há a compreensão que apesar do rural ser integrado ao urbano (WANDERLEY, 2001), e vice e versa, esses são espaços que possuem especificidade que não se pauta em dicotomias de inferioridade-superioridade, mas na própria interação objetiva e subjetiva com o meio que produz relações de existências e experiências diferentes. Segundo Silva, Torres e Lemos (2012, p.424), “o ensino ofertado na área rural sob os moldes da educação urbana apresentava-se distan- 
te e desconectado da vida cotidiana, negando os saberes e as culturas desses povos e toda forma de conhecimento que não fosse propedêutica", urbano e colonizador.

Aqui assume-se a ideia de forma radical de replicar a escola urbana no campo, e uma escola alienada ao capital, uma escola que reforça a subalternidade do camponês, como finalidade de forma mão de obra qualificada e barata, com base na industrialização do campo e da cidade.

Até os dias atuais a educação nos territórios do campo enfrenta e é atingidas pelos paradigmas da Educação Rural, que dialogam com interesses dominantes e do agronegócio, como ações reacionárias de bloqueio de repasses financeiros e com a insistência de reerguer modelos voltados para concepções da Educação Rural (RIBEIRO, 2012). Pois, há uma grande ofensiva por parte do Estado Neoliberal, colonialidade contemporânea /neocolonial, que vem com processos de desconstrução das escolas nos territórios rurais, com políticas de fechamentos de escolas, nucleação escolar e transporte dos alunos para as escolas da cidade, negando a essa qualquer vinculação com suas raízes.

Silva, Torres e Lemos (2012) sinaliza que nesse sentido a Educação escolar ofertada ao campo brasileiro tem um caráter desumanizador, urbano e instrumental

\begin{abstract}
Desumanizador por se configurar em práticas pedagógicas que negam os sujeitos-povos do campo como capazes de produzir cultura, história, saberes válidos, fragilizando a sua condição de ser humano. Urbano por ser pensada por sujeitos da cidade a se utilizar da lógica urbana. Instrumental porque objetiva o atendimento restrito das necessidades imediatas das atividades econômicas sob a lógica do capitalismo (p.424).
\end{abstract}

Desta forma, historicamente, a Educação no Brasil se coloca dentro da Colonialidade da educação brasileira, em movimentos de subalternização dos povos do Campo, sempre baseado e construindo representações sociais que 
inferiorizam a existência desses sujeitos e suas experiências enquanto fonte de produção epistemológica, social e cultural para se pensar os processos educativos, formas de lidar com a realidade nacional. Nessa sequência, a construção da Educação no Brasil se consolidado a partir da colonialidade do poder, saber, ser e dos territórios (natureza) dos povos subalternizados, para a própria construção da Educação urbana, que centralmente olhava para a consolidação da elite. Essas relações de colonialidade reverberam fortemente nos povos do campo, assim, esses por muitas décadas não foram nem pensando enquanto sujeitos passíveis de ter acesso à educação escolar, e quando são pensados, os aspectos da colonialidade perpassam a forma escolar oferecidas para eles - colonialidade da Educação.

Por conseguinte, há diversas relações de dominação e inferiorização desses sujeitos, que não se dão a partir da essencialidade, mas a partir dos percursos históricos de dominação colonial, da colonialidade e dos próprios processos educacionais institucionais. Mas esses movimentos também estão envoltos de práticas de resistência e insurgência, pontua-se rapidamente no tópico a seguir, falando especificamente da Educação do Campo.

\section{Decolonialidade - Educação do Campo ${ }^{10}$ como movimento de resistência}

Nesse trabalho discorre-se sobre os aspetos que envolveram a colonialidade da Educação, baseada no colonialismo e na colonialidade do povo do campo, para assim refletir historicamente sobre os aspectos que envolvem e

\footnotetext{
${ }^{10}$ É importante frisar que a Educação do Campo é um Movimento que tem por finalidade superar a Educação Rural, por isso é fundamental a consolidação da sua nomenclatura em todos os espaços legislativos e de discussão. $\mathrm{O}$ termo é fundamental para a afirmação do projeto político que contempla uma perspectiva pedagógica e educacional contra-hegemônica, com o objetivo emancipador das populações do campo, compreendendo suas lutas, culturas e modos de vida.
} 
estruturam a educação camponesa brasileira. Porém, não se pode deixar de pontuar, que dentro dessas Colonialidades, também houve movimentos de resistência, pois "a Colonialidade, em seus variados eixos, não conseguiu se estabelecer completamente nas relações políticas, sociais e epistêmicas nos territórios colonizados, tanto no período colonial, como no contexto neoliberal (neocolonial) contemporâneo" (SILVA e SILVA, 2014, p.167, grifos dos autores), que aqui pontuamos como projetos decoloniais - Decolonialidade.

Os projetos decoloniais são as reações dos povos subalternizados ao projeto societário colônia/moderno/urbano, que desde a colonização vem reagindo as violências imperiais. "La decolonialidad es, entonces, la energía que no se deja manejar por la lógica de la colonialidad, ni se cree los cuentos de hadas de la retórica de la modernidad" (MIGNOLO, 2007, p.27). A decolonialidade da educação se coloca no ato de se pensar, e, além disso, em uma práxis com base na insurgência, na criação, na busca de alternativas, para se construir novos percursos sociais, política, epistêmicos que fujam da dominação da coloniadade/neocolonial/neoliberal/capitalista/urbana. E, sobretudo, na busca pela construção de um percurso educativo que não se baseia em dicotômicas, dominação, racismo, machismo, mas que consiga realizar movimento interculturais. "Decolonizar na educação é construir outras pedagogias além da hegemônica", olhando para os Movimentos Sociais insurgentes que anunciam formas de educação alternativas (OLIVEIRA, s/a, p.03).

Dentro disso, nos processos educacionais sempre houve práticas Decoloniais dos grupos subalternizados, esses sujeitos vêm fazendo giros decoloniais desde o processo de colonização, mesmo sendo sufocados existencialmente, realizam diversas práticas de luta e resistência. Pois, para Bernardino-Costa e Grosfoguel (2016, p.17) a decolonialidade "consiste [...] numa prática de oposição 
e intervenção, que surgiu no momento em que o primeiro sujeito colonial do sistema mundo moderno/colonial reagiu contra os desígnios imperiais". Assim, essas práticas podem ser vistas nas experiências dos sujeitos subalternizados pela modernidade/colonialidade desde a colonização da América, seja nas resistências indígenas, nas expressões culturais dos negros escravizados, nos movimentos de resistência e luta pela terra no campo.

$\mathrm{Na}$ educação, podem-se perceber as resistências decoloniais nos processos educativos institucionais e não instrucionais, por exemplo: dos negros no período imperial, como ações e estratégias de alfabetização e educação de seus povos; as resistências dos povos indígenas e não aceitarem processos educativo coloniais de aculturação; as lutas das mulheres para a inserção na educação escolar (GONDRA e SCHUELER, 2008); a insurgência da Educação Popular de Paulo Freire, que criticou as desconecções da educação com a realidade nacional e pensou em alternativas para um educação libertadora, crítica a e problematizados das relações de dominação (FREITAS e BICCAS, 2009). Além disso, a luta pela terra e pela educação articulada pelos Movimentos Sociais do Campo, protagonizada pelo MST (Movimento de Trabalhadores Sem Terra) que desde os anos 1980/1990, período de redemocratização (saída do regime militar - que reprimiu fortemente esses movimentos no Brasil), vem resistindo a Educação Rural e as políticas educacionais neoliberais, e lutando pela Educação do Campo (CALDART, 2012). Assim, essas são algumas práticas educacionais decoloniais, sendo a Educação do Campo uma das ações decoloniais nos territórios nacionais.

Assim, assume-se aqui a Educação do Campo enquanto movimento insurgente que, além de enunciar epistemologias alternativas, tem suas origens nos movimentos decoloniais, fundamental nos Movimentos Sociais do Campo e nos percursos da Educação Popular. Mas também tem suas raízes nas lutas dos povos negros e in- 
dígenas que historicamente vem realizando práticas de resistências políticas, epistêmicas, culturais e educacionais. Destacamos nesse trajeto os Movimentos Sociais do Campo, por historicamente esses serem os articuladores das ações de resistência e enfretamento das opressões do campo. Pois, "ao tomarem a terra como elemento central de suas lutas, articulam outras dimensões constitutivas como a educação, o trabalho e a cultura nas resistências ao modelo colonial/capitalista/urbanocêntrico" (SILVA et al, 2012, p.17). Desta maneira, o protagonismo desse movimento é central na constituição desse percurso, a partir das suas experiências educativas, movimento de educação institucional e não institucional, luta pela identidade, epistemologia, cultura e terra (existência material e subjetiva), a pela própria luta por políticas públicas (onde obteve-se diversos avanços legais ${ }^{11}$ ), tencionando o Estado neoliberal/neocolonial pela ampliação dos direitos dos povos, enfrentamento da violência neocolonial/neoliberal.

A Educação do Campo, enquanto movimento sociopolítico brasileiro (CALDART, 2012), vem se constituindo a partir dos Movimentos Sociais do Campo e com a articulação de outros órgãos da sociedade, como as universidades, para se pensar formas de educação que sejam DO campo, ou seja, que tenha os povos do campo como sujeitos protagonistas desse processo, que valorize sua cultura, modos de produção, superando olhares dicotômicos e estereotipados que as colonialidade impõem. Não busca fechar-se em si mesmo, mas parte da necessidade histórica em colocar o campo como lugar visível, produtor de expe-

\footnotetext{
${ }^{11}$ Constituição Federal de 1988; Lei de Diretrizes e Bases da Educação Nacional - LDB n. 9394/96 (onde aparece a educação para povos do campo enquanto especificidade, pela primeira vez); Diretrizes Operacionais para a Educação Básica nas Escolas do Campo (Resolução CNE/CEB n. 1/2002); Diretrizes Complementares, Normas e Princípios para o Desenvolvimento de Políticas Públicas de Atendimento da Educação Básica do Campo (Resolução CNE/ CEB n. 2/2008); Política de Educação do Campo e o Programa Nacional de Educação na Reforma Agrária (PRONERA) (Decreto n. 7.352/2010) (SILVA, TORRES e LEMOS, 2012); entre outros.
} 
riências essenciais para a constituição da humanidade, e assim, busca articular as outras culturas de maneira a afirmar os valores do campo. A "Educação do Campo se sustenta em pilares pedagógicos e princípios políticos firmados no respeito e no diálogo entre as culturas na direção da construção de uma sociedade outra" (SILVA, TORRES e LEMOS, 2012, p.432, grifo dos autores). Quijano (2005, p.139) sinaliza que "é tempo de aprendermos a nos libertar do espelho eurocêntrico onde nossa imagem é sempre, necessariamente, distorcida. É tempo, enfim, de deixar de ser o que não somos". Desta forma, sinaliza-se a Educação do Campo como um dos movimentos que apontam para essa construção de uma educação e sociedade brasileira, a partir do que realmente os povos são, superando representações sociais pautadas na inferiorização, se articulando com os demais movimentos que estão nessa perspectiva, como o Movimento Negro, Feminista, LGBTT ${ }^{12}$, das periferias urbanas, entre outros.

\section{Considerações Finais}

Atualmente, as Escolas do Campo ainda possuem grandes dificuldades de se estabilizarem sobre o paradigma da Educação do Campo, pois o paradigma da Educação rural e das colonialidades do poder, saber, ser e da natureza ainda permanece nas ideias neoliberais que desestabilizam os avanços dos Movimentos Sociais do Campo na educação.

Assim, é necessário que a vigilância e que o fortalecimento de práticas, políticas e experiência insurgentes que tenham o potencial de desenvolver-se e enunciar novas epistemologias, ontologias e formas de educação institucional e não-institucional, para não permitir retrocessos. E, sobretudo, lutar para que os povos subalternos sejam pro-

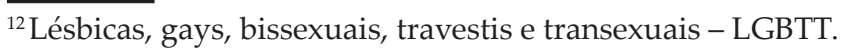


tagonistas dos processos que dizem respeito a sua própria existência, onde projetos societários e educacionais se pautem igualmente nas enunciações dos grupos sociais que constituem o Brasil e o mundo, superando assim a modernidade, o eurocentrismos e as dicotomias entre urbano-rural, criando movimentos de interculturalidade.

Desta maneira, a tônica se dá a partir da ideia onde os sujeitos do campo possam consolidar a Educação do Campo, na reivindicação de "uma educação específica e diferenciada, [que] coloca como protagonistas os povos campesinos e suas lutas históricas, incorporando de maneira mais significativa às questões de gênero, raça, sexualidade, território, unificadas pela Reforma Agrária" (SILVA et al., 2014, p.25). Rompendo as Colonialidades historicamente construídas e latentes na contemporaneidade, que perpassam as formas educacionais do nosso país, e, especificamente da educação do povo do campo.

O potencial de enunciação aberto pela Educação do Campo, enquanto movimento e possiblidade de pensar alternativas para a educação escolar do campo, não perpassa o pensar somente o campo, mas possibilita pensar sobre uns projetos decolonais de Brasil. Pois, é necessário frisar que os espaços urbanos-rurais estão interligados, e que os processos de mudanças sociais que ocorrem em um desses territórios modificam também as estruturas do outro território, assim, é necessário compreender esses enquanto espaços interligados, onde o campo não deve e nem pode ser invisibilizada ou inferiorizada, pois o desenvolvimento nacional depende intensamente desses ovimentos do campo, bem como depende dos movimentos urbanos. Para assim se construir um país sob a tônica da justiça social, na superação das relações de opressão racial, sexual, de gênero, de classe e territorial. 


\section{REFERÊNCIAS}

ASSIS, W. F. T. Do colonialismo à colonialidade: expropriação territorial na periferia do capitalismo. CADERNO CRH. Salvador, v. 27, n. 72, p. 613-627, set./dez. 2014.

BALLESTRIN, L. América Latina e o giro decolonial. Revista Brasileira de Ciência Política. Brasília, n. 11, p. 89-117, maio/ ago. 2013.

BERNARDINO-COSTA, J.; GROSFOGUEL, R. Decolonialidade e perspectiva negra. Revista Sociedade e Estado. Brasília, v. 31, n. 1, jan./abril 2016.

BOTO, C. A liturgia da escola moderna: saberes, valores, atitudes e exemplos. Revista História da Educação. v. 18, n. 44, set./dez. 2014.

. O Curso de Medicina da universidade pombalina: ciência e pedagogia no Iluminismo português. In: FONSECA, T. N. de L. As Reformas Pombalinas no Brasil. Belo Horizonte: Mazza Edições. 2011.

CALAZANS, M. J. C.; CASTRO, L. F. M. de; SILVA, H. R. S. Questões e Contradições da Educação Rural no Brasil. In.: WERTHEIN, J; BORDENAVE, J. D. (Org.). Educação Rural no Terceiro Mundo: Experiências e Novas Alternativas. Rio de Janeiro: Paz e Terra,1981, p. 161-198.

CALDART, R. S. Educação do Campo. In: ; et al. (Org.).

Dicionário da Educação do Campo. Rio de Janeiro: Escola Politécnica de Saúde Joaquim Venâncio, Expressão Popular, 2012, p. 257-265.

CASTRO- GÓMEZ, S.; GROSFOGUEL, R. In: . (Orgs.).

Prólogo. Giro decolonial, teoría crítica y pensamiento heterárquico. El giro decolonial: refl exiones para una diversidad epistémica más allá del capitalismo global. - Bogotá: Siglo del Hombre Editores; Universidad Central, Instituto de Estudios Sociales Contemporáneos y Pontifi cia Universidad Javeriana, Instituto Pensar, 2007.

CASTRO-GÓMEZ, S. Ciências sociais, violência epistêmica e o problema da "invenção do outro". In.: LANDER, E. (Org.). 
A colonialidade do saber: eurocentrismo e ciências sociais. Perspectivas latino-americanas. Colección Sur Sur, CLACSO, Ciudad Autónoma de Buenos Aires, Argentina, set. 2005.

DUSSEL, E. Europa, modernidade e eurocentrismo. In.: LANDER, E. (Org.). A colonialidade do saber: eurocentrismo e ciências sociais. Perspectivas latino-americanas. Colección Sur Sur, CLACSO, Ciudad Autónoma de Buenos Aires, Argentina, set. 2005.

FARIA FILHO, L. M. de. Cultura escolar e cultura urbana: perspectivas de pesquisa em história da educação. In.: XAVIER, L. N. et al. Escola, Culturas e Saberes. Rio de Janeiro: Editora FGV, 2005.

FONSECA, T. N. de L. e. Iluminismo e Reforma: civilidade, educação moral e práticas culturais dos professores régios. In: DORÉ, A.; SANTOS, A. C. A Temas Setecentistas: Governos e populações no Império Português. Curitiba: UFPR/Fundação Araucária, 2009.

FREIRE, P. Educação como prática da liberdade. 39. ed. São Paulo: Paz e Terra, 2016. Terra, 1987.

. Pedagogia do Oprimido. 17. ed. Rio de Janeiro: Paz e FREITAS, M. C. de; BICCAS, M. de S. História social da educação no Brasil (1926-1996). São Paulo: Cortez, 2009.

GONDRA, J. G.; SCHUELER, A. Educação, poder e sociedade no império brasileiro. São Paulo: Cortez Editora, 2008.

GONZÁLEZ STEPHAN, B. Modernización y disciplinamiento. La formación del ciudadano: del espacio público y privado. In.: GONZÁLEZ STEPHAN, B. et al. (Org.). Esplendores y miserias del siglo XIX. Cultura y sociedad en América Latina. Caracas: Monte Ávila Editores, 1995.

GROSFOGUEL, R. Descolonizando los paradigmas de la economíapolítica: transmodernidad, pensamiento fronterizo y colonialidad global. 2016. Disponível em: < http://www.manuelugarte.org/modulos/biblioteca/g/ramon_grosfoguel_des- 
colonizando_paradigmas_economia_transmodernidad.pdf $>$. Acesso em: 05 jan. 2016.

. Para Descolonizar os Estudos de Economia Política e os Estudos Pós-coloniais: transmodernidade, pensamento de fronteira e colonialidade global. In.: SANTOS, B. de S.; MENESES, M. P. (Org.). Epistemologias do Sul. Coimbra: Almedina, 2009.

JULIA, D. A cultura escolar como objeto histórico. Revista Brasileira de História da Educação. v. 1, p. 9-43, jan./jun. 2001.

LANDER, E. Apresentação. In.: (Org.). A colonialidade do saber: eurocentrismo e ciências sociais. Perspectivas latino-americanas. Colección Sur Sur, CLACSO, Ciudad Autónoma de Buenos Aires, Argentina, 2005.

LEITE, S. C. Escola rural: urbanização e políticas educacionais. São Paulo: Cortez, 1999. - (Coleção questões da nossa época: v. 70).

MALDONADO-TORRES, N. A Topologia do Ser e a Geopolítica do Conhecimento: modernidade, império e colonialidade. In.: SANTOS, B. de S.; MENESES, M. P. (Org.). Epistemologias do Sul. Coimbra: Almedina, 2009.

Sobre la colonialidad del ser: contribuciones al desarrollo de un concepto. In.: CASTRO-GÓMEZ, S.; GROSFOGUEL, R. (Org.). Prólogo. Giro decolonial, teoría crítica y pensamiento heterárquico. El giro decolonial: refl exiones para una diversidad epistémica más allá del capitalismo global. Bogotá: Siglo del Hombre Editores; Universidad Central, Instituto de Estudios Sociales Contemporáneos y Pontifi cia Universidad Javeriana, Instituto Pensar, 2007.

MIGNOLO, W. D. A colonialidade de cabo a rabo: o hemisfério ocidental no horizonte conceitual da modernidade. In.: LANDER, E. (Org.). A colonialidade do saber: eurocentrismo e ciências sociais. Perspectivas latino-americanas. Colección Sur Sur, CLACSO, Ciudad Autónoma de Buenos Aires, Argentina, 2005.

. El pensamiento decolonial: desprendimiento y apertura. Un manifiesto. In.: CASTRO-GÓMEZ, S.; GROSFOGUEL, 
R. (Org.). Prólogo. Giro decolonial, teoría crítica y pensamiento heterárquico. El giro decolonial: refl exiones para una diversidad epistémica más allá del capitalismo global. Bogotá: Siglo del Hombre Editores; Universidad Central, Instituto de Estudios Sociales Contemporáneos y Pontifi cia Universidad Javeriana, Instituto Pensar, 2007.

- Geopolítica de la sensibilidad y del conocimiento Sobre (de)colonialidad, pensamiento fronterizo y desobediencia epistémica. Traducción de Marcelo Expósito. Eipcp, 2011. Disponível: < http://eipcp.net/transversal/0112/mignolo/es>. Acesso em: 10 jan. 2016.

OLIVEIRA, L. F. de. O que é uma educação decolonial? s/a. Disponível em: <https://www.academia.edu/23089659/O_ QUE_\%C3\%89_UMA_EDUCA\%C3\%87\%C3\%83O_DECOLONIAL>. Acesso em: 10 jan. 2017.

PAIVA, J. M. A educação jesuítica no Brasil Colônia. In: LOPES, E. M. T., FARIA FILHO, L. M.; VEIGA, C. G. (Orgs.). 500 anos de educação no Brasil. Belo Horizonte: Autêntica, 2003.

PINTO, R. N. Escola Primária em Goiás na Primeira República: tensões e distensões de um "jogo de empurra”. In: ARAÚJO, J. C. S.; SOUZA, R. F. de e PINTO, R-M. N. (Orgs.). Escola primária na Primeira República (1889-1930): subsídios para uma história comparada. Araraquara, SP: Junqueira \& Marin, 2012.

PORTO- GONÇALVES, C. W. Apresentação da edição em português. In: LANDER, E. (Org.). A colonialidade do saber: eurocentrismo e ciências sociais. Perspectivas latino-americanas. Colección Sur Sur, CLACSO, Ciudad Autónoma de Buenos Aires, Argentina, 2005.

QUIJANO, A. Colonialidad y modernidad-racionalidad. In: PALERMO, Z.; QUINTERO, P. Textos de fundación. Colección El despendimiento. Buenos Aires, Argentina: Ediciones del Signo. 2014.

. Colonialidade do Poder e Classificação Social. In: SANTOS, B. de S.; MENESES, M. P. (Org.). Epistemologias do Sul. Coimbra: Almedina, 2009. 
. Colonialidade do poder, Eurocentrismo e América

Latina. In: LANDER, E. (Org.). A colonialidade do saber: eurocentrismo e ciências sociais. Perspectivas latino-americanas. Colección Sur Sur, CLACSO, Ciudad Autónoma de Buenos Aires, Argentina, 2005.

RIBEIRO, M. Educação Rural. In: CALDART, R. et al. (org.). Dicionário da Educação do Campo. Rio de Janeiro: Escola Politécnica de Saúde Joaquim Venâncio, Expressão Popular, 2012b, p. 293-299.

SANTOS, B. de S. Para além do Pensamento Abissal: das linhas globais a uma ecologia de saberes. In: ; MENESES, M. (Org.). Epistemologias do Sul. Coimbra: Almedina, 2009.

SILVA, F. da; TORRES, D. X; LEMOS, G. T. Educação do campo: a luta dos movimentos sociais campesinos por uma educação escolar específica e diferenciada. Revista Pedagógica - UNOCHAPECÓ, Chapecó, ano 15, v. 01, n. 28, jan./jun. 2012.

SILVA, F. G. P. da; SILVA, J. F. da. A crítica decolonial das epistemologias do sul e o contexto de constituição das coleções didáticas do PNLD-campo/2013. REALIS, v.4, n. 02, jul./dez. 2014.

SILVA, J. F. da et al. Paradigmas da educação do campo: um olhar a partir dos estudos pós-coloniais latino-americanos. Revista Reflexão e Ação, Santa Cruz do Sul, v. 22, n. 2, p. 09-38, jul./dez. 2014.

WALSH, C. Interculturalidad, plurinacionalidad y decolonialidad: las insurgencias político-epistémicas de refundar el Estado. Tabula Rasa, Bogotá, Colombia, n. 9, p. 131-152, jul./ dic. 2008.

WANDERLEY, M. de N. B. A ruralidade no Brasil moderno. Por um pacto social pelo desenvolvimento rural. In: GIARRACCA, N. ¿Una nueva ruralidad en América Latina? CLACSO, Consejo Latinoamericano de Ciencias Sociales, Ciudad Autónoma de Buenos Aires, Argentina, 2001. 


\section{CAPÍTULO 4}

\section{O PROTAGONISMO DOS MOVIMENTOS SOCIAIS: Possíveis interfaces entre as escolas do campo e o Pro- grama Nacional de Educação do Campo}

\section{Ramofly Bicalho dos Santos ${ }^{1}$}

Importante sinalizar neste capítulo, a continuidade das nossas reflexões acerca das pesquisas realizadas em educação do campo na sua estreita articulação com os movimentos sociais e demais entidades do campo ${ }^{2}$, desenvolvidas no Pós-Doutorado em Educação do Programa de Pós-Graduação em Educação da Universidade Federal Fluminense (UFF). Neste campo de análise, privilegiamos as interfaces entre as escolas do campo e o Programa Nacional de Educação do Campo - PRONACAMPO, enquanto política pública específica de educação do campo no Brasil. Focalizamos as relações entre as histórias de vida de educadores e educandos, no envolvimento com as lutas organizadas pelos movimentos sociais do campo, contribuindo para formação de novos sujeitos sociais, numa perspectiva popular e histórica. Acreditamos nessa dimensão educativa e no fazer pedagógico que educadores/ as das escolas do campo realizam através da organização

\footnotetext{
${ }^{1}$ Graduado em História (1999) e Mestrado em Educação (2002), ambos na Universidade Federal Fluminense (UFF). Doutorado em Educação (2007) Unicamp. Pós-Doutorado em Educação (2017) UFF. Docente na Licenciatura em Educação do Campo, PPGEA e PPGEduc - Programa de Pós-Graduação em Educação, Contextos Contemporâneos e Demandas Populares, UFRRJ. E-mail: ramofly@gmail.com

${ }^{2}$ MST - Movimentos dos Trabalhadores Rurais Sem Terra; CPT - Comissão Pastoral da Terra; FETAG - Federação dos Trabalhadores na Agricultura; MPA - Movimento dos Pequenos Agricultores; MAB - Movimento dos Atingidos por Barragens; MMC - Movimento de Mulheres Camponesas; Escolas Família Agrícolas; Comunidades Quilombolas; Caiçaras; Ribeirinhos; Pescadores; Movimentos Indígenas, Via Campesina, entre outras entidades e representações.
} 
coletiva e no fortalecimento de projetos políticos pedagógicos emancipadores (FREIRE, 1997).

Nossa intenção com esse trabalho é compreender o campo como lugar de resistência e luta pela terra, essencial para repensarmos as políticas públicas educacionais destinadas à infância, aos jovens e adultos do campo. Mostraremos a relevância dos princípios desenvolvidos pelos movimentos sociais no que toca à luta por uma educação do campo. Suas bandeiras, projetos, perspectivas e utopias. A formação política dos trabalhadores e a valorização da consciência social são alguns dos desafios. A produção de tal conhecimento nas universidades e escolas do campo, pode contribuir para reconstrução do passado, escavando memórias, recuperando fontes primárias, ressignificando identidades e histórias vividas pelos sujeitos que se articulam para superar a falta de projetos emancipadores, a opressão e as diversas cercas do analfabetismo e da fome que atingem milhares de homens e mulheres no campo.

A expressão educação do campo identifica uma reflexão pedagógica que germina das inúmeras práticas educativas desenvolvidas pelos sujeitos que vivem no campo. Consiste numa reflexão que considera o campo como espaço de produção de pedagogias. Trata-se de um projeto que reafirma a finalidade mais expressiva das práticas educativas desenvolvidas no campo. Ela contribui com o desenvolvimento mais pleno do ser humano e sua inserção consciente no contexto social do qual faz parte (CALDART, 2002). A realidade de intensa desumanização que, historicamente, caracteriza a vida da população camponesa, gerou este movimento em favor da educação básica do campo. Uma realidade que, mesmo marcada por opressões e injustiças, continua reivindicando alterações sociais, profundas e imediatas, no campo brasileiro.

O processo de exclusão social, político e econômico acompanha a história do Brasil desde o seu surgimento, firmada sob o caráter elitista. Contudo, a luta dos movi- 
mentos sociais pelo direito à educação produziu inúmeras conquistas em favor do desenvolvimento do campo brasileiro, dentre elas, o Programa Nacional de Educação do Campo - PRONACAMPO. Segundo (CALDART, 2002), o movimento por uma educação do campo se vincula a outras lutas, em favor de transformações que garantam melhores condições de vida para população camponesa. Esta conexão se justifica pela impossibilidade de educar o povo sem modificar as condições que o desumaniza.

Boa parte das escolas do campo em diálogo com os movimentos sociais, defendem projetos político-pedagógicos (PPP) emancipadores que considerem a centralidade dos conflitos de ideias e os valores de uma nova sociedade, respeitando as histórias de vida, memórias, construção coletiva, lutas por reconhecimento identitário e novas formas de coesão social. Formação político-pedagógica que envolve educadores e educandos nas escolas do campo em assentamentos e acampamentos da reforma agrária, respeitando-se os aspectos culturais vivenciados pela mística e a luta pela terra, além dos valores da solidariedade e da ética presentes nos princípios da educação do campo.

O objetivo principal deste trabalho é mostrar a estreita articulação entre educação do campo e movimentos sociais, considerando a participação dos sujeitos, individuais e coletivos, como seres históricos e culturais. Compreender que a formação continuada de educadores e educandos nas escolas do campo, pode dialogar com as atividades de ensino, pesquisa e extensão nas universidades públicas, através das Licenciaturas em Educação do campo e o Programa Nacional de Educação do Campo PRONACAMPO.

Importante ressaltar que o empoderamento das escolas do campo e a conquista do PRONACAMPO, enquanto política pública de educação, é fruto da resistência organizada dos movimentos sociais, sindicatos e demais organizações camponesas. Ela é fruto das ações dos diver- 
sos atores sociais e suas lutas em favor das universidades públicas e escolas do campo. Lutas que considerem a diversidade das famílias camponesas e a ruptura entre educação do campo e educação rural. Muito mais que uma nomenclatura, tal divisão retrata a consciência de processos educativos a serviço dos povos camponeses.

O percurso teórico-metodológico foi realizado através de pesquisas em acervos bibliográficos e análises documentais no Pós-Doutorado do Programa de Pós-Graduação em Educação da Universidade Federal Fluminense (UFF), além das rodas de conversas junto ao Programa de Educação Tutorial - PET Educação do Campo e Movimentos Sociais e a docência na Licenciatura em Educação do Campo, ambas na UFRRJ - Universidade Federal Rural do Rio de Janeiro. Trabalhamos ainda com pareceres, decretos reguladores e documentos próprios da educação do campo, produzidos pelos movimentos sociais do campo, em parceria, com sindicatos, universidades públicas e secretarias municipais de educação. Apoiamo-nos numa perspectiva eminentemente histórica e sociológica de investigação e explicação dos processos sociais de participação dos sujeitos camponeses. Este estudo tem como horizonte, o entendimento das relações sociais concretas que determinam a materialização das propostas políticas e pedagógicas em questão. Utilizamos ainda legislações, revistas, jornais, dissertações, teses, livros e artigos em periódicos científicos que demonstrem as possíveis interfaces entre as escolas do campo e o Programa Nacional de Educação do Campo.

Nessa conjuntura, é importante conhecermos os desafios e as conquistas oriundas do PRONACAMPO, compreendendo as tensões estabelecidas na relação entre movimentos sociais camponeses e Estado. O embate entre estas duas categorias resultou em experiências históricas e na contribuição para as organizações populares direcionarem outras formas de lutas, como sujeitos de direitos. Nos 
últimos anos foram identificadas muitas práticas educativas, em todas as regiões do país, originadas no interior das organizações e movimentos sociais do campo. Com o objetivo de garantir a educação básica nas comunidades rurais e formar quadros dirigentes, muitas dessas ações, ainda que isoladas, obtiveram resultados concretos e serviram para organicidade e empoderamento dos movimentos sociais. Pressionado por sujeitos, individuais e coletivos, coube ao Estado reconhecer, ampliar e desenvolver políticas públicas específicas e práticas educativas no campo. Elas representam a capacidade de articulação dos movimentos sociais e apontam a crescente necessidade de garantir projetos populares no campo, cuja organização tenha como referência a cultura e o trabalho dos grupos sociais.

Os debates acerca do Programa Nacional de Educação do Campo devem, portanto, entender a complexidade da dimensão do campo brasileiro, constituído por paisagens, lutas, organicidade, histórias, memórias, identidades e modos de vida. Neste contexto, as políticas públicas permitem reafirmar este espaço e legitimar as lutas que dali advém. São, portanto, necessárias para consolidação de um projeto popular de país. Assim, que concepção de formação para cidadania se espera da educação do campo? Qual o papel das universidades públicas para os estudantes do campo? Que saberes e aprendizagens são por eles valorizados? Qual a relação existente entre saberes teóricos e práticos da cultura? Que contribuições a educação do campo apresenta para o fortalecimento dos movimentos sociais e a pedagogia da alternância? Com tantas questões, entendemos que é essencial a atuação crítica dos movimentos sociais, cobrando do poder público, ações de fortalecimento da educação pública no campo. $\mathrm{O}$ ambiente coletivo presente nos movimentos sociais e nas escolas do campo pode colaborar com a emancipação humana e libertadora, por onde ecoarão as vozes daqueles que, em nome da ética, do respeito às diferenças e da igualdade 
foram, historicamente, silenciados.

\section{PRONACAMPO - Programa Nacional de Educação do Campo}

O PRONACAMPO - Programa Nacional de Educação do Campo, está vinculado ao Ministério da Educação e foi lançado pela presidente Dilma Rousseff, em março de 2012, com o propósito de oferecer apoio técnico e financeiro aos estados, Distrito Federal e municípios. Seu principal objetivo é viabilizar a implantação de políticas públicas em educação do campo. Ele foi previsto pelo Decreto $n^{0} 7.352$ e instituído por meio da Portaria $n^{\circ} 86$, de $1^{\underline{0}}$ de fevereiro de 2013. Oriunda das mobilizações realizadas pelos movimentos sociais, esta política pública evidencia que a luta por educação do campo e reforma agrária transcende à luta pela terra, uma vez que compreende a ocupação de diversos outros espaços de atuação dos sujeitos camponeses. Considera-se PRONACAMPO o:

Conjunto de ações articuladas que asseguram a melhoria do ensino nas redes existentes, bem como, a formação dos professores, produção de material didático específico, acesso e recuperação da infraestrutura e qualidade na educação no campo em todas as etapas e modalidades. (PRONACAMPO/MEC, 2012).

Esse programa tem como objetivo, em parceria com universidades públicas, institutos federais, secretarias de educação e movimentos sociais, formar educadores, valorizar a agricultura familiar, ofertar educação de jovens e adultos, construir escolas do campo e melhorar a infraestrutura dessas escolas. A intenção é garantir que os saberes produzidos nas instituições e movimentos sociais, em diálogo com a pedagogia da alternância, se transformem em ações de valorização dos sujeitos camponeses, elevando a produtividade nas propriedades rurais e a efetiva 
distribuição de renda nesses espaços. A educação contextualizada está prevista nas ações do PRONACAMPO. Ela pode contribuir para efetiva interação entre conhecimento científico e os diversos saberes da educação popular presente nas comunidades.

As ações do PRONACAMPO são baseadas em quatro eixos: 1) Gestão e Práticas Pedagógicas (Materiais didáticos e pedagógicos específicos; Mais educação: escolas do campo e quilombola; Escola da terra e Escola quilombola); 2) Formação de Professores (Formação inicial, continuada e pós-graduação); 3) Educação de Jovens e Adultos e Educação Profissional e Tecnológica (Programa Nacional de Acesso ao Ensino Técnico e Emprego - PRONATEC Campo, Educação de Jovens e Adultos, Saberes da Terra e PRONATEC, Alfabetização no Campo) e 4) Infraestrutura Física e Tecnológica (Construção de escolas, educação digital na escola, luz, água e reforma das escolas do campo e quilombolas, transporte escolar). A formação inicial, continuada e pós-graduação para educadores, gestores e coordenadores pedagógicos das escolas do campo e quilombolas são prioridades. Na educação de jovens e adultos, pretende-se universalizar a oferta de cursos voltados para o desenvolvimento do campo nos institutos federais. O PRONATEC - Programa Nacional de Acesso ao Ensino Técnico e Emprego apoiará a inclusão social, com bolsas de estudo para o campo.

O Primeiro eixo compreende a disponibilização de materiais pedagógicos e didáticos específicos para as populações quilombolas e do campo, tendo como referências o Programa Nacional Biblioteca da Escola - PNBE e o Programa Nacional do Livro Didático - PNLD. Apoia a educação integral e a ampliação curricular nas escolas com turmas multisseriadas e de comunidades quilombolas. Estas iniciativas atendem demandas históricas dos movimentos sociais do campo, valorizando as histórias, memórias, identidades e saberes da juventude camponesa, além 
de incentivar a permanência dos sujeitos, individuais e coletivos, nas escolas do campo. Reitera a necessidade de construção e manutenção das escolas com condições adequadas de funcionamento, inclusive, aquelas com turmas multisseriadas.

Na maioria dos casos, estas escolas estão localizadas nas comunidades rurais, distante da sede dos municípios. Geralmente apresentam quantitativo de educandos que não atinge o contingente estabelecido pelas secretarias municipais de educação para compor uma turma por série, funcionando, precariamente, em locais improvisados. De acordo com dados da SECADI - Secretaria de Educação Continuada, Alfabetização, Diversidade e Inclusão (2013), existem no país mais de 50 mil escolas multisseriadas no campo. Essa expressiva quantidade traz à tona a necessidade de estabelecer políticas de formação de professores voltadas ao atendimento dessa especificidade pedagógica. As metas desse primeiro eixo: educação integral em 10.000 escolas e distribuição de 12,4 milhões de livros didáticos.

O Segundo eixo faz referência a formação inicial e continuada dos educadores em exercício na educação do campo e quilombola. Tal formação é desenvolvida no âmbito do PROCAMPO - Programa de Apoio à Formação Superior em Licenciatura em Educação do Campo, da RENAFOR - Rede Nacional de Formação Inicial e Continuada de Profissionais da Educação Básica e da UAB - Universidade Aberta do Brasil. Está em debate atualmente, a viabilidade e relevância das Licenciaturas em Educação do Campo semipresencial ou à distância. Muitas críticas estão sendo construídas em torno deste direcionamento metodológico. As metas do segundo eixo: ampliar a oferta de cursos de licenciatura e expandir polos da Universidade Aberta do Brasil, atendendo, prioritariamente, os docentes do campo e das comunidades quilombolas.

O Terceiro eixo diz respeito à expansão da oferta de Educação de Jovens e Adultos por meio da proposta peda- 
gógica dos saberes da terra. Considera a inclusão social dos jovens e trabalhadores do campo através do fortalecimento da educação profissional e tecnológica das redes, estadual e federal. Este documento insere a formação inicial e continuada dos trabalhadores, tendo em vista, os arranjos produtivos locais. Em muitos estados brasileiros, a oferta de Educação para Jovens e Adultos é realizada através de programas descontínuos e políticas compensatórias. Portanto, o reconhecimento à necessidade de incluir os trabalhadores/as do campo no âmbito de práticas educacionais específicas foi uma resposta à histórica reivindicação dos movimentos sociais. As metas do terceiro eixo: 180.000 vagas de formação profissional para trabalhadores e jovens e 300.000 novas vagas de educação profissionalizante.

O último eixo aborda a infraestrutura física e tecnológica, um dos maiores desafios das escolas do campo na atualidade e, uma das principais reivindicações das organizações e movimentos sociais camponeses. Dentre estas reivindicações considera-se fundamental: o apoio financeiro e técnico para construção de escolas, inclusão digital, melhoria nas condições de funcionamento das escolas quilombolas e do campo e oferta de transporte escolar intracampo. (PORTARIA № 86, 1ํㅡㄹ de fevereiro de 2013). Garantir infraestrutura física adequada e recursos tecnológicos às escolas do campo e quilombolas, pode contribuir para assegurar educação de qualidade, evitando a evasão de um contingente considerável de educandos/as desmotivados nas escolas do campo, extremamente precárias. As metas do quarto eixo: apoiar a construção de 3.000 novas escolas, melhoria das condições físicas e materiais de 30.000 escolas do campo e quilombola, implantação de laboratórios de informática em 20.000 escolas do campo, garantindo acesso à internet para 10.000 escolas, aquisição de 8.000 ônibus, 2.000 lanchas e 180.000 bicicletas e capacetes.

Compreendemos que as metas do Programa Nacio- 
nal de Educação do Campo vão desde a construção de escolas até a aquisição de transporte escolar. Nessa conjuntura, os investimentos / recursos são imprescindíveis e inevitáveis para o fortalecimento da educação e escolas do campo. Necessário ainda a defesa do transporte escolar intra-campo, os laboratórios de informática, internet e quadra poliesportiva. Por outro lado, é estratégico fortalecer a estreita relação entre educação do campo e movimentos sociais, consolidando histórias de vida, desejos e sonhos de educadores, educandos e agricultores familiares.

Pelo fato de ser um Programa muito recente, o PRONACAMPO necessita ser melhor compreendido no âmbito da Educação do Campo. As possíveis restrições às ações e ao protagonismo dos movimentos sindicais e sociais na elaboração desta política, está bem distante do cenário que foram elaboradas as políticas anteriores, em especial, o PRONERA - Programa Nacional de Educação na Reforma Agrária e o PROCAMPO - Programa de Apoio à Formação Superior em Licenciatura em Educação do Campo. Neste contexto, identificamos, inclusive, ações que envolvem, por exemplo, o agronegócio na disputa por recursos públicos. A evidência desta disputa é a incorporação da formação profissional concebida pela agricultura industrial, representada pelo Programa Nacional de Acesso ao Ensino Técnico e Emprego - PRONATEC Campo. Este Programa foi criado no ano de 2011, integrado ao Programa Nacional de Educação no Campo - MEC e incorporado ao PRONATEC. Recebe apoio do Ministério do Desenvolvimento Agrário - MDA, além de disponibilizar vagas no Programa Escola Técnica Aberta do Brasil (e-Tec) e em cursos de Formação Inicial e Continuada (FIC).

Apesar desta contradição no Programa, compreendemos possibilidades de conquistas significativas no que diz respeito a formação dos educadores do campo, numa estreita articulação com a pedagogia da alternância, por meio da ampliação dessa política pública. O eixo pertinen- 
te à formação de educadores defende a concepção apresentada pelos movimentos sociais, traduzida pelo Programa de Apoio à Formação Superior em Licenciatura em Educação do Campo - PROCAMPO. (FONEC, 2012). Antevendo os desafios, (CALDART, 2004, p. 16) chama atenção para algumas questões que perpassam as políticas de financiamento, formação de educadores e produção de materiais didáticos. Essas questões são extremamente necessárias no processo de construção da educação do campo.

Não se trata de 'inventar' um ideário para a Educação do Campo; isso não repercutiria na realidade concreta. $\mathrm{O}$ grande desafio é abstrair das experiências e dos debates, um conjunto de ideias que possam orientar o pensar sobre a prática de educação da classe trabalhadora do campo; e, sobretudo, que possam orientar e projetar outras práticas e políticas de educação.

O Ministério da Educação nos governos, Lula e Dilma, propôs a construção de uma política nacional de educação do campo, a partir do diálogo com as demais esferas da gestão do Estado, movimentos e organizações sociais do campo brasileiro. Os eixos orientadores dessa política em construção seriam: diversidade étnico-cultural como valor, reconhecimento do direito à diferença e promoção da cidadania, com destaque para: construção de uma base epistemológica que buscasse a superação da dicotomia campo-cidade. Essas ações implicariam no fortalecimento da pesquisa de base, considerando as seguintes temáticas campesinas: educação do campo, segurança alimentar, desenvolvimento sustentável, agricultura familiar, agroecológica e orgânica.

Em 2012, o governo federal ao criar o Programa Nacional de Educação do Campo - PRONACAMPO, com o objetivo de implementar a política de educação do campo, através de ações voltadas para o fortalecimento e melhoria das redes existentes, amplia o acesso à educação para as populações do campo. Em função do fechamento de um 
grande número de escolas do campo nos últimos anos, o governo federal nas diretrizes e bases da educação nacional, estabeleceu a necessidade de constar a exigência de manifestação de órgão normativo do sistema de ensino, para o fechamento de escolas do campo, indígenas e quilombolas, através da Lei no 12.960, de 27 de março de 2014. Esta lei foi uma resposta às reivindicações dos movimentos sociais, garantindo, dessa forma, critérios para decisão de fechar uma escola. $\mathrm{O}$ art. 28 da Lei no 9.394, de 20 de dezembro de 1996, passa a vigorar acrescido do seguinte parágrafo único:

O fechamento de escolas do campo, indígenas e quilombolas será precedido de manifestação do órgão normativo do respectivo sistema de ensino, que considerará a justificativa apresentada pela Secretaria de Educação, a análise do diagnóstico do impacto da ação e a manifestação da comunidade escolar. (BRASIL, 2014).

De acordo com o Censo Escolar, apenas em 2013 e 2014, foram fechadas 4.084 escolas no campo, o equivalente a 340 escolas por mês e 9 por dia. Ressaltamos aqui a enorme perda de dignidade dessas populações, configurada como um verdadeiro descaso do poder público. Com tanto descaso e irresponsabilidade, uma das primeiras decisões tomadas pelas famílias de camponeses é a migração para cidade, com o objetivo primeiro de estudar. No entanto, com a decisão de sair do campo, esses sujeitos, em sua grande maioria, passam a viver distante de seu cotidiano, histórias, memórias e identidades, em condições de total abandono e precariedade. O objetivo do tópico a seguir é romper com tamanho descaso, colaborando com o empoderamento das escolas do campo, numa estreita relação com os movimentos sociais. 


\section{Escolas do campo: desafios, limites e possibilidades}

Neste tópico, nossa intenção é compreender como as escolas do campo, na interface com o Programa Nacional de Educação do Campo, podem contribuir com a organicidade dos atores, individuais e coletivos e suas ruralidades, enaltecendo a pedagogia da alternância, a luta pela terra, a inclusão da reforma agrária e das questões fundiárias na agenda nacional. As questões identitárias e de valorização das políticas públicas em educação do campo, oriunda dos movimentos sociais, são essenciais no fortalecimento dos espaços educativos. Elas promovem justiça, solidariedade e formação humana. Zela pela ética e superação dos preconceitos acerca da identidade camponesa, forjada na sociedade do século XXI, atribuindo sentido às escolas do campo, ancoradas por novos instrumentos pedagógicos e metodológicos, como por exemplo, a pedagogia da alternância. Tais instrumentos constituem espaços de lutas sociais e garantia de educação escolar pública e popular, incorporando as múltiplas dimensões da realidade campo-cidade.

O descompromisso histórico com a produção crítica do conhecimento nas escolas do campo ainda é um agravante. Ele pode provocar alienação dos educadores, em especial, o desconhecimento da pedagogia da alternância e os debates acerca da história da educação do campo e os movimentos sociais. Em relação aos educandos, o intenso desrespeito e desvalorização de suas histórias de vida e saberes populares. Por outro lado, o que nos anima é a organização coletiva dos movimentos sociais camponeses e suas lutas na valorização da identidade histórica e cultural dos povos camponeses. Tais movimentos compreendem a necessidade de resistirem, coletiva e organizadamente. Lutam por uma educação libertadora e igualitária, enfrentando a descaracterização imposta às políticas de educa- 
ção do campo. Importante ainda ressaltar neste debate, a estratégica participação e articulação de outros atores, individuais e coletivos: Programa Nacional de Agricultura Familiar - PRONAF, Política Nacional de Agroecologia e Produção Orgânica - PNAPO, Programa de Aquisição de Alimentos - PAA e Programa Nacional de Alimentação Escolar - PNAE (CAMPOS, 2015), além de universidades públicas, secretarias estaduais e municipais de educação, educadores e educandos. Essas instituições podem fazer a diferença na consolidação das escolas do campo e fortalecimento das políticas públicas de educação do campo no Brasil. (MOLINA, 2009, 2010, 2012).

Entendemos que as escolas do campo possuem identidades definidas por suas histórias, saberes, gestos, sonhos, limites, possibilidades, avanços e recuos. O campo é rico de cultura própria. Seus sujeitos, individuais e coletivos, possuem costumes e saberes específicos, diferenciados dos valores urbanos. É extremamente desagradável quando crianças, jovens e adultos, ao continuarem seus estudos nas grandes cidades, acabam perdendo suas origens. $\mathrm{O}$ avanço na conquista de políticas públicas de educação do campo pode colaborar com a continuidade dos estudos, em sintonia com as histórias de vida, educação popular e conhecimento científico. Nesse sentido, as escolas do campo contribuem na formação da consciência crítica e coletiva, e no enfrentamento das ações reprodutoras de desigualdades no campo brasileiro. As ações do Programa Nacional de Educação do Campo podem colaborar com projetos que articule escola, poesias, artes, versos, pedagogia da alternância, movimentos sociais, agricultura familiar, orgânica e agroecológica. (CALDART, 2003, 2015).

Quando as escolas do campo insistem em não oferecer a educação infantil, as séries finais do ensino fundamental, ensino médio e EJA - Educação de Jovens e Adultos, restam apenas duas possibilidades: 1) os educandos 
param de estudar e se dedicam, prioritariamente, ao trabalho agrícola; 2) abandonam o campo para continuarem os estudos nas cidades. Quando o processo educativo é ofertado, quase que exclusivamente, nos centros urbanos, os estudantes do campo se veem na obrigação de realizarem longos deslocamentos, que não contemplam a realidade campesina e seus espaços de formação política, crítica e transformadora. Por outro lado, a cantoria nos oferece a seguinte orientação: "não vou sair do campo pra poder ir pra escola, educação do campo é direito e não esmola". Podemos afirmar que a luta por uma educação do campo, vai muito além da Constituição de 1988 e a LDB 9394/96. Ela se constitui no envolvimento dos atores políticos e suas práticas educativas, socioculturais e populares presente, predominantemente, nos espaços coletivos organizados pelos movimentos sociais e escolas do campo. (AUED \& VENDRAMINI, 2009).

Boa parte dos educadores nas escolas do campo, desconhecem metodologias de trabalho que privilegiem os princípios da educação do campo e os instrumentos da pedagogia da alternância. Em sua grande maioria, utilizam as mesmas estratégias pedagógicas das escolas localizadas nas grandes cidades. Muitos educadores possuem apenas o ensino médio normal, formação de professores. Segundo dados do PRONACAMPO - Programa Nacional de Educação do Campo (2012), o campo tem um total de 342.845 professores. Sem educação superior: 160.317. Com ensino médio: 156.190. Com ensino fundamental: 4.127. Uma das maiores dificuldades dos educadores é a pouquíssima disponibilidade de tempo no envolvimento com os processos de formação continuada, oferecida pelas Instituições de Ensino Superior, através do PROCAMPO - Programa de Apoio à Formação Superior em Licenciatura em Educação do Campo e do PRONERA - Programa Nacional de Educação na Reforma Agrária.

Os educadores nas escolas do campo são, em sua 
grande maioria, mal remunerados, com carga horária exaustiva de atividades, em mais de uma escola por dia. Mesmo diante de tantas adversidades, defendem a implantação dos espaços de formação crítica. Enfrentam a opressão, o analfabetismo e outras formas de violência simbólica vivenciada pelos estudantes do campo, além do enorme desafio de encontrar materiais didáticos condizentes com as realidades camponesas, essencial no processo de formação dos estudantes na educação básica. Em sua grande maioria, seu processo de escolha nas escolas do campo, desconsidera a autonomia dos sujeitos, individuais e coletivos, sendo, praticamente, a única ferramenta dos educadores e educandos. São livros escolhidos e utilizados nos espaços urbanos, com gravuras de cidades, deformações caricaturadas dos trabalhadores rurais e, portanto, inúteis no processo de ensino-aprendizagem emancipador (MUNARIM, 2008). A produção crítica nas escolas do campo, embora com avanços, ainda é uma utopia. O PRONACAMPO garante que os estudantes do campo tenham o direito de encontrarem nos livros didáticos, sua realidade econômica e cultural, considerando suas histórias, memórias e identidades e saberes populares.

(FREITAG, 1989) já denunciava que os conteúdos dos livros didáticos estão desvinculados da realidade das crianças. Eles procuram disfarçar, omitir ou distorcer problemas e contradições encontradas em determinadas classes sociais. Trabalhar com livros didáticos de maneira inovadora e politizada exige, inclusive, uma reforma pedagógica no sistema educativo, despertando o interesse dos sujeitos, individuais e coletivos, em favor das pedagogias emancipatórias. A alienação de educadores e educandos foi detectada durante as pesquisas realizadas no Programa de Educação Tutorial - PET Educação do Campo e Movimentos Sociais e na Licenciatura em Educação do Campo, ambos na UFRRJ - Universidade Federal Rural do Rio de Janeiro. Poucos estudantes possuem contato 
com a agricultura familiar. Boa parte das escolas do campo adotam livros didáticos, práticas pedagógicas e metodológicas vinculadas aos grandes centros urbanos. Nessa conjuntura, são apenas escolas em locais de difícil acesso (BICALHO, 2016).

Os movimentos populares e os sujeitos coletivos do campo resistem diante de políticas compensatórias. Os povos camponeses com suas reflexões, experiências, realidades e interesses, defendem o campo como espaço da diversidade cultural e de políticas públicas que priorizem as questões sociais e o respeito às escolas do campo, educadores, educandos, movimentos sociais e comunidade. Tais reflexões podem auxiliar os sujeitos, individuais e coletivos, na busca por seus direitos e deveres. Nessa perspectiva, é possível que educadores e educandos do campo, no diálogo com suas histórias de vida, superem os conservadorismos, individualismos e autoritarismos presentes nos modelos de organização da sociedade brasileira.

Com muita tristeza afirmamos que a escolarização do jovem rural é, em sua grande maioria, encerrada no primeiro segmento do ensino fundamental (CASTRO, 2009). Mesmo com o avanço das políticas públicas em educação do campo, a oferta desta modalidade de ensino, ainda é muito tímida. A seguir, elencamos algumas dificuldades de permanência das crianças, jovens e adultos nas escolas do campo: 1) número muito pequeno de escolas no campo, 2) localização geográfica das escolas, em sua grande maioria, distantes da residência dos estudantes, 3) falta de professores, 4) formação de educadores e educandos que desconsidera os projetos político-pedagógicos emancipadores e a realidade histórica, social e cultural do campo, $5)$ descaso e despreparo para lidar com as turmas multisseriadas, 6) infraestrutura das escolas e salas de aula inadequadas para educadores e educandos, 7) estradas com poucas condições de uso e sem manutenção, 8) transportes em péssimas condições de conservação, inclusive, com 
riscos de acidentes para educadores e educandos, 9) organização curricular e material didático descontextualizado e com predomínio dos valores urbanos, 10) inadmissível fechamento das escolas do campo nas últimas décadas, 11) índices cada vez maiores de nucleação das escolas, 12) escolas do campo que inviabilizam a participação dos movimentos sociais nas atividades político-pedagógicas, 13) descompromisso das secretarias, municipais e estaduais, de educação com os altos índices de analfabetismo e oferta da educação de jovens e adultos no campo. 14) pouquíssima oferta de vagas para os estudantes do campo nas séries finais do ensino fundamental e médio. 15) poucos recursos utilizados na construção e manutenção das escolas do campo. 16) Recuo da agricultura familiar e avanço do agronegócio. 17) utilização cada vez maior de agrotóxicos. 18) investimentos em sementes transgênicas, em detrimento das sementes crioulas. Esses e outros aspectos, ilustram o quadro de descaso com a educação pública no campo brasileiro. (CALDART, PEREIRA, ALENTEJANO \& FRIGOTTO, 2012). Este cenário de descaso histórico está vinculado aos projetos conservadores e tradicionais de ruralidades defendidos pela chamada "educação rural".

Reitero que tais escolas, em sua grande maioria, estão localizadas em espaços de completa ausência do poder público, em especial, as questões que envolvem acesso, estradas, iluminação, segurança, estrutura física, logística, pessoal, materiais didáticos, formação dos educadores, alto índice de escolas do campo fechadas, descontinuidade de projetos e programas. Históricas injustiças que frustram os sujeitos camponeses carentes de efetivas políticas públicas. Boa parte dos estudantes, ao concluírem o ensino fundamental nas comunidades rurais, permanecem sem expectativas de continuidade dos estudos na própria comunidade. Novamente destituídos dos seus desejos e direitos.

A falta de transporte, por exemplo, para realização 
das atividades previstas nas escolas do campo, pode tornar o fazer pedagógico uma verdadeira aventura, em função das longas caminhadas. As linhas de transporte urbano, em sua grande maioria, não fazem o trajeto até as áreas de reforma agrária, aldeias indígenas e territórios quilombolas. A falta de formação pedagógica dos educadores/as é outro agravante. Tais educadores, em sua grande maioria, lidam com as dificuldades relembrando suas experiências individuais como alunos. Adotam táticas que desqualificam a potencialidade dos educandos, contribuindo para elevar os altíssimos índices de evasão nas escolas do campo. Esses problemas devem ser enfrentados com políticas públicas e o PRONACAMPO é uma delas. Não podem ser naturalizados. Políticas emergenciais, provisórias e descontextualizadas devem ser combatidas com responsabilidade, ressaltando as inúmeras experiências exitosas, compromisso político, aprendizagens, resistências e lutas dos educadores, educandos e movimentos sociais do campo (SOUZA, 2010, 2011. VENDRAMINI, 2009, 2000.)

A educação rural no Brasil ainda é uma realidade, mesmo diante de avanços consideráveis na concepção de educação do campo. Ela permanece a serviço do agronegócio, do latifúndio, do agrotóxico, dos transgênicos e da exportação. Sua prioridade é o fortalecimento da mecanização e a inserção do controle químico nas culturas, em detrimento das condições de vida do homem e da mulher camponesa (MARTINS, 2009). Esses paradigmas direcionam as políticas e práticas educativas efetuadas no meio rural. São agentes da exclusão social e educacional, além de contribuir para negação dos direitos, histórias, sonhos, gestos, religiosidades e identidade dos sujeitos. Em relação ao paradigma hegemônico do campo (FERNANDES \& MOLINA, 2005, p. 57) tecem os seguintes comentários:

Na relação homem-terra, esse paradigma se fortalece pelo princípio da exclusão de tudo que não a comporta. No paradigma do rural tradicional, há, pois, seleção e rejeição de 
ideias integradas nas teorias que fundamentam esse modelo. No contexto discutido, [...] a produção em larga escala, o uso desmesurado de agrotóxicos, a rejeição de conhecimentos e saberes da tradição de trabalhadores, dentre outros. Desse modo, o paradigma do rural tradicional elege, seleciona o que the interessa como modelo econômico e cultural.

A negação da cultura campesina nas escolas foi historicamente construída. Sua riqueza e importância para sociedade são negligenciadas e, constantemente, encaradas de maneira preconceituosa (SOUSA \& REIS, 2009). A educação rural desenvolveu-se com o intuito de proteção e assistência ao camponês. Em algumas ocasiões, as escolas tradicionais e conservadoras, defendiam que o ato de ensinar deveria pensar o homem do campo como ser ignorante. Por nada saber, não tem o que ensinar. Para (ARROYO, 1999 , p. 23) não se trata de desconsiderar a cultura urbana com suas lógicas e especificidades que, muitas vezes, se relacionam à vida rural, mas sim, de considerar que:

Há uma cultura urbana, mas, sobretudo há uma cultura da terra, da produção e do trabalho, do modo de vida rural. É verdade que não podemos romantizar a vida do campo. Sempre foi tensa a vida do homem com a terra, as relações sociais foram e são tensas. Nessa permanente tensão e não em uma relação bucólica, foram produzidas as matrizes culturais que ainda marcam todos nós. Como educadores, temos que pensar na força que tem as matrizes culturais da terra e incorporá-las em nosso projeto pedagógico. Sobretudo, incorporar as transformações que as lutas do campo provocam nessas matrizes culturais.

Compreendemos que o homem e a mulher do campo são portadores de culturas e saberes tão relevantes, quanto os da cidade. Importante considerar as reflexões sobre o PRONACAMPO na interface com a formação dos educadores, a pedagogia da alternância e a promoção de práticas diferenciadas na educação do campo. Tais peculiaridades exigirão de educadores, educandos, familiares, comunidades e movimentos sociais, autocrítica, formação 
teórica e prática, no enfrentamento dos conservadorismos e tradicionalismos acadêmicos. $\mathrm{O}$ olhar criterioso acerca das políticas públicas de educação do campo é uma preocupação estratégica desses sujeitos, relatadas nos diversos fóruns de educação do campo e nas atividades desenvolvidas pelas Licenciaturas em Educação do Campo. As escolas do campo, secretarias municipais e estaduais de educação, gestores e universidades públicas envolvidas com a produção crítica e emancipadora do conhecimento, devem compreender a grandeza de educar e aprender com crianças, jovens e adultos camponeses, num contexto de grandes desafios para sobrevivência humana, em especial, o descaso com a agricultura familiar no Brasil, se comparada com o incentivo ao agronegócio.

Obviamente, que as escolas do campo não são homogêneas para pescadores, ribeirinhos, caiçaras, atingidos por barragens, aldeias indígenas, territórios quilombolas e agricultores vinculados à FETAG - Federação dos Trabalhadores na Agricultura, CPT - Comissão Pastoral da Terra, MPA - Movimento dos Pequenos Agricultores, acampados e assentados da reforma agrária. A defesa é pela diversidade social, cultural, histórica, religiosa, étnica, de geração e gênero nesse país (MOLINA, 2009). Os projetos político-pedagógicos emancipadores das escolas do campo podem fortalecer as famílias camponesas e a realidade do entorno, garantindo a qualidade da educação, direitos e especificidades dessa população, suas histórias de vida, identidades, memórias e valorização cultural. Pode ainda contribuir na formação política, gestação de embriões de democratização e socialização do poder, superando desafios, afirmando identidades de classe e seres humanos preocupados com o trabalho coletivo. Para (CALDART, 2000) "escola é mais do que escola".

É fato que a escola tradicional não pode ser desprezada. No entanto, é urgente romper com a exclusividade da sala de aula, na produção do conhecimento. Os mo- 
vimentos sociais, em defesa dos seus espaços e projetos alternativos, ressignificam a formação crítica dos sujeitos, com diferentes formas de linguagens, documentos históricos e interpretações. A educação do campo é (re)feita por diversas mãos, em diferentes espaços e lugares distintos. A escola do campo pode ser mais um desses espaços de valorização das questões políticas, econômicas e sociais, considerando, entre outros aspectos, o engajamento nas lutas por reforma agrária (CALDART; ARROYO \& MOLINA, 2004). A escola não é o único lugar onde se estuda, mas há uma associação simbólica, cultural, muito forte entre escola e estudo (CALDART, 2008).

Que interessante seria, se todas as escolas do campo considerassem, na sua organicidade, a estreita relação entre ocupações de terras improdutivas, produção agroecológica, histórias de vida, formação político-pedagógica emancipadora, gestos, resistências, identidades e memórias de homens, mulheres, crianças, jovens e adultos do campo. Pensar numa organização pedagógica que legitima as especificidades das escolas do campo, sua infraestrutura, educadores, educandos e movimentos sociais, além dos debates em torno da segurança alimentar e do processo de desenvolvimento rural, em bases sustentáveis. Diante do aumento crescente do agronegócio e utilização dos agrotóxicos, somados à histórica concentração de terras, em detrimento do fortalecimento da agricultura familiar, é necessário compreender a importância dos movimentos sociais e escolas do campo nesse debate, valorizando seus componentes históricos, sociais e educacionais, num campo cheio de vida, histórias, memórias, identidades, sonhos, desejos, avanços e recuos, limites e possibilidades.

Para (ARROYO, 1999) a escola deve interpretar os processos educativos que acontecem fora dela, organizando conhecimentos, socializando saberes e culturas historicamente produzidas, além de intervir na realidade, a partir dos instrumentos técnico-científicos. Certamente o 
estudante que reside no campo e estuda na cidade, interpreta os fenômenos da vida desvinculados de sua realidade. Ao invés de lutarem pelas histórias, identidades e memórias que compõem as comunidades campesinas e o jeito de ser dos sujeitos camponeses, direta e indiretamente, são obrigados a abandonarem o campo, em direção aos grandes centros urbanos. Nessa conjuntura, destacamos a importância dos movimentos sociais camponeses na resistência e organização de ações que consolidem as experiências pedagógicas dos atores, individuais e coletivos.

O conhecimento emancipador não se baseia, apenas, em mera exposição de conteúdos, lições e exercícios de fixação. Conhecer implica ir além das demandas da escola tradicional e conservadora. Implica movimentos recíprocos entre educadores, educandos e os demais sujeitos envolvidos com o ato de educar, mesmo que tais escolas, em sua grande maioria, apresentem estruturas curriculares e projetos político-pedagógicos com pouca flexibilidade em relação aos conteúdos didáticos, organização curricular e participação dos familiares e comunidade no acompanhamento das atividades político-pedagógicas. As atuais experiências de luta por políticas públicas em educação do campo, exigem a consolidação das escolas do campo, e nela, a ciranda infantil, o ensino fundamental do $1^{\circ}$ ao $9^{\circ}$ ano, alfabetização e educação de jovens e adultos, além de educadores formados nas licenciaturas em educação do campo.

Em sua grande maioria, as licenciaturas em educação do campo nas universidades públicas dialogam com as escolas do campo. Nesses espaços presenciamos, inúmeros debates, conflitos de ideias e reconstrução de valores. Mecanismos que fazem emergir sonhos e esperanças de educadores, educandos, movimentos sociais e trabalhadores rurais, num projeto coerente com a realidade de vida desses sujeitos. E estratégica a valorização de tais escolas como espaços de construção da cidadania plena, 
contrária às ações reprodutivistas e produtoras das desigualdades sociais. Elas estão diretamente envolvidas com as lutas por inclusão social, defesa dos direitos humanos, soberania alimentar, agricultura familiar, agroecológica e orgânica. Combatem e denunciam a utilização dos agrotóxicos, transgênicos, assassinatos de lideranças, criminalização dos movimentos sociais e a histórica presença dos latifúndios improdutivos. Uma escola do campo que busque a igualdade e o direito à terra. Que saiba lidar, entre outras questões, com as diferenças de gênero, étnica, social e de geração, num projeto político pedagógico que contribua para emancipação de educadores e educandos, valorizando a produção escrita e oral (CALDART; STÉDILE \& DAROS, 2015. CALDART; PEREIRA; ALENTEJANO \& FRIGOTTO, 2012).

A educação é ferramenta indispensável na produção e socialização da cultura. As atividades de formação político-pedagógicas sobre os princípios da educação do campo nas escolas, podem ser espaços de vivências, produção e resgate da cultura popular, comprometida com mudanças que valorizem a classe trabalhadora. Esses procedimentos enobrecem a arte de educar com satisfação, ética e responsabilidade, senso crítico, criatividade e autoestima, a partir de uma diversidade de fontes: jornais, revistas, músicas, literatura de cordel, histórias de vida, memórias e identidades. As políticas públicas de educação campo podem ser ferramentas norteadoras na formação crítica dos educadores. Além de romper, coletivamente, com modelos autoritários e conservadores de sociedade, tem condições de alterar as relações de poder e situações de descasos com os sujeitos do campo, ampliando os processos de resistências, enfrentamentos e acúmulo de forças na promoção das mudanças que emancipam.

Apesar das inúmeras experiências educacionais importantes e denúncias realizadas pelos movimentos sociais, o cenário de descaso do campo é preocupante. É 
estratégico ressaltar que o estímulo ao fechamento das escolas do campo se consolida com as políticas de nucleação e transporte escolar. Estas medidas arbitrárias das gestões públicas impõem aos educandos uma exaustiva jornada diária de deslocamento até as escolas da cidade. Em muitos casos, a garantia de prestação do serviço pelo poder público, não atende a qualidade do transporte escolar e violam direitos básicos dos educandos, em especial, o desenvolvimento de processos educativos que contemple sua inserção nas comunidades.

Compreendemos que a consolidação e expansão das escolas do campo para aten $\neg$ der, sobretudo, as demandas de escolarização básica e superior, carece de respeito às leis nacionais e internacionais de direitos humanos, sociais e civis, pelas instituições públicas. Um exemplo do descaso com as populações camponesas, é a dura realidade de fechamento das escolas rurais. Entre 2003 e 2013 mais de $31,4 \%$ dessas escolas foram fechadas, em função da nucleação, fenômeno muito presente nas secretarias municipais e estaduais de educação no Brasil. A nucleação significa a junção de duas, três ou mais escolas rurais, numa escola do núcleo urbano, denominada escola-polo. Tais espaços possuem um número maior de carteiras para atender os estudantes, na jornada de rodar quilômetros em transportes coletivos escolares, quase sempre em condições indignas $^{3}$. A questão é tão grave que, em 28 de março de 2014, a Agência Brasil publica matéria sobre a Lei no 12.960 , de 27 de março de 2014, que dificulta o fechamento das escolas rurais, indígenas e quilombolas. Esta lei altera a LDB/1996 e concede aos Conselhos Municipais de Educação, manifestação sobre o assunto ${ }^{4}$ (OLIVEIRA, 2015, p. 51).

De todos os aspectos debatidos pelos movimentos

\footnotetext{
${ }^{3}$ Ver reportagem sobre fechamento das escolas do campo. Folha de São Paulo online, de 03 mar. 2014.

${ }^{4}$ Disponível em: <http://agenciabrasil.ebc.com.br/educacao/noticia/2014-03/ sancionada-lei-que-dificulta-fechamento-de-escolas-rurais-e-quilombolas $>$. Acesso em: 2 ago. 2015.
} 
sociais na educação do campo, o mais contraditório é a política de fechamento das escolas, por parᄀte dos sistemas estaduais e municipais de ensino, através da nucleação e oferta de transporte para deslocamento dos educandos. Esta política é reiteradamente criticada e condenada pelo MEC, pelo Conselho Nacional dos Secretários de Educação (CONSED), pela União Nacional dos Dirigentes Municipais de Educação (UNDIME) e pelo Conselho Nacional de Educação (CNE), visto que infringe, inclusive, a LDB/1996, contribui para evasão, repetência e distorção série-idade, além de afastar crianças, jovens e adultos de suas comunidades (OLIVEIRA, 2015, p. 55). Em muitos casos, educadores, educandos e instituições ficam à mercê das decisões do poder público e os problemas se avolumam, cotidianamente, quando as secretarias, estaduais e municipais, encontram inúmeras dificuldades para manter aberta as escolas do campo.

Historicamente, a solução das secretarias tem sido a criação das escolas com classes multisseriadas, funcionando nas comunidades como escola-polo. Por vários motivos, as escolas multisseriadas tem sido, gradativamente, fechadas: redução de investimentos para educação, política de nucleação e oferta de transporte escolar. Importante aqui registrar a orientação do MEC - Ministério da Educação, através do Programa Nacional de Educação do Campo - PRONACAMPO e a cobrança do FONEC - Fórum Nacional de Educação do Campo para utilização do transporte escolar intra-campo. No entanto, tal transporte é, predominantemente, utilizado para deslocamento dos estudantes do campo para cidade. Ele contribui para os altíssimos índices de escolas do campo fechadas no Brasil (JANATA \& ANHAIA, 2015). Nesse sentido, pergunto: as políticas públicas em educação do campo estão, de fato, chegando nas comunidades rurais?

A escola tradicional e conservadora do meio rural, historicamente, não reconheceu o potencial dos educa- 
dores e educandos, suas histórias de vida, valores e sonhos. Perdemos diversas oportunidades de consolidação da identidade camponesa. Nesse contexto é fundamental ressignificar olhares, lugares, trajetórias, protagonismos, histórias, memórias e identidades, em diálogo com os movimentos sociais e as políticas públicas de educação do campo. Na busca por práticas emancipadoras, as marcas dos sujeitos camponeses devem ser evidenciadas no envolvimento com leitura, escrita e oralidade. Segundo Freire (1982, p. 29): "O comando da leitura e da escrita se dá a partir de palavras e de temas significativos à experiência comum dos alfabetizandos e não de palavras e de temas apenas ligados à experiência do educador".

O educando carrega para escola conhecimentos, historicamente construídos, na relação com a educação popular. Suas histórias de vida não podem ser negligenciadas. Como salienta Paulo Freire, as lições de história começam a partir da realidade do estudante e a aceitação da palavra do outro, constitutiva de nossas próprias palavras. O conhecimento não está de antemão pronto, como um sistema que o sujeito se apropria para usá-lo. Ele se reconstitui nas atividades de linguagens, trocas e debates. Segundo (GRAMSCI, 1978 apud NOSELLA, 1992, p. 15): "É preciso desacostumar-se e parar de conceber a cultura como saber enciclopédico, para o qual o homem é um recipiente a ser enchido e no qual devem ser depositados dados empíricos, fatos brutos e desarticulados."

Esses são pontos essenciais na consolidação das políticas públicas e de atores históricos atentos ao diálogo, convívio humano e solidariedade entre os pares, engajados na defesa de ambientes socialmente justos, com distribuição de renda e terras. Entendemos que a produção crítica e dialética do conhecimento pode contribuir com diálogos, interações, reflexões, análises e sínteses provisórias. Ela promove rupturas com a concepção de "educação bancária" (FREIRE, 1975) e os saberes fragmentados, reco- 
nhecendo a diversidade camponesa e a autoestima dos sujeitos, individuais e coletivos.

Por fim, entendemos que o incentivo à apropriação crítica dos conteúdos nas escolas do campo é uma das responsabilidades do Programa Nacional de Educação do Campo - PRONACAMPO, numa estreita articulação com os movimentos sociais, secretarias de educação, universidades, educadores e educandos comprometidos com os princípios, teóricos e práticos, da educação do campo. Articulação que considere o exercício da cidadania, as questões étnicas, de gênero, etnias, classe social, necessidades especiais, identidades e memórias, saberes, gestos e histórias de vida. Nesse contexto emancipador, o acesso e a permanência dos estudantes das escolas do campo na educação básica, pode transformar a vida de muitos jovens camponeses.

\section{Considerações finais}

A sociedade brasileira construiu no seu imaginário uma estreita e injusta ligação do campo como lugar do atraso, contribuindo para omissão do Estado em relação às políticas públicas de educação e demais direitos dos povos camponeses. É de consenso na sociedade brasileira que a exclusão do direito à terra e educação contribuem para elevadas distorções sociais e aumento exagerado da violência. Com tantos problemas, até onde vai o direito de ir e vir nas escolas do campo? Esses desafios precisam ser enfrentados por políticas públicas, educadores, educandos e movimentos sociais. Entendemos que os princípios da educação do campo podem estabelecer uma estreita relação com os valores da dignidade humana, confiança, solidariedade, compreensão coletiva e valorização das histórias de vida dos sujeitos camponeses, há tempos silenciados. Tais princípios dialogam ainda com a educação popular, os movimentos sociais e a pedagogia da al- 
ternância, além da segurança alimentar, desenvolvimento sustentável, agricultura familiar, orgânica e agroecológica. São campos do saber que se aproximam e devem ser explorados por educadores e educandos nas escolas do campo, nas comunidades e ambientes familiares.

Entendemos que o Programa Nacional de Educação do Campo - PRONACAMPO, enquanto política pública, pode colaborar no enfrentamento das inúmeras dificuldades de consolidação das escolas do campo: ausência de docentes e pessoal de apoio, estradas intransitáveis, transportes inadequados e o enorme descaso das secretarias, municipais e estaduais, na organicidade da educação do campo. Nesse contexto de dificuldades, ainda é possível constatar cursos aligeirados, formação de educadores e educandos preocupados apenas com a lógica do mercado, conteudistas e superficiais, currículos tradicionais e improvisados, evasão escolar, espaço físico com infraestrutura inadequada de funcionamento, além do péssimo acesso e permanência dos jovens e adultos nas escolas do campo.

Mesmo com alguns avanços nas legislações que incorporam os debates sobre a educação do campo, vale destacar que a realidade das escolas continua ainda muito precária. Notamos que o desrespeito às identidades dos sujeitos camponeses nos meios de comunicação, imprensa, instituições públicas e privadas da sociedade brasileira contribuem com provocações, humilhações e destruição da autoestima. O campo brasileiro é uma incerteza. Faltam escolas, transporte escolar intra-campo, condições de acesso e escoamento da produção. Altos índices de contaminação pelo uso intensivo de agrotóxicos, concentração de terras, utilização de sementes transgênicas e avanço do agronegócio, em detrimento, da semente crioula e valorização da agricultura familiar.

Apesar do retrato atual, consideramos que o Programa Nacional de Educação do Campo - PRONACAMPO pode atender os anseios dos sujeitos camponeses, através 
do diálogo com as diversas esferas da gestão do Estado, movimentos e organizações sociais do campo brasileiro. Pode ainda contribuir na consolidação dos diferentes saberes oriundos das escolas do campo, através da diversidade étnico-cultural, o reconhecimento do direito à diferença, a construção de bases epistemológicas que busquem a superação da dicotomia campo-cidade, além das articulações políticas, sociais e culturais presentes na diversidade dos movimentos sociais. A mudança de paradigmas na educação do campo é essencial. Prescinde de novos olhares, fundamentação teórico-prática e recriação do sujeito histórico, rompendo com a construção equivocada de estereótipos acerca dos sujeitos, individuais e coletivos, do campo.

Tal política pública, em articulação com os movimentos sociais, universidades, secretarias municipais e estaduais de educação, tem condições de construir, coletivamente, projetos emancipadores que elevem a autoestima, criticidade e autonomia de educadores e educandos nas escolas do campo. Obviamente, essas questões não estão desvinculadas da capacidade de mobilização social e política que os sujeitos do campo constroem no seu íntimo. $\mathrm{O}$ reconhecimento identitário e as histórias de vida dos atores devem ser fortalecidas com as novas conquistas e a capacidade de propor, questionar, dialogar e refletir sobre as relações de poder e saberes historicamente estabelecidos. Quando ação e reflexão são organizadas com o objetivo de transformar a realidade dos sujeitos camponeses, a práxis libertadora pode contribuir na consolidação do PRONACAMPO e demais políticas públicas.

O respeito pelos saberes do campo orientou toda organização desse texto, zelando pela flexibilidade e possibilidades de revisão das atividades propostas, num projeto coerente com a realidade de vida das pessoas. Faço aqui alguns questionamentos? Qual a real possibilidade de implementação, em nível nacional, das políticas públicas de educação do campo, em especial, o Programa Nacional 
de Educação do Campo - PRONACAMPO? Quais as relações políticas, sociais e pedagógicas possíveis, a despeito das negações e adversidades, historicamente acumuladas, acerca da educação popular? Que práticas de leituras e escritas circulam nas escolas do campo? Que usos e funções elas possuem? É possível ir além dos espaços tradicionais e conservadores da escola regular? Educadores e educandos se mostram preocupados e flexíveis no trabalho com o novo? Contribuem na transformação dos educandos em agentes e sujeitos da história? Ou atuam, apenas, como meros participantes? Como enfrentar tantas questões?

Quero salientar que a produção do conhecimento pautada nas referências utilizadas e nas observações efetuadas não são isentas de valores. A construção crítica e coerente do saber não é neutra. Esperamos, dessa forma, estimular a produção de leituras e reflexões que contemplem as possíveis interfaces entre escolas do campo e Programa Nacional de Educação do Campo - PRONACAMPO. Nesse processo de construção histórica prevaleceu o respeito às diferenças e à valorização da identidade cultural dos povos camponeses, propondo uma educação inclusiva, questionadora e democrática, presente em diversas experiências de educação popular vinculadas à luta pela terra. Por fim, importante registrar nossa defesa em prol das políticas públicas de formação dos educadores nas escolas do campo. Sugiro aos leitores a continuidade desses estudos, com o objetivo de compreender a relevância de tais políticas no fortalecimento das relações com os movimentos sociais.

\section{REFERÊNCIAS}

ARROYO, M. G.; FERNANDES, B. M. A educação básica e o movimento social do campo. Coleção Por uma Educação Básica do Campo, n. 2, Brasília, DF: Articulação Nacional por uma Educação Básica do Campo, 1999. 
ARROYO, M. G.; MOLINA, M. C.; JESUS, S. M. S. A. de. (Orgs.). Contribuições para a construção de um projeto de educação do Campo. Coleção Por uma Educação Básica do Campo, n. 5, Brasília, DF: Articulação Nacional Por uma Educação Básica do Campo, 2004.

AUED, B. W.; VENDRAMINI, C. R. (Orgs). Educação do campo - desafios teóricos e práticos. Florianópolis: Ed. Insular, 2009.

BICALHO, R. S. Interfaces entre escolas do campo e movimentos sociais no Brasil. Revista Brasileira de Educação do Campo, Tocantinópolis, v. 1, jan./ jun. 2016.

BRANDÃO, C. R. (Org.). Pesquisa participante. 2. ed. São Paulo: Brasiliense, 1982. p. 34-41.

2006. 110 p.

O que é Educação Popular. São Paulo: Brasiliense,

BRASIL. Lei de Diretrizes e Bases da Educação Nacional LDB - o․ 9.394/96, Artigos, 28, 78, 79, 1996.

. MINISTÉRIO DA EDUCAÇÃO. Portaria no 86 de $\mathbf{1}^{\circ}$ de fevereiro de 2013. Institui o Programa Nacional de Educação do Campo - PRONACAMPO e define suas diretrizes gerais. Brasília, DF: GABINETE DO MINISTRO, 2013. Disponível em: $<\mathrm{http} / / / \mathrm{www}$. lex.com.br/legis_24140877_PORTARIA_N_86_ DE_1_DE_FEVEREIRO>. Acesso em: set. 2017.

CALDART, R. S.; ARROYO, M. G.; MOLINA, M. C. (Orgs.). Por uma Educação do Campo. Petrópolis, RJ: Vozes, 2004.

CALDART, R. S. Pedagogia do Movimento Sem Terra: escola é mais que escola. SP: Expressão Popular, 2008.

A escola do campo em movimento. In: Revista Eletrônica Currículo sem Fronteiras, v. 3, n.1, p. 60-81, jan./jun. 2003.

. Caminhos para a transformação da escola: Reflexões desde práticas da Licenciatura em Educação do Campo. SP: Expressão Popular, 2010. 
. Por Uma Educação do Campo: traços de uma identidade em construção. In: KOLLING, E. J.; CERIOLI, P. R.; CALDART, R. S. (Orgs.). Educação do Campo: identidade e políticas públicas. Brasília, DF: Articulação Nacional Por uma Educação Básica do Campo, 2002. Coleção Por Uma Educação do Campo, n. 4, p. 25-36.

CALDART, R. S.; STEDILE, M. E.; DAROS, D. [Orgs.]. Caminhos para transformação da Escola 2: Agricultura camponesa, educação politécnica e escolas do campo. SP: Expressão Popular, 2015.

CALDART, Roseli S.; et al. [Orgs]. Dicionário da Educação do Campo. SP: Expressão Popular, 2012.

CAMPOS, M. Lutas dos movimentos sociais do campo e suas contradições na construção da educação do campo. RETTA - Revista de Educação Técnica e Tecnológica em Ciências Agrícolas, Seropédica, RJ, v. 8,n. 11, jan./ jun. 2015.

FERNANDES, B. M.; MOLINA, M. C.; JESUS, S. M. S. A. (Orgs.). Contribuições para a construção de um projeto de educação do Campo. Brasília, DF: Articulação Nacional Por uma Educação Básica do Campo, 2005. Coleção Por uma Educação Básica do Campo, n. 5.

FÓRUM NACIONAL DE EDUCAÇÃO DO CAMPO, 1. Notas para análise do momento atual da Educação do Campo, Seminário Nacional. Brasília: FONEC, 2012.

FREIRE, P. Pedagogia da Autonomia: Saberes necessários à prática educativa. SP: Paz e Terra, 1997.

. Pedagogia do Oprimido. RJ: Paz e Terra, 1975.

. Educação como prática de liberdade. RJ: Paz e Terra, 1983.

. A Importância do ato de ler. SP: Cortez, 1982.

FREIRE, P.; NOGUEIRA, A. Que fazer: teoria e prática em educação popular. Petrópolis, RJ: Vozes, 2002. 
FREITAG, B. O livro didático em questão. Porto Alegre: Artmed, 1989.

GOHN, M. G. Movimentos Sociais e Educação. São Paulo: Ed. Cortez. 2001.

GRAMSCI, A. Os Intelectuais e a Organização da Cultura. RJ: Civilização Brasileira, 1978.

JANATA, N. E.; ANHAIA, E. M. Escolas/Classes Multisseriadas do Campo: reflexões para a formação docente. Revista Educação \& Realidade, Porto Alegre, Ahead of print, 2015.

MARTINS, F. J. Educação do Campo: processo de ocupação social e escolar. In: CONGRESSO INTERN. PEDAGOGIA SOCIAL, mar. 2009, São Paulo. Anais... São Paulo: USP, 2009.

MOLINA, M. C.; JESUS, S. M. S. A. de. Contribuições do PRONERA à Educação do Campo no Brasil Reflexões a partir da tríade: Campo -Política Pública - Educação. In: SANTOS, C. A. dos.; MOLINA, M. C.; JESUS, S. M. S. A. de. (Orgs.). Memória e história do Pronera: contribuições para a educação do campo no Brasil. Brasília: Ministério do desenvolvimento Agrário, 2010. p. 29-63.

MOLINA, M. C. A contribuição do PRONERA na construção de políticas públicas de educação do campo e desenvolv imento sustentável. 2003. Tese. (Doutorado em Desenvolvimento Sustentável) - Centro de Desenvolvimento Sustentável da Universidade de Brasília, Brasília, 2003.

. Educação do Campo e formação profissional: a experiência do Programa de Residência Agrária. Brasília: Ministério do Desenvolvimento Agrário, 2009.

. (Org.). Educação do campo e pesquisa: questões para reflexão. Brasília, DF: Ministério do Desenvolvimento Agrário, 2006.

$\overline{\mathrm{MEC}}, 2010$.

Educação do Campo e Pesquisa II. Brasilia, DF: MDA/

MOLINA, M. C.; FREITAS, H. C. de A. (Orgs.). Em Aberto - 
Educação do Campo. Brasília, DF: INEP/MEC, 2012.

MOLINA, M. C.; SÁ, L. M. (Orgs.) Licenciaturas em Educação do Campo: registros e reflexões a partir das experiências piloto. Belo Horizonte: Autêntica Editora, 2011. Coleção Caminhos da Educação do Campo, n. 5.

MOLINA, M. C. (Org.). Licenciaturas em Educação do Campo e o Ensino de Ciências Naturais: desafios à promoção do trabalho docente interdisciplinar. Brasília, DF: MDA/NEAD/ Debate 23, 2014.

MOLINA, M. C. Políticas de Expansão da Educação Superior no Brasil: Sub 7 - Analisar a expansão da Educação Superior do Campo, com destaque para a área de Formação de Educadores. In: XXIV SEMINÁRIO NACIONAL UNIVERSITAS / BR, 2016, Maringá. Anais... Maringá: Universidade Estadual de Maringá, 2016.

MUNARIM, A. Movimento nacional de educação do campo: uma trajetória em construção. Trabalho apresentado no GT 3: Movimentos sociais e educação, 31ํㅡㄹ Reunião Anual da ANPEd, Caxambu, MG, 2008.

NOSELLA, P. A Escola de Gramsci. Porto Alegre: Artes Médicas, 1992.

OLIVEIRA. L. M. T. Educação do campo e as lutas dos movimentos sociais pelos direitos às políticas públicas. RETTA - Revista de Educação Técnica e Tecnológica em Ciências Agrícolas, Seropédica, RJ, v. 8, n. 11, jan./jun. 2015.

SOUZA, M. A. de. Educação do Campo: propostas e práticas pedagógicas do MST. Petrópolis, RJ: Vozes, 2012.

. (Org.). Práticas educativas do/no campo. Ponta Grossa: Editora UEPG, 2011.

. Educação e Movimentos Sociais do Campo: a produção do conhecimento no período de 1987 a 2007. Curitiba: Ed. UFPR, 2010.

SOUZA, N. P.; REIS, R. M. Educação do Campo e Pratica 
Pedagógica. 2009. Monografia (Curso de pós-graduação Lato Sensu em Ensino de Geografia e História) - Faculdades Integradas do Vale do Ivaí - Univale, Umuarama, PR, 2009.

VENDRAMINI, C. R. Terra, trabalho e educação: experiências socioeducativas em assentamentos do MST. Ijuí: Ed. UNIJUÍ, 2000.

VENDRAMINI, C.; AUED, B. W. Educação do Campo: desafíos teóricos e práticos. Florianópolis: Editora Insular. 2009. 


\title{
CAPÍTULO 5
}

\section{FORMAÇÃO DE PROFESSORES NA LICENCIATURA EM EDUCAÇÃO DO CAMPO: contexto de leitores e leituras}

\author{
Célia Beatriz Piatti ${ }^{1}$
}

Este artigo apresenta dados levantados no âmbito da investigação "Sentidos e significados necessários e possíveis para a constituição do professor leitor para além da formação inicial, na licenciatura de Educação do Campo" - que compõe a pesquisa " Políticas educacionais e formação: produção, projetos e ações de educação e psicologia", aprovada em dezembro de 2015 pelo Conselho Nacional de Desenvolvimento Científico e Tecnológico - CNPq (financiada na Chamada CNPq/ MCTI № 25/2015 Ciências Humanas, Sociais e Sociais Aplicadas) que teve por objetivo investigar as políticas educacionais de formação inicial e/ou continuada, por meio da análise da produção, de programas, de projetos e de ações em Educação e Psicologia em Mato Grosso do Sul, evidenciando articulações com o contexto social, cultural e educacional do Estado.

\footnotetext{
${ }^{1}$ Graduada em Pedagogia - Licenciatura Plena - Faculdade de Filosofia, Ciências e Letras de Ituverava, com especialização em Administração Escolar e Orientação Educacional. Mestre em Educação pela Universidade Católica Dom Bosco (2006) e Doutora em Educação pela Universidade Federal de Mato Grosso do Sul (2013). Atualmente é integrante do Grupo de estudos GEPPE (Grupo de Estudos e Pesquisa em Psicologia e Educação). Professora da UFMS, lotada na Faed (Faculdade de Educação) atuando como docente no curso de Licenciatura em Educação do Campo-LeduCampo e no Mestrado do Programa de Pós-Graduação em Educação da Universidade Federal de Mato Grosso do Sul. Tem experiência na área de educação, atuando em ensino, pesquisa e extensão com os seguintes temas: Educação do Campo; Constituição do sujeito; Formação de professores na perspectiva histórico-cultural. E-mail: celiabpiatti@gmail.com

${ }^{2}$ A pesquisa "Políticas educacionais e formação: produção, projetos e ações de educação e psicologia" é coordenada pela profa . Dra. Sônia da Cunha Urt. Professora titular da Universidade Federal de Mato Grosso do Sul. Coordenadora do Grupo de Estudos e Pesquisa em Psicologia e Educação (GEPPE).
} 
A presente pesquisa é fruto do trabalho conjunto de pesquisadores que possuem uma trajetória de estudos, de pesquisas e de produções na área de Educação e Psicologia. Também, resulta de parcerias institucionais estabelecidas em diferentes contextos, seja no âmbito da pós-graduação, da graduação e com os profissionais da rede de ensino estadual e municipal de Campo Grande - MS.

Um ponto de articulação entre os pesquisadores refere-se a ações conjuntas vinculadas ao desenvolvimento de pesquisas, como a participação da universidade Federal de Mato Grosso do Sul (UFMS) pelo Grupo de Estudos em Psicologia e Educação (GEPPE) na Pesquisa nacional sobre "Violência e Preconceito na Escola", em convênio com as Universidades Federais de todo o Brasil, o Ministério de Educação (MEC) e os Sistemas de Conselhos de Psicologia. Também, outro vínculo, se estabelece pela participação em conjunto de alguns desses profissionais em cursos de extensão e aperfeiçoamento, presenciais e a distância, vinculados, entre outros, ao Programa Mais Educação do MEC. Em relação a pós-graduação, a parceria se estabelece por meio da orientação de mestrandos e doutorandos e da participação dos egressos desses cursos nos grupos de pesquisa e, mesmo, já na condição de professores de instituições de Ensino Superior, confere a continuidade e aproximação dos profissionais pelas temáticas que desenvolvem e pelo compromisso com a Educação Pública.

Outro ponto a ser justificado, é a experiência da equipe em trabalhos de pesquisa coletiva com formato temático distribuído em eixos de investigação e também o direcionamento metodológico caracterizado por projetos desenvolvidos com análise documental, de produção e de base empírica de acordo com modelos de pesquisas ação/ intervenção.

Portanto, considerando o exposto, pretende-se nessa pesquisa investigar a constituição de programas, de ações e a produção de políticas educacionais articuladas à for- 
mação docente, perpassando pelas áreas da Educação e da Psicologia. A pesquisa se constitui em cinco propostas vinculadas a dois eixos: da Educação e da Psicologia que só se separam com a finalidade didática para a investigação, mas que se articulam a partir do viés teórico que consideramos em que a educação e a psicologia se constituem em dois elos necessários para o acontecimento do processo educativo. No primeiro eixo, da Educação: 1) o impacto da política do PIBID de fomento à docência; 2) a formação continuada de professores do Ensino Médio no âmbito da educação integral e 3) um programa de ação vinculado ao Pronacampo. No eixo da Psicologia: 1) as produções e os projetos dos programas e nos programas de pós-graduação da Educação e da Psicologia em Mato Grosso do Sul que tomaram como objeto de estudo as políticas educacionais e a área da Psicologia evidenciando dessa forma o lugar da Psicologia nas políticas públicas, suas ações e interlocuções para fundamentar a formação profissional e, 2) a formação do profissional da Psicologia para atuar na interface com a Educação em Mato Grosso do Sul.

Posto isso, para esse estudo, apresentaremos o eixo dois da educação: "Sentidos e significados necessários e possíveis para a constituição do professor leitor, para além da formação inicial, na licenciatura de Educação do Campo", cujo objetivo é ouvir os professores que são estudantes de uma licenciatura em Educação do Campo. Entre diferentes temas que nos incitam a investigar a formação docente, a leitura é um deles, pois independente da área de atuação do professor, ela é alvo frequente das atividades e da própria aprendizagem do professor.

\section{A escola do campo: que espaço é esse?}

A escola do Campo tem origem na luta pela terra e, portanto, de condições e de um modo de produção de vida específico, pois conforme aponta Molina (2011, p.31) “a 
escola do campo se articula com um conjunto de princípios, conceitos e práticas em construção no conjunto das lutas empreendidas pelos trabalhadores do campo".

Nesse sentido, cabe ressaltar que "hoje no campo, como no conjunto da sociedade, predomina uma educação que conforma os trabalhadores a uma lógica que é de sua própria destruição como classe, como grupo social e cultural, como humanidade" (CALDART, 2011, p.64).

De acordo com Neto (2011, p.37) “a luta contra a lógica do capital na educação é pertinente e atual e que somente no combate a essa lógica a educação pode assumir um significado de emancipação humana".

Segundo Caldart (2011)

[...] Educação é um processo intencional (planejado e organizado objetivamente, de preferência por coletivos, em uma direção determinada) de busca de desenvolvimento omnilateral do ser humano que reúne capacidades para atividades tanto manuais como intelectuais, que trabalham diferentes dimensões que permitam o cultivo de uma personalidade harmônica e completa. (CALDART, 2011, p. 65-66).

A autora segue afirmando que a palavra omnilateral Indica a busca de um processo de formação humana ou de humanização integral, entendido como totalidade que não é apenas a soma da atuação em diferentes dimensões, mas sim a articulação que visa coerência na atuação do ser humano no mundo(CALDART, 2011, p. 65-66).

Depreende-se que na escola do campo, "a realidade é uma totalidade, por isto não há como partir dela, para seguir adiante ou retornar. Com seus diferentes territórios, constitui-se como lócus que se quer transformar". (ANTUNES-ROCHA; MARTINS, 2011, p.21).

A escola do campo não é só lugar de aprender conteúdos científicos, mas também os valores essenciais para construir o projeto de vida e, portanto, construir a identidade de quem vive e trabalha no campo. 
Conforme nos apontam Fernandes; Cerioli; Caldart (2009,p.33) um desafio para pensar a escola do campo é levar em conta a "superação da dicotomia rural - urbano, que seja o elemento positivo das contradições em curso, ao mesmo tempo em que resguarde a identidade cultural dos grupos que ali produzem vida".

Caldart nesse caminho assevera que:

Também não podemos esquecer que nossa luta continua sendo para que "a escola seja mais do que escola", no sentido de assumir-se como parte de uma totalidade formadora mais ampla, a vida, a luta por ela não cabe dentro de uma escola (mesmo que derrubadas suas paredes, suas cercas) e as lutas pedagógicas não substituem as lutas sociais e políticas mais amplas, ainda que também na pedagogia a vida não seja defendida somente com palavras... (CALDART, 2011, p.83).

O campo é um espaço de disputa política, econômica e que, para além da luta pela terra, os povos que ali vivem também buscam outros direitos, como a educação, a saúde, condições para permanecer ali em seu espaço de trabalho e de vida. Construir a Educação do Campo significa fortalecer a identidade dos povos do campo com direito a uma educação que responda às suas especificidades locais.

A partir dessas reflexões, há um compromisso em ampliar cada vez mais as possibilidades de formação dos educadores sociais, na perspectiva de reconhecer as demandas do campo nas comunidades e nas escolas.

Caldart (2009) afirma que construir uma escola do campo significa estudar para viver no campo. Ou seja, inverter a lógica que se estuda para sair do campo. Logo, construir uma escola do campo significa pensar e fazer a escola a partir do projeto educativo do campo, tendo cuidado de não projetar para ela o que sua materialidade própria não permite. Cabe, portanto, "[...] trazer para dentro da escola as matrizes pedagógicas ligadas às práticas so- 
ciais; combinar estudo e trabalho, com cultura, com organização coletiva, com postura de transformar o mundo." (CALDART, 2009, p.157).

Nesse sentido, cabe ouvir os sujeitos do campo, suas experiências, seus saberes, pois concordamos entre várias questões que:

Como a escola vai trabalhar a memória, explorar a memória coletiva, recuperar o que tem de mais identitário na memória coletiva? Como a escola vai trabalhar a identidade do homem e da mulher do campo? [...] A escola tem que se preocupar com o direito ao saber e ao conhecimento. A escola rural é pobre em saberes e conhecimentos. Só ler, escrever e contar pronto? A escola tem que ser mais rica, tem que se incorporar o saber, a cultura, o conhecimento socialmente construído. (ARROYO, 2009, p.81).

As necessidades presentes na escola do campo exigem um profissional com uma formação mais ampliada, mais totalizante, já que ele tem que dar conta de uma série de dimensões educativas presentes na realidade. (ANTUNES-ROCHA; MARTINS, 2011, p.41).

Fernandes reitera

O campo é lugar de vida, onde as pessoas podem trabalhar, estudar com dignidade de quem tem o seu lugar, a sua identidade cultural. O campo não é só lugar da produção agropecuária e agroindustrial, do latifúndio e da grilagem de terras. O campo é espaço e território dos camponeses e dos quilombolas. É no campo que estão as florestas, onde vivem as diversas nações indígenas. Por tudo isso, o campo é lugar de vida e sobretudo de educação (FERNANDES, 2009, p.137).

Assim,

quanto mais se afirma a especificidade do campo mais se afirma a especificidade da educação e da escola do campo. Mais se torna urgente um pensamento educacional e uma cultura escolar e docente que se alimentem dessa dinâmica 
formadora. Também mais se afirma a necessidade de equacionar a função social da educação e da escola em um projeto de inserção do campo no conjunto da sociedade (ARROYO; CALDART; MOLINA, 2009,p.13).

Afirma-se nessa perspectiva que a escola do campo é um espaço de luta, de trabalho e de educação.

Portanto,

[...]é um espaço que tem as suas especificidades e as suas particularidades e que é ao mesmo tempo um campo de possibilidades da relação dos seres humanos com a produção das condições de sua existência social, confere a Educação do Campo o papel de fomentar reflexões sobre um novo projeto de desenvolvimento e o papel do campo neste projeto (ARROYO; CALDART; MOLINA, 2009,p.13).

Ressalta-se que essas particularidades são reflexos das singularidades desse espaço, mas que também refletem o universal. Desse modo, "a escola do campo nasce como uma das dimensões das lutas pela conquista de um modo de produção da vida [...] se articula com um conjunto de princípios, conceitos e práticas em construção, no conjunto das lutas empreendidas pelos trabalhadores do campo" (ANTUNES-ROCHA; MARTINS, 2011, p.41).

Por fim, Caldart (2009) nos aponta que a Educação do Campo identifica uma luta pelo direito de todos à educação, os sujeitos da educação do campo são os sujeitos do campo, a educação do campo se faz vinculada às lutas sociais do campo, no diálogo entre seus diferentes sujeitos e a possibilidade de construção de um projeto educativo. Esse é o campo e a educação do campo deve ter o seu lugar garantido. 


\section{A formação de professores - no contexto da educação do campo}

A desvalorização dos conhecimentos práticos/ teóricos que trazem os sujeitos do campo, construídos a partir de experiências, relações sociais, de tradições históricas e principalmente, de visões de mundo, tem sido ação recorrente das escolas e das várias instituições que atuam nestes territórios. Como romper com o silenciamento destes saberes e legitimar outros processos de produção do conhecimento, trazendo-os para dentro da escola do campo, para dentro das universidades? (MOLINA, 2006, p.12).

A epígrafe acima nos faz um alerta que consideramos necessário para iniciar nossa discussão, a necessidade de romper o silêncio, ouvir os sujeitos do campo, valorizar suas formas de vida, seus saberes e suas experiências.

De acordo com Arroyo (2009)

Quando situamos a escola no horizonte dos direitos, temos que lembrar que os direitos representam sujeitos, sujeitos de direitos[...] Sujeitos de história, de lutas, como sujeitos de intervenção, como alguém que constrói, que está participando de um projeto social (ARROYO, 2009, p. 74).

Depreende-se que ao participar desse projeto social, a escola está inserida nele, portanto faz parte da luta. A educação é direito a identidade, a cultura, a construção do lugar de pertencimento e, nesse sentido, Fernandes (2009) nos aponta que

A Educação do Campo é um conceito cunhado com a preocupação de se delimitar um território teórico. Nosso pensamento é defender o direito que uma população tem de pensar o mundo a partir do lugar onde vive, ou seja, da terra onde pisa, melhor ainda a partir de sua realidade. (FERNANDES, 2009, p.141).

Nesse mesmo viés Caldart (2002) considera importante atentar-se aos termos do e no campo: 
"No: o povo tem direito de ser educado no lugar onde vive. Do: o povo tem direito a uma educação pensada desde o seu lugar e com a sua participação, vinculadas a sua cultura e às suas necessidades humanas e sociais" (CALDART, 2002, p.26).

Segundo a autora há um compromisso com a cultura do povo do campo - que implica resgate, conservação, recriação -, tendo como um dos eixos fundamentais:

[...] a educação de valores que busca afirmar a educação pela memória histórica, no sentido de cada pessoa ou grupo perceberem-se como parte de um processo que se enraíza no passado e se projeta no futuro no sentido do povo ser estimulado a produzir cultura, suas representações, sua arte, sua palavra. (CALDART, 2009, p. 54).

Frente a essa busca pelo direito encontra-se a necessidade de formar sujeitos que possam viver o sentido e o significado da vida no campo, por meio de situações que os representam e os façam reavivar a força de uma cultura, de uma identidade, de uma luta. Logo, considera-se que um dos aspectos proeminentes "para o funcionamento de uma escola que possa ser considerada do campo" é o reconhecimento e a valorização da identidade de seus sujeitos" (MOLINA, 2009, p,32).

Para Pires (2012), é fundamental reconhecer e conhecer, respeitar e resgatar a afirmação da diversidade sociocultural dos povos do campo. "O campo precisa ser compreendido como modo de vida sociocultural no sentido que sejam afirmadas as suas identidades, bem como as suas lutas e organizações." (PIRES, 2012, p. 43).

Para essa configuração de escola, a formação do professor constitui-se um grande desafio, pois é preciso um novo desenho das funções e dos papéis a serem desempenhados. Funções que requerem pensar novas estratégias para as ações referentes ao currículo e às práticas educativas. Pensar o currículo na Educação do Campo “[...] é sair da visão generalista, de uma visão única de conhecimento, 
de modos de pensar, de verdade, de ciência, de validade, que predomina nos currículos de educação básica" [...] "a escola traz, em sua dinâmica interna, a possibilidade da descoberta de outra cultura. A escola - deve ser ela mesma, por seus ritos, práticas e gestos"' (PIRES, 2012, p. 120).

No cerne dessa questão, a formação do professor deve levá-lo a "entender a força que o território, a terra, o lugar tem na formação social, política e cultural, identitária dos povos do campo (ARROYO, 2007, p.163). Nesse sentido, o trabalho pedagógico envolve o real, o concreto, o que significa contemplar as práticas sociais de luta, de trabalho e da cultura que permeiam os saberes da terra e do coletivo popular. $\mathrm{O}$ autor segue afirmando que sem a articulação da escola com os demais espaços do campo será difícil ser professor de um projeto educativo dessa grandeza.

Ao refletir sobre a formação docente para atuar na escola do campo algumas indagações surgem:

Tem sentido pensar em políticas de formação de educadoras e educadores do campo? Seria esta questão uma preocupação legítima para os responsáveis pela formulação de políticas públicas? Seria uma dimensão a merecer a atenção do pensamento sobre formação de educadores? Mais em concreto, seria uma preocupação necessária para o repensar dos currículos dos cursos de pedagogia e licenciatura? (ARROYO, 2007, p.158)

Ao pautar-se a concepção de educação do campo, a formação docente se faz presente, pois é preciso afirmar a pluralidade das ações que devem resultar em uma formação de professores para a educação do campo, por isso as universidades têm um compromisso social com essa população.

Concorda-se que, "situada a formação neste patamar, são interrogadas as políticas generalistas, é questionado o protótipo de profissional único para qualquer coletivo e são questionadas as normas e diretrizes generalistas 
que apenas aconselham "adaptem-se" à especificidade da escola rural" (ARROYO, 2007, p.165).

Uma das transformações na escola é o currículo que "precisa incorporar o movimento da realidade e processá-lo como conteúdos formativos" [...] Uma escola do campo precisa de um currículo que contemple necessariamente a relação com o trabalho na terra (FERNANDES, CERIOLI E CALDART, 2009, p.57). Para tanto, essa transformação perpassa a formação do professor, pois é preciso compreender o seu papel frente a essa escola e as suas singularidades.

Assim, a formação de professores para a educação do campo deve levar em conta a dinâmica social desse espaço, seus currículos são fortalecidos com a presença dos movimentos sociais, com a formação de vínculos com as lutas sociais e com a construção de identidades coletivas.

Importante ressaltar que os movimentos sociais

Não pedem um trato diferenciado para a formação de educadores(as) do campo. Reivindicam que não se esqueçam de que a educação do campo existe, e a formação de profissionais específicos que garantam o direito à educação básica de milhões de crianças e adolescentes, de jovens e adultos que vivem no campo tem de ser equacionada (ARROYO, 2007, p.167).

Frente a essa questão cabe ressaltar:

Um corpo de docentes e gestores que chega cada dia da cidade à escola rural, sem conhecer os significados dessa tensa realidade na conformação das crianças, dos adolescentes, jovens ou adultos do campo não terá condições de ser educador, educadora, docente, gestor (ARROYO, 2007, p.171).

Em meio a projetos e programas de formação de professores que se multiplicam é importante avaliar que essa formação só terá sentido se assumirem a articulação do campo com a valorização da sua população, do trabalho na terra, da sua identidade ou correm o risco de "[...] cair 
no vazio, programas isolados de formação, mantendo a ausência crônica de um projeto de campo e de políticas de educação" (ARROYO, 2007, p.171).

Nesse sentido

A educação precisa ser compreendida como prática social; tratar o conhecimento de forma inter-relacioanda; e ser incentivada à construção de novas possibilidades de vida e permanência no campo como espaço de lutas coletivas de seus sujeitos por melhores condições de vida, de trabalho e de educação (PIRES, 2012, p.118).

Considera-se que, nessa perspectiva, deve seguir a formação dos professores para atuarem nas escolas do campo. Não basta ensinar os conteúdos estabelecidos, é necessário que a formação docente tenha como objetivo formar para uma dinâmica social, política e cultural, para que a escola seja viva no campo, que represente a identidade da população do campo em toda a sua plenitude, para que a escola possa ser um dos espaços de transformação na luta pela terra que faz parte do processo educativo.

\section{Situando o contexto da pesquisa e seus sujeitos: a licenciatura em educação do campo}

No ano de 2013 atendendo ao edital no 2 SESU/SETEC/SECADI/MEC, de 31 de agosto de 2012, a universidade Federal de Mato Grosso do Sul (UFMS) criou o curso de Licenciatura em Educação do Campo (LeduCampo). O curso tem edital de matrícula específico que visa abrir vagas para quem vive e trabalha, ou tem vínculo no campo. Em sua organização segue as orientações estabelecidas no Programa de Apoio à formação Superior em Licenciatura em Educação do Campo (PROCAMPO) atendendo ao que estabelece a Resolução CNE/CEB n ${ }^{\circ} 1$, de 3/4/2002, ao Decreto no 7.352, de 04/11/2010 em acordo com o Programa Nacional de Educação do Campo (PRONACAMPO). 
De forma complementar cabe reiterar que o PROCAMPO foi criado com o objetivo de implantar cursos de licenciatura em Educação do Campo, na modalidade presencial, em regime de alternância e o PRONACAMPO ${ }^{3}$ aponta para um conjunto de ações integradas que visam a qualidade da Educação do Campo, em relação ao material didático específico e a formação de professores abrangendo todas as etapas de ensino e modalidades.

O curso é na modalidade presencial em regime de Alternância. A Pedagogia da Alternância representa uma proposta teórico-metodológica que utiliza a alternância para garantir as licenciaturas e a participação dos acadêmicos. "É uma pedagogia que tem a sua gênese nas necessidades das populações camponesas, por isso é organicamente vinculada ao campo" (CORREIA; BATISTA, 2012, p. 173). Sua organização acontece em dois momentos: tempo-universidade (momento em que os alunos permanecem na universidade com aulas teóricas) e o tempo-comunidade (momento em que os alunos em suas comunidades articulam os conteúdos aos saberes do campo).

Há ênfase em três áreas de conhecimento, Linguagem e Códigos, Matemática e Ciências Humanas e Sociais que atendem estudantes de várias localidades do estado de Mato Grosso do Sul. São jovens que finalizaram o Ensino Médio, adultos que cursaram EJA (Educação de Jovens e Adultos), portanto em formação inicial e em sua grande maioria professores com formação em diferentes áreas do conhecimento e que cursam a licenciatura em Educação do Campo para formação mais específica sobre a educação e a escola do campo.

Nessa proposta, além das disciplinas que configuram o currículo, há o incentivo para que os acadêmicos participem em pesquisas de iniciação científicas relacionadas aos campos de estágios e aos projetos de ensino e extensão nos quais estão inseridos com a finalidade de potenciali-

${ }^{3}$ Mais informações: portal.mec.gov.br. 
zar a capacidade de estudar textos científicos, debater, argumentar e redigir de forma clara e objetiva, propiciando um maior contato com áreas e temas mais específicos.

Em seu projeto de Curso a proposta apresenta uma base que

É pedagógica, mas também filosófica, política, ideológica, engajada. O Marco Referencial contextualiza e problematiza a educação escolar rural, concebida política e historicamente pelos fazendeiros, como processo educativo limitador. Em contraponto, a práxis da Educação do Campo que é evidenciada como potencialização de ações afirmativas e dialógicas. (PROJETO DE CURSO, 2014, p.7).

Nessa perspectiva e concepção

O curso pretende provocar os alunos a repensarem, filosoficamente, o ser humano e a vida no campo como espaços e tempos de ser, de estar, de conviver, de produzir bens materiais e imateriais, na possibilidade de que os alunos compreendam as ligações das partes com o todo e do todo com as partes, na busca da sustentabilidade local mediada pela organização comunitária, o coletivo, a mística, a agricultura familiar (PROJETO DE CURSO, 2014, p.7).

Também encontra-se no projeto de curso (2014) a perspectiva que aponta a alternância com a finalidade de promover o encontro entre os alunos que residem em diferentes locais e que estão no curso em diferentes áreas, oportunizando que conheçam e reconheçam as diversas experiências desenvolvidas no Estado por meio de visitas conduzidas pelos docentes às escolas do campo, às comunidades, às associações e assentamentos com o objetivo de construir uma visão concreta dos diferentes contextos da Educação do Campo em Mato Grosso do Sul.

Todas as atividades realizadas são acompanhadas por docentes do curso com orientações, consolidando e contribuindo com a construção do currículo e da proposta metodológica para que estejam em constante construção, com vistas a efetiva participação dos alunos. Nesse senti- 
do, "a matriz curricular do curso tem sua base na concepção de que apenas inserir-se na universidade não é suficiente para alterar as estruturas já consolidadas nesse processo de formação, mas pode, com o trabalho efetivado, contribuir para a transformação". (PROJETO DE CURSO, 2014, p.7).

Para promover a produção de conhecimento que tenha como pauta a Educação do Campo foi criado pelos docentes para o desenvolvimento do curso o Boletim Educarte, uma publicação mensal que tem como objetivo difundir textos que contenham uma reflexão sobre a Educação do Campo. Inicialmente, a proposta foi promover e incentivar os docentes do curso a publicarem e a incentivarem seus acadêmicos, nas disciplinas e nas atividades de pesquisa e extensão, como possibilidade de divulgação do curso e da produção do conhecimento.

A partir dessa organização, pretende-se nesse curso uma formação agregada ao contexto em que se inseri, uma formação em processo contínuo, aliada ao contexto e às necessidades locais, sem, no entanto, ignorar os debates gerais da sociedade, integrando assim, questões singulares sem perder de vista as questões universais, necessárias ao debate sobre a Educação do Campo.

Portanto, cabe ressaltar a importância de compreender o espaço que esse curso ocupa na universidade, pois depreende-se que, conforme Antunes-Rocha; Martins (2011) há três questões a serem alvo de reflexão em relação à universidade cumprir a sua função que em primeiro lugar,

pode significar o cumprimento de sua função educativa do ponto de vista inclusivo e democrático, ao acolher em seu seio grupos sociais que instauram novas formas de pensar e fazer o mundo, isto é, produzem novos conhecimentos e desejam partilhá-los e legitimá-los em um ambiente historicamente comprometido com a produção e socialização dos saberes. (ANTUNES-ROCHA; MARTINS, 2011, p.17). 
Para as autoras, ainda para a universidade em segundo lugar, considerando o uso da preposição nas expressões - da terra, do campo,

pode significar um pertencimento - à terra, ao Campo, de determinados conhecimentos que, em via de mão dupla, serão partilhados com a academia. Culturalmente, significa aprender com a Terra, aprender com o Campo os modos genuínos de olhar para a vida do homem, em sintonia com a vida na natureza. (ANTUNES-ROCHA, MARTINS, 2011, p.17).

Em terceiro lugar é função da universidade "O compromisso acadêmico e político com o processo de construção de uma sociedade justa, fraterna e sustentável". (ANTUNES-ROCHA; MARTINS, 2011, p.17). As autoras seguem afirmando que são muitos os motivos que envolvem a universidade em um projeto de formação de professores para atuação nas escolas do campo, principalmente a parceria com os movimentos sociais para juntos assumirem o compromisso de dar ao sujeito do campo o direito de "ocupar o seu papel como sujeito nessa construção".

De acordo com Neto (2011)

Os cursos de licenciatura do campo inscrevem-se dentro de propostas políticas que podem ser inovadoras para a escola e para as relações sociais, pois numa sociedade de classes, com interesses diferenciados, o compromisso com o trabalhador do campo e com a escola que interessa aos setores populares é parte da disputa hegemônica para a conquista de uma sociedade mais justa. (NETO, 2011, p. 25).

Nesse sentido, cabe ressaltar que a formação de professores para a educação do campo deve antes de tudo, possibilitar aos sujeitos em formação construir um curso com a sua identidade, com a possibilidade de confrontar e apresentar seus saberes. Logo, respeitar quem vive e trabalha no campo com consideração ao seu modus vivendi. 


\section{A leitura na formação docente: uma discussão necessária}

A formação docente nos instiga a pensar inúmeras questões sobre o que os professores precisam aprender para ensinar melhor, mas essa questão também nos permite questionar: "sabemos bem pouco sobre o que os alunos precisam, mas bem pouco ou nada sobre as necessidades dos professores para assumir o desafio imposto por 'nossas inovações' sobre a aprendizagem da leitura" (MIGUEL, PÉREZ; PARDO, 2012, p.17). Os autores seguem questionando que "lógica seguimos quando propomos aos professores que adquiram novos recursos [...] sem entender a magnitude e o custo que implica a sua aquisição"? (MIGUEL, PÉREZ; PARDO,2012, p.17).

Entende-se que ler é prática social e, portanto, faz parte do universo de cada sujeito, mas cada um tem sua trajetória de leitura e desse modo, cabe perguntar: "como a escola colabora para a formação da história de leitura do aluno? Que experiências de leitura são vivenciadas na escola"? (RANGEL, 2012, p.46).

Ressalta-se que conforme Kramer (1998, p.27) a necessidade de repensar o termo "formação" quando discute-se a formação docente.

A autora indaga:

E o que compreendemos por formação? A idéia de capacitar, ainda muito comum em inúmeras secretarias, parte do princípio de que alguém é incapaz, assim como a idéia de reciclar parte do princípio de que alguém vai jogar fora o velho e absorver o novo. Se a história das práticas escolares e das práticas de leitura e escrita não forem levadas em conta, não se correrá o risco de instituir mais uma solução aparentemente nova, mas que estará distante das necessidades reais de formação dos professores?

Parece-nos que a figura do professor tem papel importante na formação de leitores, portanto, compreender 
o seu processo de aprendizagem da leitura torna-se fator importante para entender o lugar da leitura em sua formação. De acordo com Orlandi (2000, p.41) "toda leitura tem sua história". Que história é essa que perpassa a formação dos professores?

De acordo com Lajolo (1993, p.106),

cada leitor, na individualidade de sua vida, vai entrelaçando o significado pessoal de suas leituras com os vários significados, que ao longo da história de um texto, este foi se acumulando. Cada leitor tem a história de suas leituras; cada texto, a história das suas.

Depreende-se que "a prática da leitura nos enreda desde o momento em que começamos a "entender"" o mundo que nos envolve. Com a vontade de entender quem somos, buscamos na leitura as respostas que almejamos" (SGARBI, 2013, p. 23). Nesse sentido, compreendemos que ao se constituir leitor, o processo de constituição ocorre do exterior para o interior e, nessa condição os espaços e as pessoas têm responsabilidades fundamentais na contribuição dessa formação, portanto, escola e família são partícipes nessa constituição.

De acordo com Soares a leitura é "[...] instrumento de reprodução, mas também espaço de contradição, a leitura é, fundamentalmente, processo político". (SOARES, 2005, p. 2). Ao considerá-la processo político, entende-se que quem lê toma decisões, tem intenções.

Portanto

Aqueles que formam leitores [...] desempenham um papel político que poderá estar ou não comprometido com a transformação social, conforme estejam ou não conscientes da força de reprodução e, ao mesmo tempo, do espaço de contradições presentes nas condições sociais da leitura, e tenham ou não assumido a luta contra aquela (força de reprodução) e a ocupação deste (espaço de contradição) como possibilidade de conscientização e questionamento da realidade em que o leitor se insere. (SOARES, 2005, p.28). 
Constituir-se professor-leitor não é tarefa fácil, pois se inicia antes da formação inicial dos cursos superiores, inicia-se nos bancos escolares e no dia a dia enquanto crianças, jovens e a posteriori adultos. Lajolo aponta que o professor, ao formar novos leitores deve ter vivenciado inúmeras experiências com a leitura, pois, "o privilégio da leitura do mestre decorre do fato seguinte: geralmente, a leitura do leitor maduro é mais abrangente que a do imaturo. Claro que a maturidade de que se fala aqui não é aquela garantida constitucionalmente aos maiores de idade" (LAJOLO, 1986, p. 53).

A autora segue afirmando que a maturidade do leitor se constitui ao longo da intimidade com muitos textos e que, um "leitor maduro é aquele para quem cada nova leitura desloca e altera o significado de tudo o que ele já leu, tornando mais profunda a sua compreensão dos livros, das gentes e da vida" (LAJOLO, 1986, p. 53).

Entende-se que ler nesse sentido, não é apenas a possibilidade de decifrar um código, memorizar ou interpretar o que dizem os autores. É, acima de tudo, ler o mundo e o que ele nos apresenta, é ter autonomia para pensar sobre esse mundo na perspectiva de transformá-lo e emancipar-se enquanto sujeito social que vive culturalmente o processo social.

De acordo com Perissé (2005) temos cinco dimensões da leitura: a funcional, a recreativa, a reflexiva, a formativa e a inspiradora. Segundo o autor, a funcional "é uma leitura bem-comportada, feita com anotações pertinentes, é a leitura acompanhada de pequenos resumos. O leitor nesse momento está preocupado com as palavras-chave, em fazer a lição de casa" (PERISSÉ,2005, p.55). Afirma o autor que esse tipo de leitura é de investigação, necessária para a vida universitária, para a pesquisa e a ciência.

A leitura recreativa, segundo autor também precisa funcionar. Está em jogo, aqui, em lugar do dever, o prazer (sem esquecer que o prazer é, em certa medida, um dever, 
e cumprir um dever tem lá a sua dose de prazer) [...]Uma leitura prazerosa pode ser a leitura de uma narrativa leve, uma história policial, ou a leitura de uma biografia, ou a leitura de relatos de viagens, ou a leitura tranquila de considerações simples, sobre as coisas mais simples da vida (PERISSÉ,2005, p.56).

A leitura reflexiva oposta à leitura recreativa, é um tipo de leitura exigente.

Exige que não tenhamos pressa. Reflexão requer tempo, paciência, dedicação, requer que leiamos dez vezes a mesma frase. Para ler reflexivamente precisamos nos deixa impregnar pela verdade do texto, e, sobretudo, a leitura requer perguntas, abertura de portas intelectuais (PERISSÉ,2005, p.56).

O autor nos propõe a conhecer a leitura inspiradora. Aponta que essa leitura é para quem quer produzir novos textos. É um tipo de leitura que vai à busca, com o objetivo de encontrar algo que possa ser inspirador para a sua criação, para o texto que está nascendo, pode ser para utilizá-lo ou para contestá-lo, depende da perspectiva em que se faz essa busca. "Vai ao livro, ou aos livros, sem outra pretensão senão a de vencer o ilusório sentimento interior de que não haveria mais nada a fazer ou escrever" (PERISSÉ,2005, p.58).

E, por fim, a leitura formativa, que segundo o autor "é aquela que nos transforma. Mexe conosco, remexe por dentro, marca, altera, modifica, sacode, produz" (PERISSÉ,2005, p.62). A partir dessa ideia das dimensões da leitura cabe indagar: como os professores têm organizado em seu planejamento as atividades de leitura? Quais são as situações em que a leitura surge na sala de aula? A leitura pode ser um dos eixos de transformação na escola. Ao ler o homem apropria-se de instrumentos que implica em mudanças na sua vida pois a principal característica do processo de apropriação: 
É criar no homem novas funções, funções psíquicas novas, é nisto que se diferencia do processo de aprendizagem dos animais. Enquanto esse último é o resultado de uma adaptação individual do comportamento genérico a condições de existência complexas e mutantes, a assimilação no homem é um processo de reprodução, nas propriedades do indivíduo, das propriedades e aptidões historicamente formadas na espécie humana (LEONTIEV, 2004, p.288).

Segundo Tuleski (2008, p.151)

As aquisições humanas do desenvolvimento histórico das aptidões humanas não são simplesmente dadas aos homens nos fenômenos objetivos da cultura material e espiritual, mas são apenas aí colocadas. Para que cada indivíduo se aproprie destes resultados, para que estas aptidões passem a fazer parte deles (individualmente), deve-se entrar em relação com estes fenômenos através de outros homens.

Nesse sentido, a leitura é uma interação do homem com o mundo. Essa interação acontece no movimento da história que, de acordo com Leontiev (2004) só é possível com a transmissão, às novas gerações, das aquisições da cultura humana, por meio da educação. De acordo com Vigotski [...] em todas as épocas, independentemente de sua denominação e qualquer que fora a sua ideologia: toda educação tem sido sempre uma função do regime social. Toda educação tem sido sempre essencialmente social (VIGOTSKI,1991, p.159).

Ao considerar a educação como aspecto social, a leitura tem importância como prática social, portanto por meio dela o homem entra em contato com um mundo já construído, dessa forma ele compreende o que já existe, mas compreende que é necessário a sua atuação ativa para transformá-lo.

Pensar a formação docente incita-nos a refletir que não lidamos com um produto acabado, neutro, mas em processo constante e dinâmico de desenvolvimento. Segundo Leontiev (2004) esse é um processo ativo, pois incide nas relações sociais. Qualquer que seja o tema aborda- 
do para pensar a formação de professores é preciso situar o lugar de cada sujeito. Esse lugar apresenta diferentes possibilidades de conhecê-lo e reconhecê-lo frente ao objeto de estudo, aqui a leitura, como um dos elementos de formação importante e necessário para a docência.

Desse modo

\begin{abstract}
O leitor, portanto, se constrói de forma complexa, nas práticas reais de leitura, com gestos, materiais impressos, desejo de ler, através do contato físico e íntimo com o livro. Diversos setores sociais, por meio de teias de relações, são responsáveis pela formação da identidade social destes leitores. Vista dessa maneira, a entrada no mundo da leitura depende de relações simbólicas, sociais e econômicas; em outras palavras, refere-se à cultura popular, erudita e de massa; à família, escola e a outras instituições (KRAMER, 1988, p.27).
\end{abstract}

Nesse sentido, ao narrar histórias de leitura, o sujeito reconhece seu percurso como leitor e ao se reconhecer como leitor ou não, reconhece o seu papel como docente, que tem como compromisso, a formação de leitores.

\title{
Narrar, refletir, conhecer e reconhecer... o encontro com a leitura
}

Situar o contexto, o sujeito, o tema, é um caminho para a compreensão do objeto de estudo. Entende-se que para construir conhecimento, seja em qualquer temática, seja sobre o sujeito, ou sobre a totalidade, separadamente, não impossibilita realizar uma análise dialética da relação entre o singular, particular e universal, pois a análise de um fenômeno representa avaliar o que acontece a sua volta como expressão dos fatos que foram produzidos pelos homens, cuja sociedade existe e é determinada, pela divisão de classes, pela segregação dos homens, pelo acesso aos produtos e bens construídos e produzidos pela humanidade. 
Nenhum fenômeno se expressa apenas em sua singularidade ou em sua universalidade como opostos, identificam-se, e a contínua tensão entre eles (singular-universal) se manifesta na configuração particular do fenômeno. Em sua particularidade, ele assume as especificidades pelas quais a singularidade se constitui sob dadas condições e de modo determinado por elas (MARTINS, 2015, p.37).

Nesse sentido, nosso objetivo é analisar o fenômeno a partir dessa ideia de pensá-lo em conjunto, pois não há possibilidades de pensá-lo separadamente (singular e universal), pois em qualquer análise possível sobre o fenômeno em estudo, há sempre expressões do universal.

Desse modo, nesse estudo, nos propomos a apresentar o eixo 2 de investigação na área de educação - "Sentidos e significados necessários e possíveis para a constituição do professor leitor para além da formação inicial, na licenciatura de Educação do Campo". Nesse eixo, a pesquisa foi organizada em seu campo empírico no primeiro momento, com o levantamento bibliográfico por meio do método de investigação estado do conhecimento para conhecer o que já foi produzido em relação à temática e, no segundo momento, a pesquisa de campo, contou com atividades de intervenção com oficinas de leitura, rodas de conversa e com a recolha de narrativas que visou dar voz aos atores sociais que estão na escola e vivenciam os processos de leitura em seu dia a dia. Como critérios foram selecionados sujeitos que estudaram em escolas do campo, durante os primeiros anos do ensino fundamental e que já atuam como professores em escolas do campo em diferentes áreas de conhecimento (Língua Portuguesa, Matemática, História, Geografia e Artes). Reitera-se que, os dados aqui apresentados, são os resultados presentes no relatório parcial da pesquisa, em andamento.

De posse das narrativas dos vinte participantes da pesquisa, destacaram-se onze categorias que nos conduziram a compreender diferentes aspectos e características do ato de ler na escola. São elas: 1 . Primeiro contato com os 
livros; 2. Como o professor se constitui leitor; 3. Influência da escola na formação de leitores; 3 . Leituras apresentadas na escola 4. Motivação recebida para leitura; 5. Espaço da leitura na escola; 6. Leitura: prazer ou obrigação? 7. Leituras na infância; 8. Primeiras leituras na escola; 9. Leitura como processo cultural e social 10. Práticas de leitura na escola e fora dela; 11. Relação pessoal e profissional com os processos de leitura.

Para esse estudo a categoria "primeiras leituras na escola" nos instiga a conhecer e analisar os modelos de leitura apresentados na escola. Portanto, cabe indagar: quais são as leituras apresentadas na escola? $\mathrm{O}$ que elas propiciam aos leitores em formação? O que essas leituras representam nas trajetórias de futuros formadores de leitores?

Assim, nos limites desse texto, apresentaremos cinco narrativas de professores participantes da pesquisa que se encontram identificados por uma letra do alfabeto referente à letra inicial do seu nome e um número que representa a sequência das narrativas.

Depreende-se que ao ouvir os professores em formação que atuam nas escolas do campo encontra-se a possibilidade de compreender o papel da escola, a garantia de direitos pelos quais lutam esses sujeitos que são muitas vezes, segregados, excluídos, com esses direitos cerceados.

Compreende-se que ler não é uma prática espontânea, mas criada pelo homem, por isso faz parte da constituição do sujeito, no sentido de ampliar seus conhecimentos, sua vivência, sua história. Portanto é prática cultural, traz um legado da humanidade.

Para Leontiev:

cada indivíduo aprende a ser um homem. O que a natureza lhe dá quando nasce não lhe basta para viver em sociedade. É-lhe ainda preciso adquirir o que foi alcançado no decurso do desenvolvimento histórico da sociedade humana (LEONTIEV, 2004, p. 285). 


\section{O desenvolvimento do homem é resultado desse movimento de relações adquiridas e não apenas na histó- ria acumulada pela humanidade, mas pela ação dele que, ao mesmo tempo em que internaliza o que vem do meio, também interfere no decurso da história. Portanto, sua constituição está sempre em movimento, em construção. Vemos essa realidade expressa nas narrativas dos professores:}

[...]Da escola, confesso que tenho poucas recordações dos meus momentos de alfabetização, mas algo que é bastante claro pra mim são as cartilhas lindas que eu tinha e que utilizava na escola, trazia para casa e fazia as tarefinhas que minha professora pedia. Amava as imagens, eram coloridas, cheias de vida, era o único material que manuseava para ler. Foi meu primeiro contato com a leitura e foi um contato bom e divertido, os livros mesmo, de literatura o contato foi no ginásio e também apenas aqueles que eram indicados pelos professores, pois não havia possibilidades de escolha (P1).

[...]Aprendi a ler com a cartilha Caminho Suave e depois com livros que a professora emprestava e só mais tarde livros da biblioteca municipal emprestado. Depois que aprendi a ler, não parei mais. Ler era algo mágico, pois meus pais não eram alfabetizados. Assim, me sentia importante, pois eu lia e ainda lia para eles (P2).

[...]Nunca esqueci do material em que aprendi a ler, era um caderno de capa mole o mesmo em que eu escrevia e a professora passava a atividade de escrita e em seguida todos faziam a leitura do mesmo.Todos tinham que ler e era bom. Eu me sentia importante, pois estava aprendendo a ler. Não tinha livros no acampamento. Em um acidente muitos objetos foram queimados e um deles, os livros que já eram poucos. As professoras criavam os livros com os próprios cadernos e, isso, nos incentivava muito, mas foi um aprendizado precário, pois faltavam materiais para a leitura. Livros mesmo, o contato foi raro. (P3).

[...]Me recordo que os livros trabalhados em sala eram apenas didáticos, não havia livros diferenciados ou uma aula direcionada de leitura. Em cada exercício proposto pela professora eu lia uma atividade para entender o que deveria fazer. Não tinha livros de histórias, mas tínhamos leituras todos os dias e, isso, de certa forma, nos obrigava a ler(P4).

[...]Todos os dias levava de tarefa pra casa leitura do livro, marcado pelo professor, eu folheava o livro não que era para ler, mas para 
ver a figura do livro que era lido. Com essa atividade diária, acabei sendo despertada pela vontade de ler. Penso que na época, o ensino era menos atrativo, tínhamos menos materiais de acesso, mas, mesmo assim, os professores se esforçavam para nos motivar(P5).

Parece-nos que as lembranças dos momentos das primeiras leituras na escola marcam um tempo de aprendizagem, de convivência com a leitura e com os materiais que propiciam essa leitura, pois revelam inúmeras questões que foram vivenciadas em suas trajetórias escolares e que representam suas ideias e posicionamentos frente ao tema, em discussão.

Considera-se que a escola não é o único espaço para a efetivação do ato de ler, mas é um dos ambientes propícios para que ela aconteça, porém, no ambiente escolar, a leitura, muitas vezes, é vista como necessidade de cumprir as atividades no livro didático, dos textos fragmentados, dos livros de literatura que nem sempre motivam o aluno. Depreende-se que nesse formato de momentos de leitura que acontecem na escola, nem sempre oportunizam ao leitor a produção de novos conhecimentos como processo de desenvolvimento e nem mesmo o desperta para se apropriar da leitura como possibilidade de se inserir no mundo, analisá-lo e transformá-lo. Possibilidades que a leitura oferece.

Considera-se que a trajetória de leitura na escola, vivida pelos professores podem ter reflexos na sua trajetória como professor. Uma vez que como vivenciaram esses processos eles internalizam e podem reproduzir em sua prática como professor. A leitura é um processo político, portanto, colabora para compreensão do espaço em que o sujeito vive, assim, possibilita pensar sobre esses espaços e transformá-los.

De acordo com Kramer (1996) algumas indagações são necessárias: a leitura da escola reduz-se à leitura da escola, organizada pelo registro de notas, provas de livros, fichas, resumos que ocupam o espaço destinado à fruição 
da leitura? Rangel (2012) complementa ao afirmar que "a escola não descobriu ainda o potencial mágico da leitura e permanece o ensino de uma leitura instrumental, mecânica, esvaziada de sentido" (RANGEL, 2012, p.13).

Essa afirmativa aparece nas narrativas dos professores.

Hoje, como professora, tenho tentado trazer a leitura com mais evidencia na sala de aula, mas o tempo é escasso e temos muito trabalho, inclusive com o livro didático, a divisão das disciplinas, as provas, são muitas atividades que às vezes nos impedem de fazer um bom projeto de leitura para motivar os alunos, principalmente a gostar de ler livros, uma vez que, hoje temos outros meios, muitos meios... (P1).

Sei da importância e necessidade da leitura, sempre que inicio uma atividade no livro didático possibilito que todos leiam, em voz alta, pois sei que assim, ouvem os colegas e assimilam alguns pontos necessários da disciplina que ministro que é geografia. Trago textos diferentes, além dos que estão no livro, mas um projeto de leitura mesmo, seria interessante. Por exemplo: poesias, contos, histórias em quadrinhos, são textos interessantes para a disciplina, mas nem sempre há tempo (P2).

Acho importante forçar a leitura dos alunos diariamente. Faço sempre uma rodada de leitura no livro didático, quando estou começando um tema novo. Dessa forma ofereço essa oportunidade de leitura. Motivo sempre os alunos, mas eles não gostam muito de ler, outros têm dificuldades e a turma se dispersa muito. Os alunos são muito agitados e ler obriga a ter paciência. Hoje, com tantas formas de leitura e a mídia, a leitura de livros não motiva muito (P3).

Como sou professora de Lingua Portuguesa, tenho obrigação de formar bons leitores. Propicio leituras interessantes, vou à sala de leitura, utilizo diferentes materiais para leitura, inclusive os digitais, as mídias. Ler é mágico, mas a escola precisa aprender a lidar com o tempo, os conteúdos e a leitura. O maior problema é o tempo. Se me dedico a leitura mais prazerosa, falta tempo para concluir os conteúdos necessários. Assim, tento 
priorizar a efetivação dos conteúdos. Mesmo assim, tenho me esforçado para garantir a leitura com prazer (P4).

Hoje, temos muitos materiais para acesso dos alunos. $O$ computador, trouxe inúmeras maneiras de realizar a leitura, mas ainda é preciso cultivar a leitura em sala de aula, por meio de outros recursos, mas nem sempre é possível, falta materiais para a leitura na escola e falta tempo mesmo para fazer o trabalho necessário para a formação de leitores, de bons leitores (P5).

Em seus depoimentos os professores revelam que mesmo reconhecendo a importância da leitura, ela nem sempre acontece de forma contínua e com espaço garantido. Não é prioridade nas atividades realizadas. Nesse sentido, percebe-se que a leitura ainda é apresentada e conduzida de forma mecanizada, assim, como eles vivenciaram em suas trajetórias escolares, ou seja, para cumprir o programa de conteúdos necessários para efetivar o plano de ensino.

Questão que traz à tona indagações importantes: como reconhecer-se frente às questões emergentes do campo sem que a leitura seja parte dessa caminhada? Como construir a identidade como professor do campo se a leitura não é prioridade nas atividades realizadas? Se a leitura conduz a reflexões sobre o que está a nossa volta é necessário afirmar que, aqueles que formam leitores [...] desempenham um papel político que poderá estar ou não comprometido com a transformação social, conforme estejam ou não conscientes da força de reprodução e, ao mesmo tempo, do espaço de contradições presentes nas condições sociais da leitura"' (SOARES, 2005, p.28).

Importante frisar também que a prática de leitura patrocinada pela escola precisa ocorrer num espaço de maior liberdade possível. A leitura só se torna livre quando se respeita, ao menos em momentos iniciais do aprendizado, o prazer ou a aversão de cada leitor em relação a cada livro (LAJOLO, 1993, p. 109).

Dessa forma, é necessário que no espaço escolar o lei- 
tor encontre a oportunidade de ler e de compreender que não há dois mundos - a leitura da escola e a leitura fora da escola. Assim, há uma leitura que precede à vida escolar e, portanto, é parte intrínseca do ser humano, pois este já nasce envolto ao mundo letrado.

Ao reconhecermos que a natureza social do sujeito tem ligação com o desenvolvimento da cultura e da sociedade, reforça-se que é na interação com o outro e nas relações sociais que o sujeito interioriza, aprende e interpreta os fatos do contexto em que atua. O sujeito reconhece-se como produtor de conhecimento, constrói-se nas organizações sociais, assim, se apropria da cultura no espaço onde vive e, nesse espaço, a leitura deve ter lugar garantido.

\section{O que revelam os resultados?}

Nos limites desse texto, embora tenhamos precedido uma análise, mesmo que preliminar, frente às questões em discussão, há inúmeras respostas e possibilidades de compreender os sujeitos em processos de leitura. Quando nos propomos a ouvir professores em formação, são diversas as questões que surgem e que representam as suas ações na formação de futuros leitores no espaço escolar.

A leitura acontece em outros espaços, mas às vezes tem início no espaço escolar, há sempre um mediador que ao apresentar às crianças e jovens - "o mundo da leitura" - tem papel importante para que o prazer ou a aversão ao ato de ler venham à tona na formação ou não de um leitor.

Por isso, consideramos que a leitura ao ser pensada junto aos professores das escolas do campo, revelam importância inconteste, pois pode ser um dos instrumentos de luta pelos direitos reivindicados pela população do campo.

A escola tem papel importante na apresentação das primeiras leituras, bem como para sua motivação, pois é preciso considerar quais são as leituras e como elas são 
apresentadas às crianças e aos jovens.

Compreende-se que ao serem inseridos nesse mundo de artefatos literários há um confronto de ideias, de ideais, de fantasias, mas sobretudo é preciso compreender que a leitura oferece a oportunidade de entender o que está a nossa volta, de contrapor, de confrontar e de transformar e, portanto, de promover a inserção do homem no mundo, no qual ele desempenha papel importante, pois ler é prática política e social e o espaço escolar é também, um lugar de lutas, de contradições e de resistência, portanto, espaço necessário e importante para que a leitura seja garantida como possibilidade de reflexão e atuação de alunos e professores na escola do campo, reconhecendo-a como um direito, articulado ao direito a terra, ao trabalho e à educação.

\section{REFERÊNCIAS}

ARROYO, M. Políticas de formação de educadores (as) do campo. Caderno Cedes Campinas, v. 27, p.157-176, maio/ ago.2007. Disponível em: <http://www.cedes.unicamp.br>. Acesso em: 11 ago. 2017.

ARROYO, M. G. A educação Básica e o movimento do social do campo. In: ARROYO, M. G; CALDART, R. S; MOLINA, C. M. (org.) Por uma Educação do Campo. Petrópolis, RJ: Vozes, 2009.

. Prefácio. Educação do Campo: propostas e práticas pedagógicas do MST. Petrópolis, RJ: Vozes, 2006.

ANTUNES-ROCHA, M. I; MARTINS, M. de. F. A; MARTINS, A. A. (Org.). Territórios Educativos do Campo: escola, comunidade e movimentos sociais. Belo Horizonte: Autêntica Editora, 2012. (Coleção Caminhos da Educação do Campo).

. Educação do Campo-desafios para a formação de professores. Belo Horizonte: Autêntica Editora, 2011. (Coleção Caminhos da Educação do Campo). 
CALDART, R. S. Por uma educação no campo: traços de uma identidade em construção. In: KOLLING, E. J; CERIOLI, P. R; CALDART, R. S. (Org.). Educação do Campo: identidade e Políticas, Brasília, DF: articulação nacional por uma educação do campo, v.4, 2002.

. (Org.). Caminhos para a Transformação da Escola: reflexões desde práticas da licenciatura em educação do campo. Expressão popular, 2011.

A escola do campo em movimento. In: ARROYO, M.

G; CALDART, R. S; MOLINA, M. C. (Org.). Por uma Educação do Campo. Petrópolis, RJ: Vozes, 2009.

CORREA, D. M. das N; BATISTA, M.do S.X. Alternância no Ensino Superior; o campo e a universidade como territórios de formação de educadores do campo. In: ANTUNES-ROCHA, M. I; MARTINS, M. de. F. A; MARTINS, A. A. Tempo Escola e Tempo Comunidade: Territórios Educativos do Campo: escola, comunidade e movimentos sociais. Belo Horizonte: Autêntica Editora, 2012. (Coleção Caminhos da Educação do Campo).

FERNANDES, M. B. Diretrizes de uma caminhada. In: CALDART, R. S. (Org). Por uma educação do Campo. Petrópolis, RJ: Vozes, 2009.

FERNANDES, B. M; CERIOLI, P. R; CALDART, R. S. “Primeira Conferência Nacional ‘Por uma educação básica do campo': texto preparatório". In: ARROYO, M. G; CALDART, R. S; MOLINA, M. C. Por uma educação do campo. Petrópolis: Vozes, 2009.

FUNDAÇÃO UNIVERSIDADE FEDERAL DE MATO GROSSO DO SUL. Projeto Pedagógico do Curso de Licenciatura em Educação do Campo. Campo Grande, 2014.

KRAMER, S. Leitura e escrita de professores Da prática de pesquisa à prática de formação. Revista Brasileira de Educação. Jan/Fev/Mar/Abr 1998.

LAJOLO, M. P. A Formação do Leitor no Brasil. São Paulo: Ática, 1996. 
. Do Mundo da Leitura para a Leitura do Mundo. São Paulo: Ática, 1993. (Série Educação em Ação).

. O Texto não é Pretexto. In: ZILBERMAN, R. (org.). Leitura em Crise na Escola: as alternativas do professor. 7. ed. Porto Alegre: Mercado Aberto, 1986. (Série Novas Perspectivas, volume 1 .

LEONTIEV, A. O desenvolvimento do psiquismo. São Paulo: Centauro, 2004.

MARTINS, L. M. As aparências enganam: divergências entre o Materialismo Histórico Dialético e as abordagens qualitativas de pesquisa. 29a Reunião Anual da ANPEd, Educação, cultura e conhecimento na contemporaneidade: desafios e compromissos, Caxambu, 2006.

MIGUEL, E. S.; PÉREZ, J. R. G.; PARDO, J. R. Leitura na sala de aula: como ajudar os professores a formar bons leitores. Porto Alegre: Penso, 2012.

MINISTÉRIO DA EDUCAÇÃO. Diretrizes Operacionais para a educação básica nas escolas do campo. Brasília, 2002.

MOLINA, C.M. Possibilidades e limites de transformações da escola do campo: reflexões suscitadas pela Licenciatura do Campo - UFMG. In: ANTUNES-ROCHA, M. I, MARTINS, A.A. (org.) Educação do Campo: desafios para a formação de professores, Belo Horizonte: Autêntica, 2011.

. Cultivando princípios, conceitos e práticas. Presença Pedagógica, Belo Horizonte, v.15, n. 88, p. 30-36, jul/ago. 2009.

. Educação do Campo e pesquisa: questões para reflexão. Brasília: Ministério de desenvolvimento Agrário,2006.

NETO, A. J de M. Formação de professores para a Educação do Campo: projetos sociais em disputa. In: ANTUNES-ROCHA, M. I, MARTINS, A.A. (Org.) Educação do Campo: desafios para a formação de professores, Belo Horizonte: Autêntica, 2011.

ORLANDI, E. P. Discurso e leitura. São Paulo: Cortez. Campinas/SP: UNICAMP, 2000. 
PERISSÉ, G. Elogio da Leitura. Barueri, SP: Manole, 2005.

PIRES, A. M. Educação do campo como direito humano. São Paulo: Cortez, 2012. (Coleção e Educação de Direitos Humanos v. 4). Editora, 2012.

RANGEL, N. M. J. Leitura na Escola: espaço para gostar de ler. Porto Alegre: Mediação, 2012.

SOARES, M. B. As Condições Sociais da Leitura. In: ZILBERMAN, R; SILVA, E. T da. (Org.). Leitura: perspectivas interdisciplinares. São Paulo: Ática, 2005.

SGARBI, N. M. F. Q. Linguagem e Argumentação. Dourados: Unigran,2013.

TULESKI, S. C. Vigotski: a construção de uma psicologia marxista. Maringá: EDUEM, 2008.

VIGOTSKI.L. S. Problemas teóricos y metodológicos de la psicologia. Madri:visor,1991. (Obras escolhidas,1) 



\title{
CAPÍTULO 6
}

\section{EDUCAÇÃO POPULAR: gestão, política e formação de professores}

\author{
Jussara Bueno de Queiroz Paschoalino ${ }^{1}$ \\ Priscila Andrade Magalhães Rodrigues ${ }^{2}$ \\ Luciene Cerdas ${ }^{3}$
}

\begin{abstract}
A temática da educação popular tem produzido pesquisas acadêmicas que demarcam a importância de trazer as problemáticas envolvidas nesta composição, ou seja, a educação e sua dimensão popular. Historicamente a educação formal se efetivou e se complexificou numa perspectiva antagônica ao que se designava popular. Em contraponto a esta lógica de oposição entre a educação e a lógica popular, outra dimensão se instaurou ao formar a denominação educação popular dirigida aos sujeitos ex-
\end{abstract}

\footnotetext{
${ }^{1}$ Professora Adjunta da Universidade Federal do Rio de Janeiro. Doutorado em Educação pela Universidade Federal de Minas Gerais. Doutorado Sanduíche pela Universidade do Porto. Pós-Doutorado pela Pontifícia Universidade Católica de Minas Gerais. Mestrado em Educação pela Universidade Federal de Minas Gerais. Possui graduação em Pedagogia pela Pontifícia Universidade Católica de Minas Gerais. Especialização em Educação pelo CEPEMG. Especialização em Psicopedagogia pelo CEPEMG.

E-mail: jussarapaschoalino@yahoo.com.br

${ }^{2}$ Doutora e Mestre em Educação pela Pontifícia Universidade Católica do Rio de Janeiro, graduada em Pedagogia pela Universidade do Estado do Rio de Janeiro e em Teologia pela Faculdade Batista do Rio de Janeiro. É professora na Faculdade de Educação da Universidade Federal do Rio de Janeiro. É pesquisadora do Grupo de Pesquisas em Sociologia da Educação (SOCED) e do Grupo de Estudos e Pesquisas em Didática e Formação de Professores (GEPED). E-mail: priscilaapri@gmail.com

${ }^{3}$ Professora do Departamento de Didática da Faculdade de Educação da UFRJ, atuando em disciplinas como Alfabetização e Letramento I e Prática de Ensino das Séries Iniciais do Ensino Fundamental. Doutora em Educação Escolar pelo Programa de Pós-Graduação em Educação Escolar da UNESP/ Araraquara (2012). Mestre em Educação Escolar pelo Programa de Pós-Graduação em Educação Escolar da UNESP/Araraquara (2007). Formada em Pedagogia pela UFPR (2004) e em Jornalismo pela UNESP/Bauru (1998). E-mail: lucienecerdas@hotmail.com
} 
cluídos do processo educativo. Aquela que "[...] atenda às necessidades da população excluída dos direitos básicos da existência humana e dos princípios da formação de sujeitos críticos - conscientes e construtores de sua história [...] a educação popular se configura e reconfigura como algo próprio à história da Educação [...]. (MACIEL, 2011, p.328).

Assim, de acordo com Brandão (2002 apud MACIEL, 2011, p.330):

[...] educação popular não pode ser considerada como algo realizado como um acontecimento situado e datado, caracterizado por um esforço de ampliação do sentido do trabalho pedagógico a novas dimensões culturais, e a um vínculo entre a ação cultural e a prática política. A educação popular foi e prossegue sendo uma sequência de ideias e de propostas de um estilo de educação em que tais vínculos são reestabelecidos em diferentes momentos da história, tendo como foco de sua vocação um compromisso de ida - e - volta nas relações pedagógicas de teor políticos realizados através de um trabalho cultural estendido a sujeitos das classes populares compreendidos como não beneficiários tardios de um "serviço", mas como protagonistas emergentes de um "processo". (BRANDÃO, 2002, pp.141-142).

No âmbito da produção do conhecimento, as aproximações entre educação e popular não se estabelecem prontamente, há um processo, muitas vezes, marcado pela crise epistemológica de pensar a realidade. Ressalta-se que o conhecimento é produzido constantemente e que está inserido na complexidade histórica, cultural, sociológica, psicológica, antropológica e econômica.

Para comprovar esta afirmação, uma pesquisa foi realizada no site do Banco de dados da Coordenação de Aperfeiçoamento de Pessoal de Nível Superior - CAPES por meio da busca de palavras ou termos. A presença da temática, em diversas pesquisas produzidas nas dissertações e teses que tratavam do binômio Educação Popular, foi em número expressivo. Vale salientar que o Banco da Capes apresenta resumos de dissertações e teses defen- 
didas desde 1987 e que, no período correspondente entre 2013 até 2016, inclui também a obra completa. Em relação à temática da Educação Popular se obteve 150.042 resultados para publicação de dissertações e teses entre 1987 e 2016. Ao analisar os dados referentes aos últimos cinco anos foram constatados que o número das produções acadêmicas teve um crescimento significativo.

Os dados permitem analisar que a temática Educação Popular foi se consolidando como campo de conhecimento ao se verificar que nos cinco últimos anos as produções alcançaram um total de 64.105. Isso se comprova quando se compara esse resultado à produção total desde 1987 (150.042) pela proporção de anos, pois se feita a divisão da produção pelo número de anos houve um aumento de pesquisas que alcançou quase quatro vezes mais a cada ano no período de 2012 a 2016.

\begin{tabular}{|c|c|c|c|}
\hline \multicolumn{4}{|c|}{ Dissertações e Teses } \\
\cline { 1 - 2 } Ano & No de produção & Total & Proporção \\
\cline { 1 - 2 } 2016 & 15.622 & & \\
\cline { 1 - 2 } 2015 & 14.318 & \multirow{2}{*}{64.105} & $\begin{array}{c}3.437,48 \\
\text { por ano }\end{array}$ \\
\cline { 1 - 2 } 2014 & 12.791 & anos & \\
\hline 2013 & 11.681 & & \\
\cline { 1 - 2 } 2012 & 9.603 & & $\begin{array}{c}3.437,48 \\
\text { por ano }\end{array}$ \\
\hline
\end{tabular}

Fonte: Elaborado pelas autoras - Banco CAPES $<$ http://bancodeteses.capes.gov.br/banco-teses/\#!/>

Todo este acervo científico sobre a temática de Educação Popular nos provoca e ao mesmo tempo nos instiga a repensar a educação para todos pela sua visibilidade. A compreensão de que a Educação Popular tem como uma das suas facetas a valorização da educação que seja para todos, sem deixar de lado ninguém. Assim, a educação, na condição de processo formativo "[...] é uma construção que, jamais terminada, demanda briga por ela. Demanda 
engajamento, clareza política, coerência, decisão. Por isso mesmo é que uma educação democrática não se pode realizar à parte de uma educação da cidadania e para ela. " (FREIRE, 1997, p. 119).

Ao se referir à briga pela educação, o autor supracitado evidencia o caráter transitório do conhecimento, que deve ser pautado pela educação plena do humano. As conjecturas dos conhecimentos para esta educação, que visa à cidadania, estão em constantes disputas.

Trata-se de uma crise de legitimidade do saber científico, frente à legitimidade e autonomia dos saberes dos diferentes grupos e movimentos sociais, que se configuram como uma rede múltipla e variável de relações de poder. De um lado, a explicitação destas relações de poder coloca em questão o próprio estatuto de cientificidade do saber acadêmico que, por sua configuração epistemológica, tem negligenciado dimensões essenciais da realidade e da prática social. De outro lado, os diferentes sujeitos sociais que emergem no cenário político e cultural reivindicam o reconhecimento da diferença de suas identidades, de suas práticas, de seus saberes e de suas culturas, ao mesmo tempo que a igualdade de oportunidades e de direitos no jogo social de poder. Os campos da cultura e da constituição das subjetividades, aparecem como espaços privilegiados de luta, tão importante quanto os campos político, econômico e ecológico. (ANPED, s/d, s/p).

Este fragmento do site da ANPED explicita o movimento de compreensão do campo de disputa na perspectiva do saber, que na lógica da complexidade, traz para a cena saberes diversos, por vezes ausentes de valorização até então. Dessa maneira, na atualidade a compreensão de uma educação plena perfila na interseção entre a educação tradicional e a popular, que estão cotejados na literatura acadêmica brasileira. Vale salientar que a ANPED foi:

[...] fundada em 1976, realiza reuniões anuais desde 1978. Em sua quarta reunião, sediada em Belo Horizonte em 1981, propôs-se a estruturar-se em Grupos de Trabalhos (GT). Entre estes, foi criado o GT Educação Popular, que se reuniu pela primeira vez em 1982, sob a coordenação de 
Os Grupos de Trabalho - GTs são 23 e estão constituídos sobre as temáticas pelos pesquisadores das áreas com intuito de refletir, debater e propor caminhos para a educação. Os GTs são “[...] instâncias de aglutinação e de socialização do conhecimento produzido pelos pesquisadores da área de educação." (ANPED, s/d, s/p). O GT 06 da ANPED é o destinado à Educação Popular e o acervo existente disponibiliza a temática da área específica problematizada na atualidade.

A importância desse GT se traduz no convite de pensar a educação e a interseção de saberes presentes na expressão popular. Nesse sentido, o percurso metodológico escolhido se alicerçou na análise qualitativa do material bibliográfico selecionado a partir do levantamento dos trabalhos apresentados nas últimas cinco reuniões da ANPED (2010 a 2015). A opção pelos GTs da ANPED se pautou em dois fundamentos importantes: primeiramente, pela relevância desse espaço de socialização da produção teórica e acadêmica da área da educação e também pela forma democrática de disponibilizar os textos no site para consulta pública, facilitando o acesso aos trabalhos. Ao disponibilizar as produções acadêmicas o site da ANPEd proporciona a socialização do conhecimento, ao mesmo tempo em que instiga a sociedade a repensar a educação frente as demandas atuais.

Com esta compreensão, o percurso metodológico adotado foi a pesquisa no GT 06 da Educação Popular, e nossa análise partiu da leitura dos 63 títulos de trabalhos aceitos nesse GT no período estabelecido nas últimas cinco ANPEDs e posteriormente dos resumos, com objetivo de delinearmos o mapeamento da trilogia dos conceitos: Gestão, Política e Formação de Professores, que consideramos arcabouços da ação docente e basilares da Educação Popular. Dos 63 trabalhos aprovados na ANPED, foram 
selecionados 47 , que traziam a seleção dos eixos basilares escolhidos conforme a tabela abaixo:

\begin{tabular}{|c|c|c|}
\hline Ano & $\begin{array}{c}\text { Trabalhos aprovados } \\
\text { ANPED }\end{array}$ & $\begin{array}{c}\text { Trabalhos } \\
\text { Selecionados }\end{array}$ \\
\hline 2010 & 10 & 08 \\
\hline 2011 & 10 & 09 \\
\hline 2012 & 13 & 13 \\
\hline 2013 & 12 & 11 \\
\hline 2015 & 18 & 06 \\
\hline 5 anos & 63 & 47 \\
\hline
\end{tabular}

Fonte: Elaborado pelas autoras - Site da ANPED

Vale salientar que dos trabalhos selecionados, a partir dos aprovados na Reunião 34 $4^{\text {a }}$ Nacional da ANPED, ocorrida em 2011, dois trabalhos apresentaram apenas o resumo. Em relação à 2012, não foi possível acessar um dos trabalhos.

As análises destes trabalhos nos possibilitaram analisar a Educação Popular no Brasil sob o prisma dos termos destacados: Política, gestão e formação de professores.

\section{Política}

A escolha do termo política como basilar na Educação Popular se efetiva pela dimensão de ser humano enquanto ser político e na Função da Sociedade Política que se pauta pela compreensão de que: "A verdadeira razão de ser de uma sociedade política não é outra, senão a realização da felicidade geral; ou seja, a felicidade de todos e cada um dos cidadãos. A felicidade não nos é dada, mas deve ser por nós construída." (COMPARATO, 2016, p.3).

Essa perspectiva, apresentada pelo autor supracitado, nos possibilitou analisar que nas conjecturas atuais estamos longe de vivenciar a política alicerçada na felicida- 
de individual e coletiva. Com essa compreensão, cada vez fica mais evidenciado que a procura pela política capaz de instaurar a felicidade é uma façanha hercúlea.

Numa sociedade altamente excludente, concentradora de renda e patrimonialista como a nossa, compreendemos que as lutas que emergem desses movimentos contra hegemônicos, e que de diferentes formas se expressam e articulam as classes populares, podem ampliar suas potencialidades e possibilidades, tornando-se capazes de se fazerem ouvir, pressionando de maneira ativa e crítica os processos de elaboração das políticas públicas e dos direitos à cidadania. (TAVARES, 2015, p. 10-11).

A autora evidencia a discussão de como a Educação Popular necessita ter um protagonismo diante de esquemas sociais excludentes e marcados pela falta de direitos.

Porque lutar por políticas públicas representa o confronto com a lógica do mercado, expressão da liberdade para o desenvolvimento do polo do capital. Mas uma questão que demarca o confronto diz respeito a quem tem o protagonismo na luta pela construção de políticas públicas e a que interesses elas dominantemente atenderão. A disputa do fundo público para educação, formação técnica, saúde, cultura, apoio à agricultura camponesa e ao acesso à moradia, entre outros, constitui-se em agenda permanente, dado que, cada vez mais, esse fundo tem sido apropriado para garantia da reprodução do capital e, no campo, pelo agronegócio. (DICIONÁRIO DA EDUCAÇÃO DO CAMPO, 2012, p.16).

O Dicionário da Educação do Campo teve a Organização dos professores Roseli Salete Caldart, Isabel Brasil Pereira, Paulo Alentejano e Gaudêncio Frigotto e possibilitou maior visibilidade para a temática da Educação Popular. O verbete "política" designa a política pública na condição de confronto e de luta por uma sociedade melhor.

De acordo com Maciel (2011, p.332), a Educação Popular como perspectiva política é demarcada pelas experiências advindas a partir dos anos de 1960,

[...] que passam a ter um caráter maior de organização po- 
lítica a fim de conscientizar e contribuir na organização popular. Este foi um momento de articulação dos compromissos políticos assumidos com movimentos sociais populares, os quais consideramos como movimentos de classe que tem por objetivo a condução da transformação da sociedade a partir do lugar político popular.

E Paulo Freire "aparece como principal idealizador dessa educação que proporcionasse a conscientização do analfabeto, da libertação "do oprimido que hospeda o opressor" por meio do movimento de cultura popular."(MACIEL, 2011, p.333)

Essa lógica perpassa os trabalhos do GT 06 da ANPED ao analisarem as políticas do país. O quadro a seguir evidencia a frequência desse termo política nos trabalhos selecionados a partir do site, que trazem os apresentados nas últimas Reuniões Nacionais da ANPED.

\begin{tabular}{|c|c|}
\hline Ano & Frequência do termo: Política \\
\hline 2015 & 112 \\
\hline 2013 & 228 \\
\hline 2012 & 103 \\
\hline 2011 & 41 \\
\hline 2010 & 51 \\
\hline Total & 565 \\
\hline
\end{tabular}

Fonte: Elaborado pelas autoras - Site da ANPED

O quantitativo de vezes que o termo política apareceu nos textos aprovados nas Reuniões Nacionais da ANPED, no período de 2010-2015 foi significativo, na perspectiva de que a Educação Popular se forja na lógica das disputas políticas de lutas pela valorização de saberes diversos. Importante ressaltar que na seleção dos trabalhos o termo política estava presente em praticamente todos os trabalhos, mas nem sempre no título ou no resumo, entretanto estava expresso no corpo do texto.

Assim, concepção de política é alargada nas referên- 
cias realizadas nos trabalhos ao discernirem a política como parte da dimensão do humano.

De início, deve-se observar a política como o espaço por excelência de realização maior do homem. Na sua relação com o outro, a expressão de uma vida comunitária melhor somente se faz pelo exercício constante de um diálogo entre iguais. Para que esse diálogo entre iguais se estabeleça, não devem existir sujeitos com maiores vantagens do que os outros no sistema de escolhas do destino da coisa pública. Assim, para que haja uma verdadeira participação política, a ideia de igualdade é indispensável. Por outra parte, a noção de igualdade constitui a base da concepção de justiça. Portanto, e de forma sintética, política e justiça se unem a partir do conceito de igualdade. Somente entre iguais é possível que homens, realmente livres, estabeleçam parâmetros para uma vida melhor em sociedade. (CORREIA, 2012, p.189).

Dessa forma, a reflexão sobre o âmbito da política transpassa as dimensões humanas e convoca à participação coletiva, em que todos possam ser iguais e que suas vozes possam recuar no sentido da garantia de justiça.

No âmbito da educação, a perspectiva da Educação Popular tem crescido consideravelmente na discussão acadêmica. No caminho trilhado por pesquisadores, estes ainda sentem resistências para apresentarem as análises de seus trabalhos, principalmente na perspectiva de mudança de comportamento, aspecto essencial na educação.

As políticas educacionais permanecem absolutamente insuficientes para reverter as consequências perversas das condições de desigualdades em que vive a população brasileira, dada a baixa qualidade da educação e a distribuição desigual dos insumos educacionais previstos nas políticas públicas. Essa dinâmica perversa se reproduz regionalmente, nos municípios, nos bairros e até dentro de uma mesma escola. É uma lógica recorrente o fato de quem mais necessita, menos recebe. (HADDAD, 2012, p. 222).

Se as políticas educacionais se mantêm na contramão da construção da felicidade de todos e cada um dos cidadãos, os processos inerentes a elas e estabelecidos são 
perversos. A política se efetiva nas normas legais e nas dinâmicas das gestões públicas.

\section{A gestão e suas implicações na Educação Popular}

O termo gestão, utilizado recorrentemente na literatura acadêmica, elucida dimensões que envolvem relações múltiplas que abarcam o humano, o material, o político, o financeiro, as leis, o tempo, espaço e o cuidado, e que são permeadas por acompanhamento, perspectiva de transformação, avaliação e controle. Vale salientar que para cada uma dessas dimensões abre-se um leque de outros aspectos que são inerentes à gestão. (PASCHOALINO, 2017). Nessa lógica, não há uma única forma de gestão, mas múltiplas ações que se congregam nas relações e se alteram constantemente devido aos contextos internos e também aos externos. Outro aspecto importante na condução da gestão se refere à percepção do momento em que as ações são empreendidas, ao considerar que: "a percepção é sempre um processo seletivo de apreensão." (SANTOS, 2003, p. 62). Essa percepção múltipla, desfocada, reflete a complexidade das relações humanas e de seus significados.

Assim a paisagem é socialmente construída e significada
culturalmente. É esta diversidade, portanto, este passado
dinâmico que encontramos em nossas vidas que devemos
observar conceituar e abstrair, transformando em peda-
gogias possíveis as realidades comunitárias. (TAMANINI,
2015, p.10).

As perspectivas das múltiplas pedagogias se inserem num campo de conhecimento que se refaz ao longo do tempo e nas diversas culturas. Com essa compreensão, por vezes o discurso realizado na prática se apresenta carregado de significados construídos coletivamente. "A afirmação pode ter até um viés partidário no sentido de 
"dizer" o que foi essa política de um governo que se define como popular e democrático, mas não deixa de ser o objetivo de um dos envolvidos." (STRECK, 2015, p. 11).

E a educação, na sua condição de transformação, necessita romper barreiras e padrões prontos e fechados para se efetivar num processo democrático. Ao buscar pelo termo gestão democrática no dicionário de Educação Popular, encontra-se:

[...] uma das questões mais polêmicas da gestão educacional diz respeito à exigência constitucional de ela ser democrática e, portanto, de envolver, como condição do exercício da democracia, a participação das comunidades escolar e local, e da sociedade civil organizada, nas decisões relativas às políticas e projetos educacionais, num regime de corresponsabilidade. Ela prevê, também, a participação dos profissionais da educação nos projetos político-pedagógicos das instituições de ensino. (ARELARO, 2012, p. 387.)

A educação democrática deveria extrapolar o campo educacional e se construir nas múltiplas relações humanas, pois "[...] trata-se de uma invenção social que exige um saber político, gestando se na prática de pôr ela lutar, a que se junta a prática de sobre ela refletir." (FREIRE, 1996, p. 146).

Essa lógica da gestão democrática, ancorada nos preceitos legais e alardeada num discurso fácil no cotidiano dos espaços educacionais, ainda possui lacunas difíceis de superar, ao se compreender que não é possível construir a escola democrática com instâncias políticas e burocráticas que exerçam uma cobrança contrária. (PASCHOALINO, 2017). Para fazer uma analogia aos dizeres de Freire que afirmou: "Ninguém é autônomo primeiro, para depois decidir. É decidindo que se aprende a decidir" (1996, p. 64), a escola não será democrática sozinha, mas nas relações.

O termo gestão traz na sua etimologia a evidência o cuidado e o dar a vida. Estes aspectos tomam uma conotação especial a se pensar na Educação Popular, pela valori- 
zação da cultura e pela aproximação com a realidade das pessoas participantes do processo formativo.

A prática educativa é tudo isso: afetividade, alegria, capacidade científica, domínio técnico a serviço da mudança ou, lamentavelmente, da permanência do hoje. É exatamente esta permanência do hoje. Daí 'sua politicidade, ou seja, a impossibilidade de se separar educação e política. Aliás, uma tal separação entre educação e política ingênua ou astutamente feita, enfatizemos, não apenas é irreal, mas perigosa. (FREIRE, 2001, p. 172).

Paulo Freire não apenas falou sobre a gestão na educação, mas no período em que esteve à frente da Secretaria de Educação de São Paulo, no período de (1989-1992) deixou marcas de gestão pautada na construção de uma escola pública popular e democrática.

Em sua carta dirigida aos educadores de São Paulo (DOM, 1989), publicada no Diário Oficial do Município, logo após tomar posse como Secretário, Paulo Freire anunciava a construção de uma escola voltada para a formação social e crítica dos educandos, uma escola séria, na apropriação e recriação de conhecimentos e, ao mesmo tempo alegre, estimuladora da solidariedade e da curiosidade. A abertura da escola à comunidade, a construção do currículo, de forma participativa, autônoma e coletiva, o estímulo à gestão democrática da educação, o respeito ao saber do educando, e a indispensável formação dos educadores, foram marcos fundamentais que nortearam o seu quefazer na educação de São Paulo. (SAUL, 2013, p. 2).

O legado da gestão de Freire demarca uma nova perspectiva de pensar a educação crítico-emancipadora. Estes aspectos estão normatizados nos documentos legais, no entanto, constatamos na literatura, que ainda exista dificuldade de sua efetivação.

A gestão educacional fica expressa nas relações humanas pautadas no respeito e na valorização do outro. A análise freireana de educação indica um olhar atento a lutar por um mudo possível, necessário e urgente, "que 
extermine as relações hierarquizadas de opressão e exploração do trabalho, dos recursos naturais e da vida." (MACIEL, 2011, p.339).

Na pesquisa realizada pelo termo gestão nos trabalhos aprovados no GT 06 verifica-se a incidência apresentada a seguir:

\begin{tabular}{|c|c|}
\hline Ano & Frequência do termo: Gestão \\
\hline 2015 & 06 \\
\hline 2013 & 91 \\
\hline 2012 & 22 \\
\hline 2011 & 9 \\
\hline 2010 & 9 \\
\hline Total & 137 \\
\hline
\end{tabular}

Fonte: Elaborado pelas autoras - Site da ANPED

A incidência do termo gestão aparentemente tem uma proporcionalidade menor do que o termo política, entretanto, ao ler e analisar os textos aprovados nas Reuniões Nacionais da ANPED, no período de 2010-2015 analisa-se que a gestão aparece com palavras que compõem, ou seja, objetivos, planejamento, estratégias de ação e avaliação. Os estudos e pesquisas sobre educação popular deixam evidente a lógica de se pensar e agir na educação numa perspectiva de gestão democrática.

Para vivenciarmos a gestão democrática torna-se essencial que a formação se efetive neste campo, pois com uma lógica diferente, ela precisa ser ensinada e vivida na dinâmica cotidiana da educação. 


\section{A Formação de professores/educadores}

Outro tripé dessa discussão sobre Educação Popular refere-se à formação, termo localizado nos trabalhos, de acordo com a frequência abaixo:

\begin{tabular}{|c|c|}
\hline Ano & $\begin{array}{c}\text { Frequência do termo: } \\
\text { Formação de Professores }\end{array}$ \\
\hline 2015 & 35 \\
\hline 2013 & 135 \\
\hline 2012 & 59 \\
\hline 2011 & 36 \\
\hline 2010 & 20 \\
\hline Total & 285 \\
\hline
\end{tabular}

Fonte: Elaborado pelas autoras - Site da ANPED

Embora não haja uma regularidade em relação ao termo ao longo das últimas ANPEDs, a temática da formação no âmbito da Educação Popular esteve presente em todas elas. Verificamos que o termo formação aparece nos textos a partir de três dimensões, a saber: formação para ação, formação humana e formação de professores/educadores.

É interessante destacar, que entre os trabalhos analisados, foi possível verificar também uma ocorrência significativa do termo transformação, o que indica o caráter transformador e emancipatório da Educação Popular na perspectiva freireana, bastante presente nos estudos sob análise.

No eixo formação de professores/educadores, embora algumas propostas analisadas não se denominem de formação, pois a maioria dos casos trata-se de realização de pesquisa, percebemos que o próprio modelo metodológico escolhido, como o comunicativo crítico, ou mesmo, pesquisa-ação-formação, engloba um processo formativo visando uma futura ação do sujeito, ou seja, envolvendo 
algum tipo de transformação, seja interior, seja de sua atuação profissional, seja de seu contexto de vida e da sua comunidade, o que chamamos aqui de uma formação para a ação. Tais propostas são sustentadas pelas

\begin{abstract}
"reflexões e interpretações dos protagonistas que, em processos comunicativos, colaborativos e de entendimento entre si - incluindo a pesquisadora - contribuem com conhecimentos e reflexões que lhes são próprios e que permitem a manutenção, renovação e/ou transformação de suas ações e de sua própria realidade". (MOREIRA, 2011, p.9)
\end{abstract}

Quanto a essa dimensão, destaca-se a importância da análise freireana que

se dá em conjunto com educadores e educadoras num constante e necessário diálogo com o mundo e com as possibilidades de sua transformação. É na prática dialética de escutar, refletir, engajar-se, que a teoria de Paulo Freire encontra sua necessária dimensão pedagógica-política, tão atual e necessária, tantos nos espaços formais quanto nos não formais que pretendam uma emancipação de indivíduos e grupos (MACIEL, 2011, p. 343).

O próprio termo formação de educadores do campo no Dicionário de Educação popular, destaca o papel central de formação para a ação desses profissionais enquanto "sujeitos coletivos de políticas de formação de docentes-educadores". (DICIONÁRIO DA EDUCAÇÃO DO CAMPO, 2012, p.362). Demanda que nasce dos movimentos sociais - atores centrais da educação do campo -, os professores/educadores são sujeitos ativos nas lutas por terra, reforma agrária, agricultura camponesa, e inclusive, luta por uma política de formação específica para sua atuação profissional.

Nos trabalhos analisados, há uma grande preocupação com o fato de que a formação humana aconteça para além das aprendizagens construídas nos espaços formais de ensino. A escola aparece enquanto um importante espaço de socialização, mas não único na formação de sujeitos. 
"O entorno familiar, social e cultural das pessoas exercem uma especial importância, posto que facilita e possibilita a formação". (MOREIRA, 2011, p.9). Segundo a autora, enquanto espaço de socialização de múltiplas culturas, a escola tem o potencial de transformação da realidade social, somente ao envolver-se com a comunidade e entorno familiar de seus estudantes. Deste modo, o ambiente escolar tem "a oportunidade da conscientização dos opressores e oprimidos, no sentido freireano, como forma de construção política e transformação da sociedade". (SOUZA e VASCONCELOS, p.11).

A “Educação popular - entendida como educação do povo e para o povo - torna-se necessária enquanto oportunizadora das condições intelectuais que proporcionariam maior esclarecimento dos trabalhadores para o engajamento e a participação social." (MACIEL, 2011, p.341). Tem como desafio central a humanização da educação, instrumento de transformação da consciência para uma luta contra-hegemônica, em que os sujeitos do processo educativo são vistos como produtores de sua cultura e de sua história.

Ao tratar da formação de professores / educadores os textos analisados destacam a importância do elemento de formação dos que atuam nas instituições formais de ensino que contemple desde a educação rural como as escolas comunitárias populares. A grande preocupação presente nos textos está relacionada à preparação dos educadores e docentes para uma educação contextualizada e que tenha sentido para o educando. Portanto, preocupação com o reconhecimento dos saberes da experiência torna-se fundamental neste processo. A formação de docentes e educadores demanda que estes partam "do conhecimento das pessoas, dos grupos multiculturais de aprendizagem e tendo o conhecimento de cada matéria, desde [que n] um enfoque interdisciplinar. Esse ponto de vista inclui os aspectos educativos, psicológicos, sociológicos, culturais e 
epistemológicos". (MOREIRA, 2011, p.13).

Para Freire (1996, p. 30) este é um processo de respeito aos saberes do educando, sobretudo os das classes populares, saberes estes "socialmente construídos na prática comunitária", que devem ser discutidos na relação com os conhecimentos científicos.

Guerra aponta preocupação com relação à "fragilidade da formação das professoras acerca de conteúdos relativos às ciências da natureza e da ausência de uma concepção de ciência contextualizada" (GUERRA, 2013, p.2). Neste caso, a preocupação está nas lacunas da formação inicial das educadoras de escolas comunitárias com relação aos saberes científicos - que no caso analisado são das ciências, mas que podemos estender para outras áreas -, bem como, sua relação com a vida das pessoas.

A questão da fragilidade na formação dos docentes já é bastante conhecida e está presente em todo o sistema educacional. Na educação popular, a preocupação reforça-se na necessidade de pensar uma escola que articule a vida em comunidade com o sistema formal de ensino, ou, como destaca Canário (2000, p. 136), "fazer coincidir um projeto educativo globalizado com um projeto globalizado de educação". Para tanto, faz-se fundamental nos processos de formação, como destaca Arroyo, "reconhecer os saberes do trabalho, da terra, das experiências e das ações coletivas sociais e legitimar esses saberes como componentes teóricos dos currículos". (DICIONÁRIO DA EDUCAÇÃO DO CAMPO, 2012, p.363).

A falta de incentivo à formação ou de formação continuada de professores de escolas rurais também é mencionada nos textos, especialmente em propiciar tempo/espaço para os processos de formação possam ocorrer. Falta trazer o professor para o lugar central da formação humana, política e para ação transformadora da sociedade. Para tanto, "o empoderamento" do professor como agente de transformação, a partir de educação inicial e continuada 
de qualidade, [pode] ser um dos pilares que construirão um novo movimento educacional e social [...] a caminho da ação transformadora. (SILVA, 2013, p. 17).

\section{Considerações finais}

Nas produções extraídas por meio dos trabalhos aprovados na ANPED, no período de (2010 a 2015), foi possível constatar que elas retratam o campo da educação popular sempre atualizado por suas lutas e conquistas na busca por uma educação para todos, em que os diversos saberes possam ser valorizados.

Os diferentes trabalhos seguem uma linha peculiar à lógica da Educação Popular, ou seja, a educação que se transforma constantemente. A coletividade supera o individualismo para a construção do novo, da solidariedade e do bem comum, mesmo diante das múltiplas dificuldades que perpassam esse trabalho.

Analisamos que a educação brasileira pautada pelos ditames legais, que orientam a atuação na construção democrática e participativa, vem paulatinamente se concretizando nestes aspectos e que a Educação Popular, devido a sua dimensão que visa à sociedade participativa e consciente, tem muito a contribuir.

A educação popular pode ser compreendida como diálogo de saberes que constrói conhecimento e amplia o universo de sentido dos sujeitos envolvidos. Diálogo este que possibilita trilhar o caminho de uma concepção dialética onde se reconhecem determinações ou condicionamentos das estruturas econômicas na conformação das subjetividades sociais. (ADAMS, 2013, p.4).

Este estudo constata que no material selecionado e analisado é possível afirmar o tripé da Educação Popular estabelecido pela política, pela gestão e a formação. Todo esse movimento dialógico e dialético da educação popular se constrói na lógica de políticas, que precisam estar ins- 
tauradas e acompanhadas por gestões coletivas e atuantes. Neste sentido, somente a formação poderá garantir a transformação da educação pensada para todos.

\section{REFERÊNCIAS}

ADAMS, T. Educação popular e o centro de formação em economia solidária - CFES/SUL ANPEd 2013. Disponível em: $<$ http://36reuniao.anped.org.br/pdfs_trabalhos_aprovados/ gt06_trabalhos_pdfs/gt06_2644_texto.pdf $>$. Acesso em: 15 mai. 2017.

ARELARO, L. R. G. Gestão Educacional. DICIONÁRIO DA EDUCAÇÃ̃O DO CAMPO. / Organizado por Roseli Salete Caldart, Isabel Brasil Pereira, Paulo Alentejano e Gaudêncio Frigotto. - Rio de Janeiro, São Paulo: Escola Politécnica de Saúde Joaquim Venâncio, Expressão Popular, 2012. Disponível em: <http://www.epsjv.fiocruz.br/sites/default/files/1191.pdf >. Acesso em: 20 mai. 2017.

ARROYO, M. Formação de professores do campo. DICIONÁRIO DA EDUCAÇÃ O DO CAMPO. / Organizado por Roseli Salete Caldart, Isabel Brasil Pereira, Paulo Alentejano e Gaudêncio Frigotto. - Rio de Janeiro, São Paulo: Escola Politécnica de Saúde Joaquim Venâncio, Expressão Popular, 2012. Disponível em: <http://www.epsjv.fiocruz.br/sites/ default/files/1191. pdf $>$. Acesso em: 20 mai. 2017.

CANÁRIO, R. A escola do mundo rural. Contributos para a construção de um objecto de estudo. Educação, Sociedade \& Culturas, Lisboa, n. 14, p. 121-139, 2000.

COMPARATO, F. K. A sociedade política: Estrutura e função. Disponível em: <http://www.escoladegoverno.org.br/attachments/4716_01.03.2016\%20\%20Caracter\%C3\%AD sticas\%20 do\%20poder, \%20o\%20ser\%20humano\%20como\%20ser\%20 pol\%C3\%ADtico \%20-\%20F\%C3\%A1bio\%20Comparato.pdf>. Acesso em: 28 mai. 2017.

CORREIA, M. O. G. Defesa de Direitos. DICIONÁRIO DA EDUCAÇÃO DO CAMPO. / Organizado por Roseli Salete Caldart, Isabel Brasil Pereira, Paulo Alentejano e Gaudêncio Frigotto. - Rio de Janeiro, São Paulo: Escola Politécnica de 
Saúde Joaquim Venâncio, Expressão Popular, 2012. Disponível em: <http://www.epsjv.fiocruz.br/sites/ default/files/l191.pdf $>$. Acesso em: 20 mai. 2017.

FREIRE, P. Pedagogia da autonomia: saberes necessários à prática educativa. São Paulo: Paz e Terra, 1996.

. Pedagogia da esperança: um reencontro com a pedagogia do oprimido. São Paulo: Paz e Terra, 1997.

. Ação cultural para a liberdade e outros escritos. 9. ed. São Paulo: Paz e Terra, 2001.

GUERRA, D. Ciências e educação popular comunitária: a concepção-mediação de saberes científicos no contexto sociocultural de escolas populares. ANPEd, 2011. Disponível em: $<$ http://34reuniao.anped.org.br/images/trabalhos/GT06/GT06518\%20int.pdf>. Acesso em: 15 set. 2017.

\section{HADDAD, S. DIREITO À EDUCAÇÃO. DICIONÁRIO DA}

EDUCAÇÃO DO CAMPO. / Organizado por Roseli Salete Caldart, Isabel Brasil Pereira, Paulo Alentejano e Gaudêncio Frigotto. - Rio de Janeiro, São Paulo: Escola Politécnica de Saúde Joaquim Venâncio, Expressão Popular, 2012. Disponível em: <http://www.epsjv.fiocruz.br/sites/default/files/ 1191. pdf $>$. Acesso em: 20 mai. 2017.

MACIEL, K. de F. O pensamento de Paulo Freire na trajetória da educação popular. In: Educação em Perspectiva, Viçosa, v. 2, n. 2, p. 326-344, jul./dez. 2011. Disponível em: < http://www. seer.ufv.br/seer/educacaoemperspectiva/index.php/ppgeufv/ article/viewFile/196/70> Acesso em: 24 set. 2017.

MOREIRA, R. A diversidade cultural como vantagem educativa na educação escolar. ANPEd, 2011. Disponível em: $<$ http://34reuniao.anped.org.br/images/trabalhos/GT06/GT061163\%20int.pdf $>$. Acesso em: 15 set. 2017.

PASCHOALINO, J. B. de Q. Desafios da gestão escolar. Belo Horizonte: Studium Eficaz, 2017.

SANTOS, M. S.. Memória coletiva e teoria social. São Paulo: Annablume, 2003. 
SAUL, A. M. Paulo Freire em sistemas públicos de educação no Brasil pesquisando políticas e práticas. ANPEd, 2013.

Disponível em: <http://36reuniao.anped.org.br/pdfs_trabalhos _aprovados/gt06_trabalhos_pdfs/gt06_2787_texto.pdf $>$. Acesso em: 15 mai. 2017.

SOUZA, T.; VASCONCELOS, V. Da indignação ao encantamento: alguns porquês da escravidão e a educação popular. ANPEd, 2013. Disponível em: <http://36reuniao.anped.org.br/ pdfs_trabalhos_aprovados/gt06_trabalhos_pdfs/gt06_2787_ texto.pdf $>$. Acesso em: 15 set. 2017.

STRECK, D. R. METODOLOGIAS PARTICIPATIVAS DE PESQUISA E EDUCAÇÃO POPULAR: REFLEXÕES SOBRE CRITÉRIOS DE QUALIDADE. ANPEd 2015. Disponível em:< http://www.anped.org.br/biblioteca/item/metodologias-participativas-de-pesquisa-e-educacao-popular-reflexoes-sobre-criterios>. Acesso em: 15 mai. 2017.

TAMANINI, E. Educação Popular e Patrimônio Cultural - A complexidade entre Museu, Escola e Comunidade. ANPEd 2015. Disponível em: <http://37reuniao.anped.org.br/wp-content/uploads/2015/02/Trabalho-GT06-4359.pdf $>$. Acesso em: 15 mai. 2017.

TAVARES, M. T. G. Movimentos Sociais e a luta por creches no Rio de Janeiro: A Experiência das Creches Comunitárias em São Gonçalo. ANPED 2105. Disponível em: <http://www. anped.org.br/biblioteca/item/movimentos-sociais-e-luta-por-creches-no-rio-de-janeiro-experiencia-das-creches>. Acesso em: 15 mai. 2017. 



\section{CAPÍTULO 7}

\section{AS POLÍTICAS PÚBLICAS VOLTADAS A EDUCAÇÃO DO CAMPO: olhares e concepções de licenciandos em Ciências da Natureza}

\section{Crisna Daniela Krause Bierhalz ${ }^{1}$ Eril Medeiros da Fonseca ${ }^{2}$ \\ Vitor Garcia Stoll ${ }^{3}$}

A formação inicial de professores vem sendo amplamente discutida nas últimas décadas, com a perspectiva de superar o modelo ancorado na racionalidade técnica e visão reducionista da realidade. Esse processo de formalização do conhecimento é desencadeado a partir de uma forma de estudo distante da realidade, do contexto, e da experiência, em que se priorizam conteúdos abstratos, ocorrendo consequentemente a separação entre sujeito e objeto de conhecimento (ARAUJO, 2014).

Nessa concepção instaurada nos anos 70, caracterizada de forma tecnicista e epistemologicamente positivista, o professor cumpre o papel de técnico e transmissor de conhecimentos (MONTEIRO, 2001). A relação vertical, de poder e autoridade do professor, se estabelece por sua condição de detentor do conhecimento, e ao educando cabe a condição de tabula rasa, sem voz e sem ação. Elementos condizentes com uma educação bancária, amplamente questionada nos estudos de Freire (2015).

\footnotetext{
${ }^{1}$ Licenciada em Pedagogia com Mestrado em Educação Ambiental (2007) e Doutorado em Educação (2012) pela PUC-RS - Pontifícia Universidade Católica do Rio Grande do Sul. É professora da Universidade Federal do Pampa UNIPAMPA, campus Dom Pedrito. E-mail: crisnabierhalz@unipampa.edu.br ${ }^{2}$ Licenciado em Ciências da Natureza (2016), mestrando pelo Programa de Pós-graduação em Ensino, ambos pela Universidade Federal do Pampa.. E-mail: erilmf@gmail.com

${ }^{3}$ Licenciado em Ciências da Natureza (2017) pela Universidade Federal do Pampa -campus Dom Pedrito. E-mail: vitorgarciastoll@gmail.com
} 
Por isso, discute-se uma formação de professores na perspectiva reflexiva, reflexão-na-ação e reflexão-sobre-a-ação (SCHÖN, 1998), na qual o professor torna-se pesquisador de sua prática (MALDANER, 1994), assumindo o "sentido ético, de juízo consciente de valor, de respeito às diferenças, de compromisso com a aprendizagem de todos e com a formação da cidadania" (HOFFMANN, 2001, p.18).

Imbernón (2011) ao discutir formação docente afirma a necessidade de ultrapassar a concepção de mera transmissão de conhecimentos acadêmicos, predominante no século XIX, e investir em uma educação plural, participativa, integradora, ou seja, uma formação cidadã comprometida com uma sociedade democrática.

Marcelo García (1999) defende a formação de professores como uma área de conhecimento, um encontro entre as pessoas em processo formativo, que pressupõe investigação, propostas teóricas/práticas e reflexão. Conceitua formação de professores como uma área que "estuda os processos através dos quais os professores - em formação ou em exercício - se implicam individualmente ou em equipe, em experiências de aprendizagem através das quais adquirem ou melhoram os seus conhecimentos, competências e disposições" (MARCELO GARCÍA, 1999, p. 26). Este mesmo autor afirma que os cursos de formação inicial de professores devem formar pessoas que consigam compreender a sua responsabilidade no desenvolvimento da escola e adquiram uma prática reflexiva.

Uma formação inicial reflexiva, de forma integral, perpassa também a discussão sobre diversos elementos por vezes não abordados nos cursos de licenciatura, como as modalidades de ensino, a saber: Educação Indígena, Educação de Jovens e Adultos (EJA), Educação do Campo, entre outras. Neste trabalho focalizamos as discussões em relação à Educação do Campo no âmbito da Universidade Federal do Pampa - Unipampa.

Na Unipampa, localizada na Região da Campanha 
do Rio Grande do Sul, estrutura em multicampia, são oferecidos 17 cursos de licenciaturas. Além da Licenciatura em Educação do Campo (Campus Dom Pedrito), curso específico para atuar na modalidade, apenas três possuem ementas com Componentes Curriculares que citam especificamente essa temática, são eles: Licenciatura em Música, Licenciatura em Química (Campus Bagé) e Licenciatura em Pedagogia (Campus Jaguarão), o que demarca a fragilidade e a necessidade de ampliar as discussões específicas sobre as modalidades de ensino e suas políticas nos cursos de licenciatura.

Neste sentido, essa modalidade demanda, enquanto desafio pedagógico, a criação de um "projeto educativo integral, coerente, que produza valores, convicções, visões de mundo, consciência organizativa, capacidade de ação, sentido pleno de ser humano" (MOLINA e SÁ, 2011, p.43). Exige uma ruptura com o paradigma dominante de ensino e pesquisa, quando se insere no debate eixos articuladores como a reforma agrária, agroecologia e soberania alimentar, ou seja, coloca a realidade dos sujeitos como "centro em torno do qual as ciências e outras formas de conhecimento se articulam, para que a realidade possa não apenas ser compreendida e analisada, mas também transformada" (MOLINA e SÁ, 2011, p.43).

Este silenciamento não se justifica e aos poucos vem sendo superado, pois a Educação no Brasil constitui-se pela luta de classes e pela conquista da oportunidade de estudos e escolarização de qualidade pelas minorias, reforçado na Lei de Diretrizes e Bases da Educação Nacional 9394/96, ao ressaltar que a educação se vincula aos processos formativos desenvolvidos na vida familiar, na convivência humana, no trabalho e nas instituições de ensino e pesquisa, e ainda nos movimentos sociais, organizações da sociedade civil e nas manifestações culturais. Reforçando que a Educação é dever da família e do Estado, visando à liberdade, os ideais da solidariedade humana, e tendo 
como finalidade o pleno desenvolvimento do educando, o preparo para o exercício da cidadania e a qualificação para o trabalho (BRASIL, 1996).

Um dos marcos de fortalecimento da Educação do Campo é o Programa de Apoio às Licenciaturas em Educação do Campo (PROCAMPO), vinculado à Secretaria de Educação Continuada, Alfabetização e Diversidade (Secadi), do Ministério da Educação, que apoiou a criação dos Cursos de Licenciatura em Educação do Campo no ano de 2007. Demarca um importante espaço formativo a nível superior, pois habilita profissionais em diferentes áreas do conhecimento para atuação nos anos finais do Ensino Fundamental e Médio, tendo como objeto de estudo as escolas do campo. Os cursos são ofertados em regime de alternância, com dois tempos de formação intercalados: tempo comunidade (TC) e tempo escola (TE). (MOLINA e SÁ, 2011).

A partir da experiência piloto em quatro universidades, a Licenciatura em Educação do Campo se ampliou em 2011, sendo que "trinta instituições universitárias aceitaram o desafio de ofertar o curso, com a preocupação em garantir um perfil de formação vinculado às lutas dos povos do campo" (MOLINA e SÁ, 2011, p.14).

A Educação do Campo, ao longo do tempo conquistou um espaço importante de discussão tanto como política pública como de ensino e pesquisa, mas fica a dúvida a respeito de como são tratadas as questões relacionadas à Educação do Campo nas demais Licenciaturas? São previstos em seus Projetos Pedagógicos de Curso componentes curriculares, obrigatórios ou optativos, que garantam ao futuro docente ter no mínimo noção das especificidades desta modalidade?

Com base nestas indagações, elegeu-se como lócus da investigação o Curso de Licenciatura em Ciências da Natureza (LCN) da Unipampa, mais especificamente como cenário o componente curricular obrigatório de Políti- 
cas Públicas, do quinto semestre, no qual investigamos as concepções dos licenciandos desse curso sobre as políticas públicas voltadas a Educação do Campo.

\section{A constituição da Educação do Campo}

A estrutura capitalista e a opressão a todas as formas de expressão dos indivíduos foram intensificadas durante o período de ditadura militar, compreendido comumente entre 1964 a 1985 (FICO, 2004). Esse período teve caráter autoritário e nacionalista, sob o comando de vários e sucessivos governos militares.

Barros (2007, p. 3) menciona que neste período as relações capitalistas de produção foram aceleradas no Brasil “tendo como características próprias e específicas a manutenção de relações pré-capitalistas no campo, que se transformam mais lentamente, e um caráter centralizador geograficamente", o que impediu a expansão do mercado interno e de relações entre diversas partes do país, justamente porque o poder estava monopolizado pelas indústrias.

A intervenção e expansão das atividades do Estado aumentaram o número de pessoas empregadas nas empresas estatais (BARROS, 2007), criando condições favoráveis para acumulação, "transferindo recursos e ganhos para a empresa industrial, e fazendo dela o centro do sistema" (OLIVEIRA, 1981, p.19).

Por volta de 1980 o Movimento dos Trabalhadores Sem-Terra (MST) ganhou força, tendo como um de seus principais objetivo a Educação, emergindo através destas lutas políticas públicas voltadas à Educação do Campo. Tal movimento ancorava-se na concepção de Educação Libertadora de Paulo Freire, entendida na época como uma forma de libertação, contrária ao conceito de Educação Bancária.

A Educação Bancária, conceituada por Paulo Freire, 
consiste na imposição do conhecimento por parte do professor ao aluno, pautado em uma relação vertical, em que a figura do professor sobrepõe-se a do estudante (LINS, 2011). A Educação Libertadora é aquela que vai contra a dominação, pois nesta consideram-se ações problematizadoras, mediadas pelo diálogo crítico, em uma relação horizontal, onde professor e aluno aprendem de forma igualitária (LINHARES, 2008).

Diante desse cenário de opressão, surgiu um movimento, com participação da maior parte da população, intitulado Diretas Já (por volta de 1983), que reivindicou eleições diretas para o cargo de Presidente da República e consequentemente o fim da ditadura, ganhando o apoio do Partido do Movimento Democrático Brasileiro (PMDB) e do Partido Democrático Social (PSD). Esse movimento, que tinha a cor amarela como símbolo, além de mobilizar o voto direto, já sinalizava possíveis mudanças tanto econômicas como sociais (BARROS, 2007).

Em 1988 foi aprovada a nova Constituição Federal, consolidando a luta da população por um país digno e democrático. Essa nova lei promulgava a soberania, a dignidade do ser humano, a cidadania, os valores do trabalho e o pluralismo político, tendo como objetivos: construir uma sociedade livre, justa e solidária, garantir o desenvolvimento nacional, erradicar pobreza, reduzir desigualdades e promover o bem de todos (BRASIL, 1988). São perceptíveis indícios de uma nova concepção de relações sociais, de desenvolvimento e da própria democracia.

Como forma de Estado tem-se a Federação, constituída pela União, Distrito Federal, Estados e municípios, e como forma de Governo, a República, seguindo a eletividade, temporalidade e responsabilidade, sabendo que os entes federados possuem uma união indissolúvel, porém são autônomos entre si.

Em relação à Educação, a Constituição Federal aborda em seu artigo 205 que esta é "direito de todos e dever do 
Estado e da família, sendo promovida e incentivada com a colaboração da sociedade, visando ao pleno desenvolvimento da pessoa, seu preparo para o exercício da cidadania e sua qualificação para o trabalho" (BRASIL, 1988).

Essa deliberação também mobilizou os sistemas de ensino, pois as escolas deveriam conduzir seus processos educativos com base no pluralismo de ideias, na liberdade de aprender, ensinar, pesquisar e divulgar, além de serem gratuitas. Sobre a educação em espaços rurais ainda se percebia um silenciamento, pois não havia uma atenção específica voltada às populações rurais.

Com a instauração em 1996 da Lei de Diretrizes e Bases da Educação Nacional, os espaços de formação das escolas rurais começam a ser valorizados, a partir do artigo 28, que reforça a urgência dos sistemas de ensino considerarem em suas propostas pedagógicas, bem como em sua organização didática-metodológica a realidade ou o contexto local, o que perpassa pela adequação do calendário letivo as condições climáticas da região e as fases do ciclo agrícola (BRASIL, 1996).

Até então, os povos destas localidades eram considerados como uma população "atrasada", na qual se tenta imprimir uma concepção de inferioridade, para justificar os baixos investimentos, inclusive em Educação, a exemplo de escolas precárias, qualidade das estradas e desvalorização dos professores e sua formação.

Tendo em vista a visão dicotômica entre campo e cidade (bom/ruim, moderno/atrasado, inferior/superior) e a relação de subordinação do rural ao urbano, Educação sustentada pela expansão do agronegócio, sobrepondo os interesses dos latifundiários a dos pequenos produtores assentados de reforma agrária e agricultores familiares, na oferta de uma escolarização aos povos do campo. Não obstante, salienta-se que o sistema militar brasileiro também favoreceu o processo de exclusão do direito à educação das classes trabalhadoras do campo, já que muitos 
conflitos envolvendo os mesmos ocorreram na época do Regime Militar (PRIEBBERNOW, 2015).

Na pretensão de contrapor essa ideia, se intensificou a luta por uma Educação no/do Campo, dando origem a realização do "I Encontro dos Educadores e Educadoras da Reforma Agrária (ENERA), ocorrido em 1997, em Luziânia/Goiás, tendo como articulador o MST. "Nesse Encontro foi possível a adesão de outros movimentos sociais, tais como Associação em Áreas de Assentamentos no Estado do Maranhão - ASSEMA e a Confederação Nacional dos Trabalhadores na Agricultura - CONTAG" (ROCHA, 2009, p. 3).

A partir desse encontro também surgiu o Programa Nacional de Educação na Reforma Agrária (PRONERA), com uma articulação interinstitucional entre Estado, universidades e movimentos sociais, buscando promover a educação em assentamentos de Reforma Agrária, criando e desenvolvendo projetos educacionais com metodologias específicas para o campo. O Programa começou com alfabetização e formação de educadores assentados, evoluindo para os anos finais do Ensino Fundamental e Médio, e logo se incorporou aos cursos técnicos profissionalizantes e superiores para trabalhadores rurais assentados (MOLINA e ANTUNES-ROCHA, 2014).

A primeira Conferência Nacional: Por uma Educação Básica do Campo, realizada em 1998, contribuiu para a consolidação do PROCAMPO, política de formação de educadores, com edital aprovado em 2006, conquistada através das demandas apresentadas ao Estado pelo Movimento da Educação do Campo. Como já mencionado a experiência piloto envolveu quatro universidades convidadas pelo Ministério da Educação, das quais: Universidade Federal de Minas Gerais; Universidade de Brasília; Universidade Federal da Bahia e Universidade Federal de Sergipe (MOLINA e ANTUNES-ROCHA, 2014). Isso também impulsionou uma política nacional de Educação do 
Campo, promovida pelo Programa Nacional de Educação do Campo (PRONACAMPO).

Tendo em vista a delineação da Educação do Campo, percebem-se que tanto na Constituição Federal, como nas demais Leis educacionais brasileiras houve, uma negação e ocultamento do direito à educação às populações do campo ou povos que integram o meio rural (ROCHA, 2009).

Essa negação acabou sendo reafirmada pelo disposto no Plano Nacional de Educação (PNE) 2001-2011, que considerava as populações do campo ainda como rurais em espaços rurais. No mesmo ano esses povos reivindicaram o reconhecimento pela denominação de campo e a necessidade de propostas pedagógicas vinculadas a sua realidade/diversidade, favorecidos pelo Parecer nº 36/2001 do Conselho Nacional de Educação (CNE).

A efetivação desses aspectos deve ser viabilizada pelo poder público, no intuito de garantir a todas as populações do campo o acesso à educação. Neste sentido, as Diretrizes Operacionais para a Educação Básica nas Escolas do Campo constituem-se como uma conquista dos direitos dos povos do campo a terem uma educação digna e coerente com a sua realidade, considerando a sua cultura local.

Tem como base os saberes próprios dos estudantes relacionados à temporalidade, e também a "memória coletiva que sinaliza futuros, na rede de ciência e tecnologia disponível na sociedade e nos movimentos sociais em defesa de projetos que associem as soluções exigidas por essas questões à qualidade social da vida coletiva no país" (BRASIL, 2002, p. 1).

Educação do Campo aqui caracterizada como uma educação destinada ao conjunto de trabalhadores do campo, compreendendo vários processos educativos que formam sujeitos autônomos, críticos, capazes de compreender seus deveres e lutar por seus direitos. É definida por 
Caldart (2012, p. 263) como uma prática social ainda em processo de constituição histórica, que "combina luta pela educação com luta pela terra, pela Reforma Agrária, pelo direito ao trabalho, a cultura, território e soberania alimentar".

Ao longo do tempo, percebe-se várias políticas públicas que corroboraram para consolidar a Educação do Campo enquanto espaço democrático por educação e manifestação cultural, a exemplo do PRONERA, Diretrizes operacionais para a Educação Básica nas Escolas do Campo e PROCAMPO.

A materialização de tais políticas contribuiu para a aprovação do PRONACAMPO, pelo Decreto no 7.352/2010, que promoveu um conjunto de ações articuladas para assegurar a melhoria do ensino nas redes existentes, bem como, a formação dos professores, produção de material didático específico, acesso e recuperação da infraestrutura e qualidade da educação no campo em todas as etapas e modalidades.

Identificam-se vários movimentos, na legislação educacional brasileira, que contribuem para pensar e Educação do Campo não apenas como uma modalidade de ensino, mas uma possibilidade de articular saberes populares, lutas de direitos e deveres e promoção de espaços democráticos para emancipação.

Reforçando as políticas anteriormente mencionadas o PNE 2014-2024 dentre suas metas e estratégias também traz algumas orientações descritas pela necessidade de atender as especificidades das populações do campo, como equidade educacional e diversidade cultural, além da formação de professores para essas comunidades, produção de materiais didáticos específicos, transporte e a articulação entre ambiente escolar e comunidades.

Mesmo com algumas conquistas diante a legislação educacional brasileira, percebe-se com o tempo uma negação e/ou ocultamento do direito à educação às populações 
do campo ou povos que integram o meio rural (ROCHA, 2009), reforçando a importância da luta constante em prol de uma educação de qualidade.

\section{Caminho metodológico}

Metodologicamente essa pesquisa possui natureza qualitativa, alicerçada em aspectos da realidade que não podem ser quantificados, ou seja, trabalha com um universo de crenças, motivações, valores e demais singularidades que não se restringem à operacionalização de variáveis (MINAYO, 2001).

Em relação aos objetivos, classifica-se como explicativa, pois discute as compreensões dos licenciandos em Ciências da Natureza sobre as políticas voltadas a Educação do Campo. Para Gil (2002), esse tipo de pesquisa é que mais se assemelha com a realidade, uma vez que, busca explicar a razão de determinado fenômeno, o porquê das coisas.

Quanto aos procedimentos técnicos caracteriza-se como um estudo de caso, que tem como propósito: explorar situações da vida real, preservar o caráter do objeto estudado, descrever situações do que está sendo investigado, formular hipóteses ou teorias e explicar as causas de determinado fenômeno (GIL, 2002).

Os dados utilizados neste estudo foram obtidos através de um questionário semiestruturado aplicado, no mês de junho de 2017, aos licenciandos do quinto semestre do curso de LCN no componente curricular de Políticas Públicas, totalizando 20 sujeitos. A análise dos resultados foi embasada na Análise de Conteúdo de Bardin (2009), organizada em três etapas: (I) pré-análise, (II) exploração do material e (III) tratamento dos resultados e interpretação.

Na pré-análise realizou-se a organização do material para torná-lo operacional. Para tanto, foi feita a leitura flutuante dos questionários com o intuito de compor uma 
sistematização de ideias e elaborar um plano de análise.

$\mathrm{Na}$ etapa da exploração do material, foi feita a codificação dos dados e criadas quatro categorias de análise, conforme quadro 1.

\section{Quadro 1 - Categorias elencadas para análise dos resultados}

\begin{tabular}{|c|c|c|}
\hline Categoria & O que descreve? & Perguntas analisadas \\
\hline \multirow{3}{*}{$\begin{array}{l}\text { Relação dos licenciados } \\
\text { com o contexto do campo }\end{array}$} & \multirow{3}{*}{$\begin{array}{l}\text { Pertencimento dos } \\
\text { licenciados com a } \\
\text { realidade do campo }\end{array}$} & Estudou em uma escola do campo? \\
\hline & & Conhece uma escola do campo? \\
\hline & & $\begin{array}{l}\text { Possui algum familiar ou amigo que } \\
\text { estuda/estudou na escola do campo? }\end{array}$ \\
\hline \multirow{4}{*}{$\begin{array}{l}\text { Formação } \\
\text { pedagógica }\end{array}$} & \multirow{4}{*}{$\begin{array}{l}\text { Em quais componentes } \\
\text { curriculares da LCN é } \\
\text { abordada a modalidade } \\
\text { da Educação do Campo. } \\
\text { Nessa categoria analisou-se } \\
\text { também o PPC do curso. }\end{array}$} & $\begin{array}{c}\text { Estudou alguma compomente } \\
\text { curricular que abordou educação do } \\
\text { Campo antes de Políticas Públicas? }\end{array}$ \\
\hline & & $\begin{array}{l}\text { Acredita que no curso de LCN } \\
\text { deveria ter um componente } \\
\text { curricular obrigatório sobre } \\
\text { Educação do Campo? }\end{array}$ \\
\hline & & $\begin{array}{l}\text { Acredita que no curso de LCN } \\
\text { deveria ter um componente } \\
\text { curricular optativo sobre } \\
\text { Educação do Campo? }\end{array}$ \\
\hline & & $\begin{array}{l}\text { Tem interesse em cursas algum } \\
\text { componente curricular na Licen- } \\
\text { ciatura em Educação do Campo? }\end{array}$ \\
\hline \multirow{2}{*}{ Atuação Docente } & \multirow{2}{*}{$\begin{array}{c}\text { Interesse dos educandos } \\
\text { em atuar na docência, em } \\
\text { especial na escola do campo. }\end{array}$} & $\begin{array}{l}\text { Tem a intenção de ser } \\
\text { professor de Ciência? }\end{array}$ \\
\hline & & $\begin{array}{l}\text { Tem a intenção de ser professor } \\
\text { de Ciências na escola do campo? }\end{array}$ \\
\hline \multirow{3}{*}{$\begin{array}{l}\text { Concepções sobre } \\
\text { Políticas do campo }\end{array}$} & \multirow{3}{*}{$\begin{array}{l}\text { Compreensão dos } \\
\text { licenciandos sobre as } \\
\text { políticas públicas voltadas } \\
\text { para a Educação Campo. }\end{array}$} & Conhece o PRONACAMPO? \\
\hline & & Conhece o PROCAMPO? \\
\hline & & Conhece o PRONERA? \\
\hline
\end{tabular}

Fonte: Autores (2017)

Na última etapa desenvolveu-se o tratamento das informações através dos resultados obtidos e a interpretação dos dados. 
Universidade Federal do Pampa e a Licenciatura em Ciências da Natureza

A Universidade Federal do Pampa - Unipampa surgiu de uma reivindicação da comunidade da região da Campanha, Rio Grande do Sul, mobilizada pelo movimento político de expansão das instituições federais de Ensino Superior, promovida pelo Governo Federal, no ano de 2008. É organizada em uma estrutura multicampi, com um total de 10 (dez) campi, nos municípios de Jaguarão, Caçapava do Sul, Bagé, Alegrete, Itaqui, São Borja, Santana do Livramento, São Gabriel, Uruguaiana e Dom Pedrito, como se observa na figura 1. (FONSECA e BIERHALZ, 2016).

\section{Figura 1 - Localização dos municípios que compõem a Unipampa}

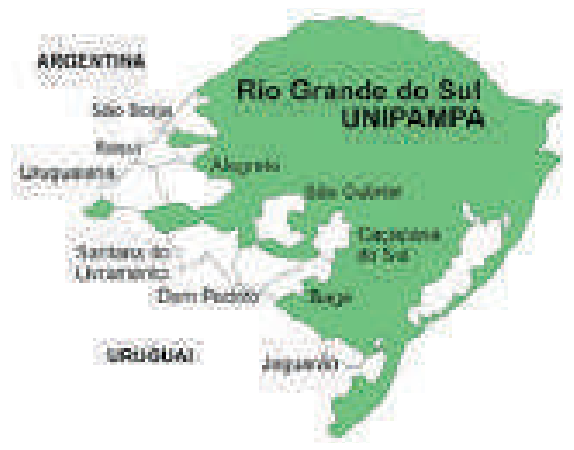

Fonte: http://porteiras.r.unipampa.edu.br/portais/cap/nos/

No Campus Dom Pedrito funcionam cinco cursos de graduação: Bacharelado em Enologia, Zootecnia, Tecnologia em Agronegócio, Licenciatura em Educação do Campo e Licenciatura em Ciências da Natureza (LCN), sendo este último foco deste estudo.

A LCN forma professores de Ciências da Natureza, habilitados a lecionar nos anos finais do Ensino Funda- 
mental e no Ensino Médio (UNIPAMPA, 2015). Espera que o futuro docente seja capaz de compreender a realidade social, na qual se insere a escola, atuando com dinamismo diante das rápidas transformações da sociedade, bem como de forma interdisciplinar estabeleça interconexões entre as áreas do conhecimento e entre os diferentes saberes, despertando nos educandos a curiosidade científica e a reflexão sobre as questões da sociedade e natureza (UNIPAMPA, 2015).

Em relação à organização curricular, estrutura-se em quatro eixos temáticos: (1) Formação Pedagógica, (2) Tecnologias e Desenvolvimento Sustentável, (3) Universo e (4) Vida na Terra, conforme figura 2.

Figura 2 - Diagrama da Matriz Curricular Integrativa

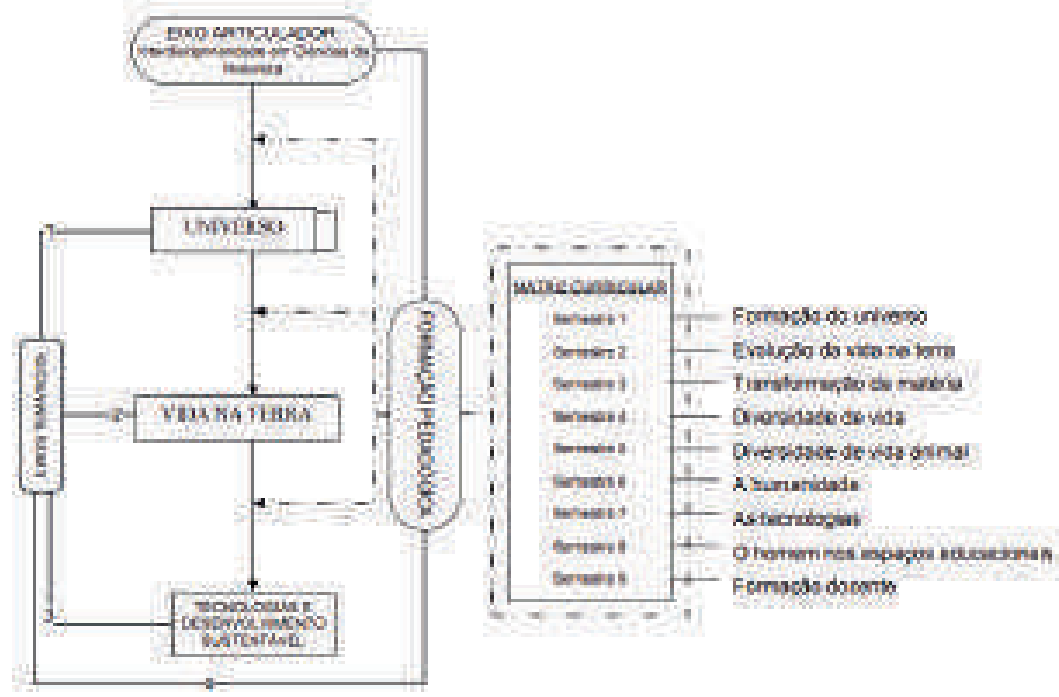

Fonte: Projeto Pedagógico de Curso (UNIPAMPA, 2015)

O curso está organizado em nove semestres, com 52 componentes curriculares obrigatórios que totalizam uma carga horária de 2430 horas. Em dez (10) componentes são percebidas possibilidades de discussão das questões 
relacionadas à Educação do campo, a exemplo: Práticas Pedagógicas: Educação em Ciências, cuja ementa prevê a análise do Ensino de Ciências na comunidade, na perspectiva de uma construção da área que influência no contexto atual da Educação Básica. Não há a especificação de que esta análise seja em uma escola urbana, portanto presume-se a abertura.

No componente curricular de Políticas Públicas três tópicos da ementa contemplam a discussão sobre Educação do Campo, são eles: Estado e suas relações com as políticas públicas e políticas educacionais; Organização dos sistemas educacionais brasileiros e Legislação Educacional. (UNIPAMPA, 2015).

Também não se evidencia nos componentes de Estágio Supervisionado nenhum impedimento do desenvolvimento da regência em uma escola do Campo.

Através da análise das ementas do Projeto Pedagógico do Curso (UNIPAMPA, 2015) não foi possível identificar nenhuma menção direta a Educação do Campo, porém não é possível afirmar que não sejam contempladas pelos docentes, como exemplificado acima, alguns tópicos são abertos.

Cabe a reflexão sobre o que justifica o silenciamento sobre as modalidades educativas que tratam de minorias historicamente excluídas. Nesse sentido Brito (2011, p.166) questiona sobre as razões, em um "cenário contemporâneo, da exclusão ao acesso aos bens produzidos da maioria das crianças e jovens do campo e da cidade; das instituições educativas ainda ensinarem conteúdos marcados por uma visão eurocêntrica, centrada em homens, heterossexuais, brancos e bem sucedidos". E reforça sobre a urgência destas discussões principalmente nos cursos de formação de professores.

O desafio de por o saber científico ao alcance de um público escolar em escala sem precedentes - público representado, pela primeira vez em nossa história, por todos os segmentos 
sociais e com a maioria expressiva oriunda das classes e culturas que até então não frequentava, a escola, salvo exceções - não pode ser enfrentado com as mesmas práticas docentes das décadas anteriores ou da escola de poucos para poucos (DELIZOICOV; ANGOTTI e PERNAMBUCO, 2002, p. 33).

Britto (2011) reforça a importância dos formadores dos futuros educadores construírem em conjunto um projeto formativo que supere a compreensão generalista, com predomínio de uma visão única e fragmentada de conhecimento, pensamento, verdade e ciência, permitindo ao futuro educador uma formação globalizada e articulada dos conhecimentos.

\section{Relação dos Licenciandos com o contexto do campo}

Ao serem questionados a respeito de terem estudado no campo durante sua trajetória estudantil, dos vinte (20) licenciandos, a maioria, quinze (15) respondeu que não estudou em uma escola do campo, dois (02) acadêmicos estudaram em escola do campo e três (03) não responderam.

Contudo, treze (13) sujeitos mencionaram conhecer uma escola do campo, sendo sete (07) deles por terem amigos ou familiares que estudam ou já estudaram, e em decorrência desta proximidade acabam frequentando-a em momentos festivos ou reuniões. $\mathrm{O}$ fato de seis (06) acadêmicos não conhecerem e nem se quer ter ideia do funcionamento de uma escola do campo causa estranheza, principalmente em decorrência da rede de ensino municipal ser composta em sua maioria por escolas do campo. Também pelas características econômicas da cidade, que tem a economia agrícola, com forte destaque para o cultivo do arroz.

Percebe-se que a menção dos licenciandos em relação a escola do campo é relacionada a experiências que já tiveram ou pelo contato que amigos ou familiares possuem 
com estas e não está relacionada às oportunidades formativas vivenciadas na Licenciatura, pois quando pensamos a Educação do Campo como uma modalidade de educação, assim como a EJA, Educação Especial entre outros, acredita-se que esteja contemplada nas discussões de um curso de licenciatura por descreverem um cenário pertinente tanto de atuação dos licenciandos como da própria formação integral destes.

Convém destacar que a questão do desconhecimento da realidade da educação do campo pelos licenciandos influencia na capacidade de decidirem em relação a possibilidades formativas sobre o tema. A grande parte não possui um vínculo direto com o contexto do campo, o que contribui para não considerarem o estudo do mesmo pertinente para a própria formação.

\section{Formação Pedagógica}

Percebe-se um silenciamento a respeito da Educação do Campo na LCN, visto que dezessete (17) licenciandos responderam que não cursaram componentes curriculares que abordassem a modalidade de Educação do Campo, além de Políticas Públicas.

Tais resultados podem estar vinculados ao fato do Projeto Pedagógico de Curso (PPC) (UNIPAMPA, 2015) não possuir nenhum componente curricular que aborde especificamente as questões voltadas para Educação do Campo. Constata-se uma dicotomia entre os componentes ofertados no PPC e a realidade do município, pois no próprio documento são exaltados os índices de êxodo rural da região da Campanha e de Dom Pedrito, destacando como possíveis motivos: o tipo de economia, a falta de infraestrutura das estradas e os problemas relacionados à sucessão familiar.

Além desses aspectos, o PPC também menciona que no ano de 2012, data de sua aprovação, o município pos- 
suía trinta e sete (37) escolas municipais, sendo vinte e três (23) na zona rural, funcionando de forma multisseriada. Elementos da realidade local que por si só justificam a necessidade de permearem os componentes curriculares, pois é bem provável que os licenciandos desenvolverão atividades nestas escolas durante as 400 horas de práticas pedagógicas ou durante as 400 horas de estágio supervisionado.

Contudo, ao serem indagados se o curso de LCN deveria ter um componente obrigatório sobre Educação do Campo, sete (07) licenciandos responderam que sim, seis (06) acreditam que não, três (03) nunca pensaram a respeito e quatro (04) são indiferentes a essa proposição, resultados que são apresentados no gráfico 1.

Gráfico 1 - Quantitativo de licenciandos interessados em disciplina obrigatória sobre Educação do Campo
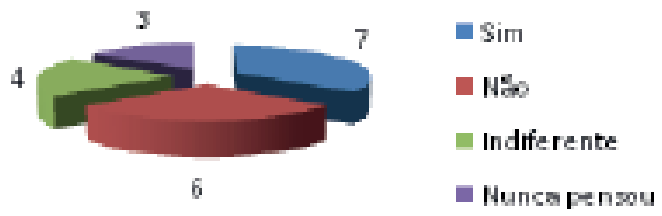

Fonte: Autores (2017)

As respostas podem ser analisadas a partir de dois aspectos: o primeiro já mencionado, a falta de relação e de conhecimento sobre o campo, o que subsidia a decisão de não acreditar na importância desses assuntos durante a sua formação e acarretar mais tarde ao assumirem a docência em uma escola do campo, a docência em uma escola do campo em um ensino urbanocêntrico.

O segundo apoiado na distância entre teoria e prática há tanto discutida nos cursos de formação de professores. Diniz Pereira (2006) menciona a dicotomia existente entre 
os componentes pedagógicos e os específicos da licenciatura e rememora o documento final do Encontro Nacional de Reformulação dos Cursos de Formação de Educadores, em 1983, que sugeria o trabalho conjunto entre professores responsáveis pela formação pedagógica e pela área específica nas licenciaturas.

O autor ainda ressalta o importante papel integrador que os componentes curriculares de prática de ensino e instrumentação em ensino possuem, porém critica o fato de estarem, geralmente, ao final dos cursos. Assim, essas questões contribuem para gerar dúvidas e incertezas, que são reforçadas por dificuldades de proposição e implementação nos cursos (DINIZ PEREIRA, 2006), que poderiam ser amenizados se os próprios licenciandos participassem de um processo de pesquisa e intervenção sobre tais problemáticas, constituindo um movimento de ação-reflexão-ação. Essa discussão é reforçada no pensamento de Mello (2000, p. 3):

Ninguém facilita o desenvolvimento daquilo que não teve oportunidade de aprimorar em si mesmo. Ninguém promove a aprendizagem de conteúdos que não domina, a constituição de significados que não compreende nem a autonomia que não pô de construir. É imprescindível que o professor que se prepara para lecionar na educação básica demonstre que desenvolveu ou tenha oportunidade de desenvolver, de modo sólido e pleno, as competências previstas para os egressos da educação básica.

Quando são questionados se o curso deveria ofertar um componente curricular optativo o resultado se altera e a maioria dos discentes concorda com esta alternativa, demonstrada no gráfico a seguir. 
Gráfico 2 - Quantitativo de licenciandos interessados em componente curricular optativo sobre Educação do Campo

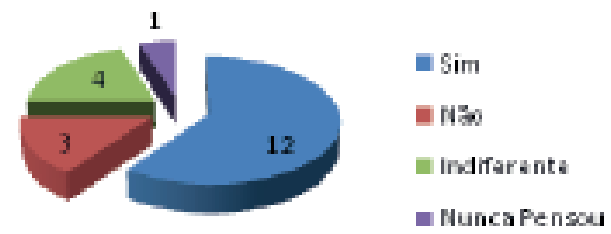

Fonte: Autores (2017)

Já quando questionados se cursariam componentes na Licenciatura em Educação do Campo, apenas oito (08) licenciandos afirmaram que sim, em contrapartida três (03) responderam que não fariam e nove (09) que são indiferentes a proposição.

As Licenciaturas em Educação do Campo são possibilidades de provocar o debate sobre as transformações na escola, a partir de "outros objetivos formativos e do acúmulo de discussão pedagógica e das matrizes de tradição emancipatória" (CALDART, 2011, p.100). Esta mesma autora ressalta que o encontro entre a Educação do Campo e uma licenciatura terá resistência e tensões ocasionadas por dois principais motivos. Primeiro porque o formato legal dos cursos existentes expressa uma concepção de formação de educadores e de escola que diverge dos debates originários da Educação do Campo, e segundo porque os sujeitos envolvidos: movimentos sociais, governos e universidades possuem dinâmicas próprias de atuação.

A partir do descrito por Caldart (2011) é possível compreender o total distanciamento entre os dois cursos de Licenciatura da Unipampa - Campus Dom Pedrito - e percebe-se a necessidade de ampliar as discussões formativas em relação às políticas públicas entre os professores 
universitários.

\section{Atuação Docente}

Quando questionados se intencionam ser professores de Ciências percebe-se que quase a totalidade tem este desejo e esta intenção. Já sobre ser professor de Ciências no campo, percebe-se que a maioria (15) não pretende exercer a docência em uma escola do campo, conforme o gráfico 3.

Gráfico 03 - Quantitativo de licenciandos interessados na docência em Ciências e em Ciências na Educação do Campo



Fonte: Autores (2017)

Ao mesmo tempo em que as respostas sobre a intenção de ser professor de Ciências no campo, são interessantes, já que acreditamos que é necessária uma formação voltada para o campo, causa preocupação, pois em muitos casos estes são os professores que vão trabalhar nas escolas do campo sem o menor embasamento teórico e vivência prática.

Ao mencionarem os saberes necessários à atividade docente, Silva e Bastos (2012) ressaltam que os professo- 
res necessitam, inicialmente, saber problematizar as situações de ensino, para que estejam, de fato, preparados para exercerem sua tarefa de articular os conhecimentos a serem ensinados aos estudantes em cada contexto, considerando o local, a faixa etária, os interesses e as necessidades identificadas.

Pimenta e Lima (2008) reforçam que se espera dos professores a construção de seus saberes e fazeres a partir das necessidades e desafios que o ensino como prática social impõe no cotidiano. Pimenta (2009, p. 45) afirma que o professor deve compreender que (...) “toda prática social é determinada por um jogo de forças: interesses, motivações, intencionalidades; pelo grau de consciência de seus atores; pela visão de mundo que os orienta; pelo contexto onde esta prática se dá; pelas necessidades e possibilidades próprias à realidade em que se situam".

\section{Concepções sobre Políticas Públicas do Campo}

A maior parte dos licenciandos demonstrou não conhecer nenhuma política pública voltada para a Educação do Campo (18), da mesma forma em que mencionaram também não conhecer o PRONACAMPO (18).

Segundo o decreto $\mathrm{n}^{\mathrm{0}} 7.352$, de 4 de novembro de 2010, o PRONACAMPO caracteriza-se por um conjunto de ações articuladas, visando melhorias do ensino sobre formação de professores, produção de material didático específico para a realidade do campo, acesso e recuperação da infraestrutura do ensino voltado para o campo, em todas as modalidades e etapas. Está estruturado em quatro eixos: Gestão e Práticas Pedagógicas; Formação Inicial e Continuada de Professores; Educação de Jovens e Adultos e Educação Profissional; Infraestrutura Física e Tecnológica (BRASIL, 2013).

De forma análoga dois (02) discentes mencionaram conhecer o PROCAMPO e dezoito (18) não o conheciam. 
O PROCAMPO, aprovado em 2006, contribuiu para pensar, de forma mais significativa, a formação de professores para a realidade do campo, em instituições públicas de ensino superior no país, por áreas de conhecimento, a partir das demandas dos movimentos sociais, visando à formação inicial de professores para a docência na Educação Básica em escolas do campo e para atuação nos anos finais do Ensino Fundamental e no Ensino Médio (BRASIL. 2006).

É importante destacar este dado pois na Unipampa - Campus Dom Pedrito - há um Curso de Educação do Campo, com ênfase em Ciências da Natureza, vinculado a Secadi, e os discentes parecem não conhecer o contexto da universidade.

Em relação ao PRONERA, dezenove (19) sujeitos mencionaram não conhecer o programa e um afirmou não saber. O PRONERA é caracterizado como uma articulação interinstitucional entre Estado, universidades e movimentos sociais, buscando promover a educação em assentamentos de Reforma Agrária, criando e desenvolvendo projetos educacionais com metodologias específicas para o campo. As Diretrizes Operacionais para a Educação Básica nas Escolas do Campo, em 2002, demonstraram uma conquista dos direitos dos povos do campo a terem e pertencerem ao lugar de onde lhes é de direito e ter neste espaço a oportunidade de uma educação digna e coerente com a sua realidade (BRASIL, 2002).

\section{Considerações Finais}

Este estudo investigou as concepções dos licenciandos de um curso de licenciatura em Ciências da Natureza sobre as políticas públicas voltadas a Educação do Campo, os resultados evidenciaram entre os futuros docentes, desconhecimento em relação a diretrizes e/ou normativas que orientam a prática docente no campo, a exemplo do 


\section{PROCAMPO, PRONACAMPO e PRONERA.}

Além disso, identificou-se um ocultamento sobre o contexto do campo e as escolas que fazem parte desta realidade, visto que no município de Dom Pedrito as escolas do campo constituem maior parte do sistema municipal de ensino. Da mesma forma, os licenciandos consideram interessante o estudo sobre o contexto do campo apenas como um componente curricular optativo, não demonstrando interesse em atuar, em Ciências, em escolas do campo, visto que demandaria um embasamento teórico maior, que a estrutura do curso não possibilita ou por preconceito.

Percebeu-se também um distanciamento entre os dois cursos de licenciatura da Unipampa - Campus Dom Pedrito, pois mesmo tendo o contexto diferenciado, possuem a mesma área de atuação como foco, o que poderia possibilitar um enriquecimento nas discussões das matrizes curriculares e consequentemente na formação dos discentes.

Assim sendo, aponta-se para a relevância de se (re) pensar a estrutura curricular dos cursos de licenciatura no sentido de contemplar os estudos e aprofundamentos sobre todas as modalidades de ensino e políticas públicas relevantes para o campo de formação de professores, de modo que contribuam de forma integral para a prática docente.

\section{REFERÊNCIAS}

ARAÚJO, U. F. Temas transversais, pedagogia de projetos e mudanças na educação. 1. ed. São Paulo: Summus Editorial, 2014.

BARROS, C. M. Ensino superior e sociedade brasileira: análise histórica e sociológica dos determinantes da expansão do ensino superior no Brasil (décadas de 1960/70). Dissertação (Mestrado em Educação). Faculdade de Educação e Letras da Universidade Metodologia de São Paulo, São Bernardo do 
Campo, 2007.

BARDIN, L. Análise de Conteúdo. Lisboa, Portugal; Edições 70, LDA, 2009.

BRITTO, N. S. Formação de Professores e professoras em Educação do Campo por área de conhecimento - Ciências da Natureza e Matemática. In: MOLINA, M. C.; SÁ. L. M. (orgs). Licenciaturas em Educação do Campo: Registros e Reflexões a partir das experiências piloto. Belo Horizonte: Autêntica Editora, 2011.

BRASIL. Constituição da República Federativa do Brasil. 1988.

. Ministério de Educação e Cultura. LDB - Lei no 9394/96, de 20 de dezembro de 1996. Estabelece as diretrizes e bases da Educação Nacional. Brasília: MEC, 1996.

. Ministério da Educação. Diretrizes Operacionais para a educação básica nas escolas do campo. Brasília, 2002.

. Ministério da Educação - MEC. Programa de Apoio à Formação Superior em Licenciatura em Educação do Campo - PROCAMPO. Brasília, 2006. Disponível em: <https://goo.gl/ f1UMcx>. Acesso em: 10 nov. 2017.

Ministério da Educação. Programa Nacional de Educação do Campo PRONACAMPO: Documento orientador. Brasília, 2013.

CALDART, R. S. Licenciatura em Educação do Campo e projeto formativo: qual o lugar da docência por área. In: MOLINA, M. C.; SÁ. L. M. (orgs). Licenciaturas em Educação do Campo: Registros e Reflexões a partir das experiências piloto. Belo Horizonte: Autêntica Editora, 2011.

. Educação do Campo. In: CALDART, R.; PEREIRA, I. B.; ALETEJANO, P.; FRIGOTTO, G. (Orgs.). Dicionário de Educação do Campo. Rio de Janeiro, São Paulo: Escola Politécnica de Saúde Joaquim Venâncio, Expressão Popular, 2012.

DELIZOICOV, D; ANGOTTI, J. A.; PERNAMBUCO, M. M. 
(Orgs). Desafios para o Ensino de Ciências. In: Ensino de Ciências: Fundamentos e Métodos. São Paulo: Cortez, 2002.

DINIZ-PEREIRA, J. E. Formação de professores nas licenciaturas: velhos problemas, novas questões. In: . Formação de professores: pesquisas, representações e poder. 2 . ed. Belo Horizonte: Autêntica, 2006.

FICO, C. Versões e controvérsias sobre 1964 e a ditadura militar. Revista Brasileira de História. São Paulo, v. 24, n. 47, p.29-60, 2004.

FONSECA, E. M.; BIERHALZ, C. D. K. Discutindo articulações entre ensino de Ciências e Educação do Campo através da análise dos cadernos. Revista Brasileira de Educação do Campo, Tocantinópolis, v. 1, n. 2, p. 255-278, 2016.

FREIRE, P. Pedagogia do oprimido. 51. ed. Rio de Janeiro: Paz e Terra, 2015.

GIL, A. C. Como elaborar projetos de pesquisa. 4. ed. São Paulo: Atlas, 2002.

HOFFMANN, J. Avaliar para promover: As setas do caminho. Porto Alegre: Mediação, 2001.

IMBERNÓN, F. Formação docente e profissional: formar-se para a mudança e incerteza. São Paulo: Cortez, 2011.

LINHARES, L. L. Paulo Freire: Por uma Educação libertadora e humanista. In: CONGRESSO NACIONAL DE EDUCAÇÃO, 2008, Curitiba. Anais... Curitiba: Champagnat, 2008. 1 CD-ROM.

LINS, M. J. S. da C. Educação Bancária: uma questão filosófica de aprendizagem. Revista Educação e Cultura Contemporânea, v. 8, n. 16, 2011.

MALDANER, O. A. A formação de grupos de professores pesquisadores como fator de melhoria da qualidade educacional. In: VII ENDIPE, 1994, Goiânia. Anais... Goiânia: UFG, 1994. 
MARCELO GARCIA, C. Formação de professores: Para uma mudança educativa. Porto: Porto Editora, 1999.

MELLO, G. N. de. Formação inicial de professores para a Educação Básica: uma revisão radical. São Paulo em Perspectiva, v. 14, n. 1, 2000.

MINAYO, M. C. de S. (Org.). Pesquisa Social. Teoria, método e criatividade. 18. ed. Petrópolis: Vozes, 2001.

MOLINA, M. C.; ANTUNES-ROCHA, M. I. Revista Reflexão e Ação, Santa Cruz do Sul, v. 22, n. 2, 220-253, jul./dez.2014.

MOLINA, M. C.;; SÁ. L. M. (Orgs). Licenciaturas em Educação do Campo: Registros e Reflexões a partir das experiências piloto. Belo Horizonte: Autêntica Editora, 2011.

MONTEIRO, A. M. F.da C. Professores: entre saberes e práticas. In: Educação \& Sociedade. ano XXII. n. 74. Abril/2001. Disponível em <http://www.scielo.br/pdf/es/v22n74/ a08v2274>. Acesso em: 10 nov. 2017.

PIMENTA, S. G. Saberes Pedagógicos e atividade docente. São Paulo: Cortez, 2009.

PIMENTA, S. G..; LIMA, M. S. L. Estágio e docência. 2. ed. São Paulo: Cortez, 2008.

OLIVEIRA. F. de. A economia brasileira: crítica à razão dualista. 4. ed. Petrópolis: Vozes, 1981.

PRIEBBERNOW, H. M. Perspectivas da juventude rural: um estudo a partir da Escola Municipal de Ensino Fundamental Heitor Soares Ribeiro - Canguçu/RS. 95f. Trabalho de Conclusão de Curso. Instituto de Ciências Humanas da Universidade Federal de Pelotas, 2015.

ROCHA, H. O. Da educação rural à educação do campo: as "velhas" lutas políticas como espaço de emergência de novos conceitos. In: Atas do I Seminário Nacional de Sociologia e Política - UFPR, 2009.

SCHÖN, D. A. La formación de profesionales de losprofesores. In: Série Fundamentos. n. 9, ed. 1. Sevilla: Díada, 1998. 
SILVA, V. F.; BASTOS, F. Formação de Professores de Ciências: reflexões sobre a formação continuada. ALEXANDRIA Revista de Educação em Ciência e Tecnologia, v. 5, n. 2, p. 150-188, 2012.

UNIVERSIDADE FEDERAL DO PAMPA. Campus Dom Pedrito. Projeto Político Pedagógico (PPC) do Curso de Licenciatura em Ciências da Natureza, 2015. Disponível em: <https:// goo.gl/2VtA2N>. Acesso em: 10 nov. 2017. 


\title{
PERSPECTIVAS PARA O ENSINO DE ARTES VISUAIS NO CONTEXTO DA EDUCAÇÃO DO CAMPO BRASILEIRA*
}

\author{
Milena Guerson ${ }^{1}$ \\ Hertha Silva ${ }^{2}$ \\ Daniela Schneider ${ }^{3}$
}

A trajetória do Ensino de Arte $^{4}$ no Brasil do Modernismo ao Pós-modernismo remonta à passagem de uma perspectiva pedagógica de livre-expressão para uma tendência mais crítica no ensino/aprendizagem da Arte. Conforme Barbosa (2003), a década de 1930 representa uma etapa de abertura modernista no contexto do Ensino de Arte, quando há o surgimento gradativo de cursos e escolas especializadas em Arte como atividade extracurricular para crianças e adolescentes. Anita Malfatti é um dos nomes que se destaca no empreendimento desses cursos, lançando mão de um ensino baseado na livre-expressão.

\footnotetext{
*As autoras são docentes na área das Artes Visuais e seu ensino na Universidade Federal do Tocantins, no Curso de Educação do Campo/ Linguagens e Códigos/ Artes Visuais e Música. Integram o Grupo de Estudos e Pesquisas em Educação do Campo - GEPEC/UFT-Arraias.

${ }^{1}$ Graduada em Artes Plásticas e em Psicologia, Especialista em Ensino de Artes Visuais, Mestra em Estudos Literários e Mestra em Artes, Cultura e Linguagens, com formações realizadas na UFJF e na UFMG. Desenvolve atividades de ensino, pesquisa e extensão nas áreas de Ensino de Arte e Processos de Criação. E-mail: milenaguerson@uft.edu.br

${ }^{2}$ Licenciada em Artes Visuais, Especialista em História Cultural e Mestra em Comunicação, com ênfase em Mídias e Cultura pela UFG. Desenvolve pesquisas buscando conversações entre os campos da Comunicação e das Artes Visuais. E-mail: hertha@uft.edu.br

${ }^{3}$ Licenciada em Artes Visuais, Especialista, Mestre e Doutoranda em Educação pela UFPel. Desenvolve pesquisas na área de Ensino de Arte, com ênfase em formação estética. E-mail: daniela.schneider@uft.edu.br

${ }^{4}$ Sempre que a expressão Ensino de Arte for grafada com maiúsculas, estaremos nos referindo a esta área ou campo de conhecimento específico, como uma variação da comum designação Arte-Educação.
} 
Mário de Andrade, igualmente interessado no caráter espontâneo da expressividade artística infantil, coloca em analogia o desenho da criança e a arte primitiva, como parte da fundamentação do curso de Filosofia e História da Arte que então ministrava na Universidade do Distrito Federal ${ }^{5}$.

Esses fatos indicam que na década de 1930 estavam em voga reflexões em busca da especificidade da Arte. O próprio Anísio Teixeira, ao interpretar o pensamento de John Dewey no contexto da Escola Nova, destacava que a Arte possuía uma instrumentalidade fundamentada no estético, ou seja, a existência de um conteúdo e de uma função em si deveriam orientar as práticas pedagógicas desta disciplina específica. Contudo, na passagem da teoria à prática, as ideias propostas por Anísio Teixeira acabaram sendo interpretadas de maneira equivocada pelos educadores. A Arte é entendida como "exercício de fixação" nos contextos educacionais da década de 30, havendo um esvaziamento de seu potencial estético e de seu entendimento enquanto conteúdo. Colocava-se em jogo uma função singularmente cognitiva da Arte, no sentido de que ela consistia em uma atividade que permitia melhor compreensão do conteúdo de outras matérias. Sob esse olhar, a Arte até adquiriu algum status no rol das disciplinas escolares, mas um status vinculado ao propósito de sua utilização como ferramenta, ficando privada do próprio aspecto da fruição estética, cerne de sua existência. (GOUTHIER, 2008, p. 14-15).

É na esteira desse processo que, de 1937 a 1945, no contexto do Estado Novo, irá vigorar uma utilização instrumental da Arte, destacando-se, segundo Barbosa (2003), “o desenho geométrico na escola secundária e na escola primária, o desenho pedagógico e a cópia de estampas usadas para as aulas de composição em língua portuguesa" Esses procedimentos se consolidam, demonstrando "o

${ }^{5}$ Ressalte-se que o Distrito Federal, à época, era ainda o Rio de Janeiro. 
início da pedagogização da arte na escola. Não veremos, a partir daí, uma reflexão acerca da arte-educação vinculada à especificidade da arte [...], mas uma utilização instrumental da arte na escola para treinar o olho e a visão ou para liberação emocional." (BARBOSA, 2003, s/p). Apenas a partir do fim do Estado Novo a abertura modernista preconizada na década de 30 alcançaria maiores desdobramentos, quando se configura o Movimento das Escolinhas de Arte do Brasil (MEA).

As chamadas "Escolinhas" começaram a surgir a partir de 1947/48, tratando-se de ateliês voltados à oferta de cursos de Arte para crianças que se multiplicam em diversas cidades do Brasil. Os ateliês e cursos eram independentes em relação à educação regular, mas começariam a influenciar os ambientes escolares por meio da formação de professores à luz de "argumentos psicológicos" e com a "exploração de uma variedade de técnicas." É quando a tendência pedagógica da livre-expressão (laissez-faire) se consolida, sendo que Barbosa (2003) coloca em destaque: "O livro de Victor Lowenfeld, traduzido em espanhol, Desarollo de la capacidad creadora, [...], tornou-se então uma espécie de bíblia dos arte-educadores de vanguarda" (s/p).

De início, a influência das "Escolinhas" sobre o ensino regular não se fazia efetiva, pois os programas do MEC em vigor precisavam ser seguidos pelas escolas, tolhendo a autonomia do professor no sentido das possibilidades de inserção da livre-expressão em suas práticas. Em 1958, porém, "uma lei federal permitiu e regulamentou a criação de classes experimentais", o que possibilitou a investigação de "variáveis para os currículos." Com isso, multiplicaram-se não só as práticas da Arte como "livre-expressão", como também práticas reformistas sobre o ensino do Desenho. É o caso do "programa de desenho da escola secundária" que, apesar de ter sido desenvolvido por Lucio Costa em 1948, somente começa a acarretar influências transcorridos dez anos de sua existência; isto, 
pela barreira que a não oficialização do programa pelo MEC acarretara para a implementação da proposta. (BARBOSA, 2003, s/p).

A Lei de Diretrizes e Bases (LDB), de 1961, corrobora as experiências curriculares iniciadas em 1958, pois elimina a vigorante "uniformização dos programas escolares", mas isso não significou uma presença mais efetiva e plural da Arte na escola. A ênfase das tendências pedagógicas do Ensino de Arte na década de 1960 recai sobre um contexto de ditadura, no qual vigorava o Tecnicismo. Conforme Barbosa (2003), nas escolas particulares seguia-se uma "linha metodológica de variação de técnicas", enquanto nas escolas públicas primárias vigoravam "desenhos alusivos à comemorações cívicas, religiosas e outras festas", já nas escolas públicas secundárias permanecia "imbatível o desenho geométrico". São heranças dessa época alguns dos principais condicionamentos que se pode encontrar ainda hoje em alguns contextos escolares, tratando-se da redução do Ensino de Arte à realização de trabalhos manuais, à produção de enfeites para datas comemorativas, à perpetuação de estereótipos visuais nos espaços escolares, além do puro ensino de geometria em lugar do conteúdo específico da disciplina de Arte.

A Lei de Diretrizes e Bases (LDB), de 1971, tornou a Arte disciplina obrigatória no Ensino Básico, o que agregou certo reconhecimento à área e acarretou, em 1973, a criação, pelo governo federal, dos cursos superiores para a formação do professor de Educação Artística. No entanto, é quando se desdobra a questão da polivalência no Ensino de Arte, pois esses cursos tinham a duração mínima de dois anos (licenciatura curta), embora o professor pudesse seguir os estudos por mais dois anos, direcionando-se para uma das habilitações, em Artes Plásticas, Desenho, Artes Cênicas ou Música (licenciatura plena). É impensável hoje vislumbrar que, com uma formação de apenas dois anos, pautada no ensino simultâneo dessas diferentes formas de 
manifestações artísticas, os profissionais pudessem ter o domínio de um conhecimento sobre Arte a ser trabalhado de maneira suficiente nos espaços escolares; mesmo que esses espaços previssem a oferta da disciplina Arte de modo generalista.

Contemporaneamente, as formações superiores em Arte estruturam-se por áreas específicas - Artes Cênicas, Artes Visuais, Dança e Música -, enquanto no contexto do Ensino Básico esteve recentemente em pauta o projeto de Lei 7.032/10, que visou alterar a LDB/96, propondo que as Artes Visuais, o Teatro e a Dança se tornassem as linguagens constituintes do componente curricular Arte, junto a Música, que já tinha a sua obrigatoriedade prevista ${ }^{6}$ A aprovação do projeto culminou na lei ordinária no 13.278 , de 2 de maio de $2016^{7}$. A modificação proposta pela lei tende a significar a reversão das práticas de polivalência, que perduram nos contextos educacionais do Ensino Básico até mesmo pelo cunho generalista que a nomenclatura "Ensino de Arte" possui. Ao se especificar os quatro tipos básicos de manifestações artísticas, ocorre a desmistificação da expressão generalista e valoriza-se simultaneamente os respectivos campos de conhecimento.

Ao revisitarmos a História do Ensino de Arte no Brasil, é possível ver como os avanços alcançados nesse meio surgem por entre descontinuidades. Os caminhos da Arte no contexto educacional brasileiro se constituíram - e se constituem - ardilosamente, entremeados por entraves e avanços. São exílios e naturalizações da funcionalidade intrínseca do conteúdo artístico, que nos permitem antever a ambiência complexa da área que ora se discute. Barbosa, na constituição de seus estudos, analisa, entre as continuidades e descontinuidades históricas, as interações sucessi-

\footnotetext{
${ }^{6}$ A LDB de 96 foi alterada pela Lei nº 11.769, de 2008, incluindo no parágrafo sexto "a música como conteúdo obrigatório, mas não exclusivo" do ensino de Arte.

${ }^{7}$ A lei está disponível em <http://www.planalto.gov.br/ccivil_03/_ato20152018/2016/lei/113278.htm>. Acesso em 14 set. 2017.
} 
vas do campo do Ensino da Arte no Brasil em relação ao contexto sociocultural do país e às influências de modelos estrangeiros na Educação.

Na Década de 1980, Barbosa sistematiza a Abordagem Triangular para o Ensino da Arte, que se pauta em uma dupla triangulação, referente ao processo ensino-aprendizagem - fazer artístico, leitura da obra e contextualização - e aos modelos conceituais estrangeiros que podem ser correlacionados à sua sistematização ${ }^{8}$. A demanda pela organização da proposta triangular advém das dificuldades encontradas a partir dos anos 80 quanto à aceitação do uso da imagem na aplicação das aulas de Artes Visuais: "lecionam arte sem oferecer a possibilidade de ver. É como ensinar a ler sem livros na sala de aula" (BARBOSA, 2007, p. 12).

Barbosa explica que a mentalidade dos educadores estava focada na "livre-expressão", resultado das práticas difundidas pelas Escolinhas de Arte do Brasil, mas, acima disso, resultado da situação reforçadora estabelecida pela deficiência dos cursos universitários criados na década de 70, cujo currículo não supria o embasamento necessário para uma adequada formação de professores e, logo, para um Ensino de Arte consistente. Para Barbosa, os professores diplomavam-se, mas se mostravam incapacitados para "promover uma educação artística e estética". (BARBOSA, 2007, p. 23). A autora aponta que os professores na década de 80 não concretizavam aulas condizentes com

\footnotetext{
${ }^{8}$ Os modelos estrangeiros que inspiram a sistematização da Abordagem Triangular são as Escuelas al Aire Libre, vigorantes no México após a revolução de 1910, podendo ser observadas "como movimento precursor da multiculturalidade, articulando arte como expressão e como cultura"; o Critical Studies ou Cross Cultural, em vigor na Inglaterra de 1970 a 1980, considerando "os trabalhos artísticos com base em uma percepção estética precisa" e analisando "seus processos formativos, suas causas espirituais, sociais e políticas", além de "seus efeitos culturais"; por fim, o Disciplined Based Art Education (DBAE) - poderndo ser traduzido como Arte entendida como disciplina -, vigorante nos Estados Unidos a partir de 1982, difundindo a valorização do conteúdo da Arte. (GOUTHIER, 2008, p. 20).
} 
suas convicções, ou seja, se defendiam a Arte como livre-expressão, desenvolviam aulas em desacordo com esta concepção. Confirmava-se o comum desnível entre as teorias educacionais que, supostamente, deveriam ser norteadoras das práticas, mas que acabam subvertidas em sua aplicação cotidiana.

Tudo isso ocorria em um contexto em que o criticismo era solicitado na Educação, em detrimento do puro "deixar fazer", de cunho psicológico, que orientava a livre-expressão. A expressividade em Arte foi uma conquista do Ensino de Arte modernista, mas no contexto pós-moderno seria necessário agregar a essa conquista uma perspectiva mais crítica e multicultural sobre o universo das imagens. É esse papel que a Abordagem Triangular se propôs a cumprir, ou seja, levar à respeitabilidade do conteúdo artístico enquanto conhecimento e à consequente valorização da Arte enquanto disciplina. Nesses quesitos, as necessidades colocadas pelo arcabouço teórico-metodológico da Proposta Triangular trouxeram avanços inegáveis para a(s) Arte(s) na Educação, apesar da mesma dificuldade apresentada pelos professores na aplicação da livre-expressão na década de 80 ter sido sentida pelos professores das décadas subsequentes a respeito do uso prático da Abordagem Triangular.

Afinal, a "imagem" precisava estar presente nas classes das escolas públicas brasileiras que, em sua grande maioria, não possuíam estrutura física e conceitual para o desenvolvimento de um trabalho mais efetivo com Arte. Barbosa sistematiza a Abordagem Triangular dentro de um Museu, situado em uma metrópole, conforme afirma a autora:

A abordagem triangular, a gente começou a trabalhar com ela, sem chamá-la assim. Começamos a desconfiar de que é importante ver o absurdo de proibir a imagem na sala de aula com medo de cópia e ressaltar os efeitos positivos. Em 1983, eu comecei no Festival de Inverno de Campos do Jordão a agir assim: aproximar o ver do fazer. (...). E fomos 
levando e pesquisando mais até que eu consegui, em 1987, 1988 e 1989, sistematizar, no Museu de Arte Contemporânea, quando eu organizei o museu, essa tripliciação para a aprendizagem da arte: o VER, o FAZER e o CONTEXTUALIZAR, que não necessariamente tem esta ordem. Pode-se começar pelo fazer, pelo ver, ou pelo contextualizar. (BARBOSA, 2005, s/p. $)^{9}$

Em oposição à estrutura que um Museu repleto de obras de Artes Visuais pode oferecer, a maioria das escolas públicas brasileiras - ainda hoje - não tem estrutura para dar suporte ao professor de Arte. Esses profissionais são premidos pelo sistema escolar em que atuam, pois precisam enfrentar desde os problemas de inadequação da estrutura física das salas até as deturpações conceituais ocorridas em relação ao conteúdo de sua disciplina dentro dos espaços educacionais. Ser Arte-educador, ontem e hoje, consiste em assumir uma postura de constante luta em favor da preservação do conteúdo da disciplina de Arte na escola, uma tarefa que não se torna nada fácil diante da vida corrida que o tempo contemporâneo impõe às pessoas, devendo-se destacar a previsão de apenas um encontro semanal de Arte por turma nos espaços escolares. Podemos considerar que a viabilidade dos recursos físicos/ estruturais para o ensino de Arte, bem como o cuidado com a não transformação da imagem em mera cópia ou releitura nos contextos das aulas são dois dos principais desafios colocados pela proposta triangular na tentativa de sua aplicação ${ }^{10}$.

Acrescente-se que os próprios professores de Arte, que são orientados ao longo de sua formação a tratarem os conteúdos da disciplina de modo não polivalente, quando

\footnotetext{
${ }^{9} \mathrm{O}$ Capítulo 5 do livro A Imagem no Ensino da Arte narra, de maneira bastante interessante, uma prática fundamentada na Abordagem Triangular, desenvolvida no MAC/USP.

${ }^{10}$ A respeito da problemática da releitura, conferir: BARBOSA, Ana Amália. Releitura, citação, apropriação ou o quê. In: BARBOSA, Ana Mae. (Org.). Arte/Educação contemporânea: consonâncias interna $\operatorname{cionais.~} 2$ ed. São Paulo: Cortez, 2008. (p. 143-149).
} 
entram nas escolas, encontram exigências de ministrarem conteúdos de forma polivalente. Todos esses detalhes vão se configurando enquanto estressores para o cotidiano profissional dos Arte-educadores e, como resultado dos constantes embates, muitos profissionais que se formam na área de Arte acabam abrindo mão da profissão. Professores com formação em outras áreas assumem as aulas, mas sem a gama de conhecimentos específicos torna-se difícil que os objetivos do ensino se cumpra a contento. Cria-se, assim, um círculo vicioso que alarga ainda mais o abismo entre teoria e prática no campo do Ensino de Arte no Brasil.

\section{Convergências do Ensino de Arte em direção à Educação do Campo}

Ampliando o horizonte da problemática, vale ressaltar que se as escolas públicas urbanas - estejam elas situadas em cidades de grande, médio ou pequeno porte - integram o complexo quadro do Ensino de Arte exposto até o presente momento, o que se pode esperar das escolas do campo, nas quais a escassez de recursos físicos, pedagógicos e administrativos costuma ser ainda maior? Os professores do campo precisam lidar frequentemente com o trabalho em classes multisseriadas e com alunos que apresentam déficits de aprendizagem em diferentes nuances. O Museu a céu aberto das escolas do campo são as estradas de terra que ganham continuidades infindáveis por entre as paisagens naturais brasileiras. O Decreto 7.352, de 2010, define as escolas do campo como aquelas situadas na zona rural ou aquelas situadas na zona urbana, mas que acolhem de forma predominante alunos provenientes de áreas rurais. Há diferentes categorias camponesas, como assentados, ribeirinhos, trabalhadores da pesca, agricultores, criadores, extrativistas, assalariados, quilombolas, caiçaras, entre outras populações tradicionais. Onde e como 
fica a Arte no contexto de uma Educação que pretende ser voltada para essas populações?

Quando o campo do Ensino de Arte no Brasil ganhava seus ares modernistas, com Malfatti e Mário de Andrade na década de 1930, ainda se iniciava, em solo francês, o esboço do que viria a ser a Pedagogia da Alternância ${ }^{11}$, sistema basilar das práticas em Educação do Campo. Especificamente a respeito do contexto brasileiro - apesar de já se poder identificar, mais sistematicamente, debates e demandas em torno da afirmação de uma Educação "rural" no país desde o início do século XX, no âmbito do ruralismo pedagógico ${ }^{12}$ - segundo Nosella (2014), a implantação das primeiras Escolas-Família Agrícola (EFAs) apenas se difundiria no final da década de 1960, a partir do estado do Espírito Santo; o primeiro Centro de Formação de monitores (docentes) para atuarem nas EFAs foi implantado no município de Anchieta, com o ingresso da primeira turma em $1971^{13}$.

\footnotetext{
${ }^{11}$ A Pedagogia da Alternância é um sistema de ensino que considera o revezamento entre dois espaços diferenciados, mas que devem estar interconectados: o contexto cotidiano/familiar em que se vive (tempo-comunidade) e o contexto da instituição de ensino, onde se busca direcionamentos e mediações (tempo-escola). É a procura pela articulação entre as vivências e os saberes construídos nesses dois espaços que leva à ressignificação de fatores culturais e sociais dos atores envolvidos no processo. A respeito da história do sistema de Alternância, conferir: NOSELLA, Paolo. Educação do Campo: origens da Pedagogia da Alternância no Brasil. Vitória: Edufes, 2014.

${ }^{12} \mathrm{O}$ Ruralismo pedagógico foi um "movimento que discutiu, elaborou e divulgou proposições para a educação escolar das populações rurais a partir de 1920. [...]. Segundo Queda e Szmrecsányi (1973), o ideário do Ruralismo foi elaborado por educadores, políticos e religiosos obtendo apoio dos setores agrário e industrial. Esse Movimento incentivou a criação em quase todos os estados brasileiros de grupos, missões, núcleos e associações em defesa da escola e da cultura rural. No final dos anos 40 do século XX, o Movimento do Ruralismo Pedagógico conquistou junto ao Governo Federal, a criação das Escolas Normais Rurais, construídas em diferentes regiões do País." (MOLINA; ANTUNES-ROCHA, 2014, p. 223).

${ }^{13}$ Nosella (2014) descreve que as primeiras Escolas-Família Agrícola (EFAs) se difundiram no Brasil no final da década de 1960, a partir do estado do Espírito Santo, e assim como ocorreu na experiência francesa - desencadeada na década de 1930 pela ação do abade Pierre-Joseph Granereau (1885-1987)
} 
Os primórdios da formação de professores para atender o Ensino Básico nas EFAs é, portanto, um fator contemporâneo à formação de professores de Arte, iniciada em 1973. Apesar disso, muitos percalços ainda se colocariam para a efetiva consolidação das práticas de Educação do Campo no Brasil, que apenas mais recentemente vem sendo alvo da concretização de Políticas Públicas voltadas para a valorização da diversidade e das práticas de inclusão social no contexto educacional, devendo-se frisar que as terminologias "rural" e "do campo", que designam o termo Educação, possuem sentidos diferenciados.

Dentre as políticas públicas mencionadas, as seguintes devem ser aqui especificadas, conforme a respectiva ordem de seus aparecimentos: 1. PRONERA (Programa Nacional de Educação na Reforma Agrária), que teve início no final da década de 1990, com o objetivo de apoiar e promover projetos de Educação voltados para o desenvolvimento das áreas de reforma agrária; é executado pelo Ministério do Desenvolvimento Agrário e pelo Instituto Nacional de Colonização e Reforma Agrária (Incra). 2. PRONACAMPO (Programa Nacional de Educação do Campo), que surge para viabilizar a concretização das ações previstas no Decreto no 7.352/2010, que instituiu a Política Nacional de Educação do Campo ${ }^{14}$. 3. PROCAMPO (Programa de Apoio à Formação Superior em Licenciatura em Educação do Campo), instituído em 2006 pelo MEC, em parceria com a Secretaria de Educação Continuada, Alfabetização e Diversidade (SECADI), Secretaria de Educação Superior (SESU) e Fundo Nacional de Desenvolvimento da Educação (FNDE).

\footnotetext{
-, essa implantação também foi impulsionada pela ação de um sacerdote, da ordem dos Jesuítas, chamado Humberto Pietrogrande (1930-2015). Por ter origem italiana e desempenhar atividades no Brasil, Pietrogrande visava criar um "movimento 'Ítalo-brasileiro' para o desenvolvimento religioso, cultural, econômico e social do Estado do Espírito Santo". (p. 61-62).

${ }^{14}$ Site oficial do programa disponível em <http://pronacampo.mec.gov.br/>. Acesso em 25 set. 2017.
} 
O PROCAMPO tem por objetivo oferecer graduação a professores das escolas rurais que lecionam nos anos finais do Ensino Fundamental e no Ensino Médio. Conforme informações a respeito do programa, apontadas pela Assessoria de Comunicação Social do MEC, "Segundo o Censo Escolar 2009, trabalham em escolas rurais 338 mil educadores. Destes, 138 mil têm nível superior. O desafio da União, estados e municípios é oferecer graduação a 196 mil professores que lecionam no campo apenas com formação de nível médio." ${ }^{15}$ Acrescente-se que se fosse feito um mapeamento sobre o número de professores do campo que possuem habilitação nas áreas das Artes - seja em Artes Cênicas, Artes Visuais, Dança ou Música -, a porcentagem encontrada seria, por certo, muito baixa.

Molina e Antunes-Rocha (2014) elucidam que a implementação das Licenciaturas em Educação do Campo, via PROCAMPO, remontam às experiências anteriores, desenvolvidas nos cursos de Pedagogia da Terra do PRONERA, bem como à experiência piloto, realizada em quatro universidades federais (UFMG, UnB, UFBA e UFS) para verificação das viabilidades da proposta de implementação das Licenciaturas. A partir do projeto-piloto desenvolvido, o MEC lançou editais em 2008, 2009 e 2012, para que outras Universidades passassem a ofertar o curso. Enquanto os editais de 2008 e 2009 previam a oferta por uma única vez, o edital de 2012 surgiu para viabilizar a oferta permanente desses cursos nas instituições, podendo ser hoje contabilizada a existência de 42 cursos de Educação do Campo, cujos perfis de habilitação são pautados no regime de alternância, na docência por área de conhecimento e na gestão de processos educativos escolares e não escolares.

Molina e Antunes-Rocha (2014) acrescentam que

\footnotetext{
${ }^{15}$ Conforme informações sobre o PROCAMPO, disponíveis em <http://portal.mec.gov.br/ultimas-noticias/208-591061196/16002-decreto-organiza-politicas-publicas-educacionais-no-campo>. Acesso em 15 set. 2017.
} 
"A matriz curricular proposta desenvolve uma estratégia multidisciplinar de trabalho docente, organizando os componentes curriculares a partir de quatro áreas do conhecimento: Artes, Literatura e Linguagens; Ciências Humanas e Sociais; Ciências da Natureza, Matemática; e Ciências Agrárias." (p. 242). Uma das justificativas para se considerar essa formação por grandes áreas é a necessidade de se garantir e "ampliar as possibilidades de oferta da educação básica no campo", tendo em vista a carência de profissionais atuantes nesse contexto. $\mathrm{O}$ trabalho com formações específicas não daria vazão à demanda de profissionais por disciplinas no Ensino Básico do campo. Por outro lado, a intencionalidade maior da formação por grandes áreas é "a de contribuir com a construção de processos capazes de desencadear mudanças na lógica de utilização e de produção de conhecimento no campo"; isto, no sentido de promover, por meio dos processos formativos, uma "maior compreensão dos sujeitos do campo da totalidade dos processos sociais nos quais estão inseridos" (MOLINA; ANTUNES-ROCHA, 2014, p. 242).

Todavia, sabendo da supremacia que a linguagem discursiva exerce no contexto da tradição ocidental, que é orientada por uma perspectiva logocêntrica, cabe aqui ressaltar que a área de Artes, Literatura e Linguagens é contemplada em muitas das instituições que conduzem os cursos de Educação do Campo hoje existentes, mas desdobra-se uma tendência natural nesses cursos de dar ênfase ao universo das Letras (das palavras), ficando a Arte irremediavelmente como apêndice, devido à intrínseca natureza que a embasa, além das próprias incompreensões que comumente perpassam esse campo de conhecimento.

Apenas a Universidade Federal do Tocantins, ao criar dois cursos de Educação do Campo com habilitação conjunta em Artes Visuais e Música - nos campi de Arraias e Tocantinópolis - tratou de enfatizar a Arte (que não aquela realizada por palavras) enquanto alvo da forma- 
ção, tendo em vista a carência de professores com esta formação específica no estado, uma demanda que ocorre de maneira ainda mais especial nas áreas rurais. Destaque-se que enquanto o campus da UFT/Arraias está situado no sudeste do estado do Tocantins, em município que é limítrofe ao estado de Goiás, implicando em um contexto de remanescências quilombolas, o campus da UFT/Tocantinópolis possui sede no extremo norte do estado, estando próximo a áreas indígenas.

A existência de Cursos de Educação do Campo com foco na(s) Arte(s) nos possibilita uma abertura, um caminho de diálogo entre os aportes teórico-metodológicos da Educação do Campo e do Ensino de Arte no Brasil. Daí, se uma formação conjunta em Música e Artes Visuais pode nos remeter, num primeiro momento, à formação polivalente em Educação Artística iniciada em 73, ela sugere, por outro lado, a necessidade de se considerar toda uma conjuntura que avaliza o sistema específico da Educação do Campo, que não requer uma adequação simples, sucinta, unilateral dos pressupostos do sistema de Educação tradicional aos seus modos de atuação, requer, sim, uma mudança radical nos modos usuais de se fazer Educação.

As estruturações que perpassam a Educação do Campo constituem um sistema ousado, desafiador e contemporâneo, que questiona os limiares do sistema de Educação tradicional, buscando revolver práticas hegemônicas, fragmentadas e disciplinarizadas. Considerando a dissociação entre teoria e prática que, em geral, perpassa os sistemas institucionais do Brasil, não se pode prever em que medidas a completa operacionalização dessa proposta se efetivará, mas é fato que esta operacionalização está viva, em processo e traz - precisa trazer - o ensino de Arte para junto de si. Nesse contexto, enquanto o curso de Educação do Campo da UFT/Arraias encontra-se em um processo de consolidação da formação nas duas áreas inicialmente propostas - Artes Visuais e Música -, o curso de Educação 
do Campo da UFT/Tocantinópolis, por demandas da operacionalização do curso, caminha no sentido de manter a formação em Música e de alterar a formação de Artes Visuais pela de Artes Cênicas, o que, caso se concretize, pode ser bastante promissor, visto que se abrangeria uma área ainda não contemplada no contexto em pauta.

A aproximação entre Ensino de Arte e Educação do Campo gera uma abertura que nos obriga a repensar as bases históricas e epistemológicas desses saberes, num caminho que já vem sendo descortinado há algum tempo, visando a inclusão social de atores que historicamente peregrinaram nas margens da Educação e do próprio sistema de Arte. Basta lembrar que, por meio da lei 10.639, de 2003, A LDB de 96 foi alterada, tornando obrigatório "o ensino de conteúdos referentes à História e Cultura Afro-Brasileira, ministrados no âmbito de todo o currículo escolar, em especial nas áreas de Educação Artística, de Literatura e História Brasileiras." Essa lei foi substituída pela 11.645, de 2008, que acrescenta aos conteúdos abordados a temática indígena. A Educação do Campo - área recentemente firmada nas universidades brasileiras - vem acusar em seu bojo que Arte e Cultura Afro-Brasileira e Indígena - além da Arte e Cultura de outras populações historicamente afins ao contexto agrário no Brasil - são temáticas prioritárias, merecedoras de um sistema que se pretende específico. Molina e Antunes-Rocha (2014) afirmam que no âmbito desse sistema...

A formação por áreas de conhecimento tem por intencionalidade promover estratégias que contribuam para superar a fragmentação do conhecimento, criando, propondo e promovendo ações docentes articuladas interdisciplinarmente, associadas intrinsecamente, às transformações no funcionamento da escola e articuladas, ainda, às demandas da comunidade rural na qual se insere essa escola. (p. 242-243).

O alvo da Educação do Campo é, portanto, lidar com o conhecimento de forma introjetada na ação, objetivando 
promover ressignificações de identidades e sentidos relacionados à realidade específica das populações do campo, "possibilitando uma leitura crítica que, a partir dessa realidade, seja capaz de perceber as determinações sociais que assim a produzem, considerando a totalidade maior que a contém." (MOLINA; ANTUNES-ROCHA, 2014, p. 230). Trata-se de desenvolver um processo de ensino e aprendizagem que considera movimentos de contração e expansão entre o micro e o macro, na interação de saberes entre escola(s) e comunidade(s), pois compreende que o movimento da vida deve/precisa ser maior que a tautológica institucionalização das práticas educacionais.

\begin{abstract}
Nesse sentido, a alternância de tempos e espaços tem por objetivo, uma atuação orientada pela lógica da articulação teoria/prática, visando instrumentalizar o educando, na percepção dos problemas vivenciados em sua realidade cotidiana, bem como intervir, significativamente, neste campo de atuação. A construção da alternância está alicerçada em experiências diferenciadas, mas que estão conectadas pela necessidade de promover a articulação entre teoria/prática. (MOLINA; ANTUNES-ROCHA, 2014, p. 243).
\end{abstract}

Conforme proposições divulgadas pela Secretaria de Educação Continuada, Alfabetização e Diversidade (2007), a LDB de 1961 mencionava a manutenção de escolas na zona rural com o intuito de "frear a onda migratória que levava um grande contingente populacional do campo para as cidades, gerando problemas habitacionais e estimulando o crescimento dos cinturões de pobreza hoje existentes nos grandes centros urbanos." (p. 16). Em seu artigo 105, a lei previa que as escolas rurais deveriam ser capazes de "favorecer a adaptação do homem ao meio e o estímulo de vocações profissionais." (p. 11). Já a LDB de 1971 colocava "como função central da escola a formação para o mercado de trabalho, em detrimento da formação geral do indivíduo. A educação para as regiões rurais foi alvo dessa mesma compreensão utilitarista ao ser coloca- 
da a serviço da produção agrícola." (p. 16). A Educação do Campo em uma perspectiva da diversidade e da inclusão começa a ser contemplada a partir da constituição de 1988.

A Constituição de 1988 é um marco para a educação brasileira porque motivou uma ampla movimentação da sociedade em torno da garantia dos direitos sociais e políticos, dentre eles o acesso de todos os brasileiros à educação escolar como uma premissa básica da democracia. Ao afirmar que "o acesso ao ensino obrigatório e gratuito é direito público subjetivo" (Art. 208), ergueu os pilares jurídicos sobre os quais viria a ser edificada uma legislação educacional capaz de sustentar o cumprimento desse direito pelo Estado brasileiro. No bojo desse entendimento, a educação escolar do campo passa a ser abordada como segmento específico, prenhe de implicações sociais e pedagógicas próprias. (CADERNOS SECAD/MEC, 2007, p. 16).

A LDB de 1996 já reconhece, com maior propriedade, a diversidade sociocultural, o que permite pensar diretrizes operacionais para a Educação do Campo, ou seja, reconhecer finalidades, conteúdos e metodologias próprias ao que é específico do campo, solucionando preocupações conceituais e estruturais dos movimentos sociais que são históricas. As Diretrizes Operacionais para a Educação Básica nas Escolas do Campo, dadas pela resolução CNE/ CEB $n^{0} 1$, de 03/04/2002, vêm reconhecer a necessidade de uma educação diferenciada para as pessoas ligadas ao campo, tratando-se de uma demanda que "extrapola a noção de espaço geográfico e compreende as necessidades culturais, os direitos sociais e a formação integral desses indivíduos." (CADERNOS SECAD/MEC, 2007, p. 9). Dentre essas necessidades e direitos solicitados, destacam-se os seguintes pleitos...

[...] o reconhecimento e a valorização da diversidade dos povos do campo, a formação diferenciada de professores, a possibilidade de diferentes formas de organização da escola, a adequação dos conteúdos às peculiaridades locais, o uso de práticas pedagógicas contextualizadas, a gestão democrática, a consideração dos tempos pedagógicos diferen- 
Diante do exposto, um dos desafios centrais que se coloca para a inserção das Artes Visuais na Educação do Campo brasileira é o entendimento das especificidades da área, com a migração dos aportes teórico-metodológicos existentes para o contexto específico das escolas do campo, além da "re-configuração" de novos aportes, próprios para os ambientes educacionais estabelecidos em áreas rurais. Saviani (2014, p. 24) assevera que "a escola, desde suas origens, foi posta do lado do trabalho intelectual; [...], as funções manuais, entre as quais se inclui o cultivo da terra, não requeriam preparo escolar". A formação para essas tarefas - de lides com a terra - acontecia em seu próprio exercício, ou seja, na prática. É o mesmo sentido do ensino no contexto das corporações de ofício medievais, nas quais a formação dos artífices era regida pelo princípio do aprender fazendo, sob a orientação de um mestre, detentor de experiência (STEINER, 2010). O status das Artes Visuais e a sua compreensão enquanto disciplina no contexto escolar também carregam esse sentido de trabalho menor (não intelectual), por igualmente envolver as manualidades.

Sintetizando a questão por meio de outros termos, não importa como o indivíduo trabalhe a terra, se é com uma "enxada" ou com uma porção de "argila", o fato de as manualidades serem associadas ao trabalho pesado no contexto logocêntrico da tradição ocidental tende a diminuir o valor dessas atividades. Isso significa que lavradores e professores de Artes Visuais tem uma luta em comum, em favor do reconhecimento de suas práticas. Os cursos de Educação do Campo, assim como as Artes Visuais no contexto da escola e da sociedade, sofrem constantes desqualificações pela incompreensão de seus diferenciais pedagógicos e epistemológicos. Como consequência, são 
áreas que precisam se reafirmar constantemente, demonstrando as especificidades e diferenças que agregam.

A consolidação da Arte enquanto área de conhecimento é o embate principal que percorre todos os caminhos estruturados por Barbosa (2006) na construção de sua abordagem sobre a Arte-Educação no Brasil. O grande mote das Artes no contexto da educação brasileira é a luta pelo reconhecimento dos conteúdos artísticos e a consequente valorização das áreas enquanto disciplinas, considerando-se as epistemologias e metodologias de ensino específicas das diferentes linguagens ou meios de expressão, como o Teatro, a Dança, a Música e aqui, de maneira especial, as Artes Visuais. Esses meios não devem estar ausentes da Educação do Campo brasileira.

\section{Arte-educação e Educação do Campo: ampliando possibilidades a partir da Cultura Visual}

O projeto da Educação do Campo, em sua práxis, tem produzido diálogos, reflexões e produções que contribuem para uma maior compreensão a respeito do contexto em que os sujeitos do campo vivem, suas condições de vida, trabalho, relações sociais, território, direitos, deveres etc. Questionamentos como: Que lugar quero ocupar? Que lugar ocupo? Que caminhos almejo seguir? Quais ideias e práticas quero fortalecer? Propõem reflexões que tem despertado a valorização e o reconhecimento da identidade e da cultura dessas populações.

Nesse sentido, compreendemos uma confluência entre perspectivas da Cultura Visual e da Educação do Campo. A Cultura Visual ainda é uma perspectiva emergente na Educação. Com uma concepção transdisciplinar, ou pós-disciplinar, como defendem alguns autores, opõe-se em estabelecer fronteiras disciplinares e metodológicas. De forma ampla, propõe uma abordagem cultural às re- 
presentações visuais. Empenha-se em desvelar o modo como o discurso, em suas diferentes materializações, afeta nossa maneira de pensar, ver, dizer e fazer, compreendendo as imagens como portadoras de significados sociais e questionando as visualidades (o modo como vemos).

Em uma época de intensa proliferação do visual, a compreensão da imagem como portadora de significados torna-se substancial, e essas problematizações são imprescindíveis para o ensino de Artes Visuais na contemporaneidade. Tanto que, cada vez mais, as contribuições da Cultura Visual têm sido debatidas e repercutidas no âmbito da Arte-educação. Para além das especificidades do campo ou da cidade, o processo de reflexividade na educação da cultura visual "nos ajuda a tomar consciência da posição de onde falamos e, ao mesmo tempo, a experienciar outros modos de ver" (MARTINS; TOURINHO; MARTINS, 2013, p. 59).

Percebemos a existência de uma demanda para que o Ensino de Artes Visuais também se torne um campo expandido ${ }^{16}$, assim como a própria produção artística, sendo a educação da cultura visual reflexo às condições visuais contemporâneas. "As Artes Visuais, para a criação de suas representações, mostram-se cada vez mais (de)pendentes da cultura dos meios de comunicação e das formas de visualidades geradas na vida cotidiana" (DRUCKER apud HERNÀNDEZ, 2007, p.34). E se a prática artística está mudando, se torna necessário que essas mudanças ocorram também no enfoque dado às práticas de ensino na Escola ${ }^{17}$.

Percebemos que elementos da Cultura Popular estão cada vez mais presentes em 'obras ${ }^{18 \prime}$ de Arte Contemporâ-

\footnotetext{
${ }^{16} \mathrm{O}$ ponto de partida do conceito de campo expandido foi apresentado por Rasalind Krauss no ensaio Passages to Modern, em 1979.

${ }^{17}$ Escola com maiúscula faz referência a todas as instituições dedicadas a formar indivíduos dentro de um regime de regulamentos e sanções (HERNÁNDEZ, 2007, p. 13).

${ }^{18} \mathrm{O}$ conceito de obra não abarca a diversidade de formas que a arte se apresenta na contemporaneidade, por isso, sempre que for utilizado o termo, será
} 
nea. No entanto, as interações estéticas entre Artes Populares e Arte Contemporânea são quase sempre caminhos de mão única - no sentido de uma apropriação de elementos da Cultura Popular pelo sistema de A $\neg \neg \neg$ rte dominante.

A perspectiva da Cultura Visual, multiculturalista e crítica, para a Arte-educação nas escolas do campo pode ser uma possibilidade de transitar também no caminho inverso, construindo uma dupla-troca, produzindo diálogos, reflexões e produções que permitam a experienciação artística, em todo o seu discurso de campo expandido, por sujeitos do campo.

Sobre interações entre Cultura Popular e Arte Contemporânea, tomemos como exemplo a $32^{\circ}$ Bienal de São Paulo, cujo tema foi Incerteza Viva. Como apresentado em material de divulgação da Bienal (BIENAL SP, 2016):

A arte se alimenta da incerteza, da chance, do improviso, da especulação e ao mesmo tempo tenta contar o incontável ou mensurar o imensurável. Ela dá espaço para o erro, para a dúvida e até para os fantasmas e receios mais profundos de cada um de nós, mas sem manipulá-los. Não seria o caso, então, de fazer com que os vários modos de pensar e de fazer da arte pudessem ser aplicados a outros campos da vida pública? [grifo nosso]

Produções artísticas contemporâneas tomam como referência o cotidiano num amálgama com outros saberes onde elementos da Cultura Popular são apropriados, fundidos, significados e ressignificados. Artistas como os brasileiros Bené Fonteles e Jonathas de Andrade, que participaram da $32^{\circ}$ Bienal de São Paulo, tem suas produções marcadas pela esfera ritual, estabelecendo diálogos com questões ambientais e saberes populares. A instalação Ágora: OcaTaperaTerreiro de Bené Fonteles, que ocupava parte significativa do piso térreo da exposição, "abriga composições em que são usados materiais orgânicos, resquícios trazidos pelo mar, artefatos tradicionais e objetos coleta-

colocado entre aspas simples. 
dos por Fonteles durante suas jornadas a diferentes regiões do país" (BIENAL SP, 2016). O título da obra busca interligar tempos e conhecimentos distintos, considerando o terreiro como um espaço de celebrações e oferendas.

Figura 1: Fonteles, Bené. Ágora:

OcaTaperaTerreiro, 2016.

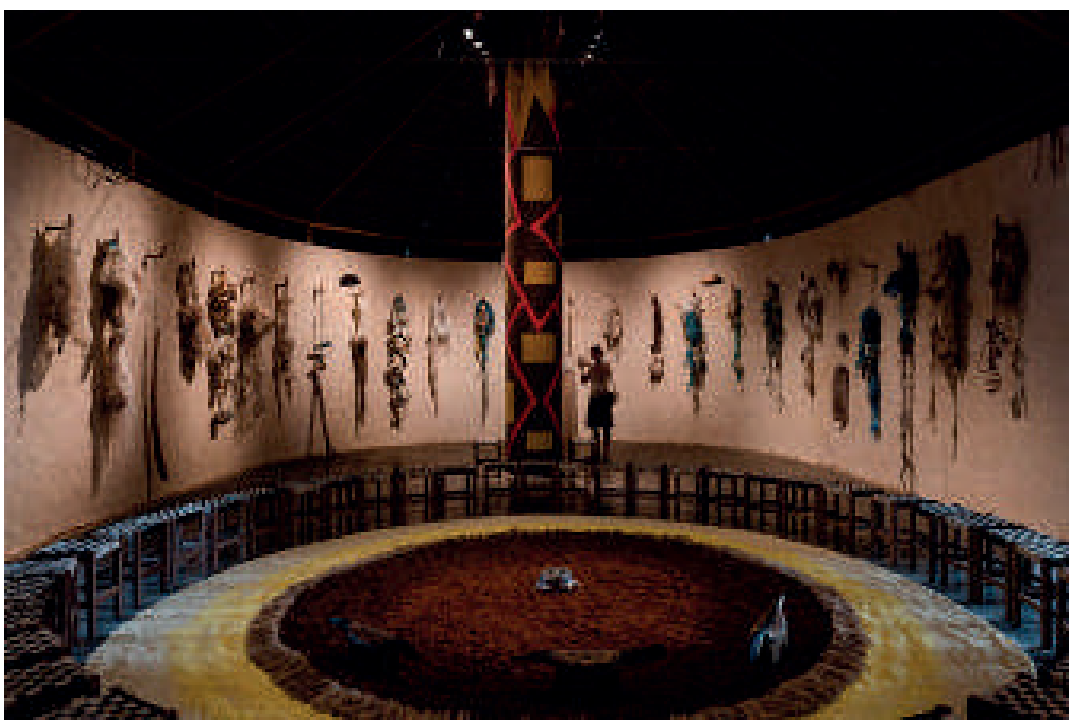

In: <<http://www.32bienal.org.br/pt/participants/o/2536>> Acesso em: 01 ago. 2017.

O filme O Peixe (2016), do artista Jonathas Andrade "acompanha pescadores pelas marés e pelos manguezais de Alagoas, que utilizam técnicas tradicionais de pesca, como rede e arpão, na espera pelo tempo necessário para capturar a presa" (BIENAL SP, 2016). Na imersão ritual/ performance, o pescador retém o peixe em seus braços até o momento de sua morte, "uma espécie de abraço entre predador e presa, entre vida e morte, entre o trabalhador e o fruto do trabalho, no qual o olhar - do pescador, do peixe, da câmera e do espectador - desempenha papel crucial" (BIENAL SP, 2016). 
Figura 2: ANDRADE, de Jonathas.

Fotograma de O peixe, 2016.

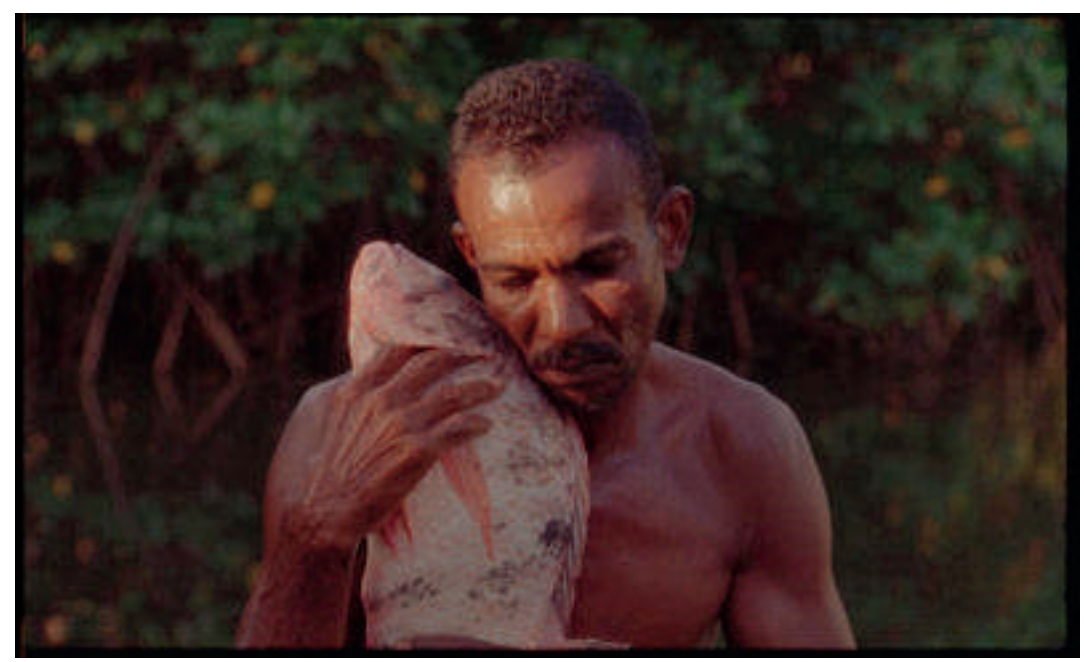

In: http://www.32bienal.org.br/pt/participants/o/2562 Acesso em: 01 ago. 2017.

Essas obras incorporam aspectos e a própria materialidade da Cultura Popular, como crenças, rituais, objetos, técnicas tradicionais de labor, interligando vários tempos e saberes. Diante disso, podemos tomar e efetivar a questão lançada pela exposição - a "de fazer com que vários modos de pensar e de fazer da arte pudessem ser aplicados a outros campos" (BIENAL SP, 2016) - para, a partir das próprias referências artísticas e culturais campesinas, provocar novos sentidos artísticos com base na experiência; compreendendo o conceito de experiência para além do enfoque do "acumulado", do "vivido", daquilo que nos atravessa, ou por nós é atravessado.

Segundo John Dewey (2010), experiência é construção de conhecimento, implica mais do que a consideração de repertórios pessoais, é reconhecer a potencialidade do já assimilado, no sentido de estimular iminentes construções e reconstruções. Experiência que não se deriva do ser, mas do vir a ser. Jorge Larrosa (2002, p. 12), mesmo afir- 
mando a impossibilidade de conceituar experiência, nos diz que esta

\begin{abstract}
ultrapassa imediatamente a qualquer conceito, porque excede qualquer ideia que trate de determina-la. A experiência seria precisamente o indeterminado da vida, esse passar do que nos passa quando não sabemos o que nos passa, essas afecções que nos levam a questionar o que já sabemos, o que já queremos, tudo o que se deixa submeter sem dificuldades a medida do que já somos.
\end{abstract}

A Cultura Visual propõe uma nova narrativa para a Educação Escolar. E como nos apresenta Fernando Hernández (2007, p. 37) "os estudos da Cultura Visual nos permitem a aproximação com estas novas realidades a partir de uma perspectiva de reconstrução das próprias referências culturais". Assim, por meio da experiência as tramas entre as Artes Visuais e a Cultura podem de ser exploradas e debatidas. Para Raimundo Martins (2015, p. 91), "a cultura visual se configura como um campo amplo, múltiplo, no qual se abordam espaços e maneiras como a cultura se torna visível e o visível se torna cultura".

O estudo da Cultura Visual, segundo Hernández (2000), coloca em evidência os papéis sociais das imagens, que denotam as particularidades de referenciais de cada indivíduo na produção cultural. Assim, ampliam-se as possibilidades para que todos possam compreender o significado cultural das imagens e intervenham na sua existência, tanto por meio da reflexão como da produção.

\title{
Notas conclusivas: proposições para uma Arte/ Educação do Campo
}

Pensar conjuntamente em como a Arte produz em nós alguma coisa e como nós podemos produzir a nós mesmos, mais especificamente, enquanto Arte/educadores do campo; quais transformações nós podemos operar 
no nosso modo de agir e de ser professor entrando em contato com a Arte? O que esses diferentes modos de proceder nos fazeres da Arte podem inspirar para a prática docente? Não é apenas conhecer a Arte; saber dos seus conteúdos; é vivenciar a Arte enquanto uma prática, um modo de trabalho e a partir dessa experiência ser capaz de se re-criar enquanto professor, a partir do contato com esses diferentes modos de fazer da Arte. A conjunção Artes Visuais e Educação do Campo, assim, se propõe aqui na forma de Arte/Educação do Campo, indicando para a necessidade de se construir uma autonomia docente; para uma autonomia criadora docente.

Bosi (1985), ao construir suas reflexões à luz das ideias estéticas de Pareyson, sugere que não existe um método único para a produção de Arte, pois novos métodos são constantemente inventados e reconfigurados à medida que as obras são criadas. A proposição das obras dá condições para a emergência dos métodos, configurando o sentido da experimentação artística. Isso implica em uma relação entre a liberdade e as técnicas, pois, no âmbito da construção da obra de Arte, "a liberdade exige e cria uma norma interna." (p. 16). É nesse sentido que o autor sugere: "A técnica produziu, ao longo da história de cada arte, um conjunto de regras úteis ao projeto e à execução da obra. Desde a Antiguidade formou-se uma tradição normativa." (p. 17). Uma tradição na qual se criam "normas internas" nas lides com o Desenho, a Pintura, a Escultura, entre outros meios.

Segundo as proposições de Pareyson, recuperadas por Bosi, "o fazer do artista é tal que, enquanto opera, inventa o que deve fazer e o modo de fazê-lo." (1985, p. 16). Esse potencial inventivo, que se alia à técnica no momento de criação, coloca-se como potência no campo da Arte/Educação; nesse sentido, Arte é construção, por ser um canal que viabiliza o desdobramento de seus próprios modos de elaboração. 
A Arte é construção de seus próprios meios de feitura. A Arte Contemporânea deixa isso claro quando incorpora gestos de espera, de coleta, de deriva; quando busca fora dos materiais e técnicas tradicionais da Arte modos de criar relações inusitadas com a vida; quando traz o efêmero, a transitoriedade, a precariedade como elementos constituidores das suas proposições poéticas.

Como que olhar, atentar, compreender os diferentes modos de produção de Arte pode nos inspirar uma autonomia criadora docente? Compreendendo que docência, que ser professor, não é da ordem da instrumentalização. Ser Arte-educador do campo demanda que criemos nossos procedimentos e nossa prática pedagógica, dentro e a partir das condições em que estamos trabalhando. Hernández (2007) inspira pensar a potência das diferenças, em vez do acirramento da homogeneização:

Todos olham para o mesmo horizonte: entrar no sistema produtivo ou chegar à universidade. E não se pensa que a educação para todos pode ter outra finalidade em um mundo incerto e de subjetividades mutáveis. Por isso, é importante a pluralidade em contraposição à homogeneização. Aproveitar as diferenças em vez de considerá-las um problema. A partir daí, torna-se necessário que as diversas vozes diferentes sejam escutadas, as histórias individuais, reconhecidas e a inventividade de todos e de cada um valorizada. (p. 15-16).

A instalação Ágora: OcaTaperaTerreiro, de Fonteles, mostra modos de proceder: o da espera, pelos objetos que vêm do mar, por aquilo que pode ser respigado da natureza; o dos artesanatos, produzidos em um tempo que é introduzido no interior da obra; o da caminhada, da busca, daquele que mantêm a postura de quem coleta, de quem cata, de quem espera; a atitude de quem tem a sensibilidade para a captura da diferença, contrapondo-se a modos de homogeneização. Produz-se aí um modo de proceder, de agir, de constituir ação, que são internos às condições de emergência de uma obra. Fonteles, na figura de um ar- 
tista, é sujeito exposto, é sujeito de experiência (LARROSA, 2002).

O sujeito da experiência é como um território de passagem, exposto e aberto, permitindo que algo ocorra ali. Isso porque na experiência há sempre transformação. Alteram-se os modos de pensar, de sentir, de perceber. Há uma interferência no sujeito mesmo, conferindo à experiência uma dimensão formativa. Não uma en-formação, não processo de homogeneização, mas um movimento de desestabilização e inquietude no próprio potencial sensível do sujeito. Trata-se de um sujeito no qual os acontecimentos têm lugar e para o qual ele está aberto. Ele está aberto para os encontros e para o inusitado. Aberto ao não-saber: não saber lugar daquilo se passa com ele, não saber por não encontrar as palavras que possam dar sentido a tal experiência, não saber o que faz com o silêncio que produz uma experiência. Mas, uma coisa este sujeito sabe, que algo lhe aconteceu, que algo o inquieta e o faz estremecer em seu próprio ser. Pois, não se trata tanto de estar disponível para o acontecimento, mas de abrir-se para os efeitos do acontecimento no próprio eu: "por isso é incapaz de experiência aquele se põe, ou se opõe, ou se impõe, ou se propõe, mas não se "ex-põe"". É incapaz de experiência aquele a quem nada lhe passa, a quem nada lhe acontece, a quem nada lhe sucede, a quem nada o toca, nada lhe chega, nada o afeta, a quem nada o ameaça, a quem nada ocorre" (LARROSA, 2002, p. 25).

A proposição de uma Arte/Educação do Campo passa por certa conservação dessa atitude: ser sujeito exposto, deixar-se contaminar, tornar-se território de passagem. Parte da premissa: ter uma experiência com a Arte e vertê-la em ação docente. A Arte como essa capacitora de vivência, um gérmen de experimentação do mundo e de si mesmo, que produz no sujeito formas de se relacionar com o mundo. Esse modo de experimentação coaduna-se ao projeto de uma Educação do Campo que privilegia a aten- 
ção às singularidades, àquilo que diz de um território existencial pautado pela particularidade de uma Cultura e/ou Identidade. A experiência aqui pensada não apenas como conceito descolado de realidade, mas ela mesma como um modo de produzir pontos de contato, relações com realidades. A experiência como uma atitude profundamente ligada à vida; a encarnação dos saberes; a valorização da experimentação com Arte como um modo de opor-se radicalmente à pobreza da experiência, materializada em práticas formativas coaguladas em pressupostos absolutos, que atendem realidades massificadas por princípios que não entram em contato com as realidades do campo.

Pobreza de experiência: não se deve imaginar que os homens aspirem novas experiências. Não, eles aspiram a liberdade de toda a experiência, aspiram a um mundo em que possam ostentar tão pura e tão claramente sua pobreza externa e interna, que algo de decente possa resultar disso. Nem sempre eles são ignorantes ou inexperientes. Muitas vezes, podemos afirmar o oposto: eles "devoraram" tudo, a "cultura" e os "homens", e ficaram saciados e exaustos. (BENJAMIN, 1994, p. 118).

Assim, trata-se de nos constituirmos como Arte/ Educadores do Campo, a partir da materialidade da experimentação com a Arte, que é o substrato de trabalho daquele que opera com o ensino de Arte; criar para si uma poética docente como ato de autonomia; intrínseco a uma produção do sujeito por ele mesmo, por meio das escolhas, decisões e posturas que encarna e experimenta no seu ethos professoral: "ninguém é autônomo primeiro para depois decidir. A autonomia vai se constituindo na experiência de várias, inúmeras decisões que vão sendo tomadas" (FREIRE, 2016, p. 105). Ainda na esteira de Freire, a autonomia é uma forma de amadurecimento para si, é um processo, é um tornar-se. É esse exercício e trabalho de si, que vem se propondo até aqui, que arranca o sujeito da estagnação, para colocá-lo em movimento; movimento 
que se principia com tomadas de decisão. Liberdade e escolha refletida estão atreladas. Escolha refletida a partir de onde pisam os nossos pés: lemos o mundo e intervimos no mundo a partir de onde pisam os nossos pés. Atitudes que são criadas a partir do contexto com a qual me encontro. E, com isso, aborda-se uma demanda que é cara tanto à Arte/ Educação quanto à Educação do Campo: saberes contextualizados; práticas pedagógicas contextualizadas.

A Arte é uma manifestação cultural, produzida dentro e a partir de um contexto histórico, que constitui regimes de sensibilidade, dando, assim, visibilidade e/ou tornando sensível um modo de estar e ler o mundo. Condensa formas de se relacionar e produzir a cultura em que se está inserido. Trata-se, portanto, de um modo de expressar a experiência particular no e com o mundo.

Bernardo Fernandes, Paulo Cerioli e Roseli Caldart (2011), na Primeira Conferência Nacional "por uma educação básica do campo", defendem que "não basta ter escola no campo; queremos ajudar a construir escolas do campo, ou seja, escolas com um projeto político-pedagógico vinculado às causas, aos desafios, aos sonhos, à história e à cultura do povo trabalhador do campo" (p. 27). A diferença entre as preposições no e do campo sugere que não apena se tenha escolas no campo, mas que elas sejam efetivamente do campo. Que tratem dos saberes tradicionais do campo, que evidenciem quais são as lutas do campo e a proposição de uma Educação do Campo comprometida com a autonomia.

E, então, a pergunta que conclui efetivamente as reflexões aqui apresentadas: Como as Artes Visuais podem se articular a esse projeto de Educação do Campo? Certamente, de inúmeras formas que aqui não foram abordadas: através de sua dimensão política; a partir de seu caráter problematizador; desde sua potencialidade para a sensibilização e construção de um sentimento de pertença e identidade cultural. Em vez dessas dimensões formativas tão importantes e necessárias das Artes Visuais, optou-se 
por abordar o aspecto da experiência com a Arte; da relevância de olhar para esses diferentes procedimentos e modos de fazer. Tal escolha ocorre, por acreditar-se que esse olhar pode inspirar uma atitude de reflexão constante, de compreensão que cada contexto, que cada obra, que cada problema demanda soluções provenientes desde esse mesmo contexto. Soluções construídas no interior de uma contextura que demanda atenção e escuta ao lugar onde se está pisando os pés; modos de fazer refletidos desde a contextura em que o problema se coloca e aponta para soluções menos universalizadas, absolutas, homogeneizadas por lógicas culturais dominantes e opressoras.

O que se propõe nessa conjunção Arte/Educação do Campo é pensar uma docência de autonomia criadora, sensível a essa abertura e escuta; capaz de criação como forma de liberdade. E, ainda com Freire, o ético passa pelo estético nesse processo pois "não há prática docente verdadeira que não seja ela mesma um ensaio ético e estético" (FREIRE, 2016, p. 46).

\section{REFERENNCIAS}

$32^{\circ}$ BIENAL DE SÃO PAULO. Incerteza Viva. [online] Disponível em: <http://www.bienal.org.br/evento.php?i=2365>. Acesso em: 01 set. 2016.

BARBOSA, A. M. A imagem no ensino da arte. 6. ed. São Paulo: Perspectiva, 2007.

2006.

Arte-Educação no Brasil. 5. ed. São Paulo: Perspectiva,

. Arte Educação no Brasil: do modernismo ao pós-modernismo. In: Revista Digital Art\&, out. 2003. Disponível em: $<$ www.revista.art.br/site-numero-00/anamae.htm>. Acesso em: 25 abr. 2009.

. Conversando com Ana Mae Barbosa. Disponível em: $\overline{<w w w . c d r . u n c . b r / P G / R e v i s t a V i r t u a l / ~ N u m e r o S e t e / E n t r e v i s t a . ~}$ htm>. Acesso em: 14 set. 2005. 
. Arte/Educação contemporânea: consonâncias inter-

naาcionais. 2. ed. São Paulo: Cortez, 2008.

BARBOSA, A. M.; CUNHA, F. P. (Orgs.). Abordagem triangular no ensino das artes e culturas visuais. São Paulo: Cortez, 2010.

BENJAMIN, W. Documentos de cultura, documentos de barbárie. São Paulo: EDUSP, 1986.

BOSI, Alfredo. Reflexões sobre a Arte. São Paulo: Ática, 1985.

CALDART, R. S. Elementos para construção do Projeto Político e Pedagógico da Educação do Campo. In: Por uma Educação do Campo: contribuições para a construção de um Projeto de Educação do Campo. Articulação Nacional "Por uma Educação do Campo", n. 5, 2004, Brasília, DF.

. Por uma educação do campo: traços de uma identidade em construção. In: ARROYO, M., CALDART, R., MOLINA, M. C (Orgs). Por uma educação do campo. Petrópolis/RJ: Vozes, 2009.

DEWEY, J. Arte como Experiência. São Paulo: Martins Fontes, 2010.

FREIRE, P. Pedagogia da Autonomia. Rio de Janeiro: Paz e Terra, 2016.

HERNÁNDES, F. Catadores da cultura visual. Porto Alegre: Mediação, 2007.

. Cultura visual: mudança educativa e projeto de trabalho. Porto Alegre: Artes Médicas Sul, 2000.

HENRIQUES, R. et al (Orgs.). Educação do Campo: diferenças mudando paradigmas. Cadernos da Secretaria de Educação Continuada, Alfabetização e Diversidade. v. 2. Brasília: Şecad/ MEC, 2007. Disponível em: <http://portal.mec.gov.br/pnaes/194-secretarias-112877938/secad-educacao-contin uada-22 3369541/13605-cadernos-tematicos-da-sec ad>. Acesso em: 17 jun. 2017.

LARROSA, J. Notas sobre a experiência e o saber de experiên- 
cia. In: Revista Brasileira de Educação, nº 19, 2002.

MARTINS, R. MARTINS, A. TOURINHO, I. Entre subjetividades e aparatos pedagógicos: $\mathrm{O}$ que nos move a aprender? In:

Revista Visualidades, v.11, n.2, jul-dez 2013.

MARTINS, R. Deslocamentos perceptivos e conceituais da cultura visual: implicações para a formação de professores. In: A Formação do professor e o ensino das artes visuais. Santa Maria: Editora UFSM, 2015.

MOLINA, M. C.; ANTUNES-ROCHA, M. I. Educação do Campo: história, práticas e desafios no âmbito das políticas de formação de educadores - reflexões sobre o PRONERA e o PROCAMPO. In: Revista Reflexão e Ação, Santa Cruz do Sul, v.22, n.2, p.220-253, jul./dez. 2014 Disponível em: <http://online.unisc.br/seer/index.php/reflex/index>. Acesso em: 14 set. 2017.

NOSELLA, P. Educação do Campo: origens da Pedagogia da Alternância no Brasil. Vitória: Edufes, 2014.

GOUTHIER, J. História do Ensino da Arte no Brasil. In: PIMENTEL, L. (Org.). Curso de Especialização em ensino de Artes Visuais. 2. ed. Belo Horizonte: Escola de Belas Artes UFMG, 2008. (p. 11-22)

SAVIANI, D. Prefácio. In: NOSELLA, P. Educação do Campo: origens da Pedagogia da Alternância no Brasil. Vitória: Edufes, 2014. p. 25-32.

STEINER, G. Lições dos Mestres. Rio de Janeiro: Record, 2010. 


\title{
CAPÍTULO 9
}

\section{PROGRAMA NACIONAL DE EDUCAÇÃO DO CAM- PO: seu discurso formulador e os princípios da Educa- ção do Campo}

\author{
Cátia Wanderley Lubambo ${ }^{1}$ \\ Wivianne Fonseca da Silva Almeida ${ }^{2}$
}

O presente capítulo reflete parte dos resultados construídos a partir de pesquisa desenvolvida no Programa de Pós-Graduação em Gestão Pública da Universidade Federal de Pernambuco (UFPE), vinculada à linha de pesquisa: Instituições e Políticas Públicas.

A intenção foi avaliar o Programa Nacional de Educação do Campo (Pronacampo), buscando fortalecer o arcabouço dos instrumentos utilizados na luta social por uma gestão pública de qualidade no âmbito da Educação do Campo, contribuindo na compreensão dos diversos fatores e elementos imbricados que repercutem e influenciam na eficácia das ações desenvolvidas na esfera do referido programa.

O Pronacampo foi formulado para ser coordenado pelo Ministério da Educação (MEC), por meio da Secretaria de Educação Continuada, Alfabetização, Diversidade e Inclusão (Secadi), que, recentemente, encontra-se com frágil capacidade de atuação. Essa realidade torna a discussão sobre o Pronacampo ainda mais significativa, pois, aos elementos de análise de seu desempenho até aqui, so-

\footnotetext{
${ }^{1}$ Doutora em Sociologia pela Universidade Federal de Pernambuco. Pesquisadora da Fundação Joaquim Nabuco- FUNDAJ e Docente do Mestrado em Gestão Pública para o Desenvolvimento do Nordeste/MGP - UFPE. catia.lubambo@gmail.com

${ }^{2}$ Graduada em Pedagogia com Mestrado em Gestão Pública (2016) pela UFPE - Universidade Federal de Pernambuco. É coordenadora municipal de educação do campo na Secretaria Municipal de Educação de Afogados da Ingazeira, Pernambuco. E-mail: wiviannefs@gmail.com
} 
mam-se aspectos referentes ao seu encaminhamento/continuidade a partir de agora.

Os movimentos sociais do campo, enquanto sujeitos coletivos protagonizaram conquistas que interrogam o modelo urbanocêntrico de desenvolvimento rural. Entre os avanços conquistados, sem dúvida, a inserção do tema na agenda de discussão por políticas públicas e a obtenção de marcos legais e programas educacionais específicos para os povos do campo são grandes avanços. No entanto, questões como a formulação de um projeto de educação integrado com um projeto político de transformação social, ainda são desafios da realidade contemporânea (MOLINA; FREITAS, 2011).

\section{PERCURSO TEÓRICO-METODOLÓGICO DA PESQUISA}

O estudo caracterizou-se por uma abordagem qualitativa:

É um meio para explorar e para entender o significado que os indivíduos ou grupos (incluindo o pesquisador) atribuem a um problema social ou humano. O processo de pesquisa envolve as questões e os procedimentos que emergem, os dados tipicamente coletados no ambiente do participante, a análise dos dados indutivamente construída a partir das particularidades para os temas gerais e as interpretações feitas pelo pesquisador acerca do significado dos dados (CRESWELL, 2010, p. 26).

Na pesquisa qualitativa, portanto, para que seja possível a interação com o objeto em estudo, é fundamental que o pesquisador tenha claras suas concepções e valores pessoais, tomando como base os conhecimentos já produzidos sobre o tema pesquisado e estabelecendo diálogo entre os dados levantados e o desvendamento das problemáticas apresentadas e interpretadas.

Este trabalho, deste modo, não se constituiu em exer- 
cício simples, mecânico ou fechado, mas exigiu a labuta de construção contínua de conhecimento, tomando o ato de conhecer a partir da definição de Santos Filho e Gamboa (2000, p. 95), segundo a qual: "Conhecer é compreender os fenômenos em suas diversas manifestações e contextos. Para tanto, o sujeito tem que intervir interpretando, procurando seu sentido e utilizando técnicas abertas que permitam a manifestação profunda dos fenômenos".

O percurso de pesquisa buscou verificar a convergência entre a proposta de atuação do Pronacampo e os princípios/diretrizes da concepção de Educação do Campo.

Iniciou-se com um estudo exploratório, o qual, segundo Gil (2008), é realizado para se ter uma visão geral de um fato, essencialmente quando é pouco explorado. No presente estudo, a fase exploratória delineou-se:

\begin{abstract}
a) no mapeamento das condições que formaram o ambiente político-institucional nos setores públicos atuantes e das estratégias institucionais, sob a dimensão da intersetorialidade governamental, da coordenação e das articulações entre os atores, com vistas à formulação do Pronacampo;

b) na análise documental do Documento Orientador (BRASIL, 2013) e da Portaria MEC no 86/2013, que regulamentam o Pronacampo, considerando como referências os fundamentos da Educação do Campo expressos na legislação educacional: Diretrizes Operacionais para a Educação Básica nas Escolas do Campo (Resolução CNE/CEB nº 1/2002), Resolução CNE/CEB nº 2/2008 e Decreto nº 7.352/2010, que dispõem sobre diretrizes complementares e princípios norteadores da política de Educação do Campo, respectivamente.
\end{abstract}

Constatou-se que têm sido pouco privilegiados os estudos que se dediquem a explicar as condições de articulação para a implantação e gestão de programas descentralizados a partir do governo central.

Neste sentido, consideraram-se os conceitos tomados do neoinstitucionalismo histórico e sociológico (HALL et al., 2003), por meio dos quais se buscou o momento crítico 
de implantação de cada unidade de análise da interiorização e as condições político-institucionais que favorece$\mathrm{ram} /$ dificultaram o processo.

Ainda como parte da revisão teórica, incluíram-se referências que abrigam a discussão sobre Educação do Campo. Entre outros, tomaram-se as contribuições apresentadas por Alencar (2010), Arroyo (2004), Caldart (2000, 2009), Caldart et al. (2012), Kuhn (2015), Ribeiro (2010) e Munarim (2011).

Nessa etapa, fez-se fundamental, contíguo à análise documental, a coleta de dados junto aos atores diretamente envolvidos no processo de consolidação do discurso formulador do Pronacampo. Desse modo, realizou-se entrevistas e coleta de impressões a partir de grupo focal.

\section{EDUCAÇÃO DO CAMPO: conceito, fundamentos e princípios}

Ter clareza do conceito que se acredita sustentar a Educação do Campo é fundamental para o início de qualquer proposta de discussão nesse âmbito. Arroyo (2004, p. 92) destaca que a visão do campo e, por consequência, o entendimento sobre a educação que dever ser oferta a esse campo, ainda presente na formulação de políticas públicas, é um dos fatores geradores da precarização observada nessa área: "sem corrigir essa visão, a formulação de políticas não mudará". Bourdieu e Chartier (2011) endossam esse entendimento e, discutindo acerca do nominalismo - uso de categorias supostamente universais e que nunca mudam -, destacam que uma mesma palavra pode ser utilizada por vários grupos, em diversos contextos e apresentar significados diferentes, frutos de sua trajetória cronológica e social.

No verbete do Dicionário da Educação do Campo, Caldart (2012), define a Educação do Campo como: 
Um fenômeno da realidade brasileira atual, protagonizado pelos trabalhadores do campo e suas organizações, que visa incidir sobre a prática de educação desde os interesses sociais das comunidades camponesas. Objetivo e sujeitos a remetem às questões do trabalho, da cultura, do conhecimento e das lutas sociais dos camponeses e ao embate (de classe) entre projetos de campo e entre lógicas de agricultura que têm implicações no projeto de política pública, de educação, e de formação humana (CALDART, 2012, p. 257, grifo do autor).

É este o conceito adotado neste trabalho: um conceito de Educação do Campo forjado a partir da luta pela terra e por políticas públicas educacionais que considerem as especificidades do campo e as ações desenvolvidas pelos movimentos sociais campesinos. Munarim (2011) enfatiza que a concepção de Educação do Campo não está elaborada de forma definitiva, formada ou hegemônica. Sendo um conceito novo, está em disputa pelas contradições da realidade social que expressa e, estando em construção, representa uma categoria de análise da situação ou práticas e políticas de educação dos trabalhadores do campo: no passado, no presente e na realidade por vir (CALDART, 2012).

Nesse sentido, pontuam-se questões importantes na discussão do conceito de Educação do Campo. Aspectos que são essenciais, por sinalizarem contradições que estão na raiz da materialidade de sua origem.

\section{a) A Educação do Campo é diferente da Educação Rural}

Para compreender o que significa Educação do Campo, urge a compreensão do que ela não é: uma educação que objetiva formar grupos semelhantes aos que vivem na área urbana, desconsiderando valores culturais próprios do campo. Esta seria, grosso modo, a definição para Educação Rural.

A diferença de Educação do Campo e Educação 
Rural não se refere apenas a uma questão de nomenclatura; demarca, sobretudo, uma concepção de educação. A Educação do Campo surge como um novo paradigma de educação que objetiva o desenvolvimento sustentável do campo e a valorização dos povos campesinos, contrapondo-se à Educação Rural, que, sendo uma educação com valores urbanos, favorece a migração e valoriza o latifúndio e o agronegócio (ALENCAR, 2010).

Considerando-se os espaços e os protagonistas, fica evidente a diferença entre as concepções de Educação do Campo e Educação Rural:

[...] enquanto a Educação do Campo vem sendo criada pelos povos do campo, a Educação Rural é resultado de um projeto criado para a população do campo, de modo que os paradigmas projetam distintos territórios. Duas diferenças básicas desses paradigmas são os espaços onde são construídos e seus protagonistas (FERNANDES; MOLINA, 2004, p. 24).

Alencar (2010) enfatiza que o entendimento a respeito do conceito de rural tem influência direta na concepção de educação que vai referendar as políticas públicas destinadas aos povos do campo. Assim, sintetizando essas relações, apresenta uma relação das características essenciais entre a Educação do Campo e a Educação Rural (Quadro 1).

Quadro 1 - Características entre

\begin{tabular}{|c|c|}
\hline Educação do Campo & Educação Rural \\
\hline Educação como direito subjetivo. & Educação como adaptação, assistência e controle. \\
\hline $\begin{array}{c}\text { Lugar de desenvolvimento que fomenta } \\
\text { a permanência no campo, valorizando o } \\
\text { trabalho, os saberes e a cultura. }\end{array}$ & $\begin{array}{c}\text { Lugar do atraso que fomenta a } \\
\text { migração, o abandono do campo. }\end{array}$ \\
\hline Diálogo campo-cidade. & Confronto campo-cidade. \\
\hline
\end{tabular}




\begin{tabular}{|c|c|}
\hline $\begin{array}{c}\text { Educação escolar como processo } \\
\text { de apropriação e elaboração } \\
\text { de novos conhecimentos }\end{array}$ & $\begin{array}{c}\text { Educação escolar como processo } \\
\text { de adaptação e adequação aos } \\
\text { conhecimentos urbanos. }\end{array}$ \\
\hline $\begin{array}{l}\text { Educação para valorização } \\
\text { da identidade camponesa. }\end{array}$ & Educação para forjar identidade urbana. \\
\hline $\begin{array}{c}\text { Educação que retrata a } \\
\text { diversidade Sociocultural do campo. }\end{array}$ & $\begin{array}{l}\text { Educação que busca a homogeneidade } \\
\text { nacional a partir do urbano. }\end{array}$ \\
\hline $\begin{array}{l}\text { Valorização dos diferentes saberes } \\
\text { (formais, não formais e informais) } \\
\text { no processo educativo. }\end{array}$ & $\begin{array}{c}\text { Valorização dos saberes formais } \\
\text { (conhecimentos científicos, instrumentais) } \\
\text { no processo educativo. }\end{array}$ \\
\hline $\begin{array}{l}\text { Educação do questionamento, da pergunta, } \\
\text { da reflexão da realidade. É uma educação } \\
\text { da relação: reflexiva, consequente, } \\
\text { transcendente e temporal. }\end{array}$ & $\begin{array}{l}\text { Educação do transmitir, do } \\
\text { (re)passar conhecimento. É uma educação } \\
\text { do contato: reflexo, inconsequente, } \\
\text { intranscendente e intemporal. }\end{array}$ \\
\hline Política pública de efetivação de direitos. & Política pública compensatória. \\
\hline $\begin{array}{l}\text { Currículo em movimento - currículo } \\
\text { práxis que trabalha identidade, história, } \\
\text { memória, cultura e relações sociais } \\
\text { presentes no campo. }\end{array}$ & $\begin{array}{l}\text { Currículo essencialmente urbano, } \\
\text { que trabalha a adaptabilidade, } \\
\text { deslocado das necessidades e } \\
\text { da realidade do campo. }\end{array}$ \\
\hline Educação no e do campo & Educação para o campo. \\
\hline
\end{tabular}

Fonte: Alencar (2010).

Muitos estudiosos ligados aos movimentos sociais do campo ainda utilizam a expressão Educação Rural buscando enfatizar que a escola atual ainda é na área rural e ainda enfrenta enormes dificuldades, como a multisseriação. No entanto, Ribeiro (2012) destaca que a Educação Rural permanece sendo relacionada a uma concepção preconceituosa a respeito dos povos do campo, representa a escola destinada a oferecer conhecimentos iniciais de leitura e ensino de operações matemáticas básicas, não tendo nenhum compromisso com o letramento e a emancipação dos sujeitos. A expressão Educação do Campo, pelo contexto no qual foi evidenciada, é que vem carregar essa perspectiva de significado. 
b) $\mathrm{O}$ conceito refere-se à educação no campo ${ }^{3}$ e do campo, assumindo-se, assim, como uma educação específica

O conceito de Educação do Campo está centrado numa concepção de educação como processo de formação humana, que constrói referências culturais e políticas para a intervenção das pessoas e dos sujeitos sociais na realidade (FERNANDES et. al., 2009). Possui, neste sentido, a compreensão de que no campo deve haver a oferta de educação básica, ou seja, todos os níveis e modalidades da escolarização brasileira, buscando superar a oferta de educação elementar e deficitária presente na área rural historicamente. É nesse contexto que a discussão é por uma educação do campo e no campo.

As preposições em destaque, aparentemente de pouca relevância, na verdade, expressam, pela história da educação dos homens e mulheres do campo, a diferença entre "processos educativos alienadores e mantenedores da ordem do capital, e processos educativos que pautam o horizonte da emancipação humana e das formas sociais que cindem o gênero humano" (FRIGOTTO, 2011, p. 35).

Não se trata de ater-se ao sentido semântico, mas inferir o seu conteúdo histórico e o que ele representa em relação às reivindicações no plano educacional:

- Educação do Campo: considera as particularidades da realidade dos homens e mulheres que produzem sua vida no campo. Assume a existência de especificidades que devem ser consideradas pela Educação. É a escola pensada a partir dos conflitos existentes no dia a dia do camponês, tendo clareza que este pode ser agricultor familiar, sertanejo, boia-fria, indígena, quilombola, caiçara,

\footnotetext{
${ }^{3}$ A definição de "espaço urbano" (cidade) e "espaço rural" (campo) é bastante ampla, com muitas relações e contradições. Tem sido foco de diversos debates, entre eles: Veiga (2002) e Sposito e Whitacker (2006).
} 
ribeirinho, assentado, pescador etc., pois existe, no meio rural, uma diversidade de sujeitos que trabalham e vivem em "diferentes campos", mas todos com constantes disputas.

- Educação no campo: expressa o questionamento feito à educação preliminar oferecida aos povos do campo, que, mesmo hoje, precisam ir aos centros urbanos para vivenciarem por completo seus níveis de escolarização. É a educação presente no campo e com projeto político-pedagógico ligado às causas do campo, sem, contudo, postular o localismo e o particularismo, pois a discussão de questões globais é essencial para a construção do conhecimento e da visão de universalidade.

\section{c) A materialidade de origem (ou de raiz) do con-} ceito de Educação do Campo exige que ela seja pensada/ trabalhada a partir da tríade: campo - política pública educação (CALDART, 2000).

Uma das tensões da Educação do Campo, no que se refere às políticas públicas implementadas, é a ruptura, a separação destas com a Educação do Campo, mesmo aquelas políticas desenvolvidas pelas Secretarias Estaduais e Municipais de Educação (MOLINA, 2012).

Ao se falar sobre os vários campos que integram a Educação do Campo, deve-se pensar nos termos da tríade proposta como um único elemento, pois configuram sua intenção política e pedagógica: a Educação do Campo se faz vinculada às lutas sociais do campo, no diálogo entre seus diferentes sujeitos, representando um movimento pelo direito de todos à educação pública de qualidade (CALDART, 2009).

Em cada um dos termos, portanto, os três se manifestam, pois exigem que se pense de maneira integrada sobre eles: que concepção de campo tem orientado as políticas públicas implementadas para as escolas da área 
rural? Em que sentido as ações fundadas na perspectiva da Educação do Campo têm sido contraponto à concepção liberal de educação, presente na contemporaneidade?

Fundamental, à guisa de conclusão dos elementos que estão da discussão do conceito de Educação do Campo, retomar os Princípios Pedagógicos da Educação do Campo, pontuados no Decreto no 7.352/2010:

Art. $2^{\circ}$ São princípios da educação do campo:

I - respeito à diversidade do campo em seus aspectos sociais, culturais, ambientais, políticos, econômicos, de gênero, geracional e de raça e etnia;

II - incentivo à formulação de projetos político-pedagógicos específicos para as escolas do campo, estimulando o desenvolvimento das unidades escolares como espaços públicos de investigação e articulação de experiências e estudos direcionados para o desenvolvimento social, economicamente justo e ambientalmente sustentável, em articulação com o mundo do trabalho;

III - desenvolvimento de políticas de formação de profissionais da educação para o atendimento da especificidade das escolas do campo, considerando-se as condições concretas da produção e reprodução social da vida no campo;

IV - valorização da identidade da escola do campo por meio de projetos pedagógicos com conteúdos curriculares e metodologias adequadas às reais necessidades dos alunos do campo, bem como flexibilidade na organização escolar, incluindo adequação do calendário escolar às fases do ciclo agrícola e às condições climáticas; e

V - controle social da qualidade da educação escolar, mediante a efetiva participação da comunidade e dos movimentos sociais do campo.

Art. $3^{\circ}$ Caberá à União criar e implementar mecanismos que garantam a manutenção e o desenvolvimento da educação do campo nas políticas públicas educacionais, com o objetivo de superar as defasagens históricas de acesso à educação escolar pelas populações do campo, visando em especial:

I - reduzir os indicadores de analfabetismo com a oferta de políticas de educação de jovens e adultos, nas localidades onde vivem e trabalham, respeitando suas especificidades quanto aos horários e calendário escolar;

II - fomentar educação básica na modalidade Educação de Jovens e Adultos, integrando qualificação social e profissional ao Ensino Fundamental;

III - garantir o fornecimento de energia elétrica, água potável e saneamento básico, bem como outras condições neces- 
sárias ao funcionamento das escolas do campo; e

IV - contribuir para a inclusão digital por meio da ampliação do acesso a computadores, à conexão à rede mundial de computadores e a outras tecnologias digitais, beneficiando a comunidade escolar e a população próxima às escolas do campo (BRASIL, 2010a).

\section{PRONACAMPO: avanços e recuos na política pública de Educação do Campo}

Iniciando-se com a discussão sobre o ambiente político-institucional com vistas à formulação do Pronacampo e, na sequência, discutindo sobre a convergência dos documentos oficiais que regulamentam o Pronacampo com os princípios da Educação do Campo, configuramos a correspondência do discurso formulador do Pronacampo com os fundamentos centrais da Educação do Campo.

Lançado oficialmente no dia 20 de março de 2012, o Pronacampo representa um marco histórico, pois configura, no âmbito do Estado brasileiro, a "primeira política estruturada de educação voltada para todos os grupos sociais que constroem suas condições materiais de existência do/no campo" (KUHN, 2015, p. 196).

O Pronacampo, institucionalizado pela Secadi, é resultado de uma trajetória de luta coordenada pelos movimentos sociais. Em reconhecimento a esse papel articulador de debate, e ainda no âmbito das questões de regulamentação legal, criou-se o Grupo Permanente de Trabalho (GPT), que, posteriormente, por meio da Portaria MEC no 674/2013, instituiu a Comissão Nacional de Educação do Campo (Conec). A Conec é órgão colegiado de caráter consultivo, com a atribuição de assessorar o MEC na formulação de políticas para a Educação do Campo e, atualmente, é responsável pelo Pronacampo.

De acordo com o Documento Orientador (BRASIL, 2013b), o Pronacampo ${ }^{4}$ foi construído pelo Grupo de Tra-

${ }^{4}$ Todas as informações referentes ao Pronacampo foram retiradas da página 
balho coordenado pelo MEC/Secadi, formado pelo Conselho dos Secretários Estaduais de Educação (Consed), União dos Dirigentes Municipais de Educação (Undime), Contag, MST, Federação dos Trabalhadores da Agricultura Familiar (Fetraf), Rede de Educação do Semi-Árido Brasileiro (Resab), UnB e Universidade Federal de Minas Gerais (UFMG), buscando atender às demandas dos sistemas de ensino e dos movimentos sociais. As propostas específicas para a implantação da política da educação quilombola foram discutidas com a Secretaria de Políticas para a Promoção da Igualdade Racial (Seppir), sendo submetido à consulta junto à Comissão Nacional Quilombola (Conaq).

Ainda contribuíram com as discussões a Secretaria de Educação Superior (Sesu), da Secretaria de Educação Profissional e Tecnológica (Setec), da Secretaria de Educação Básica (SEB), da Capes e do Fundo Nacional de Desenvolvimento da Educação (FNDE). Numa perspectiva de intersetorialidade das políticas públicas, o Fonec, os Centros Familiares de Formação por Alternância (Ceffas), a Secretaria Nacional da Juventude (SNJ), o MDA e o Ministério do Desenvolvimento Social e Combate à Fome (MDS) também integraram o processo de debate.

Entre os atores envolvidos, destaca-se a Secadi, a qual, criada para contribuir com o desenvolvimento inclusivo dos sistemas de ensino, visando à efetivação de políticas públicas transversais e intersetoriais, deveria articular as demais secretarias do MEC na gestão do Pronacampo: organizando reuniões, elaborando documentos e coordenando ações dentro de cada nível de ensino (FERROLA, 2013).

O Movimento de Educação do Campo, lutando por muito mais que escola, busca o reconhecimento e fortalecimento do processo de resistência e emancipação dos

oficial do MEC, disponível em: <http://pronacampo.mec.gov.br>. Também estão contidas em Brasil (2012b, 2012c, 2013a, 2013b). 
povos do campo (MUNARIM, 2011). Com essa estratégia, garantiu o surgimento de momento crítico para a implantação de políticas públicas na área da Educação do Campo. O Estado, materializando-se como articulador do processo de discussão e formulação do Pronacampo, buscou ampliar as condições político-institucionais que favorecessem o atendimento a esse contexto.

A ampliação das instituições e sujeitos envolvidos na discussão que antecedeu a criação do Pronacampo indica uma virada no modo de conceber as relações entre as instituições e/ou sujeitos coletivos num contexto de formulação de políticas públicas. Indicam, numa referência ao neoinstitucionalismo, a compreensão do papel desempenhado pelas instituições na determinação de resultados sociais e políticos (HALL; TAYLOR, 2003, p. 194).

Ferrola (2013) destaca o caráter integrador do Pronacampo, que, naquele momento, articulando secretarias e diretorias do MEC em processos colaborativos, contemplou políticas já existentes e instituiu novas ações específicas para o ambiente rural. A autora enfatiza o processo de formulação do Pronacampo, iniciado pelas reivindicações dos movimentos sociais organizados e sistematizado por grupos de trabalho, como uma elaboração "em cultura de cooperação" (FERROLA, 2013, p. 118).

Contudo, é fundamental observar a ausência de dois atores centrais em um processo como esse: as instâncias subnacionais e as escolas do campo. O Brasil é uma República Federativa, onde os estados (mais o Distrito Federal) e os municípios são agentes importantes a serem envolvidos na formulação de políticas públicas, especialmente na área educacional, pois, tendo o governo federal a responsabilidade de elaborar as diretrizes básicas, caberá aos governos estaduais e municipais o oferecimento dos serviços diretamente à população. No entanto, a presença desses entes federados está contida apenas na participação de duas associações: o Consed e a Undime. 
Em relação às escolas do campo, sua presença nesse processo ocorre apenas com os Centros Educativos Familiares de Formação em Alternância (Ceffas), representados pela União das Escolas Famílias Agrícolas do Brasil (Unefab). Não há a presença de órgão representativo das escolas ou de sindicatos de professores nessa instância de diálogo e negociação, a diversidade das diversas escolas do campo, portanto, não foi contemplada nessa etapa.

Essas considerações são ratificadas pelo posicionamento das instâncias que representam os movimentos sociais ligados ao Movimento de Educação do Campo. Por meio do documento Notas para Análise do Momento Atual da Educação do Campo (FONEC, 2012), os movimentos sociais que integram o Fonec expõem a fragilidade desse processo de colaboração durante a formulação do Pronacampo:

\begin{abstract}
Vale destacar que a presença dos movimentos e organizações sociais em reuniões que debateram a construção do Programa na Comissão Nacional de Educação do Campo (Conec/MEC), não conseguiu assegurar que ele atendesse a expectativa proposta pelo Decreto $n^{0}$ 7352. Muitas ações incluídas no Pronacampo não passaram pelo debate na Conec, sendo resultado de discussões internas ao governo, e seguindo a lógica das orientações políticas que vêm sendo explicitadas em políticas públicas apresentadas à sociedade, a exemplo do Pronatec (FONEC, 2012, p. 17).
\end{abstract}

Recorrendo à abordagem de Mainardes (2006), pode-se perceber que, durante a formulação do Pronacampo, os movimentos sociais conquistaram espaço no contexto de influência, pois, participando dessa fase em que os discursos foram construídos, puderam disputar autoridade na definição das finalidades do referido programa. Contudo, há indícios de que as demandas e/ou os interesses mais estreitos dos movimentos sociais perderam articulação na etapa seguinte, ou seja, no contexto de produção do texto legal que oficializa o Pronacampo.

O Pronacampo é formado por quatro eixos de atua- 
ção com cinco, quatro, duas e seis ações ou programas, respectivamente. No eixo 1 (Gestão e Práticas Pedagógicas), estão situadas as ações relacionadas ao trabalho pedagógico dos(as) professores(as), às questões intrínsecas à gestão e ao funcionamento da escola de modo geral. Embora as ações nesse eixo configurem, em sua maioria, programas já existentes no MEC, ele apresenta cenário positivo e afinidade pertinente com a realidade.

\section{a) Programa Nacional do Livro Didático (PNLD) Campo}

Instituído a partir de edital realizado em 2011 (Edital PNLD/FNDE n 5/2011), busca fomentar a produção de obras didáticas condizentes com as Diretrizes Operacionais da Educação do Campo e, assim, garantir que os livros didáticos usados nas escolas do campo estejam coerentes com a matriz referencial da Educação do Campo.

No Guia de Livros Didáticos (BRASIL, 2012a) do PNLD Campo 2013, pesquisadores referência nos estudos de Educação do Campo, como Maria Isabel Antunes Rocha e Mônica Castagna Molina, estavam na Comissão Técnica responsável pela avaliação das obras inscritas no edital. Isso indicava qualidade na intenção de alcançar o objetivo proposto.

Contudo, o desafio dessa ação, avaliada como positiva, está em duas questões: (a) conseguir a adesão das editoras na produção de livros didáticos nessa perspectiva (nos dois processos de escolha já realizados - PNLD Campo 2013 e PNLD Campo 2016 -, havia apenas duas coleções como opções para as escolas do campo); e (b) avançar nas etapas de ensino envolvidas nesse processo de escolha, pois apenas os Anos Iniciais do Ensino Fundamental foram contemplados com a possibilidade de escolher um livro didático específico para as escolas do campo. 


\section{b) Programa Nacional Biblioteca da Escola (PNBE)}

Temático

A partir de edital específico realizado em 2012, essa ação, que já era garantida às escolas do campo, passou a ter como critério a disponibilização de obras com temáticas da educação indígena, do campo e quilombola, entre outras pertinentes ao contexto de Educação do Campo. A implementação contemplou a entrega das coleções aos sistemas de ensino, entretanto, o acervo é insuficiente (em número e em frequência de aquisição) em relação à demanda de livros necessários para o fomento à leitura nas escolas do campo.

\section{c) Mais Educação Campo}

Assim como o PNBE Temático, essa ação passou na época apenas por ajustes de conteúdo. Em 2012, acrescentou, entre seus macrocampos (propostas de trabalho para o contraturno escolar), atividades como Agroecologia e Memória e História das Comunidades Tradicionais, buscando oportunizar a elaboração de planos de atendimento mais próximos do Projeto Político-Pedagógico das unidades escolares do campo.

Seu elo crítico está no financiamento. Apresentando-se como política indutora de educação em tempo integral, o Mais Educação Campo não estimula os estados e municípios ao processo de adesão, pois os governos subnacionais, por questões de infraestrutura e/ou logística locais, arcam com várias demandas não previstas na contrapartida.

\section{d) Programa Escola da Terra}

Substituindo o Programa Escola Ativa, duramente criticado pelos movimentos sociais ligados ao campo, o 
Escola da Terra, mediante processos de formação de professores que atuam em turmas multisseriadas dos Anos Iniciais do Ensino Fundamental e escolas quilombolas, buscou fortalecer a escola como espaço de vivência social e cultural dos povos do campo.

Segundo o representante da Coordenação Nacional do Pronacampo: A Escola Ativa tinha um papel específico muito voltado para professores leigos, o Escola da Terra ele amplia isso na formação estimulando que os professores também possam ter um percurso de formação mais ampliado. Ele também atua na própria produção de material didático dentro desse eixo que o Pronacampo contempla, então é uma visão diferenciada.

O curso de aperfeiçoamento, de, no mínimo, 180 horas, realizado dentro do Escola da Terra, propõe metodologia centrada na alternância entre encontros presenciais, no tempo universidade (de 90 a 120 horas) e atividades no tempo escola-comunidade (de 60 a 90 horas), sob a coordenação da Instituição Formadora.

A limitação do programa está, novamente, centrada no estímulo à adesão por parte dos estados e municípios. O curso deve ser vivenciado diretamente com os(as) professores(as), não há, a exemplo de ações anteriores, o trabalho com formadores multiplicadores que participam da formação e depois "repassam" essa vivência localmente. Considerando-se que as atividades presenciais ocorrem na sede da Unidade Formadora, os estados e municípios têm que assumir os custos com hospedagem, alimentação e transporte de todos os participantes.

No contexto do Pronacampo, pertinente a esse eixo de atuação, também foram consolidadas ações legais, com vistas a amparar melhor as escolas e a Educação do Campo, como as aprovações:

- Do PL nº 3.534/2012, para alteração da Lei n 9.394, de 20 de dezembro de 1996, com alteração da Lei no 9.394, de 20 de dezembro de 1996, que estabelece as diretrizes e bases 
da educação nacional, para fazer constar a exigência de manifestação de órgão normativo do sistema de ensino para o fechamento de escolas do campo, que deverá considerar “a justificativa apresentada pela Secretaria de Educação, a análise do diagnóstico do impacto da ação e a manifestação da comunidade escolar."

- Da Medida Provisória no 562 de 2012, convertida na Lei no 12.695 de 25 de julho de 2012 para viabilizar assistência financeira à oferta da Educação do Campo, contemplando a proposta pedagógica por alternância realizada por instituições conveniadas com os sistemas de ensino, a educação de jovens e adultos por meio da proposta Saberes da Terra e o Programa Nacional da Reforma Agrária - Pronera (BRASIL, 2013b, p. 3).

Em relação à Medida Provisória no 562/2012, é bastante significativa a inclusão das Ceffas no Fundeb. No caso do Projeto de Lei (PL) no 3.534/2012, que regulamenta a questão do fechamento das escolas do campo, problema de enorme gravidade no país, considera-se positiva a tentativa de dificultar o referido processo. No entanto, Kuhn (2015) alerta:

[...] é recorrente na literatura sobre como funcionam os conselhos que deliberariam pelo fechamento ou não. Em grande parte, eles são muito manipulados pelos poderes locais e são, também, pouco representativos da sociedade. Assim, mais uma vez, se reafirma a necessidade da presença, vigilância e mobilização constantes dos movimentos sociais para tentar evitar o processo de fechamento das escolas [...] (KUHN, 2015, p. 198-199).

O eixo 2, Formação Inicial e Continuada de Professores, contempla as ações: Procampo, Expansão de polos da UAB, Curso de Extensão, Aperfeiçoamento e Especialização (PDE Interativo), Observatório de Educação e Programa de Extensão Universitária (Proext). Entre as propostas previstas no Pronacampo, as ações desse eixo apresenta maior afinidade com as concepções históricas da Educação do Campo. O programa acolhe a política para a área concebida pelos movimentos sociais (FONEC, 2012) e mantém as características da proposição originária da li- 
cenciatura em Educação do Campo - Procampo, contudo, atualmente há.

Os movimentos sociais reconhecem a conservação dos pressupostos ético-filosóficos da Educação do Campo nas ações propostas para a Formação Inicial e Continuada de Professores, mas não deixam de pontuar aspectos que exigem debate contínuo:

Questões que deveremos seguir discutindo: qual a importância do Pronacampo ter incorporado esta proposta político-pedagógica de formação inicial dos professores do campo; quais os avanços e as contribuições que as Licenciaturas em Educação do Campo podem trazer à proposta de formação dos camponeses, na perspectiva de contribuir com a transformação do modelo de desenvolvimento hegemônico no campo e com as mudanças na sociedade brasileira (FONEC, 2012, p. 21).

O Pronacampo estabeleceu uma meta de formação de educadores do campo para os três primeiros anos de sua vigência, distribuindo-a entre três estratégias de formação de educadores do campo: (a) os cursos do Procampo; (b) os cursos desenvolvidos mediante a Plataforma Freire, via Parfor; e (c) os cursos pontuados como elo crítico entre as ações desse eixo, realizados mediante a educação a distância, via UAB.

O movimento da Educação do Campo tem avaliado a formação de educadores à distância por um elo crítico do Pronacampo. Por acreditar que essa modalidade, por suas características, não dá conta das diferentes dimensões da formação profissional necessária ao projeto educativo dos trabalhadores (FONEC, 2012), o movimento tem se posicionado contrário à essa estratégia de formação de educadores do campo:

Convém relembrar que o tema da formação inicial de educadores à distância e os gravíssimos problemas e lacunas que gera a partir de uma perspectiva multilateral de formação, tem sido foco de intensos debates, também pelas organizações que estudam e pesquisam o tema como, por exemplo, 
a Associação Nacional pela Formação de Profissionais da Educação - Anfope e a Associação Nacional de Pós-Graduação e Pesquisa em Educação - Anped, e mais recentemente, pela Conferência Nacional de Educação - Conae. Todas elas são unânimes em criticar duramente a formação inicial de educadores a distância (FONEC, 2012, p. 22).

Essa posição não significa negar o direito (e até dever) dos educadores e educadoras das escolas do campo em formação de acessar novas tecnologias e ampliar sua prática pedagógica a partir de experiências dessa nature$\mathrm{za}$, trata-se de estabelecer como papel secundário e não central dessas tecnologias nas atividades de formação inicial e/ou continuada dos(as) professores(as).

O Procampo se apresenta como sendo uma consistente proposta de formação de docentes para o campo, e tece, no contexto do Pronacampo, relação positiva com os pressupostos ético-filosóficos da Educação do Campo. Entretanto, é fundamental que haja acompanhamento contínuo à proposta, para que seu sentido essencial não seja alterado.

Além disso, é também essencial a vigilância constante em relação às condições de funcionamento do Procampo. Em pronunciamento recente, a Comissão Nacional de Avaliação das Licenciaturas de Educação do Campo sinaliza uma derrocada da manutenção dos cursos em todo país. Segundo avaliação da comissão, todos os 42 cursos em funcionamento no Brasil necessitam de recursos para alimentação e transporte.

O eixo 3, EJA e EPT, inclui apenas dois programas (Pronatec - Cursos, Bolsa-Formação e eTec - e o EJA Saberes da Terra), no entanto, é a linha de atuação do Pronacampo mais fortemente criticada. São diversos os questionamentos e aspectos tomados como contrários aos princípios da Educação do Campo, pela participação dos setores ligados ao agronegócio brasileiro na formatação do Pronatec Campo, esse eixo é considerado território visível da intervenção do Estado pela configura- 
ção do projeto dominante de educação.

“Ou seja, há uma disputa em torno da Educação do Campo e o Pronacampo é a expressão mais clara dessa disputa. Está sendo no contexto do Pronacampo que as contradições estão se tornando mais evidentes" (KUNH, 2015, p. 213).

A oferta do Pronatec pelo Serviço Nacional de Aprendizagem Rural (Senar) e o espaço de influência dado à Confederação Nacional da Agricultura (CNA), sempre ilustrado pelas presenças e falas da senadora Kátia Abreu (Partido Social Democrático (PSD)/TO), representante da bancada ruralista no Congresso Brasileiro, em eventos públicos relacionados à área: no próprio lançamento do Pronacampo, a senadora foi a única parlamentar que usou a palavra, mesmo estando instituída no Congresso a Frente Parlamentar pela Educação do Campo, presidida pelo deputado federal Padre João (Partido dos Trabalhadores $(\mathrm{PT}) / \mathrm{MG})$, que, ainda presente no ato, não se pronunciou durante a cerimônia.

Nesse contexto, o que o Pronatec sinaliza sobre a política de educação profissional no Brasil é que:

[...] trata-se de assumir como política de educação a concepção pragmática da "instrução que serve ao mercado", dentro de uma opção cada vez mais explícita por um projeto de capitalismo neoliberal e dependente. $\mathrm{O}$ embate atual sobre as novas diretrizes da educação profissional, em que o Pronatec se insere, demonstra um grande retrocesso em relação às primeiras discussões dos próprios governos desse período [...] (FONEC, 2012, p. 18).

O Fonec destaca, ainda, o Pronatec, no contexto do Pronacampo, como uma estratégia de "inclusão enviesada":

[...] o desenho do Pronatec como um todo, integrando a política educacional brasileira atual, precisa ser entendido na mesma característica de ambivalência que ordena o conjunto das ações do governo federal: trata-se de uma política 
de pretensa inserção social, preparando mão-de-obra para uma expansão conjuntural (e precária) de empregos. Não chega a integrar uma estratégia de desenvolvimento nacional (que incluiria prioridade à indústria e à perspectiva de soberania alimentar, energética, territorial), mas ao mesmo tempo se coloca na perspectiva de democratização do acesso ao ensino técnico visando um projeto que se apresenta à sociedade como desenvolvimentista e inclusivo (FONEC, 2012, p. 18).

A "inserção produtiva" tratada como conquista aos trabalhadores do campo tem, por um lado, o caráter estratégico para a preparação de mão de obra para o trabalho de baixa qualidade que o agronegócio demanda e, por outro, representam alternativas de preparação técnica para amenizar a situação dos chamados "agricultores pobres", tentando-se, assim, trabalhar com a política ardilosa do "espaço para todos" dentro do agronegócio: da monocultura de exportação aos os pequenos agricultores que produzem sua subsistência (FONEC, 2012). Esse cenário é um elo extremamente crítico na configuração do Pronacampo, pois toma esse programa como recurso de construção da hegemonia da agricultura capitalista que se pretende dominante no âmbito das políticas educacionais.

O eixo 4, Infraestrutura Física e Tecnológica, reúne seis ações: Construção de Escolas, Inclusão Digital, PDDE Campo, PDDE Água, Luz para Todos e Transporte Escolar. Esses programas são vistos como bastante significativos no sentido de qualificar a estrutura de funcionamento das escolas do campo. Além de medidas paliativas, como a de Inclusão Digital, realizada mediante a disponibilização de notebook do programa Um Computador por Aluno (UCA), para as escolas com até 20 matrículas (quando seria ideal a garantia de infraestrutura para instalação de laboratório), esse eixo do Pronacampo traz na Construção de Escolas e no Transporte Escolar ações que demandam observações mais específicas.

A Construção de Escolas demandada no âmbito do 
Pronacampo utiliza a definição prévia da arquitetura padronizada dessas escolas, utilizando com instrumento de regularização um "Edital de Regime Diferenciado de Contratações Públicas para Registro de Preços de Construção de Escolas Padronizadas do Pronacampo" (BRASIL, 2013b, p. 15). Esse aspecto fere o reconhecimento dos diferentes campos que compõem a Educação do Campo, haja vista que as diferenças de clima e relevo no Brasil são bastante significativas e impõem especificidades para qualquer tipo de construção civil.

Em sua fala, o representante da Coordenação Nacional do Pronacampo admite que, embora a construção de escolas no campo seja positiva, a padronização dos projetos de construção é aspecto frágil para gerenciar: O MEC disponibiliza determinados padrões de escolas, assim, você garante de certa forma uma qualidade também e tal. Tem uma série de fatores que é positivo essa questão, mas por outro lado também foge muito da realidade, então a gente tem muita dificuldade nesse contexto, principalmente quando a gente trabalha com educação indígena não é, ou mesmo com os quilombos, e há alguns casos também com algumas comunidades de escolas de campo que tem uma determinada característica e que as vezes aquele padrão ali não se adequa.

O Transporte Escolar, na contramão da construção de escolas, pode impulsionar o fechamento de unidades escolares no campo. É inquestionável a importância da aquisição de lanchas, bicicletas e ônibus escolares destinados ao atendimento da população do campo. No entanto, se o cumprimento dos termos do PL no $3.534 / 2012$ não tiver o acompanhamento das organizações que atuam na Educação do Campo, junto com a Frente Parlamentar de Educação do Campo, a ampliação da possibilidade de transportar os alunos, intra ou extracampo, pode estimular o fortalecimento da política de nucleação de escolas do campo. 
Em linhas gerais, o Pronacampo promoveu uma reforma superficial em relação às ações educacionais destinadas ao campo brasileiro. Mesmo agregando os programas, na tentativa de unidade, o Pronacampo não promoveu uma transformação, de fato, estrutural nesse âmbito. Elementos centrais da política ficam a cargo dos governos subnacionais, que apenas "recebem" sua demanda ou indicação de "contrapartida", sem que seja garantida a discussão prévia de quais são as condições ou insumos necessários para a materialização qualitativa dessas ações em seus territórios.

O objetivo do programa, "disponibilizar apoio técnico e financeiro aos Estados, Municípios e Distrito Federal para a implementação da Política de Educação do Campo" (BRASIL, 2013b, p. 6) indica a fragilidade da relação entre os entes federados para a implementação das ações previstas.

Essa questão também é uma percepção da Coordenação Nacional, por meio da fala de seu representante:

O Pronacampo é a política. Ele resume a política de educação do MEC para a Educação do Campo, ele consiste muito mais em um auxílio, uma ajuda aos municípios técnica e financeiramente para desenvolver as ações que contribuem para o fortalecimento da população da educação do campo, entendendo essa com a sua diversidade, com a sua especificidade, com as características pertinentes ao campo (grifo nosso).]

Esse caráter superficial entre os governos subnacionais para a implementação das ações do Pronacampo é respaldado no modelo federativo brasileiro. Tomando-se esse fato como basilar na análise, destaca-se o que Souza (2013), ao analisar o percurso das políticas de Educação do Campo nos governos petistas de 2003 a 2011, conclui sobre a relação entre Estado e movimentos sociais: "Dessas relações o que constamos é que, o Estado, enquanto instrumento de classe, vai sempre agir para a manutenção 
da ordem, com algumas concessões a depender da correlação de força, da classe ou da fração de classe que estiver no poder" (SOUZA, 2013, p. 24).

O Pronacampo, segundo a autora, situa-se no período e, que foi necessário "ceder para incorporar". Assim, o referido programa carrega, em sua gênese, os conflitos estabelecidos entre a Educação Rural e a Educação do Campo. Por seus elos críticos, pode-se situar o Pronacampo muito mais próximo a uma política de "Educação Rural", considerando-se todos os aspectos que essa definição carrega na forma de pensar a política educacional para os trabalhadores do campo no Brasil, do que dos sujeitos e das práticas sociais que constituem a Educação do Campo. "O Pronacampo não é linearmente contra os trabalhadores, mas também não representa a vitória do polo do trabalho na definição da política" (FONEC, 2012, p. 17).

\section{Considerações finais}

O conhecimento produzido neste estudo permite dialogar sobre aspectos significativos da política de educação do campo implementada no Brasil, ressaltando as questões centrais reveladas através do Pronacampo.

A ampliação dos sujeitos envolvidos na discussão que antecedeu a criação do Pronacampo indica uma inovação no modo de conceber as relações entre as instituições e/ou sujeitos coletivos num contexto de formulação de políticas públicas, contudo, as instâncias subnacionais e as escolas do campo, atores centrais no âmbito da questão, estiveram presentes nesse processo apenas pela representação pertinente ao Consed, à Undime e à Unefab, respectivamente.

Essa fragilidade de representatividade, somada à diferença significativa de poder político entre as diversas organizações, implicou expressivamente o equilíbrio do poder de deliberação, requerendo dos movimentos sociais 
esforço superior para garantir a valorização de suas demandas, o que não impediu que questões consideradas importantes fossem pouco discutidas e inseridas no Pronacampo sem a aprovação dessas instâncias.

Assim, observa-se que, entre o Pronacampo teoricamente discutido, numa tentativa de valorização do diálogo intra e extragovernamental, e o Pronacampo institucionalizado pelo texto legal há limitações e/ou questionamentos impostos, na perspectiva da construção coletiva, por aqueles que deveriam ser seus próprios autores.

Sobre a convergência entre a proposta de atuação do Pronacampo e os princípios/diretrizes da concepção de Educação do Campo, destaca-se a definição de "populações do campo" a partir dos termos do Decreto $\mathrm{n}^{\circ}$ 7.352/2010, reconhecendo como fundamento a concepção que está na base dos Documentos Finais da I Conferência Nacional por uma Educação Básica do Campo, realizada em 1998: todos os grupos sociais que vivem no campo têm o direito de uma política pública de educação específica que os atendam.

Outro ponto que também merece destaque é o não estabelecimento da questão agrária como diretriz das suas ações educacionais. Assim como no objetivo geral do programa, faltou ao Pronacampo assumir que a Educação do Campo nasceu como crítica/denúncia ao conceito de campo e ao modelo de educação para esse campo, perpetuados pelo Estado brasileiro.

Em relação à estrutura/desenho de atuação, o Pronacampo é composto por diversas ações menores, com processos de formação específicos e características diversas entre si. Essa complexidade, latente pelo caráter de programa "guarda-chuva", ressalta ao Pronacampo, além da existência de significativas demandas em torno da Educação do Campo, o poder de evidenciar a disputa em torno do projeto, considerando-se a multiplicidade de "filosofias" expressas nas ações que seus eixos de atuação incor- 
poram.

Em linhas gerais, o Pronacampo promoveu uma reforma superficial em relação a política educacional destinada ao campo brasileiro. Pelos conflitos estabelecidos entre a Educação Rural e a Educação do Campo em seu interior, pode-se situar o Pronacampo, portanto, muito mais próximo a uma política de "Educação Rural", considerando-se todos os aspectos que essa definição carrega na forma de pensar a política educacional para os trabalhadores do campo no Brasil, do que dos sujeitos e das práticas sociais que constituem a Educação do Campo.

\section{REFERÊNCIAS}

ALENCAR, M. F. S. Educação do Campo e a Formação de Professores: construção de uma política educacional para o campo brasileiro. Ciência \& Trópico, Recife, v. 34, n. 2, p. 207-226, 2010.

ARROYO, M. G. Por um tratamento público da educação do campo. In: MOLINA, M. C.; JESUS, S. M. S. A. Educaçã̃o do campo: contribuições para a construção de um projeto de educação do campo. Brasília: Articulação Nacional por Uma Educação do Campo, 2004. (Coleção por uma Educação do Campo, 5). p. 92-98.

BARDIN, L. Análise de conteúdo. Lisboa: Edições 70, 2011. BOURDIEU, P.; CHARTIER, R. O sociólogo e o historiador. Belo Horizonte: Autêntica, 2011.

BRASIL. Decreto no 7.352, de 4 de novembro de 2010. Dispõe sobre a política de educação do campo e o Programa Nacional de Educação na Reforma Agrária - Pronera. Diário Oficial [da] República Federativa do Brasil, Brasília, DF, 5 nov. 2010a.

. Ministério da Educação. Guia de livros didáticos: PNLD Campo 2013. Brasília: MEC, 2012a.

Ministério da Educação. Portaria MEC no ${ }^{\circ 6}$, de $1^{\circ}$ de fevereiro de 2013. Institui o Programa Nacional de educação do Campo - Pronacampo, e define suas diretrizes gerais. Diá- 
rio Oficial [da] República Federativa do Brasil, Brasília, DF, 4 fev. 2013a.

Ministério da Educação. Secretaria de Educação Continuada, Alfabetização, Diversidade e Inclusão. Educação do Campo: marcos normativos. Brasília: MEC/Secadi, 2012b.

- Ministério da Educação. Secretaria de Educação Continuada, Alfabetização, Diversidade e Inclusão. Programa Nacional de Educação do Campo (Pronacampo): Documento Orientador. Brasília: MEC/Secadi, 2013b.

Ministério da Educação. Secretaria de Educação Continuada, Alfabetização, Diversidade e Inclusão. Pronacampo. Brasília: MEC/Secadi, 2012c.

CALDART, R. S. A escola do campo em movimento. In: CÉSAR, B.; CALDART, R. S. (Orgs.) Educação do Campo: Projeto popular e escolas do campo. Brasília: Incra; MDA, 2000. p. 6081. (Nead Especial, 3).

. Por uma educação do campo: traços de uma identidade em construção. In: ARROYO, M. G.; CALDART, R. S.; MOLINA, M. C. (Orgs.). Por uma Educação do Campo. Petrópolis: Vozes, 2009, p. 147-160.

. Educação do Campo. In: CALDART, R. S.; PEREIRA, I. B.; ALETANJANO, P.; FRIGOTTO, G. (Orgs.). Dicionário da Educação do Campo. Rio de Janeiro, São Paulo: Escola Politécnica de Saúde Joaquim Venâncio, Expressão Popular, 2012. p. 257-264.

CRESWELL, J. W. Projeto de pesquisa: métodos qualitativo, quantitativo e misto. Tradução de Magda Lopes. 3. ed. Porto Alegre: Artmed, 2010.

FERNANDES, B. M. Diretrizes de uma caminhada. In: ARROYO, M. G.; CALDART, R. S.; MOLINA, M. C. (Orgs.). Por uma Educação do Campo. Petrópolis: Vozes, 2009. p. 133-146.

FEROLLA, L. M. Processos colaborativos na gestão pública: estudo das relações estabelecidas no contexto do Programa Nacional de Educação do Campo. 2013. 206 f. Dissertação 
(Mestrado em Administração de Organizações) - Universidade de São Paulo, Ribeirão Preto, 2013.

\section{FÓRUM NACIONAL DE EDUCAÇÃO NO CAMPO. Notas} para análise do momento atual da Educação do Campo. Brasília, 2012.

FRIGOTTO, G. Projeto societário contra-hegemônico e Educação do Campo: desafios de conteúdo, método e forma. In: MUNARIM, A.; BELTRAME, S.; CONDE, S. F.; PEIXER, Z. I. Educação do Campo: reflexões e perspectivas. 2. ed. Florianópolis: Insular, 2011. p. 19-46.

GIL, A. C.. Métodos e técnicas de pesquisa social. 6. ed. São Paulo: Atlas, 2008.

HALL, P. A.; TAYLOR, R. C. R. As três versões do Neo-institucionalismo. Lua Nova, São Paulo, n. 58, p. 193-223, 2003.

KUHN, E. R. A. Análise da política de educação do campo no Brasil: meandros do Pronera e do Pronacampo. 2015. 287 f. Tese (Doutorado em Geografia) - Universidade Federal da Bahia, Salvador, 2015.

MAINARDES, J. Abordagem do ciclo de políticas: uma contribuição para a análise de políticas educacionais. Educação \& Sociedade, Campinas, v. 27, n. 94, p. 47-69, jan./abr. 2006.

MOLINA, M. C.; FREITAS, H. C. A. Avanços e desafios na construção da Educação do Campo. Em Aberto, Brasília, v. 24, n. 85, p. 17-31, abr. 2011.

MOLINA, M. C. Políticas públicas. In: CALDART, R. S.; PEREIRA, I. B.; ALETANJANO, P.; FRIGOTTO, G. (Orgs.). Dicionário da Educação do Campo. Rio de Janeiro, São Paulo: Escola Politécnica de Saúde Joaquim Venâncio, Expressão Popular, 2012. p. 585-593.

MUNARIM, A. Prefácio - Educação do Campo: desafios teóricos e práticos. In: MUNARIM, A.; BELTRAME, S.; CONDE, S. F.; PEIXER, Z. I. Educação do Campo: reflexões e perspectivas. 2. ed. Florianópolis: Insular, 2011. p. 9-18.

RIBEIRO, M. Educação Rural. In: Dicionário da Educação do 
Campo. Rio de Janeiro, São Paulo: Escola Politécnica de Saúde Joaquim Venâncio, Expressão Popular, 2012, p. 293-298.

SANTOS FILHO, J. C.; GAMBOA, S. S. Pesquisa educacional: quantidade-qualidade. 4. ed. São Paulo: Cortez, 2001.

SOUZA, R. L. Educação do Campo: análise das reivindicações dos trabalhadores do campo e das propostas dos governos de Luiz Inácio Lula da Silva e Dilma Rousseff. Revista Tamoios, São Gonçalo, n. 2, p. 5-28, jul./dez 2013.

SPOSITO, M. E. B.; WHITACKER, A. M. (Orgs.). Cidade e campo: relações e contradições entre urbano e rural. São Paulo: Expressão Popular, 2006.

VEIGA, J. E. Cidades imaginárias: o Brasil é menos urbano do que se calcula. Campinas: Autores Associados, 2002. 


\section{CAPÍTULO 10}

\section{FORMAÇÃO DE PROFESSORES EM CIÊNCIAS HUMANAS E SOCIAIS NA EDUCAÇÃO DO CAMPO}

\section{Alexandre Alves de Andrade ${ }^{1}$ \\ Marcos Paulo de Azevedo}

Pensar a formação de professores para o ensino de Ciências Humanas e Sociais no Brasil requer um exercício de compreensão da institucionalização de um currículo de Ciências Humanas e Sociais na escola brasileira, considerando as especificidades e condicionantes políticos, econômicos e sociais de cada período histórico. Desse modo, estruturamos este texto em três partes, considerando: 1) a institucionalização do currículo de Ciências Humanas e Sociais, de influência francesa, que vigorou no Brasil até meados do século XX; 2) a ruptura democrática ocorrida nos anos 1960 com o golpe militar e seus reflexos na escola e na formação de professores; e 3) a redemocratização do país no final dos anos 1980 e o fortalecimento dos movimentos sociais, em especial o movimento camponês.

$\mathrm{Na}$ exposição, estabelecemos o elo entre esses momentos históricos e a efetivação do currículo de Ciências Humanas e Sociais, com foco na escola do campo. O objetivo deste texto é mostrar as descontinuidades na formação de professores como estratégia de manutenção da estrutura de classe pautada pelos interesses latifundiários e a negação de um currículo das Ciências Humanas e Sociais que leve em consideração a realidade do camponês e contribua para superação das dificuldades. O texto não tem a pretensão de abarcar toda discussão acerca da temática apresentada, espera, em vez disso, contribuir com a discussão e o fortalecimento teórico sobre a formação de

\footnotetext{
${ }^{1}$ Doutorando em Geografia - UFRN

${ }^{2}$ Mestre em Letras - UERN
} 
professores, e em especial sobre a formação de professores com foco em uma proposta educativa que considere as múltiplas realidades postas no campo brasileiro, entendo o campo como um território marcado por usos e interesses distintos que imprimem marcas de apropriação, expropriação e delimitação de poderes.

Acreditamos que a Educação do Campo é um instrumento na delimitação de um território camponês soberano em saberes articulados entre o conhecimento escolar e a conhecimento prático das ações cotidianas, com vistas à superação das desigualdades sociais, à formação cidadã e à construção de uma escola capaz de atender às necessidades dos povos do campo, historicamente marginalizados.

\section{A formação de professores no contexto da escola do campo no Brasil}

A oferta das Ciências Humanas no Brasil decorreu, num primeiro momento, da necessidade de preparar os filhos da elite nacional ao ingresso nas faculdades de Direito, Medicina e Engenharia. Em 1837, a oferta das disciplinas de História e Geografia passam a ser obrigatórias no Colégio Pedro II, no Rio de Janeiro. Soma-se a este currículo secundarista de Ciências Humanas o estudo de Literatura, Oratória e tópicos de realidade brasileira. O intuito destes componentes curriculares era o fortalecimento do sentimento patriótico e nacionalista. Metodologicamente, as práticas pedagógicas pautavam-se na memorização de fatos, nomes de rios, descrição da paisagem e de acontecimentos do cotidiano. A escola no Brasil recebia fortes influências do pensamento francês na organização das Ciências Humanas e Sociais e dos ideais difundidos pela Belle Époque (VLACH, 2004).

A escola e o currículo desse período (1837-1950) estavam destinados à educação da classe latifundiária, que se reproduzia enquanto classe política do país. Aos filhos 
do camponês, quando lhe era possível frequentar a escola, tinha acesso, apenas, aos estudos iniciais destinados à alfabetização. Neste modelo de ensino a intenção principal era manter inalterada a ordem social e a estrutura de classe vigente. $\mathrm{O}$ reflexo nítido e claro desta realidade era uma enorme massa de trabalhadores rurais analfabetos (MOLINA E ANTUNES-ROCHA, 2014).

Os professores que atuavam no exercício das Ciências Humanas e Sociais, em sua maioria, eram oriundos dos grupos políticos e econômicos que comandavam a vida no país. Esses sujeitos não recebiam formação específica ao magistério, tão pouco ao ensino das Ciências Humanas e Sociais; a maior parte eram advogados, padres, engenheiros ou sujeitos autodidatas que apresentam afeição pelas questões sociais e se autodeclaravam humanistas (ROCHA, 2000).

Nos anos de 1930 o ensino de Ciências Humanas e Sociais passa por mudanças, influenciado pela criação das faculdades de Geografia, História e Ciências Sociais dentro da Universidade de São Paulo e posteriormente na Universidade Nacional, no Rio de Janeiro. Os cientistas franceses Fernand Braudel, Emile G. Leornad, Lucien Febvre, Emile Coonaert, Pierre Monbeig, Claude Lévi Strauss, Paul Arbousse Bastide, Pierre Deffontaines (NADAI, 1993) foram alguns dos nomes que contribuíram para a criação de cursos universitários e métodos de pesquisas para formação de professores. Este momento tornasse um avanço na formação de professores e na formação de um currículo que abarcasse uma educação mais contextualizada com a realidade.

No entanto, estas mudanças que vieram com a criação das Faculdades de Geografia, História e Ciências Sociais foram interrompidas com o golpe militar de 1964, assim como o direcionamento dado à política educacional (VLACH, 2004). Dentre as mudanças impostas, ocorreu a retirada do currículo da educação básica das disciplinas 
de Geografia e História e em seus lugares ocorre a criação e a obrigatoriedade da disciplina de Estudos Sociais. Para Versentini (1996), a disciplina de Estudos Sociais mascarava a intenção do governo militar de sufocar uma educação crítica e libertadora.

Estas rupturas iniciam um segundo momento na formação de professores das Ciências Humanas e Sociais, marcando um agravamento das condições de vida do homem do campo, uma vez que mantiveram os privilégios da classe latifundiária, trançando políticas de educação aos trabalhadores desvinculada da realidade - o que não possibilitava a emancipação política, econômica e social destes sujeitos. Um exemplo disso foi o Movimento Brasileiro de Alfabetização (MOBRAL).

O golpe militar também foi um golpe na luta pela distribuição de terras e na luta dos movimentos sociais por condições dignas de moradia no campo. Como destaca Fernandes (2012), o campo brasileiro é um território historicamente marcado pela opressão ao camponês. Os movimentos sociais da época, como a União dos Lavradores e Trabalhadores Agrícola do Brasil (ULTAB), Movimento dos Agricultores Sem Terra (MASTE) e as Ligas Camponesas foram duramente perseguidos, seus líderes torturados e mortos e suas famílias, destruídas. Os interesses dos latifundiários foram incorporados nas ações do Estado brasileiro (GRAZIANO DA SILVA, 1998, GONGALVES NETO, 1997).

Surge neste período as Licenciaturas curtas, cursos de graduação com duração de dois anos, ofertados, na maior parte das vezes, nas áreas interioranas do país. Uma formação rasa com o intuito de promover uma atuação profissional rasa também. A expansão das escolas no campo denominada de escolas rurais, assim com as escolas das áreas urbanas, permitiam o ingresso de profissionais sem formação específica para o magistério, fato que dificultava ainda mais a construção de um sistema de ensino 
que valorizasse o professor e promovesse a emancipação dos sujeitos.

No âmbito político e econômico, após os anos 1950, o Brasil passa por intenso processo de industrialização e urbanização. As políticas de crédito rural foram direcionadas aos latifundiários, favorecendo a formação dos Complexos Agroindustriais (CAI), promovendo um acirramento dos conflitos pela posse da terra e pela reprodução do camponês no campo (GRAZIANO DA SILVA, 1998). Os CAI são a materialização de um processo excludente de modernização que o campo brasileiro passou. Dentre as consequências nocivas desse processo, comandado pelo Estado, tivemos um intenso êxodo rural e um agravamento dos conflitos no campo, em especial com a negação do Estado na oferta de serviços básicos; como educação e saúde para as populações rurais.

O fim dos anos 1980 e início dos anos 1990 marca o terceiro período que estamos periodizando: a redemocratização. O movimento de retomada da democracia foi seguido e/ou impulsionado pelo fortalecimento dos movimentos sociais do campo, pautado na organização popular, buscando formas de libertação imposta pelo modelo agronegocista de exploração da terra, do trabalho e do homem que modela não só as formas de produzir, mas também as relações sociais, legitimado pelo poder estatal.

A luta pela reforma agrária, tão sucumbida durante os anos de repressão limitar, ganhou novos impulsos e anexou em sua pauta a luta por uma educação pública, gratuita e de qualidade nos espaços do campo, como estratégia de quebrar os laços de subordinação, opressão e alienação impostos pela estrutura latifundiária secular vigente (GUIMARÃES, 1977). A luta por uma efetiva reforma agrária estava agora pautada não só na distribuição de terra, mas por condições dignas de reprodução econômica e social no campo.

A redemocratização do país tornou possível a reto- 
mada das disciplinas escolares das Ciências Humanas e Sociais na Educação Básica, como é caso da História e da Geografia, assim como possibilitou a oferta da disciplina de Sociologia no Ensino Médio. Enquanto medida de direcionamento democrático na esfera educacional tivemos a aprovação da Lei 9.394/96 de Diretrizes e Bases da Educação Nacional, criando as possibilidades de construção de currículos e práticas pedagógicas condizentes com a realidade dos povos do campo, assim as Diretrizes Curriculares Nacionais para Educação Básica definem,

\begin{abstract}
A Educação do Campo, tratada como educação rural na legislação brasileira, tem um significado que incorpora os espaços da floresta, da pecuária, das minas e da agricultura, mas os ultrapassa ao acolher em si os espaços pesqueiros, caiçaras, ribeirinhos e extrativistas. $\mathrm{O}$ campo, nesse sentido, mais do que um perímetro não-urbano, é um campo de possibilidades que dinamizam a ligação dos seres humanos com a própria produção das condições da existência social e com as realizações da sociedade humana (BRASIL, 2013, p. 95-96).
\end{abstract}

A definição clara dos espaços que englobam a Educação do Campo contribui na formação de sujeitos que atuam nesses espaços de modo a articular teoria e prática e promover uma prática pedagógica atrelada à realidade. A redemocratização nacional promoveu significativas mudanças na esfera educacional, em especial na retomada dos cursos de Licenciaturas Plenas e na obrigatoriedade do exercício decente por profissionais licenciados.

Nos anos 1990 os movimentos sociais do campo incluíram em sua agenda de lutas a formação de um currículo que contemplasse não somente os saberem escolares e acadêmicos das áreas de formação, mas também as especificidades e as identidades dos povos do campo em suas multiplicidades de saberem e de culturas. Surge assim, em 1998, o Programa Nacional de Educação na Reforma Agrária (PRONERA), com o objetivo de possibilitar processos formativos para educação do e no campo de modo pleno, 
contextualizado com sua realidade em todos os níveis e modalidades de ensino (MOLINA E ANTUNES-ROCHA, 2014).

Um grande passo para a Educação do Campo no Brasil foi a incorporação da pedagogia da alternância como princípio educativo. O Conselho Nacional de Educação reconheceu em 2006 que a organização curricular por alternância favorece a integração dos conhecimentos escolares e dos conhecimentos cotidianos. Nessa perspectiva, a organização curricular é concretizada na organização do Tempo Escolar (TE) e do Tempo Comunidade (TC), não de modo sectário ou sucessivo, mas de modo a aliar saberes escolares à vivência cotidiana na comunidade, entendida como uma comunidade educativa.

A organização dos processos formativos na Educação do Campo no regime de alternância não é uma mera divisão dos conteúdos ou do tempo de estudo, ou mesmo do local de estudo. O princípio educativo da alternância consiste na organização do currículo reconhecendo o papel desempenhado pela comunidade, pela vivência em grupo, pelos saberes socialmente construídos na formação educacional, política e social do sujeito em um território em que ele é protagonista de suas práticas e saberes (MOLINA, 2012, ANTUNES-ROCHA E MARTINS, 2012).

A organização curricular por alternância divide o processo educativo entre escola e comunidade (TE/TC). Desse modo, os conteúdos estudados devem promover reflexões teóricas e práticas em busca de superar os desafios e adversidades oriundas da vivência coletiva nos espaços do campo, incluindo nessa seara os conflitos promovidos pela desigualdade de poderes exercidos entre a grande empresa agrícola capitalista e a unidade de produção camponesa.

Nesse contexto, para que o currículo das Ciências Humanas e Sociais seja repensando a partir das demandas dos sujeitos do campo e operacionalizado pelo regime da 
alternância é necessário repensarmos a formação dos professores. De modo geral, somos ensinados a pensar de modo fragmentado, não considerando a interdisciplinaridade do conhecimento na vida cotidiana. Superar a dicotomia na formação dos sujeitos que atuarão como docentes, seja no campo ou na cidade, é fundamental para superarmos as desigualdades de pensamento e de ações frente aos problemas que dificultam a existência de uma educação plena, que liberte os sujeitos da alienação vigente, imposta aos espaços do campo. Outro problema nesse cenário são as representações dos espaços do campo em que a ideia de escassez e miséria é colocada como imperativo à vida camponesa, imagem essa difundida no imaginário popular, na literatura, nos livros didáticos e até mesmo nas políticas públicas.

Nesse contexto, surge em 2012 o Programa de Apoio à Formação Superior em Licenciaturas do Campo (PRONACAMPO), incentivando a oferta de cursos de graduação multidisciplinar para formação de professores aptos a atuarem nas escolas do campo. Esse programa é resultado da luta dos movimentos sociais em parcerias com universidades e pesquisadores na construção efetiva de uma proposta educativa pautada na realidade da vida concreta e que possibilite formas concretas de nela intervir (ANTUNES E ROCHA, 2012).

Destarte, a formação de professores das Ciências Humanas e Sociais não pode ser fragmentada. O sujeito docente, enquanto ser coletivo e de identidade coletiva, deve receber em sua formação, construções teóricas complexas que lhe permita compreender a complexidade da sociedade, em especial as lutas forjadas nos espaços do campo, na delimitação e manutenção de territórios (FERNANDES, 2012).

O professor das Ciências Humanas e Sociais deve receber uma formação acadêmica que o faça pensar e agir a partir da realidade em que esteja inserido e possa desen- 
volver estratégias pedagógicas que leve o aluno a pensar sua realidade e as formas de intervir nela, sua escala local de vivência e reprodução social.

A formação do professor da Educação do Campo deve ter como princípio dos seus processos formativos a alteridade, o reconhecimento da diversidade cultural e o respeito à diferença como forma de consolidar a democracia plena, com garantias de acesso e permanência à escola. A Educação do Campo é a materialidade das lutas dos movimentos sociais, como forma de resistência às múltiplas formas de opressão às quais são submetidos os povos do campo, seja pela ação do agronegócio latifundiarista, seja pela omissão do Estado em prover condições dignas de vivência e reprodução social no campo.

\section{Considerações finais}

A atuação dos professores das Ciências Humanas e Sociais na Educação do Campo é fundamental para processos formativos que sejam oriundos da realidade e que promovam emancipação social, econômica, política e intelectual dos sujeitos na busca por educação, terra, dignidade e cidadania na demarcação do território social camponês.

A formação de professores na engenharia educacional brasileira esteve pautada nos interesses classistas e na manutenção da estrutura social vigente, consolidando a expropriação dos povos do campo que, relegados a uma estrutura fundiária excludente, viram na educação uma ferramenta a somar na no pleito de uma reforma agrária capaz de romper com as desigualdades presentes no campo.

A oferta de cursos como as licenciaturas em Educação do Campo é um movimento importante para formar professores que atuarão nas escolas do campo como agentes de transformação, não só educativa, mas, também, na 
estrutura social dos espaços do campo. No entanto, ressaltamos a necessidade de fortalecermos a formação de professores, em especial os da área de Ciências Humanas e Sociais, frente às reformas propostas pelo Estado brasileiro, reformas estas pautadas numa ideia de flexibilização que mascara a intenção de enfraquecer a qualificação de pessoas na atuação docente com estes saberes.

\section{REFERÊNCIAS}

BRASIL. Diretrizes Curriculares Nacionais para a Educação Básica: diversidade e inclusão / Organizado por Clélia Brandão Alvarenga Craveiro e Simone Medeiros. - Brasília: Conselho Nacional de Educação: Ministério da Educação, Secretaria de Educação Continuada, Alfabetização, Diversidade e Inclusão, 2013.

ANTUNES ROCHA, MARTINS, M. de F. A. Tempo escola e Tempo Comunidade: Territórios Educativos na Educação do Campo. In: . ANTUNES-ROCHA, M. I.; MARTINS, M. de F. A.; MARTINS, A. A. (Orgs). Territórios educativos na Educação do Campo: escola, comunidade e movimentos sociais. 2. ed. Belo Horizonte: Gutemberg, 2012.

FERNANDES, B. M. Territórios da Educação do Campo. In:_ . ANTUNES-ROCHA, M. I.; MARTINS, M. de F. A.; MARTINS, A. A. (Orgs). Territórios educativos na Educação do Campo: escola, comunidade e movimentos sociais. 2. ed. Belo Horizonte: Gutemberg, 2012.

GONÇALVES NETO, W. Estado e Agricultura no Brasil: política agrícola e modernização econômica brasileira 1960-1980. São Paulo: Hucitec, 1997.

GRAZIANO DA SILVA, J. Do complexo rural aos complexos agroindustriais. In: . A nova dinâmica da agricultura brasileira. 2. ed. Campinas: Ed.Unicamp: 1998.

GUIMARÃES, A. P. Quatro séculos de latifúndio. 4. ed. Rio de Janeiro: Paz e Terra, 1977.

MOLINA, M. C.; ANTUNES-ROCHA, M. I. Educação do Campo: história, práticas e desafios no âmbito das políticas 
de formação de educadores - reflexões sobre o PRONERA e o PROCAMPO. Revista Reflexão e Ação, Santa Cruz do Sul, v. 22, n. 2, p. 220-253, jul./dez.2014 Disponível em:<http://online. unisc.br/seer/index.php/reflex/index>. Acesso em: 10 out. 2017.

MOLINA, M. C. Educação do Campo: Novas práticas construindo nos territórios. In: . ANTUNES-ROCHA, M. I.; MARTINS, M. de F. A.; MARTINS, A. A. (Orgs). Territórios educativos na Educação do Campo: escola, comunidade e movimentos sociais. 2. ed. Belo Horizonte: Gutemberg, 2012.

NADAI, E. O ensino de história no Brasil: trajetória e perspectiva. Revista Brasileira de História. São Paulo. v. 13, n. 25/26, p. 143-162. 1993. Disponível em: <http://sipeadturmae4. pbworks.com/w/file/fetch/115496701/semana2_ nadai.pdf>. Acesso em: 10 out. 2017.

ROCHA G. O. R. Uma breve história da formação do(a) professor(a) de Geografia no Brasil. Terra Livre. São Paulo: AGB, n.15. 2000.

VESENTINI, J. W. O novo papel da escola e do ensino da geografia na época da terceira revolução industrial. Terra Livre. São Paulo, AGB, n.11-12, p. 209-224, jul. 1996.

VLACH, V. R. F. O ensino de geografia no Brasil: uma perspectiva histórica. In: VESENTINI, J. W. O ensino de geografia no século XXI. Campinas: Papirus, 2004. 



\title{
CAPÍTULO 11
}

\section{PRONACAMPO: os desafios para a consolidação da Educação do Campo como Política Pública}

\author{
Alessandra Gomes de Castro ${ }^{1}$ \\ Patricia Basilio Teles Stabile ${ }^{2}$
}

Sou feita de retalhos. Pedacinhos coloridos de cada vida que passa pela minha e que vou costurando na alma. Nem sempre bonitos, nem sempre felizes, mas me acrescentam e me fazem ser quem eu sou.

Em cada encontro, em cada contato, vou ficando maior... Em cada retalho, uma vida, uma lição, um carinho, uma saudade... Que me tornam mais pessoa, mais humana, mais completa.

E penso que é assim mesmo que a vida se faz: de pedaços de outras gentes que vão se tornando parte da gente também. E a melhor parte é que nunca estaremos prontos, finalizados...

Cora Coralina

A Educação para os sujeitos do campo assim como o poema de Cora Coralina é como uma colcha de retalhos, construída ao longo da história, no coletivo, por muita gente, quer seja, dos movimentos populares e de base, do meio acadêmico, das dioceses, da cultura, da educação, entre outros. E de diversas formas por meio de oficinas, teatros, dinâmicas, estudos, encontros, formações, rodas de conversas, trabalhos de base. Atividades essas que foram construídas e desenvolvidas na perspectiva de se pensar uma outra forma de educação, ser humano, justiça, cidadania e também projeto societário.

\footnotetext{
${ }^{1}$ Graduada em Serviço Social Pontifícia Universidade Católica de Goiás - PUC-Goiás (2003) Mestrado em Serviço Social pela Universidade Católica Portuguesa - UCP (2010). Doutoranda em Educação pela Universidade Federal Fluminense - UFF. É professora da Universidade Federal de Goiás - UFG - Regional Goiás. E-mail: alessandraledocufg@gmail.com

${ }^{2}$ Graduada em Serviço Social UNESP (2002) e Mestrado em Serviço Social pela Universidade Estadual Paulista UNESP/Franca. Doutoranda em Educação Universidade de Brasília UnB. É professora da Universidade Federal de Goiás UFG - Regional Goiás. E-mail: patriciaestabile@hotmail.com
} 
Mejía (2012, p. 26) ao discorrer acerca da educação e a pedagogia crítica na América Latina, considera que a educação popular tem uma concepção de educação que não é homogênea e ao ser desenvolvida possuí diversas interpretações, práticas, metodologias, teorias, enfoques, pedagogias, e uma opção ética de transformação. Sendo, que "a busca de transformação se deu em diferentes grupos, que animaram a construção de uma educação popular como resposta para fazer efetivas as modificações necessárias ao sistema de dominação".

No contexto latino-americano, milhares de educadores populares realizaram diversas experiências de educação popular, nas mais variadas frente de atuações, desenvolvendo práticas pedagógicas com os sujeitos que ficavam às margens da educação formal ou que eram objetos de um processo educacional que os preparava não para ser sujeitos da história, mas indivíduos considerados subalternos, sem cultura, alienado, carente, desorganizado e marginal que necessitavam se ajustar ao projeto dominante de sociedade.

No Brasil a educação popular buscava se distanciar das concepções dominantes de educação voltada para garantir a prática da dominação "mantendo a ingenuidade dos educandos, o que pretende, em seu marco ideológico (nem sempre percebido por muitos dos que a realizam), é indoutriná-los no sentido de sua acomodação ao mundo da opressão (FREIRE, 2011, p. 92).

Ao discorrer sobre as experiências mais significativas que foram desenvolvidas no país, Brandão (2002, p. 31) um dos intelectuais da educação popular no Brasil, assegura que:

No pequeno domínio de teorias e trabalhos que pensamos haver inventado entre 1960 e 1964 e que anos mais tarde demos o nome de educação popular, surgiu e por algum tempo floresceu um tipo relativamente inovador de prática pedagógicas. Ela recriou para sua identidade e uso um sentido novo para um nome antigo: cultura popular. Envolveu 
pessoas como Paulo Freire e seus primeiros companheiros nordestinos de trabalho e difundiu-se entre diferentes categorias de sujeitos sociais: o estudantado secundarista e universitário, intelectuais militantes cristãos, artistas eruditos e populares, dirigentes de agremiações e de partidos políticos.

No decorrer desse momento histórico movimentos educativos e de cultura popular foram conquistando terreno no desenvolvimento de ações culturais baseadas em uma educação diferenciada. Entre as experiências mais significativas entre os anos de 1960 à 1964, encontram-se os processos educativos desenvolvidos no Movimento de Cultura Popular (MCP); Campanha "De pé no chão também se aprende a ler; Movimento de Educação de Base (MEB), o Centro Popular de Cultura (CPC) entre outros. Esses grupos "pensaram e praticaram o que mais tarde algumas pessoas vieram a chamar de "teoria da Educação Popular"'" (Idem).

Além dos movimentos citados anteriormente algumas igrejas cristãs por meio da ação social cristã e tendo como base as propostas do marxismo, a teologia da libertação também tinha grupos que desenvolvia práticas de Educação Popular, como por exemplo: o Movimento Ação Católica, com seus diversos setores: a Juventude Operária Católica (JOC), A Juventude Estudantil Católica (JEC). No meio acadêmico, antes do golpe de 1964, as ações eram tidas como de cultura popular e era considerada "não como uma ação oficial das políticas acadêmicas universitárias, mas como inspiração de muitas das práticas sociais que estudantes, professores e intelectuais mais inquietos iam tentando implementar nos espações livres de seus trabalhos" (VASCONCELOS, 2011, p. 17).

Os trabalhos de Freire, principalmente por meio das suas obras Pedagogia do Oprimido e Pedagogia da Liberdade contribuíram para estruturar a educação popular no Brasil. As ideias pedagógicas, o método, ou a teoria do autor deram o norte ao desenvolvimento das atividades, 
quer seja de cultura ou de educação. Assim, ao realizar uma peça de teatro, um curso de alfabetização, a intencionalidade do diálogo era contribuir para que os oprimidos pudessem ter uma reflexão crítica diferente da sua realidade. "A ação política junto aos oprimidos tem de ser, no fundo, "ação cultural" para a liberdade, por isto mesmo, ação com eles" (FREIRE, 2011, p. 73).

Daí que intelectuais, estudantes, lideranças populares e religiosas, educadores, foram implementando ações de transformação com as classes populares urbanas e do campo. As práticas educativas tinham como pilares a cultura, a educação, o diálogo, a indignação, a leitura crítica do mundo, a amorosidade, a fé no ser humano e em sua capacidade de lutar para ser mais. No intento de romper com a concepção de educação bancária na qual o educador é o que detêm o conhecimento e os educandos são os que nada sabem "para a qual a educação é o ato de depositar, de transferir, de transmitir valores e conhecimentos" (Idem, p. 82).

A desqualificação do saber popular ao longo da história foi algo tão interiorizado pelos camponeses que Freire chegou a narrar a seguinte experiência:

\footnotetext{
Não são poucos os camponeses que conhecemos em nossa experiência educativa que após alguns momentos de discussão viva em torno de um tema que lhes é problemático, param de repente e dizem ao educador: "Desculpe, nós devíamos estar calados e o senhor falando. O senhor é o que sabe; nós, os que não sabemos". Muitas vezes insistem em que nenhuma diferença existe entre eles e o animal. "É mais livre do que nós", dizem [FREIRE, 2011, p. 69-70].
}

Foi com o intuito de romper com essa situação opressora que as práticas educativas populares preconizavam o saber popular e a capacidade criadora dos camponeses. A Educação Popular foi um instrumento fundamental para a organização dos povos do campo e também contribuíram para o processo de organização política dos trabalhadores 
do campo. Isso porque, as diversas práticas pedagógicas desenvolvidas junto a esses povos, preconizavam contribuir para que os mesmos pudessem ser sujeitos de seu próprio destino e do processo histórico de transformação social. E, não ser massa de manobra das classes dominantes do setor agrário ou pessoas estigmatizadas como desprovidas de conhecimentos.

A educação no Brasil voltada para a população do campo "foi considerada, ao longo da história do Brasil, como fator de mobilidade e civilidade e funcionou de forma precária, estando sempre a serviço dos grupos detentores do poder e dos interesses externos em cada época" (SOUZA, 2014, p. 99).

A educação para os povos do campo durante um longo tempo foi conceituada como educação rural. Para Kolling et al (2002, p. 19) "na história do Brasil, toda vez que houve uma sinalização de política educacional ou de projeto pedagógico específico isto foi feito para o meio rural e muito poucas vezes com os sujeitos do campo".

Os termos educação rural e educação do campo nas discussões sobre educação vem sendo tomadas como se fosse uma só, o que é um equívoco, pois ambos possuem uma carga histórica significativa para a educação no/do campo. Portanto, definir esses termos é necessário para realizar uma análise da educação na perspectiva dos camponeses.

A educação rural, segundo Ribeiro e Souza (2006) expressa um sentido do termo rural enquanto arcaico, na qual o Brasil é tido como essencialmente urbano. A educação oferecida permite ao povo do campo aprender a ler e a escrever somente, entendendo que ele não precisa de nada mais além disso. Nessa perspectiva, o termo rural atende aos interesses da cidade porque ele foi mais difundido no período da modernização da agricultura, época em que houve uma repressão da vida das famílias camponesas.

Na contramão dessa concepção, a Educação do Cam- 
po possibilita a reflexão e construção de uma escola do campo que valoriza a identidade camponesa e que possua uma pluralidade das ideias e das concepções pedagógicas do camponês. Nas palavras de Ribeiro e Souza (2006, p. 140) "o termo do campo em vez de rural, vem sendo empregado com o intuito de incluir uma reflexão sobre o sentido do trabalho camponês e das lutas sociais e culturais que tentam garantir esse trabalho". Nesse sentido, a escola deve reconhecer a pluralidade cultural do campo e possibilitar que sua importância seja o caminho para a construção da escola.

A Educação do Campo é um conceito em construção e representa um projeto de sociedade e de educação contra hegemônico dos trabalhadores e trabalhadoras camponesas e está vinculada a vários movimentos sociais do campo.

A luta para a constituição da Educação do Campo, tem a sua origem nas lutas pela transformação da realidade educacional das áreas de Reforma Agrária, protagonizadas especialmente pelo Movimento Nacional dos Trabalhadores Rurais Sem Terra (MST), o qual preconiza uma educação para o conjunto dos trabalhadores do campo. Essas lutas estão intrinsecamente vinculadas às experiências históricas de luta e resistência das Escolas Famílias Agrícolas (EFA's), do MEB, das organizações indígenas e quilombolas, do Movimento dos Atingidos por Barragens (MAB), organizações sindicais, diferentes comunidades e escolas rurais, entre outros (CALDART, 2012).

Além desses grupos sociais, o movimento Por uma Educação do Campo, nasceu como crítica à realidade da educação brasileira, particularmente à situação educacional do povo brasileiro que trabalha e vive no/do campo. Para a autora, o no indica que o povo tem o direito a ser educado no lugar onde vive. E o do, implica no direito que o povo tem a ter uma Educação que seja pensada, com base em sua realidade, com a sua participação, com co- 
nhecimentos de sua cultura e às suas necessidades sociais. (CALDART, 2011).

O projeto educacional que esse movimento defende, preconiza uma educação que coloca "os trabalhadores e as trabalhadoras do campo, e suas famílias, em um movimento de construção de alternativas abrangentes de trabalho, de vida, que rompam com a lógica de degradação humana da sociedade capitalista e que sejam concretamente sustentáveis" (CALDART, 2010, p. 19).

Para Molina (2014, p. 12):

O movimento da Educação do Campo compreende que a Escola do Campo deva ser uma aliada dos sujeitos sociais em luta para poderem continuar existindo enquanto camponeses e para continuar garantindo a reprodução material de suas vidas a partir do trabalho na terra. Para tanto, é imprescindível que a formação dos educadores que estão sendo preparados para atuar nestas escolas considere, antes de tudo, que a existência e a permanência (tanto destas escolas, quanto destes sujeitos) passam, necessariamente, pelos caminhos que se trilharão a partir dos desdobramentos da luta de classes, do resultado das forças em disputa na construção dos distintos projetos de campo na sociedade brasileira.

No âmbito da Educação do Campo esses grupos foram desenvolvendo trabalhos de formação de professores para atuarem em escolas constituídas em Assentamentos Rurais e/ou acampamentos do MST. Essa formação foi elaborada com a parceria de Universidades, que via projetos de extensão e pesquisa, fora contribuindo com esses grupos e movimentos, demostrando a possibilidade de se ter uma Educação que respeite a cultura, o calendário agrícola, que ensine com os elementos presentes na realidade de cada grupo.

Assim, o período do plantio e o seu cotidiano. As necessidades do transporte - via de escoamento da produção, comercialização, bem como, os recursos para investimentos na produção, por exemplo, são elementos para po- 
tencializar o aprendizado da matemática, do português, da ciência, da história, da química, da física, das relações sociais, entre outros. Nesse sentido, além de promover o ensino sobre essas questões, a Escola do Campo é o lugar que também possibilita que os pais e os membros da comunidade possam auxiliar em temáticas trabalhadas no dia a dia. E a partir dessas experiências toma corpo as reivindicações por uma política pública para as populações camponesas.

Com o intento de construir uma educação em contraposição às políticas compensatórias da educação rural e na defesa do direito dos povos do campo às políticas públicas de educação com respeito às suas especificidades, a I Conferência Nacional por uma Educação Básica do Campo, realizada em Luziânia, Goiás, em 1998, constrói nesse encontro a Educação Básica do Campo. Assim, o conceito propriamente dito de Educação do Campo "só foi instituído a partir das discussões do Seminário Nacional realizado em Brasília de 26 a 29 de novembro de 2002" (CALDART, 2012, p. 258).

A partir dos anos 2000, surgem as primeiras respostas do Estado na tentativa de atender às demandas e prioridades educacionais para a Educação do Campo. Desse processo, por exemplo, resultou a criação de legislações que vão oportunizar políticas públicas destinadas a esse setor. Entre as mudanças significativas está a aprovação das Diretrizes Operacionais para a Educação Básica para as Escolas do Campo, lançadas pela Resolução de no 1 , de 3 de abril de 2002 e aprovadas pelos CNE/CEB. No parágrafo único do artigo $2^{\mathrm{o}}$ das Diretrizes estão definidas a identidade das escolas do campo de acordo com as necessidades da população camponesa. De outro modo:

A identidade da escola do campo é definida pela sua vinculação às questões inerentes à sua realidade, ancorando-se na temporalidade e saberes próprios dos estudantes, na memória coletiva que sinaliza futuros, na rede de ciência e tecnologia disponível na sociedade e nos movimentos so- 
ciais em defesa de projetos que associem as soluções exigidas por essas questões à qualidade social da vida coletiva no país [BRASIL, 2002, p. 1].

Essa vinculação às questões próprias da realidade faz parte das Diretrizes, registrando-se, ainda, a possibilidade de elaboração de propostas pedagógicas articuladas aos saberes próprios dos sujeitos implicados, ou seja:

Propostas pedagógicas que valorizem, na organização do ensino, a diversidade cultural e os processos de interação e transformação do campo, a gestão democrática, o acesso do avanço científico e tecnológico e respectivas contribuições para a melhoria das condições de vida e a fidelidade aos princípios éticos que norteiam a convivência solidária e colaborativa nas sociedades democráticas [BRASIL, 2002, p. 3].

Podemos observar também a ênfase nesses princípios no órgão gestor denominado Secretaria de Educação, Continuada, Alfabetização e Diversidade - Ministério da Educação (SECAD/MEC, 2007). Em seu documento há de se observar que essas Diretrizes são emblemáticas no que diz respeito à educação no campo. Em outras palavras:

[Elas] representam um importante marco para a educação do campo porque contemplam e refletem um conjunto de preocupações conceituais e estruturais presentes historicamente nas reivindicações dos movimentos sociais. Dentre elas o reconhecimento e valorização da diversidade dos povos do campo, a formação diferenciada de professores, a possibilidade de diferentes formas de organização da escola, a adequação dos conteúdos às peculiaridades locais, o uso de práticas pedagógicas contextualizadas, a gestão democrática, a consideração dos tempos pedagógicos diferenciados, a promoção, através da escola, do desenvolvimento sustentável e do acesso aos bens econômicos, sociais e culturais [SECAD/MEC, 2007, p. 17].

Ao analisarmos essas legislações percebemos que elas vão ao encontro das bandeiras de luta dos movimentos sociais do campo em prol de uma educação que atenda 
os anseios da população do campo. Educação essa que leve em conta a realidade social das crianças, jovens e adultos do campo.

Outro avanço relevante, é a instituição, pelo MEC, da Portaria no 1374, de 3 de junho de 2003, que cria o Grupo Permanente de Trabalho do Campo e uma coordenadoria vinculada à SECAD/MEC. Esse grupo tem a atribuição de articular as ações do Ministério pertinentes à educação do campo, como também divulgar, debater e esclarecer as Diretrizes operacionais para a educação básica nas escolas do campo a serem observadas nos projetos das instituições que integram os diversos sistemas de ensino, estabelecidas na Resolução - CER no 1, de 3 de abril de 2002. Outra função desse grupo é o apoio na elaboração de seminários nacionais e estaduais para a implementação dessas ações. Das ações desse grupo, há de se destacar o que de inovador se institui no MEC, isto é, a apropriação da nova nomenclatura proposta pelos movimentos sociais: o nome Educação Rural foi substituído por Educação do Campo (SOUZA, 2014).

Na II Conferência Nacional de Educação do Campo, realizada em 2004, a luta por educação do campo perpassa o movimento Por uma Educação do Campo e sensibiliza outras organizações e sujeitos sociais, inclusive as universidades que nacionalmente articulam a defesa de uma educação do campo para além da educação básica (educação infantil, fundamental e médio), mas também uma educação de nível superior, por compreenderem que o "campo também necessita de diversos profissionais qualificados para atuarem nessa realidade da educação do campo" (PINHEIRO, 2011, p. 09).

A partir da pressão e das demandas apresentadas ao Estado pelo Movimento da Educação do Campo, o MEC cria o Programa de Apoio à Formação Superior em Licenciatura em Educação do Campo (PROCAMPO) com o objetivo de apoiar a implementação de cursos regulares nas 
instituições públicas de ensino superior que são voltadas especificamente para a formação de educadores para a docência em escolas rurais nas séries finais do ensino fundamental e no ensino médio (FREITAS, 2011).

estabelecer critérios e procedimentos para fomento de cursos regulares de Licenciatura em Educação do Campo, para a formação de professores para a docência nos anos finais do ensino fundamental e ensino médio nas escolas localizadas em áreas rurais, mediante assistência financeira às Instituições Públicas de Ensino Superior - IES [BRASIL, 2009].

Com esse Edital o MEC/SECADI procura não só atender as reivindicações das organizações e movimentos sociais. Assim como, oportunizar que se preparem educadores para atuarem em escolas rurais e dessa forma superar historicamente o apêndice dessas unidades de ensino às escolas urbanas. Ou seja, observa-se a necessidade de se constituir uma política de formação de professores identificada com as questões do campo. Essa decisão deve-se a compreensão das reivindicações das organizações e movimentos sociais, do trabalho de docentes e pesquisadores na área e da intencionalidade política de instituir uma Educação do Campo focada na realidade dos sujeitos que vivem no e do campo.

Educação essa que se constitua com ideais da práxis dos movimentos e organizações sociais, tendo como princípios a Filosofia da Educação Freiriana ${ }^{3}$, implicando teoria e prática advindas das condições de vida dos trabalhadores do campo. Isto é, a Educação do Campo reflete a luta dos trabalhadores do campo por Políticas Públicas que garanta o seu direito à educação.

\footnotetext{
${ }^{3}$ Conforme Vasconcelos (2011, p. 16), "Paulo Freire foi um pioneiro do trabalho de sistematização teórica da Educação Popular, mas não é o seu inventor (...). A Educação Popular não é uma teoria pedagógica criada por um intelectual; é um saber e uma teoria que foram sendo construído coletivamente, nesse movimento social de intelectuais, técnicos e lideranças populares engajados na transformação da sociedade de forma a superar as estruturas políticas e econômicas geradoras de pobreza e de opressão".
} 
Para Paludo (2012, p. 283), apesar dos "transformismos" realizados pelo Estado e por outras instituições, atualmente a Educação do Campo é uma importante experiência brasileira, que tem como protagonista os próprios sujeitos populares e "pode ser identificada como uma das propostas educativas que representa elementos importante da concepção de educação popular e, ao mesmo tempo, os ressignifica, atualiza e avança nas formulações e práticas direcionadas a um público específico".

Diante do exposto cabe nesse espaço diminuto destacar que os avanços referentes a efetivação de políticas públicas educacionais para os sujeitos do campo se consolidam num espaço de contradições e permeiam uma história escrita com tintas de sangue e suor oriundas das lutas sociais na conquista por direitos.

\section{O PROGRAMA NACIONAL DA EDUCAÇÃO DO CAMPO (PRONACAMPO)}

O Programa Nacional de Educação do Campo (Pronacampo), foi instituído em março de 2012, inserido na Medida Provisória n. 562/2012, que foi transformada no Projeto de Lei n. 12.695/2012, sancionada pelo Presidente da República em 25 de julho do corrente ano. Com a aprovação da Lei, empregam possibilidades para concretização dos objetivos elencados no documento legal, assim dentre os objetivos do programa estão entre outras coisas: possibilitar ações voltadas ao atendimento das escolas do campo e quilombolas, levando em conta que são cerca de 76 mil escolas, com 6,2 milhões de matrículas e $342 \mathrm{mil}$ professores, em quatro frentes: gestão e práticas pedagógicas; formação de professores; educação de jovens e adultos; educação profissional e tecnológica (MEC, 2012).

No Brasil de acordo com dados do Instituto Brasileiro de Geografia e Estatística (IBGE) (2010) existem 76 mil escolas localizadas em territórios rurais, com mais de 
6,2 milhões de matrículas e 342 mil professores, 23,18\% da população do campo com mais de 15 anos é analfabeta e 50,95\% não concluiu o Ensino Fundamental. Esses dados apontam fatos importantes a serem averiguados no que concerne o direito a educação e a estruturação de políticas públicas que deem condições reis de lacance para as comunidades que vivem no campo.

O PRONACAMPO (Programa Nacional de Educação do Campo) de acordo com suas diretrizes vai atender escolas do campo e quilombolas, posteriormente a adesão dos estados, municípios e Distrito Federal por meio do Plano de Ações Articuladas (PAR).

Nessa direção, as metas para o PRONACAMPO, estavam prognosticadas para até o final da gestão de governo Dilma Russef: a) A construção de 3.000 escolas do campo; b) A formação inicial de 45.000 educadores e a formação continuada de outros 45.000 educadores do campo; c) A implantação do Programa Escola da Terra, com a formação de 7mil professores das escolas rurais e Quilombolas multisseriadas; d) PRONATEC Campo - qualificação de 30.000 jovens e adultos da agricultura familiar (BRASIL, 2013).

Diante do invólucro planejado para o desenvolvimento do PRONACAMPO outros itens elencados são "livros didáticos específicos para as escolas do campo, o programa Mais Educação para as Escolas do Campo e Quilombolas, educação digital nas escolas do campo, subsídio ao transporte escolar, Inclusão das Escolas dos Centros Familiares de Formação por Alternância (CEFFAS) no Fundo de Manutenção e Desenvolvimento da Educação Básica e de Valorização dos Profissionais da Educação (FUNDEB).

O Brasil possui 76,2 mil escolas rurais, de acordo com dados do Censo Escolar 2011. A mesma pesquisa mostra que, desse total, 42 mil são multisseriadas, quase 15\% ainda não possuem energia elétrica, $89 \%$ não têm biblioteca e $81 \%$ não 
contam com laboratório de informática. Além da infraestrutura precária, um levantamento do Fundo das Nações Unidas para a Infância (Unicef) feito com base na Pesquisa Nacional por Amostra de Domicílios (Pnad) de 2009 indica que $2,5 \%$ das crianças e dos adolescentes com idade entre 7 e 14 anos que vivem no campo estão fora da escola. Isso revela que ainda estamos longe de universalizar o acesso à Educação Básica na zona rural e de garantir a qualidade dele. Outro desafio é a formação dos professores que atuam nas escolas do campo. Segundo dados do Instituto Nacional de Estudos e Pesquisas Educacionais (Inep), aproximadamente 160 mil (44\%) não possuem sequer ensino superior. (Molina 2012 p.01)

Ao impetrar as discussões que envolvem a educação do campo nos deparamos com fatos concretos da vivência cotidiana dos sujeitos e entendemos que as demandas educacionais para os sujeitos do campo ocupam uma amplitude maior que as metas estabelecidas pelo PRONACAMPO podem abarcar. Nessa direção, a própria estrutura escolar precarizada denuncia a fragilidade das políticas públicas no alcance dos objetivos dos programas supracitados.

A maioria dos prédios é bastante precária. Dar condições de funcionamento às instituições é importante para garantir minimamente os processos de ensino e aprendizagem. Faltam energia elétrica em 15\% das escolas, bibliotecas em $89 \%$ e laboratórios de Ciências em 99\%! Melhorar a estrutura é um dos eixos que compõem o Programa Nacional de Educação do Campo (Pronacampo)

(Molina 2012 p.01))

O Ministério da Educação demostrou por intermédio de dados estatísticos considera que as taxas de atendimento da Educação Infantil/Creche no campo é de 6,98\%, da Educação Infantil/Pré-Escola é de 66,80\%, do Ensino Fundamental é de 91,96\%, do Ensino Médio é de 18,43\%, da EJA - Ensino Fundamental é de $4,34 \%$ e da EJA - Ensino Médio é de 3,10\%. Contudo, nos últimos anos foram fechadas 13.691 escolas do campo, situadas nas pequenas comunidades rurais, fechamento gerado pela falta de in- 
fraestrutura e os estudantes conduzidos para as escolas nucleadas, com o emprego de transporte escolar. Ainda, em consonância com os dados do ministério da Educação do total de professores que atuam na educação campesina, 160.317 não são graduados, destes 156.190 possuem ensino médio e 4.127 ensino fundamental.

Esses dados denotam que apesar das políticas instituídas para qualificação do ensino que aquilatem os construtos sociais das comunidades localizadas no campo, observamos, que as estratégias ainda dedilham para concepções ainda distantes do almejado pelos sujeitos que pleteiam uma educação de qualidade que comungue com as aspirações históricas de uma educação capaz de trilhar um caminho para emancipação humana, onde os participantes do processo educativo possam ser sujeitos da sua própria história.

Segundo Fernandes \& Molina, (2004), o campo é um local de particularidades e matrizes culturais. É um espaço de possibilidades políticas, formação crítica, resistência, mística, identidades, histórias e produção das condições de existência social. Assim, cabe à educação do campo, o papel de fomentar reflexões que acumulem forças e produção de saberes.

O PRONACAMPO ofertou 180 mil vagas pelo Programa Nacional de Acesso ao Ensino Técnico e Emprego, (PRONATEC) para formação tecnológica de jovens e trabalhadores do campo, definiu a construção de 3 mil novas escolas e investimentos em infraestrutura. Nessa direção a universalização do direito à educação para as populações campesinas, igualmente quanto a assegurar a ampliação e sustentação da política de educação do campo nos sistemas de ensino, fica sujeito a implementação e fortalecimento do regime de coparticipação entre os entes federativos; e do controle social das políticas educacionais (MEC, 2013).

Segundo Molina (2012) o PRONACAMPO incorpo- 
rou os princípios da Educação do campo em alguns aspectos mas os deixam ainda distantes. O Programa Nacional de Acesso ao Ensino Técnico e Emprego (Pronatec), sob a ótica da autora é um dos projetos agregados que necessita ser revisto.

Embora exista uma discussão sobre a concepção de campo e a respeito de que tipos de profissionais são necessários para construir um modelo de desenvolvimento para o meio rural, os cursos do Pronatec não estão adequados à proposta da agricultura camponesa. Eles foram pensados segundo a lógica das grandes monoculturas, quando deveriam estar ligados à sustentabilidade e à agroecologia. Precisamos refletir sobre como a Educação pode fortalecer um modelo que permita a permanência das pessoas no campo. Abaixo a ruralidade de espaços vazios! Queremos que o campo tenha gente capaz de diversificar a produção e com automia em relação à própria inserção no mercado (Molina 2012).

A educação popular se encontra nas discussões e reflexões dos sujeitos que pleteiam uma educação do campo integrada e integrativa que valorize aspectos sociais e culturais na produção do conhecimento a partir de metodologias que garantam a continuidade das comunidades localizadas no campo, a discussão permeia a construção de uma educação no sentido stricto que determine condições estruturais para os sujeitos do campo para assim poderem definir sua saída ou continuidade nos espaços por eles ocupados.

Nesse sentido, a educação tem que ser libertadora para que os sujeitos do campo possam definir os caminhos pelos quais desejam seguir, desobrigados a acatarem os ditames insurgentes da exploração e expropriação do trabalho árduo do campo definidos pela lógica do agronegócio cerceadores das classes marginalizadas. Perfilhar o papel basilar da educação numa sociedade cada vez mais globalizada é reconhecer uma educação baseada no diálogo, que tribute valores culturais ao conhecimento universal. Dessa forma, há que se alvitrar que a Educação do 
Campo seja apropriada para aperfeiçoar universalmente os sujeitos em toda a sua integridade, reconhecendo suas singularidades e particularidades confiando que esta educação seja capaz de ressignificar os espaços cotidianos da vida humana.

\section{Considerações finais}

O intento dessa trabalho foi realizar uma reflexão de como a Educação Popular contribuiu para a construção da Educação do Campo. A priori não teve a intenção de realizar um resgate denso da Educação Popular, mas sim relacionar como as práticas educacionais e culturais dos diversos movimentos educacionais populares foram sendo "retalhos" para tecer outras propostas educacionais voltadas para uma educação construída com os sujeitos do campo.

Compreende-se que as pontuações feitas no decorrer do texto merecem estudo aprofundado, o que corrobora para a realização de outros trabalhos. Esta colcha ainda está inacabada ou como disse Cora Coralina "haverá sempre um retalho novo para adicionar à alma".

A Educação pensada para as comunidades localizadas no campo necessita ser efetivada de forma a não segregar os sujeitos a partir de uma lógica capitalista de formação de mão de obra para desenvolver as necessidades da grande produção, mas sim parametrizada na lógica de direitos previstos pela Carta Magna de 1988. A constituição de 1988 determinou direções legais para a construção de políticas que garantam a qualidade, equidade e respeito sem diferenciação de sujeitos por uma questão geográfica ou questões meramente econômicas. Seguindo tais determinações a educação do campo deve ultrapassar os parâmetros de uma simples proposta pedagógica, bem como, estar amalgamada à visão de campo, de produção do conhecimento, do respeito as desigualdades locais, re- 
gionais e nacionais para o incremento e emprego no campo da sociedade brasileira.

Ao falamos de Educação do Campo estamos fazendo referência aos sujeitos que vivem no campo (assentados, índios, colonos, seringueiros, camponeses, agricultores familiares, quilombolas, sem-terra, posseiros, trabalhadores rurais e outros). São mulheres, homens, jovens, crianças, pessoas na terceira idade que há muitos anos buscam seus direitos.

As populações do campo convivem com o desemprego, a precarização, informalização do trabalho e a carência de políticas sociais e vivem à margem do Estado, os serviços essenciais poucos ou quase inexistentes. A carência de bens e serviços, políticas públicas, leva boa parte deles a separação das famílias (êxodo rural) em busca da educação formal, trabalho para garantir melhores condições de vida a seus familiares, muitos não retornam ao local de origem.

Os camponeses, por vários séculos, foram negligenciados pelo Estado que ao longo dos anos prestou serviços públicos básicos mínimos a essa população. As mudanças no mundo do trabalho com o avanço das técnicas e da maquinaria expandiram-se para o campo, forçando o êxodo rural. A parcela dos trabalhadores que permaneceram no campo passou a conviver com a pressão dos capitalistas agrários (agronegócio) por suas terras, como também a exploração de sua mão de obra.

Nesse sentido, é necessário entender a Educação do Campo como luta para superação dessa lógica educativa - que vem ao longo dos anos induzindo a classe dos trabalhadores a uma formação escolar alienante, por reproduzir a lógica do sistema capitalista que desconhece a realidade dos sujeitos do campo na lógica dos trabalhadores. Assim, é necessário refletir com a população que vive no campo e com a comunidade escolar do campo sobre a sua realidade, ou seja, debater sobre o sentido da existência de 
escolas e de sujeitos no campo e de políticas públicas que garantam não só o acesso à terra, mas também à educação e outras que garantam a permanência no campo.

A Educação do Campo se localiza em espaços onde operam projetos societários antagônicas em disputa. Dessa forma de um lado estão os camponeses e os movimentos sociais lutando pela sobrevivência e condições de trabalho no campo, pleiteiam a estruturação de uma política educacional que ampare as comunidades localizadas no campo e de outro lado imperam os interesses capitalistas difusos que pleiteiam a ampliação dos espaços geográficos para a apropriação das terras para difusão e expansão das commodities no agronegócio e para expropriação da mão de obra dos camponeses que necessitam desses espaços para sua subsistência.

A relevância da Educação do Campo/ no campo e das conquistas alcançadas no decorrer da história da educação brasileira é notória como se observa atualmente como por exemplo a partir de Políticas Públicas educacionais e a criação do Pronacampo. Mas é mister ressaltar que apesar do avanço ainda tem uma árdua caminhada até alcanças os objetivos almejadas nas lutas onde os sujeitos do campo são os protagonistas.

A luta por uma educação que integre mudanças societárias significativas faz parte de um projeto societário que vislumbra um modelo de sociedade muito além do que se projetam políticas e programas compensatórias de governos, mas que abarquem um conteúdo voltado para o interesse da classe trabalhadora e que conservem o ecossistema como Patrimônio da Humanidade, considerando a fauna e a flora componentes indispensáveis para produção e reprodução da vida humana.

O Pronacampo é o consequência das lutas dos Movimento Sociais do Campo, mas teceu em seu bojo diretrizes de organismos internacionais como o Banco Mundial e do agronegócio que visam nesse invólucro a formação 
dos sujeitos do campo para o "emprego". Os desafios na estruturação de uma educação alicerçada nos saberes populares do campo que busca a emancipação humana estão distantes no debate do programa. Mas, não se pode negar a força politica dos movimentos sociais do campo para tornar o Pronacampo uma Politica Publica de Estado.

Assim, a Educação do Campo não emerge no vazio e nem é iniciativa das políticas públicas vindas das boas intenções do Estado. Emerge de um movimento social, da mobilização dos trabalhadores do campo, da luta social. É fruto da organização coletiva dos trabalhadores. Dessa forma, é indissociável de políticas públicas para as populações do campo: reforma agrária, política agrícola, econômica, lazer, saúde, transporte, infraestrutura, Educação de Jovens e Adultos, entre outras.

\section{REFERÊNCIAS}

BRANDÃO, C. R. A Educação como Cultura. Campinas: Mercado das Letras, 2002.

BRASIL. MINISTÉRIO DA EDUCAÇÃO - MEC. Detalhes de Relatório de Gestão da SECADI 2012. Disponível em: <http:// portal.mec.gov.br/index.php?option=com_docman\&task=doc_ details\&gid=14256\&Itemid=122>. Acesso em: 18 ago. 2017.

. Ministério da Educação. Secretaria de Educação Continuada, Alfabetização e Diversidade - SECAD. Diretrizes Operacionais para a Educação Básica nas Escolas do Campo. Resolução CNE / CEB noำ 1, 03 de abril de 2002. Disponível em: $<$ http://portal.mec.gov.br/cne/arquivos/pdf/CEB012002.pdf $>$. Acesso em: 15 ago. 2017.

CALDART, R. S. Educação do Campo. In: CALDART, R. S. et al (Org). Dicionário da Educação do Campo. Rio de Janeiro, São Paulo: Escola Politécnica de Saúde Joaquim Venâncio, Expressão Popular, 2012, p. 257-265.

. Por uma Educação do Campo: traços de uma identidade em construção. In: ARROYO, M. G.; CALDART, R. 
S.; MOLINA, M. (Orgs.) Por uma Educação do Campo. 5. ed. Petrópolis, RJ: Vozes, 2011.

. O MST e a escola: concepção de educação e matriz

formativa. In: CALDART, R. S. et al (Org.). Caminhos para transformação da escola: reflexões desde práticas da Licenciatura em Educação do Campo. São Paulo: Expressão Popular, 2010.

CORALINA, C. Colcha de Retalhos. Disponível em: $<\mathrm{http}: / /$ www.50emais.com.br/45351-2/>. Acesso em: 18 ago. 2017.

FERNANDES, B. M.; MOLINA, M. C. \& JESUS, S. M. S. A. (Org.). Contribuições para a construção de um projeto de educação do Campo - Brasília, DF: Articulação Nacional Por uma Educação Básica do Campo, 2004. Coleção Por uma Educação Básica do Campo, n. 5.

FREIRE, P. Pedagogia do oprimido. 50. ed. rev. e atual. Rio de Janeiro: Paz e Terra, 2011.

FREITAS, H. C. de A. Rumos da Educação do Campo. Em Aberto, Brasília, v. 24, n. 85, p. 35-49, abr. 2011.

KOLLING et al. (Org.) Educação do Campo: Identidade e Políticas Públicas. Brasília, DF: articulação nacional Por uma Educação do Campo, 2002. Coleção Por uma Educação do Campo, n. 4.

MEJÍA, M. R. Educação e Pedagogias Críticas a partir do Sul: Cartografias da Educação Popular. Rio de Janeiro, NOVAMERICA, 2012.

MOLINA, M. C. (Org). Licenciaturas em Educação do Campo e o ensino de Ciências Naturais: desafios à promoção do trabalho docente interdisciplinar. Brasília: MDA, 2014.

Entrevista Nova Escola. 2012 Disponível em: <https:// novaescola.org.br/conteudo/970/entrevista-com-monica-molina-especialista-em-educacao-do-campo $>$. Acesso em: 18 ago. 2017.

PALUDO, C. Educação Popular. In: CALDART, R. S. et al. (Orgs). Dicionário da Educação do Campo. Rio de Janeiro, São 
Paulo: Escola Politécnica de Saúde Joaquim Venâncio, Expressão Popular, 2012, p. 280-293.

PINHEIRO, Maria do Socorro Dias. A concepção de educação do campo no cenário das políticas públicas da sociedade brasileira. Monografia (2011). Disponível em: $<$ http://br.monografias. com/trabalhos915/educacao-campo-politicas/educacao-campo-politicas2.shtml.>. Acesso em: 18 ago. 2017.

RIBEIRO, V. S; SOUZA, F.E. de. A educação Escolar no campo em Goiás. In: Pedagogia da Alternância: construindo a educação do campo. Goiânia: Ed. Universa, 2006.

SECRETARIA DE EDUCAÇÃO, CONTINUADA, ALFABETIZAÇÃO E DIVERSIDADE - MINISTÉRIO DA EDUCAÇÃO (SECAD/MEC). Educação do Campo: diferenças mudando paradigmas. CADERNOS SECAD 2, Brasília, DF, março, 2007.

SOUZA, M. M. de. Imperialismo e educação do campo. São Paulo: Cultura Acadêmica, (Temas em Educação Escolar, n.19), 2014.

VASCONCELOS, E. M. Apresentando Educação Popular na Universidade. In: VASCONCELOS, E. M; CRUZ, P. J. S. C. (Orgs). Educação Popular na formação universitária: reflexões com base em uma experiência. São Paulo: Hucitec; João Pessoa: Editora Universitária da UFPB, 2011, p. 15-24. 


\title{
CAPÍTULO 12
}

\section{MARCAS DO CAMPESINATO: a luta pela terra e educação no cerrado goiano}

\author{
Fernanda Lima Ferreira ${ }^{1}$ \\ Adão Machado Lima ${ }^{2}$ \\ Juliano da Silva Martins de Almeida ${ }^{3}$
}

Habitar debaixo de lonas, convivendo sob pressão (e opressão) e lutando por um fragmento de terra é a realidade comum a muitos trabalhadores rurais brasileiros. Diante deste cenário, dia após dia, o homem do campo está sendo "impulsionado" para a cidade, torna-se indivíduo espoliado e explorado, e sem emprego, submete-se a ser homem proletariado. Desta forma, transubstanciando a natureza, percebe-se a significativa mudança da função social da terra, pois esta foi deslocada da concepção de natureza e responsável para subsistência e tornou-se, neste contexto político-econômico, uma mercadoria, capaz de aflorar na humanidade seus instintos mais cruéis de outrora.

Dito isto, à priori, nosso intuito é observar teoricamente as variáveis da realidade brasileira nas décadas entre 1950 e 1980 . No segundo momento, trazemos um relato de experiência sobre as dificuldades impostas às popula-

\footnotetext{
${ }^{1}$ Graduanda em Licenciatura em Química pelo Instituto Federal de Educação, Ciência e Tecnologia Goiano, Campus Iporá. E-mail: nanda1842@hotmail.com ${ }^{2}$ Mestrando do Programa Pós-Graduação stricto sensu em Ciências Moleculares (PPGCM), no nível de Mestrado Acadêmico, da Universidade Estadual de Goiás (UEG) e licenciado em Química pela Universidade Federal do Tocantins (UFT). Atualmente é professor no Colégio da Polícia Militar de Goiás e no Colégio Estadual de Aplicação Professor Manuel Caiado, ambos na Cidade de Goiás (GO). E-mail: adaoqui@gmail.com.

${ }^{3}$ Doutor e Mestre em Ciências pela Universidade Federal de Uberlândia (UFU). Licenciado em Química pelo Instituto Luterano de Ensino Superior de Itumbiara - ILES/ULBRA. Professor de Química no Instituto Federal de Educação, Ciência e Tecnologia Goiano, Campus Iporá. E-mail: juliano.almeida@ ifgoiano.edu.br
} 
ções do campo para frequentar a escola e demonstrarmos as intensas contradições impostas pelo capitalismo no campo da educação.

Na mesma direção, será publicizada a vivência de uma mulher que vivia embaixo das lonas, mas que superou os obstáculos quase intransponíveis e conseguiu adentrar em um curso superior, embora seja do e resida no campo. Por esta justificativa, neste primeiro momento, utilizemo-nos da primeira pessoa do discurso. No segundo instante, utilizaremos da terceira pessoa quando nos referirmos aos aspectos teóricos da discussão, pela nossa inserção numa militância marcada pela enunciação coletiva.

\section{RELATO DE EXPERIÊNCIA - FERNANDA}

Transmutando do macro para o micro, gostaria de contar um pouco da minha lida no campo até chegar onde cheguei, e tudo que conquistei. A minha vida nunca foi fácil. Vim de uma família bastante carente. Minha mãe ainda era criança quando, aos 13 anos de idade, teve filhos. Sem condições financeiras para nos criar, eu, minha mãe e irmã ficamos acampadas por mais de quatro anos com meus avós, aguardando a liberação do governo para habitar um pequeno fragmento de terra neste território marcadamente pela desigualdade, diferença e injustiça, como descrito por Moraes (2002) - cujas teorias nos alongaremos mais adiante.

Recordo que para estudarmos, eu e minha irmã, tínhamos que deslocar do campo para a zona urbana diariamente. A minha rotina escolar era muito dificultosa, visto que acordávamos muito cedo para pegarmos o ônibus. Como nossa família era de classe baixa, não tínhamos outro recurso a não ser o campo. Era dali que tirávamos nosso sustento e não podíamos mudar para a cidade, pois lá as dificuldades eram maiores. A maior parte de nosso dia era na estrada. Muitos negativavam esta experiência, mas eu via este momento como uma oportunidade de sair de casa, estar com os amigos, poder conversar e ver outras pessoas semelhantes a mim. Apesar de cansativa, era uma trajetória bastante divertida e socializadora. Na escola, focávamos muito na hora do lanche, que era praticamente nosso almoço. A professora sempre notava que eu estava com fome e pedia para sair da sala e ir até o refeitório pedir comida. Isso me deixava envergonhada, pois os outros alunos me chamavam de "morta de fome".

Nesta fase, pude perceber o injusto preconceito dos alunos da zona urbana com os alunos da zona rural, devido às suas condições financeiras, às vestimentas e vários outros motivos, através de deboches, piadinhas e até mesmo palavras agressivas. Alguns desses fatos me constrangiam tanto, que às vezes nem dava vontade de ir para escola. Porém, o que ocorria ficava ali mesmo; não tinha coragem de contar para ninguém de minha família com medo da reação deles. Após o término das aulas, retornávamos para o campo. Logo que almoçávamos, íamos ajudar meus azôs com os afazeres do campo, tais como aguar a horta e alimentar porcos e galinhas, afinal de contas minha família fazia parte dos pequenos produtores rurais inseridos na frente de expansão, como 
apontada em Martins (2009).

Às vezes, tínhamos que lavar roupa no rio, o que era feito com alegria, semelhante a uma brincadeira. Lembro que no final da tarde reuníamos todos os vizinhos e primos e brincávamos de pega-pega e esconde-esconde. Eram verdadeiros momentos de socialização e ludicidade. Na minha adolescência consegui encarar os preconceitos no ambiente escolar com mais tranquilidade e pouco ligava ao que os outros falavam ou pensavam sobre mim. Isso, de fato, não mais me atingia.

Para completar este difícil cenário, a maior parte da minha família mal terminou o ensino fundamental. Meu pai é analfabeto, pois na sua infância tinha que ajudar seus pais na roça e isso lhe tomava bastante tempo. Recordo-me que eles sempre contavam suas histórias de vida e compreendíamos os níveis de dificuldade. Não demorou para que eles depositassem seus sonhos em mim, minha irmã e nos meus primos. Isso me dava uma responsabilidade imensa de não decepcioná-los e sempre focar mais e mais nos estudos. Na escola, cada dia eu imaginava a história de meus pais e avós e fazia deste lugar de aprendizagem um palco, onde eu era a plateia e estava assistindo a apresentação de minha vida. Um inegável espetáculo de ensino, que sei bem o quanto foi e é importante para mim.

Por não terem a oportunidade de estudar, eles não acreditavam que eu seria capaz de fazer um distante e tão sonhado curso superior. O dia em que ingressei no Instituto Federal de Educação, Ciência e Tecnologia Goiano, no curso de Licenciatura em Química, foi muito gratificante e emocionante. O final do primeiro semestre foi um problema: percebi que eu estava com dificuldades em algumas matérias. No período, muitos alunos ventilavam a possibilidade de desistir, mais isso nunca passou pela minha cabeça, pois eu queria superar os obstáculos, seguir em frente e demonstrar para mim mesma minha capacidade de alcançar meus antigos sonhos, agora metas! Hoje já estou no sexto período do curso, continuo tendo algumas dificuldades, mas procuro superá-las sempre e nunca (nunca mesmo!) fraquejar. Tenho o maior orgulho de estar onde cheguei, pois sei que cada uma dessas conquistas são méritos meus. Foram muitas pessoas que acreditaram em mim e me deram a oportunidade de ser reconhecida, uma delas é o professor Juliano Martins.

Atualmente, sou professora do Colégio Estadual Previsto de Moraes em Caiapônia (GO), $318 \mathrm{~km}$ ao sul da capital Goiânia. Tenho muito a agradecer a Deus por abençoar meus caminhos e por ter me dado a oportunidade de chegar até aqui. Agradeço também às pessoas que não acreditaram em mim e que tentaram, de todas as formas, me jogar para baixo, me humilhar, me fazer desistir... Sem sucesso! A partir das palavras negativas delas, criei forças para lutar e buscar novos saberes profissionais, morais e éticos - importantes para formar um bom cidadão e hoje eu acredito que tenho caminhado nesta direção.

No colégio onde trabalho, a maioria dos meus alunos são da zona rural. Neste lugar de fronteira e de descoberta do outro, como diz Martins (2009), compreendo que a trajetória destes estudantes também não é ou será fácil, mas tento sempre aconselhá-los e motivá-los para não desistirem dos seus objetivos. Mostro ainda que, ninguém consegue roubar o saber. Tenho consciência que ministrar aulas para alunos do campo é uma responsabilidade imensa e que me vejo em cada um deles, no intuito de dar forças para que consigam uma boa profissão e ser orgulho para suas famílias, como hoje sou. 


\section{Território e fronteira: dimensões de uma realidade}

É neste contexto de lutas, desigualdades, emancipação política e dificuldades de ensino que centramos o território brasileiro. Nosso intuito é de contextualizar este Relato de Experiência, bem como tentar entender as principais problemática e, consequentemente, de que lugar falam os autores deste artigo, conferindo-lhes realidade aos depoimentos e experiências circunscritos ao cerrado, aqui visualizado como bioma palco de intersecção da natureza, sociedade, história, cultura e saberes. Neste ambiente, a questão agrária brasileira é tema binário: antigo e atual, porém, apesar disso, é assunto mais divergência a convergente. É este panorama que pretendemos tratar e traçar a partir do próximo parágrafo.

Buscando contextualização histórica, consideramos que há seis décadas, o território geográfico brasileiro atravessou por uma série de significativas mudanças no que diz respeito à ocupação de seus espaços, em grande parte impulsionada pela modernização das cadeias produtivas agrícolas, relativamente independentes dos demais complexos. No século passado, o Brasil viveu as ocupações da Amazônia, do Centro-Oeste e de Rondônia - apenas para citar três importantes exemplos.

Quem traz boas contribuições sobre este assunto é o professor Antônio Carlos Robert de Moraes (2002). Ele nos possibilita a compreensão da noção de Estado e território numa perspectiva histórica e apresenta o conceito de Estado Moderno como sinônimo de Estado-Nação (país), também dotado de um território ou Estado Territorial. Para ele, o Estado se configura como um espaço demarcado pelo exercício de poder em que o,

Território passa a ser visto como um resultado histórico do relacionamento da sociedade com o espaço, o qual só pode ser desvendado por meio do estudo da sua gênese e desen- 
volvimento. Tal concepção resgata o diálogo da geografia com a história, na busca da explicação do que Milton Santos denominou com propriedade de "relações espaço-temporais" (MORAES, 2002, p. 63).

O conceito de território não diz respeito, neste caso, à dimensão de geografia do espaço físico - nos dizeres do autor: "acidente geográfico da superfície da Terra" -; ou ainda como, por vezes, nos induz o senso comum, o qual pressupõe sensibilidade de "captar uma articulação de processos sociais que resultaram em intervenções humanas nos lugares e na criação de materialidades e ordenamentos no espaço terrestre" (MORAES, 2002, p. 64). Aqui, $\mathrm{o}$ autor refere-se à germinação da nacionalidade que foi capaz de formar o território brasileiro, projetando o que a geografia crítica das décadas de 1960 e 1970 sinalizava.

Seguindo esta linha, mais adiante, em, pelo menos cinco vieses distintos, o autor enumera os processos que conformaram os territórios do mundo contemporâneo:

\footnotetext{
O território é, concomitantemente, uma construção militar [ou bélica] (um resultado da conquista espacial, que tem de ser reiterada sempre que contestada) e uma construção política (como área de exercício de um poder soberano), mas também uma construção econômica (como suporte de estruturas e atividades produtivas e como um mercado), e uma construção jurídica (que tem de ser legitimada em fóruns adequados de relacionamento internacional), e ainda uma construção ideológica (que fundamenta uma identidade social de base espacial e uma psicologia coletiva) (MORAES, 2002, p. 74-75).
}

Destarte, podemos sugerir que a questão agrária brasileira atravessa as cinco dimensões apresentadas no conceito de território. Do mesmo modo, a questão da terra perpassa por todos estes âmbitos que vão do espacial ao ideológico, sempre localizada numa região de tensão. Dito isto, convém-nos completar que o Estado é o gerador e responsável pelo território e, portanto, ambos os conceitos estão "profundamente entrelaçados no mundo moderno", 
regido pelo capitalismo, de acordo com Moraes (2002, p. 61). Um adendo. Referimo-nos a um território que transita por todas as instâncias da vida social e seja capaz de reconfigurar-se conforme sua modernização.

Um dos mais importantes cientistas sociais brasileiros com vasta produção acadêmica sobre questões agrárias no Brasil, José de Souza Martins, em obra de 2009, problematiza os conceitos de fronteira e degradação do outro. $\mathrm{O}$ autor apresenta o território da contradição no tempo da fronteira, marcados por resistências, revoltas, protestos, sonhos e esperanças, do qual foi testemunha em décadas de pesquisas de campo. Conforme o autor, a história contemporânea da fronteira em nosso país é repleta de lutas étnicas e sociais (MARTINS, 2009). Afirma ele,

O que há de sociologicamente mais relevante para caracterizar a definir a fronteira no Brasil é, justamente, a situação de conflito social. E esse é, certamente, o aspecto mais negligenciado entre os pesquisadores que têm tentado conceituá-la. Na minha interpretação, nesse conflito, a fronteira é essencialmente o lugar da alteridade. É isso que faz dela uma realidade singular. À primeira vista é o lugar do encontro dos que por diferentes razões são diferentes entre si, como os índios de um lado e os ditos civilizados do outro; como os grandes proprietários de terra, de um lado, e os camponeses pobres, de outro. Mas o conflito faz com que a fronteira seja essencialmente, a um só tempo, um lugar de descoberta do outro e de desencontro (MARTINS, 2009, p. 133, grifo do autor).

José de Souza Martins entende a fronteira como o lugar de exercício da alteridade, que é colocar-se na condição do outro, estabelecendo-se assim uma clara relação de contraste. Sociologicamente falando, a fronteira no Brasil é caracterizada e definida, segundo o autor no excerto, pela situação de conflito social.

Ainda segundo Martins (2009), a fronteira possui o desencontro das temporalidades históricas e deixa de existir apenas quando o conflito se desfaz, os tempos se unem, a alteridade original dá lugar à alteridade política, 
pois o outro se torna parte antagônica de nós. Quando a história passa a ser a nossa história - de nossa pluralidade e diversidade, e "nós já não somos nós mesmos porque somos antropofagicamente nós e o outro que devoramos e nos devorou" (MARTINS, 2009, p. 134), - é que podemos denominar de vínculo coletivo. E na fronteira que se descobre o outro.

Martins (2009) expõe também sobre a diversidade histórica dos modos de ver a fronteira e fases de momento de ocupação do espaço brasileiro. Para ele, a fronteira no Brasil foi gerada a partir de duas designações: frente de expansão e frente pioneira, que são modos diferentes de como as populações civilizadas se expandem territorialmente e como vivem no espaço novo.

Para o autor, a frente de expansão (ou fronteira demográfica) foi assim definida pelos antropólogos a partir da década de 1950 e tem como referência as populações indígenas. É considerada uma frente de deslocamento da população civilizada (popularmente, 'ocupações') e das atividades econômicas (frente econômica) aquelas que são de algum modo reguladas pelo mercado. Além disso, o autor inclui nesta frente as populações pobres, rotineiras, não-indígenas ou mestiças, como também os garimpeiros, vaqueiros, seringueiros, castanheiros e pequenos agricultores.

A noção de frente de expansão [...] se apoia essencialmente em subentendidos. Esses subentendidos afloram nas duas últimas décadas, nos trabalhos dos autores que fizeram pesquisa na região amazônica. Para uns, a frente de expansão aparece como sendo expansão da sociedade nacional; para outros, como expansão do capitalismo e para outros, até como expansão do modo capitalista de produção. Originalmente, era expansão da fronteira da civilização (MARTINS. 2009, p. 136).

Assim como conceituou Martins, asseguramos que a frente de expansão mais evidente para nós brasi- 
leiros encontra-se na Amazônia. Para ilustrar o que nosso argumento, Maisonnave e Almeida (2016) retratam um dos "braços" da frente de expansão do desmatamento na Amazônia para dar lugar ao grande capitalista. Segundo a reportagem da Folha de São Paulo, a Transamazônica 2 é a última parada que sedia a nova frente de expansão do desmatamento na Amazônia. Possível de conferência na imagem abaixo, tais demandas marcam a região norte, mas não difere do mesmo ocorrido em tantas regiões outras do país. Nisso, basta pensarmos no interior de São Paulo norte goiano.

Figura 1 - Palafitas em Lábrea (AM)

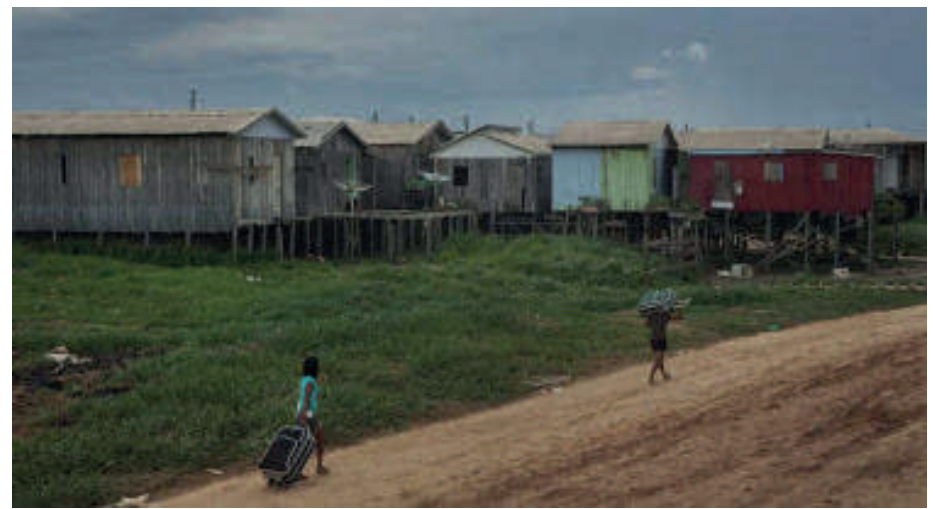

Fonte: Maisonnave e Almeida (2016)/ Foto: Lalo de Almeida 30.set.2016/Folhapress

Já a frente pioneira (ou fronteira econômico capitalista) foi definida na década de 1940 pelos geógrafos e que leva em conta o empresário, o fazendeiro, o comerciante e o pequeno agricultor moderno e empreendedor, movimento que marca e fortalece o descaso para com grupos sociais vulneráveis como os pequenos agricultores que estão espalhados por todo o Brasil. Na visão de Martins (2009, p.135-6)

A frente pioneira é mais do que o deslocamento da popula- 
ção sobre territórios novos, mais do que supunham os que empregam essa concepção no Brasil. A frente pioneira é também a situação espacial e social que convida ou induz à modernização, à formulação de novas concepções de vida, à mudança social. Ela constitui o ambiente oposto das regiões antigas, esvaziadas de população, rotineiras, tradicionalistas e mortas.

Em outras palavras, esta frente diz respeito ao deslocamento de várias pessoas para a ocupação de determinado espaço nacional, transformando, em poucos anos, terras consideradas ociosas em povoadas e, inevitavelmente, produtivas. Uma das principais características dessa frente, no que diz respeito a fronteira agropecuária em muitos estados brasileiros, é o desenvolvimento do rebanho bovino, como indício de produtividade das terras (GIRARDI, 2008).

Podemos perceber que a frente pioneira, também no lócus amazônico, no fim do século XIX, quando inicia-se o ciclo da exploração da borracha brasileira na Amazônia, devido a Revolução Industrial e cuja matéria-prima era importada para as fábricas inglesas em grandes volumes. Entre os anos 1870 e 1900, pelo menos 300 mil nordestinos saíram de suas terras para a Amazônia no intuito de trabalharem nos seringais. Poucos anos depois, em 1943, no intuito de contribuir para o armamento bélico norte-americano durante a Segunda Grande Guerra, o governo brasileiro após acordo assinado recruta cerca de $60 \mathrm{mil} \mathrm{jo-}$ vens para trabalharem nos seringais. A maioria deles também eram nordestinos. Estima-se quee apenas do Ceará tenham partido cerca de 30 mil (ARAÚJO e NEVES, 2015). A foto retrata bem o período em questão. 
Figura 2 - Despedida dos "soldados da borracha" de suas terras de origem

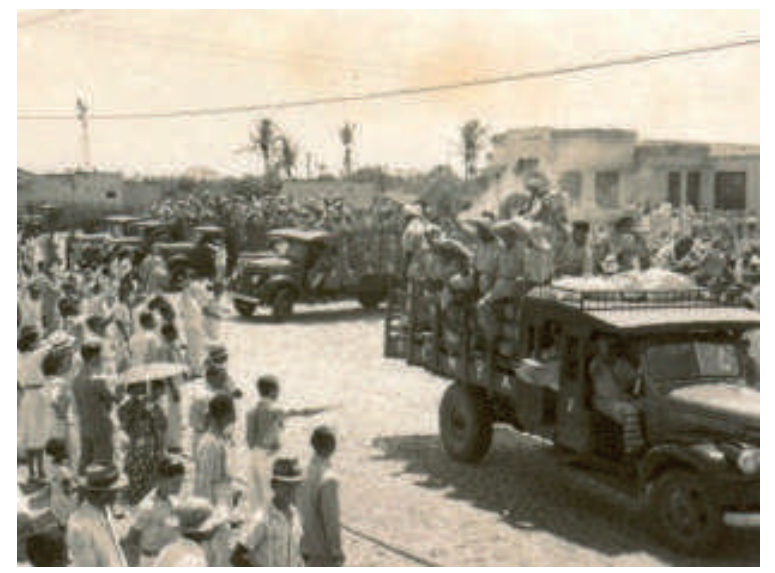

Fonte: ARAÚJO e NEVES, 2015 / Foto: Arquivo/SEMTA

Martins, portanto, não separa as duas perspectivas e afirma que as concepções são "expressões diferentes da mesma coisa", já que "se referem a realidades sociais substantivas, modos singulares de organização da vida social, de definição dos valores e das orientações sociais" (MARTINS, 2009, p. 135-136). Assim, afirma o ilustre autor (2009, p. 141): “a categoria mais rica e apropriada para a reflexão sociológica é a frente de expansão, porque ela se refere a lugar e tempo de conflito e de alteridade". Apropriando-nos da fala de Martins (2009), entendemos que os pequenos produtores, os acampados, os assentados e todos os trabalhadores rurais marginalizados do território brasileiro fazem parte da frente de expansão.

Por assim ser, na fronteira da humanidade, os trabalhadores rurais resistem ao desmonte do campesinato e de todas as políticas públicas de garantia de direitos à terra, que embora, levando em consideração a finalidade da Reforma Agrária implementada por décadas, em grande parte dos exemplos, demonstra ser em vão e pouco eficiente. Nosso exemplo, o que abre este relato, é uma 
exceção dentro deste contingente, mas traz as marcas de luta que custou tal caminhada. A partir dessa referência, podemos considerar que há uma política perversa de não reconhecimento e de empobrecimento das classes já injustiçadas no Brasil.

\section{Realidade de conflitos no Cerrado Goiano (2014-2016)}

Para trazer uma mostra de alguns conflitos e resguardados o período temporal de ambas as análises, trouxemos dados divulgados pela Comissão Pastoral da Terra $(\mathrm{CPT})^{4}$, sobre os conflitos por terra no Brasil. Nosso enfoque será o Estado de Goiás, a fim de estudarmos e compreendermos a realidade que está próxima a nós. Selecionamos para este levantamento as edições $30^{\underline{a}}$, $31^{\underline{a}}$ e $32^{\underline{a}}$ do "Conflitos no Campo Brasil", respectivamente dos anos 2014, 2015 e 2016.

De acordo com o documento, em 2016 foram registradas 1.295 ocorrências de conflitos por terra, entre os quais despejos, ameaças de despejos, expulsões, bens destruídos e pistolagem. Em 2015 foram 998 ocorrências, contra os já citados 1.295 registros. Em 2014, foram 1.018 embates por terra. No ano passado, foram computados 58 homicídios, onze a menos que em 2015 (69) e 22 a mais que em 2014 (36). Já em relação aos conflitos trabalhistas, os mesmos no relatório ficaram assim dispostos: 141 casos em 2014, 80 em 2015 e 60 em 2016. Pessoas envolvidas nos conflitos, também nesta sequência de anos, os números saíram de 2.493, passaram para 1760 e, por fim, 751; já a superexploração, saiu de 10 em 2014, foi para 4 em 2015, e caiu para

\footnotetext{
${ }^{4}$ A Comissão da Pastoral da Terra (CPT) é um órgão ligado à Igreja Católica, fundada após o Regime Militar, em 1985, e tem como principal missão "ser uma presença solidária, profética, ecumênica, fraterna e afetiva, que presta um serviço educativo e transformador junto aos povos da terra e das águas, para estimular e reforçar seu protagonismo" (CPT, 2010, p.01).
} 
apenas um caso em 2016. Esses dados coadunam com o depoimento de nossa participante.

Em Goiás, conforme o relatório da CPT, o Centro de Documentação Dom Tomás Balduíno registrou 18 ocorrências de violência contra ocupação e posse, em 2016, 19 a menos que em 2015 (quando foram registrados 37). Em 2014, foram registradas 10 ocorrências, segundo a CPT. Em 2016, 4.348 famílias foram envolvidas nos conflitos, 12.263 a menos que 2015 (16.611). Em 2014, este número chegou a 7.407 famílias envolvidas; 1.020 famílias foram despejadas em 2016 - número quatro vezes menor que 2015, quando ficaram sem teto 4.130 famílias. Em 2014, um total de 50 famílias ficaram sem ter onde morar. Em 2016 foram 1.275 famílias ameaçadas de despejo, número inferior a 2015, quando 5.160 foram ameaçadas pelo mesmo motivo. Em 2014, foram registradas 3.612 ameaças desta natureza. Também houve casos de pistolagem nos dois últimos anos. Em 2015 foram 350 casos, e 2016, apenas um caso. Em 2014 não teve registro. Nos dois anos, não foram computados casos de famílias expulsas e com moradias destruídas, em compensação, em 2014, 300 casas foram destruídas. Nenhuma família foi expulsa.

Em relação à violência contra a pessoa - aqui inclusos assassinatos, tentativas de homicídio, ameaças de morte, prisão e tortura -, no Estado, no ano passado foram 27 registros de conflitos, 12 a menos que em 2015 (que registrou 39). Em 2014, foram 21 embates desta ordem. O número de pessoas envolvidas era de 38.784 em 2014, saltou para 83.060 em 2015 e diminuiu para 29.636 em 2016. Não houve registro de homicídio, porém, em cada ano (2015 e 2016), foi computada uma tentativa de assassinato. Ameaçados de morte e agredidos fisicamente em 2016 não teve registros, diferentemente de 2015, quando foram registrados 1 em cada 30 casos, respectivamente. Em compensação, em 2015, ninguém foi preso; em 2016, foram três pessoas. Estes indicadores aparecem zerados no relatório de 2014. 
Em relação aos conflitos no cerrado, assim diz um texto da CPT, divulgado à imprensa:

O Cerrado é a "principal área de expansão/invasão do agronegócio, detém 14,9\% da população rural do país, mas registrou $24,1 \%$ do total das localidades envolvidas em conflitos, o que lhes dá um índice de $1.67 \%$, ou seja, o número de conflitos é relativamente maior (67\%) do que sua população", analisa o professor da Universidade Federal Fluminense (UFF), Carlos Walter Porto-Gonçalves, em texto no relatório divulgado pela CPT.

Segundo este autor, o Estado protela a realização da reforma agrária, por ser o guardião da ordem capitalista e por defendê-la (NETO, 1997, p. 117). Mas uma dúvida que nos assaltou durante este levantamento de dados em Goiás: Por que aparentemente os números de conflitos no campo diminuíram? Estamos certos em afirmar que, embora estejamos vivenciando a era tecnológica, os casos ainda são timidamente registrados nos órgãos responsáveis, e quase sempre o camponês não tem acesso aos meios para registrar suas denúncias, o que implica dizer que os números são ainda maiores. Ainda observando dados dos três anos (2014, 2015 e 2016) percebe-se que de 2015 para 2016 os números de conflitos e violência no campo em Goiás reduziram, porém, avalizando 2014 para 2015, percebemos, em muitos casos citados, que houve um considerável aumento. Acreditamos também, que, em grande parte, os trabalhadores estão mais cientes dos seus direitos e deveres.

De outro modo, convém-nos afirmar que, em Goiás, estes números refletem seu forte caráter político e estrutura fundiária arcaica e patriarcal. O Estado de Goiás foi palco do coronelismo, o qual se disseminou pelo país com uma complexa estrutura de poder social e político, durante a República Velha (1889-1930). Os princípios basilares do fenômeno eram a grande propriedade rural (latifúndios) e seus interesses particulares. Também, Goiás 
foi berço da União Democrática Ruralista (UDR), em 1985. De acordo com o professor Glauber Lopes Xavier (2015, p.144), a UDR foi o "movimento patronal rural [que] cimentou as bases do que hoje é conhecida como Bancada Ruralista" e que também projetou o nome do goiano Ronaldo Caiado, um de seus principais articuladores e "cuja história da atuação política [...] se confunde com a história da UDR". Citando Mendonça, Xavier destaca também que a UDR justificava a violência como mecanismo para a defesa das propriedades, resistindo ao Programa Nacional de Reforma Agrária (PNRA) e qualquer outra investida de reforma agrária no país (XAVIER, 2015).

Ao que se percebe, ambos os movimentos, de formas complementares, sempre estiveram presentes como principais características deste Estado e ainda hoje mantém viva a tradição, também no Congresso Nacional, de impedir a aprovação de projetos de lei a favor da reforma agrária. Diante do exposto, podemos aferir que, com o passar dos anos, em especial no recorte de 1950 a 1980, e entre 2014 a 2016, os processos sociais de conflitos de classes tem vitimado em muitos casos o trabalhador rural, a quem Marx reconhece como proletariado.

Não é de hoje que a questão agrária no Brasil tem sido uma preocupação para todos os envolvidos. Na polaridade das classes sociais, cabe-nos ressaltar que para a grande burguesia a concepção de terra era distinta daquela defendida pelo trabalhador camponês. Para este último, a terra possuía uma ligação física, porém mais sentimental. Para o capital, a terra torna-se propriedade privada, mercadoria, suscetível à compra e venda. Quando chegava ao campo esta ideologia, o campesinato perdia suas terras, cultura, tradição, valores e hábitos comuns a ele, naquela fração do território.

Notamos ainda que o capital estrangeiro teve favorável abertura, em especial em alguns planos de governo e citados por autores, no decorrer deste ensaio. Vale des- 
tacar ainda que os projetos agropecuários, em favor da acumulação de capital, contaram com o apoio financeiro e creditício do Estado Burguês ${ }^{5}$, sob o pretexto de modernização e progresso técnico. Apregoavam, no entanto, que o capitalismo leva a civilização ao progresso, com o objetivo de converter tudo em mercadoria, mesmo o que não é produto do trabalho. Ao transformar a natureza em mercadoria, permite-se que o capitalismo se instaure e se consolide.

Nas décadas de 1960 a 1980, foi perceptível que a burguesia com seu poder político e econômico procedente do centro-sul do país, avançou para o norte do Brasil. Reconhecemos a investida para formação e expansão da empresa capitalista no campo e o ingresso do Brasil no modo de produção capitalista. Para ocupar as terras adjetivadas de "vazio", era válido todos os instrumentos de violência para assegurar o direito à propriedade e a comprovação do documento, que garantem a acumulação primitiva. A paulatina "legalização" das terras contavam com grileiros, jagunços e pistoleiros para intimidar e adquirir a terra por um preço muito baixo, quando raramente havia negociações.

As expropriações demonstram a retirada de direitos do campesinato e sua total supressão. Diante deste quadro, só restou ao trabalhador vender sua força de trabalho para os latifundiários ou partirem para as cidades. Quase sempre eles são explorados e gera ao patrão a mais-valia, uma espécie de renda extra à burguesia, que vai além dos custos e gastos e contribui significativamente para acumulação primitiva de capital. Além disso, não é de se estranhar, que nesta ambiência, a legislação tomava partido em favor do capital, tais como demonstram as legislações dos registros públicos, certidões cartoriais, medições de super-

\footnotetext{
${ }^{5} \mathrm{Na}$ Teoria Marxista, Estado Burguês refere-se àquele através do qual a burguesia exerce o poder político através de uma determinada combinação de instituições políticas.
} 
fícies, etc.

Percebemos que, no caso do Brasil, a modernização não foi proporcional à distribuição das terras de forma igualitária. Se houve êxito no mundo, o Brasil não conseguiu implantar a reforma agraria e não superou a distribuição de terras. Podemos destacar pontos como entraves ao contexto histórico do território brasileiro: a sua formação por sesmarias e capitanias; os quatro séculos de escravidão; e os pactos das elites para continuarem no poder político. Portanto, ainda que, apesar de passados quase 60 anos, as mudanças são irrisórias.

A reforma agrária não saiu do papel, e com a aprovação da Reforma Trabalhista, foi possível ao novo governo abrir as portas da Amazônia ao grande capital, como mais uma forma de acumulação primitiva, principal interesse da burguesia. Em termos comuns e de fácil entendimento, trata-se do acúmulo de riqueza para os donos de grandes quantidades de mercadorias. Por fim, acreditamos, como Murilo de Carvalho (2011, p. 229), que "a desigualdade é a escravidão de hoje, o novo câncer que impede a constituição de uma nova sociedade democrática", enquanto isso, no Brasil, no contexto da luta pela terra, a burguesia é capaz de matar e o proletariado/campesinato é a maior vítima do sistema.

\section{Considerações Finais}

Gostaríamos de concluir que a reforma agrária reassumiu uma posição de destaque na política nacional, apresentada nas mídias e as pessoas longe dos espaços em que ocorre, como um vetor de promoção do desenvolvimento sustentável no campo, verdades até bem vendidas ao país. Porém, mensurar os índices de sustentabilidade alcançados pelos assentamentos organizados no âmbito da política de reforma agrária que buscou tal ação parece desnecessária, uma vez que mostra mais o fracasso que o 
sucesso de tal ação. $\mathrm{O}$ estudo aqui apresentado, sustentado num relato de experiência de uma estudante de do estado de Goiás, nos traz a realidade vivenciada pelas famílias assentadas, destacando, inclusive, as novas oportunidades e os desafios a serem superados após o acesso à terra e a exposição em que são submetidos nos anos que se seguem ao assentamento.

Se os dados de desenvolvimento ocorrem com base em indicadores de sustentabilidade, sendo enfocados os aspectos econômico, social e ambiental, percebemos que é preciso mensurar a qualidade de vida dessas populações. Podemos afirmar que os indicadores apontam sérios problemas estruturais nos assentamentos e que limitam o estabelecimento de processos produtivos, agravam problemas ambientais e restringem as condições de vida das famílias assentadas, sua sobrevivência e permanência na terra.

Portanto, reforçamos que não é de hoje que a população mais carente tem enfrentado situações de espoliação por parte do grande capitalista, porém, tem demonstrado sua garra através da Educação para conquistar seus objetivos. A Educação tem demonstrado ser o único e mais eficiente instrumento para empoderar o homem do campo e conscientizá-los de seu lugar no sistema capitalista. É neste lugar da fronteira marcada pela desigualdade e permeado pelas frentes que sempre utilizam o trabalhador como "escada", que renasce, em muitos deles, forças para continuar a luta pela vida e deixar de ser a maior vítima do atual sistema.

\section{REFERÊNCIAS}

ARAÚJO, A.; NEVES, M. V. Soldados da borracha: os heróis esquecidos. São Paulo: Escrituras, 2015.

CARVALHO, J. M. de. Cidadania no Brasil: o longo caminho. Rio de Janeiro: Civilização 
Brasileira, 2011.

GIRARDI, E. P. Proposição teórico-metodológica de uma Cartografia Geográfica Crítica e sua aplicação no desenvolvimento do Atlas da Questão Agrária Brasileira. 2008. Tese (Doutorado em Geografia) - Faculdade de Ciências e Tecnologia, Universidade Estadual Paulista, Presidente Prudente, 2008.

MAISONNAVE, F.; ALMEIDA, L. de. Transamazônica: crime e abandono. Folha de São Paulo, São Paulo, 22 out. 2016, p. $1-6$.

MARTINS, J. de S.. Fronteira: a degradação do outro nos confins do humano. São Paulo: Contexto, 2009.

MORAES, A. C. R. Território e História no Brasil. São Paulo: Hucitec, 2002.

GONÇALVES NETO, W. Estado e Agricultura no Brasil. São Paulo: Hucitec, 1997.

XAVIER, G. L. "Senhores da Lei, Donos da Terra": o arauto da bancada ruralista na Câmara dos Deputados (2009-2014). Revista Estudos Sociedade e Agricultura, v. 23, n. 1. Rio de Janeiro, 2015, p. 131-165. 


\section{CAPÍTULO 13}

\section{EL MODELO CRA (COLEGIO RURAL AGRUPADO): una alternativa organizativa de la escuela rural en España}

Pilar Abós Olivares ${ }^{1}$

Juan Lorenzo Lacruz ${ }^{2}$

Tal y como señala Santamaría (2012), el modelo de escolarización basado en la escuela unitaria ${ }^{3}$ pervivió en España desde la Ley Moyano de 1858 hasta la Ley General de Educación de 1970, teniendo como origen el Plan de Instrucción de 1838 en el que se establecía la creación de escuelas en municipios de más de 500 habitantes, de modo que, aunque si el número de alumnos era suficiente existían dos escuelas unitarias en cada municipio, una de niños y otra de niñas, las características de ruralidad existentes hasta bien entrado el siglo XX, ofrecían un panorama de escuelas mixtas (niños y niñas) en la mayoría de pueblos y aldeas y una situación era de olvido generalizado.

\footnotetext{
${ }^{1}$ Doctora en Ciencias de la Educación y Licenciada en Filosofía y Ciencias de la Educación. Profesora Titular de Universidad del Departamento de Ciencias de la Educación de la Universidad de Zaragoza. Principales líneas de investigación centradas en la educación en contextos rurales en España e Iberoamérica, la historia de la escuela rural española, la formación inicial del profesorado de primaria y de secundaria y los procesos de innovación pedagógica en contextos rurales.

Email: pabos@unizar.es

${ }^{2}$ Doctor en Ciencias de la Educación y Licenciado en Historia. Profesor asociado del Departamento de Ciencias de la Educación de la Universidad de Zaragoza. Principales líneas de investigación centradas en la historia de la renovación pedagógica y las distintas corrientes pedagógicas alternativas, la educación en contextos rurales actuales, el Análisis Crítico del Discurso aplicado al ámbito educativo y la aplicación didáctica de las Tecnologías del Aprendizaje y el Conocimiento (TAC) en la formación inicial de docentes. Email: jlorenzo@unizar.es
}

${ }^{3}$ Un grupo de alumnos/as bajo la supervisión de un solo maestro cualquiera que fuera su edad y nivel 
Olvido manifiesto teniendo en cuenta que muchas de las escuelas de las que hablaba la Ley seguían sin existir, el índice de escolarización sobre la población total era de $1 / 12$, un $60 \%$ de la población infantil en edad escolar permanecía sin escolarizar y las tasas de analfabetismo eran del $73 \%$ en términos absolutos y el $50 \%$ efectivo sobre los habitantes en edad de escolarización (Moreno, 1998). Situación que dio lugar al alzamiento de algunas voces como la de Cossío, en el Congreso Nacional Pedagógico de Madrid celebrado en 1882 cuando señala que a las escuelas rurales hay que enviar a los mejores maestros en sabiduría y vocación, o la de Costa quien en 1899 propone una reorganización de las escuelas rurales y la adecuada remuneración de sus maestros.

La creación de Ministerio de Instrucción Pública y Bellas Artes en marzo de 1900, consecuencia de la demanda efectuada desde sectores progresistas y liberales (Viñao, 2004), daba nuevas esperanzas para la equiparación del sueldo del profesorado en las escuelas rurales y la construcción de escuelas, aunque las presiones de la Iglesia y los sectores más conservadores impidieron su puesta en práctica (Moreno, 1998).

Habrá que esperar a algunas acciones de la política educativa republicana en su primera etapa (1931-33) inspirados en los principios de la Institución Libre de Enseñanza, para pensar en una escuela rural en positivo: el incremento del número de escuelas y de la remuneración de los maestros, la preparación del magisterio a través del Plan Profesional, las Misiones Pedagógicas, la creación de Bibliotecas...influyeron claramente en la potenciación de la escuela pública, y por consiguiente de la escuela rural. Pero la alegría duró poco: el estallido de la contienda civil acabó con las esperanzas de la población rural española y la depuración de maestros, muchos de ellos de escuelas rurales, fue una de las acciones más representativas del periodo inmediatamente posterior, teniendo en cuenta 
que las escuelas rurales eran consideradas como una obra al servicio de Dios y de los nuevos valores de la España de Franco (Serrano de Haro, 1941).

La Ley de Educación Primaria de 1945, aunque rebaja la creación de escuelas a 1/250 habitantes, no supuso grandes variaciones, ya que, aunque suponía una mejora en el acceso a la educación, en el contexto rural ésta se limitaba a los estudios elementales. Además, la labor educativa se dejaba en manos de personas de reconocida moralidad, tuvieran o no la titulación adecuada. En este nuevo contexto, las agrupaciones escolares que surgen a partir de los años 60 van a suponer el comienzo de la progresiva desaparición de las escuelas unitarias que culmina en la LGE de 1970, considerada como el antecedente inmediato de nuestro actual sistema educativo.

\begin{abstract}
"Las concentraciones escolares tienen su precedente en las agrupaciones escolares, a comienzos de los sesenta (...). Pero es a partir de la Ley General de Educación y más concretamente de las Órdenes Ministeriales para la Transformación y clasificación de centros, 30-XII-1971 y 14-2-1972, cuando comienza la fiebre de creación de centros comarcales de enseñanza y consiguientemente la supresión de escuelas unitarias y mixtas" (Jiménez, 1983,29)
\end{abstract}

Concentraciones que, en defensa de la graduación, la homogeneización y la igualdad de oportunidades como banderas de la calidad, escondían fuertes razones de índole económica que implicaron el cierre de muchas escuelas unitarias e incompletas. Surgen así los denominados Centros Comarcales ${ }^{4}$ y las Escuelas Hogar ${ }^{5}$. No obstante la política concentradora a tuvo un fuerte rechazo desde diferentes sectores educativos ${ }^{6}$ y políticos surgidos durante los

\footnotetext{
${ }^{4}$ Centro completo al que acuden alumnado de diferentes localidades con servicio de transporte y de comedor.

${ }^{5}$ Centros en los que el alumnado de zonas dispersas y/o alejadas permanecían de lunes a viernes en régimen de internado.

${ }^{6}$ Movimientos de Renovación Pedagógica, Escuelas de Verano, Revistas Educativas.
} 
últimos años de la Dictadura en defensa de un derecho a la educación en condiciones de igualdad con independencia del lugar de residencia. Había que tener en cuenta que el cierre de escuelas suponía la pérdida de otros servicios económicos, sanitarios y sociales.

"El medio rural, la sociedad rural tradicional debía ser desmantelada y sustituida cuanto antes por otro tipo de sistema de producción y comercialización agropecuaria, y su población debía trasladarse masivamente a las ciudades, abandonar el sector primario en su inmensa mayoría para incorporarse al sector industrial y de servicios. La escuela, en este contexto, debía desempeñar un papel social y económico, invitando expresa o indirectamente a la salida del pueblo, o formando adecuadamente a los niños y adolescentes para adaptarse más pronto, y con menor riesgo, a la nueva realidad que van a encontrar en la sociedad urbana" (Hernández, 2000, 132-133)

La muerte de Franco y la promulgación de la Constitución de 1978 en cuyo artículo 27 se proclama el derecho de todos los ciudadanos a una educación básica y gratuita, dan lugar a otro episodio en la historia de nuestra escuela rural, aunque el porcentaje de escuelas unitarias respecto al porcentaje total de unidades en la escuela pública había descendido del $68 \%$ en el curso 1951-52 al 12\% en el curso 1974-75 (INE, 1954; MEC, 1993). Además la nueva configuración administrativa del Estado de un marcado carácter descentralizado, podía permitir que las Comunidades Autónomas configuraran su organización escolar de una manera más cercana a las características de su territorio a través del desarrollo de sus competencias.

Los movimientos en defensa de la escuela rural tuvieron, con la llegada al Gobierno de España del Partido Socialista Obrero Español en las elecciones de 1982, la oportunidad de poner en práctica algunas de sus reivindicaciones. La publicación del Real Decreto sobre Educación Compensatoria de 27 de abril de 1983 "en beneficio de aquellas zonas geográficas o grupos de población que por sus especiales características requieren una atención educati- 
va preferente" (art. 1) y de la Ley Orgánica reguladora del Derecho a la Educación (LODE) de 3 de julio de 1985, por su planteamiento de compensación de desigualdades y la posibilidad de adaptación al contexto en el que se ubiquen los centros (art, 15), significó un importante salto cualitativo (Domingo, 2013). Todo ello posibilitó que, a partir del Proyecto de Educación Compensatoria desarrollado en el Valle de Amblés en la provincia de Ávila, en el que nueve escuelas unitarias, trabajando con un proyecto común evitaron el desplazamiento del alumnado a las concentraciones escolares ${ }^{7}$, se constituyera el primer Colegio Rural Agrupado $^{8}$ y se normativizara su organización a través del Real Decreto 2731/1986, de 24 de diciembre, sobre constitución de Colegios Rurales Agrupados de Educación General Básica.

\section{El modelo de Colegio Rural Agrupado (CRA) ${ }^{9}$ : nacimiento y evolución}

El breve recorrido histórico realizado pone de manifiesto el interés predominante de importar el modelo urbano al medio rural, principalmente a través de la uniformidad curricular y de la estructura graduada, tratando de imponer homogeneidad en contextos heterogéneos (Sanz, 2009). Además la política concentradora "lejos de alcanzar el objetivo de reducir las disparidades existentes entre el medio urbano y el rural (...) tendió a agravar las carencias de este último dificultando el desarrollo educativo y afectivo de los alumnos y contribuyendo a su desarraigo cultural"10.

${ }^{7}$ Se desarrolló sin respaldo legal durante los cursos 1983-84 y 1984-85

${ }^{8}$ Resolución de la Subsecretaría del Ministerio de Educación y Ciencia de 12 de abril de 1985

${ }^{9}$ A partir de este momento se utilizará el acrónimo CRA

${ }^{10}$ Real Decreto sobre constitución de Colegios Rurales Agrupados de EGB (1986) 
Ante esta situación la aparición del modelo CRA supuso un revulsivo para la defensa del mantenimiento de las escuelas rurales, al menos desde el punto de vista organizativo, al establecerse como una respuesta para la gestión de los recursos humanos y materiales de aquellas escuelas que pertenecieran a un mismo entorno físico, social y natural (Bernal y Lorenzo, 2014). El nuevo modelo garantizaba la permanencia del alumnado de preescolar y de ciclos inicial y medio de la Educación General Básica en su localidad de residencia, así como diferentes fórmulas para el del ciclo superior ${ }^{11}$ y se estructuraba en torno a las siguientes características:

- Unidades ${ }^{12}$ de diferentes localidades se agrupan en un único Colegio Rural Agrupado con capacidad académica y de gestión, permaneciendo el alumnado en sus localidades de origen.

- La constitución de un CRA implicará el análisis de las condiciones geográficas de la zona implicada, así como los factores funcionales y pedagógicos que avalan la agrupación.

- Los docentes de las diferentes unidades y localidades formarán parte de un único claustro y compartirán documentos institucionales y proyectos, de manera que los planteamientos didácticos y organizativos serán los mismos. Del mismo modo los órganos de gobierno (equipo directivo y consejo escolar), serán únicos.

- El alumnado de cada una de las unidades tendrá asignado un maestro/a tutor/a y recibirá la atención de los maestros itinerantes especialistas de música, lengua extranjera y educación física.

\footnotetext{
${ }^{11}$ La Educación Preescolar era una etapa no obligatoria de los 4 a los 6 años y la Educación General Básica constituía en ese momento la educación obligatoria y gratuita para todos ( 6 a 14 años) y constaba de tres ciclos: inicial ( $1^{\mathrm{o}} \mathrm{y}$ $\left.2^{\mathrm{o}}\right)$, medio $\left(3^{\mathrm{o}}, 4^{\underline{\mathrm{o}}}\right.$ y $\left.5^{\mathrm{o}}\right)$ y superior $\left(6^{\mathrm{o}}, 7^{\mathrm{o}}\right.$ y $\left.8^{\mathrm{o}}\right)$.

${ }^{12}$ Se entiende por unidad cada una de las aulas perteneciente a una escuela incompleta
} 
De este modo el CRA supone un modelo organizativo y pedagógico promovido desde la administración educativa y las comunidades rurales que permite el mantenimiento de escuelas unitarias e incompletas en las localidades de origen del alumnado (Domingo, 2013). Cada CRA está formado por la unión de pequeñas escuelas que conforman un único centro escolar. En cada una de dichas escuelas asisten niños desde los 3 a los 12 años ${ }^{13}$ que son atendidos por sus correspondientes tutores, uno en cada aula, y los maestros itinerantes (Gómez, 2007). Las escuelas que se agrupan son aquellas en las que el número de alumnos no permite tener un curso por nivel educativo (in completas) (Tapia y Castro, 2011). Supuso y supone un modelo alternativo que abre el horizonte a la innovación y al cambio (Bernat, 2009). No obstante, el desarrollo del modelo no ha estado exento de sombras (Bernal, 2009), algunas de las cuales se refieren a los vaivenes legislativos ocurridos desde entonces, de los que nos ocupamos en este apartado.

En una primera instancia hay que señalar que aunque el Libro Blanco (1989) que se elaboró antes de la LOGSE (1990) insistía en la necesidad de mantener la escuela próxima al entorno de los niños y ello condujo a la inclusión de un Título Quinto dedicado a la Compensación de las Desigualdades en la Educación, entre las que representan un capítulo importante aquellas desigualdades derivadas de razones geográficas u ocasionadas por la residencia del alumnado en el ámbito rural, la ley no afronta de forma clara los problemas pendientes y las cuestiones endémicas de la escuela rural (Bernal y Lorenzo, 2014). A ello hay que unir la nueva estructura del sistema escolar que, al ampliar la edad de escolaridad obligatoria hasta los 16 años dividiéndola en dos etapas: primaria de 6 a 12 años y educación secundaria obligatoria de 12 a 16, provoca nuevos problemas respecto al cómo y dónde se debe cursar

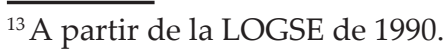


esta segunda etapa. La nueva estructura obliga a modificar la organización de los centros educativos y a partir de $1996^{14}$ la planificación de la enseñanza será la que delimite la creación y/o supresión de centros, incluidos los CRAs.

Diez años después de su nacimiento se pierde la implicación y participación de la comunidad educativa en su constitución: la administración comienza a asumir la tarea y se olvidan algunos de los principios por los que nacieron. No obstante, los sucesivos informes del Consejo Escolar del Estado hacen referencia explícita a este tipo de centros y reiteran algunas de sus necesidades: fijar las plantillas en los CRAs (1997); adaptar las ratio en las unidades que acogen niños de diferentes edades (1998); aumentar las partidas presupuestarias para disminuir las diferencias con las escuelas urbanas en cuanto a recursos y profesorado; fomentar la formación permanente del profesorado y elaborar planes específicos (1999); desarrollar políticas específicas (2000); elaborar un plan específico que contemple medidas de discriminación positiva (2001); cambiar aquellas políticas territoriales y educativas que llevan a una concentración de la población en zonas determinadas mientras que en otras se produce una desertización poblacional y mejorar las condiciones del profesorado itinerante (2002); fomentar el aprendizaje del uso de los medios informáticos y proveer por los medios públicos el acceso gratuito a la Red (2003); dotar de plantillas suficientes (2004).... El modelo sigue vigente, pero su desarrollo no está exento de lagunas y deficiencias. La escuela rural sigue siendo la hermana pobre del sistema escolar y su alumnado es considerado como de segunda categoría.

La reforma educativa planteada por la Ley Orgánica de Calidad de la Educación (LOCE, 2002) no olvida que es preciso establecer recursos suficientes para la consecución de la igualdad de oportunidades para una educa-

\footnotetext{
${ }^{14}$ Real Decreto por el que aprueba el Reglamento Orgánico de las Escuelas de Educación Infantil y los Colegios de Educación Primaria (1996).
} 
ción de calidad, especialmente en aquellas zonas que por su orografía se dificulte o impida al alunado recibir una educación similar a la de otras zonas geográficas, pero los conceptos de homogeneización y de compensación educativa vuelve a aplicarse de manera generalizada al mundo rural. El modelo CRA persiste, pero el envoltorio economicista que se ciñe sobre la educación tal vez hizo pensar en la vuelta a la sombra de las concentraciones y la desaparición de las escuelas unitarias e incompletas.

Las reivindicaciones descritas en los anteriores informes del Consejo Escolar del Estado siguen estando presentes (2005) y comienzan a aparecer muchas referencias a las diferencias existentes entre las Comunidades Autónomas, fruto no solo de sus características poblacionales, sino también de sus políticas educativas. La Ley Orgánica de Educación (LOE, 2006) establece, en su capítulo dedicado a la equidad en la educación que todo el alumnado debe tener acceso a los medios que garanticen su pleno desarrollo, y en el de compensación de la desigualdades en educación, se parte de que el territorio es un elemento que provoca desigualdad y que por lo tanto precisa de medidas compensatorias. No obstante se reconoce el carácter particular de la escuela rural a fin de proporcionar los medios y sistemas organizativos necesarios para atender sus necesidades específicas y garantizar la igualdad de oportunidades (artículo 82). La homogeneización parece que da cabida al reconocimiento de la diferencia y diversidad, por lo que cabría preguntarse ¿estamos ante otro panorama?. El modelo CRA no cambia pero se reconoce la necesidad de que se adapte a contextos y condiciones diferentes de los existentes cuando nació hacía 20 años. El Consejo Escolar del Estado así lo señala al indicar que es necesario ofrecer a todos los alumnos en las zonas rurales la aplicación a la enseñanza de las nuevas tecnologías, para compensar la situación de mayor aislamiento cultural y la falta de medios y recursos (2007 y 2008). No obstante, y a pesar de pro- 
mover el mantenimiento de escuelas abiertas con cuatro alumnos, insta a la creación de centros integrados desde infantil hasta educación secundaria obligatoria (2008). La atención a la diversidad requiere una mayor dotación de profesorado de apoyo (2009); la dignificación de la condiciones laborales del profesorado fomentará su estabilidad (2011); así como la adaptación a los cambios acaecidos en la estructura y características del medio rural (2012).

Por su parte, la Ley Orgánica para la Mejora de la Calidad Educativa (LOMCE, 2013), mantiene los principios establecidos en la LOE y precisa que en los programas de cooperación territorial se tendrá en cuenta, como criterio para la distribución territorial de recursos económicos, la singularidad de estos programas en términos orientados a favorecer la igualdad de oportunidades. Se valorará especialmente el fenómeno de la despoblación de un territorio, así como la dispersión geográfica de la población, la insularidad y las necesidades específicas que presenta la escolarización del alumnado de zonas rurales (artículo 9). Además, indica la consolidación del modelo CRA para la atención al alumnado de Educación Infantil y Primaria de los municipios de población escolar reducida, dato que también aparece en los Informes del Consejo Escolar del estado de los años 2015 y 2016, a pesar de la disminución de alumnado escolarizado en estos centros, compatible con la caída demográfica en las zonas rurales españolas, así como al cierre de escuelas ubicadas en zonas rurales por los recortes experimentados en el ámbito educativo en los últimos cuatro cursos (2016). En suma, el modelo CRA como modelo organizativo y pedagógico se ha consolidado, pero el cierre de las pequeñas escuelas de que se nutre puede determinar su desaparición. 


\section{El modelo CRA en las diferentes Comunidades Autónomas}

La Constitución de 1978 en su Título VIII sobre la Organización Territorial del Estado manifiesta "El Estado se organiza territorialmente en municipios, en provincias y en las Comunidades Autónomas que se constituyan. Todas estas entidades gozan de autonomía para la gestión de sus respectivos intereses".

Las Comunidades Autónomas (CCAA) son entes públicos territoriales con facultades de autogobierno y autonomía legislativa, cuya norma institucional básica es el Estatuto de Autonomía que determina su sistema institucional y las competencias que asume, existiendo dos vías fundamentales de acceso a dichas competencias una especial (artículo 151) y otra lenta (artículo 143), lo que implica que el traspaso de competencias en materia educativa haya tenido fechas diferentes, marcando distintas líneas en la organización de la escuela rural en cada una de ellas. En este sentido, la Disposición Final Primera del Real decreto de 1986 de Constitución de los CRA señala que el modelo no será de aplicación en las CCAA que, teniendo competencia en materia de enseñanza, hayan recibido los correspondientes traspasos de funciones y servicios ${ }^{15}$.

El siguiente mapa (Figura 1) nos muestra la ubicación geográfica de las diecisiete Comunidades Autónomas y las dos Ciudades Autónomas, así como, marcadas con una flecha y con el Real Decreto correspondiente, las CCAA que en 1986 ya tenían traspasadas las competencias en educación.

15 Con anterioridad a 1986 Cataluña, Galicia, Euskadi y Andalucía. 
Tabla 1 nos muestra el modelo organizativo de la escuela rural en cada Comunidad Autónoma antes y después del traspaso de competencias y a partir de la constitución del modelo CRA.

\section{Tabla 1 - El modelo CRA en las \\ Comunidades Autónomas}

\begin{tabular}{|c|c|c|c|c|}
\hline $\begin{array}{l}\text { Comunidad } \\
\text { Autónoma }\end{array}$ & $\begin{array}{c}\text { Estatuto } \\
\text { Autonomía }\end{array}$ & $\begin{array}{c}\text { Transferencias } \\
\text { Educativas }\end{array}$ & $\begin{array}{c}\text { CRA } \\
(1986) \\
\end{array}$ & $\begin{array}{l}\text { Modelo Escuela Rural } \\
\text { (después transferencias) }\end{array}$ \\
\hline Adalucía & 1981 & 1983 & NO & Colegio Público Rural (CPR) (1988) \\
\hline Aragón & 1982 & 1998 & SI & CRA \\
\hline Asturias & 1981 & 1999 & SI & CRA \\
\hline Baleares & 1983 & 1998 & $\mathrm{NO}$ & Colegio de Infantil y Primaria (no agrupados) \\
\hline Canarias & 1982 & 1983 & NO & Colectivo de Escuelas Rurales (CER) (1999) \\
\hline Cantabria & 1981 & 1998 & SI & CRA \\
\hline $\begin{array}{c}\text { Castilla-La } \\
\text { Mancha }\end{array}$ & 1982 & 1999 & SI & CRA: 2009 Normativa Autonómica \\
\hline Castilla-León & 1983 & 1999 & SI & CRA \\
\hline Cataluña & 1979 & 1980 & $\mathrm{NO}$ & Zona Escolar Rural (ZER) (1988) \\
\hline $\begin{array}{c}\text { Comunidad } \\
\text { de Madrid }\end{array}$ & 1983 & 1999 & SI & CRA \\
\hline $\begin{array}{l}\text { Comunidad } \\
\text { Valenciana }\end{array}$ & 1982 & 1983 & SI & CRA : 1997 Normativa Autonómica \\
\hline Euskadi & 1979 & 1980 & NO & Escuelas Pequeñas (no agrupadas) \\
\hline Extremadura & 1983 & 1999 & SI & CRA \\
\hline Galicia & 1981 & 1982 & SI & CRA : 1988 Normativa Autonómica \\
\hline La Rioja & 1982 & 1998 & SI & CRA \\
\hline Murcia & 1982 & 1999 & SI & CRA \\
\hline Navarra & 1982 & 1990 & SI & CRA \\
\hline
\end{tabular}

Nota. Fuente: Elaboración propia

\section{La escuela rural y el modelo CRA en la actualidad, datos para la reflexión}

La población residente en España se situó en 46.449.565 habitantes a 1 de enero de 2015, lo que supuso 62.634 personas menos que a 1 de enero de 2014, lo que representa, en términos porcentuales, una caída del 0,13\% anual. Esta población, tiene sin embargo una distribución 
diferente entre las comunidades autónomas que depende de diferentes factores geográficos, sociales, históricos, económicos y culturales: cuatro comunidades autónomas incluyen casi el $60 \%$ de la población total.

\section{Tabla 2 - Comunidades Autónomas con mayor población (2014)}

\begin{tabular}{|c|c|c|}
\hline $\begin{array}{c}\text { Comunidad } \\
\text { Autónoma }\end{array}$ & Población absoluta & $\begin{array}{c}\% \\
\text { (sobre total) }\end{array}$ \\
\hline Andalucía & 8.388 .875 & 18 \\
\hline Cataluña & 7.416 .237 & 15,9 \\
\hline $\begin{array}{c}\text { Comunidad } \\
\text { de Madrid }\end{array}$ & 6.378 .297 & 13,7 \\
\hline $\begin{array}{c}\text { Comunidad } \\
\text { Valenciana }\end{array}$ & 4.956 .427 & 10,6 \\
\hline Total & $\mathbf{2 7 . 1 3 9 . 8 3 6}$ & $\mathbf{5 8 , 2}$ \\
\hline
\end{tabular}

Nota. Elaboración propia. Fuente INE

$\mathrm{Al}$ dato anterior debemos unir el de la densidad de población como uno de los factores que más incide sobre el sistema educativo, y más concretamente sobre la escuela rural. Las diferencias en el panorama español son alarmantes.

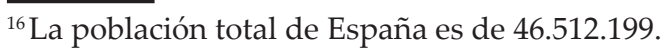




\section{Tabla 3 - Densidad de Población por Comunidades Autónomas}

\begin{tabular}{|c|c|c|c|}
\hline $\begin{array}{c}\text { Comunidad } \\
\text { Autónoma }\end{array}$ & Densidad km2 & España & Lugar \\
\hline $\begin{array}{c}\text { Comunidad } \\
\text { de Madrid }\end{array}$ & 794.5 habitantes & 91.9 & 1 \\
\hline Euskadi & 299.4 habitantes & 91.9 & 2 \\
\hline $\begin{array}{c}\text { Castilla-La } \\
\text { Mancha }\end{array}$ & 26 habitantes & 91.9 & 17 \\
\hline $\begin{array}{c}\text { Extremadura } \\
\text { 26,28 habitantes }\end{array}$ & 91.9 & 16 \\
\hline Castilla-León & 26,3 habitantes & 91.9 & 15 \\
\hline Aragón & 27,8 habitantes & 91.9 & 14 \\
\hline
\end{tabular}

Nota. Elaboración propia. Fuente INE

Tabla 4 Población en municipios de menos de 2000 habitantes $^{17}$

\begin{tabular}{|c|c|c|}
\hline Comunidad Autónoma & $\%$ & España \% \\
\hline Galicia & 48,7 & 9,4 \\
\hline Asturias & 25,7 & 9,4 \\
\hline Castilla-León & 25,7 & 9,4 \\
\hline Baleares & 1 & 9,4 \\
\hline Comunidad de Madrid & 0.8 & 9,4 \\
\hline Canarias & 0.6 & 9,4 \\
\hline
\end{tabular}

Nota. Elaboración propia. Fuente INE

${ }^{17}$ Para las comunidades autónomas del Principado de Asturias, Galicia y la Región de Murcia, se refiere al porcentaje de población en entidades singulares de población con menos de 2.000 personas. 
Todos estos datos poblacionales tienen una incidencia directa en las políticas educativas, ya que afectan a las necesidades de escolarización, inciden sobre los costes unitarios ${ }^{18}$ y repercuten en los recursos requeridos por el sistema educativo. Además, el impacto del nivel de formación sobre el nivel de riqueza podrá dar lugar a mayores diferencias si las políticas educativas no fomentan el aprendizaje a lo largo de la vida cualquiera que sea el lugar de residencia.

Tabla 5 - Colegios Rurales Agrupados y modelos análogos (ver tabla 1) por Comunidades Autónomas Curso 2014-15

\begin{tabular}{|c|c|c|c|c|c|}
\hline $\begin{array}{l}\text { Comunidad } \\
\text { Autónoma }\end{array}$ & Centros & Localidades & Unidades & Alumnado & $\begin{array}{c}\% \text { alumnado } \\
\text { del total }\end{array}$ \\
\hline Andalucía & 113 & & 1130 & 11.750 & 14.9 \\
\hline Aragón & 74 & 328 & 757 & 9.102 & 11.6 \\
\hline Asturias & 28 & 100 & 191 & 1.926 & 2,4 \\
\hline Canarias & 24 & 24 & 192 & 2.237 & 2,8 \\
\hline Cantabria & 4 & 8 & 17 & 194 & 0,2 \\
\hline Castilla y León & 188 & 623 & 1.499 & 15.981 & 20.3 \\
\hline $\begin{array}{c}\text { Castilla-La } \\
\text { Mancha }\end{array}$ & 77 & 252 & 812 & 8.968 & 11.4 \\
\hline Cataluña19 & 278 & 276 & 851 & 10.954 & 13.9 \\
\hline $\begin{array}{l}\text { Comunidad } \\
\text { Valenciana }\end{array}$ & 46 & 144 & 550 & 6.254 & 8.4 \\
\hline Extremadura & 40 & 144 & 443 & 4.167 & 6.6 \\
\hline Galicia & 27 & 201 & 211 & 2.548 & 3,2 \\
\hline $\begin{array}{l}\text { Comunidad } \\
\text { de Madrid }\end{array}$ & 8 & 31 & 124 & 1.678 & 2,1 \\
\hline Murcia & 9 & & 108 & 1.268 & 1,6 \\
\hline Navarra & 1 & 2 & 5 & 58 & 0,07 \\
\hline Rioja & 11 & 48 & 145 & 1.636 & 2 \\
\hline Total & 928 & 2.181 & 7.035 & 78.721 & 100 \\
\hline
\end{tabular}

Nota. Elaboración propia. Fuente Subdirección General de Estadística. MEC

${ }^{18}$ La dispersión de la población y su distribución geográfica se refleja en el coste del puesto escolar (el sueldo de un maestro de un aula con 25 alumnos es el mismo que el de otro con 5).

${ }^{19}$ Para Cataluña la información corresponde a centros independientes agrupados en Zonas Escolares Rurales (ZER) 
Aunque el alumnado total no supone más que un $1,8 \%$ del alumnado total de educación infantil y primaria, tiene derecho a recibir un servicio educativo con los mismos niveles de calidad que el que se presta en el resto del territorio nacional. No obstante los datos indican una disminución importante en el alumnado escolarizado en CRAs en los últimos años, compatible con la correspondiente caída demográfica en el medio rural y la crisis económica que ha obligado a volver a sus países de origen a mucha población inmigrante.

La gran diversidad de peculiaridades geográficas y la diferencia en las políticas educativas implican el desarrollo de actuaciones muy heterogéneas para atender al alumnado de las zonas rurales. Su análisis debería ser un objeto prioritario de la investigación educativa, el cual desborda la finalidad de este trabajo, centrado en las características del modelo CRA.

\section{La investigación al servicio de la mejora}

La situación actual de la escuela rural española organizada fundamentalmente en torno al modelo CRA se caracteriza por un fenómeno generalizado de despoblación cuyas causas son, en primer lugar, de carácter económico. No obstante, no debemos olvidar que las diferencias existentes entre el entorno rural y el urbano, y por ende entre la escuela rural y la urbana, son considerables tal y como hemos podido observar a través de las sucesivas reivindicaciones que el Consejo Escolar del Estado lleva realizando desde hace más de 20 años.

La educación como servicio público y garante de un derecho constitucional es y puede ser un motor de desarrollo territorial, de modo que la escuela rural es un actor dinámico en la dimensión territorial y lo es desde varias perspectivas que se complementan entre sí: como miembro activo de un sistema institucional territorial, como re- 
ceptora de identidades y emociones, como capital social local y como elemento configurador en la construcción social rural (Boix, 2014). La escuela rural, considerada por muchos autores como la escuela inclusiva por excelencia (Domingo, 2012), asume la tarea de superar la desigualdad en el medio rural, asumiendo su diversidad y convirtiéndose en un foco de cultura con unas funciones socioculturales asumidas desde el comunitarismo y la dualidad simbiótica entre cultura y educación (Lorenzo, 2014) al ser una institución de clara participación social, un centro de actividad cultural, social, de relación y participación (Sepúlveda y Gargallo, 2011).

Sin embargo, todas las afirmaciones anteriores precisan de un aval basado en la evaluación. Las organizaciones, entre las que incluimos las escolares, hablan de evaluar y señalan su necesidad e importancia, pero la evaluación acaba convirtiéndose en una actividad secundaria, que solo aparece cuando existe algún tipo de presión o problema (Sanders, 2002). Además la evaluación de centros escolares, se puede realizar con diferentes propósitos (acreditación, rendición de cuentas, mejora, incentivos...) que pueden conducir a la toma de decisiones "blandas y duras" (Ravela, 2006), aunque debería estar siempre al servicio de estrategias de cambio y mejora para los mismos.

El modelo CRA es el modelo más generalizado de escolarización en educación infantil y primaria en el contexto rural español (Santamaría, 2017) y sin embargo no ha existido un planteamiento de evaluación global del mismo, que permita, con el apoyo de evidencias, seguir sirviendo, tal y como se indicaba en sus orígenes, a garantizar el derecho a la educación de todos los ciudadanos en aquellas condiciones ajustadas a las características de una escuela del siglo XXI y un contexto rural diferente. Calidad y equidad a la que debe contribuir la evaluación del sistema educativo, tal y como señalan los artículos 140 y 141 de la LOMCE (2013). No obstante es importante seña- 
lar que sí que existen datos de investigación que aportan información sobre las luces y sombras a las que nos referimos en el epígrafe, teniendo en cuenta, además, que el estudio de la escuela rural en el ámbito de la investigación, tanto sociológica como pedagógica, comienza fundamentalmente a partir de la década de los 80, al mismo tiempo que la constitución de los colegios rurales agrupados. Por ello, no debemos olvidar las obras de Grande (1981), centrada en Castilla-León; Subirats (1983), en Cataluña y Garcés (1983), en Aragón, así como las de Jiménez (1983) sobre la escuela unitaria y la de Carmena y Regidor (1984), una de las más citadas en cualquier trabajo histórico sobre la escuela rural española.

Centrándonos en el modelo CRA, la primera obra directamente relacionada con su puesta en práctica fue La escuela rural: un proyecto educativo en marcha, del colectivo Campos de Castilla y Publicada en 1987 y que hace referencia al proyecto originario del modelo. En el año 2000, Palomares publica el primer análisis valorativo tanto cuantitativo como cualitativo del modelo CRA en el que se señala que los CRA favorecen la práctica docente y mejoran la calidad de la enseñanza. Por Comunidades Autónomas existen algunos trabajos realizados en Castilla- León, en Extremadura (Blázquez, Rodríguez y Rubio, 1998) y en Aragón que señalan las ventajas de su implantación.

El interés por la escuela rural entra en el ámbito universitario, tanto desde el punto de vista sociológico como pedagógico y comienzan a realizarse Tesis Doctorales que aportan evidencias sobre su realidad. Un ejemplo lo representa la investigación de Grande (1994): La escuela rural en España. De la L.G.E. a la LOGSE. Balance y perspectivas, en cuyas conclusiones se indica que, a pesar del modelo CRA, en España no ha existido un planteamiento diferenciado y específico $^{20}$ que responda de modo global a las necesidades y características del medio rural, lo que ha llevado a un

${ }^{20} \mathrm{El}$ estudio llega hasta los años 90. 
deterioro del servicio público educativo en dicho medio.

Con otra estructura nos encontramos aquellos estudios doctorales centrados en determinadas zonas geográficas en los que adquieren un papel primordial las diferentes políticas educativas desarrolladas a nivel autonómico por parte de las Comunidades Autónomas.

\section{Andalucía}

Uno de los primeros trabajos que incluye elementos de investigación cuantitativa y/o cualitativa es el de Corchón (1997): Estudio evaluativo de la escuela rural andaluza, en el que se incluye un análisis del funcionamiento de los Centros Públicos Rurales ${ }^{21}$, ofreciendo a la administración educativa una serie de sugerencias tendentes a mejorarlos en cuanto a su ordenación territorial, la formación del profesorado, los servicios de apoyo o incluso a sistemas alternativos de organización.

El trabajo de Bustos (2006): Los grupos multigrado de educación primaria en Andalucía, destaca la exclusividad de la escuela pública en contextos rurales y llena un vacío por el desconocimiento del funcionamiento de las escuelas rurales cuya característica pedagógica fundamental es la existencia de aulas multigrado. Los resultados son interesantes en cuanto a las percepciones del profesorado, ya que la mayor experiencia en aulas multigrado está en estrecha relación con la preferencia para trabajar con este tipo de aulas, así como que la escasa formación inicial en temas relacionados con la escuela rural es una de las principales razones de las dificultades encontradas por el profesorado. Por otro lado, el trabajo en equipo que posibilitan los Centros Públicos Rurales es considerado como uno de sus pilares fundamentales. En cuanto a los resultados académicos, el estudio señala que el alumnado de los CPR obtiene mejores resultados académicos que el matricula-

${ }^{21}$ Modelo desarrollado en Andalucía equivalente al CRA. 
do en otros centros de Andalucía (ib.: 395), siendo algunas de sus causas el menor número de alumnos por aula, aun siendo de diferentes niveles, así como la existencia de lo que el autor denomina el aprendizaje contagiado.

Raso (2012) en su trabajo sobre La escuela rural andaluza y su profesorado ante las tecnologías de la información y la comunicación (TICS): estudio evaluativo, constata la importancia de las TIC en modelos de escuelas agrupadas y el valor que el profesorado les otorga en cuanto a la motivación, la mejora del aprendizaje o el establecimiento de relaciones docentes sin barreras. De ello se deduce, no solo la mejora de la formación inicial y permanente del profesorado, sino también una organización adecuada de los recursos TIC existentes. Además, es importante la referencia que hace a la necesidad de superar las concepciones urbanocéntricas a partir de las que se valora y evalúa la escuela y el medio rurales. Otro trabajo del mismo autor realizado en 2015 sobre Satisfacción del profesorado de la escuela rural en la provincia de Granada: estudio evaluativo, nos indica que el mayor nivel de satisfacción está en relación con el interés del alumnado por aprender, así como por el reconocimiento de su labor docente tanto entre el alumnado como entre la comunidad local. En el otro extremo los datos indican que los aspectos relativos al clima profesional y al ambiente de trabajo pueden y deben mejorarse necesariamente para optimizar la calidad del trabajo educativo en este tipo de instituciones (Raso, 2015: 402). En cuanto a los aspectos organizativos, los más valorados son la existencia de un proyecto de trabajo común, así como las posibilidades de participación real en la toma de decisiones, y uno de los menos, la implicación y el apoyo de la administración educativa en los problemas específicos que tiene la escuela rural.

El estudio integrado de García (2015): Escuela, medio rural y diversidad cultural en un contexto global, señala, entre otras cosas, que el formato de Centros Públicos Ru- 
rales es un formato bien considerado por el profesorado, pero debe mantener la identidad colectiva.

Aragón

Domingo (2013) con su trabajo sobre Origen y evolución del modelo CRA-colegio rural agrupado-. Situación en Aragón y estudio de caso de la realidad turolense, constata las ventajas e inconvenientes que los diferentes actores otorgan al modelo CRA, destacando, por parte del profesorado, la importancia de compartir experiencias y proyectos con otros compañeros. El alumnado hace hincapié en el aprendizaje compartido y la vivencia de la diversidad, y la comunidad educativa y social, en la importancia de la existencia de la escuela para el mantenimiento de los pueblos.

Lorenzo (2014) al estudiar el MRP Aula Libre en su trabajo El Movimiento de Renovación Pedagógica "Aula Libre" (1975-2000): contextos, discursos y prácticas, analiza la influencia de la escuela pública del medio rural como un elemento clave para entender cómo Aula Libre recoge distintos referentes educativos y culturales para plasmarlos en una pedagogía y una propuesta educativa propias.

\section{Castilla León}

Uno de los primeros trabajos se lo debemos a Infestas (1985): Crisis rural y escuela (estudio de la sociedad rural y de su escuela en la provincia de Zamora; en la que aborda las consecuencias de la aplicación de la LGE de 1970 a la escuela rural, siendo un estudio previo a la aparición de los CRAs.

El trabajo de Morales (2008): La escuela en el medio rural de Castilla y León: aspectos condicionantes y contribución como organización, analizar las relaciones que se establecen entre escuela y medio y en las que la escuela aporta un valor añadido.

Barba (2011) en su tesis sobre El desarrollo profesional 
de un maestro novel en la escuela rural desde una perspectiva crítica, plantea la evolución de un maestro en su trabajo en escuelas rurales destacando la problemática de su inserción profesional inicial a nivel de aula y de centro. En este sentido destaca la preocupación por la descontextualización de los contenidos, así como por la necesidad de abordar la docencia desde planteamientos innovadores.

Marugan (2016): La participación de las familias en la escuela rural de la sierra de Segovia. Una oportunidad para el empoderamiento comunitario, es un trabajo en el que se pone de manifiesto la importancia de la participación familiar para la necesaria revalorización de la escuela rural.

\section{Cataluña}

Un interesante aporte sobre la formación del profesorado es el realizado por Boix (1993) sobre La escuela rural y la formación permanente del maestro rural. Estudio de las necesidades y propuestas de mejora para la formación permanente del profesorado rural de la comarca del Alto Penedés. La investigación se centra en el análisis de las acciones docentes que se producen en los procesos de enseñanza-aprendizaje en las aulas rurales, con el objetivo de conocer la necesidad de configurar una formación permanente adecuada a las realidades educativas de los docentes rurales.

La Tesis de Domingo (2014) Contribuciones pedagógicas de la escuela rural. La inclusión en las aulas multigrado: un estudio de Caso, profundiza en las posibilidades que ofrece la escuela rural para la inclusión educativa, destacando la ayuda entre los alumnos para potenciar un aprendizaje colaborativo, y por tanto, menos competitivo. Además, el fomento de la responsabilidad y de la autonomía son valores intrínsecos a una escuela inclusiva en la que todos pueden aprender de todos. Las diferencias como recurso didáctico permiten una organización espacial y temporal esencialmente inclusiva. 


\section{Comunidad Valenciana}

Santamaría (1997): La escuela rural entre 1970 y 1990. Análisis de la zona del Río Villahermosa, una de cuyas principales aportaciones es la idea de que la escuela rural puede contribuir a la mejora del medio rural.

Pero la investigación educativa no se puede circunscribir a las Tesis Doctorales y, por ello destacamos en este último apartado algunas de las líneas más sobresalientes de la investigación española en temas relacionados con la escuela rural ya que, es importante reducir la distancia entre investigación y escuela rural para que la acumulación de conocimientos sobre la escuela rural se convierta en una base sólida sobre su futuro (Bustos, 2011).

La necesidad de buscar modelos organizativos adaptados a las características y transformaciones del contexto rural y de la educación es señalada por Corchón (2005) y en relación a ello, Berlanga (2003) incidía en la importancia del trabajo coordinado e incardinado en el territorio para potenciar una educación de calidad con igualdad de oportunidades. Esta misma idea, pero con una visión más adecuada a las transformaciones acaecidas en el medio rural, se sitúan los planteamientos de Bustos (2011) y de Alcalá y Castán (2014), quienes inciden en la optimización de recursos que proporciona el modelo CRA y sus análogos. Las potencialidades didácticas y organizativas de la escuela rural son señaladas por Boix (2011), desarrolladas bajo el modelo CRA/ZER y señaladas por Llevot y Garreta (2008). Cuando se habla de ventajas e inconvenientes de la escuela rural Hamodi y Aragues (2014) corroboran los datos de investigaciones anteriores, destacando como ventajas la diversidad y el trabajo cooperativo. El tema del profesorado y su formación también ha sido uno de los ejes de la investigación (Bustos, 2008; Abós, 2007 y 2011; Barba, 2011...), destacándose la necesidad de amoldar el desarrollo profesional de maestros y maestras al contexto rural en el que trabajan como medio de facilitar su vin- 
culación y permanencia. A la falta de capacitación para ejercer su profesión en un medio que desconoce se une el aislamiento geográfico propio del mundo rural con lo que se genera una mentalidad profesional que sitúa a la escuela como un tránsito provisional hacia destinos más atractivos, generalmente de tipo urbano (Lorenzo, Abós, Nolasco, Domingo y Ramo, 2017). Además tal y como señala Morales (2017b) los colegios rurales agrupados tienen una excesiva dependencia en cuanto a su funcionamiento del profesorado que trabaja en ellos y de su nivel de implicación

Uno de los temas que ha tenido un especial interés en los últimos años es el del uso de las TIC como medio de mejorar la igualdad de oportunidades para el alumnado de escuelas rurales, destacando los trabajos de Del Moral, Villalustre y Neira (2014 a y b) En ambos trabajos se destaca que, a pesar de las limitaciones del contexto y la brecha digital existente, las TIC suponen grandes oportunidades para la actualización del profesorado y la adopción de metodologías acordes con las aulas multigrado. El estudio de Morales (2017a) resalta el hecho de que el alumnado de escuelas rurales realiza un uso tecnológico incluso mayor que el de escuelas urbanas, a pesar de lo cual, sigue existiendo una verdadera brecha digital.

Todos los datos aportados nos llevan a señalar que la pertinencia de la investigación educativa en el ámbito de los Colegios Rurales Agrupados debe ir dirigida a ofrecer instrumentos para analizar de manera crítica la realidad, comprenderla y transformarla. Su objetivo final debe ir encaminado a proporcionar a la comunidad en la que se realiza resultados considerados como útiles, teniendo en cuenta sus contextos históricos, ambientales, económicos, políticos, sociales y culturales.

\section{A modo de conclusión: luces y sombras del mo-}




\section{delo CRA}

La escuela rural española se encuentra en estos momentos en una fase caracterizada por la heterogeneidad de sus contextos y su incesante transformación, precisando de nuevos planteamientos respecto al concepto de ruralidad y de escuela rural, o más bien, de escuela en contextos rurales. Si uno de los objetivos básicos del modelo CRA es ofrecer al alumnado una enseñanza de calidad minimizando los efectos negativos que pueda acarrear el contexto, y aprovechando aquellos otros que añaden un valor añadido a la educación, su logro, así como el mantenimiento del propio modelo, pasa obligatoriamente por una mayor participación de la comunidad educativa, así como por una toma de decisiones apoyada en una rigurosa evaluación.

\section{Luces}

- El modelo CRA ha sido y debe seguir siendo el garante del derecho a una educación de calidad en condiciones de equidad, permitiendo la dotación de mayores recursos al tener éstos el carácter de compartidos entre sus aulas. - La institucionalización del modelo dentro del sistema educativo ha permitido la superación de localismos y del aislamiento social y pedagógico tanto del profesorado como del alumnado, así como facilidades burocráticas y mejoras organizativas (Bernal, 2009)

- La relación del CRA con el territorio y la comunidad local convierte a la escuela rural en un importante factor de transformación social y la función docente en motor de desarrollo (Calvo, 2003), en instrumento para garantizar el mantenimiento de la sociedad rural y su transformación hacia nuevos horizontes, enmarcados en un concepto de nueva ruralidad superador de prejuicios.

- El modelo organizativo que subyace al CRA posibilita 
los intercambios del centro con el exterior de una manera sistematizada incorporando elementos situados fuera de sus muros y aportando oportunidades a la comunidad. - El modelo CRA puede ofrecer un modelo educativo basado en sus características diferenciadoras que apoye los procesos de enseñanza-aprendizaje en planteamientos globalizadores que conduzcan a aprendizajes funcionales basados en el entorno y sus posibilidades. De este modo el medio se convierte en un recurso didáctico y socioeducativo (Lorenzo, 2014), siempre y cuando se opte por una adaptación y flexibilización curricular.

- La escuela rural, integrada en el modelo, potencia una metodología y unos valores socio-educativos alejados del rol normativo y acrítico de los grandes centros urbanos, asumiendo en su fuero un compromiso transformador. En palabras de Calvo, esta concepción de la educación rural permite convertir "todas las vivencias en fuente de nuevos aprendizajes" (MRP Aula Libre, 1990: 77) sin limitarlas a lo puramente académico-disciplinar y multiplicando las posibilidades de aprendizaje.

- La estructura internivelar de la escuela rural borra las fronteras artificiales entre los diferentes grupos de edad. En consecuencia incluye en sí misma un planteamiento inclusivo y de compensación educativa que refuerza los aprendizajes y permite crear un microsistema social basado en el compañerismo y el respeto, valores propios de una escuela de calidad, de metodologías activas y participativas, así como de una educación integral y globalizada. Además, las estrategias didácticas participativas son una gran oportunidad, contextualizando los aprendizajes, para favorecer el desarrollo de las competencias clave.

- Los programas Escuela 2.0 han sido un revulsivo para las escuelas rurales tanto desde el punto de vista pedagógico como de trabajo cooperativo del profesorado (Del Moral, Villalustre y Neira, 2014a), en el marco de un 
contexto globalizado.

- La escuela rural y su modelo organizativo actual (CRA) es una propuesta alternativa a una educación neoliberal y mercantilista en la que prima el coste de mantenimiento frente al derecho a la educación de todos.

- El menor número de alumnos por aula, aunque de diferentes niveles, permite una enseñanza más personalizada, así como experiencias de tutorías entre iguales, el desarrollo de aprendizajes "contagiados" y de enseñanza "circular o concéntrica" (Feu, 2004: 10).

\section{Sombras}

- La despoblación producida por el éxodo rural y el crecimiento vegetativo, así como el desarraigo son los principales enemigos de la escuela rural. Sin planes integrales que fomenten la consolidación de los habitantes y la atracción de otros nuevos, será imposible paliar las desventajas que augura el sistema económico actual para el medio rural. En este sentido la falta de atención al periodo de 0-3 años es una de las lagunas fundamentales (Morales, 2017)

- Existe una falta de normativa específica pues el desarrollo legislativo ha tenido y sigue teniendo una preferencia y primacía por el modelo urbano, lo que agudiza determinados problemas propios del modelo.

- La formación inicial y permanente precisa de su adaptación a las características de la nueva escuela rural, convirtiéndose en una formación contextualizada que pasa por la innovación, la flexibilidad curricular y la creatividad como retos para lograr superar el desafío docente que plantea (Abós, 2011). Es preciso dotar al profesorado de herramientas útiles que les sirvan para hacer frente a aulas en las que la diversidad empapa los espacios y los tiempos escolares.

- Las dificultades socio-laborales que plantea el medio 
rural para su profesorado (Morales, 2010) no permiten que los nuevos maestros rurales valoren como es debido este medio, su cultura y su función, por lo que es difícil mantener cierta estabilidad entre el profesorado. Además se profundizan las trabas para llevar a cabo proyectos educativos coordinados e innovadores de largo alcance en el tiempo (Lorenzo, 2014). De este modo, la inestabilidad del profesorado unida a la provisionalidad de los equipos directivos (Bernal, 2009), impiden el planteamiento de proyectos de centro, tanto de innovación como de mejora, a medio y largo plazo.

- El futuro del modelo exige un compromiso educativo y sociopolítico, un esfuerzo conjunto y coordinado de las propias comunidades rurales. El papel predominante que ejerce la administración va en detrimento de la necesaria autonomía para la mejora del modelo.

- La brecha digital existente entre el medio rural y urbano impiden maximizar el valor añadido que suponen el uso de las TIC (Morales, 2017).

- El menor número de alumnos puede suponer dificultades en el desarrollo de habilidades sociales y de intercambio entre iguales, que deben ser compensadas con ofertas extracurriculares de convivencia y participación (CRIE, actividades extraescolares...).

Las escuelas rurales que en los años 80-90 promovieron el actual modelo CRA asumieron la tarea de promover la igualdad de oportunidades para los habitantes de las zonas rurales. Algunos de sus problemas endémicos han cambiado (transporte, recursos, aislamiento...), otros son todavía una realidad (formación del profesorado, inestabilidad, currículum con planteamientos urbanos...) y surgen otros nuevos y/o con diferentes perspectivas (disminución del número de alumnos, contextos rurales diferentes, globalización...). Sin embargo, la escuela rural todavía tiene importantes funciones sociales y educativas que cu- 
brir, e incluso, puede convertirse en un ámbito potencial de propuestas para el futuro además de considerarse "como laboratorio de innovación, investigación y formación de maestros" (Bernat, 2009: 3). La escuela rural sigue existiendo y el modelo CRA, así como sus análogos, pervive, de modo que, junto a los retos históricos de defensa del derecho a la educación, el siglo XXI le plantea la visibilidad de su modelo pedagógico vinculado a la diversidad y al territorio, garante de una educación de calidad.

Queremos concluir este capítulo con unas palabras del profesor Ortega (1995) que, aunque pronunciadas hace 25 años, siguen teniendo plena vigencia en la escuela rural española del siglo XXI:

"El discurso progresista exige, por lo tanto, un profesorado dispuesto a reflexionar sobre cuestiones centrales de su trabajo, incluyendo entre ellas algunas que no están referidas directamente a su dimensión didáctica. Evaluar cuál es la función que está desempeñando, investigar la coherencia de sus actitudes cotidianas con sus ideas explícitas e implícitas sobre educación, cuestionar si la escuela representa una factor de integración o desintegración de la comunidad, preguntarse sobre la suficiencia-insuficiencia de los canales de comunicación y participación existentes en la escuela y en la sociedad, reflexionar sobre la pertinencia de desarrollar un trabajo de colaboración y no de imposición y sobre los caminos que pueden abrirse para hacerlo, buscar un modelo, en fin, de participación efectiva- y no sólo nominaldel alumnado y de las familias- de todas las familias- en la tarea cotidiana de la escuela... parecen ser algunas de esas cuestiones por resolver y algunas de las tareas que pueden merecer la pena acometer dentro de una posición a favor de la escuela rural".

\section{REFERENCIAS}

ABÓS, P. La escuela rural y sus condiciones itienen implicaciones en la formación del profesorado? Aula Abierta, 35 (1,2), p. 83-90, 2007. 
Planes de Estudio de los Grados de Maestro en Educación Infantil y Primaria de las Universidades Españolas. Profesorado: Revista de Currículum y Formación del Profesorado, 15 (2), p. $39-52,2011$.

ALCALÁ, M. L ; CASTÁN J. L ¿Hacia dónde camina la escuela rural? Forum Aragón: revista digital de FEAE-Aragón sobre organización y gestión educativa, 2014. Disponible em: $<$ https://dialnet.unirioja.es/servlet/articulo?codigo=4727847>.

BARBA, J. El desarrollo profesional de un maestro novel en la escuela rural desde una perspectiva crítica. Tesis doctoral Universidad de Valladolid. 2011. Disponible en: <http://uvadoc.uva.es/bitstream/10324/822/1/tesis96-110331.pdf >.

BERLANGA, S. Educación en el medio rural: análisis, perspectivas y propuestas. Zaragoza: Mira, 2003.

BERNAL, J. L. Luces y sombras en la escuela rural. Ponencia presentada en las Jornadas sobre Educación en el Medio Rural: encrucijadas y respuestas, Teruel, España, 2009.BERNAL, J. L.;

CANO, J. Y LORENZO, J. Organización de los centros educativos. LOMCE y políticas neoliberales. Zaragoza: Mira, 2014.

BERNAT, A. Escuela rural e ideologías. Ponencia presentada en las Jornadas sobre Educación en el Medio Rural: encrucijadas y respuestas (mayo, 2009), Teruel, España, mayo, 2009.

BLÁZQUEZ, M.P; RODRÍGUEZ, C Y RUBIO, F. Colegios Rurales Agrupados en Extremadura, 1998. Disponible em: <http:// redined.mecd.gob.es/xmlui/handle/11162/83524>.

BOIX, R L'escola rural i la formacio permanent del mestre rural. Estudi de les necessitats i propostes de millora per a la formacio permanent del professorat rural de la comarca de L'Alt Penedes. Tesis Doctoral. Barcelona: Universidad de Barcelona, 1993.

¿Qué queda de la escuela rural? Alguna reflexiones sobre la realidad pedagógica del aula multigrado. Profesorado: Revista de curriculum y formación del profesorado, 15 (2), p. 13-23, 2011. 
. La escuela rural en la dimensión territorial. Innovación Educativa, 24, p. 89-97, 2014.

BUSTOS, A. Los grupos multigrado de educación primaria en Andalucía. Tesis doctoral.Universidad de Granada, 2006. Disponible em: <http://hera.ugr.es/tesisugr/16158933.pfd>.

Docentes de escuela rural. Análisis de su formación y sus actitudes a través de un estudio cuantitativo en Andalucía. Revista de Investigación Educativa, 26 (2), p. 486-519, 2008.

Investigación y escuela rural ¿irreconciliables? Profesorado: Revista de curriculum y formación del profesorado, 15 (2), p. 155-170, 2011.

CALVO, M. La educación rural: el horizonte de una nueva cultura. Aula Libre, por una práctica libertaria en la educación, 79, p. 26-39, 2003.

CARMENA, R. ; REGIDOR, J. La Escuela En El Medio Rural. Madrid: Mec, 1985.

COLECTIVO CAMPOS DE CASTILLA. La escuela rural: un proyecto educativo en marcha. Madrid: Narcea, 1987.

CONSEJERÍA DE EDUCACIÓN Y CIENCIA . Decreto 29/1988, de 10 de febrero, sobre constitución de Colegios Públicos Rurales en la Comunidad Autónoma de Andalucía. BOJA, n. 19, 4 marzo 1988.

CONSEJERÍA DE EDUCACIÓN Y CIENCIA. Orden de 15 de abril de 1988 por la que se desarrolla el Decreto 29/1988, de 10 de febrero, sobre constitución de Colegios Públicos Rurales en la Comunidad Autónoma de Andalucía. BOJA, n. 33, 26 abr. 1988.

CONSEJERÍA DE EDUCACIÓN Y ORDENACIÓN UNIVERSITARIA. Decreto 63, de 17 de marzo, sobre constitución de Colegios Públicos Rurales Agrupados de EGB y Preescolar (DOG, 13 mayo 1988).

CONSELLERIA DE CULTURA, EDUCACIÓN Y CIENCIA. 
Orden de 15 de mayo por la que se regula la constitución de Colegios Rurales Agrupados en la Comunidad Valenciana. (DOGV, 4 jul. 1997).

CONSEJERÍA DE EDUCACIÓN, CULTURA Y DEPORTES. Decreto 109/1999, de 25 de mayo por el que se regula el régimen de creación y funcionamiento de los Colectivos de Escuelas Rurales (BOC, 18 jun. 1999)

CONSEJERÍA DE EDUCACIÓN Y CIENCIA. Orden de 25 de marzo por la que se regulan los procesos de constitución, supresión y modificación de Colegios Rurales Agrupados (Diario Oficial de Castilla-La Mancha, 6 abr. 2009).

CONSEJO ESCOLAR DEL ESTADO: Informes sobre el Estado y Situación del Sistema educativo $(1997,1998,1999,2000,2001$, 2002,2003,2004,2005,2007,2008,2009,2011,2012,2015,2016). Disponibles en: <http://www.educacion.es/cesces/texto-informes. htm.>.

CONSTITUCIÓN ESPAÑOLA. (BOE de 29 dic. 1998) CORCHÓN, E. Estudio evaluativo de la escuela rural andaluza. Tesis doctoral no publicada. Granada: Universidad de Granada, 1997.

La escuela en el medio rural. Modelos organizativos. Barcelona: Da Vinci, 2005.

DEL MORAL, M.E.; VILLALUSTRE, L. Y NEIRA, M. Variables asociadas a la cultura innovadora con TIC en escuelas rurales. Profesorado: Revista de curriculum y formación del profesorado, 18 (3), p. 9-25, 2014a.

Oportunidades de las TIC para la innovación educativa en las escuelas rurales de Asturias. Aula Abierta, 42(1), p. 61$67,2014 b$.

DEPARTAMENT D'ENSENYAMENT. Decret 195/1988, de 27 de juliol, sobre laconstitució de zones escolars rurals per a centres públics d'ensenyament primari. (DOGC, n. 1032, 19 agosto 1988.

DEPARTAMENT D'ENSENYAMENT . Ordre de 31 d'octubre 
de 1988, de convocatoria per a l'establiment de quinze zones escolars rurals i per a la regulació del seu procés de constitució. (DOGC, n. 1069, 16 nov. 1988).

DOMINGO, V. La escuela rural, modelo de escuela inclusiva. Quaderns Digitals. Monográfico Estrategias Didácticas Inclusivas, 71, 2012.

. Origen y evolución del Modelo CRA (Colegio Rural Agrupado). Situación en Aragón y estudio de caso de la realidad turolense. Tesis Doctoral, 2013. Universidad de Valencia. Disponible en: <http://roderic.uv.es/bitstream/handle/10550/30429/DOC\%20COMPLETO\%20TESIS\%205\%20sept. pdf? sequence $=1 \&$ is Allowed $=y$. $>$.

. Contribuciones pedagógicas de la escuela rural. La inclusión en las aulas multigrado: un estudio de Caso. Tesis Doctoral, 2014. Vic: Universidad de Vic. Disponible en: <http:// www.tdx.cat/handle/10803/283165.>

FEU, J. La escuela rural en España: apuntes sobre las potencialidades pedagógicas, relacionales y humanas de la misma. Revista Digital eRural. Educación, cultura y desarrollo rural, 2 (3), p. 1-13, 2004.

FMRP: Federación de Movimientos de Renovación Pedagógica. (1987). Projecte de Zones Escolars per a l'Escola Rural: Conclusions de les VI Jornades d'Escola Rural de Catalunya, Banyoles.

FRAILE, C.; IRIARTE, J.A; OLALLA, M.T. La LOGSE vista desde el medio rural. Revista de Educación 322, 55-57, Madrid: MEC, 2000.

GARCÉS, R. Concentraciones escolares y escuelas hogar. Zaragoza: ICE, 1983.

GARCÍA. Escuela, medio rural y diversidad cultural en un contexto global, Currículum, materiales didácticos y práctica docente de Conocimiento del medio. Situación, límites y posibilidades en centros onubenses. Tesis Doctoral. Huelva: Universidad de Huelva, 2015. Disponible en: $<$ http://rabida. uhu.es/dspace/handle/10272/11440.>. 
Gómez, C. Lo rural en los planes educativos el Gobierno de Aragón. Revista de Desarrollo Rural y Cooperativismo Agrario, 10, p.83-104, 2007.

GRANDE, M. La Escuela Rural. Situación educativa en el medio castellano-leonés. Granada: Escuela Popular, 1981.

La escuela rural en España. De la L.G.E. a la LOGSE. Balance y perspectivas. Tesis Doctoral. No publicada. Salamanca: Universidad de Salamanca, 1994.

HAMODI, C.; ARAGÜES, S. La escuela rural: ventajas, inconvenientes y reflexiones sobre sus falsos mitos. Palabra, 14, p. 46-61, 2014.

HERNÁNDEZ, J. M. La escuela rural en la España del siglo XX. Revista de Educación, Número extraordinario, p. 113-136, 2000.

INFESTAS, A. Crisis rural y escuela (estudio de la sociedad rural y de su escuela en la provincia de Zamora. Tesis Doctoral no publicada. Madrid. Universidad Complutense, 1985.

INSTITUTO NACIONAL DE ESTADÍSTICA. Anuario Estadístico, 1954. Disponible en :<http://www.ine.es/inebaseweb/ treeNavigation.do?tn=103501.>.

JIMÉNEZ, J. La escuela unitaria. Barcelona: Laia, 1983.

LORENZO, J. El Movimiento de Renovación Pedagógica

"Aula Libre" (1975-2000): contexto, discursos y prácticas. Tesis Doctoral. Zaragoza. Universidad de Zaragoza, 2014. Disponible en :<http://zaguan.unizar.es/record/17194>.

LORENZO, J., ABÓS, P., NOLASCO, A., DOMINGO, V.; RAMO, R. Los Centros Rurales Agrupados en la provincia de Teruel: dirección y liderazgo (en prensa), 2017.

Ley de Instrucción Pública de 9 de septiembre de 1857.

Ley de 7 de julio de 1945 sobre Educación Primaria (BOE de 18 de julio). 
Ley 14/1970, de 4 de agosto, General de Educación y Financiación de la Reforma Educativa (BOE de 6 de agosto).

Ley Orgánica 8/1995, de 3 de julio Reguladora del derecho a la Educación (BOE de 4 de julio).

Ley 1/1990 de 3 de octubre, de Ordenación General del Sistema Educativo (BOE de 4 de octubre)

Ley Orgánica 10/2002, de 23 de diciembre de Calidad de la Educación (BOE de 24 de diciembre)

Ley Orgánica 2/2006, de 3 de mayo, de Educación (BOE de 4 de mayo).

Ley Orgánica 8/2013 de 9 de diciembre para la mejora de la calidad educativa (BOE de 10 de diciembre).

LLEVOT, N.; GARRETA, J. Escuela rural y sociedad. Lleida: Edicions de la Universitat de Lleida. 2008.

MARUGAN, L. La participación de las familias en la escuela rural de la sierra de Segovia. Una oportunidad para el empoderamiento comunitario. Valladolid: Universidad de Valladolid, 2016. Disponible en :<https://www.educacion.gob.es/teseo/ imprimirFicheroTesis.do.>.

MINISTERIO DE EDUCACIÓN Y CIENCIA. Estadísticas de la enseñanza en España, 1993. Disponible en: <https://www. mecd.gob.es/servicios-al-ciudadano-mecd/estadisticas/educacion/no-universitaria/alumnado/matriculado/Publicaciones-cursos-anteriores.html.>.

MORALES, N. La escuela en el medio rural de Castilla y León: aspectos condicionantes y contribución como organización. Tesis Doctoral. Salamanca: Universidad de Salamanca, 2008.

Escuelas-red y medio rural ¿un dúo quimérico?, Témpora. Revista de historia y sociología de la educación, 13, p. 61-87, 2010.

.Las TIC y los escolares del medio rural, entre la brecha 
digital y la educación inclusiva. Bordón, 69(3), p. 41-56, 2017a. .The Spanish rural school from the New Rural paradigm. Evolution and challenges for the future. Revista Colombiana de Ciencias Sociales, 8(2), p. 412-438, 2017b.

MORENO E. Historia de la escuela pública en España: balance de dos siglos. Granada: Servicio de publicaciones del sector de enseñanza de CSI - CSIF, 1998.

MRP Aula Libre. Aula Libre: aportaciones desde la práctica educativa. Fraga: Movimiento de Renovación Pedagógica Aula Libre, 1990.

ORTEGA, M.A. La parienta pobre. Significantes y significados de la Escuela Rural. Madrid: CIDE, 1995.

PALOMARES, M. C. Centros rurales y calidad educativa. Madrid: MEC, 1995.

.Variables que condicionan la satisfacción de los profesores que trabajan en Colegios Rurales Agrupados, Bordón 52 (2), p. 213-227, 2000.

RASO, F. La escuela rural andaluza y su profesorado ante las Tecnologías de la Información y la Comunicación -TIC: estudio evaluativo. Tesis doctoral. Granada: Universidad de Granada, 2012. Disponible en: <http://hera.ugr.es/tesisugr/20771666.pdf>.

.Satisfacción del profesorado de la escuela rural en la provincia de Granada: estudio evaluativo. Tesis Doctoral. Madrid: Universidad Complutense, 2015.

RAVELA, P. Para comprender las evaluaciones educativas. Fichas didácticas. Perú: Programa de Promoción de la Reforma Educativa en América Latina (PREAL), 2006.

Real Decreto 1174/1983, de 27 de abril sobre Educación Compensatoria (BOE de 11 de mayo).

Real Decreto 2731/1986, de 24 de diciembre, sobre constitución de Colegios Rurales Agrupados de Educación General Básica. (BOE 9 de enero 1987) 
Real Decreto 82/1996, de 26 de enero, por el que aprueba el Reglamento Orgánico de las Escuelas de Educación Infantil y los Colegios de Educación Primaria (BOE de 20 de febrero). SANDERS, J. R. Presidential address: On mainstreaming evaluation. American Journal of Evaluation, 27 (3), p. 253-259, 2002.

SANTAMARÍA, R. La escuela rural entre 1970 y 1990. Análisis de la zona del Río Villahermosa. Tesis Doctoral. Castellón: Universidad Jaume I, 1997. Disponible en:<http://www.tdx.cat/ handle/10803/84066.>.

. Un poco de historia de la escuela rural. Escuelarural.net. 2012. Recuperado de <http://escuelarural.net/un-poco-de-historia-enla-escuela.>.

Directriz Especial de Política Demográfica y Contra la Despoblación de Aragón desde la educación rural . 2017. Recuperado de <http://escuelarural.net/directriz-especial-de-politica,277>.

SANZ, M. A. Educación y territorio. Encrucijadas socioculturales. Ponencia presentada en las Jornadas sobre Educación en el Medio Rural: encrucijadas y respuesta. Teruel, España, mayo 2009..

SAURAS, J. P. Escuelas Rurales. Revista de Educación, 322, p. 29-378. Madrid: MEC, 2000.

SEPÚLVEDA, M. P.; GALLARDO, M. La escuela rural en la sociedad globalizada: nuevos caminos para una realidad silenciada. Profesorado: Revista de curriculum y formación del profesorado, 15 (2), p. 141-153, 2011.

SERRANO DE HARO, A. La escuela rural. Madrid: Escuela Española, 1941.

SUBIRATS, M. La escola rural a Catalunya. Barcelona: Ediciones 62,1983 .

TAPIA, L.; CASTRO, P. Experiencia educativa, educar desde un CRA. Tendencias Pedagógicas, 24, p. 415-428, 2014.

VIÑAO, A. Escuela para todos. Educación y modernidad en la España del Siglo XX. Madrid: Marcial Pons, Ediciones de 
Historia, 2004. 


\title{
CAPÍTULO 14
}

\section{EDUCAÇÃO RURAL, NO CAMPO E DO CAMPO: origens e percursos históricos}

\author{
Sebastiana Aparecida Moreira ${ }^{1}$ \\ Maria Zeneide Carneiro Magalhães de Almeida ${ }^{2}$ \\ Nívea Oliveira Couto de Jesus ${ }^{3}$
}

\section{INTRODUÇÃO}

A Educação no meio rural brasileiro retrata uma história que acompanha a evolução das reformas sociais e agrárias do país. Neste texto, tratar-se-á, da diferenciação de educação rural, no campo e do campo, para o entendimento do uso de educação do campo. Isto porque, em muitos contextos políticos, não foi vista a preocupação com a necessidade de um ensino do campo especializado.

A história da educação aponta que nos períodos que antecederam o século XX no Brasil a preocupação com a educação rural ocorria de forma bastante limitada. Conforme aponta Pires (2012), era uma inquietação limitada e condicionada as necessidades de formação de mão de obra especializada para agricultura, do desenvolvimento urbano - industrial, e também para conter o fluxo migratório nos anos de 1920 e 1930 das populações rurais para as cidades. Ao longo do século XX, inúmeras leis foram pro-

\footnotetext{
${ }^{1}$ Pedagoga e Historiadora. Mestre e Doutora em Educação. Docente na rede Estadual e Municipal de Ensino de Rio Verde - GO. Membro do Grupo de Pesquisa: Educação, História, Memória e Cultura em diferentes espaços sociais. E-mail: tianinharv@yahoo.com.br

${ }^{2}$ Professora adjunto da Pontifícia Universidade Católica de Goiás. Líder do Grupo de Pesquisa: Educação, História, Memória e Cultura em diferentes espaços sociais. E-mail: zeneide.cma@gmail.com

${ }^{3}$ Pedagoga e Historiadora. Mestre em Educação. Coordenadora Pedagógica na rede Estadual e professora na rede Municipal de ensino de Rio Verde-GO. Membro do Grupo de Pesquisa: Educação, História, Memória e Cultura em diferentes espaços sociais niveacouto@hotmail.com
} 
mulgadas e projetos implantados sem nenhum resultado expressivo.

A menção específica da obrigação de cuidar da educação rural é mostrada por estudiosos como apenas preocupação teórica, já que somente a partir do século XX, essa educação teve destaque prático no cenário brasileiro. Para Ilma Ferreira Machado (2003):

Foi por volta de 1920, com o crescimento da migração rural, que a educação rural começou a ter destaque no cenário nacional, sendo pensada como um mecanismo capaz de fixar o trabalhador ao campo mediante uma formação técnica específica, a exemplo dos cursos de técnico industrial que proliferaram na cidade. Para o presidente Getúlio Vargas, essa se transformou em uma estratégia governamental para por fim a um problema social, como se a educação pudesse [...] resolver um problema que era econômico. Para os educadores tratava-se de uma forma de defender a cultura rural, estabelecendo-se um currículo apropriado às características e aos valores rurais, num movimento denominado de ruralismo pedagógico, intensificado no período de 1930 com o 'entusiasmo pela educação'. Nessa época um número expressivo de escolas foi criado na zona rural (MACHADO, 2003, p. 54).

A defesa da educação rural expressa em lei foi desenvolvida de acordo com os cenários políticos do país, como mecanismo de proteção da cultura rural e do direito de acesso à Educação. Para isso, o currículo deve ser apropriado com os valores rurais.

Em 1923 apareceu a primeira referência à educação como educação rural, nos Anais do $1^{\circ}$ Congresso de Agricultura do Nordeste Brasileiro, surgindo o modelo de educação rural patronado, destinada aos menores pobres das regiões rurais que privilegiava o estado de dominação das elites agrárias sobre os trabalhadores. Desta forma surge o ruralismo pedagógico que foi segundo Leite (1999, p. 28) uma tentativa de responder à questão social provocada pelo inchaço das cidades e incapacidade de absorção de toda a força de trabalho disponível pelo mercado de tra- 
balho urbano.

A falta de atenção especial das autoridades suscitou iniciativas privadas, voltadas para o campo, no século XIX. Entretanto, a defesa da escola rural típica apresentou a deficiência de não haver currículos adequados e peculiaridades rurais. A educação revelou apenas a pretensão de enraizar o homem no seu meio, atendendo o contexto brasileiro de produção e de se livrar do inchaço urbano com iminência da desordem social (CALAZANS, 1993).

A educação rural foi mencionada claramente pela primeira vez em texto legal na Constituição Federal de 1934 , no artigo 121, $\S 4^{\circ}$. No texto da Lei, observa-se a promoção das condições do trabalho no campo, mas tendo em vista os interesses econômicos, além do cuidado com a educação rural. A regulamentação do trabalho agrícola, sendo especial, infere que a educação rural também requer sua singularidade:

A lei promoverá o amparo da produção e estabelecerá as condições do trabalho, na cidade e nos campos, tendo em vista a proteção social do trabalhador e os interesses econômicos do País. [...]

$\S 4^{\circ}$ - O trabalho agrícola será objeto de regulamentação especial, em que se atenderá, quanto possível, ao disposto neste artigo. Procurar-se-á fixar o homem no campo, cuidar da sua educação rural, e assegurar ao trabalhador nacional a preferência na colonização e aproveitamento das terras públicas (BRASIL. CONSTITUIÇÃO FEDERAL DE 1934).

No parágrafo único do artigo 156 da mesma Constituição cabe a União a responsabilidade pelo financiamento de ensino nas áreas rurais "Para a realização do ensino nas zonas rurais, a União reservará, no mínimo, vinte por cento das cotas destinadas à educação no respectivo orçamento anual". Porem conforme afiança Pires (2008), mesmo sendo asseguradas legalmente, as políticas públicas para o cumprimento dessa determinação nunca foram desenvolvidas.

A proteção constitucional para o trabalho rural en- 
volve a educação rural, para atender as necessidades e os interesses de quem vive em áreas rurais. A Constituição de 1937 proclama no artigo 128: "a liberdade da iniciativa individual e de associações ou pessoas públicas e particulares" em relação ao ensino. Sendo mais moderada ao tratar a questão da educação como dever do Estado, consideram neste artigo as necessidades de atender a industrialização, vincula a educação ao mundo do trabalho.

Até meados de 1940 não se observa nenhuma ação concreta em torno da implantação da escola rural no meio rural. Isto ocorre em 1942, com a criação do Fundo Nacional do Ensino Primário. O Fundo estabelecia a colaboração financeira da União com os Estados mediante a doação de auxílio financeiro e assistência técnica para o desenvolvimento do Ensino Primário. Coube aos Estados o encargo pelo Ensino Primário, sendo a escolarização nas áreas urbanas e aos municípiosdelegaram a responsabilidade das áreas rurais (ROCHA, 2014, p.15).

A Constituição de 1946 estabelece no artigo 168, inciso IV, a obrigatoriedade de as empresas industriais e comerciais ministrarem aos seus trabalhadores menores, mas não contemplou as empresas agrícolas, demonstrando o desinteresse do Estado pela aprendizagem rural, pelo menos a ponto de emprestar-lhes status constitucional é o que aponta as Diretrizes Educacionais da Educação do Campo (BRASIL, 2002. p. 9).

Em 1961, período politicamente tenso, próximo do golpe militar de 1964, foi sancionada a Lei 4.024/61 que fixou as Diretrizes e Bases da Educação (LDB) para o ensino, há no texto da Lei no Título XIII, intitulado "Disposições Gerais e Transitórias" o seguinte Artigo relacionado aos povos das zonas rurais:

“Art. 105 - Os poderes públicos instituirão e ampararão serviços e entidades, que mantenham na zona rural escolas ou centros de educação, capazes de favorecer a adaptação do homem ao meio e o estímulo de vocações e atividades pro- 
Em 1950, o Brasil possuía uma população de 51,9 milhões de habitantes, dos quais dois terços viviam no campo. No entanto, mesmo o Brasil sendo um país agrário, a LDB não se referiu à educação voltada aos povos dos territórios rurais. Na LDB 5692/71 houve uma estagnação da Educação do Campo.

A partir de meados da década de 1980, as organizações da sociedade civil, especialmente as ligadas à educação popular, incluíram a educação do campo na pauta dos temas estratégicos para a redemocratização do país. A ideia era reivindicar e simultaneamente construir um modelo de educação sintonizado com as particularidades culturais, os direitos sociais e as necessidades próprias à vida dos camponeses.

A Constituição de 1988 é um marco para a educação brasileira, porque motivou uma ampla movimentação da sociedade em torno da garantia dos direitos sociais e políticos, dentre eles o acesso de todos os brasileiros à educação escolar como uma premissa básica da democracia. Ao afirmar que o acesso ao ensino obrigatório e gratuito é direito público subjetivo (Art. 208), ergueu os pilares jurídicos sobre os quais viria a ser edificada uma legislação educacional capaz de sustentar o cumprimento desse direito pelo Estado brasileiro. A educação escolar do campo passa a ser abordada como segmento específico, cheia de implicações sociais e pedagógicas próprias (BRASIL, 1988).

A atual Lei de Diretrizes e Bases da Educação Nacional (Lei $n^{\circ}$ 9.394/96) estabelece uma base comum a todas as regiões do país, a ser complementada pelos sistemas federais, estaduais e municipais de ensino e determina a adequação da educação e do calendário escolar às peculiaridades da vida rural e de cada região. Estabelece em seu artigo 28:

Na oferta da educação básica para a população rural, os 
sistemas de ensino proverão as adaptações necessárias à sua adequação, às peculiaridades da vida rural e de cada região, no inciso: I - conteúdos curriculares e metodologia apropriada às reais necessidades e interesses dos alunos da zona rural; II - organização escolar própria, incluindo a adequação do calendário escolar às fases do ciclo agrícola e às condições climáticas; III - adequação à natureza do trabalho na zona rural. (BRASIL, 1996).

\section{Educação do campo: espaço de diversidades}

De acordo com Rocha (2014, p. 19) são considerados povos do campo: educadores e educandos dos Movimentos Sem-Terra, Movimento dos Atingidos por Barragens, Agricultores e Familiares, Comissão Pastoral da Terra, Indígenas, Quilombolas e Associação de Assalariados Temporários. É, portanto um universo vasto, que abrange várias culturas, várias concepções de educação, tornando a Educação do Campo um espaço de diálogo entre diversidades.

Desta forma, a construção do saber do homem do campo está relacionada ao compromisso ético capaz de desenvolver as condições inerentes à liberdade e à democracia da educação do campo. O discurso da Educação está carregado de atos políticos. Evandro Ghedin destaca

A Educação é um ato político, portanto ninguém educa sem um projeto de formação cultural, e esse projeto passa, necessariamente, por uma intencionalidade política. Entenda-se que o ato político do qual falamos não é o ato político partidário, mas o ato capaz de despertar o gosto pela liberdade, a solidariedade, a responsabilidade para com o ser do outro e pelo mundo, pelo próprio destino, condições que fazem do ser humano um verdadeiro revolucionário. Isto se traduz em uma postura a favor da liberdade, da justiça, da ética e do bem comum (GHEDIN, 2012, p. 37).

A educação do campo é reflexo de cenários políticos, sendo pensada como meio de prender o homem em regiões rurais, formando uma espécie de endereçamento: "pa- 
ra o campo". Além disso, visava controlar a sociedade em metrópoles, evitando seu inchaço populacional. De acordo com Heloisa da Silva Borges (2012, p. 101), a década de 1990 desencadeou

[...] a Educação do Campo e não mais para o campo. Pois os movimentos sociais, particularmente o MST, passaram a discutir e a cobrar do governo (na época FHC e depois como o governo Lula) políticas específicas para atender ao seguimento do campo e sua realidade.

O entendimento da educação rural como do campo aponta para a criação de políticas específicas que atendam às necessidades locais. Para Arroyo; Caldart; Molina (2011), a necessidade de implementação de uma educação específica e diferenciada ou alternativa deve fazer parte do processo educacional:

[...] a educação compreende todos os processos sociais de formação das pessoas como sujeitos de seu próprio destino. Nesse sentido, educação tem relação com cultura, com valores, com jeito de produzir, com formação para o trabalho e para a participação social (KOLLING; CERIOLI; CALDART, 2002, p. 19).

A ideia é desenvolver uma formação humana do campo. Os sujeitos participam da cultura da escola, entendendo a realidade como meio de mudança para sua vida. A educação do campo é desafiadora para os processos educativos que dimensionem a diversidade social, política e cultural, sendo do campo, mas parte de um movimento global para o meio local e vice-versa:

A educação é vista pelo movimento como um processo global, que se realiza no âmbito da escola e da vida do assentamento [...] a partir de uma escola que ensine a ler, escrever e contar vinculados à realidade de vida e de trabalho das crianças [...] desenvolvendo a reflexão e o espírito crítico e preparando-as técnica e politicamente para a conquista do seu espaço nesta sociedade e para a conquista de uma nova sociedade (VENDRAMINI, 1992, p. 128). 
Percebe-se a educação do campo atenta às ações pedagógicas com sentido específico: o ensino está ligado à realidade. O campo é espaço de viver a democratização educativa. A educação do campo nasce de outro olhar

[...] sobre o papel do campo em um projeto de desenvolvimento e sobre os diferentes sujeitos do campo. Um olhar que projeta o campo como espaço de democratização da sociedade brasileira e de inclusão social, e que projeta seus sujeitos como sujeitos de história e de direitos; como sujeitos coletivos de sua formação enquanto sujeitos sociais, culturais, éticos e políticos. [...] Tratando desses processos formadores trataremos de educação (ARROYO; CALDART; MOLINA, 2011, p. 12).

A Educação abrange diferentes perspectivas pedagógicas, dependendo do local e do contexto de implantação da escola e dos que estão envolvidos no processo de aprendizagem. A educação do campo deve contar com processos formadores do homem com sua cultura, sendo sujeito social valorizado:

A aprendizagem como processo de construção de conhecimento se concretiza, na relação sujeito, objeto de conhecimento e contexto em que se inserem. Então, com uma intencionalidade mais ampla, percebe-se uma tríplice articulação que possibilita dar sentido ao ato do conhecimento (PEREIRA; SANTOS, 2012, p. 161).

A articulação do conhecimento abrange a aprendizagem como processo da atividade educacional, o ato de ensinar e a possibilidade do desenvolvimento cognitivo dos que aprendem. Os recursos usados no ensino devem ser desenvolvidos com especificidades: é educação do campo. O processo do conhecimento escolar deve estar relacionado ao conhecimento de vida dos envolvidos no diálogo dos saberes, de acordo com o Decreto n. 7.352/2010:

Art. 6o Os recursos didáticos, pedagógicos, tecnológicos, culturais e literários destinados à educação do campo deverão atender às especificidades e apresentar conteúdos 
relacionados aos conhecimentos das populações do campo, considerando os saberes próprios das comunidades, em diálogo com os saberes acadêmicos e a construção de propostas de educação no campo contextualizadas. (BRASIL. DECRETO 7.352/2010).

Pelo fragmento, as ações pedagógicas são feitas considerando o conhecimento já adquirido pelo aluno para conjugar com o que ele precisa saber. O papel do professor na escola dá importância aos conhecimentos, às culturas. A aprendizagem é dirigida valorizando o outro. A prática educativa faz parte do processo de construção de saberes e habilidades com humanização, pois o que o aluno já sabe é estudado como cultura. Com isso, pode-se dizer de uma educação problematizadora, respondendo à consciência:

[...] a educação libertadora, problematizadora, já não pode ser o ato de depositar, ou de narrar, ou de transferir, ou de transmitir 'conhecimentos' e valores aos educandos, meros pacientes, à maneira da educação 'bancária', mas um ato cognoscente. Como situação gnosiológica, em que o objeto cognoscível, em lugar de ser o término do ato cognoscente de um sujeito, é o mediatizador de sujeitos cognoscentes, educador, de um lado, educandos, de outro, a educação problematizadora colocar, desde logo, a exigência da superação da contradição educador-educandos. Sem esta, não é possível a relação dialógica, indispensável à cognoscibilidade dos sujeitos cognoscentes, em torno do mesmo objeto cognoscível (FREIRE, 1987, p. 39).

A questão educacional adentra na conjuntura da cultura. O movimento é social, atuando com dinamicidade e de forma educativa. A educação do campo assim reflete direitos individuais e coletivos. Desse modo, a aprendizagem é problematizadora, envolve relações intersetoriais e democráticas.

Caldart (2000) aborda sobre a história da educação do campo, a partir do MST, com sua luta pelo direito de acesso à educação, desde o Ensino Básico ao Ensino Superior, e com a construção da nova pedagogia para o meio rural. Esta pedagogia intui a valorização do homem do campo, 
com seus conhecimentos. A escola busca as condições para o caráter educativo omnilateral, na acepção da teoria marxiana, como estabelecimento da formação humana.

O MST, pela instituição de assentamentos, sinaliza a educação do campo envolvida com as políticas públicas. A estratégia do MST para a Educação viabiliza a escola com sua proposta educativa pedagógica voltada para a realidade local. As sugestões e orientações "[...] vêm apontar caminhos e ajudar a reflexão sobre a Educação como um todo, mas especialmente sobre como fazer uma educação para o meio rural nas escolas públicas dos assentamentos e acampamentos" (CAMINI, 1998, p. 59).

Refletir sobre a Educação no País implica a discutir as mudanças que envolvem o entendimento sobre educação rural, no campo e do campo. A primeira foi absorvida como meio de encerrar o homem num território rural, vendo-o como pessoa de pouco entendimento, de poucos recursos. A tentativa era de impedi-lo de inchar as grandes cidades. Além disso, a educação rural encenava claramente a ação pedagógica da cidade. Por outro lado, a educação no campo e a educação do campo remetem para os modelos pedagógicos na escola:

[...] as diferenças entre escola no campo e escola do campo são pelo menos duas: enquanto escola no campo representa um modelo pedagógico ligado a uma tradição ruralista de dominação, a escola do campo representa uma proposta de construção de uma pedagogia, tomando como referência as diferentes experiências dos seus sujeitos (KOLLING; CELIOLI; CALDART, 2002, p. 67, grifos dos autores).

A educação no campo transfigura o pensamento de que o lugar é o mais importante. A escola localizada no campo, por si, configura a educação ruralista, encena a tradição. Já a educação do campo veicula a ideia de uma pedagogia que inova o ensino, pois valoriza conhecimentos, culturas, etnias. Preocupa-se então com o conteúdo 
do ensino que deve estar voltado para a realidade local. Busca-se a aprendizagem democrática, desenvolvendo a formação aluno-professor, a partir de políticas públicas específicas para o campo.

\section{Diferenças entre educação rural, no campo e do campo}

As interpretações de ações pedagógicas diferenciam as ideias sobre educação rural, no campo e do campo. $\mathrm{O}$ termo "educação do campo" teve notoriedade, a partir da I Conferência Nacional "Por uma educação do campo", que se realizou em 1998, no interior do Estado de Goiás. Os debates abordaram a questão do nome "educação do campo", pela sua importância advindas das mudanças das Diretrizes Operacionais para a Educação Básica nas Escolas do Campo:

O surgimento da expressão 'Educação do Campo' pode ser datado. Nasceu primeiro como Educação Básica do Campo no contexto de preparação da I Conferência Nacional por uma Educação Básica do Campo, realizada em Luziânia, Goiás, de 27 a 30 de julho 1998. Passou a ser chamada Educação do Campo a partir das discussões do Seminário Nacional realizado em Brasília de 26 a 29 de novembro 2002, decisão posteriormente reafirmada nos debates da II Conferência Nacional, realizada em julho de 2004. As discussões de preparação da I Conferência iniciaram-se em agosto de 1997, logo após o I Encontro Nacional dos Educadores e Educadoras da Reforma Agrária (Enera), realizado pelo Movimento dos Trabalhadores Rurais Sem Terra (MST) em julho daquele ano, evento em que algumas entidades desafiaram o MST a levantar uma discussão mais ampla sobre a educação no meio rural brasileiro. [...] $\mathrm{O}$ argumento para mudar o termo Educação Básica do Campo para Educação do Campo aparece nos debates de 2002, realizados no contexto da aprovação do parecer do Conselho Nacional de Educação (CNE) no 36/2001, relativo às Diretrizes Operacionais para a Educação Básica nas Escolas do Campo (CALDART et al., 2012, p. 259-260). 
A percepção da educação do campo remete para a pedagogia da alternância, distanciando do modelo antigo da educação rural e da educação no campo. As Diretrizes Operacionais para a Educação Básica nas Escolas do Campo (DOEBEC) expõem as questões inerentes à realidade do campo que devem ser observadas nos projetos institucionais na integralização do ensino:

Art. 1ํ A presente Resolução institui as Diretrizes Operacionais para a Educação Básica nas escolas do campo a serem observadas nos projetos das instituições que integram os diversos sistemas de ensino.

Art. $2^{\circ}$ Estas Diretrizes, com base na legislação educacional, constituem um conjunto de princípios e de procedimentos que visam adequar o projeto institucional das escolas do campo às Diretrizes Curriculares Nacionais para a Educação Infantil, o Ensino Fundamental e Médio, a Educação de Jovens e Adultos, a Educação Especial, a Educação Indígena, a Educação Profissional de Nível Técnico e a Formação de Professores em Nível Médio na modalidade Normal.

Parágrafo único. A identidade da escola do campo é definida pela sua vinculação às questões inerentes à sua realidade, ancorando-se na temporalidade e saberes próprios dos estudantes, na memória coletiva que sinaliza futuros, na rede de ciência e tecnologia disponível na sociedade e nos movimentos sociais em defesa de projeto. [...]

Art. $4^{\circ} \mathrm{O}$ projeto institucional das escolas do campo, expressão do trabalho compartilhado de todos os setores comprometidos com a universalização da educação escolar com qualidade social, constituir-se-á num espaço público de investigação e articulação de experiências e estudos direcionados para o mundo do trabalho, bem como para o desenvolvimento social, economicamente justo e ecologicamente sustentável.

Art. $5^{\circ}$ As propostas pedagógicas das escolas do campo, respeitadas as diferenças e o direito à igualdade e cumprindo imediata e plenamente o estabelecido nos artigos 23,26 e 28 da Lei 9.394, de 1996, contemplarão a diversidade do campo em todos os seus aspectos: sociais, culturais, políticos, econômicos, de gênero, geração e etnia.

Parágrafo único. Para observância do estabelecido neste artigo, as propostas pedagógicas das escolas do campo, elaboradas no âmbito da autonomia dessas instituições, serão desenvolvidas e avaliadas sob a orientação das Diretrizes Curriculares Nacionais para a Educação Básica e a Educação Profissional de Nível Técnico (BRASIL. RESOLUÇÃO 
A educação do campo passa a ser tratada de forma distinta da educação urbana, por exemplo, tendo sua resolução própria. Estabelecem-se princípios e procedimentos adequados ao projeto institucional pedagógico. Atem-se para a identidade do homem e da escola campo, ligando o ensino a sua realidade. A universalização educacional do campo é muito mais que a consideração do lócus:

A educação do campo, tratada como educação rural na legislação brasileira, tem um significado que incorpora os espaços da floresta, da pecuária, das minas e da agricultura, mas os ultrapassa ao acolher em si os espaços pesqueiros, caiçaras, ribeirinhos e extrativistas. $\mathrm{O}$ campo, nesse sentido, mais do que um perímetro não-urbano, é um campo de possibilidades que dinamizam a ligação dos seres humanos com a própria produção das condições da existência social e com as realizações da sociedade humana (KOLLING; CELIOLI; CALDART, 2002, p. 33).

A educação do campo reflete a realidade concreta de seu meio. É uma educação que anseia por transformações sociais, que busca alcançar seus interesses e direitos garantidos não apenas pela manutenção da demarcação territorial, mas para que o homem se realize enquanto membro da sociedade humana. Os sujeitos são empenhados em mudar sua situação de desvantagem quanto aos projetos e programas do meio urbano, reconhecendo que

[...] as práticas de educação do campo têm se movido pelas contradições do quadro atual, às vezes mais, às vezes menos conflituoso, das relações imbricadas entre campo, educação e políticas públicas. Houve avanços e recuos na disputa do espaço público e da direção político-pedagógica de práticas e programas, assim como na atuação das diferentes organizações de trabalhadores, conforme o cenário das lutas mais amplas e da correlação de forças de cada momento. O enfrentamento das políticas neoliberais para a educação e para a agricultura continua como desafio de sobrevivência (CALDART et al., 2012, p. 262). 
A vida do homem do campo enfrenta as lutas de força, por meio de movimentos sociais, de projetos com objetivos específicos do que se almeja alcançar, entre outros. As contradições do ensino pedagógico e as desigualdades têm sido pouco amenizadas, por isso, enfrentar políticas que privilegiam o capitalismo é necessário. $\mathrm{O}$ importante é romper com o modelo prático pedagógico, para estabelecer a educação de caráter libertador.

O desenvolvimento de tudo que está relacionado com o campo é assunto para desmistificar a ideia de que "rural" é sinônimo de atraso. O campo é lugar de possibilidades para as condições de vida social e cultural adequada para as famílias. Promove-se o respeito dos seus interesses e dos valores da educação do campo, diferenciando-se da educação rural e da educação no campo, como pode ser perceber no quadro a seguir:

\section{Quadro 1 - Educação rural, no campo e do campo}

\begin{tabular}{|c|c|c|c|}
\hline & Rural & No Campo & Do Campo \\
\hline $\begin{array}{l}\text { A localização } \\
\text { da escola }\end{array}$ & $\begin{array}{l}\text { A escola está no meio rural, } \\
\text { diferenciando-se totalmente } \\
\text { do meio urbano }\end{array}$ & $\begin{array}{l}\text { A escola está especificamente no } \\
\text { campo }\end{array}$ & $\begin{array}{l}\text { Art. } 1^{\circ} \text {, II - escola do campo: aquela } \\
\text { situada em área rural, conforme } \\
\text { definida pela Fundação Instituto } \\
\text { Brasileiro de Geografia e Estatística - } \\
\text { IBGE, ou aquela situada em área } \\
\text { urbana, desde que atenda predominan- } \\
\text { temente a populações do campo } \\
\text { (BRASIL. DECRETO } 7.352 / 2010 \text { ) }\end{array}$ \\
\hline $\begin{array}{l}\text { Entendimento } \\
\text { sobre educação }\end{array}$ & $\begin{array}{l}\text { Educação foi absorvida como } \\
\text { meio de encerrar o homem } \\
\text { num território rural, vendo-o } \\
\text { como pessoa de pouco } \\
\text { entendimento, de poucos } \\
\text { recursos. A tentativa era de } \\
\text { impedi-lo de inchar as grandes } \\
\text { cidades Além disso, a } \\
\text { educação rural encenava } \\
\text { claramente a ação pedagógica } \\
\text { da cidade }\end{array}$ & $\begin{array}{l}\text { A educação no campo transfigura } \\
\text { a tradição do pensamento } \\
\text { ruralístico. }\end{array}$ & $\begin{array}{l}\text { A educação do campo veicula a ideia } \\
\text { de uma pedagogia que inova o ensino, } \\
\text { pois valoriza conhecimentos, culturas, } \\
\text { etnias. Preocupa-se então com o } \\
\text { conteúdo do ensino que deve estar } \\
\text { voltado para a realidade local. Busca-se } \\
\text { a aprendizagem democrática, } \\
\text { desenvolvendo a formação aluno-pro- } \\
\text { fessor, a partir de políticas públicas } \\
\text { específicas para o campo. }\end{array}$ \\
\hline $\begin{array}{c}\text { Conceito } \\
\text { de educação }\end{array}$ & $\begin{array}{l}\text { Pode-se dizer que o conceito } \\
\text { de educação é genérico. }\end{array}$ & $\begin{array}{l}\text { Pode-se dizer que o conceito de } \\
\text { educação é genérico. }\end{array}$ & $\begin{array}{l}\text { A educação do campo é um campo de } \\
\text { possibilidades que dinamizam } \\
\text { convivências entre homens, com as } \\
\text { condições da existência e das } \\
\text { realizações sociais. } \\
\text { Educação como meio de de } \\
\text { demoratização da sociedade, de } \\
\text { inclusão social, atenta aos sujeitos de } \\
\text { história e de direitos, estabelecendo } \\
\text { políticas específicas do campo e sua } \\
\text { realidade. }\end{array}$ \\
\hline
\end{tabular}


Quadro 1 - Educação rural, no campo e do campo

conclusão

\begin{tabular}{|c|c|c|c|}
\hline $\begin{array}{l}\text { Princípios } \\
\text { pedagógicos } \\
\text { de ensino }\end{array}$ & $\begin{array}{l}\text { Pouca ou nenhuma } \\
\text { importância dada às ações } \\
\text { pedagógicas voltadas para o } \\
\text { sujeito e seu conhecimento }\end{array}$ & $\begin{array}{l}\text { Pouca ou nenhuma importância } \\
\text { dada às ações pedagógicas } \\
\text { voltadas para o sujeito e seu } \\
\text { conhecimento }\end{array}$ & $\begin{array}{l}\text { Art. } 60 \text { Os recursos didáticos, } \\
\text { pedagógicos, tecnológicos, culturais e } \\
\text { literários destinados à educação do } \\
\text { campo deverão atender às } \\
\text { especificidades e apresentar conteúdos } \\
\text { relacionados aos conhecimentos das } \\
\text { populações do campo, considerando os } \\
\text { saberes próprios das comunidades, em } \\
\text { diálogo com os saberes acadêmicos e a } \\
\text { construção de propostas de educação } \\
\text { no campo contextualizadas (BRASIL. } \\
\text { DECRETO } 7.352 / 2010 \text { ). }\end{array}$ \\
\hline $\begin{array}{l}\text { Algumas } \\
\text { diferenças }\end{array}$ & $\begin{array}{l}\text { Processo de aprendizagem } \\
\text { sem diferenciação da educação } \\
\text { urbana }\end{array}$ & $\begin{array}{l}\text { Focaliza o lócus, mas o processo } \\
\text { de aprendizagem é sem } \\
\text { diferenciação da educação } \\
\text { urbana; } \\
\text { escola no campo representa um } \\
\text { modelo pedagógico ligado a uma } \\
\text { tradição ruralista de dominação }\end{array}$ & $\begin{array}{l}\text { Educação pedagógica que ressalta o } \\
\text { respeito e preservação das identidades } \\
\text { individuais, sendo parte essencial da } \\
\text { aprendizagem. } \\
\text { Processo de aprendizagem voltado } \\
\text { para a realidade local, considerando } \\
\text { suas necessidades, diferenciando de } \\
\text { ações pedagógicas da educação } \\
\text { urbana; a escola do campo representa } \\
\text { uma proposta de construção de uma } \\
\text { pedagogia, tomando como referência } \\
\text { as diferentes experiências dos seus } \\
\text { sujeitos. }\end{array}$ \\
\hline
\end{tabular}

Fonte: Autoras

As interpretações da educação e da escola rural, no campo e do campo mostram as conquistas e os desafios que a educação do campo revela. Esta é oposta à educação rural e à educação no campo. O sentido educacional do campo representa avanço para a pedagogia do movimento da terra.

Para a Educação do Campo, é necessário um paradigma epistemológico que possa romper/superar o da Educação Rural, que sejam criadas propostas teóricas e metodológicas que priorizem o direito dos sujeitos de direito, delimitando um território teórico e prático, vendo o campo como parte do mundo e não como aquilo que sobra além das cidades (FERNANDES, 2009, p. 136), que seja vinculado às questões inerentes à realidade camponesa e às lutas sociais. 


\section{ALGUMAS CONSIDERAÇÕES}

A concretização da Educação do Campo tomando como referência os avanços legais, ainda é um desafio. É defendida pelas pessoas do campo, acima de tudo movimentos sociais, cujo objetivo é obter uma educação voltada para emancipação humana e, portanto, libertadora, que leva seus sujeitos a pensar criticamente sobre sua posição diante das situações que incubem um olhar mais profundo e que se concretizem em ações efetivas de transformação da realidade. Isso exige, clareza teórica de quem conduz os processos escolares no campo e ainda é um horizonte a se alcançar.

De fato, somente com a Constituição de 1988 é que a educação torna-se um direito público subjetivo, pois deveria atender todos os sujeitos, independentemente de onde vivem. No entanto, esse direito para ser alcançado em sua totalidade demanda a contínua peleja na inserção de políticas públicas de valorização da educação do campo, sobretudo na construção de novos percursos históricos da educação.

\section{REFERENNCIAS}

ARROYO, M. G.; CALDART, R. S.; MOLINA, M. C. (Orgs.). Por uma educação do campo. 5. ed. Petrópolis, RJ: Vozes, 2011.

BRASIL. Constituição Federal de 1934.

. Lei no 4.024, de 20 de dezembro 1961. Fixa as Diretrizes e Bases da Educação Nacional. Brasília, 1961.

. Lei $\mathrm{n}^{\mathrm{0}}$ 5692//71 de 11 de agosto de 1971. Fixa Diretrizes e Bases para o ensino de $1^{\circ}$ e $2^{\circ}$ Graus e dá outras providências. Brasília, 1971.

cação nacional.

. LDB 9394/1996. Estabelece as diretrizes e bases da edu- 
. CONSELHO NACIONAL DE EDUCAÇÃO CÂMARA DE EDUCAÇÃO BÁSICA. RESOLUÇÃO CNE/CEB 1, DE 3 DE ABRIL DE 2002. Institui Diretrizes Operacionais para a Educação Básica nas Escolas do Campo.

. Decreto n. 7.352, de 4 de novembro de 2010. Dispõe sobre a política de educação do campo e o Programa Nacional de Educação na Reforma Agrária - PRONERA.

.(2016). Constituições Federais, 2016. Disponível em: <www.planalto.gov.br/ccivil_03/Constituicao/principal.htm.>. Acesso em: mar. 2017.

BORGES, H. da S. Formação Contínua de Professores(as) da Educação do Campo no Amazonas (2010 a 2014). 2015. Tese (Doutorado em Educação) - Universidade Federal do Amazonas, Manaus, 2015.

CALAZANS, J. Para compreender a educação do Estado no meio rural - traços de uma trajetória. In: THERRIEN; DAMASCENO (Coords.). Educação e escola no campo. Campinas: Papirus, 1993.

CALDART, R. S. Escola é mais do que escola na pedagogia do movimento sem terra. Petrópolis: Rio de Janeiro, 2000.

CAMINI, I. O cotidiano pedagógico de professores e professoras em uma escola de assentamento do MST: limites e desafios. 1998. Dissertação (Mestrado em Educação) - Porto Alegre: Universidade Federal do Rio Grande do Sul, 1998.

FERNANDES, B. M. Por uma educação básica do campo. In: ARROYO, M. G.; FERNANDES, B. M. A EducaçãoBásica e o Movimento Social do Campo. p. 44-55. Brasília, DF: Ministério do Desenvolvimento Agrário, 1999.

FREIRE, P. Pedagogia do oprimido. 17. ed. Rio de Janeiro: Paz e Terra, 1987.

GHEDIN, E. et al. Currículo e ensino básico. Manaus: Universidade do Estado do Amazonas, 2004.

JUNQUEIRA, L. A. P., INOJOSA, R. M.; KOMATSU, S. Des- 
centralização e intersetorialidade na gestão pública municipal do Brasil: a experiência de Fortaleza. Caracas: XI Concurso de Ensayosdel CLAD, 1997.

KOLLING; CELIOLI; CALDART (Orgs.) Por uma educação do campo: educação do campo identidade e políticas públicas. Brasília, DF: Articulação Nacional Por uma Educação do Campo, 2002. (Coleção Por uma Educação do Campo, n. 4).

LEITE, S. C. Escola Rural: urbanização e política educacional. São Paulo: Cortez, 1999.

MACHADO, I. F. A organização do trabalho pedagógico em uma escola do MST e a perspectiva de formação omnilateral. 2003. Tese (Doutorado em Educação) - Universidade Estadual de Campinas, Campinas, SP, 2003.

PEREIRA, L. A.; SANTOS, R. B. Uma experiência na educação do campo: o enfoque materialista histórico-dialético em sala de aula. In: GHEDIN, E. Perspectivas sobre a identidade do educador do campo. In: ____ (Org.). Educação do campo: epistemologia e práticas. São Paulo: Cortez, 2012. p. 159-168.

PIRES, A. M. Educação do campo como direito humano. São Paulo: Cortez, 2012.

ROCHA, M. I. A. Da Educação Rural à Educação do Campo: construindo caminhos. In: Educação rural e do campo. v. 2. In:__(Org.) CARVALHO, H.; CASTRO, M. Uberlândia: EDUFU, 2014.

TEIXEIRA, E. S.; BERNARTT, M. de L.; TRINDADE, G. A. Estudos sobre Pedagogia da Alternância no Brasil: revisão de literatura e perspectivas para a pesquisa. Educ. Pesqui., São Paulo, v. 34, n. 2, maio/ago. 2008.

VENDRAMINI, C. R. Ocupar, resistir e produzir: um estudo da proposta pedagógica do Movimento Sem Terra. 1992. Dissertação (Mestrado em Educação) - São Carlos: UFSCar, 1992. 


\title{
CAPÍTULO 15
}

\section{POLÍTICAS PÚBLICAS EM EDUCAÇÃO DO CAMPO NO BRASIL: tecendo fios}

\author{
Darlene Camargo Queiroz ${ }^{1}$ \\ Ramofly Bicalho ${ }^{2}$ \\ Renata Felicio Maia ${ }^{3}$
}

\section{INTRODUÇÃO}

Este artigo é fruto das atividades realizadas no Fórum de Políticas Públicas em Educação do Campo, entre os dias 11 e 13 de dezembro de dois mil e dezessete, no CIBEPOC - Congresso Interinstitucional Brasileiro de Educação Popular e do Campo, Universidade Federal de Goiás, Campus Catalão. Importante sinalizar neste trabalho, a continuidade das nossas reflexões acerca das pesquisas realizadas em educação do campo na sua estreita articulação com os movimentos sociais. Neste campo de análise, privilegiamos as seguintes políticas públicas: Programa Nacional de Educação na Reforma Agrária - PRONERA; Diretrizes Operacionais para a Educação Básica nas escolas do campo; Pedagogia da alternância e seus instrumentos pedagógicos; Programa de Apoio à Formação Superior em Licenciatura em Educação do Campo - PROCAMPO e o Programa Nacional de Educação do Campo - PRONACAMPO. Focalizamos as relações entre as histórias de

\footnotetext{
${ }^{1}$ Docente CTUR/UFRRJ

Doutoranda em Humanidades, culturas e Artes /Unigranrio email:profdarlenequeiroz@gmail.com

${ }^{2}$ Docente na Licenciatura em Educação do Campo

UFRRJ - Universidade Federal Rural do Rio de Janeiro email:ramofly@gmail.com

${ }^{3}$ Docente PMNI

Mestre em Humanidades, Culturas e Artes/Unigranrio email:renatam12felicio@gmail.com
} 
vida dos sujeitos, individuais e coletivos, no envolvimento com as lutas organizadas pelos movimentos sociais do campo, numa perspectiva popular e histórica.

Nossa intenção com esse trabalho é compreender o campo como lugar de resistência e luta pela terra, essencial para repensarmos as políticas públicas educacionais destinadas à infância, aos jovens e adultos do campo. Mostraremos a relevância dos princípios desenvolvidos pelos movimentos sociais no que toca à luta por educação do campo. Suas bandeiras, projetos, perspectivas e utopias. A formação política dos trabalhadores e a valorização da consciência social são alguns dos desafios. A produção de tal conhecimento nas escolas do campo pode contribuir para reconstrução do passado, escavando memórias, ressignificando identidades e histórias vividas pelos sujeitos que se articulam para superar a opressão e as diversas cercas do analfabetismo e da fome que atingem milhares de homens e mulheres no campo.

Durante séculos a formação destinada às classes populares do campo, vinculou-se a um modelo "importado" de educação urbana. Os valores presentes no meio rural, quando comparados ao espaço urbano, são tratados com descaso, subordinação e inferioridade. Num campo estigmatizado pela sociedade brasileira, multiplicam-se, cotidianamente, preconceitos e estereótipos. A racionalidade moderna formatou a educação rural, justificada socialmente nas diferenças entre raças, classes e gênero, repercutindo num saber/fazer praticista (pouca reflexão) e discriminatório dos povos camponeses. O espaço/tempo escolar-rural, carrega a marca do produtivismo e da segregação social, reproduzindo as representações do modelo agrário-exportador dependente, além do pensamento evolucionista e discriminador do modo de vida campesino. (BICALHO \& OLIVEIRA, 2011). A educação rural se consolida, historicamente, na dupla dicotomia do ensinar a reproduzir conhecimentos do rural hegemônico e pro- 
duzir com produtividade. Uma educação escolar rural que não corresponde às demandas populares do campo, por acesso à educação básica.

Por outro lado, a expressão educação do campo identifica reflexões pedagógicas que germinam das inúmeras práticas educativas desenvolvidas pelos sujeitos que vivem no campo. Consiste em reflexões que consideram o campo como espaço de produção de pedagogias. Trata-se de projetos que reafirmam a finalidade mais expressiva das práticas educativas desenvolvidas no campo. Ela contribui com o desenvolvimento mais pleno do ser humano e sua inserção consciente no contexto social (CALDART, 2003). A realidade de intensa desumanização que, historicamente, caracteriza a vida da população camponesa, gerou este movimento em favor da Educação Básica do Campo. Uma realidade que, mesmo marcada por opressões e injustiças, continua reivindicando alterações sociais, profundas e imediatas no campo brasileiro.

$\mathrm{Na}$ construção dos referenciais teórico-metodológicos, privilegiamos a análise documental e acervos bibliográficos. Trabalhamos ainda com pareceres, decretos reguladores, documentos próprios da educação do campo e formação por alternância. Consultamos documentos produzidos pelos movimentos sociais do campo, em parceria, com sindicatos e universidades públicas, além da nossa participação no Fórum de Políticas Públicas em Educação do Campo / CIBEPOC. Apoiamo-nos numa perspectiva eminentemente histórico e sociológica de investigação e explicação dos processos sociais de participação dos sujeitos camponeses.

Na seleção da vasta bibliografia sobre educação do campo, nosso destaque é para os documentos oficiais produzidos pelos movimentos sociais do campo e Ministério da Educação - MEC. Utilizamos ainda revistas, jornais, textos produzidos por educadores e educandos das escolas do campo, dissertações, teses, livros e artigos em peri- 
ódicos científicos que demonstram a relevância da educação do campo, suas bandeiras e sujeitos coletivos - escolas do campo, secretarias estaduais e municipais de educação, universidades, agentes pastorais, sindicatos e movimentos sociais.

Os debates realizados no Fórum aprofundaram as seguintes temáticas: 1) História da educação do campo no Brasil; 2) Movimentos sociais; 3) Reforma agrária e agroecologia; 4) Escola do campo; 5) Educação do Campo X Educação Rural; 6) Práticas curriculares e educação do campo; 7) ENERA - Encontro Nacional de Educadores e Educadoras da Reforma Agrária; 8) PRONERA - Programa Nacional de Educação na Reforma Agrária; 9) Diretrizes Operacionais para a Educação Básica nas escolas do campo; 10) SECAD - Secretaria de Educação Continuada, Alfabetização e Diversidade; 11) PROCAMPO - Programa de Apoio à Formação Superior em Licenciatura em Educação do Campo; 12) Pedagogia da alternância; 13) PRONACAMPO - Programa Nacional de Educação do Campo; 14) Fechamento de escolas do campo.

\section{Movimentos sociais}

Como podemos perceber, a história da educação rural no Brasil foi marcada pelo abandono do poder público. Foi em oposição a esta situação que surgiram diversas iniciativas de movimentos sociais, sindicais e populares que, paralelamente, construíram inúmeras experiências educativas de reflexão acerca da realidade e interesses dos povos camponeses. São iniciativas que defendem o meio rural como espaços de vida, diversidade cultural e identitária, lutas, resistências e sonhos, portanto, territórios que carecem de políticas direcionadas a esta realidade. Não apenas uma mera transposição do meio urbano para o rural. O alcance e a expressividade dessas ações podem ser consolidados, entre outros aspectos, nas parcerias entre 
educadores e educandos das escolas do campo e movimentos sociais, ressignificada na luta por histórias de vida, valores e reconhecimento identitário. Nesse sentido, o campo é mais que uma concentração espacial geográfica. É o cenário de uma série de lutas e embates políticos. Nos últimos anos foram identificadas muitas práticas educativas, em todas as regiões do país, originadas no interior das organizações e movimentos sociais do campo (GOHN, 2001, 2002).

Inúmeros obstáculos são enfrentados pelos sujeitos, individuais e coletivos, do campo, em especial, as tensões entre movimentos sociais camponeses e Estado. O embate entre estas duas categorias resultou em experiências históricas e na contribuição para as massas populares direcionarem outras formas de lutas, enquanto sujeitos de direitos. Com o objetivo de garantir a educação básica nas comunidades rurais e também formar quadros dirigentes, muitas dessas ações, ainda que isoladas, tiveram resultados concretos e serviram para que os movimentos sociais e organizações não se inibissem. Pressionado pela massa popular, coube ao estado reconhecer estas experiências e desenvolver políticas públicas específicas para o campo, de modo que as práticas educativas fossem ampliadas e reconhecidas pela sociedade.

A ocupação da universidade pública nos últimos anos trouxe para o debate, inúmeros conflitos e tensões com os movimentos sociais. Obrigou a universidade rever seus cursos, práticas pedagógicas e formação docente, contemplando os aspectos da diversidade. O esforço dos seminários, encontros, congressos, lutas e militância desenvolvidos pelos movimentos sociais camponeses colaboraram no processo de sensibilização dos gestores, incluindo a educação como direito absoluto. Nessa conjuntura, as relações de poder são enfrentadas e as tensões afloram.

Os movimentos sociais são formuladores de políti- 
cas públicas. Eles provocam debates acerca do contexto da luta de classe no campo brasileiro. Afirmam sua identidade campesina, quilombola, caiçara e indígena. Defendem o reconhecimento de suas histórias e culturas. Enquanto sujeitos do conhecimento, carregam formas específicas de atuação e visão de mundo. Os movimentos sociais não estão isolados na luta contra a pobreza extrema, o latifúndio e a exploração. Existe toda uma enorme articulação à nível mundial, expressa, entre outras, pela Via Campesina. Por sua relevância social, política e acadêmica, criminalizar os movimentos sociais é um enorme equívoco. A experiência adquirida ao longo de décadas de atuação deve ser aproveitada, pois suas conquistas são oriundas dos enfrentamentos e lutas em favor da educação emancipadora e não pela generosidade da burguesia com seus objetivos altamente conservadores.

Os movimentos sociais, na sua diversidade, colaboram para ressignificar a formação docente, as teorias pedagógicas e políticas públicas. Historicamente, aprendem e ensinam, organizam-se e resistem, embora a sociedade tenha dificuldades em reconhecer essas lutas. São produzidos politicamente na própria dinâmica histórica e nos conflitos de ideias, colaborando na construção de práticas e valores que ressignificam as atividades coletivas. Nos debates sobre educação do campo, os movimentos sociais reivindicam a estreita articulação com as iniciativas de reforma agrária popular, agricultura familiar, agroecológica e orgânica, além de combater o agrotóxico, o transgênico, o latifúndio e a monocultura. A radicalidade política pode transformar a escola do campo e emancipar educadores, educandos, gestores e comunidade. Por outro lado, o atual modelo não responde aos interesses sociais, ambientais, políticos e culturais, na perspectiva da educação popular (GOHN, 2003). 


\section{Reforma agrária e agroecologia}

Impor a derrota ao agronegócio. Talvez seja esse um dos principais objetivos da reforma agrária popular defendida pelos movimentos sociais. Nesse sentido, as alianças e o trabalho coletivo são essenciais. Deixar de lado as pequenas contradições e olhar para contradição maior: o capital. Da década de 90 em diante, o capital financeiro, as empresas transnacionais e multinacionais, os bancos e a classe dominante no campo, integrados ao mercado mundial, se apropriaram das terras e formas de produção, além de controlarem as sementes e fixarem preços.

O agronegócio é um modelo de produção agrícola baseado na monocultura, em grandes extensões de terras, com baixíssima utilização de mão de obra e mecanização intensiva, altamente poluente e prejudicial ao meio ambiente. Romper com esse modelo de produção, onde a prioridade é sempre o lucro em altíssima escala, é uma das prioridades na reforma agrária popular, defendida pelos movimentos sociais. Esta política de distribuição de terras pode gerar renda nos assentamentos e condições dignas de permanência do homem e da mulher no campo. Só o conhecimento liberta verdadeiramente as pessoas, pois a luta contra a ignorância também faz parte da reforma agrária (ALTIERI, 2014).

A produção agroecológica e seus alimentos saudáveis salvam vidas e não agride a natureza. A agroecologia com seus princípios, conceitos e metodologias, pode colaborar com o desenvolvimento sustentável dos inúmeros assentamentos presentes no território brasileiro, desde que os créditos, a negociação das dívidas históricas, a merenda escolar e a produção de alimentos limpos, façam parte das prioridades estabelecidas pelo poder público. Pode ainda, apresentar alternativas à atual realidade da agricultura familiar no Brasil, com bases científicas de apoio ao processo de transição para a agricultura sustentável. 
Historicamente, os agricultores familiares são os que mais protegem o meio ambiente. Nesse sentido, é estratégico reverter os processos históricos de exclusão vivenciados por esses agricultores. A agroecologia pode ser essa ferramenta de transformação do meio rural. Ela fortalece a agricultura familiar com metodologias educativas e participativas, além da utilização sustentável dos recursos naturais, tais como: solo, água, florestas e meio ambiente. As técnicas utilizadas pelos agricultores dialogam com suas histórias de vida, desejos e sonhos, numa estreita relação com as ações culturais, políticas, sociais e coletivas (ALTIERI, 2014).

É estratégico articular os debates acerca da reforma agrária, educação do campo e território. Essas temáticas são indissociáveis na luta pela terra e fundamentais no desenvolvimento do campo, dos acampamentos e assentamentos. Uma das estratégias do capital é a desterritorialização constante, representada pela ofensiva das empresas transnacionais. O processo de desumanização dos sujeitos passa por sua desterritorialização. Por outro lado, campesinato, pequeno agricultor, quilombolas, indígenas e demais povos da floresta não vivem sem o território e os enfrentamentos são constantes.

No território do agronegócio predominam as relações de subordinação ao capital. Os alimentos são apenas mercadorias, em vez de direito das pessoas. Constantemente, campesinato e agronegócio disputam territórios. O campesinato luta pelo território que produz alimentos saudáveis, soberania e perspectiva de desenvolvimento, reagindo à perversidade da desterritorialização. Nessa configuração, a educação do campo, nas suas várias dimensões, se articula às lutas por reforma agrária, agricultura familiar, agroecológica e orgânica. As escolas do campo, nesse contexto, podem colaborar na formação de sujeitos preocupados com os variados projetos de emancipação humana, vinculados a arte, música, cultura, identidades e 
história de vida.

\section{Escola do campo}

Em sua grande maioria, a escola tradicional nega os saberes dos estudantes camponeses e comunidade. Ela serve aqueles que detêm o poder político e econômico na sociedade de classes. A escola burguesa, classificatória, polarizada, autoritária e conservadora, não dá conta dos interesses da classe trabalhadora. Mantendo a expropriação, acaba servindo de instrumento para consolidar o status quo de uma minoria. A organização escolar urbana, linear, segregadora e tradicional não serve para as escolas do campo e nem mesmo para cidade. A organização curricular nas escolas do campo é crescentemente urbanocêntrica, privilegiando o poder atrativo das cidades. Em sua grande maioria, desconhecem as diretrizes e legislações acerca dos princípios da educação do campo. Falta infraestrutura e materiais didáticos, a formação docente inadequada é uma constante, estradas intransitáveis, entre tantos outros aspectos (CALDART, ARROYO \& MOLINA, 2004).

Importante o seguinte questionamento. $\mathrm{O}$ que querem os sujeitos, individuais e coletivos, nas escolas do campo? Gestão democrática, coletiva, comunitária e popular, com igualdade de acesso e permanência. Organização escolar e conteúdos curriculares que enalteçam a estreita relação entre prática, teoria e prática na produção emancipadora do conhecimento. Despertar a consciência da liberdade e a formação humana pode ser uma das funções dessa escola.

É estratégico reconhecer as especificidades das escolas do campo e a legitimidade de um projeto de educação que responsabilize o poder público pela universalização do acesso da população camponesa à educação básica. A escola ocupa um espaço singular nesse processo de participação política, quando pensada a partir da sua própria 
realidade e diversidade de saberes. Ela tem intencionalidades, identidades, escolhas, experiências e práticas pedagógicas que reconhecem o campo como espaço de produção do saber, conhecimentos, mitos, histórias e experiências, a partir do planejamento coletivo entre educadores e educandos.

Nas experiências da ciranda infantil organizadas pelo MST, as crianças afirmam que também querem escolas do campo para os seus pais. Cobram, inclusive, projetos de educação popular e alfabetização de jovens e adultos. A educação infantil, nessa conjuntura, contribui para compreender a educação do campo como direito social e dever político, através de lutas, manifestações e marchas.

Uma escola que possibilite ao educando usufruir do saber historicamente acumulado. Que enfrente a burocratização e o isolamento das disciplinas, valorizando a produção textual dos estudantes, a partir das suas histórias de vida, desejos e realidade. Escola que aprofunde os debates acerca da organização e lutas camponesas, privilegiando seus interesses sociais, políticos e econômicos. Uma escola do campo que apresente o trabalho como matriz pedagógica, formativa e de humanização das pessoas, além da pesquisa como instrumento educativo e estratégia pedagógica, que possibilite tempos de estudo, individual e coletivo, para educadores e educandos.

Que sujeitos do campo se quer formar numa educação emancipadora? Sujeitos de direitos que rompem com as políticas públicas de educação pensadas apenas nas cidades, adaptadas ao campo e distante das diversas realidades históricas. Sujeitos, individuais e coletivos, que enfrentam a possibilidade de saída do jovem camponês para cidade, fruto dos altíssimos índices de fechamento das escolas do campo no Brasil. Que compreendam os tempos e espaços de formação dos educadores, educandos e comunidade no interior das escolas do campo. Sujeitos que defendem a resistência camponesa, a agroecologia, os proje- 
tos alternativos e lutam para que o campo não se confunda com o lugar do atraso, da Morte Severina e do Jeca Tatu. Esta educação emancipadora interessa aos trabalhadores/ as e movimentos sociais, pois denuncia os agrotóxicos e rompe com os modelos dependentes dos produtos químicos (CALDART, PEREIRA, ALENTEJANO \& FRIGOTTO, 2012).

Por outro lado, é muito pequeno o número de escolas do campo com quadras poliesportivas, bibliotecas equipadas, laboratórios de ciências e internet. Boa parte dos docentes nessas escolas, atuam com contratos temporários e ausência de propostas pedagógicas contextualizadas. As condições de trabalho dos educadores, em sua grande maioria, são péssimas, em função da inadequada infraestrutura, turmas multisseriadas, ausência de água potável e energia elétrica, material didático distante da realidade camponesa e altíssima rotatividade dos docentes nas escolas do campo, além de um precário sistema de transporte escolar para educandos e educadores.

\section{Educação do Campo X Educação Rural}

Importante ressaltar que a conquista dos princípios da educação do campo é fruto da resistência organizada dos movimentos sociais e demais organizações do campo, em especial, o MST - Movimento dos Trabalhadores Rurais Sem Terra. Ela é fruto das ações dos diversos atores sociais e suas lutas em favor da realidade e diversidade das famílias camponesas nas escolas do campo. Lutas que marcam a ruptura entre educação do campo e educação rural. Muito mais que uma nomenclatura, tal divisão retrata a consciência de processos educativos a serviço dos povos camponeses, sujeitos históricos protagonistas na consolidação de uma sociedade baseada nos princípios da solidariedade e sustentabilidade do planeta.

Segundo (LEITE, 1999): A educação rural no Brasil, 
por motivos socioculturais, sempre foi relegada a planos inferiores e teve por retaguarda ideológica o elitismo, acentuado no processo educacional aqui instalado pelos jesuítas e a interpretação político-ideológica da oligarquia agrária, conhecida popularmente na expressão: "gente da roça não carece de estudos". Isso é coisa de gente da cidade. Historicamente, as políticas públicas para a chamada "educação rural" esteve vinculada a projetos conservadores e tradicionais de ruralidades para o país, em geral centrada no agronegócio, no latifúndio, no agrotóxico, nos transgênicos, na exportação e exploração indiscriminada dos recursos naturais, marcada, profundamente, pelo abandono e tropeços do poder público. Tais paradigmas direcionam as políticas e práticas educativas efetuadas no meio rural. Eles são agentes da exclusão social e educacional. Contribuem para negação dos direitos, histórias, sonhos, gestos e identidade dos sujeitos. A educação rural no Brasil ainda é uma realidade, mesmo diante de avanços consideráveis na concepção de educação do campo.

Foram em oposição a esta situação que os movimentos sociais, sindicais e populares construíram inúmeras experiências educativas acerca dos interesses dos povos camponeses. Iniciativas de defesa do meio rural como espaço de vida, diversidade cultural e identitária, lutas, resistências e sonhos. O paradigma da educação do campo supera o antagonismo campo e cidade. Esses espaços são complementares e de igual valor, com tempos e modos diferentes de ser, viver e produzir, contrariando a pretensa superioridade do urbano sobre o rural.

Romper com a educação rural é uma das prioridades da educação do campo. A mudança na compreensão desse conceito reflete muito mais do que uma simples nomenclatura. Ela é inevitavelmente o resultado de um olhar politicamente referendado na busca pelos direitos sociais e nas questões que envolvem a defesa da educação politécnica (CALDART, STEDILE \& DAROS, 2015), a agroeco- 
logia (ALTIERI, 2014), agricultura orgânica, reforma agrária, soberania alimentar, entre outros aspectos. Esses são fatores indispensáveis na concretização de projetos político-pedagógicos emancipadores que busquem encarar a realidade e atender as necessidades das populações do campo. Ações que pressionam as lideranças governamentais na criação e organização de políticas públicas para/ com os trabalhadores e trabalhadoras do campo.

(FERNANDES, MOLINA \& JESUS, 2005) defendem o campo como espaço de particularidades, matrizes culturais e sociais. Esse campo é repleto de possibilidades políticas, formação crítica, resistência, mística, identidades, histórias e produção das condições de existência social. Cabe, portanto, à educação do campo, o papel de fomentar reflexões que acumulem forças e produção de saberes que contribuam para negar e desconstruir o imaginário coletivo acerca da visão hierárquica que há entre campo e cidade. Essas ações podem ajudar na superação da visão tradicional do imaginário social do jeca-tatu e do campo como espaço atrasado e pouco desenvolvido.

A Educação do Campo nasceu das experiências de luta pelo direito à educação e por um projeto político pedagógico vinculado aos interesses da classe trabalhadora do campo, na sua diversidade de povos indígenas, povos da floresta, comunidades tradicionais e camponesas, quilombolas, agricultores familiares, assentados, acampados à espera de assentamento, extrativistas, pescadores artesanais, ribeirinhos e trabalhadores assalariados rurais (FÓRUM NACIONAL DE EDUCAÇÃO DO CAMPO, 2012, p. 3).

\section{Práticas curriculares e educação do campo}

A educação do campo tem sido historicamente marginalizada na construção de políticas públicas. Inúmeras vezes tratada como política compensatória. Suas demandas e especificidades raramente têm sido objeto de pesquisas no espaço acadêmico ou na formulação de currículos 
em diferentes níveis e modalidades de ensino. Neste cenário de exclusão, a educação do campo é trabalhada a partir de discursos, identidades, perfis e currículos, marcados essencialmente, por conotações urbanas. Currículos geralmente deslocados das necessidades locais e regionais.

Com a aprovação da Constituição de 1988 e do processo de redemocratização do país, inúmeros debates foram organizados em torno dos direitos sociais da população campesina. Nessa mesma linha de raciocínio, são aprovados direitos educacionais bastante significativos, consolidando o compromisso do Estado e da sociedade brasileira na promoção da educação, respeitando as singularidades culturais e regionais. Em sintonia com essas concepções foram elaboradas reformas educacionais que desencadeou na LDBEN - Lei de Diretrizes e Bases da Educação Nacional, 9394/96. O reconhecimento da diversidade e a singularidade do campo são defendidos, a partir da concepção de uma educação para todos, presente nesta LDB.

Vários instrumentos legais estabelecem orientações para atender esta realidade, de modo a "adequar" as suas especificidades, como exemplificam os artigos 23, 26 e 28, que tratam das questões de organização escolar e pedagógicas. A LDB, em seu artigo 28, estabelece as seguintes normas para educação no meio rural: $\mathrm{Na}$ oferta da educação básica para a população rural, os sistemas de ensino proverão as adaptações necessárias à sua adequação, às peculiaridades da vida rural e de cada região, especialmente: I- conteúdos curriculares e metodologia apropriada às reais necessidades e interesses dos alunos da zona rural; II- organização escolar própria, incluindo a adequação do calendário escolar às fases do ciclo agrícola e às condições climáticas; III- adequação à natureza do trabalho na zona rural. (BRASIL, 1996).

No artigo 28, podemos observar avanços políticos, educacionais e culturais referentes à educação no meio 
rural: educação básica para toda população; conteúdos curriculares e metodologias integradas aos interesses e necessidades dos educandos, assim como, autonomia dos espaços educativos, que poderão organizar seu calendário de acordo com as atividades e trabalhos desenvolvidos na comunidade.

Outro aspecto importante foi a aprovação, no ano de 2002, das Diretrizes Operacionais para a Educação Básica nas escolas do campo, fruto das diversas lutas travadas pelos Movimentos Sociais do campo. Em seus vários artigos presenciamos a preocupação de articular o projeto institucional das escolas do campo às diretrizes curriculares nacionais para a educação básica. O Reconhecimento das especificidades do campo e a legitimidade de um projeto de educação próprio. A identidade da escola do campo e a vinculação às questões inerentes à sua realidade. A importância da educação escolar para o exercício da cidadania e o desenvolvimento do país. O mundo do trabalho, o desenvolvimento social, economicamente justo e ecologicamente sustentável. As propostas pedagógicas das escolas do campo e as diversidades em todos os seus aspectos: sociais, culturais, políticos, econômicos, de gênero, geração e etnia. A regulamentação das estratégias específicas de atendimento escolar do campo e a flexibilização da organização do calendário escolar. As atividades curriculares e pedagógicas articuladas com os projetos de desenvolvimento sustentável e as demandas provenientes dos movimentos sociais.

\section{ENERA - Encontro Nacional de Educadores e Educadoras da Reforma Agrária}

Em 1997, foi organizado pelo MST, com apoio da UnB - Universidade de Brasília e demais entidades, o I Encontro Nacional de Educadores e Educadoras da Reforma Agrária - ENERA. Neste evento foi lançado um desa- 
fio: pensar a educação pública para os povos do campo, considerando seu contexto em termos políticos, econômicos, sociais, culturais e familiares. Valorização da pedagogia da alternância e suas formas de conceber os tempos e espaços de formação dos sujeitos camponeses. Respeito ao meio ambiente, à produção, ao trabalho e organização coletiva. Segundo (CALDART, 2002) durante o I ENERA foram colocadas em pauta as reflexões e práticas pedagógicas possíveis para o meio rural. Utilizava-se uma nova perspectiva de pensar a educação do campo, descentralizando as discussões nos estados e municípios. Nesse encontro surge a ideia de uma Conferência Nacional Por Uma Educação Básica do Campo. Segundo a autora, esse evento foi um grande avanço nas discussões que influenciariam as políticas públicas do país, permitindo a intensa participação popular.

Toda vez que houve alguma sinalização de política educacional ou de projeto pedagógico específico, isto foi feito para o meio rural e muito poucas vezes com os sujeitos do campo. Além, de não reconhecer o povo do campo como sujeito da política e da pedagogia, sucessivos governos tentaram sujeitá-lo a um tipo de educação domesticadora e atrelada a modelos econômicos perversos (CALDART, 2002, p. 28).

Esses debates pontuaram os anseios da população que questionava, sobretudo, a formação dos indivíduos com interesses, apenas, econômicos e políticos da classe dominante brasileira. A crítica surge em função da desconsideração das histórias, sonhos, desejos, limites e possibilidades dos povos camponeses. Contestavam ainda as dimensões do agronegócio que fortalece, exclusivamente, a lógica da monocultura para exportação, em detrimento da agricultura familiar e da produção diversificada para abastecer o mercado nacional. Nesse contexto, as políticas públicas de educação implementadas nas áreas rurais, não têm dado conta de acompanhar as especificidades regionais, geográficas e históricas do campo, além da necessá- 
ria formação que atenda às demandas desta realidade.

Este encontro serviu de preparação para os próximos desafios dos movimentos sociais e foi considerado o marco do surgimento da concepção de Educação do Campo no Brasil. No final dos anos 90, presenciamos a criação de diversos espaços públicos de debates sobre a educação do campo. Em 1998 foi criada a Articulação Nacional por uma Educação do Campo, entidade máxima que reunia as organizações de classe e movimentos sociais do campo, promovendo ações voltadas para Educação Básica do Campo.

\section{PRONERA - Programa Nacional de Educação na Reforma Agrária}

No governo Fernando Henrique Cardoso foi criado o Programa Nacional de Educação na Reforma Agrária PRONERA, em 16 de abril de 1998, por meio da Portaria n⿳‥ 10/98, vinculado ao gabinete do Ministério Extraordinário da Política Fundiária. Em 2001, o Programa passa a fazer parte do INCRA - Instituto Nacional de Colonização e Reforma Agrária, no MDA - Ministério do Desenvolvimento Agrário. O PRONERA é a expressão do compromisso firmado entre o Governo Federal, as instituições de ensino, os movimentos sociais, sindicatos de trabalhadores/as rurais, governos estaduais e municipais, considerando a diversidade dos atores sociais envolvidos no processo de luta por terra e educação no país.

\section{Diretrizes Operacionais para a Educação Básica nas escolas do campo}

Em 2002 foi aprovada a Resolução CNE/CEB №. 01 de 03 de abril que instituiu as Diretrizes Operacionais para a Educação Básica nas escolas do campo, contendo 15 artigos. Ela consolida um importante marco na história da 
educação brasileira, em especial, a educação do campo. É fruto das diversas lutas em defesa da educação do campo, como direito dos sujeitos e dever do estado. Ela mantêm viva a memória dos povos camponeses, suas raízes e saberes. Nessas diretrizes é nítida a preocupação com a formação continuada dos educadores e a promoção das expressões culturais dos sujeitos, individuais e coletivos. Importante ressaltar que a lentidão na implementação de tais políticas de direito, dificultou seu alcance e efetivação nas escolas do campo.

\section{SECAD - Secretaria de Educação Continuada, Alfabetização e Diversidade}

No governo Lula foi criada, em 2004, a Secretaria de Educação Continuada, Alfabetização e Diversidade (SECAD), no âmbito do Ministério da Educação. Ela tem como objetivo contribuir na redução das desigualdades educacionais, visando a efetivação de políticas públicas. $\mathrm{Na}$ SECAD foi criada a Coordenação Geral de Educação do Campo. Ela é composta por quatro departamentos: Departamento de Educação de Jovens e Adultos; Departamento de Educação para Diversidade e Cidadania; Departamento de Desenvolvimento e Articulação Institucional e Departamento de Avaliação e Informações Educacionais. Este fato significou a inclusão, na estrutura federal, de uma instância responsável pelo atendimento das demandas do campo, a partir do reconhecimento de suas necessidades e singularidades. De acordo com o MEC, a Secretaria tem como objetivo contribuir para o desenvolvimento inclusivo dos sistemas de ensino, voltado para valorização das diferenças e diversidades, promoção da educação inclusiva, direitos humanos e sustentabilidade socioambiental, visando a efetivação de políticas públicas transversais e intersetoriais. 


\section{PROCAMPO - Programa de Apoio à Formação Superior em Licenciatura em Educação do Campo}

Importante sinalizar que as experiências acumuladas pelo PRONERA, nos mais diversos âmbitos de abrangência, influenciou a concepção e elaboração de novas políticas públicas, tendo em vista o desenvolvimento do campo através de inúmeras ações educativas na formação dos sujeitos, como por exemplo: o Programa de Apoio à Formação Superior em Licenciatura em Educação do Campo (PROCAMPO).

O PROCAMPO foi criado no ano de 2007, através do Ministério da Educação, com a iniciativa da então Secretaria de Educação Continuada, Alfabetização e Diversidade - SECAD. Surge por meio de parcerias com as Instituições Públicas de Ensino Superior, viabilizando a criação de cursos regulares de Licenciatura em Educação do Campo. Seu principal objetivo é promover a formação de professores da educação básica, especialmente, para docência nos anos finais do ensino fundamental e ensino médio nas escolas do campo. O Programa foi implantado inicialmente na Universidade Federal de Minas Gerais (UFMG), Universidade Federal da Bahia (UFBa), Universidade Federal de Sergipe (UFS) e na Universidade Federal de Brasília (UnB).

\section{Pedagogia da alternância}

A Pedagogia da Alternância, em sua grande maioria, estabelece práticas curriculares flexíveis para atender aos objetivos de que, em tempos e espaços alternados Tempo Escola (TE) e Tempo Comunidade (TC) - os jovens do campo tenham condições de acesso à escolarização e conhecimentos científicos, além dos valores produzidos em família e nas comunidades. A pedagogia da alternân- 
cia contribui com a flexibilização do calendário curricular nas escolas do campo e nas Licenciaturas em Educação do Campo oferecidas por Universidades Públicas, em diálogo com os movimentos sociais.

Ao alternar períodos na escola / universidade e na vivência de sua comunidade, os estudantes constroem conhecimentos dialogando com os saberes da escola e do cotidiano, das histórias de vida, memórias, identidades e gerações. Essa estreita relação pode valorizar a diversidade cultural e as práticas curriculares emancipatórias. Assim, a pedagogia da alternância pode contribuir na formação dos jovens, desenvolvendo a reflexão crítica, a responsabilidade individual e coletiva, além de fortalecer as famílias camponesas, na tentativa de envolver os sujeitos, individuais e coletivos, na busca de um mundo mais solidário, justo, humano e ético (GIMONET, 2007).

\section{PRONACAMPO - Programa Nacional de Educação do Campo}

O PRONACAMPO - Programa Nacional de Educação do Campo, vinculado ao Ministério da Educação, está previsto pelo Decreto $\mathrm{n}^{\mathrm{o}} 7.352$ e instituído por meio da Portaria $n^{\circ}$ 86, de $1^{\circ}$ de fevereiro de 2013. Foi lançado pela presidente Dilma Rousseff em março de 2012, com o propósito de oferecer apoio financeiro e técnico para viabilização de políticas no campo. Oriundo da mobilização das organizações e movimentos sociais, esta política pública evidencia que a luta pela educação do campo e pela reforma agrária transcende à luta pela terra, uma vez que compreende a ocupação de outros espaços.

O PRONACAMPO é um conjunto de ações articuladas que asseguram a melhoria do ensino nas redes existentes, bem como, a formação dos professores, produção de material didático específico, acesso e recuperação da infraestrutura e qualidade na educação no campo em todas as 
etapas e modalidades. (PRONACAMPO/MEC, 2012). Ele está estruturado em quatro eixos: Gestão e Práticas Pedagógicas, Formação de Professores, Educação de jovens e adultos, Educação Profissional e Tecnológica e Eixo Infraestrutura Física e Tecnológica.

\section{Fechamento de escolas do campo}

Em função do fechamento de um grande número de escolas do campo nos últimos anos, o governo federal nas diretrizes e bases da educação nacional, estabeleceu a necessidade de constar a exigência de manifestação do sistema de ensino, para o fechamento de escolas do campo. A Lei n⿳0 12.960, de 27 de março de 2014 e a Portaria nº 391, de 10 de Maio de 2016, MEC, estabelecem orientações e diretrizes aos órgãos normativos dos sistemas de ensino para o processo de fechamento de escolas do campo, indígenas e quilombolas. Estas leis foram implementadas em função das reivindicações dos movimentos sociais, garantindo, dessa forma, critérios para decisão de fechar uma escola. O art. 28 da Lei no 9.394, de 20 de dezembro de 1996, passa a vigorar acrescido do seguinte parágrafo único:

O fechamento de escolas do campo, indígenas e quilombolas será precedido de manifestação do órgão normativo do respectivo sistema de ensino, que considerará a justificativa apresentada pela Secretaria de Educação, a análise do diagnóstico do impacto da ação e a manifestação da comunidade escolar (BRASIL, 2014).

De acordo com o Censo Escolar, apenas em 2013 e 2014, foram fechadas 4.084 escolas no campo, o equivalente a 340 escolas por mês e 9 por dia. Ressaltamos aqui a enorme perda de dignidade dessas populações, configurada como um verdadeiro descaso pelo poder público. Com tanta irresponsabilidade, uma das primeiras decisões tomadas pelas famílias de camponeses é a migração para ci- 
dade, com o objetivo primeiro de estudar. Com a decisão de sair do campo, esses sujeitos, em sua grande maioria, passam a viver distante de seu cotidiano, histórias, memórias e identidades, em condições de total abandono e precariedade.

É estratégico ressaltar que o estímulo ao fechamento das escolas do campo se consolida com as políticas de transporte escolar e nucleação das escolas. Estas medidas arbitrárias das gestões públicas impõem aos educandos uma exaustiva jornada diária às escolas da cidade. Em muitos casos, a garantia de prestação do serviço pelo poder público, não atende a qualidade do transporte escolar e violam direitos básicos dos educandos, em especial, o desenvolvimento de processos educativos que contemple sua inserção nas comunidades.

\section{CONSIDERAÇÕES FINAIS}

Este texto teve a intenção de fortalecer a perspectiva da educação popular e da autoformação, numa estreita relação com os movimentos sociais camponeses. Ele rompe com as posições políticas e ideológicas de formação tradicional nas escolas do campo e universidades, defendendo, entre outros aspectos a pedagogia da alternância, a agricultura familiar, orgânica e agroecológica. Os princípios da educação do campo são incompatíveis com o agronegócio. Este artigo supera ainda a lógica da escola urbanocêntrica, voltada exclusivamente para o capital. Uma escola que produz exclusão para classe trabalhadora e estabelece uma relação de subordinação entre professores e aluno. Se queremos lutadores do futuro, a organicidade desta escola não interessa aos objetivos da classe trabalhadora. As lutas devem ser organizadas, considerando as especificidades das escolas, os interesses de educadores, educandos e comunidades, suas práticas pedagógicas e a diversidade das frações de classes. 
Não me parece que os projetos alternativos de escolas emancipadoras nascerão no isolamento das universidades, gabinetes de secretários municipais e estaduais de educação, distante das reflexões teórica e práticas defendidas nos movimentos sociais do campo. A produção crítica do conhecimento acerca da identidade de gênero e racial, o desenvolvimento sustentável dos povos do campo e o trabalho coletivo não se encaixam em cursos prontos. A centralidade da escola na produção do conhecimento precisa ser questionada, pois ela não está deslocada da vida e distante das contradições sociais. Transformar a escola do campo num lugar que reflita a cultura local e o trabalho formativo, incentivando a formação de professores do campo em todas as suas dimensões social, política e econômica.

Os movimentos sociais são atores estratégicos dos resultados e conquistas até aqui alcançadas acerca das políticas públicas de educação do campo. Nestas considerações finais, de tantas práticas pedagógicas que se configuram aquelas mais intensas e articuladas, destacaremos as seguintes políticas públicas: PRONERA, PROCAMPO e o PRONACAMPO. O Programa Nacional de Educação na Reforma Agrária - PRONERA, foi criado no ano de 1998 e está vinculado ao INCRA - Instituto Nacional de Colonização e Reforma Agrária. Este Programa estabeleceu parcerias entre o Governo Federal, instituições de ensino, movimentos sociais e a diversidade dos atores sociais envolvidos no processo de luta por terra e educação no país. Desenvolveu inúmeros projetos vinculados à alfabetização de jovens e adultos, cursos técnicos em agroecologia e ensino superior.

As experiências acumuladas pelo PRONERA, contribuíram para criação, no ano de 2007, do Programa de Apoio à Formação Superior em Licenciatura em Educação do Campo (PROCAMPO). Este Programa surgiu da necessidade de formação inicial para educadores/as do cam- 
po nos anos finais do ensino fundamental e médio. Contribuiu para fortalecer o debate acerca das políticas públicas educacionais e enfrentar, com seriedade, questões que ainda não haviam sido discutidas pelo governo brasileiro.

O PRONACAMPO - Programa Nacional de Educação do Campo, criado no ano de 2012, teve o propósito de oferecer apoio financeiro e técnico para viabilização de políticas públicas no campo. Está estruturado em quatro eixos: Gestão e Práticas Pedagógicas, Formação de Professores, Educação de jovens e adultos, Educação Profissional e Tecnológica e Eixo Infraestrutura Física e Tecnológica. A preocupação das políticas públicas acima é com o fortalecimento dos laços entre educação popular, movimentos sociais, diversidade cultural e identitária. A intenção foi romper com os paradigmas conservadores verificados na história desse país, onde o campo, a instituição escolar, as práticas curriculares, educadores e educandos, em sua grande maioria, são considerados a extensão da cidade.

Entendemos que os objetivos deste trabalho foram alcançados pelas atividades realizadas no Fórum de Políticas Públicas em Educação do Campo no CIBEPOC - Congresso Interinstitucional Brasileiro de Educação Popular e do Campo. Consideramos as histórias de vida de educadores e educandos, memórias e vida cultural, constitutivas de valores, conflitos de ideias, lutas pelo reconhecimento identitário e novas formas coletivas e democráticas de relacionamentos. Queremos salientar que a produção do conhecimento pautada nos dados coletados e nas observações efetuadas não foi isenta de valores. A construção crítica e coerente do saber não é neutra. Assim, a história pessoal dos autores permeou todo o desenvolvimento desse trabalho.

Esperamos, dessa forma, estimular a produção de leituras e reflexões que contemplem entre outros aspectos a formação de educadores do campo. Nesse processo de construção histórica prevaleceu o respeito às diferenças e 
a valorização da identidade cultural dos povos camponeses, propondo uma educação inclusiva, questionadora e democrática, presente em diversas experiências de educação popular vinculada à luta pela terra. Por fim, importante registrar nossa defesa às políticas públicas que contribuam na formação de educadores nas escolas do campo brasileira. Sugerimos aos leitores a continuidade desses estudos com o objetivo de compreender a relevância de tais políticas no fortalecimento das relações com os movimentos sociais.

\section{REFERÊNCIAS}

ALTIERI, M. Agroecologia: a dinâmica produtiva da agricultura sustentável. Porto Alegre: Editora UFRGS, 2014.

BICALHO, R.; OLIVEIRA, L. M. T. Educação do campo e atores político-institucionais: construindo novos processos identitários na Universidade? In: Berenblum, Andrea \& Oliveira, Lia Maria Teixeira de. Educação: diálogos do cotidiano. Seropédica (RJ): Outras letras Editora, 2011.

BICALHO, R.; BUENO, M. C. M. Educação do campo, pedagogia da alternância e formação do educador. Educação \& Linguagem, v. 19, n. 1, p. 189-204, jan./jun. 2016.

BICALHO, R. A concepção de educação do campo no contexto do Movimento dos Trabalhadores Rurais Sem Terra (MST). INTER-AÇÃO (UFG. ONLINE), v. 42, n. 2, p. 297-310, maio/ago. 2017. Disponível em: <http://dx.doi.org/10.5216/ia. v42i2.46007>. Acesso em: 12 dez. 2017.

BICALHO, R.; OLIVEIRA, J. R. Interfaces entre educação profissional e pedagogia da alternância. SÉRIE-ESTUDOS (UCDB), Campo Grande, MS, v. 22, n. 46, p. 195-212, set./dez. 2017.

BICALHO, R. História da educação do campo no Brasil: o protagonismo dos movimentos sociais. Teias, Rio de Janeiro, v. 18, n. 51, p. 210-224, out./dez. 2017. 
BICALHO, R.; ABBONIZIO, A. C. O. A pedagogia da alternância e a Licenciatura em Educação do Campo na UFRRJ Universidade Federal Rural do Rio de Janeiro: o ensino médio e a formação de educadores do campo. Dialogia (UNINOVE. Impresso), São Paulo, n. 23, p. 69-79, jan/jun, 2016.

BICALHO, R.; SILVA, M. A. Políticas públicas em educação do campo: PRONERA, PROCAMPO e PRONACAMPO. Revista Eletrônica de Educação (São Carlos), v. 10, n. 2, p. 135-144, 2016.

BICALHO, R. Interfaces entre escolas do campo e movimentos sociais no Brasil. Revista Brasileira de Educação do Campo, Tocantinópolis. v. 1, n. 1, p. 26-46, jan./jun. 2016.

. Os movimentos sociais do campo e a formação do educador. Textura Canoas - ULBRA, v. 18, n. 17, p. 5-26, maio/ ago. 2016.

BICALHO, R.; COSTA, M. de O.; SILVA, E. (Orgs.). Educação na Amazônia Campesina: Processos de construção do conhecimento no campo. 1. ed. Curitiba: CRV, 2017. v. 1. 168p.

BICALHO, R. Possíveis Interfaces entre Educação do Campo, Educação Popular e Questões Agrárias. 1. ed. Curitiba: Appris, 2017. v. 1. 234p.

BRASIL. Constituição da República Federativa do Brasil. Título 1, Artigo 3ํ 1V e Seção l - Da Educação, Artigo 206. 1988.

. Lei de Diretrizes e Bases da Educação Nacional LDB - no. 9.394/96, Artigos, 28, 78, 79. 1996.

. Presidência da República. Casa Civil. Subchefia para Assuntos Jurídicos. Lei no $\mathbf{1 2 . 9 6 0}$, de 27 de março de 2014 Imprensa Nacional, 2014. 27 de março de 2014. Disponível em: $<$ http://www.planalto.gov.br/ccivil_03/_Ato2011-2014/2014/ Lei/L12960.htm.>. Acesso em: 12 dez. 2017.

PROCAMPO - Programa de Apoio à Formação Superior em Licenciatura em Educação do Campo. Ministério da Educação. 2007. 
. Resolução no 4, de 13 de Julho de 2010. Define as Diretrizes Curriculares Nacionais Gerais para a Educação Básica e, nela, a educação do campo como modalidade de ensino.

- Instituto Nacional de Colonização e Reforma Agrária (Incra). Programa Nacional de Educação na Reforma Agrária (Pronera): manual de operações. Brasília, 2004. Disponível em: $<$ http://www.incra.gov.br/portal/arquivos/ projetos_programas/0127102302.pdf.>. Acesso em: 12 dez. 2017.

. Secretaria de Educação Continuada, Alfabetização e Diversidade. Referências para uma política de educação do campo: caderno de subsídios. Brasília, 2ª ed. 2005.

. Secretaria de Educação Continuada, Alfabetização e Diversidade. (SECAD), 2004.

. Decreto $\mathrm{n}^{\mathrm{0}}$ 7.352, de 4 de novembro de 2010. Dispõe sobre a política de educação do campo e o Programa Nacional de Educação na Reforma Agrária -PRONERA. Diário Oficial da União, Brasília, Sessão1, 5 nov. 2010. Disponível em: <http:// www.planalto.gov.br/ccivil_03/_ato2007-010/2010/decreto/ d7352.htm>. Acesso em: 12 dez. 2017.

BRASIL - MINISTÉRIO DA EDUCAÇÃO. Portaria no 86 de $\mathbf{1}^{0}$ de Fevereiro de 2013. Institui o Programa Nacional de Educação do Campo - PRONACAMPO, e define suas diretrizes gerais. Brasília/DF: GABINETE DO MINISTRO. Disponível em: $<\mathrm{http} / / / w w w . l e x . c o m . b r /$ legis_24140877_PORTARIA_N_86_ DE_1_DE_FEVEREIRO>. Acesso em: 12 dez. 2017.

. Conselho Nacional de Educação. Câmara de Educação Básica. Parecer n. 36/2001. Diretrizes Operacionais para a Educação Básica nas Escolas do Campo. Brasília, 2001.

\section{Diretrizes Operacionais para Educação Básica nas}

escolas do campo. Resolução Conselho Nacional de Educação/ Câmara de Educação Básica n 1/ 2002.

. Diretrizes Complementares da Educação Básica do campo. Resolução Conselho Nacional de Educação/ Câmara de Educação Básica. 2008.

. MDA - Ministério do Desenvolvimento Agrário. PRO- 
NERA. Manual de Operações. Brasília, 2004.

. Portaria no 391, de 10 de maio de 2016. Estabelece

orientações e diretrizes aos órgãos normativos dos sistemas de ensino para o processo de fechamento de escolas do campo, indígenas e quilombolas.

. Presidência da República. Casa Civil. Decreto n. 6.040 de 7 de fevereiro de 2007. Institui a Política Nacional de Desenvolvimento Sustentável dos Povos e Comunidades Tradicionais. Brasília, 2007.

. Ministério da Educação. Conselho Nacional de Educação. Câmara de Educação Básica. Resolução n. 4 de 13 de julho de 2010. Define Diretrizes Curriculares Nacionais Gerais para a Educação Básica. Brasília, 2010.

. Ministério da Educação. Conselho Nacional de Educação. Câmara de Educação Básica. Resolução n. 8 de 20 de novembro de 2012: Define as Diretrizes Curriculares Nacionais para a Educação Escolar Quilombola na Educação Básica. Brasília, 2012.

CALDART, R. S. et al (Orgs.). Por uma Educação do Campo. Petrópolis, RJ: Vozes, 2004.

CALDART, R. S. Pedagogia do Movimento Sem Terra: escola é mais que escola. SP: Expressão Popular, 2008.

A escola do campo em movimento. In: Revista Eletrônica Currículo sem Fronteiras, v. 3, n.1, p.60-81, jan./jun. 2003.

. Caminhos para a transformação da escola: Reflexões desde práticas da Licenciatura em Educação do Campo. SP: Expressão Popular, 2010.

. Por Uma Educação do Campo: traços de uma identidade em construção. In: KOLLING, E. J.; CERIOLI, P. R.; CALDART, R. S. (Orgs.). Educação do Campo: identidade e políticas públicas. Brasília: 2002. Coleção Por Uma Educação do Campo, n. 4, p. 25-36.

CALDART, R. S.; STEDILE, M. E.; DAROS, D. (Orgs). Cami- 
nhos para transformação da Escola 2: Agricultura camponesa, educação politécnica e escolas do campo. SP: Expressão Popular, 2015.

CALDART, R. S.; PEREIRA, I. B.; ALENTEJANO, P.; FRIGOTTO, G. (Orgs). Dicionário da Educação do Campo. SP: Expressão Popular, 2012.

CAMPOS, M. Lutas dos movimentos sociais do campo e suas contradições na construção da educação do campo. RETTA - Revista de Educação Técnica e Tecnológica em Ciências Agrícolas. v. VIII, n. 11, jan./jun. 2015.

CONFERÊNCIA NACIONAL POR UMA EDUCAÇÃO BÁSICA DO CAMPO, 1., Compromissos e desafios. 1998. Goiás: CNBB, MST, UNICEF, UNESCO, UnB, 1998.

FERNANDES, B. M.; MOLINA, M. C.; JESUS, S. M. S. A. (Orgs.). Contribuições para a construção de um projeto de educação do Campo - Brasília, DF: Articulação Nacional Por uma Educação Básica do Campo, 2005. Coleção Por uma Educação Básica do Campo, n. 5.

FÓRUM NACIONAL DE EDUCAÇÃO DO CAMPO, 1., Notas para análise do momento atual da Educação do Campo. 2012, Seminário Nacional. Brasília: FONEC, 2012.

FREIRE, P. Pedagogia da Autonomia: Saberes necessários à prática educativa. SP: Paz e Terra, 1997.

. Pedagogia do Oprimido. RJ: Paz e Terra, 1975.

. Educação como prática de liberdade. RJ: Paz e Terra, 1983.

GIMONET, J. Praticar e compreender a pedagogia da alternância dos CEFFAs. Petrópolis: Editora Vozes; Paris: AIMFR, 2007.

GOHN, M. G. (Org.) Movimentos sociais no início do século XXI: antigos e novos atores sociais. Petrópolis/RJ: Vozes, 2003.

. Movimentos Sociais e Educação. Ed. Cortez. 2001. 
LEITE, S. Escola Rural: Urbanizações e políticas educacionais. São Paulo: Cortez, 1999.

MOLINA, M. C. A contribuição do PRONERA na construção de políticas públicas de educação do campo e desenvolvimento sustentável. 2003. Tese. (Doutorado em Desenvolvimento Sustentável). Centro de Desenvolvimento Sustentável da Universidade de Brasília, Brasília, 2003.

MOLINA, M. C.; JESUS, S. M. S. A. de. Contribuições do PRONERA à Educação do Campo no Brasil Reflexões a partir da tríade: Campo -Política Pública - Educação. In: SANTOS, C. A. dos; MOLINA, M. C.; JESUS, S. M. S. A. de. (Orgs).

Memória e história do Pronera: contribuições para a educação do campo no Brasil. Brasília: Ministério do Desenvolvimento Agrário, 2010. p. 29-63.

MOLINA, M. C. Educação do Campo e formação profissional: a experiência do Programa de Residência Agrária. Brasília: Ministério do Desenvolvimento Agrário, 2009.

. Educação do campo e pesquisa: questões para reflexão. Brasília, DF: Ministério do Desenvolvimento Agrário, 2006.

Educação do Campo e Pesquisa II. MDA/MEC 2010.

MOLINA, M. C.; FREITAS, H. C. de A. (Orgs). Em AbertoEducação do Campo. INEP/MEC 2012.

MOLINA, M. C.; SÁ, L. M. (Orgs). Licenciaturas em Educação do Campo: registros e reflexões a partir das experiências piloto. Belo Horizonte: Autêntica Editora, 2011. Coleção Caminhos da Educação do Campo, 5. 


Esperamos que esse livro contribua para o debate político e filosófico sobre a educação. Afirmamos que caso seja infringido qualquer direito autoral, imediatamente, retiraremos a obra da internet. Reafirmamos que é vedada a comercialização deste produto.

Formato A5

1ª Edição $\quad$ Maio de 2019

Navegando Publicações

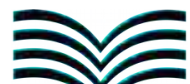

NAVEGANDO

www.editoranavegando.com

editoranavegando@gmail.com

Uberlândia - MG

Brasil 


A colecta "Educacăo popular e do Gampo" do Congrossa Interinstitucianal Brasileiro de Educação Popular e do Campo-CIBEFor de uma obra financiada pela Capes (Proposta $640602-03 / 2013)$ e pela Secretaria de Educacăo Continuada, Alfabetizaca. Diversidade e Inchusao Secadi, por meio do Programa Escola da Terra: - GO. A colecáo reune trabalhos de diversos autores nacionais e internacionais que se debrucam sobre as estudos da Educacao popular e do campo em diversas perspectivas deste os fundamentos sociais, históricos, poilticos. culturais, filosóficos,

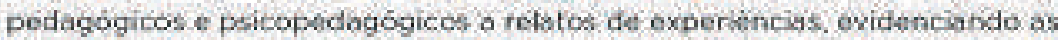
relacoes entre a dimensab da Formaçao de ptofessotes, sujeitos e práticas de ensino em espacos escolares e nác escolares, eonhecimento é cultura e clesiguatdades educacionais.

A Colecto possui 6 livros e este a o Livra 7 da eciecaol Boa Leitural $O$ Invo e gratuito e pode ser baixado na varsabo fi-book no site da editora Nevegando ne seguinte endereco www.editoranavegendocom:


NAVEGANDO 